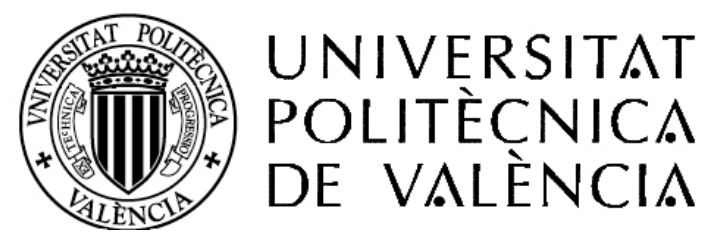

Facultad de Bellas Artes de San Carlos

Departamento de Dibujo

\title{
RASGOS DE IDENTIDAD EN LA PINTURA CHILENA EN INICIOS DEL SIGLO
} XXI

Presentada por

Cristián Benavente Millán

Dirigida por

Profesor Doctor Carlos Plasencia Climent

Co- tutor Dr. Juan Carlos Arañó Gisbert

2015 
A Isabel Millán Arrate, mi madre 
Agradecimientos:

A Carlos Plasencia C. el esfuerzo realizado para que se concretara este programa en Chile, su gran paciencia $y$ amistad.

A Ignacio Villegas V. el haber abierto las puertas de la Universidad Católica para acoger este programa y velar por su desarrollo. En lo personal por su incondicional apoyo. 


\section{Resumen}

Iniciado el siglo XXI, la palabra identidad invade los medios de comunicación, las redes sociales y el mundo de la cultura en Chile. Muchas han de ser las causas de esta preocupación, pero algunos expertos señalan al modelo económico, a la inserción de Chile en escenarios internacionales y al masivo acceso a la tecnología, como las posibles causas. A propósito de este hecho, el mundo de la cultura observó algunos acomodos en la manera en que el teatro, la arquitectura o la música estaban dando cuenta de este fenómeno. En Artes Visuales observamos una tendencia al uso -polarizado- de estrategias de producción visual que por una parte tendían a asociarse en aspectos formales, temáticos e iconográficos con la producción europea y/o norteamericana y, por el lado opuesto, esos mismos aspectos se trabajaban en asociación a una idea de país, a una posible identidad.

La presente tesis da cuenta de una investigación tendiente a identificar rasgos de una posible identidad chilena, en la obra pictórica producida/exhibida en este país entre los años 2000 y 2015.

El proceso de búsqueda de dichos rasgos se basó en el análisis formal, iconográfico y temático de la obra de 180 artistas, registrados en los libros y catálogos de las más relevantes exposiciones de pintura, montadas en Chile en el período en estudio.

La información se registró en fichas que permitieron un análisis connotativo y denotativo, sobre cuya base que levantaron las conclusiones. La investigación muestra que del total de obras analizadas, el $36.1 \%$ presenta temas (paisajes, escenas, personas, objetos) y/o imágenes y formas (colores, motivos y configuraciones), asociados a los rasgos de identidad propios de Chile, pudiéndose estructurar así una batería de recursos visuales, que podríamos señalar como el imaginario de una "pintura chilena contemporánea". 


\section{Abstract}

The word identity began to invade all means of communication, social networks and the cultural world in Chile at the dawn of the XXI century. There are several factors that led to such focus of attention, some experts pointing to the economic model, Chile's active participation in international scenarios, as well as the massive development of accessible technology as possible causes. Amidst these changes, the cultural world was also experiencing certain adjustments in how theater, architecture and music were embracing this focus on identity. In the realm of visual arts there was a polarized trend in the strategies that were being used, which on the one hand leaned toward formal, thematic and iconographic aspects of European and/or North American art, and on the other hand delved into exploring the notion of Chilean nationality, and possibly identity.

The present thesis reports on research into the identification of possible aspects related to Chilean identity, through visual art works produced and exhibited in this country between the years 2000 and 2015.

The process of searching for such aspects of identity was based on formal, iconographic and thematic analyses of the work by 180 artists documented in books and catalogues resulting from the most important art exhibitions in Chile during the abovementioned time period. Relevant information was recorded, and analyzed from connotative and denotative standpoints, from which conclusions were drawn. This research shows that out of all the art work analyzed, $36.1 \%$ include themes (landscapes, scenery, people and objects) and/or images and forms (colors, motifs and configurations) associated to aspects of Chilean identity. This resulted in a set of selected visual resources, which could be considered to represent the notion of what can be termed "contemporary Chilean painting". 
Resum

Al començament del segle XXI, la paraula identitat invadeix els mitjans de comunicació, les xarxes socials i el mon de la cultura a Xile.Moltes han de ser les causes d'aquesta preocupació, però alguns experts assenyalen al model econòmic, a la inserció de Xile als escenaris internacionals i al massiu acces a la tecnología, com a possibles causes. Per aquest fet, el mon de la cultura va observar alguns acomodaments en la manera en la que el teatre, l'arquitectura o la música estaven evidenciant aquest fenòmen. A les arts visuals observem una tendència a l'ús -polaritzat- d' estratègies de producció visual que, per una banda, mostraven tendencia a asociarse amb aspectos formals, temàtics e iconogràfics amb la producción europea i/o Nordamericana, i per altra banda, aquestos mateixos aspectes es treballaven amb associació a una idea de país, a una possible identitat.

La present tesi mostra una investigación tendent a identificar trets d’una possible identitat Xilena amb l' obra pictòrica produida/exhibida en aquest país entre els anys 200 i 2015.

El procés de recerca d' aquestos trets es va basar en l' anàlisi formal connotatiu i denotatiu, sobre la base de la que després s'obtingueren les conclusions. La investigació mostra que del total d'obres analitzades, el 36,1\% presenta temes (paissatges, escenes, persones, objectes) i/o imatges i formes(colors, motius i configuracions) associats a trets d' identitat propis de Xile, podent-se estructurar així una batería de recursos visuals, que podriem asenyalar com l'ímaginari d'una "pintura Xilena Contemporanea". 
INDICE

\section{INTRODUCCIÓN}

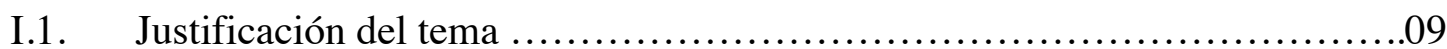

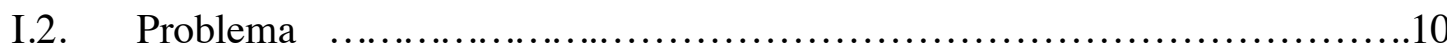

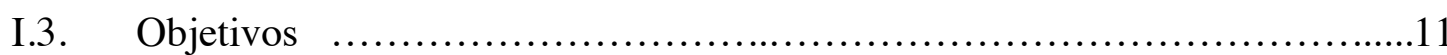

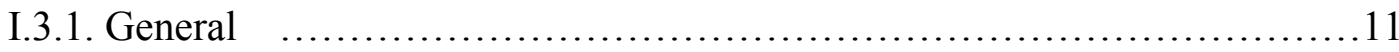

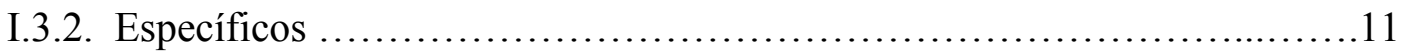

I.3.3. Preguntas de investigación............................................ 12

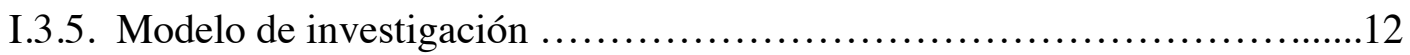

I.3.6. Objeto de estudio ............................................... 17

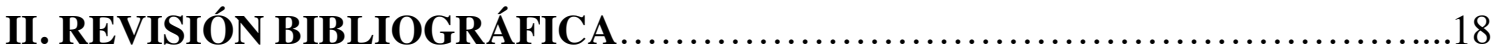

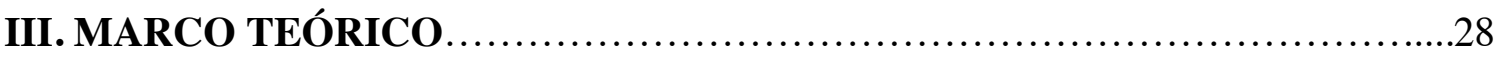

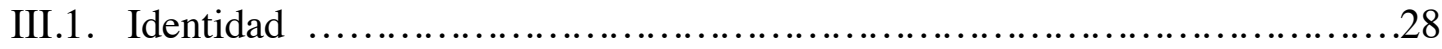

III.1.1. Noción de identidad ..............................................28

III.1.2. Globalización y cambio cultural........................................30

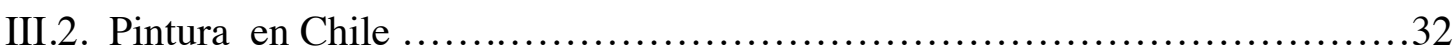

III.2.1 Dimensiones de la pintura .......................................33

IV. DESARROLLO DE LA INVESTIGACIÓN...............................41

IV.1. Cultura - identidad .................................................................. 41

IV.2. Cultura e identidad en Chile en el contexto de la globalización...............47

IV .2.1. Chile y la modernidad ..........................................49

IV .2.2. Identidad colectiva .............................................52

IV.2.3. El miedo a la diversidad..........................................53

IV .2.4. Identidad e identidades.............................................55

IV .2.5. Lazos primordiales e identidad..................................55

IV .2.6. Múltiples identidades............................................ 56

IV.3. Tres momentos del desarrollo de la formación plástica y pictórica en Chile.... 57

IV.4. La experiencia estética ...........................................62

V. TRABAJO DE CAMPO ...................................................

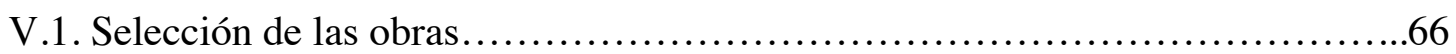

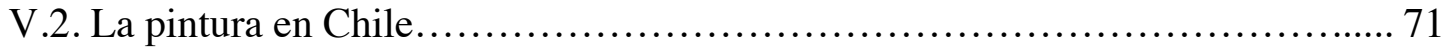

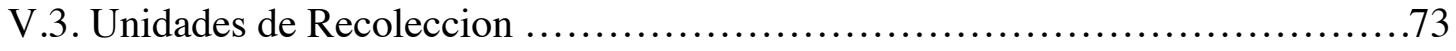

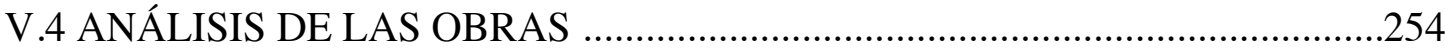

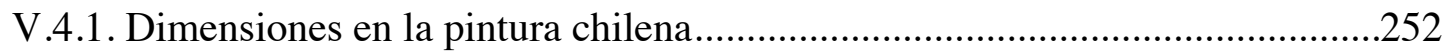

V .4.1.1 Dimensión Forma materia.......................................................................253

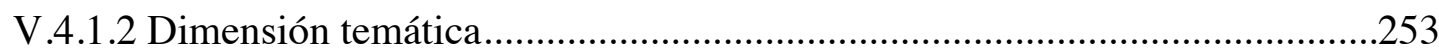




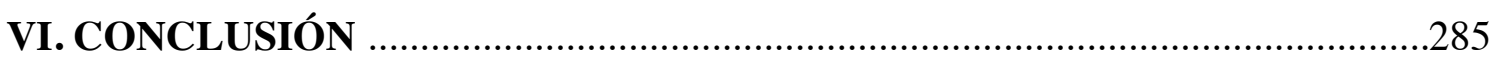

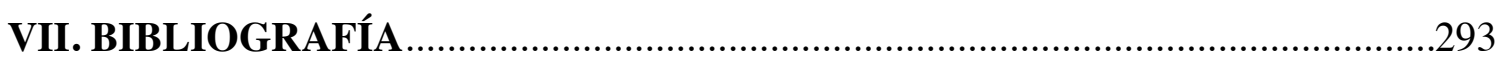

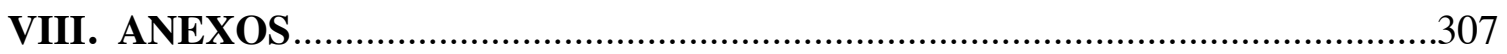




\section{INTRODUCCIÓN}

\section{I.1. Justificación del tema}

La presente tesis es el resultado de una investigación que, por diversos motivos, tuvo un alcance de ocho años. Si bien se inició como una revisión de la pintura contemporánea, concluyó en una investigación respecto a los indicios de una identidad nacional en la obra de pintura de artistas chilenos contemporáneos.

El lector encontrará claramente dos focos centrales. Por una parte los datos respecto a la pintura nacional de cuya herencia se levanta la obra de los artistas chilenos contemporáneos. Por otra parte, podrá observar las relaciones entre esa obra pictórica y la noción de identidad para ver cruzadas después dichas nociones con un análisis de un conjunto relevante de obras.

Este estudio propone un análisis de las producciones pictóricas chilenas contemporáneas, con el objetivo de identificar algunas constantes, si es que las hay, en lo referente al tema, procedimientos, forma y contenidos, tanto como tendencias y filiaciones que se pudieren presentar en las producciones visuales chilenas. Interesa específicamente la producción pictórica de inicios del siglo XXI (2000-2015) y, en este grupo, aquella que permita verificar rasgos propios de nuestro país, entendido esto como "identidad". Para lo cual el lector podrá observar constantes cruces entre la producción pictórica y las vicisitudes políticas del país las que junto al desarrollo de la noción de identidad, permiten comprender cruces e infiltraciones de diversa naturaleza, a veces ideológicas, otras formales e iconográficas o simplemente temáticas. Se trata aquí de verificar si existe en la pintura chilena, del siglo XXI, rasgos que permitan aseverar que hay una identidad, un "ser nacional" presente en la pintura chilena.

Una problematización como esta, se entiende en Chile solo en virtud de aceptar que en los pocos años de este siglo XXI, existe una fuerte proliferación de artistas jóvenes, que buscan en su mayoría la consolidación de una carrera internacional, una inscripción que rompa las barreras del país natal.

La literatura sobre el tema es pobre, los textos que más encontramos tratan justamente de cómo la obra nacional es similar a la de los grandes países desarrollados, principalmente estados Unidos y Europa. Pretende, esta investigación, aportar a un punto de vista crítico a tales afanes internacionalistas. 


\section{I.2. Problema}

En un país joven sin una tradición ni cultura artística, como tampoco con grandes obras representativas del arte occidental, la producción artística se desarrolla tomando modelos, concepciones, tendencias y obras producidas en países con una mayor tradición cultural. Dichos referentes son convertidos rápidamente en hechos paradigmáticos a la hora de plantear lineamientos tanto en la educación artística, como en las pautas editoriales o curatoriales de salas y museos. Este no es un hecho nuevo, ya en siglo pasado se hacían observaciones al respecto:

"Hasta este momento, la influencia y las normas de que se ha venido nutriendo nuestro arte formal, llegan desde París. Desde ahora en adelante se abrirá un paréntesis y serán los nombres de Velásquez, Goya, Zurbarán, El Greco, etc. los que intervendrán de preferencia en las discusiones de los corrillos en torno a la Academia del Parque Forestal". (Bontá, 1959, p. 19)

La influencia europea en las artes visuales en Chile, comienza a desarrollarse en las primeras décadas de la república, cuando desde Francia e Italia se importó un modelo de enseñanza que se materializó al inaugurarse la Academia de Pintura en 1849. Desde ese instante el Estado manifestó la firme convicción de sustentar una forma oficial: el incorporar el arte a la sociedad para lograr de esta forma la institucionalización de un sistema de enseñanza artística en el país. Esta opción pretendió reproducir gradualmente en nuestra Academia, el modelo de las instituciones europeas, que luego se consolidaría en la exposición de 1910 que inaugura en Santiago el Palacio de Bellas Artes (hoy Museo Nacional de Bellas Artes), edificio que albergará a partir de ese momento, a la Escuela de Bellas Artes de la Universidad de Chile. La concepción artística que define su enseñanza encuentra su referente en las Academias de Bellas Artes francesas (Zamorano, 2011) ${ }^{1}$.

Ciento diez años más tarde, se genera en Chile un segundo modelo de enseñanza universitaria en artes visuales, inspirado en el modelo de la Bauhaus propuesto por Joseph Albers en Estados Unidos (Galáz, 2011), con éste se inaugura la Escuela de Arte de la UC

\footnotetext{
1 Artes visuales en Chile durante la primera mitad del siglo xx: Una mirada al campo teórico. Atenea (Concepción), (504), $193-212$. (Recuperado en 02 de junio de 2015, de: http://www.scielo.cl/scielo.php?script=sci_arttext\&pid=S071804622011000200011\&lng=es\&tlng=es. 10.4067/S0718-04622011000200011.)
} 
$(1959)^{2}$. Como se puede observar, ninguno de los modelos y concepciones tomadas como patrones, nace del resultado de un devenir propio de concepciones educativas y estéticas inherentes a nuestra idiosincrasia. Surgen -por el contrario- de la necesidad de desarrollar modelos que nos asemejen a nuestros referentes culturales. Agréguese a esto la condición geográfica de un país al sur del mundo en condición prácticamente de isla, donde el contacto con el arte es esencialmente de naturaleza enciclopédica, es decir a través de reproducciones.

La expansión y globalización del modelo neo liberal, de mercado, la participación cada vez mas activa de nuestro país en los procesos de globalización, el afianzamiento de los gobiernos democráticos junto al esfuerzo por establecer pactos interregionales de libre comercio, incidiría en la influencia cultural, voluntaria o involuntaria, expresada en filiaciones y tendencias, que asumen las expresiones culturales nacionales.

Marchán sostiene que las estimaciones mercantiles inciden $\mathrm{y}$, hasta cierto punto, determinan los juicios artísticos, subordinándose estos a los intereses del mercado. Por lo cual, se genera la necesidad de innovaciones artísticas en forma constante, produciéndose en el arte un fenómeno similar al de la moda, lo que, según este autor, incide en que la obra haya ido perdiendo progresivamente los valores culturales locales y de uso a favor del puro valor de cambio.

\begin{abstract}
"La innovación, además, está afectada por otras determinaciones. Destacando en primer lugar, la incidencia de los modos productivos y la transformación de las formas artísticas bajo las actuales condiciones de producción. Las técnicas productivas, sobre todo la electrónica, informática, cibernética, etc. han repercutido en la transformación de técnicas y formas artísticas”. (Marchán, 1994, p.14)
\end{abstract}

Cabría preguntarse, entonces, por el nivel de incidencia que estas nuevas concepciones, condiciones y modos tienen en nuestra producción artística especialmente en nuestra pintura y si este hecho otorga, produce o ayuda a la emergencia de rasgos propios e identitarios. Podríamos preguntarnos también, parafraseando a Mari Carmen Ramírez (Jiménez, J., 1999), ¿hasta qué punto la rearticulación de fronteras económicas y

\footnotetext{
${ }^{2}$ El 28 de julio de 1958, sesiona la "Comisión de reforma y confección del plan de estudios" de la nueva Escuela de Arte. Con el nombramiento de Mario Valdivieso como director de ésta (marzo de 1959); el 18 de abril del mismo año se realiza el $1^{\text {er }}$ llamado, por la prensa, a los estudiantes; de tal modo que el 1 junio es el inicio de clases.

Fuente: Villegas, I., Novoa, P., Farías, M."1959-2009, 50 años de la Escuela de Arte UC". p.117.
} 
la condición de constante desplazamiento que vive un importante sector de nuestros artistas representa también la descentralización de sus prácticas artísticas con respecto a sus contextos nacionales o locales? Y asimismo con respecto a las corrientes mundiales ¿Dónde se ubica la especificidad de la "pintura chilena"?

Para definir este fenómeno se hace necesario el establecimiento de un tipo de análisis de obra(s) que permita la identificación de constantes y rasgos que caractericen el hacer artístico pictórico en nuestro país.

El análisis de obra implica intentar una mirada que facilite una lectura, lo más objetiva posible, de los elementos que la constituyen, como asimismo nos permita identificar la problemática o contenido de la misma.

El establecimiento de un instrumento para el estudio de obra y su uso en el análisis de producciones pictóricas realizadas a nivel nacional, desde el 2000 al 2015, ha permitido registrar algunos rasgos relativos a los procedimientos, técnicas, formas y problemas en la imagen pictórica, como asimismo los temas, contenidos y filiaciones estilísticas que pudieran presentarse como constantes y características de las producciones pictóricas locales, producto de nuestra práctica artística.

\section{3. Objetivos}

\section{I.3.1. General}

Identificar en la producción pictórica chilena del siglo XXI (2000 - 2015) rasgos identitarios asociados a la cultura nacional.

\section{I.3.2. Específicos}

a) Identificar en los archivos oficiales y someter a estudio un conjunto representativo de obras pictóricas elaboradas en Chile entre 2000 y 2015, para determinar y agrupar sus constantes formales, estilísticas y temáticas con relación a la cultura e identidad nacional.

b) Determinar a través del análisis de contenido de las obras aquellos elementos significantes de la obra pictórica, que tengan relación con aspectos asociados a la identidad chilena.

c) Determinar posibles influencias de estilos, corrientes, y problemáticas del arte internacional occidental, en la producción pictórica nacional actual. 


\subsubsection{Delimitación del tema.}

Esta investigación está referida a aspectos culturales, formales, iconográficos y temáticos contenidos en una muestra representativa de la pintura chilena producida en el siglo XXI (2000 y 2015) por 180 artistas pintores nacionales,

\section{I.3.4. Preguntas de Investigación.}

Dado el sesgo exploratorio de esta investigación, las preguntas de investigación se basan en hechos sin establecer sus causas, aunque de algún modo se comprueben. Más bien como corresponde a este tipo de investigación, a partir del análisis de datos, se describen semejanzas y diferencias entre las variables, es decir, se interpretan las relaciones entre ellas, pero sin someterlas a pruebas empíricas de confirmación. En resumen se establecen relaciones y luego se analizan los resultados a fin de sacar conclusiones.

La imagen plástica supone una selección de la realidad, o la construcción de una nueva, lo que se hace a partir de un repertorio de elementos concretos. En el contexto de la cultura occidental, se dan espacios menores en que se inscriben matices culturales de algún modo distinguibles y apreciables como representativos de recorridos históricos particulares y sistemas de tradiciones construidos desde idiosincrasias y contextos respectivamente distintos. A partir de esta idea nos preguntamos:

¿Es posible identificar algunos rasgos que pudiesen ser característicos en la pintura chilena en lo relativo a los procedimientos, técnicas, formas, etc. como asimismo, temas, contenidos y filiaciones estilísticas que pudieran presentarse como constantes y características identitarias de las producciones pictóricas nacionales?

Por defecto nos preguntamos también ¿existe en la pintura chilena contemporánea rasgos provenientes de otras culturas y que no logramos identificar con asuntos propios del país?

\section{I.3.5. Modelo de investigación.}

Analizar una obra implica estudiar lo que ésta posee física y visualmente de permanente e invariable, su estructura interna, su naturaleza y las relaciones que en ella se establecen y generan sentido; de modo que al observar sus relaciones y establecer una 
sintaxis y una semántica a partir de ellos, se construya el marco teórico de la propia imagen. (Parsons, 2002)

En el desarrollo del presente estudio, se adoptó una metodología de investigación cualitativa (Eisner -2004) y estudio de casos (Vasilachis de Gialdino, 2007) de carácter exploratorio que abarca la producción pictórica del período (2000-2004) de cada artista incorporado a los casos en estudio. Para ello se diseña una estrategia que permite estudiar las obras pictóricas de manera, más o menos objetiva, sistemática, a la vez que posibilita agrupar los contenidos en dimensiones, categorías y subcategorías basada en la secuencia que establece Michael J. Parsons (2002), a saber:

Fase 1: Selección. Mediante el criterio del investigador, a partir de aquello que -como rasgo saliente de la obra pictórica- es consecuente con su búsqueda.

Fase 2: Tema. Organización de las partes de la imagen en torno al concepto de representación.

Fase 3: Contenido. Sentido o significado de la obra en relación al contexto o problema de investigación.

Fase 4: Estilo y procedimiento. Adscripción a un modelo determinado de trabajo en el cual se valida la obra.

Fase 5: Juicio. El arte se valora como una forma de suscitar preguntas más que una transmisión de verdades. La emisión de un juicio personal del analista/observador respecto a la obra y en concordancia con el problema central al que apunta.

Definición estrategias de selección y análisis de obra (basadas en la secuencia planteada por Parsons, 2002 p. 23).

\begin{tabular}{|c|l|l|l|}
\hline FASE & \multicolumn{1}{|c|}{ ASPECTO } & \multicolumn{1}{|c|}{ CRITERIO } & \multicolumn{1}{c|}{ INDICADOR } \\
\hline 1 & $\begin{array}{l}\text { Selección. } \\
\text { (Aquello que el } \\
\text { investigador destaca de la } \\
\text { obra) }\end{array}$ & $\begin{array}{l}\text { Pinturas 200-2015 de artistas } \\
\text { pintores nacionales cuya obra } \\
\text { se encuentre registrada en la } \\
\text { bibliografía del MNBA y el } \\
\text { MAC }\end{array}$ & $\begin{array}{l}\text { La obra pictórica presenta o } \\
\text { representa un tema que } \\
\text { comprende algún aspecto } \\
\text { particular de la cultura } \\
\text { nacional. }\end{array}$ \\
\hline 2 & Tema & $\begin{array}{l}\text { La imagen representa o } \\
\text { presenta imágenes relativas a la } \\
\text { cultura nacional. }\end{array}$ & $\begin{array}{l}\text { Retratos, objetos, paisajes, } \\
\text { escenas, que pertenezcan al } \\
\text { imaginario nacional. }\end{array}$ \\
\hline 3 & Contenido & $\begin{array}{l}\text { Relativo a la cultura e } \\
\text { idiosincrasia nacional. }\end{array}$ & $\begin{array}{l}\text { Vinculado al imaginario e } \\
\text { imaginería chilena; Iconografía, } \\
\text { temas, narraciones, formas } \\
\text { asociadas a Chile (es decir } \\
\text { todo) }\end{array}$ \\
\hline
\end{tabular}




\begin{tabular}{|c|l|l|l|}
\hline 4 & Estilo y procedimiento & $\begin{array}{l}\text { Pintura y sus desvíos } \\
\text { vinculados a su campo } \\
\text { expandido }\end{array}$ & $\begin{array}{l}\text { La obra inscrita como pintura } \\
\text { se propone como una revisión o } \\
\text { reinscripción de los asuntos que } \\
\text { plantea }\end{array}$ \\
\hline 5 & Juicio & $\begin{array}{l}\text { La obra se propone como una } \\
\text { subversión. Como un gesto } \\
\text { subversivo frente a lo } \\
\text { convencional }\end{array}$ & $\begin{array}{l}\text { Toda pintura que se plantee } \\
\text { como un reposicionamiento en } \\
\text { alguno de los temas vinculados } \\
\text { a la cultura nacional }\end{array}$ \\
\hline
\end{tabular}

Según Rudolf Arnheim (1979), en las artes visuales, la imagen es la conjunción de elementos visuales en un todo, tal integración se considera un acto de comprensión porque establece relaciones significativas entre los diferentes elementos; estas relaciones son las que contribuyen a la significación estética.

Para Parsons (2002), los juicios sobre el arte pueden ser objetivos, debido a que, aunque el arte expresa necesidades y emociones, a través del estudio de los elementos constituyentes de la obra se puede establecer una lectura más o menos racional, por tanto, los juicios que se emitan pueden ser más o menos defendibles. Existe posible que no sean ciertos ni erróneos, pero sin duda, son más o menos adecuados. La idea estética es, en cierto modo, el contenido inteligible que desprende la "pauta interna" de la obra, la cual rige como principio desde donde puede ser determinada su propia artisticidad.

El problema guarda relación, por una parte, con la forma de análisis de obras, esto es, establecer criterios objetivos, desde una perspectiva cuantitativa, que permitan una identificación y lectura de los elementos y partes interactuantes de cada imagen pictórica, descomponiéndola en sus partes constituyentes o componentes para comprender mejor el conjunto, y la posible constitución de cada una de la declaraciones visuales, sin excluir la interpretación.

Por otra parte, a partir de este análisis es posible identificar rasgos y constantes que pudieren presentarse en la producción pictórica chilena a inicios del siglo XXI, entendiendo esta producción como un documento visual de la época y lugar (Bryson, 1991; Baxandall, 1978) producto de una multiplicidad de visiones coexistentes en un mismo espacio y época.

Los datos para la presente investigación se han levantado de la producción de artistas pintores chilenos, producidas en el período 2000-2015. Estos datos se extraen de lo que el tesista denomina "registros oficiales". Con esto se hace referencia a los principales libros o catálogos elaborados en Chile los que, por ser amplios, abarcativos, completos o bien documentados, dan cuenta de las producciones de pintura. Algunas de las cuales fueron exhibidas en el contexto de relevantes muestras que dieron vida a la 
escena nacional en el período estudiado. Las exposiciones y sus respectivos catálogos son: "Chile Cien años, Artes Visuales" (2000), que alcanzó a incluir obras ejecutadas ese año; "Cambio de Aceite", pintura chilena contemporánea" (2003); "Del pasado al presente. Migraciones" (2010); “Revisión Técnica, pintura en Chile 1980 -2010” (2010); "Chile Arte Extremo" (2011); "Ch.ACO, Chile Arte Contemporáneo" (versión 2009 a 2014).

Por último, se han considerado la nominación de los artistas y sus obras en el libro “Pintura Chilena 200 Años”, Bindis, R., (2006, 2ªed. 2009)³. La participación y cita de los artistas, con sus obras, en los archivos consultados en una de estas muestras y textos, lo señalan como un válido representante de las tendencias actuales de la pintura nacional y, por tanto, incorporado a este estudio. Se destaca que todas las obras seleccionadas -aparte de cumplir los requisitos mencionados- son obras que circulan en la WEB. Para la información respecto a las más relevantes exposiciones de pintura del siglo XXI, se consideró la consulta a dos fuentes relevantes: El Museo Nacional de Bellas Artes y el Museo Nacional de Arte Contemporáneo, ambos pertenecientes al Estado, el primero bajo la tutela de la Dirección Nacional de Archivos y Museos (DIBAM), y el segundo bajo la administración de la Universidad de Chile.

Chile, no obstante, ser una larga y angosta faja de tierra al sur del mundo ${ }^{4}$, ha definido su organización política, administrativa y cultural de modo absolutamente centralizado. Las provincias y regiones alejadas tanto al norte como al sur de la capital no cuentan con la infraestructura cultural de la capital, ni con la capacidad de comunicación con el resto del mundo, lo que obliga a que la transmisión de la cultura así como la formación artística, en general, se haya realizado a través de reproducciones y en escasas oportunidades en contacto con las obras originales (Rojas, 2013). Esto justifica que la presente investigación no recurra a otros repositorios y archivos.

La selección de obras, producidas a inicio del siglo XXI, en Chile, es analizada en sus dimensiones con el propósito de constatar y registrar aquellas características relevantes con relación a aquellos rasgos iconográficos que pudiesen vincularse con aspectos de la cultura nacional, de tal modo que pudiesen señalarse como identitarios.

\footnotetext{
${ }^{3}$ Historia del arte y de la pintura chilena desde los primeros autores coloniales hasta nuestros días.

4 El país comprende una larga y estrecha franja de tierra en la costa occidental del Cono Sur que se extiende mayormente desde la ribera sudoriental del océano Pacífico hasta la cordillera de los Andes, entre los paralelos $17^{\circ} 29^{\prime} 57^{\prime \prime} \mathrm{S}$ y $56^{\circ} 32^{\prime} \mathrm{S}$, a lo largo de $4270 \mathrm{~km}$. Alcanza un ancho máximo de $445 \mathrm{~km}$ en los 52²1'S, a la altura del estrecho de Magallanes, y un ancho mínimo de $90 \mathrm{~km}$ en $31^{\circ} 37^{\prime} \mathrm{S}$, entre Punta Amolanas y Paso de la Casa de Piedra
} 
En efecto, se elabora catastro con la información visual que es posible determinar en la producción pictórica 2000-2015 de cada artista-pintor seleccionado. Esto permite generar unidades de análisis, con el fin de constatar la presencia, o no, de determinados rasgos y características que pudieran presentarse como constantes en la producción plástica y que estén vinculadas con el imaginario nacional. Así se puede establecer cruces con la información como asimismo cuantificar y realizar estadísticas con relación a aquellos aspectos que se registren en forma reiterativa (constantes), como también estudiar el nivel de frecuencia porcentual de algún rasgo con relación al total de los artistas.

Este catastro implica la confección de una ficha por cada artista, la cual permite registrar y precisar las características de las producciones pictóricas realizadas en el período enunciado anteriormente, en dos aspectos, uno vinculado al plano denotativo y otro al connotativo. En el plano de lo denotativo, se registran aquellos aspectos que pudieren presentarse como constantes en la práctica pictórica actual en Chile. El segundo aspecto dice relación con el registro de evidencias identitarias vinculadas al plano connotativo de las obras analizadas.

Caracterización de la ficha:

\begin{tabular}{|c|l|l|}
\hline $\mathrm{N}^{\mathrm{O}}$ & \multicolumn{1}{|c|}{ Ítem } & \multicolumn{1}{c|}{ Dimensiones } \\
\hline 1. & \multicolumn{2}{|l|}{ Identificación del artista: nombre / estudios / exposiciones } \\
\hline 2. & \multicolumn{2}{|l|}{ Identificación de su obra, con relación al periodo de ejecución y tema } \\
\hline \multirow{2}{*}{3.} & \multirow{2}{*}{ Análisis denotativo } & $\mathrm{a}$ - Dimensión materia-forma \\
\cline { 3 - 3 } & & $\mathrm{b}$ - Dimensión temática \\
\hline \multirow{2}{*}{4.} & \multirow{2}{*}{ Análisis connotativo } & $\mathrm{a}$ - Dimensión sentido \\
\cline { 3 - 3 } & & $\mathrm{c}$ - Dimensión referencia \\
\cline { 3 - 3 } & &
\end{tabular}

A partir de este instrumento, se diseña una versión para la web con el único propósito de establecer un sistema de registro en línea, lo que permite un proceso dinámico de consignación y acopio de datos para su análisis estadístico en sistema Excel.

Como se ha expresado anteriormente, el registro en línea, solo cumple el rol de acopio, selección de obra y anotación de algunos aspectos susceptibles de ser cuantificados como información adicional al análisis propiamente tal. Por otra parte cada obra es estudiada y analizada con relación a los ítems incluidos en la ficha. 
http://duoc.tipddy.cl/index.php/survey/index/sid/216316/newtest/Y/lang/es

De lo expuesto hasta el momento se puede concluir que este estudio corresponde a una investigación exploratoria efectuada a través del análisis y estudio de obras pictóricas, a partir de la observación de sus componentes y contenido. Junto a ello se considera el correspondiente análisis bibliográfico y teorías estéticas que sustenta y fundamenta la investigación, junto con contexto histórico del país. El estudio de casos y análisis de los componentes de obra, ya mencionados, se realiza considerando los rasgos formales e iconográficos y los temas contenidos en la producción de obras pictóricas en Chile a principios del siglo XXI. Se busca constatar la existencia y presencia reiterada de rasgos identitarios y de contenido vinculados al imaginario nacional en la pintura chilena contemporánea

\section{I.3.6. Objeto de estudio}

El objeto de estudio lo constituye un conjunto de pinturas elaboradas en Chile por 180 artistas, expuestas en los últimos 15 años en este país en muestras relevantes. Estos datos se extrajeron de los documentos (catálogos y libros) de los repositorios el MNBA y en el MAC, tal como se señala en el anterior ítem 1.3.5. 


\section{REVISIÓN BIBLIOGRÁFICA}

\section{II.1. Identidad}

La revisión se centra principalmente en dos áreas o focos: por una parte identidad y por otra la pintura en Chile a comienzos del siglo XXI. En relación al primer foco de documentos resulta relevante y pertinente la obra de J. Larraín y de J. Gissi.

1) “Cultura e identidad en América Latina” Gissi, J., Larraín, J.; Sepúlveda, F. 1995. Instituto chileno de estudios humanísticos ICHEH. Santiago de Chile.

Este texto presenta parte de la diversidad de tratamientos y enfoques sobre el tema de ala identidad latinoamericana. Los autores plantean que la discusión sobre nuestra identidad implica una serie de discusiones acerca de los principios y valores ordenadores de nuestra cultura, los cuales son abordados del siguiente modo:

A partir de ciertas generalidades históricas, culturales y psicosociales, Jorge Gissi levanta una defensa ante la crítica del concepto "Identidad Latinoamericana". Larraín, por su parte, pone en tela de juicio las teorías que denomina esencialistas, que definen la identidad como una esencia inconmovible constituida en un momento privilegiado de la historia anteponiendo la teoría de la identidad como una construcción discursiva dinámica, que no se detiene y de la cual existen diversas versiones.

El tercer autor, Sepúlveda, propone una concepción de la identidad cultural tendida sobre el eje del tiempo, pasado-presente-futuro entendida como vida que cobra sentido a partir de una red de relaciones con lo trascendente, con lo otro natural, lo otro humano y con el arte. En él lo importante es la identificación de las líneas matrices o ejes temáticos en torno a los cuales se articula la cosmovisión.

2) ¿América Latina moderna?. Globalización e identidad. Larraín, J. 2005. LOM Ediciones. Santiago de Chile.

El autor abre una reflexión sobre la situación tanto de las identidades individuales como de las identidades nacionales, en correspondencia al tipo de relación que han generado estos conceptos con el postmodernismo y el neoliberalismo en América Latina.

Larraín se detiene a analizar el fenómeno de mediatización de la cultura, que pone de relieve la importancia de los medios de comunicación masiva para controlar el contenido de las transmisiones, que está acompañada por una creciente mercantilización de las formas simbólicas. Esto ha generado un enorme impacto en la polaridad de la cultura como arte y expresión intelectual y, por otro lado, en el modo de vida de la gente común y en las expresiones discursivas y musicales. 
Distingue, además, tres aspectos analizados que como problemáticas, permitirán abordar algunas de las principales interrogantes que se plantea sobre la pregunta de fondo:

- La primera de ellas se refiere a la relación existente entre modernidad y tiempo, en la medida en que la noción temporal excede la mera referencia a un período histórico determinado y, en cambio, este es capaz de dotar de sentido a una época, dejando atrás el pasado y proyectar el futuro.

- El segundo de los aspectos analizados es la afirmación de algunos autores como Giddens o Weber, adscritos a las teorías de la modernización, en el sentido de que existe una única modernidad asociada a procesos de racionalización y esta ha correspondido a Europa occidental.

- El tercero de los aspectos se refiere a los contenidos esenciales de la modernidad que constituye el más importante de todos ellos, puesto que variará de acuerdo a la percepción que tiene una determinada sociedad del discurso filosófico que la sustenta. Los aportes de este autor abren la reflexión sobre la modernidad y la identidad en América Latina desde una visión que se centra en destacar los componentes esenciales de su dinámica, sin analizar la realidad histórica latinoamericana, aplicando modelos de interpretación que impiden el ajuste a su propias dinámicas sociales y culturales o que no logran adentrarse realmente en los problemas que son constitutivos de su proceso modernizador.

Un tercer texto de este sociólogo que ha permitido delinear un perfil de la identidad chilena, lleva precisamente ese título.

3) “Identidad chilena”. Larraín, J. 2001. LOM Ediciones. Santiago de Chile.

Ante la pregunta ¿en qué consiste ser chileno?, el texto va mostrando como se ha ido construyendo históricamente un concepto en estrecha relación con los procesos modernizadores desde la independencia. Se analizan 6 discursos sobre la chilenidad, que construidos en diferentes épocas y que hoy tienen una presencia importante. Expone algunos rasgos formales y de contenido de la identidad chilena y el como ésta esta siendo afectada por la globalización.

\section{II.2. Pintura chilena contemporánea}

En relación al foco asociado a pintura chilena contemporánea, hay varios textos que se acercan al asunto que nos interesa, pero de manera indirecta, es decir, a partir de otras aristas, ya sean disciplinarias o epistemológicas. Del conjunto destaca: Mellado, J.P., (Escritura funcionaria, 2013; Textos de Batalla, 2009); Lara, Machuca, Rojas, (2011); 
Madrid, Nordenflich, Varas (Revisión/Remisión de la historiografía de las artes visuales chilenas contemporáneas 2011); Voinmaa, F. (Escultura pública, 2004); Goffard, N. (Imagen criolla, 2014); Alvarez, P. (Historia de Diseño Gráfico en Chile, 2005); Berry, V. (Animación: la magia en movimiento, 2010). Estos autores y sus textos muestran un análisis sobre el arte contemporáneo en Chile desde un conjunto de disciplinas, pero todas ellas sin tocar el asunto central de nuestro interés: la identidad; estos documentos solo nos permiten rodear el problema. No obstante, hay seis documentos sobre los cuales es conveniente detenerse, pues creemos aportan algunas ideas, datos y discusiones pertinentes a esta investigación.

1) “Chile. Dos Siglos de Pintura”. Rodríguez Meza, M.; Novoa, P. 2010. Edit. Kactus, Santiago de Chile.

El texto se centra en la relación de los estilos artísticos (1810-2010) que aparecen en Chile, confrontados con los modos imperantes en Europa, durante el siglo XIX y la primera mitad del siglo XX. A la vez, se incluyen las influencias provenientes desde Estados Unidos a partir de los años 60, y las diversas tendencias emergentes que se vislumbran en el mundo a consecuencia de la globalización de las comunicaciones, que se vive en la actualidad.

El libro fue escrito en el marco del Bicentenario Nacional, con la intención de esbozar y caracterizar la pintura chilena en tres grandes momentos de su construcción lestética y que, tangencialmente, coinciden con tres etapas de la historia nacional.

El texto trata los comienzos de la pintura en Chile, con la obra de Gil de Castro y los pintores viajeros europeos y el inicio de la presencia del Naturalismo y el Realismo en el arte. Este período, según el autor, coincide con la Independencia y la formación de la República y el desarrollo de las estructuras sociales y culturales del siglo.

El primer momento se centra en la temática "La Pintura como Exaltación”. El segundo momento "El Valor de las Formas" está dedicado al desarrollo de la innovación en la pintura chilena y su relación con los grandes momentos de la vanguardia europea.

El tercer momento y el más atingente a nuestra investigación hace referencia a "Estilos y Tendencias; hacia la madurez". Versa sobre la diversidad de estilos y tendencias en la pintura desde los años cincuenta hasta la pintura actual en Chile, siglo XXI. Pone énfasis en la liberación de las formas y el carácter de búsqueda exploratoria en los temas, en las técnicas y fundamentalmente, en la actitud de registro sensorial, ya sea del artista como del espectador frente a la obra. Este libro deja establecido que si bien hay temas chilenos, los 
modelos de construcción de imagen han pertenecido sistemáticamente a escuelas extranjeras.

2) "Cambio de Aceite/Pintura Chilena Contemporánea" ${ }^{5}$. González L, J.; Bravo, V.; Zeballos, M. 2003. Ocho libros Editores, Santiago de Chile.

Libro-Catálogo de la exposición, producto de un proyecto que se postula como revisión crítica y temática del periodo 1980-2000 (20 años). Este periodo se considera relevante dentro de la historia de la pintura nacional, pues junto con ser final de siglo comprende los últimos diez años de dictadura y el periodo considerado como transición a la democracia, con gobierno democrático, pero aún con resabios de la dictadura en las instituciones del Estado como el Ejército, la Cámara de Diputados y el Senado. Es el tiempo en que la escena de las artes visuales presenta situaciones transformadoras y desarrollos con un alto grado de complejidad. El texto hace referencia especial al hecho de haber fijado su atención a la práctica de la pintura, considerando las pugnas internas, las rupturas, los distintos agenciamientos materiales, las oscilaciones temáticas y demás variables que de algún modo han incidido en la inscripción formal de la obra en el circuito nacional. Con relación a ello señalan cuatro aspectos, según sus autores.

a.- El hecho de que, a pesar del sesgo "anti pictórico" de algunas de las propuestas más significativas así como de los agenciamientos poéticos que de esto se derivan, la práctica de la pintura no haya desaparecido del todo,

b.- La pintura constituye no sólo una práctica en crisis, sino también un campo de operaciones, muchas obras declaradas o leídas como no pictóricas, se tramaron desde una reflexión crítica sobre la pintura ${ }^{6}$.

c.- Que si la práctica pictórica registra una presencia, más o menos sostenida en el tiempo, merecería ser re-pensada y re-evaluada en la relación histórica y crítica que ha establecido y establece aún con sus correlatos objetuales e institucionales como el cuadro, el museo, la

\footnotetext{
${ }^{5}$ Exposición realizada en el MAC, entre los meses de marzo y mayo del 2003, fue una de las más destacadas exposiciones de ese año. Ella comprendió una revisión realizada a un período cercano de la plástica nacional: 1980-2000, bajo la curatoría y producción de los artistas visuales Jorge González Löhse, Víctor Hugo Bravo y Mario Zevallos, quienes enfatizaron el acento en la problemática de la producción pictórica actual. El catálogo de esta muestra, estuvo a cargo de Francisco Brugnoli, sus curadores, Gonzalo Arqueros, Pablo Chiuminatto, Ricardo Loebell, Guillermo Machuca, Catalina Mena, Sergio Rojas y Willy Thayer- y el contenido gráfico -fotografías de sus obras y montaje- dando cuenta del objetivo de esta exposición. Las reseñas biográficas de los artistas y el registro del material de prensa reunido, conforman además una interesante fuente de información.

${ }^{6}$ Entendiendo la pintura como institución paradigmática de la ideología occidental de la representación visual o como género emblemático de la historia del arte en Chile.
} 
galería, el mercado, la enseñanza y la historia. Al mismo tiempo, reconocer la presencia paradojal de obras que determinan su producción, conservando una distancia con los procesos creativos propios de la visualidad más actual.

d.- La exposición constituye un ejercicio, una evaluación de la continuidad pictórica, no tan sólo como un fenómeno extemporáneo, sino muy especialmente como un fenómeno más bien incómodo en tanto inscrito en el contexto de la globalización de las artes visuales contemporáneas.

Los artistas, seleccionados, representan la persistencia de la pintura desde principios de los años '80, sin embargo, las obras presentes en esta exposición fueron creadas, por los mismos, durante los últimos cinco años, habiendo incluso muchas pintadas durante el año 2003, de ahí el valor y pertinencia para con esta investigación.

Este proyecto vino a llenar un vacío, tanto en la línea expositiva como en la editorial, pues hasta esa fecha, no se habían realizados proyectos que unificaran tal cantidad de pintores, cuarenta en total, y que propusiera al público en general una re-visión de la visualidad y práctica pictórica, desde la mirada de los propios artistas.

3) "Revisión técnica //100 pintores, pintura en Chile 1980-1910". 2010. González L, J. Ocho Libros Editores, Santiago de Chile.

Revisión Técnica es un proyecto editorial planteado como la continuación lógica de la exposición "Cambio de Aceite" (2003). Esta publicación presenta, de algún modo, una visión panorámica de las prácticas pictóricas actuales en Chile, contribuyendo así al conocimiento, debate y difusión del arte y la visión que se tiene hoy de la pintura, en nuestro país, por parte de los artistas. Se da prioridad a la muestra de autores y sus respectivas obras. La edición contempla el acercamiento al trabajo de arte de cien artistas, una reseña monográfica de cada uno de ellos y dos ensayos críticos e históricos de la pintura chilena entre 1980 y 2010.

El material compilado y editado, en este libro, es sin duda, un aporte significativo para comprender los diversos caminos y filiaciones que ha emprendido la pintura en nuestro país en las últimas décadas.

Este proyecto amplía el registro de los cuarenta autores convocados para la exposición de "Cambio de Aceite", incluyendo, en su edición, a otros sesenta autores que, por diversas razones, no estuvieron considerados en la anterior muestra, concluyendo así en una presentación de cien artistas-pintores. Este proyecto se plantea, como objetivo, el 
recuperar una línea más histórica. Amplia así la visión del ejercicio pictórico, mostrando primordialmente a los creadores y a sus obras, posibilitando una mejor lectura, tanto de las piezas, como de la comprensión de líneas de acción, desvíos y deserciones que se pudiesen haber producido con cada artista y que, en líneas generales, permitan elaborar preguntas y dar algunas respuestas del estado de la pintura chilena contemporánea.

El libro se compone de dos textos: uno de Ana María Risco y otro de Gonzalo Pedraza. Este último señala la diferencia entre la "pintura chilena" y "pintura en Chile", lo que nos permite entender la pintura, en el segundo caso, como una sistema de convenciones establecido en un contexto distinto al chileno, que tiene una llegada material e ideológica en una determinada época y que se ha extendido hasta nuestros días en un territorio concreto, Chile. "Pintura chilena" significa, en cambio, considerar la idea de una pintura "nacional" que asume per se una identidad en figuras simbólicas que a grandes rasgos permean una actitud analítica necesaria para comprender el problema. Este pensar en la "pintura chilena" significa considerar a los pintores foráneos como síntomas de dominio imperial, y a los pintores locales como estandartes y guías identitarios, que en conjunto, permiten "construir la idea de nación”. Este modelo propio del siglo XIX. Desde allí analiza la relación de pintura y visualidad como conceptos contrapuestos que en su choque dan lugar a multiplicidades. El concepto de pintura chilena basado en la instalación de la Academia de Pintura (academia1849) y la influencia de los pintores viajeros, postula una segunda etapa en que la Academia, como el espacio de regulación de las convenciones y los pintores extranjeros -desde su legado visual- condicionan desde afuera los hábitos de la pintura local. Desde esta idea plantea la revisión de las cuatro décadas que aborda este proyecto haciendo hincapié en los modelos visuales dominantes y las regulaciones de las instituciones, artísticas, entendiendo estas últimas como sistemas de validación, circulación y exhibición de las obras pictóricas.

Ana María Risco, por su parte, hace referencia a lo que define, ya no como "pintura chilena", sino "pintura hecha en Chile". Una producción que, dicho en sus palabras, suscribe en virtud de sus propias búsquedas a los límites del género los principios que informan al arte contemporáneo. Analiza el devenir de la pintura en Chile como género protagonista en los relatos instituyentes del ideario nacionalista en la historia chilena. "Territorio de alianzas subterráneas e históricas entre la voluntad progresista de la oligarquía, los marcos del discurso institucional, los marcos dorados museales y las lógicas de movilidad que dominan el registro mercantil de la obra de arte" (Risco, 2010, p.31).

Risco señala a cuatro artistas emblemáticos que han realizado una revisión epistemológica de la práctica pictórica nacional. El primero de ellos, E. Dittborn a través de 
una exposición de dibujos titulada "Delachilenapintura, historia" (sic) que señala una primera movida tendiente a una desarticulación reflexiva de la pintura como sistema, y como práctica, asentada sobre una óptica histórica de imposiciones, exclusiones y omisiones, que la contingencia política hace particularmente visible. El segundo artista considerado por la autora es C. Altamirano quien, en sus trabajos iniciales, lanza la pregunta a algunos agentes interesados en el mundo del arte, ¿existe un arte nacional? Para luego presentar su "versión residual de la pintura chilena" (Risco, p. 181) a través de lo que él titula como un "sudario de la pintura chilena", transportándolo en un recorrido por sectores del transitar cotidiano de la urbe, registrando fotográficamente la acción. La autora sostiene que Altamirano en su obra, desnuda, con ciertas dosis de ironía, aquellas dimensiones de la pintura tradicional atesorada como patrimonio en "el museo" ${ }^{7}$. Obras que han ido volviéndose obsoletas ante la expansión de un aparato objetivo y mecánico de producción y reproducción de imágenes, mucho más gravitante que la obra en la configuración del ojo social.

En un tercer lugar menciona a G. Díaz con la obra "Historia sentimental de la pintura chilena" donde se hace eco de la interdicción en que se encuentra el lenguaje pictórico, poniendo en juego un repertorio de operaciones, recursos y motivos que señalan zonas reprimidas y subrepticias al interior del marco pictórico tradicional. La pintura, símbolo de una cultura de élite obsoleta y del modelo de obra tradicional, viene a experimentarse bajo nuevos cristales como territorio engañoso, históricamente tramado, en sus manifestaciones locales, por la lógica de la copia y de lo poco auténtico.

Finalmente cita a J. Domingo Dávila el cuarto artista fundamental dentro del cuadro de época, según Risco, puesto que abre estética a ciertos procesos sociales marcados por la superposición de identidades, historias y memorias. Su propuesta acelera el proceso de resituación de la pintura: "el cuerpo de/en la pintura, es un conjunto de trabajos que se exhibe en Santiago en 1979. El libro entrega claves fundamentales para comprender algunos fenómenos posteriores en el siglo XXI.

4) "Chile arte extremo / nuevas tendencias en el cambio de siglo". 2005. Lara, C.; Machuca, G.; Rojas, S. FONDART (PDF online). Santiago de Chile.

Es un libro que propone un acercamiento a la escena crítico-experimental surgida en el país de posdictadura, ya que se perfila desde las voces de sus propios protagonistas: reúne las entrevistas a veinte artistas chilenos emergentes entre las décadas de los 90 y de los 2000, una recopilación de fotografías de obras permiten recorrer desde sus inicios las

${ }^{7}$ El subrayado es mío, alude a la señalización de un único museo a nivel nacional. 
respectivas trayectorias para verificar nexosy singularidades. Los autores entregan sus propias lecturas sobre un arte reconocido genéricamente como "neoconceptual" y que en Chile ha acontecido en un contexto de grandes transformaciones políticas, sociales y culturales. En un intento por acercar esta nuevas propuestas artísticas a la gente, en un momento en que se pasaba del discurso público al ejercicio de las políticas de apoyo cultural.

El documento propone un diálogo entre el periodismo especializado, la teoría del arte y la filosofía, efectuando lecturas y cruces no necesariamente historiográficos sobre las prácticas emergidas el último tiempo, donde también hablan los protagonistas de estas narraciones. Contempla una selección de veinte artistas egresados de universidades locales, entre las décadas del 90 y de los 2000. Cada uno de ellos fue entrevistado con la idea de abrir sus propuestas a nuevos públicos, de entender en qué consisten estas nuevas tendencias e ir en busca de aquello que aún no ha sido dicho a través de la infinidad de catálogos que han incitado, según lo declaran los propios autores. Producto de estas entrevistas, los autores abordan problemáticas tales como la relación con las prácticas precedentes, la academización de los lenguajes, la renovación de los géneros, la noción de instalación y neo-vanguardia, la internacionalización de las estrategias, el vaciamiento político, más la problemática relación arte-contexto.

En "Euforia y desapego", Machuca propone un corte inaugural para la escena de los '90 dado por dos exposiciones clave: Zona Fantasma (1994, Galería Gabriela Mistral) y la $1^{\text {a }}$ Bienal de Arte Joven (1996 en el Museo Nacional de Bellas Artes), curada por él mismo. En ella se consagran artistas de fines de los '80 junto a algunas individualidades surgidas a comienzos de la década de los '90. Además de proponer los ejes que permiten una lectura general del grupo, determinada por operaciones de desplazamiento de la pintura y del grabado, por innovaciones escultóricas, el posminimalismo, la cosmética del consumo, la lejanía de los referentes internacionales y el problema de la precariedad en el arte chileno, entre otros. Asimismo, el autor aborda algunas condiciones propias del contexto actual, como la dilución de las categorías de lo local, la crisis del arte y su situación en los entramados de la cultura global.

Además plantea que, dentro de la enseñanza universitaria "la academización del arte como la del pensamiento crítico" serían algunas de las condiciones que explican las actuales características del campo plástico local. En estrecha relación con esto señala que "habría que contemplar un creciente proceso de vaciamiento o adelgazamiento de determinados contenidos formales y narrativos de índole socio-político tal cual habían sido producidos por el arte chileno desde la década de los 60 hasta la recuperación democrática" (Machuca, 
p.11).

Por su parte, Sergio Rojas realiza una análisis de las condiciones del arte chileno actual en su ensayo "El contenido es la astucia de la forma". Ejemplifica sus reflexiones con análisis de obras que exceden la selección de este libro; ordenando, al mismo tiempo, su texto en temas como el problema de lo internacional y la localidad, arte y dictadura, la reflexión irónica, la interrogación al poder desde el arte, para culminar con un capítulo en el que intenta dilucidar una pregunta inmensa: “¿Por qué el arte es hoy tan “importante?”.

Una clave para Rojas es si las generaciones más recientes de artistas pueden ser comprendidas efectivamente bajo el rótulo de "posdictadura", donde temas y recursos usuales son lo cotidiano, la parodia, el fragmento, el work in progress y la relación crítica con el poder. “...en muchos casos, dicho tema opera, más bien, como un recurso o pretexto para investigaciones estéticas y formales acerca de sus propios procesos de producción" (p.13).

En definitiva, el libro se acerca a mostrar una escena artística, perfilada en posdictadura y en sintonía con las corrientes internacionales, desde un país que intenta superar su carácter insular enfrentándose a las redes de la globalización, entre el ocaso de los ideales y el despuntar de un nuevo milenio. Un arte extremo en el tiempo, en el espacio geográfico y en una sociedad refundada entre el trauma y el fulgor engañoso de un éxito económico donde los líderes son efímeros y los ídolos colectivos no son más que creaciones de farándula.

5) "Copiar el Edén. Arte reciente en Chile". 2006. Mosquera, G. (Ed.).

Ediciones Puro Chile. Santiago de Chile. Versión en línea: http://www.copiareleden.com

"Copiar el Edén. Arte reciente en Chile" editado por el curador internacional Gerardo Mosquera, en una publicación bilingüe (español/inglés), reúne lo que en el circuito artístico se considera como lo más relevante de la producción chilena desde 1973 a 2009, con textos de teóricos y críticos nacionales y con un recorrido por las obras de 74 artistas, tanto emergentes como aquellos considerados consagrados. Se trata de un registro y valoración de la historia del arte chileno contemporáneo, pensando además en el posicionamiento de los artistas en el circuito nacional e internacional.

Entre los artistas que menciona y analiza, se combinan a distintas generaciones con análisis a base de breves textos introductorios. Incluye ensayos sobre diferentes aspectos del arte en Chile y América Latina, escritos por Guillermo Machuca-María Berríos, Justo Pastor Mellado, Catalina Mena, Nelly Richard y Adriana Valdés, todos ellos teóricos y críticos de 
arte, presentando, además, una documentación visual al respecto. A modo de introducción, el editor, analiza Chile desde una perspectiva internacional. Luego, en un anexo, se revisa los principales textos sobre arte contemporáneo chileno de los últimos 30 años, y la correspondiente bibliografía del período. Tal vez lo más relevante de este libro es justamente un objetivo oculto: vincular la producción chilena en artes visuales con la escena internacional, describiendo las formas -de diverso tipo- en que esta vinculación ocurre.

6) "Pintura Chilena Contemporánea: práctica y desplazamientos disciplinares desde la Escuela de Arte UC". 2015. De Nordenflycht, J.; Ampuero, C; Novoa P.; Schwember F. Ediciones Universidad Católica Santiago de Chile.

Se trata de un documento resultado de la curatoría de una exposición antológica, que compromete la obra de los profesores y ex alumnos de la Escuela de Arte de la Universidad Católica de Chile, que desarrollan obra en pintura. El documento narra las formas de desplazamiento/evolución de las obras de los académicos, en un recorrido histórico, que se asoma a ratos a entender su evolución y traslapo con otras disciplinas. De los temas y problemas que dicen relación con esta exposición, es posible encontrar varias obras que dan cuenta del problema de la identidad de la pintura chilena actual, y es posible desentrañar aquí orígenes y posibles destinos de la obra de este conjunto de artistas, algunos de los cuales ya están retirados.

Este libro examina además el aporte específico de la Escuela de Arte UC a la pintura y a la educación a lo largo de sus 55 años de existencia incluyendo un análisis crítico sobre los fundamentos pedagógicos, epistemológicos y artísticos que han sustentado su desarrollo en la escena nacional. Entre sus contenidos es posible encontrar algunas alusiones a los cambios que han operado en los temas de la pintura chilena en los últimos veinte años. Lo más relevante y pertinente para esta investigación, está contenido en la obra y biografía de pintores nacidos en la década de los 70, que han realizado su mayor (y mejor) producción en el período de nuestro interés: 2000-2014, lo que permite a este tesista verificar temas, imágenes y contenidos de la pintura chilena joven y contemporánea. 


\title{
III. MARCO TEÓRICO
}

\author{
III.1. Identidad
}

La búsqueda de rasgos formales e iconográficos en la producción de pintura de los últimos 14 años, lleva a preguntarnos por una definición de la noción de identidad, más propiamente sobre dicha noción aplicada a la realidad de América Latina y la chilena en particular. Para ello revisaremos la conceptualización que nos permite dibujar un marco de ideas orientadoras, basándonos en las reflexiones de un conjunto de teóricos que unen la incidencia recíproca de identidad, cultura y globalización, asuntos que serán desarrollados en el cuerpo de la tesis.

La identidad es una noción relacional, ya lo dijo Durkheim: uno sabe quien es uno, en relación o en comparación con otros (1974). La otredad, el ver al otro, define la propia individualidad e identidad.

La historia y los autores que realizan análisis sociológicos han mostrado cómo la noción de cultura ha ido evolucionando desde una categoría más o menos omnicomprensiva, hacia una noción que enfatiza los aspectos simbólico-expresivos o ideacionales. Debido a esta elaboración, el concepto tiende a ser delimitado dentro de un cierto ámbito ideacional (Cuevas, 1995). Por ello se hace imprescindible reconsiderarla en su contexto histórico material y estructural para no caer en la ilusión de la total autonomía del campo cultural. Esto se hace particularmente relevante al momento de tomar en cuenta los mecanismos y aparatos productores y reproductores de cultura, los que influyen en la producción y difusión de las versiones de identidad en el contexto masivo.

La identidad esencial no está más allá de la configuración cultural, sino que está modelada (socialmente) de una manera concreta y reflexiva. Existen diferentes civilizaciones, comunidades, cada una de las cuales modela una forma característica de identidad.

Las identidades colectivas son el resultado, de un entramado de eventos, experiencias, símbolos, metáforas, mitos y narrativas que sea capaz de crear un argumento que le dé a un grupo una historia compartida y única.

Las identidades étnicas, religiosas, regionales y también aquellas que se vinculan a elementos que se consideran biológicos como las de género y raza, se enmarcan a su vez en clasificaciones sociales y conceptualizaciones que, con frecuencia, se apoyan en las creencias y los comportamientos. Toda persona, sociedad o nación, estructura sus maneras 
de existir y pensarse a si misma y a las que la rodean, por medio de negociaciones, es decir, por prácticas retóricas, formales o no, de carácter narrativo, o a través de símbolos de alcances intertextuales. El discurso que configura identidades aparece, en cada caso, constreñido y condicionado por la matriz cultural a la que estén ligados quienes participan en el correspondiente proceso con su propia estrategia retórica. (De Alba y otros, 1995)

Hasta hace poco tiempo, la idea de nación aparecía como natural o consustancial al devenir de las sociedades en la época moderna. A fines del siglo veinte, se produce una percepción de la crisis de las naciones y del nacionalismo. Muchas de éstas que parecían muy firmes y "tradicionales" se vieron tan fuertemente sacudidas y conflictuadas, terminaron desmembrándose en numerosos países con estados independientes. La crisis del concepto de nación se hizo evidente. Como señala el antropólogo Manuel Gutiérrez, se comienza a producir el conflicto entre "el amor a la tribu y el amor a la Patria". La identidad nacional comienza a verse discutida y también complementada con otras identidades locales ya sea de carácter regional, de carácter étnico, religioso, etc.

El sociólogo Jorge Larraín se pregunta (2000) si las identidades nacionales están destinadas a desaparecer, poniendo en tela de juicio aquella concepción que fija la cultura como algo inamovible, determinado y consolidado, en que "lo propio" sea necesario de mantener como algo inamovible. Esta propuesta de una reconstrucción de los principios identitarios (con una cierta dosis de proteccionismo) en la globalización, se presenta quizá como un aspecto nuevo en el debate sobre identidad.

Desde otra mirada, pero coincidente con esta postura, el antropólogo Claudio Lomnitz, (1982), considera la identidad como una "performance discursiva", sin el cual las sociedades y los seres humanos no pueden sobrevivir. Asimismo sostiene que esas identidades nacionales principalmente se producen (construyen) en zonas de contacto, esto es en espacios de controversia, de tensión entre procesos globales, influencias externas y procesos provenientes de la historia, la reconstruida tradición, etc. Hoy, por ejemplo, uno de los principios identitarios sería la tensión o zona de contacto entre comunidad y modernización y ésta sería vista como peligrosa y perjudicial si no está normada por la comunidad.

En la sociedad moderna, señala, pareciera que se impone el principium relationis que es aquel de la emoción compartida, de la cultura del sentimiento, de un desarrollo tecnológico orientado hacia la interacción, la "tactilidad", por esencia apolítico". Son las formas postmodernas de "orgía divina y trance", que establecen las nuevas adscripciones, las nuevas identidades, los procesos de reconstrucción de las viejas ideas de nación, patria y ciudadanía. 
El autor afirma la necesidad de una fuerte identidad para proyectarse exitosamente en el mundo del siglo XXI, no obstante, al mismo tiempo señala que para ello no sirven las identidades llamadas "tradicionales".

\section{III.1.2. Globalización y cambio cultural}

No cabe duda que el fenómeno de la globalización -que se viene desarrollando ya desde hace muchos años- se ha llevado a cabo en gran medida a la expansión de los medios de comunicación. Medios como la televisión y el cine, la imagen impresa e Internet se han transformado en los vehículos más importantes para el desarrollo de la denominada "cultura global de masas". A raíz de lo anterior, un nuevo tipo de individuo, el consumidor, se ha transformado en la base sobre la cual funciona esta nueva "gran cultura". Ésta lo abarca todo; la educación, los medios de comunicación, la tecnología, las modas y la producción cultural, todo crece bajo la influencia de esta nueva forma de concebir la vida de las personas. El sociólogo J. Larraín señala al respecto:

(...) las formas de entretención y ocio están crecientemente dominadas por imágenes electrónicas que son capaces de cruzar con facilidad fronteras lingüísticas y culturales y que son absorbidas en forma más rápida que otras formas culturales escritas. (1996, p.110)

De este modo, la globalización se expande, homogeneizando y absorbiendo aspectos de diferentes culturas e impregnándolas de una concepción mercantilista del mundo. Es así como lo local comienza a funcionar dentro de la lógica de lo global.

Las transformaciones profundas que se han dado con la globalización tienden a producir rápidamente nuevas formas de organización y tecnología, a la vez que muchas prácticas quedan rápidamente obsoletas.

Con la globalización, las fronteras culturales tienden ha desaparecer. Todas las regiones del mundo parecen estar al alcance del fenómeno de la internacionalización de la economía y el poder de las grandes organizaciones financieras multinacionales influye cada vez más en la vida de los países.

El proceso de globalización afecta también a las comunicaciones, la política y la cultura que están cada vez más interconectadas e interdependientes en todo el mundo, principalmente a través del factor económico, elemento esencial para el funcionamiento de la lógica capitalista, instaurada a nivel mundial. Del mismo modo, la globalización de las 
comunicaciones a través de los medios ha producido que las relaciones sociales vayan más allá del espacio y el contexto local que tradicionalmente había servido de escenario para la interacción cotidiana de cada grupo humano. Las imágenes, las formas, los gustos, las tendencias que antes pertenecían a una cultura determinada, tienden a ser de uso masivo con desbordes y traslapos multinacionales.

La modernidad, por medio de la globalización, toma cada vez más importancia. En palabras de Larraín (1996, p. 20) este concepto hace referencia a un modo de vida y de organización social que combina la democracia con el industrialismo, la educación generalizada con la cultura de masas, los mercados con las grandes organizaciones burocráticas.

La modernidad ha sido "proyectada" desde las potencias industrializadas hacia el resto del mundo, gracias a la globalización. Nuevamente, los medios de comunicación han jugado un papel fundamental en este proceso, permitiendo que la influencia "moderna" alcance prácticamente todo rincón del planeta. Así, la modernidad se ha impuesto como el criterio con el cual los países evalúan su estado de desarrollo, a la vez que también se ha convertido en un fin en sí misma, una meta que todos los países debieran alcanzar. A decir de Carlos Fuentes: "Somos un continente en búsqueda desesperada de su modernidad" (en Brunner, 1994).

Esta modernidad, desarrollada en el contexto de un sistema capitalista absolutamente masificado, se concibe sobre la base del factor económico. Es decir, el sistema ha impuesto que el intercambio de bienes (o en otras palabas, de consumo) sea la manera a través de la cual las personas pueden acceder a la modernidad (Larraín, 1996).

En estricto rigor, hoy la modernidad ha dejado de ser una elección, es un hecho de la época, viene de la mano con la globalización de los mercados y de la democracia, con la expansión de la educación y de las industrias culturales, con la ampliación de las expectativas de consumo y la mutación de los valores, con los cambios en la estructura demográfica y familiar, con los procesos de urbanización y de masificación de la vida en general (Brunner, 1994).

En síntesis, podemos señalar que la noción de cultura es cada vez más compleja de definir, debido a los traslapos que la economía, las comunicaciones y la globalización, con sus procesos de transculturación, ejercen día a día sobre los países. No obstante, los eventos, experiencias, símbolos, metáforas, mitos y narrativas continúan siendo la clave y que según Lomnitz (1982) junto a la emoción compartida y la cultura del sentimiento, generan un principium relationis bajo el cual se construyen nuevas identidades, reconstruyéndose las nuevas ideas de patria, nación y ciudadanía. 


\section{III.2. Pintura en Chile}

La pintura ha sido, en la historia chilena, una práctica heterogénea en concordancia con los cambios de época, influencias culturales externas y formas de expresión inherentes a nuestra sociedad y, por ende, a la cultura en que se ha desarrollado. La tradición muralista de los años 40, así como las expansiones de los campos disciplinares en las expresiones artísticas contemporáneas han alterados los límites de la pintura, los cuales se han dilatado y expandido de forma tal que puede incluir cualquier elemento para su concepción. Todo es factible, sostenía ya en 1979 Rosalind Krauss; la pintura puede extenderse hacia distintos soportes ya sean de carácter bidimensional, virtual o tridimensional, como el cuerpo, la arquitectura, el paisaje y la utilización de diversos recursos materiales, por ejemplo, aquellos de carácter, virtual, industrial, tecnológicos, digitales sin dejar de ser pintura.

Excluyendo a aquellos usos de la pintura que no tienen relación con el arte y no manifiestan función estética, el arte de la pintura hoy, implica comprender también aquellos objetos artísticos que presentan alguna materia pictórica entre sus componentes; incluyendo matices y excepciones que tanto la tradición como la práctica artística contemporánea contemplan. Así en textos de historia del arte chileno, como en otros referidos a expresiones artístico-visuales, se encuentra una serie de cuadros u obras que sin utilizar como sustancia integrante el tradicional óleo o acrílico (la pintura)- forman parte de lo que se denomina como territorio ampliado de esta práctica, aquellas que, como lo sostiene Krauss (1979) no se definen con relación a un medio dado, sino más bien en relación con las operaciones lógicas en una serie de términos culturales.

Actualmente es complejo hablar de pintura y arte en Chile, sin considerar su expansión hacia territorios ampliados por nuevos procesos de elaboración y realización, tal como sucede con la escultura, debido a la permeabilidad respecto a otros medios (Krauss, 1979). En este sentido, la experiencia del arte contemporáneo ha sido paradigmática; en gran medida, la flexibilidad y extensión que se ha otorgado a la pintura y sus caracteres es consecuencia de las tensiones internas de aquello que denominamos arte desde el siglo pasado.

Es así que los rasgos característicos de la pintura se han desdibujado hasta adquirir sentido de pintura sólo después de su combinación y variación, reconocidos intuitivamente 
desde la experiencia colectiva y la práctica de los artistas, en constante interacción y combinación respecto de cualquiera otras artes, medios en general e instrumentos cognitivos susceptibles de ampliar su territorio.

\section{III.2.1 Dimensiones de la pintura}

Cuando se plantea la identidad (en la pintura) como problema a investigar, siempre se está frente a un conjunto de aspectos que "hipotéticamente" constituyen aquella particularidad por la que se intenta distinguir una cosa de otra, o diferenciar entre personas, o a un grupo humano de otro. La identidad se configura como una ficción metodológica que otorga una fisonomía a una persona, a un grupo o un país (Larraín, 2001).

"Asedio a la pintura chilena" (1969) es un libro escrito por Antonio Romera en Chile, en el que se preguntaba -entre otras cosas- por la identidad en el arte nacional. Para intentar una respuesta Romera utilizó dos conceptos con los cuales buscó establecer criterios generales y particulares para abordar el análisis de la pintura nacional, a saber, las <<constantes y claves $>>$, las primeras permiten agrupar las direcciones que sigue la producción pictórica y las segundas como signos que van señalando la tónica a lo largo del desarrollo histórico de la pintura nacional. Las primeras permanecen en tanto que las claves cambian. Para la presente investigación ha resultado interesante constatar esa preocupación entre los observadores de la pintura chilena del siglo pasado. Se trata de una herramienta útil, sin embargo estructurada por nociones ambiguas y confusas, como "la exaltación" o "el influjo francés". Para el presente trabajo se observarán aspectos contenidos en la obra a los que siguiendo a Romera- se le denominará "dimensiones", es decir, a los componentes de una pintura. ${ }^{8}$ Se establecen dimensiones en dos planos el primero comprende el plano denotativo de la obra en lo relacionado con la dimensión materia-forma, y la dimensión temática. En un segundo plano se considera lo connotativo con dimensiones referidas al sentido de la obra, lo referencial, lo contextual.

\section{La imagen pictórica}

Aumont (1992) sostiene que el arte es "una forma simbólica", y con ello ha querido decir que es un recurso inventado con el propósito de aprehender y comunicar algo de la realidad. En esta concepción el arte, por medio de la producción de "formas Simbólicas" que según las sociedades y las épocas en que se producen, permiten producir ideas, a la vez que

\footnotetext{
${ }^{8}$ Sobre este asunto se volverá en IV. 6.
} 
hacen percibir y sentir el mundo. Según el autor, una característica del arte respecto a otras "formas simbólicas", es que produce obras, de características y propiedades variadas, según la estética que se considere. Percibir una imagen visual artística supone, en primer lugar, la experiencia de percibir esta forma de expresión.

Arnheim (1971) propone tres funciones para las imágenes, a saber; representación, símbolo y sigo:

- Un valor de representación: la imagen representativa es la que representa cosas concretas (p. 135).

- Un valor de símbolo: la imagen simbólica es la que representa cosas abstractas. El valor simbólico de una imagen se define pragmáticamente, por la aceptación social de los símbolos representados.

- Un valor de signo: una imagen sirve como signo en la medida en que denota un contenido particular cuyos caracteres no refleja visualmente (p. 134).

Una imagen particular puede ser utilizada para cada una de estas funciones y con frecuencia sirve a más de una al mismo tiempo.

Wunenburger (1997) sostiene que el término imagen, por su etimología y por su historia, tiene una relación con las representaciones visuales, como así mismo se aplica a las representaciones lingüísticas (metáfora). La imagen literaria, gemela de la imagen visual, amplía la categoría, por un procedimiento semántico de analogía. De este modo reconoce que la función visual y la función del lenguaje son dos ramas divergentes de la generación de imágenes, sin que esta divergencia entrañe un corte entre ellas. Eso quiere decir que se pueden articular (Carrere \& Saborit 2000). Los sistemas estéticos han buscado resolver por sistemas de equivalencia, de correspondencias o de homologías estas dos familias de imágenes, que tienen sus raíces en una función expresiva única.

Asimismo Wunenburger, reconoce dos líneas que conducen la interpretación contemporánea de las imágenes, una de corriente positivista que, (vinculada a la objetividad científica en el establecimiento de los hechos), asimila la imagen a la categoría de signos (Bryson, 1991-Panofsky 1966) y otra de tendencia filosófica que relaciona la imagen con una dimensión simbólica (Cassirer 1975).

La imagen, metáfora, alegoría, son procedimientos que consisten en decir una cosa para significar otra, es decir, plantean un desvío sémico. 


\section{Plano Denotativo}

Sabemos que la denotación pertenece a un orden interno de la imagen y sus códigos no rigen fuera de los límites del cuadro: el reconocimiento de una escena, un retrato se aprende como un conocimiento específico que puede ser aplicado a las imágenes y su objetivo es identificar correctamente los temas representados (Bryson 1991, p. 82). "La denotación resulta de procedimientos de reconocimiento que están gobernados por códigos iconográficos" (p. 76).

\section{III.2.1.1. Dimensión materia-forma}

Esta dimensión hace referencia al medio, que a su vez dice relación con el material con el que se trabaja, con el cual se realiza la obra que el espectador verá. En el caso de este estudio, se trata de la pintura u otro que asuma dicho rol, como también de la superficie donde ésta se deposita, esto es, el lienzo u otro soporte.

Según Carrere y Saborit (2001), las características tradicionales de la pintura han sido modificadas con aportaciones contemporáneas dentro de las cuales se podrían mencionar, entre otras, las siguientes: la materia, la superficie o espacio plástico y el color, la unicidad relativa al carácter autográfico de la obra y la significación pictórica.

a.- Pintura: La materia pintura, propiamente tal, tiene una pastosidad variable, permitiendo su aplicación a modo de veladura hasta en forma de empaste grueso, ya sea con pincel como también con espátula, esponja, manos trapos, palos, etc. sobre una superficie convenientemente preparada, sobre todo en lo que se refiere a su absorción.

La extensión -contemporánea- del terreno de la pintura, implica variaciones, en cuanto a la consistencia y aplicación del material y amplían su territorio técnico y expresivo más allá de la norma de procedimientos de representación tradicional heredados del renacimiento. Esta norma era consecuente con una pintura que ocultaba la materia en la ilusión de la representación y pervive aún -en algunos casos- hasta nuestros días. En el rigor de esa tradición, algunas materias, su consistencia y modos de aplicación habituales, en el arte actual, no serían viables, puesto que la materia en sí adquiere un valor expresivo. Este carácter expresivo la convierte en elemento de significación explícita y esencial, ampliándose a través del descubrimiento de pigmentos, pinturas industriales y otras materias de aplicación similar a las pinturas artísticas tradicionales. El uso de este rasgo ha 
posibilitado a los artistas, nuevas texturas y acabados que solo se pueden obtener desde su especificidad. Por otro lado, el desarrollo de la tecnología y la imagen digital, ha posibilitado la expansión del campo pictórico hacia soportes virtuales y tridimensionales.

Considerando estos elementos, además de la pérdida de los límites y propiedades de la materia pictórica, al introducirse en los cuadros todo tipo de materiales, cabría señalar que por pintura se entenderá, entonces, por un lado aquella obra que presenta materia pictórica; y por otro, aquellas que sin esta presencia se postulan como tales dentro del territorio ampliado. Es decir una definición que viene indicada, no tanto por la presencia de la materia que llamamos pintura, sino por la presencia en equilibrio de los diferentes rasgos que la caracterizan y muy especialmente por su significación, los procesos y elementos, materiales por una parte y por otra aquellos que son determinantes, en este sentido, los visuales e intelectivos, que participan del fenómeno.

b.- Superficie y espacio plástico: en cuanto a estas aportaciones contemporáneas, es importante señalar que cada vez se producen más rupturas con la herencia renacentista que establece la convención de la pintura (la obra) bidimensional colgada verticalmente en un muro.

Una vez cuestionado el modo habitual de montaje/exposición en una pared, se intentan establecer nuevas relaciones entre el espectador y obra, pero mostradas de un modo diferente, creando situaciones ambiguas de montaje e interacción. Por ejemplo, podríamos decir que con la obra de Pablo Langlois Prado ${ }^{9}$, que incorpora, óleos sobre tela, copias y detalles de pinturas tradicionales, costuras, aplicaciones de objetos, hilvanes y ojetillos, no se está exactamente frente a una pintura ni una escultura, pero también podemos entender que a través de desplazamientos como éstos, el territorio de la pintura se amplía.

c.- Color: No siendo el color un elemento exclusivo de la materia pictórica, sí ha constituido un rasgo distintivo de la pintura con respecto a la escultura, y muy particularmente con respecto al dibujo. Como consecuencia del uso particular que se dio a cada técnica en el proceso de elaboración, ha derivado su influencia hacia el valor artístico otorgado socialmente. Así el dibujo se ha asociado (Gómez Molina, 2005) a la fase de análisis del natural (en especial en el proceso de formación artística) y abocetado de la

\footnotetext{
${ }^{9}$ Pablo Langlois Prado (1964) se proponen desde concepciones pictóricas, producto de sus estudios con J. Albers como lo es "Virian y Rojo Saturno" presentada en el MAC. Con el propósito de evitar confusiones se pone de manifiesto que es hijo de Juan Pablo Langlois Vicuña,(1936- ) Artista Visual chileno, que en 1969 presenta un trabajo en el Museo Nacional de Bellas Artes que da inicio a las prácticas de las instalaciones en Chile.
} 
pintura, a un tratamiento más gráfico (con predominio de la línea sobre la mancha) y a la monocromía. Este rasgo, con ser significativo de algunos aspectos de la tradición, resulta muy poco determinante si no se asocia a otros factores.

d.- La unicidad se relaciona con el modo en que una "pintura" realiza significados desde su ser lo que es. A partir de su formato, sus cualidades táctiles, cromáticas, matéricas, etc. configura un todo único, indisoluble en su significado incluyendo el lugar donde se instala. (Goodman, 1976). Con la posibilidad de la reproducción fotográfica o digital, se podría decir que "la pintura" perdería la unicidad de su imagen, puesto que su significación se multiplica y se fragmenta en numerosas significaciones, dado que todas las reproducciones introducen una distorsión mayor o menor, respecto al original. Sin embargo, podríamos aún sostener que la pintura original sigue siendo única. Por ejemplo, la reproducción fotográfica, de una pintura, colgada de una pared no es comparable, según Berger (2012, p.39) con el original, "el silencio y la quietud que impregnan el material real, la pintura, en la que es posible seguir el rastro de los gestos inmediatos del pintor, tiene el efecto de acercar en el tiempo el acto de pintar el cuadro y nuestro acto de mirarlo”. Deleuze (2007) insistirá en el carácter esencialmente manual de la pintura.

e.- La significación pictórica apunta al procedimiento, estrategias y operaciones artísticas como un todo comunicacional; donde la imagen es el medio material, sensible y concreto, a través del cual se hace posible la representación. Por otro lado, la materialidad de la imagen pictórica puede ser el soporte creado necesario, único y privilegiado de la significación por su cualidad de adecuación y correspondencia a ésta (Aumont, J. 1992).

En cuanto a la referencia a ciertos modelos de representación, a los géneros, la dialéctica entre figuración y abstracción, el formalismo visual y el conceptualismo por nombrar algunos, en que se ha manifestado históricamente la práctica pictórica, transmitiendo una concepción del mundo y reclamando la atención hacia la complejidad de la experiencia artística y de la propia noción de arte que transmiten, se entiende, en la comunidad de destinatarios del arte, como una interpretación consciente dentro del tipo de fenómeno cognitivo que llamamos pintura. Proceso en el que participan tres elementos inseparables: la materia, los signos visuales básicos (plásticos e icónicos) y los sistemas a través de los cuales materia y signo articulan un conocimiento.

Los sistemas y procesos de la práctica pictórica siguen siendo la base de una parte del arte que se realiza en nuestros días (y desde luego en el pasado) e incluso una referencia ineludible que rebasa o parece rebasar los límites habitualmente (aunque cada 
vez menos) marcados de la pintura y de aquello que tradicionalmente se considera como Bellas Artes (volveremos sobre este tema más adelante).

Considerando que la extensión de la pintura toca los espacios de instalación de obra, Lippard (2001) establece categorías que diferencian los tipos de arte público, y que podemos aplicar a la práctica pictórica. Así, podemos encontrar obras concebidas para exposiciones de interior convencionales que hacen referencia a la comunidad, la historia o el medio local; el arte público tradicional de exteriores, las obras de arte site-specific. La hibridez alcanza a generar traslapos con otras disciplinas: las performances, el street-art, entre una serie de otras propuestas.

III.2.1.2. Dimensión temática.

Esta dimensión se asocia a la parte más literaria de la estructura visual de una obra. El tema es la apariencia y su relación con la manera en que nombramos aquello que vemos y va desde un simple punto, línea o color, hasta la estructuración compleja de un relato, una anécdota o una historia.

Los temas más recurrentes en la pintura que analizamos son: retrato/ objeto/ paisaje / figuración y escenas de la vida cotidiana, lo que se inscribe en aquello que Diderot, en Essais sur la peinture (1766) calificó de genre.

La llamada "pintura de género o costumbrismo" estaba pensada como el polo opuesto de la pintura mitológica. Era vulgar en lugar de noble. Su propósito era demostrar el éxito social o financiero. $\mathrm{Y}$ así todos aquellos que podían comprar estos cuadros confirmaban, sus virtudes personales (Berger 2000).

- RETRATO: su origen está en el deseo de trascendencia, de inmortalidad en los griegos y de los patricios romanos y en el artista la noción de replica, del símil, la mimesis fisonómica. El Retrato formal, según Berger (2000), debe insistir en una fidelidad que pone a una distancia formal, ya que el sujeto debe ser visto de cerca y de lejos simultáneamente, distinto del autorretrato o el retrato informal de un amigo o familiar del pintor. Al persistir la tradición, la pintura del rostro fue adquiriendo un carácter más y más general, se rompe la tradición con el retrato informal, cuando el pintor da cuenta de su mirada sobre el sujeto retratado.

- Objetos y Bodegones: los antiguos se enterraban con sus objetos más preciados, éstos son sinónimo de poder; según Baudrillard (2010) "los objetos pintan ante nuestros ojos los 
límites de una configuración simbólica llamada morada”. Muchas pinturas al óleo eran demostraciones de lo que se podía comprar con oro o con dinero. Las mercancías se convirtieron en tema real de las obras de arte. Cuadros de objetos, objetos que llegarán a recibir el nombre de objets d'art, Berger (2012). Se podría señalar, quizás como una característica de la pintura de objetos en sus inicios, en Chile, el hecho de que, si bien los cuadros aluden a cosas inanimadas e inmóviles, las flores, frutas cosechadas, pescados y aves cazadas, hacen referencia a la presencia de la vida en lo cotidiano, al alimento, aquello que llena la mesa y la mirada del espectador, conectado a la vida y la muerte en un mismo plano (Galaz, 1981).

- Paisaje: En la historia de la pintura, el paisaje fue adquiriendo cada vez más relevancia, desde su aparición como fondo de escena de otros géneros (como la pintura de historia o retrato), hasta constituirse como género autónomo en la pintura holandesa del siglo XVII. Adquirió autonomía iconográfica en el siglo XVI. Desde sus orígenes la pintura paisaje fue una actividad independiente, no respondía a ninguna necesidad social directa, sus cultores heredaron los métodos y las normas de la tradición, sin embargo también cuando la tradición sufrió modificaciones impactaron en esta práctica de tal modo que, según Berger (2000), las innovaciones les llevaron progresivamente desde lo sustancial y tangible a lo indeterminado e intangible.

- Escena: El crítico de arte Quatremère de Quincy, reservó el concepto peinture de genre para las escenas de la vida cotidiana. Sin embargo este tipo de pinturas tiene su origen en la escena mitológica, histórica o religiosa cuando se asumía que el arte tenía un contenido intelectual y creativo que debía volcarse en temas cultos y en ensalzar a personajes de categoría, de las clases altas, nobles del pasado. Su polo opuesto, la escena costumbrista, era vulgar, su propósito el de demostrar, positiva o negativamente, que en este mundo se recompensa la virtud con el éxito social o financiero (Berger 2000). Allí estaba la moraleja que ilustraba la escena con la cual se identificaba la burguesía. A partir del siglo XVII se empezó a valorar más la representación de aquello que el arte clásico consideraba

«comedia»: lo cotidiano, las historias menores de gente vulgar. Chile posee una cultura popular rica en expresiones ya sean religiosas, profanas, políticas, sociales, entre otras.

\section{Plano connotativo}

Las connotaciones requieren un trabajo hermenéutico, cuyos códigos operan en general en la sociedad pero de una manera difusa, aunque pueden ser transferidos a la 
pintura. A diferencia de la denotación que sí dispone de un léxico o recopilación escrita disponible, los códigos de connotación carecen de la codificación que, por el contrario, si tienen los códigos iconográficos o denotativos. Al carecer de léxico o recopilación escrita disponible, no pueden ser aprendidos ni enseñados de memoria y el conocimiento de su funcionamiento ha de ser adquirido por el ejemplo de un contexto material presente. No pudiendo ser abstraídos de su contexto, sus significados están sujetos a fluctuación según los cambios de contexto; los significados de los códigos de connotación, a diferencia de los códigos iconológicos son, por tanto, no-explícitos y polisémicos (Bryson 1991, p. 84-85).

\section{III.2.1.3. Dimensión sentido.}

En la pintura representativa, la noción de sentido está íntimamente asociada a la imagen, dado que ésta es portadora natural de significación. Sin embargo no se reduce solo a su significatividad. Aunque signifique algo, por ser una imagen, resulta necesario contemplarla en sí misma prescindiendo de su dimensión semántica, porque las formas pictóricas, no son signos, que, en cuanto tales, tengan por misión, como todo signo, el hacemos conocer algo distinto de ellos, sino que son realidades auto-significativas Gilson (1963), cuyo sentido y valor artístico reside únicamente en sí mismas (noción de diagrama Deleuze, 2007). Su condición de imagen no debe eclipsar su propia índole artística. En ese sentido sería equívoco, según el autor, equiparar la noción de forma con la de imagen, como con la de signo, así lo advierte Focillon (1983): "Siempre trataremos de buscar otro sentido a la forma, fuera de ella misma y de confundir la noción de forma con la de imagen, que implica la representación de un objeto, y sobre todo con la designo. El signo significa, mientras que la forma se significa". Tampoco son símbolos, puesto que estos son imágenes que significan algo distinto de lo que visiblemente se muestra o aparece. Ante una forma cualquiera, representativa o no, el espectador tratará espontáneamente de leerla, de buscarle un sentido. En el ámbito artístico parece imperar la convicción de que el arte es la "comunicación de un sentido, que el artista formula y el espectador comprende" (Gilson 1963, p. 21). Sin embargo, la experiencia estética exige un algo distinto. Para experimentarla habrá que contemplar la obra en sí misma y apreciarla por sí misma, prescindiendo de su presunta significación o nivel representacional.

\section{III.2.1.4. Dimensión referencial.}

Esta dimensión incorporada al análisis de las obras sometidas a estudio, presenta dos niveles. El primero de ellos dice relación con la imagen representativa que se define por su intención referencial: designa, muestra la realidad. En un segundo plano, la pintura -en 
cuanto imagen elaborada- da cuenta de una modalidad que proviene de su ser lo que es. Una obra pictórica comprende en sí misma la historia de la pintura, en ese sentido, la vemos con relación a lo que sabemos de ello, asociándola a sus referencias históricas, vinculándola siempre con sus posibles ascendencias y/o filiaciones.

\section{III.2.1.5. Dimensión contextual.}

La pintura chilena durante la segunda mitad del siglo XX y, esencialmente, desde los años noventa hasta hoy ha estado marcada principalmente por la búsqueda de nuevas expresividades plásticas y por la creciente vinculación del artista con el contexto político y social. Los unos entendiendo el arte como una acción política, otros utilizándolo para inscribirse políticamente o usándolo para hacer política y aquellos que, adscribiéndose al mercado, se sitúan al margen de dicho contexto pero en la industria cultural.

\section{DESARROLLO DE LA INVESTIGACIÓN.}

\section{IV.1. Cultura - identidad}

La cultura constituye el contexto para la construcción de las identidades sociales así como de toda actividad humana, no es exclusiva de ciertos individuos o grupos sociales sino que es una capacidad y una posesión generalizada del Hombre, compartida por todos (Kottak, 1994). Ernesto Livacic (1992) complementa esta visión señalando que: como la cultura consiste en el constante quehacer humano por transformar y humanizar, a través del tiempo, el mundo en un sentido general, no es una realidad acabada, sino que es totalmente dinámica y cambiante.. Nunca llega a manifestarse como un todo determinado estático, es siempre un proceso en marcha.

La cultura podría definirse, según Terry Eagleton (2001), como un producto de las acciones mediante las cuales hombres y mujeres, en una locación espacial y temporal definible, organizadamente reaccionan ante sus entornos naturales y sociales y reducen su complejidad, para lo cual hacen uso tanto de ideas como herramientas y organizaciones productivas. En consecuencia, la cultura es el patrimonio material, social, e ideacional, que es comunicado a las nuevas generaciones al modo de la herencia, y cuya función es facilitar la adaptación de las comunidades a sus respectivos ambientes o entornos complejos. Comprende la totalidad de los aspectos técnicos-materiales, institucionalorganizacionales e ideacionales de la vida social. Siendo éste último en el que el análisis 
cultural ha puesto el énfasis, precisamente en el campo del imaginario, ocupándose de las manifestaciones simbólico-expresivas de la cultura, tales como las religiones, las ideologías, los mitos, las artes y el folclor, los preconceptos, las percepciones y los conceptos e ideas. Desde este punto de vista, la cultura, o más bien cada cultura, es concebida como una particular manera de organizar con sentido el mundo, la vida propia y la convivencia.

Este quehacer humano nace de la constante interacción entre los individuos de una sociedad y consiste, según José J. Brunner, en la producción y transmisión de sentidos que van conformando el mundo simbólico dentro del cual los sujetos se relacionan entre sí (1994). Kottak (p. 370), citando a Quinn y Strauss, dice: “una red de comprensiones compartidas y un producto cambiante que implica negociación por parte de sus miembros individuales".

Es entonces una actividad humana inacabable y compartida. Por lo tanto, la construcción de la cultura es esencialmente universal. La existencia de todo grupo humano implica necesariamente la presencia de una determinada cultura.

La producción simbólica propia de toda cultura se manifiesta en la práctica mediante creencias aprendidas, valores, normas y costumbres que sirven para regular el comportamiento de los individuos.

Fernández Collado (1986) engloba el concepto señalando: "La cultura es un sistema de símbolos compartidos, creados por un grupo de gente para permitirles manejar su medio ambiente físico, psicológico y social". Este sistema constituiría el marco referencial cognoscitivo general, dentro del cual las personas pueden comprender su mundo y funcionar dentro de él. Esto le permite al individuo interactuar con otras personas y hacer predicciones de expectativas y acontecimientos.

Por lo tanto, es a través de la cultura que somos capaces de dar cuenta de la realidad que nos rodea y a la vez crearla, fundamentalmente por medio del lenguaje, a través el mismo de este se establecen las redes de pertenencia identitaria, "somos lo que somos a partir de las relaciones que establecemos con los demás” (Echeverría, 1996).

La cultura supone un "nosotros" en base a códigos compartidos que clasifican y diferencian, la identidad opera por la diferencia "todos nosotros supone un otros, en función de rasgos, percepciones y sensibilidades compartidas y una memoria común, que se hacen más notables frente a otros grupos diferentes, con los cuales la comunicación encuentra obstáculos" (Marguillis, 1997). Según el autor, en todas las sociedades conviven grupos diferenciados, sin embargo varía el grado que los separa de los "otros". Dicha diferenciación se hace más notable con los procesos de migratorios donde el migrante es 
recibido por los locales con una distancia mayor que a un coterráneo, en estos casos se puede presenciar la discriminación, así mismo los migrantes se fortalecen como pequeños grupos al interior de la sociedad receptora, lo que implica un salto cultural.

Según Gorosito “...se adquiere identidad con la incorporación satisfactoria de un modo particular de significar la realidad" (1997, p. 102). Dicha identidad, sostiene el autor, tiene un protocolo de expresión pública a partir de una memoria colectiva, red de conversaciones, espacio geográfico y comunidad compartida, diferente de otros de expresión privada, o de tantos otros como tipos de situaciones marcadas socialmente que también son posibles dentro de este microcosmos cultural.

Los sujetos pueden manifestar múltiples identidades, pero estas distintas modalidades de expresión de la identidad no constituyen rupturas internas del sujeto, no formalizan discontinuidades abruptas que puedan disolverlos en tantos sujetos como situaciones distintas exijan la demostración de aspectos diversos. Gorosito (1997) considera, también, al sujeto como el haz de manifestaciones cambiantes de su identidad culturalmente provista, así como la cultura es el haz de significaciones posibles creadas y a crear, por lo que concluye que las identidades son dinámicas, en constante modificación e interacción entre lo colectivo comunitario y lo individual.

Así podría definirse la identidad, colectiva e individual, como la cultura internalizada en sujetos, subjetivada, apropiada bajo la forma de una conciencia de sí en el contexto de un campo de significaciones compartidas con otros.

La identidad se desenvuelve en las relaciones sociales, las fortalece en la medida que se vive como una hermandad con otros sujetos, crea esferas de identificación. "La cultura proporciona símbolos a las personas así como el contexto para comunicar algo de ellas mismas a otras personas". (Fernández, 1986, p. 200)

Es a través de las redes de comunicación que se tejen, como resultado de las interacciones cotidianas, dentro de una sociedad, que se construyen los códigos y símbolos comunes que los individuos utilizan para comunicarse entre sí.

Todas las culturas proporcionan al individuo un sistema que privilegia ciertas maneras de hacer, pensar, solucionar y satisfacer necesidades y a su vez estas maneras caracterizan la cultura. En otras palabras, la cultura determina una manera de estar en el mundo y viceversa.

"Mi propia identidad se funda en la identidad del espíritu humano; lo que me hace ser quien soy es mi esencia, o sea, la especie a la que pertenezco. La cultura es el espíritu de la humanidad individualizándose en obras específicas; su discurso 
conecta lo individual con lo universal. Lo universal no es opuesto al individuo, sino su mismísimo paradigma" (Eagleton, 2001, p. 88)

Hoy, frente a los procesos de internacionalización y globalización de las comunicaciones y de la vida social, los pueblos se conocen cada vez mejor, por lo que resulta más fácil percatarse de las similitudes y diferencias que subsisten en las culturas de las diferentes regiones. Incluso en un mismo país como Chile. En general en las naciones americanas han emergido una diversidad tan grande de manifestaciones culturales que tienden a poner en tela de juicio el concepto de "identidad cultural" (Guadarrama, 1992, p.120). La identidad latinoamericana es cultural y macro social: envuelve e incluye varias identidades parciales que se superponen, no negándose pero si diferenciándose.

La identidad es la respuesta a la pregunta quién soy, a nivel individual; o quiénes somos, a nivel grupal, étnico, nacional o continental. Por lo que la respuesta no puede ser sino plural. De este modo, y debido a que la sociedad está hecha de diferentes culturas, y en cierto modo no consiste más que en ellas, "el problema de la identidad" es siempre de las identidades. En ese sentido habrá que concebir la identidad cultural como una trama de niveles, no siempre concordantes, por lo que pueden producirse "conflictos de identidad" (Gissi, 1982, p. 158).

Cualquier tipo de identidad, solo puede darse, en palabras de Pérez (en Jiménez Castro, 1999), en la propia multiplicidad, es decir, en la incertidumbre y en la dispersión o en la conciencia de una perpetua otredad y en la tensión de un constante y enriquecedor extrañamiento, pleno de particularidades que nos obligan a subrayar que no podemos seguir refiriéndonos a Latinoamérica como un espacio prisionero de un proceso de representación esencialista. Como a ningún país que la integra como una unidad unidimensional.

La identidad actúa como discurso legitimador de una determinada cultura, que responde a unos interese políticos muy determinados. Chile como Argentina, no tienen más historia que la del siglo XX. Perú y México tienen otra historia: el mundo precolombino, Chile al igual que Argentina, no está en el pasado, es una invención diaria, algo que debemos hacer. En México, el pasado no se puede abandonar pero tampoco regresar a él; una tensión entre un pasado extraño y un presente igualmente extraño.

En lo que respecta a Chile, sin descontextualizarlo de lo latinoamericano, Larraín (2001) señala que nuestra cultura e identidad no es ni ha sido algo estático e inamovible, pero a su vez presenta dos aspectos constitutivos: 
- Una cultura de la elite dominante, que procede de una oligarquía, comenzó desde la independencia a elaborar un sentido de su propia identidad, separada de clase, que da paso, en el siglo XX, a una incorporación de las clases medias a las estructuras de poder, mantiene, en el tiempo, el carácter conservador, esencialista, pero, a su vez, es imitativo y carente de originalidad, es fuertemente influida por la cultura europea y norteamericana, éstas proveen son los parámetros de educación adoptados por nuestras universidades, en las cuales se desarrollan los programas de formación artística.

- El otro aspecto se expresa en una contracultura popular, independiente, con características distintivas y un énfasis en lo religioso, permeada constantemente por expresiones culturales foráneas que son asimiladas e incorporadas al contexto. En éste sentido ha sido y es más dinámica y no se plantea como esencialista. Esta cultura popular es, para la elite, un aspecto folclórico de la idiosincrasia popular. En ella se integran las culturas indígenas del norte por lado y del sur por otro de modo independiente.

A estos dos aspectos constitutivos, este autor, agrega ocho rasgos distintivos que le otorgan, en la actualidad, una particular identidad (2001).

Clientelismo, tradicionalismo y sociedad civil débil:

Larraín recalca el profundo clientelismo que existe hasta hoy en día en donde la movilidad social esta apegada a la red de "contactos" con los que cuenta un individuo produciéndose una inmovilidad institucional bastante seria, asimismo señala que en Chile existe un tradicionalismo que apoya las ideas neoliberales pero que no se aliena totalmente con los preceptos valóricos propios del liberalismo dándose una suerte de paradoja. Y finalizando, este autor, señala que en Chile existe un escaso desarrollo de la sociedad civil que puede estar dado por la inexistencia histórica de una clase burguesa fuerte y robusta que funcionara con prescindencia del estado.

Despolitización, democracia y derechos humanos.

La despolitización ha sido la tónica de las ultimas décadas en contraposición a la atmosfera vivida en los años previos al golpe militar, la sociedad chilena no siente un apego o aprecio por la política, eso en parte se puede deber a la descentralización que ha tenido esta en torno a los asuntos económicos del país. Por otra parte, la democracia se ha 
consolidado en el último tiempo gracias factores de diverso origen a su vez que los derechos humanos han sido el gran tema que cultural del último tiempo.

Autoritarismo, machismo y racismo oculto.

Un aspecto muy importante de la cultura chilena es la fuerte preponderancia del autoritarismo, tendencia de la cual hay abundantes ejemplos en la historia del país. Por otra parte, el machismo determina al hombre como el centro del orden social relegando a las mujeres a planos secundarios de acción, sus causas se pueden deber al hecho de que los conquistadores no traían a sus mujeres y trataban con inferioridad a las indígenas, como también la prolongación de la guerra de Arauco que creó una figura masculina lejana pero decisiva. Otro rasgo colonial se centra en la forma en cómo los chilenos se relacionan con la autoridad apegándose y respetando las normas pero en la praxis se alejan de ellas, esta "simulación” puede ser la causa de la hipocresía chilena, en este apartado se concluye con el racismo chileno y a la exacerbada importancia que se le atribuye a la "blancura".

Fatalismo, exclusión y solidaridad.

El fatalismo tiene su centralidad en la pobreza y la marginalidad. Esta se caracteriza por un pesimismo y desesperanza de las acciones individuales para un mejor porvenir. En tanto, la marginalidad no contribuye de buena manera a la identidad. Al contrario la solidaridad permite recuperar la confianza en el mundo exterior de manera que la beneficia como elemento constitutivo de la identidad.

\section{Religiosidad}

La religión en Chile es de suma importancia, ya que su nivel de influencia y arraigo en la sociedad es tremendo. Distingue claramente dos tipo de religión, por una parte la católica y por otra a la indígena, ambas determinan modos de vida distintos. Esto explica por ejemplo por qué el proceso de secularización se desarrollo tardíamente en el país. También cabe destacar la creciente importancia de los evangélicos en Chile que presentan mayores niveles de compromiso con su credo.

\section{Mediatización de la cultura y eclecticismo}

Larraín hace hincapié en la importancia que han tenido los medios de comunicación en los últimos tiempos sobre todos en medios como la televisión que ocupan el ocio de miles de chilenos, esto tiene un impacto directo sobre la construcción de identidades individuales generándose nuevos iconos de influencia cultural. Por otra parte se hace 
referencia a la clara característica de Chile de tener una cultura muy ecléctica que asimila características provenientes de otras culturas y regiones del mundo lo que habla del carácter imitativo de nuestra cultura.

Consumismo, ostentación y fascinación con lo extranjero.

El consumo en Chile gracias al vertiginoso establecimiento de una economía neoliberal se ha conformado como un modo especifico de cultura en donde se mercantilizan elementos simbólicos a la vez que los individuos se transforman en consumidores. Esto podría estar dado -según Larraín- por la nueva forma de construir nuestras identidades en donde la expresión de nuestra identidad esta sujeta a la forma en como consumimos, la búsqueda de reconocimiento se transforma en el pilar fundamental de esta concepción. Además es importante decir que este reconocimiento está dado por lo que podamos ostentar socialmente. Por otra parte, existe una fascinación por lo extranjero ya que nuestro modo vivir "insular" nos impulsa a demostrarnos que a pesar de todo somos un país civilizado.

El malestar de la cultura.

Junto con el crecimiento económico, existe una preocupante tendencia en la sociedad chilena y que habla del malestar existencial de los chilenos producto del ajetreado mundo moderno, al cual Chile se suscribió a través del desarrollo de políticas neoliberales. Este malestar guarda relación con la vida en ciudades cada vez más congestionadas, el endeudamiento, el temor a la delincuencia, la desconfianza, la inseguridad, entre otros que presentan un grave problema de nuestra sociedad actual.

IV.2. Cultura e identidad en Chile en el contexto de la globalización.

Desde el punto de vista de la lógica política, la nación es una territorialización del poder. Desde la lógica cultural, en cambio, la nación está constituida por una herencia, por el lenguaje, por las costumbres, por los modos de ser, por los particularismos culturales, es decir, por la idiosincrasia. Y no siempre en la constitución y desarrollo de una nación latinoamericana, se produce una relación armónica entre ambas. Hay naciones que se han constituido en términos históricos e identitarios, en una relación armónica y más o menos articulada entre estos dos polos. Otras, en cambio, se han construido con un énfasis en el polo cultural, y otras, como es el caso de Chile -con un claro predominio de la lógica política- la construcción de nuestra identidad nacional se ha inscrito ostensiblemente en un 
carril político ilustrado bajo la conducción de las elites (Subercaseaux, 1991). Se trata de una trayectoria cuyo objetivo ha sido formar un país civilizado y de progreso, en que van quedando sumergidos, sin presencia sectores que no armonizan con esa utopía republicana, como los mundos de los particularismos culturales y de las etnias. Junto al itinerario histórico concurre, entonces, la concepción de una identidad chilena homogénea, más bien europea (el mito de la "Suiza" o la "Inglaterra" de América Latina), y la conciencia histórica de un país de excepción en el ámbito latinoamericano. Es dentro de esta forma de construcción de la nación que se va hacer patente la tesis de un déficit de espesor cultural de origen étnico o demográfico, y de un predominio de lo ideológicopolítico en que la cultura es apenas un detalle de esa dimensión.

Comparativamente con otros países de América Latina, Chile ha sido un país de interculturalidad abortada, un país en que, por nexos y hegemonías sociopolíticas, las diferencias culturales de base étnica o demográfica no se han potenciado, en que los diversos sectores culturales y regionales que integran la nación no se han convertido en actores culturales a plenitud. Aquellas expresiones ocasionales de energía, en que han aflorado algunos sectores y adquirido cierta visibilidad en el imaginario nacional, han sido motivados por las circunstancias políticas más que por la fuerza cultural de ellos mismos. Desde la dimensión de lo político y la práctica social, se han generado los flujos de energía y los momentos más dinámicos en la historia de la cultura chilena (en las primeras décadas del siglo XX las manifestaciones y movilizaciones estudiantiles y obreras, la bohemia y la vanguardias; posteriormente el frente popular y la generación del 38; luego la década de los sesenta, los proyectos de emancipación y el gran movimiento cultural que incluyó desde la nueva canción chilena hasta el muralismo), llegando a su máxima expresión, con el triunfo electoral de Salvador Allende al frente de la Unidad Popular.

En términos de identidad nacional, se advierte en Chile un déficit de espesor cultural socialmente circulante, a diferencia de otros países latinoamericanos; las inmigraciones tampoco han significado un aporte sustantivo y permanente en lo cultural. De lo anterior no debe entenderse que no haya expresión y/o espesor cultural de origen étnico o demográfico; si lo hay, el problema es que ha permanecido enghettado, con escasa circulación y casi sin proyección en la identidad nacional. Ello explica la escasa y poco frecuente osmosis entre lo culto y lo popular, salvo contadas excepciones que se dan en la producción artística nacional (PNUD, 2004) $)^{10}$

\footnotetext{
${ }^{10}$ En un informe del PNUD (Prog. Naciones Unidas para el Desarrollo), sobre Desarrollo Humano del 2002 detectó, a través de una encuesta, que lo chileno o la identidad chilena era percibida como una herencia bastante difusa y cuestionada
} 
En las últimas décadas se han asentado importantes transformaciones en el escenario cultural y comunicativo de Chile, principalmente por tres factores que se podrían indicar como los más relevantes de estos cambios: la massmediatización de la cultura; los cambios tecnológicos y la instalación casi sin matices de una sociedad de mercado. Chile con alrededor de 17 millones de habitantes no es una isla y su debilidad por importar modelos extranjeros, no le ha permitido sustraerse a tendencias de fuerte impronta internacional.

Así gran parte de la vida y actividad cultural del país pasa por las industrias culturales audiovisuales que operan con una lógica de mercado y de people meter, pero, a la vez, inciden también en el panorama identitario, nutriendo y alimentando micro identidades culturales, como, por ejemplo, las tribus urbanas, la visibilización de los problemas y cultura mapuche, las barras bravas en el futbol, etc.

\section{IV .2.1. Chile y la modernidad}

"La modernidad es la época en que la que, el hecho de ser moderno, se convierte en un valor dominante" (Vattimo, 1990). A pesar de la gran envergadura e influencia omnipresente del fenómeno global, no es un misterio que las culturas latinoamericanas no han logrado alcanzar un estado de real modernidad. Esto, porque no han vivido en forma propia y natural las profundas transformaciones, reformas y revoluciones que implican el paso a la modernidad, no así el resto de los países de occidente. La modernidad se implantó de forma abrupta como resultado de la influencia y del poder que ejercen las grandes potencias hacia el resto de los países. Ni siquiera la implementación del capitalismo daría a nuestro presente un carácter moderno. Sólo se estaría en presencia de una forma de modernidad simulada, en la cual los medios de comunicación masiva cumplen un rol fundamental, al ser uno de los principales responsables de construir una realidad que consiste en un "simulacro" de sociedad moderna, principalmente a través de la ideología del consumo. Chile no ha sido la excepción. Por citar un ejemplo, de un total de 15.211.308 de habitantes, en nuestro país, el 14,8 vive en extrema pobreza, cuyo promedio de escolaridad es de siete años, con un promedio de deserción escolar del 70\%.

Chile, país diferente, ganador, competitivo; "Chile moderno". Así se quiso "vender" la imagen de Chile en el extranjero a través de aquel iceberg llevado a la Expo Sevilla el año 1992 (Subercaseaux, 1996). Sin embargo, este concepto responde a una historia reduccionista de la modernidad, valorando sólo una visión tecnocrática-racional mensurable en cifras, propio de la ideología neoliberal, ignorando del todo el aspecto 
cultural. Esta "modernidad" no se concibe como un proceso natural de desarrollo integral que debiera vivir un país, acorde a su realidad y potencial local.

Tomás Moulián (1997), critica este Chile aparentemente moderno, imagen que se ha ido construyendo exclusivamente sobre la base del discurso neoliberal y del supuesto éxito económico que ha logrado nuestro país. Según Moulián, esta idea del Chile jaguar, Chile desarrollado o Chile moderno es el resultado de una estrategia pensada para vender el concepto $<<$ Chile $>>$ tanto en el extranjero como al interior de nuestro propio país. Hacia el extranjero, tendría como objeto atraer a los grandes inversionistas. Pero también, internamente, busca afianzar entre nosotros mismos la idea - fuerza de "Chile admirado", "Chile moderno", lo cual, según el autor, es un concepto muy atractivo para una sociedad como la nuestra, obsesionada con la grandeza.

Eugenio Tironi (1999) revela un aspecto importante que describe a la sociedad chilena de la modernidad. Según el autor, los profundos cambios ocurridos tras la vuelta a la democracia, los procesos de liberación política, el crecimiento económico y la apertura internacional, provocaron un paso desde una actitud apocada y pesimista que, según los historiadores, ha distinguido el "carácter chileno", hacia una actitud orgullosa y optimista y de pronto hasta arrogante. En los 90, la actitud de los chilenos hacia si mismos y hacia el país cambió profundamente.

Tomás Moulián plantea su punto de vista al respecto señalando que:

"el bloqueo de la memoria afectaría profundamente a nuestra sociedad, provocando una falta del habla y una carencia de un discurso común para describir o nombrar lo vivido en el pasado. Trauma para algunos, victoria para otros. Se trata de una negación socialmente determinada de una experiencia colectiva, pero que se resignifica en forma individual o particular". (1997, p. 31).

Este fenómeno es un obstáculo para lograr un desarrollo íntegro de la identidad chilena. No se puede olvidar que uno de los elementos esenciales en la construcción identitaria, de los grupos humanos, corresponde a la existencia de una memoria histórica común y su asimilamiento por parte de los individuos que conforman dicho grupo.

"El espacio público y el privado fueron uno solo. El arte se confundió trágicamente con la vida, duele describirlo hoy a los más jóvenes. Era una fiesta total y declarada donde, como en el carnaval, todo es posible (...)".

"El Golpe militar cayó como un rayo. Se construía una sociedad imaginaria que resultaba amenazante y peligrosa para quienes no estaban dispuestos a 
permitirlo. La muerte andaba por ahí, andaría, suelta por la calle. La palabra fue absolutamente puesta en sospecha y el arte retirado de circulación (...)”.

“Las palabras quedaron hechas añicos". (De la Parra, 1999, p. 90).

La democracia y la extensión de la economía de mercado habrían marcado, según Tironi, una honda transformación social, cultural y política en la sociedad chilena y en su identidad. Habría, según el autor, una sensación de que los chilenos se han convertido en personas consumistas, despreocupadas por su medio ambiente, que no protegen su patrimonio y cultura, que serian individuos materialistas y ordinarios. Sin embargo, piensa que el progreso económico del país no podría haber sucedido sin que los chilenos también hubiesen evolucionado en un sentido positivo.

Debemos considerar que la idiosincrasia chilena actual a la que se refiere Tironi no se genera abruptamente con el advenimiento de la democracia y la apertura internacional, sino que viene gestándose desde los tiempos del régimen autoritario, en el cual la irrupción del modelo neoliberal y el capitalismo produjeron cambios durante los años de dictadura, generando una sociedad centrada en el productivismo y en el consumo y en la cual el aspecto social y cultural son dejados de lado.

Como vemos, el desarrollo o "despegue" económico que ha experimentado la sociedad chilena no han garantizado hasta ahora un mejoramiento del aspecto social y cultural de la población. Sería un reduccionismo afirmar que la existencia de un mayor desarrollo económico necesariamente implica un mejoramiento integral de la calidad de vida de los ciudadanos.

¿Como puede construirse, a partir del espíritu de la modernidad, una forma ideal interna que no se limite a ser un simple remedo de las múltiples formas históricas de manifestación de la modernidad, ni tampoco le sea impuesta a esta desde afuera?

Las identidades colectivas son el resultado de un entretejido de eventos, experiencias, símbolos, metáforas, mitos y narrativas que sean capaces de crear un argumento que le dé sentido a una historia compartida.

La construcción de la diversidad en Chile ha sido y es un proceso largo y complejo. Durante largos períodos se constata "el silencio de la diversidad". La autoimagen de Nación y Estado que se trató de construir requería la negación de las diversidades. Era su presupuesto fundamental. Sin embargo, esa idea de Nación parece concluir. Los últimos veinte años han sido intentos infructuosos de construir la unidad del Estado y la Nación en torno a las "ideas-fuerza" de carácter republicano, como se decía antiguamente. El país tiene conciencia de que su identidad nacional está erosionada. Los jóvenes no asisten 
ganosos al servicio militar y el sentimiento de Patria se complejiza con reivindicaciones étnicas, en que como señala Manuel Gutiérrez (2001), "el amor a la Tribu compite con el amor a la Patria".

Extrañamente, y aún tratándose de un país con altos niveles de integración, en los últimos tres años han surgido tendencias cada vez más disruptivas. El caso más expresivo es de los mapuches del sur del país, que han levantado banderas etnicistas y en que las demandas por autonomía política y territorial no están ausentes. Pero no son los únicos. En una investigación realizada en el marco de proyectos con fondos estatales (FONDECYT $\left.\mathrm{N}^{\mathrm{0}} 1020266,2001\right)^{11}$ con grupos juveniles urbanos, se percibe una intensa demanda por diversidad, por un modelo alternativo de integración, diferente al propuesto por el Estado nacional del período industrialista que dominó el siglo veinte. Hay regiones que hoy sostienen un proceso de demandas por una mayor posibilidad de control de sus decisiones.

\section{IV .2.2. Identidad colectiva.}

Discurso histórico, a modo de memoria colectiva se presenta aquí con la intensión de evidenciar el sustrato de una serie de discursos que los artistas del siglo XXI traen a colación a través de sus obras

La identidad colectiva se construye y se organiza en torno al rito, a los mitos colectivos en los cuales los habitantes se identifican, a la noción del tiempo que acompaña a la nostalgia, a la visión "subjetiva" del tiempo. La identidad cultural es una suma de depósitos añorados por los habitantes presentes en esa sociedad que miran el pasado con una cierta nostalgia. Es por ello que las identidades son irracionales, obedecen a recuerdos, creencias, afectos, nemotecnias colectivas que hacen de un grupo humano un todo con sentido, con pasado y con futuro, allí en la comunidad, es donde las cosas adquieren sentido, proyección verdadera (Bengoa, 1996).

En América Latina y en Chile en particular, la escuela y la enseñanza pública ha sido tradicionalmente el instrumento de homogeneización cultural, de trasmisión de los símbolos patrios, comunes a todos los ciudadanos. En los países de alta migración extranjera, Argentina por ejemplo y en menor medida en Chile, la escuela ha jugado un papel central. En muchos países, como en Chile desde el siglo XIX, ha sido el ejército, que al reclutar a los jóvenes para la guerra, los ha puesto no solo bajo una misma bandera sino

\footnotetext{
${ }^{11}$ La Comisión para el Bicentenario de la República ha sido creada por el Presidente de Chile, Sr. Ricardo Lagos, con el objeto de promover un debate nacional en la perspectiva de los 200 años de la Independencia de Chile. El autor es miembro de esa comisión.
} 
que los ha formado en los valores ciudadanos, en el rigor de la obediencia militar y en la disciplina necesaria para la sociedad industrial.

Los discursos nacionales y nacionalistas son o han sido casi siempre discursos estatistas, intentos de dar unidad a la diversidad, coherencia a las incoherencias de la historia, sentido a las contradicciones. Los discursos nacionalistas más virulentos son generalmente aquellos que se construyen cuando no existe un Estado que represente los intereses expresados o deseados.

En Chile se suele señalar que el discurso nacionalista y racial es débil. Probablemente se deba a que no es preciso la existencia de discursos altamente constructivista ya que existe un nacionalismo auto aprendido y bebido desde la cuna, sobre el cual no hay dudas en la población. Solo los procesos inmigratorios recientes están debilitando este rasgo.

IV .2.3. El miedo a la diversidad.

Durante un largo período histórico de la sociedad chilena, las ideas respecto a la identidad de nuestra sociedad estuvieron dominadas por la oposición entre civilización y barbarie. Es evidente que esta manera de comprender a los otros y comprenderse a sí mismo, impedía la realización de estudios objetivos del mundo rural, regional, indígena y a la vez, impedía la comprensión de los asuntos étnicos. La cuestión étnica fue, durante muchos años y principalmente en el siglo XIX, reducida a un asunto histórico.. Para algunos de los más destacados historiadores chilenos, como por ejemplo Mario Góngora, era el asunto decisivo en la interpretación social, política y sobre todo cultural de la sociedad chilena. Como ya ha mencionado, el tema desaparece de las páginas de la historia durante el siglo diecinueve en que los historiadores se ocupan centralmente de la formación del Estado, la lucha política y las acciones del gobierno. Sin embargo, hoy vemos que el hecho de que los "pueblos originarios" reclamen un espacio de presencia en el imaginario nacional como una cultura viva, se ha convertido en un tema de absoluta vigencia que se ha incorporado a nuestra vida cotidiana y forma parte ya de todo discurso político que se precie de correcto.

La oposición entre civilización y barbarie dominó por años la concepción histórica y social del país y construyó el temor a reconocer la diversidad. El Estado se transformó en el símbolo de la civilización frente al conjunto de fenómenos que recorrían en particular las regiones (denominadas provincias), los campos llenos de bandoleros, los campamentos mineros plagados de pillos y gente violenta y los suburbios de las ciudades. La noción de 
barbarie permitió comprender la sociedad chilena hasta muy entrado el siglo veinte y posibilitó aplicar políticas represivas frente al bajo pueblo, sin que los "integrados" reparasen en ello.

Afortunadamente, la erosión de la dualidad, civilización y barbarie, contribuye a fomentar la diversidad cultural, en los últimos años.

Levi Strauss (1993) en su discurso ante la UNESCO defiende la diversidad e incluso los estereotipos. El principio de alteridad aparece como un elemento constitutivo de las sociedades y no existiría el principio de identidad sin el de alteridad. La mirada del otro no siempre debe ser vista como negativa dice el antropólogo. Adelantando su mirada a lo que se venia perfilando en el mundo, la emergencia y fomento de las identidades locales en medio de la globalización. Geertz (1996) discute esa postura al tratar los usos de la diversidad en un artículo al respecto: "Parece que el mundo va pareciéndose más a un bazar kuwatí que a un club de caballeros ingleses" dice, señalando que es preciso comprender la cultura como un collage.

\section{IV .2.4. Identidad e identidades.}

Los grupos humanos más diversos buscan su propia imagen. ¿Qué somos? La búsqueda del nosotros pareciera marcar a las sociedades contemporáneas, quizás como una conducta reactiva frente a la globalización de las comunicaciones así como a la transversalidad de la cultura visual.

Una mirada positiva y dinámica de las identidades considera que todas las culturas son esencialmente dinámicas, interdependientes y cambiantes. Las identidades son procesos cambiantes producto de la construcción permanente. Como señala Castel, R. (1997), las identidades se van metamorfoseando, esto es, van cambiando permanentemente. Parte de lo antiguo es recuperado y al mismo tiempo transformado. Es por ello que nunca se puede afirmar de la existencia de una identidad social. Siempre la identidad es un proyecto.

La búsqueda de la propia identidad social y cultural pareciera ser una de las características de los tiempos que vivimos y en esto Chile no se escapa de la regla general, ello se expresa a través de una búsqueda compulsiva de signos identitarios provenientes, ya sea de la memoria o bien en el ámbito de la cultura popular. Una revisión de lo vernacular a través de la producción artístico-pictórica marca la primera década del siglo XXI, como veremos más adelante. 
Las identidades locales, comunitarias, o de cualquier tipo (en particular las étnicas) se construyen en la medida que reconocen una alteridad. El centralismo santiaguino, los huincas (extranjeros) para los mapuches.

La cuestión central en el debate acerca de las identidades es el principio de alteridad. La conciencia de un otro pareciera determinante para establecer y construir la conciencia de un nosotros. Chile se construyó, al decir de Góngora (1979) y otros historiadores frente al "otro indígena", tanto el indio al interior de las fronteras, como el indio fuera de ellas, el latinoamericano. Se transformó en mito patrio el considerarse diferente a los países ingobernables de América latina y auto declararse de raza blanca o mestiza y de carácter europeo ("Los ingleses de América").

El principio clásico de alteridad se basaba en el jus solis y el jus sanguinis. En el primero, la identidad se da por el territorio y los otros son los que viven en espacios separados. En el segundo caso, étnico, la identidad se da por el poseer o no poseer los rasgos de la etnia. El primero es inclusivo el segundo excluyente. Chile ha sido tradicionalmente abierto al extranjero construyendo su identidad en base al principio territorial, lo que le ha permitido recibir migraciones y adaptar su población a los cambios por ella producido. La historia del siglo veinte, desde el italiano descendiente Alessandri hasta el suizo descendiente Frei es testimonio de ello.

Las migraciones internas han jugado un papel muy importante en la conformación de identidades nacional estatales y en la disolución de identidades locales regionales o locales. Santiago (la capital) se construyó con poblaciones migrantes o del campo a la ciudad o del extranjero. Arica, en el extremo norte, también sometido a la frontera indígena andina, se construye en una política explícita del Estado de chilenización.

\section{IV .2.5. Lazos primordiales e identidad}

Los llamados lazos primordiales (o lo que la gente cree que son sus lazos primordiales o ancestrales) pueden ser construidos o no, es decir las identidades sociales son producto de la construcción social. Malek Chebel (1998) señala que la "la identidad no es un dato biológico....sino...una dimensión interactiva compuesta por una parte por elementos innatos y por la otra por los datos sociales, culturales y familiares...La identidad es una acumulación y un resultante." A partir de allí se puede comprender que los lazos así llamados primordiales son también un objeto de construcción, un objeto de acumulación y finalmente, un resultado de ello. Uno de las características de lo que podríamos llamar "identidad nacional" y que tiene que ver con la cultura popular, que es donde se 
distinguen con mayor fuerza las tradiciones que son precisamente resultante de la acumulación de datos que se inscriben en la cultura y juegan un papel preponderante en la memoria colectiva.

Independientemente de los peligros que conllevan los procesos de autoidentidad extrema y los fundamentalismos identitarios del tribalismo moderno no cabe duda que las identidades grupales son la principal fuente de sentidos, a partir del sentimiento de pertenencia identitaria, epocal y geográfica.

La globalización actual, al no poseer un principio de racionalidad más que instrumental, ha conducido a un creciente sin sentido. La globalización de las comunicaciones, de los bienes y servicios, de gustos y sistemas de recreación y tiempo libre, es un ámbito que no otorga significado a la vida privada de las personas.

Las identidades locales, en cambio, sí lo son. Otorgan sentido a los individuos. Pues permiten establecer con relativa claridad un conjunto de preguntas de las cuales es difícil desentenderse para sobrevivir: cuál es el origen, quién forma la comunidad con la cual me identifico, cuáles son los principios morales que la constituyen y cuáles son los ideales que defiende.

En un largo período histórico los discursos nacionalistas lograron dar la base afectiva a los grupos e individuos en muchas sociedades del mundo y en Chile en particular. La crisis (erosión) de estas lealtades producto de la misma globalización conduce en la actualidad a la revalorización de los espacios locales y las adscripciones particulares (religiosas, de género, ecologistas, etc.) como fuente de sentido o de la vida personal. En Chile, ciertos rasgos característicos de este proceso se pueden observar cuando se abren paso propuestas que inscriben, en el medio local, una conciencia autorreflexiva respecto al medio pictórico, sus recursos fundamentales y el cuestionamiento al límite que separa al artista, su obra de la realidad contextual, en un momento de expansión de las expectativas de transformación socio-política. Autorreflexión ya inaugurada en los años 70, pero que cobra su real dimensión y expresión con el retorno a la democracia los años 90.

\section{IV .2.6. Múltiples identidades.}

El "hibridismo" se entiende por la yuxtaposición en las culturas latinoamericanas, por ejemplo, de un sinnúmero de fragmentos culturales (y por tanto identidades culturales) las que no tienen muchas veces más relación que el estar pegadas como un collage.

Pareciera, hipotéticamente por cierto, que en Chile la sociedad se encuentra en un tiempo transicional, en que de la unívoca imagen de identidad nacional, se pasa a formas cada vez más complejas. La existencia de identidades múltiples es una de las 
características del fenómeno identitario moderno (o postmoderno según algunos autores). Aunque en el territorio chileno esto se produce desde la era precolombina con las sucesivas migraciones que dieron origen a las diversas culturas que se sucedieron y convivieron en el país, desde el norte con los pueblos atacameños, incas, chinchas, diaguitas, etc., en el centro sur los araucanos, mapuches, onas, chonos, y otros, hasta el sur austral con la cultura de los alacalufes, los huilliches, selknam, entre varias que se desarrollaron de acuerdo a la geografía local. Para pasar luego a la conquista por los españoles y las reiteradas migraciones europeas.

Hoy, la globalización creciente a la que está sometido este pequeño país del sur de América conlleva la necesidad de comprender un sistema de identidades superpuestas, en que los individuos transiten sin mayores traumas.

En la sociedad chilena se habría fragmentado la identidad estatal nacional popular construida durante el siglo veinte. Hay fragmentos que han sufrido con mayor evidencia la erosión. Y otros se mantienen con mayor vigor.

Los fragmentos más erosionados dicen relación con los símbolos de la nacionalidad y con la $<<$ Historia Oficial $>>$ que une o uniría a los chilenos. La imposibilidad de acuerdo frente a los hechos históricos próximo pasados es un hecho evidente de lo que se señala. No hay una misma interpretación de los hechos históricos y más bien la Historia divide. La identificación frente a símbolos, de pretendido carácter nacional, es débil.

Se ha producido un quiebre o desconfianza respecto a lo que supuestamente se consideraba como tradicional en Chile. Larraín (2005) señala que es consecuencia de la globalización y se pregunta si acaso es negativo, tomando en cuenta que la llamada tradición de carácter rural, agrario, hacendal, estaba contaminada de autoritarismo, machismo, racismo y numerosos otros atributos hoy día poco aceptables por el conjunto de la población.

Hay fragmentos de la identidad nacional menos erosionados, como son aquellos que se relacionan con la "manera como nos ven" desde el extranjero, y diversos aspectos que hacen aparecer al colectivo nacional como un cuerpo denso frente a otros diferentes, en particular frente a las crisis que afectan a muchos países latinoamericanos.

Los fragmentos identitarios más fuertes, sin embargo, son todos aquellos que se relacionan con el mundo privado, social. Como se ha dicho, se ha producido una "privatización de las identidades", en que cada grupo se manifiesta en el imaginario de su comunidad. Los paisajes, las maneras de convivir, la lengua y diversos aspectos cotidianos de la cultura aparecen como la fuente de mayor sentido, emoción y capacidad de aglutinamiento colectivo. 
IV.3. Tres momentos y tradiciones del desarrollo de la formación artística en Chile.

En este apartado, el lector podrá identificar no solo el origen, sino también las filiaciones que asume la práctica pictórica en Chile en el marco de la formación académica como rasgos que perduran hasta hoy.

La práctica artística en Chile, en especial la pintura, se desarrolla primeramente al interior, de la Academia de Pintura (1849) y luego en las escuelas de formación artística universitaria: Universidad de Chile (1910) y Universidad Católica (1956). Se trata de dos modelos implantados en Chile en momentos distintos y con tradiciones epistemológicas diferentes. Posteriormente, a partir de 1981 (Decreto Ley No 1/1980), podemos señalar un cambio. A las dos universidades "tradicionales" se les ha sumado ya en esa fecha, la Universidad de Concepción, U. Católica de Temuco, U. Austral, U. Playa Ancha y Universidad ARCIS, debido a la multiplicación del espectro de universidades que imparten la formación artística que de algún modo fusionan y sincretizan los modelos anteriores (luego volveremos sobre este punto). Lo anteriormente señalado, evidencia el contexto en el cual se desarrollada la pintura reconocida como "pintura oficial" en Chile. La universitarización de la práctica artística hace que casi no exista la producción independiente, esto debido a la existencia de artistas autodidactas que graviten en el arte nacional al mismo nivel de significación que aquellos provenientes de las escuelas es mínimo (alrededor del 9\%). En Chile, los artistas sostienen una filiación declarada con la escuela que los formó. No es difícil rastrear en la historia de los dos modelos de enseñanza, los patrones formales que se sostienen hasta el día de hoy. Revisemos rápidamente dicha historia.

En 1849 se funda la Academia de Bellas Artes de Chile. Previo a esta fecha la formación en arte se realizaba de modo precario en el Instituto Nacional (fundado en 1813). En 1849, con la creación de la Academia de Pintura, los estudios artísticos se desarrollan, en nuestro país, de forma organizada y sistemática. El director de esta Academia, quien da el sesgo que la caracterizará en adelante, es el pintor napolitano Alejandro Cicarelli. Su experiencia europea le daba autoridad para estructurar los estudios de las Bellas Artes de acuerdo a los métodos más avanzados en su época.

De los datos fundacionales descritos anteriormente, se puede podemos deducir que la enseñanza sistemática de la pintura, en la formación artística, se inicia en Chile en la Academia de Bellas Artes (1849) que dio origen, en 1910, a la Escuela de Bellas Artes de la Universidad de Chile. La concepción artística que define su enseñanza encuentra su 
referente en las Academias de Bellas Artes francesas, cuya concepción de la representación se basa en las nociones del arte neoclásico ${ }^{12}$, que sostiene que la belleza en el arte es superior a la belleza en la naturaleza, por ello lo importante es conocerla, observando sus leyes en la obra de los maestros. Partiendo por el arte greco- romano.

\begin{abstract}
“(...)aquel que no ha estudiado o dibujado las más escogidas obras antiguas o modernas (...) no puede mejorar las cosas que copia de la vida dándoles la gracia y la perfección en que el arte sobrepasa a la naturaleza”. (Vassari (1665) en Gómez Molina $1995)^{13}$
\end{abstract}

El aprendizaje se inicia con el estudio de las soluciones y obras producidas por los antiguos y/o grandes maestros, donde el profesor, también en su calidad de maestro, es otro ejemplo digno de imitar.

Siempre es necesario copiar la naturaleza y aprender a ver bien. Por este motivo es preciso estudiar a los antiguos y a los maestros, no para imitarles, sino, una vez más, para aprender a ver. (Ingres 1780-1867) $)^{14}$

Esta concepción del arte donde la belleza se concibe a partir de cánones ideales que se convierten en normas y leyes estéticas, cae en un manierismo que finalmente pone en crisis a la propia Academia, introduciéndose una nueva tendencia: el realismo naturalista que si bien conserva el concepto renacentista de las proporciones, su mirada se orienta, ya no hacia la belleza sublime, sino al natural, a la escena cotidiana, a ver el modelo a través de la sensibilidad del artista, influencia de la concepción romántica, que contradice la aplicación de cánones matemáticos y normas en la representación del natural, dejando al ojo sensible del artista este tipo de soluciones. Esto confiere al maestro y a su expertiz la autoridad de decretar lo correcto o incorrecto en una representación.

\footnotetext{
${ }^{12}$ En el proyecto de investigación FONDECYT Regular 2015 que desarrolla el académico Pedro Zamorano director del Instituto de Estudios Humanísticos "Juan Ignacio Molina" de la Universidad de Talca. Indaga la falta de una estrategia explícita del Estado en los procesos artísticos generados en Chile. En su texto "Ausencia de una política o política de la ausencia. Institucionalidad y Desarrollo de las Artes Visuales en Chile" Zamorano sostiene que, en un sistema desregulado, la única preocupación estatal consistió en acciones de carácter administrativo vinculadas al financiamiento en formación, difusión y patrimonio. De igual modo, señaló que en ausencia de un marco programático explicitado, las decisiones quedaron expuestas al voluntarismo y a los personalismos, que actuaban tanto al interior como fuera de la esfera gubernamental.
}

Según señala Zamorano, la institucionalidad artística en Chile (enseñanza, difusión y patrimonio) ha estado fuertemente imbricada con el Estado. Desde la fundación de las primeras instancias de formación académica - la Academia de Pintura y la Escuela de Artes y Oficios, en 1849 , y la clase de Escultura en $1854-$, ha habido una influencia gubernamental sobre este campo, que se ha expresado a través de los distintos consejos y entidades creadas, o través de las decisiones económicas y administrativas que, en su momento, tomaron las autoridades.

De otra parte, y en lo que respecta a la ideología estética - el canon-, inicialmente, se adoptó el modelo de las academias europeas, la francesa y la italiana especialmente, el que fue reeditado con cierta literalidad en nuestro país.

Este modelo tuvo en su desarrollo en Chile matices distintos, abarcando concepciones propias del neoclasicismo, el romanticismo y el realismo, cuando no planteamientos sincréticos.

${ }^{13}$ Lino cabezas, Las lecciones del dibujo pp. 349

${ }^{14}$ Traducido por Marchan, S. Revista de Ideas Estéticas $\mathbf{N}^{\circ} 101,1968$ pp. 100 
El segundo modelo se implanta en Chile en el año1959, con la fundación de la Escuela de Arte de la Universidad Católica, por iniciativa de Don Sergio Larraín GarcíaMoreno, arquitecto y Decano de la Facultad de Arquitectura, con la colaboración de otros arquitectos y artistas.

Colaboró, además, en este proyecto el departamento de Arte de la Universidad de Yale, dirigido en ese tiempo por el maestro Joseph Albers, destacado artista y ex docente de la Bauhaus, junto a otros profesores del mismo departamento. Se trataba de crear un centro de arte contemporáneo con una nueva metodología para la enseñanza de las artes plásticas, con conceptos renovados del lenguaje visual y nociones de un arte ligado al conocimiento científico y a la psicología de la forma. Aunque la influencia es hoy día discutible; de algún modo la concepción relativa a la enseñanza del arte guarda relación con los modelos heredados de la Bauhaus, como lo escuela de diseño de Basilea, de hecho en sus inicios la formación en diseño, arte y arquitectura presentan asignaturas comunes.

Con la creación de esta nueva Escuela de Arte (1959) se introduce en nuestro ámbito educativo otro modelo de enseñanza, en este caso alemán y contemporáneo, que enfatiza el estudio analítico del natural y la configuración estructural para su representación, junto con los principios y aportes de la psicología Gestalt. Corresponde decir que esta escuela desarrolla una concepción modernista de la educación, que niega los referentes academicistas y la copia como forma de aprendizaje; asimismo el estudio de la obra de los maestros, a modo de ejemplos y soluciones dignas de imitar; por el contrario, propende al desarrollo de la capacidad de observación analítica, a la creatividad y autonomía del estudiante. Es más, la idea de dibujar, lejos de consistir en la copia de yesos, procede con una organización elemental antes que cualquier otra descripción parcial del objeto, de modo que la estructuración de la imagen real vendrá dada por un conjunto elemental de trazos, que mediante una congruente organización en el plano, manifieste una aproximación básica al objeto o figura a representar (Villegas y Mayor, 1992).

Como se puede observar, los modelos y concepciones expuestas tienen su origen en Europa, no nacen como el resultado de un devenir propio de concepciones estéticas inherentes a nuestra cultura, ni que consideren quizás la inclusión de aspectos y concepciones estéticas propios, sino como la necesidad de desarrollar modelos que nos asemejen a aquellos que son considerados como nuestros referentes culturales. Se adjunta a ello la dificultad, por la distancia geográfica, de obtener referentes de primera línea. Generalmente, el material didáctico que llega es de tercer o cuarto orden, por lo que la trasmisión de saberes, se basa mayoritariamente en la comunicación oral de aquello que el maestro oyó y practicó bajo la tutela de su profesor y que ahora va a transmitir, según su 
versión, a los que son sus alumnos. Así las concepciones originales se desperfilan, pierden el sentido y se mezclan con otras ideas y concepciones que pudieran, incluso, ser contradictorias, quizás allí emerjan rasgos propios producto de la hibridación de las concepciones vistas.

El tercer momento estaría determinado por el actual panorama de la formación artística en Chile. A partir de la década de los 90, se ha diversificado y las escuelas de arte se han multiplicado, con la emergencia de una gran cantidad de universidades privadas que, a su vez, han creado nuevas escuelas de formación artística.

“El Decreto con Fuerza de Ley Nº 1 de diciembre de 1983, cambió definitivamente la perspectiva de la educación superior en Chile, pues posibilitó la creación de universidades privadas, hecho que multiplicó la oferta universitaria en casi todas las áreas del conocimiento. Las artes visuales o artes plásticas no se mantuvieron ajenas al fenómeno, no obstante la creación de escuelas de arte de nivel universitario no ha sido veloz ni abundante: en 30 años solo se han creado 11 programas nuevos". (Villegas, 2012) ${ }^{15}$

Sin embargo no se visualiza que en su origen haya una nueva mirada o propuesta en la formación artística, sino una concepción más bien híbrida y poco nítida, tanto de la formación como del arte mismo. Ello queda en evidencia en las conclusiones que presentadas ante la comisión de acreditación de las carreras artísticas de las universidades chilenas.

“(...)es posible que existan perfiles de egreso elaborados por personas y no por la comunidad formativa y ante esto, la posibilidad de que ante cambios de la autoridad o en el proyecto formativo, es posible cambios en los perfiles, considerando además que cada Escuela del área tiene su ideología”. (...) el tema abre un debate, que se debiera realizar, relacionado con la generación de conocimiento sobre lo que es y debiera ser la educación en formación de artistas”. $(\mathrm{CNCA}, 2010)^{16}$

\footnotetext{
${ }^{15}$ D.F.L. $\mathrm{N}^{\circ}$ 1.- Santiago, 30 de Diciembre de 1980.- Visto, lo dispuesto en el decreto ley $\mathrm{N}^{\circ} 3.541$, de 1980, FIJA NORMAS SOBRE UNIVERSIDADES

Ver también en http://www.leychile.cl/Navegar?idNorma=3394\&r=1. CALIDAD EN LA EDUCACIÓN No 36, julio 2012223

${ }^{16}$ Relato del focus group de las artes visuales, en "Mesas técnicas de Educación Superior" Junio 2010.
} 
A pesar de ello y reconociendo que la mayoría de los artistas docentes (95\%), en Chile, son egresados, licenciados o bien han tenido algún tipo de formación en las escuelas de arte nacionales, la práctica de la pintura, en el día de hoy y a diferencia de lo ocurrido en generaciones anteriores, no se rige ni manifiesta concordancia exacta con los modelos de enseñanza- aprendizaje practicados en sus aulas. Más bien todo lo contrario, en general, la práctica artística y asimismo la pintura, muestra de un tiempo a esta parte, una historia, un recorrido y una forma de ser absolutamente independiente y desligada de los procesos y concepciones desarrolladas al interior de las escuelas de formación artística, aunque sus protagonistas sean los mismos.

"La oferta de programas de licenciatura en arte que las universidades entregan al mercado nacional, paradójicamente, no es creativa ni variada. Dichos programas poseen rasgos estructurales comunes con la tendencia a reproducir un modelo curricular, lo que se manifiesta en similares procesos de enseñanza-aprendizaje en el aula, sistemas evaluativos y enfoques epistemológicos" (Villegas I. 2012) ${ }^{17}$.

Según Villegas (2012, pp. 220-231) no se evidencian grandes diferencias ni distinción en dichos modelos, debido a la existencia de una diversidad de universidades que dictan programas de licenciatura en arte e incluso presentando ideas y posturas diversas, en lo que a su modelo de formación artística se refiere. Más bien se reitera la misma concepción y modelo educativo. ${ }^{18}$

\section{IV.4. La Experiencia Estética}

El símbolo puede manifestar un modo contingente o ser revelador de sí mismo. Es decir, puede reflejar un significado virtualmente contenido en la estructura semántica que le sirve de base o irradiar sin limitaciones, a través de una suerte de espiritualización de la forma en que aparece. Ocurre lo primero, cuando el modo de remitir a un significado es convencional; lo segundo, cuando el sentido se hace patente a partir de la naturaleza propia de la cosa que representa. El rasgo esencial de cualquier simbolismo lo constituye la heterogeneidad entre el signo y lo denotado por él (Schwartzmann, 1966).

\footnotetext{
${ }^{17}$ El mismo Villegas agrega, al respecto, que la estructura de la enseñanza se basa en programas de promedio 4,2 años de duración con mallas curriculares de rasgos comunes: promedio de 45 créditos por semestre; una línea de cursos troncales programados en orden de complejidad o avance, centrados en la producción de obras; talleres de técnicas tradicionales; incorporación de recursos digitales como herramientas de producción de obra; exigencia para graduarse mediante un proyecto de obra y un texto.

${ }^{18}$ Perfil de Las Licenciaturas en Arte del Sistema Universitario Chileno// Calidad en la Educación No36, julio 2012

http://www.cned.cl/public/secciones/seccionrevistacalidad/revista_calidad leer revista.aspx?idPublicacion=73
} 
La presencia de elementos expresivos desbordan lo enunciado según Schwartzmann (1966), de ello se desprende que una comprensión de la expresión de las artes, cuando es compleja, es una construcción social e histórica, un producto conjunto, aunque se deba captar individualmente (Danto, 2002).

El lenguaje simbólico al que pertenecen las obras de arte es estructuralmente un lenguaje plural, cuyo código está hecho de manera que cualquier obra tenga múltiples significados (Parsons, M. J. 2002); de acuerdo a la teoría polisémica, lo esencial en las obras de arte es que suscitan interpretaciones divergentes. La experiencia estética, afirma el autor, solo ocurre cuando nuestra comprensión sobrepasa el nivel de reconocimiento y transforma los elementos reconocidos en un material, en el que selecciona determinaciones que relaciona entre sí.

\section{TRABAJO DE CAMPO}

El objeto de estudio lo constituye un conjunto de pinturas, elaboradas en Chile por 180 artistas, que han participado en muestras relevantes en los últimos 15 años. Estos datos se extrajeron de documentos (catálogos y libros) de los repositorios el MNBA y en el MAC, tal como se señala en el ítem 1.3.5.

El trabajo de campo se realiza con relación a los siguientes pasos:

1- Definir unidades de recolección, en este caso la producción pictórica de artistas nacionales de reconocida presencia en la escena artística nacional, permite una aproximación e identificación de las unidades de análisis que son aquellas pinturas que presentan signos, símbolos, vinculados al imaginario cultural nacional. Las obras son seleccionas en relación con la evidencia de dichos rasgos ya sea en un nivel denotativo o connotativo.

2- Identificación y selección de las unidades de análisis. Producción pictórica nacional con referencia al imaginario cultural identitario. El mecanismo que estructura la búsqueda, se expone en página 13 de este documento. Las tipologías de objetos, paisajes y retratos se pueden consultar en el capítulo siguiente 
3- El material recopilado ha sido extraído de catálogos, registros realizados por el investigador, páginas web (mencionadas a pie de cada ficha de artista), el acceso al material se realizó a través de semanas de trabajo en terreno (bibliotecas y archivos físicos y digitales), este aspecto implicó una demora no considerada a inicios de este trabajo, el tener que realizar un seguimiento a través de exposiciones y publicaciones.

4- Se recopila el material a través de registros fotográficos in situ, bajada de archivos web textos e imágenes, estudio de catálogos y libros ad hoc, observación y análisis del material visual.

5- El análisis de la información con relación al propósito enunciado. El método utilizado, a modo de guía es la clasificación en unidades temáticas (género) descripción, selección de unidades de análisis, análisis aspecto denotativo y/o denotativo, interpretación, conceptualización y conclusión. El análisis empieza por la codificación:

a) Codificación abierta se atribuyen nombres y categorías conceptuales a las partes relevantes de las imágenes De los datos visuales surgen categorías conceptuales, atributos y dimensiones.

b) Codificación axial; se ubican las categorías principales en el modelo paradigmático (Parson 2002), el cual permite ordenar la observación y el registro de las evidencias, en cuanto a elementos constituyentes de la imagen, sus posible connotaciones y el contexto nacional, el fenómeno principal y su vinculación con el imaginario cultural nacional.

c) Codificación selectiva, se establece para cada categoría una lista de cotejo proveniente de lo que tradicionalmente se vincula con el imaginario cultural identitario.

6 - El análisis es asistido por un programa informático. EXEL en línea. (http://duoc.tipddy.cl/index.php/survey/index/sid/216316/newtest/Y/lang/es)

7- Las unidades de análisis son las pinturas que presenten elementos que hacen referencia al imaginario cultural nacional como rasgo identitario.

8- Limitaciones del trabajo: La limitada producción, difusión, información y publicaciones referidas a la producción pictórica contemporánea en Chile, a inicios de la década 20002010, es un aspecto que limita el estudio. Nos encontramos con escasas fuentes de información. En efecto, una de las mayores dificultades que ha incidido en la fluidez del 
trabajo la encontramos en la carencia de estudios y publicaciones desde la crítica y teoría del arte.

\section{Trabajo de Campo}

En las obras propuestas por los artistas chilenos, según Gaspar Galaz (2002), hay algo que las distingue y no es que coloquen las tradicionales imágenes representativas de una cultura agraria, como el huaso, las espuelas o la botella de vino. Pero sin embargo observamos ciertas características que bien podrían ser muy nuestras, referidas a un comportamiento colectivo, más exactamente a un imaginario cultural identitario propio de nuestro país. Hay características, imágenes, actitudes que nos van identificando así como otras, que naturalmente se han ido perdiendo, porque las identidades no son situaciones estables sino que se modifican de acuerdo a los contextos.

Por otra parte incide en la conciencia colectiva, los procesos de globalización e internacionalización acelerada de la economía, de los medios y por ende de la cultura y el arte en los últimos años. Al mismo tiempo, la ampliación de los espacios de circulación y exhibición del arte no solo a nivel local, sino en el plano internacional, así como el peregrinaje de los artistas en circuitos internacionales ha implicado como consecuencia lógica una revisión de la historia nacional del arte, de la pintura y de los imaginarios que la han alimentado. Ello ha motivado en gran parte este trabajo la búsqueda e identificación de aquellos elementos que pudiesen distinguir la pintura chilena y a través de ésta algunos aspectos identitarios de la cultura nacional.

Nuestro trabajo de campo se inicia con la identificación de artistas pintores nacionales que de algún modo son representativos de la escena actual, para ello se 
identifican y registran autores que circulan en el ámbito nacional especialmente en torno al MNBA, el MAC, galerías estatales y publicaciones que recogen y dan cuenta de la escena

\begin{tabular}{|c|c|c|c|c|c|}
\hline \multirow{3}{*}{ ual } & Magdalena Atria, & Catalina Donoso, & Cristian Jaramillo & Gerardo Pulido & Jorge Tacla \\
\hline & Carlos Altamirano & Gonzalo Díaz & Rainer Krause & M. Victoria Polanco & Manuel Torres \\
\hline & Pilar Aguirre, & Eugenio Dittborn, & Sebastián Leython & Ángela Ramírez & Bruna Truffa \\
\hline \multirow{2}{*}{ del } & Natalia Babarovic & Arturo Duclós & Consuelo Lewin & Pablo Rivera & Francisco Valdés \\
\hline & José Balmes & Josefina Fontecilla & Gonzalo Mezza & Carolina Ruff & Rodrigo Vega \\
\hline \multirow{2}{*}{ arte } & Yeniferth Becerra & Ana María Fell, & Carlos Montes de Oca & Patricio Rueda & Ignacio Valdés \\
\hline & Mónica Bengoa & María Fca. García & Norton Maza & Andrés San Fuentes & Andrés Vio \\
\hline \multirow{2}{*}{ en } & Julen Birke & Andrea Goic, & Livia Marín & Carolina Salinas & Eugenia Vargas \\
\hline & Macarena Bordalí & Nury González, & Kika Mazry & Patrick Steeger & Ricardo Villarroel \\
\hline \multirow[b]{2}{*}{ gen } & Víctor Hugo Bravo & Ignacio Gumucio & Claudia Missana & Cristina Silva & Alejandra Wolf \\
\hline & Rodrigo Cabezas & Josefina Guillisasti & Carlos Navarrete & Mariana Silva & Alonso Yañez \\
\hline \multirow{3}{*}{ eral } & Claudio Correa & Patrik Hamilton & Mario Navarro & Cristian Silva Avaria & Francisca Yáñez \\
\hline & Mría.Elena Cárdenas & Claudio Herrera & Bernardo Oyarzun & Antonio Silva V. & Camilo Yáñez \\
\hline & Paola Carocca & Alfredo Jaar & Álvaro Oyarzun, & Ximena Somoza & Mario Z \\
\hline $\mathrm{y}$ & Alexis Carreño & Voluspa Jarpa & Sebastián Preece & Damián Shopf, & Enrique Zamudio \\
\hline
\end{tabular}

de la pintura en lo particular. En ese sentido nuestra primera referencia surge del texto "la cultura durante el periodo de la transición a la democracia 1990-2005" publicado por el Consejo Nacional de la Cultura en 2006, a cargo de los editores Eduardo Carrasco y Bárbara Negrón, que comprende una especie de diagnóstico del desarrollo cultural y estado del arte en dicho período. En esta publicación se registran autores que se inician y desarrollan presencia ya en la década del '90 y se consolidan en la primera década del siglo XXI, proyectándose tanto en el ámbito nacional como internacional, en este último aspecto, representado a Chile en bienales como la de Sao Pablo, Venecia, Documenta de Kassel, la Habana y exposiciones internacionales organizadas y promovidas por el Consejo de la Cultura y el Ministerio de Relaciones Exteriores de Chile, entre ellos encontramos mencionados a artistas como: 


\section{V.1. Selección de las obras}

El seguimiento a estos artistas así como la incorporación de otros que fueron emergiendo dada su participación en exposiciones en el circuito nacional a partir del $2000 \mathrm{al}$ 2015 integran la unidad de recopilación y posterior unidad de análisis para este trabajo. Considerando su producción pictórica y participación en eventos como las exposiciones; "Cambio de Aceite, pintura chilena contemporánea", "Revisión Técnica, 100 pintores", "Chile arte Extremo", entre otras señaladas a inicios de este trabajo, su nominación en textos referidos a la historia y/o crítica del arte nacional así como sus referencias en repositorios tales como el MNBA, el MAC, y sus anexos en la Web "www.portaldelarte" "www.artistasplásticoschilenos" se fue configurando una nómina de 180 "pintores" que constituyen finalmente la unidad de recolección de información. Aunque el listado es extenso, conviene exponerlo:

UNIDAD DE RECOLECCIÓN

\begin{tabular}{|c|l|c|}
\hline \multicolumn{2}{|c|}{ LISTA DE ARTISTAS (180) } \\
\hline Ficha & \multicolumn{1}{|c|}{ Artista } & Género \\
\hline & \multicolumn{1}{|c|}{} \\
\hline 1 & Magdalena Atria & 3 ABSTRACCIÓN \\
\hline 2 & Carolina Fresno & 3 ABSTRACCIÓN \\
\hline 3 & Consuelo Lewin & 3 ABSTRACCIÓN \\
\hline 4 & Denisse Blanchard & 3 ABSTRACCIÓN \\
\hline 5 & Félix Lazo & 3 ABSTRACCIÓN \\
\hline 6 & Francisca Sutil Servoin & 3 ABSTRACCIÓN \\
\hline 7 & Susana Cox & 3 ABSTRACCIÓN \\
\hline 8 & Antonella Gallegos & 3 ABSTRACCIÓN \\
\hline 9 & Claudio Herrera & 3 ABSTRACCIÓN \\
\hline 10 & Francisco de Corcuera & 3 ABSTRACCIÓN \\
\hline
\end{tabular}




\begin{tabular}{|c|c|c|}
\hline 11 & Josefina Fontecilla & 3 ABSTRACCIÓN \\
\hline 12 & Fernando Cifuentes & 3 ABSTRACCIÓN \\
\hline 13 & Francisco Bustamante Gübbins & 3 ABSTRACCIÓN \\
\hline 14 & Leonardo Godoy Muhsam & 3 ABSTRACCIÓN \\
\hline 15 & MIguel De Lanu & 3 ABSTRACCIÓN \\
\hline 16 & Marcel Sola & 3 ABSTRACCIÓN \\
\hline 17 & Paca Jiliberto & 3 ABSTRACCIÓN \\
\hline 18 & Cristian Abelli Correa & 3 ABSTRACCIÓN \\
\hline 19 & Alamiro Carrasco & 3 ABSTRACCIÓN \\
\hline 20 & Andrés Vio & 3 ABSTRACCIÓN \\
\hline 21 & Camilo Yanes & 1 PAISAJE \\
\hline 22 & Ciro Beltrán & 3 ABSTRACCIÓN \\
\hline 23 & Andrés Díaz Contreras & 2 FIG. HUM. \\
\hline 24 & Daniela Gasic & 3 ABSTRACCIÓN \\
\hline 25 & Francisca Castaño & 3 ABSTRACCIÓN \\
\hline 26 & Francisco moran & 3 ABSTRACCIÓN \\
\hline 27 & Giancarlo Bertini González & 1 PAISAJE \\
\hline 28 & Jorge Guerrero & 3 ABSTRACCIÓN \\
\hline 29 & Manuel Torres & 1 PAISAJE \\
\hline 30 & Oscar Concha & 6 OBJETOS \\
\hline 31 & Pablo Jansana & 3 ABSTRACCIÓN \\
\hline 32 & Pamela Bozinovic & 3 ABSTRACCIÓN \\
\hline 33 & Patricio Court & 3 ABSTRACCIÓN \\
\hline 34 & Pablo Langlois Prado & 3 INSTALACION \\
\hline 35 & Rodrigo Galecio & 3 ABSTRACCIÓN \\
\hline 36 & Rubén Fernández Silva & 1 PAISAJE \\
\hline 37 & Samy Benmayor & 3 ABSTRACCIÓN \\
\hline 38 & Ximena Mandiola & 3 ABSTRACCIÓN \\
\hline 39 & Ximena Velasco & 3 ABSTRACCIÓN \\
\hline 40 & Alejandra Cigarroa & 3 ABSTRACCIÓN \\
\hline 41 & Loreto Corvalán & 2 LA FIG. HUM. \\
\hline 42 & Luis Cuello Madariaga & 6 OBJETOS \\
\hline 43 & Matías Movillo & 3 ABSTRACCIÓN \\
\hline 44 & Jorge Tacla & 3 ABSTRACCIÓN \\
\hline 45 & Sebastián Maqueira & 6 OBJETOS \\
\hline 46 & Pablo Langlois Prado & 5 CONCEPTUAL \\
\hline 47 & Alex Chellew Murillo & 5 CONCEPTUAL \\
\hline 48 & Bruna Truffa & 2 FIG. HUM. \\
\hline 49 & Carlos Bogni Fajardo & 6 OBJETOS \\
\hline 50 & Juan Dávila Willshaw & 2 FIG. HUM. \\
\hline 51 & Arturo Duclos & 5 CONCEPTUAL \\
\hline 52 & Eugenio Téllez & 5 CONCEPTUAL \\
\hline 53 & Juan Enrique Gabler & 5 CONCEPTUAL \\
\hline 54 & Rainer Kraus Dannheising & 5 CONCEPTUAL \\
\hline 55 & Gonzalo Díaz Cuevas & 5 CONCEPTUAL \\
\hline 56 & Judith Jorquera & 5 CONCEPTUAL \\
\hline 57 & Alejandra Wolff & 2 FIG. HUM. \\
\hline 58 & Benito Rojo & 2 FIG. HUM. \\
\hline 59 & Ismael Frigerio Ibar & 2 FIG. HUM. \\
\hline 60 & Matías Vergara & 2 FIG. HUM. \\
\hline 61 & Rene Poblete Urquieta & 2 FIG. HUM. \\
\hline 62 & Rodrigo Vega Rodríguez & 2 FIG. HUM. \\
\hline 63 & Adrián Gout Hiriart & 2 FIG. HUM. \\
\hline 64 & Catalina Abbott & 2 FIG. HUM. \\
\hline 65 & Klaudia Kemper & 2 FIG. HUM. \\
\hline 66 & Marcela Trujillo & 2 LA FIG. HUM. \\
\hline 67 & Norton Maza & 2 LA FIG. HUM. \\
\hline 68 & Víctor Hugo Bravo & 4 OTRO \\
\hline
\end{tabular}




\begin{tabular}{|c|c|c|}
\hline 69 & Ximena Cousiño Prieto & 2 FIG. HUM. \\
\hline 70 & Adolfo Bimer & 2 FIG. HUM. \\
\hline 71 & Fernando Allende Bellido & 2 FIG. HUM. \\
\hline 72 & Antonio Guzmán Quintana & 2 FIG. HUM. \\
\hline 73 & Alejandro Arrepol & 2 FIG. HUM. \\
\hline 74 & Carlos Eduardo Maturana (Bororo) & 2 FIG. HUM. \\
\hline 75 & Cesar Gabler Santelices & 2 FIG. HUM. \\
\hline 76 & Diego Hernández & 1 PAISAJE \\
\hline 77 & Gonzalo Cienfuegos Browne & 2 FIG. HUM. \\
\hline 78 & Ignacio Gana & 2 FIG. HUM. \\
\hline 79 & Jorge Opazo Ellicker & 2 FIG. HUM. \\
\hline 80 & Leonardo Casas García & 2 FIG. HUM. \\
\hline 81 & María Elena Cárdenas & 2 FIG. HUM. \\
\hline 82 & Mario Ibarra & 1 PAISAJE \\
\hline 83 & Pablo Ferrer Keith & 2 FIG. HUM. \\
\hline 84 & Basco Vazko & 2 FIG. HUM. \\
\hline 85 & Jorge González & 4 OTRO \\
\hline 86 & José Luis Villablanca & 6 OBJETOS \\
\hline 87 & Omar Gatica Rivera & 2 FIG. HUM. \\
\hline 88 & Rodrigo Cabezas Mardones & 3 OBJETOS \\
\hline 89 & Carmen Aldunate & 2 FIG. HUM. \\
\hline 90 & Víctor Alegría & 2 FIG. HUM. \\
\hline 91 & Soledad Alsina & 6 OBJETOS \\
\hline 92 & Cristóbal Anwandter & 2 FIG. HUM. \\
\hline 93 & Claudia Peña & 2 FIG. HUM. \\
\hline 94 & Eduardo García de la Sierra & 2 FIG. HUM. \\
\hline 95 & Felipe Christensen & 2 FIG. HUM. \\
\hline 96 & Iván Urbina & 2 FIG. HUM. \\
\hline 97 & Matías Camus & 2 FIG. HUM. \\
\hline 98 & Natalia Babarovic & 2 FIG. HUM. \\
\hline 99 & Pablo Serra Marino & 2 FIG. HUM. \\
\hline 100 & Patricia Ossa Brahm & 2 FIG. HUM. \\
\hline 101 & Roser Bru Llop & 2 FIG. HUM. \\
\hline 102 & Tatiana Lastarria Cádiz & 1 PAISAJE \\
\hline 103 & Francisco Álvarez Flores & 6 OBJETOS \\
\hline 104 & Josefina Guilisasti Gana & 6 OBJETOS \\
\hline 105 & María Paz García Silva & 6 OBJETOS \\
\hline 106 & Patrick Hamilton Dellomodarme & 6 OBJETOS \\
\hline 107 & Rosario Carmona Yost & 6 OBJETOS \\
\hline 108 & Ximena Cristi Moreno & 6 OBJETOS \\
\hline 109 & María Victoria Polanco & 6 OBJETOS \\
\hline 110 & Rodrigo Canala Echeverría & 6 OBJETOS \\
\hline 111 & Virginia Álvarez Ebner & 6 OBJETOS \\
\hline 112 & Mónica Bengoa & 6 OBJETOS \\
\hline 113 & Paul Fuguet & 6 OBJETOS \\
\hline 114 & Francisco Schwemberg & 6 OBJETOS \\
\hline 115 & Julia San Martín & 1 PAISAJE \\
\hline 116 & María Luisa Stewart Letelier & 6 OBJETOS \\
\hline 117 & Fernando Prats & 5 CONCEPTUAL \\
\hline 118 & Rodrigo Zamora & 1 PAISAJE \\
\hline 119 & Cristian Silva Avaria & 3 ABSTRACCIÓN \\
\hline 120 & José Caerols (yisa) & 4 OTRO \\
\hline 121 & Sebastián Leyton Saavedra & 6 OBJETOS \\
\hline 122 & Álvaro Oyarzun Sardi & 2 FIG. HUM. \\
\hline 123 & Daniela Montecinos Valdivia & 6 OBJETOS \\
\hline 124 & Patricia de Israel & 6 OBJETOS \\
\hline 125 & Patricio Rueda & 2 FIG. HUM. \\
\hline 126 & Voluspa Jarpa & 5 CONCEPTUAL \\
\hline
\end{tabular}




\begin{tabular}{|c|c|c|}
\hline 127 & Catalina Donoso Barros & 1 PAISAJE \\
\hline 128 & Sonia Etchard & 1 PAISAJE \\
\hline 129 & Carmen Gloria Cucurella & 1 PAISAJE \\
\hline 130 & Axel Ekdahl Escobar & 1 PAISAJE \\
\hline 131 & Francisco Moya & 1 PAISAJE \\
\hline 132 & José Basso Sáez & 1 PAISAJE \\
\hline 133 & Pablo Domínguez Díaz & 1 PAISAJE \\
\hline 134 & Roberto Geisse Navarrete & 1 PAISAJE \\
\hline 135 & Carlos Altamirano Valenzuela & 1 PAISAJE \\
\hline 136 & María Carolina Barros Sánchez & 1 PAISAJE \\
\hline 137 & Carolina Landea Burchard & 1 PAISAJE \\
\hline 138 & Felipe Cusicanqui Montes & 1 PAISAJE \\
\hline 139 & Loreto Enríquez & 2 FIG. HUM. \\
\hline 140 & Pablo Chiuminatto Muñoz & 1 PAISAJE \\
\hline 141 & Sebastián Garretón Kralemann & 1 PAISAJE \\
\hline 142 & José Ignacio León Silva & 1 PAISAJE \\
\hline 143 & Tatiana Josefa Álamos Adriasola & 3 ABSTRACCIÓN \\
\hline 144 & Patricia Claro & 1 PAISAJE \\
\hline 145 & Paulina Beyer & 1 PAISAJE \\
\hline 146 & Oscar Barra Sepúlveda & 1 PAISAJE \\
\hline 147 & Ruperto Cádiz Rivas & 1 PAISAJE \\
\hline 148 & Amelia Errázuriz & 1 PAISAJE \\
\hline 149 & Andrea Casanova & 1 PAISAJE \\
\hline 150 & Carlos Araya (Carlanga) & 1 PAISAJE \\
\hline 152 & Carlos Eguiguren & 1 PAISAJE \\
\hline 152 & Enrique Zamudio Rosales & 1 PAISAJE \\
\hline 153 & Silvia Gleisner & 1 PAISAJE \\
\hline 154 & José Balmes Parramón & 5 CONCEPTUAL \\
\hline 155 & Margarita Echenique & 3 ABSTRACCIÓN \\
\hline 156 & Luz María Benavente & 3 ABSTRACCIÓN \\
\hline 157 & Rodrigo Yánez & 5 CONCEPTUAL \\
\hline 158 & Claudio Correa Vasgallo & 4 OTRO \\
\hline 159 & Enrique Mathey Correa & 5 CONCEPTUAL \\
\hline 160 & Jorge Vilches & 2 FIG. HUM. \\
\hline 161 & Alejandro Quiroga Vial & 2 FIG. HUM. \\
\hline 162 & Muñoz De Marco & 3 FIG. HUM. \\
\hline 163 & Ignacio Gumucio & 1 PAISAJE \\
\hline 164 & Iván Duran & 2 FIG. HUM. \\
\hline 165 & Juan Martínez Bengoechea & 2 FIG. HUM. \\
\hline 166 & Nicolás Grum & 2 FIG. HUM. \\
\hline 167 & Pilar Contardo & 2 FIG. HUM. \\
\hline 168 & Sarjo Prem & 2 FIG. HUM. \\
\hline 169 & Víctor Castillo & 2 FIG. HUM. \\
\hline 170 & José Pedro Godoy & 2 FIG. HUM. \\
\hline 171 & Maite Izquierdo & 3 ABSTRACCIÓN \\
\hline 172 & Paz Castañeda & 2 FIG. HUM. \\
\hline 173 & Ernesto Barreda & 2 FIG. HUM. \\
\hline 174 & Waldo Gómez & 2 FIG. HUM. \\
\hline 175 & Mariana Acuña & 1 PAISAJE \\
\hline 176 & Ricardo Araya & 1 PAISAJE \\
\hline 177 & Víctor Manuel Pavez & 5 CONCEPTUAL \\
\hline 178 & Gastón Laval Possel & 2 FIG. HUM. \\
\hline 179 & José Luis Aravena & 2 FIG. HUM. \\
\hline 180 & Francisco Cansino & 5 CONCEPTUAL \\
\hline
\end{tabular}


Asimismo se identifica cada autor con un género pictórico o una forma de expresión pictórica, ya sea en el campo de lo conceptual como en un "otro" (a definir en lo particular) que ha marcado de algún modo una tendencia en su trayectoria, aunque ésta sea versátil y cambiante. La versatilidad es una característica bastante destacada en aquellos pintores que desarrollan la figuración, más que en aquellos que exploran la abstracción. A partir de esta unidad de recolección hemos determinado las unidades de análisis, éstas fundamentalmente las integran aquellas obras que evidencian signos, símbolos, o bien contenidos vinculados al imaginario cultural nacional. La distinción de estos aspectos surge de una gama de posibilidades enunciadas por diversas fuentes, las que de algún modo están vinculadas al ámbito de la cultura nacional y al tema en específico. Otras evidencias son aquellas que los propios artistas señalan, rescatan e instalan como parte del imaginario cultural nacional.

Las unidades de análisis se ordenan y agrupan con relación a su dimensión formal, procedimiento y luego en función al género, tema, contenido de las producciones pictóricas.

\begin{tabular}{|l|l|l|l|}
\hline I.- DIMENSION FORMAL \\
\hline Estrategias & Recurso iconográfico & Recurso plástico & Recurso lingüístico \\
\hline Representacional & Formas regulares & Collage & Texto manuscrito \\
\hline Abstracción & Formas orgánicas & Acciones & Texto impreso \\
\hline Objetual & Objeto soporte & Impresión digital & Audio / grabación \\
\hline Conceptualización & Signos icónicos y palabras & Impresión digital//pintura & \\
\hline Video & Simbólico & Performance & \\
\hline Desplazamientos & Realismo & Chorreado / gestual & \\
\hline Expansión del campo & Ficción & Manchas & \\
\hline Instalación & Naturalismo & Luz & \\
\hline
\end{tabular}




\begin{tabular}{|c|c|c|c|c|c|}
\hline \multicolumn{6}{|c|}{ II. DIMENSION TEMATICA } \\
\hline $\begin{array}{c}\text { Categoría } 1 \\
\text { PAISAJE }\end{array}$ & $\begin{array}{c}\text { Categoría } 2 \\
\text { FIG. HUM. }\end{array}$ & $\begin{array}{c}\text { Categoría } 3 \\
\text { ABSTRACCIÓN }\end{array}$ & $\begin{array}{c}\text { Categoría } \\
4 \text { RELIGIOSO }\end{array}$ & $\begin{array}{c}\text { Categoría } 5 \\
\text { CONCEPTUAL }\end{array}$ & $\begin{array}{l}\text { Categoría } 6 \\
\text { OBJETOS }\end{array}$ \\
\hline Subcategorías & Subcategorías & Subcategorías & Subcategorías & Subcategorías & Subcategorías \\
\hline Urbano & E 1 desnudo & Juego de formas & Anunciación & Arte analítico & Naturaleza muerta \\
\hline Forestal & Retrato/Autorretrato & Color & Sacrificio & $\begin{array}{l}\text { Análisis y percepción } \\
\text { de la realidad }\end{array}$ & Flora \\
\hline Costero & $\begin{array}{l}\text { En una escena no } \\
\text { costumbrista }\end{array}$ & Gestual & Resurrección & Body art & Bodegón \\
\hline Marino, & Escena Costumbrista & Óptico & Procesión & Video art & Vanitas \\
\hline Cordillerano & En acción o movi. & $\mathrm{B} / \mathrm{N}$ & Simbolismo Religioso & Proyectos art & Representación de objetos \\
\hline Interior psicológico & Otro & Monocromo & Demoniaco & Eventos & Presentación de objetos \\
\hline Psicológico & & Formas regulares & Fetiche & Acciones & El objeto/soporte y signo. \\
\hline Interior habitación & & Formas orgánicas & Santería & Contexto & Objeto simbólico. \\
\hline Lacustre & & & Pantocrátor & Mail art & \\
\hline Ambientac. Atmosféric & & & Virgen y niño & Propuestas/ Declarac, & \\
\hline Bélico & & & Los evangelios & Enunciados & \\
\hline & & Otro & Otro & Performance & Otro \\
\hline
\end{tabular}

\section{V.1. La pintura en Chile}

Cuando se plantea la identidad como problema a investigar, siempre se está frente a un conjunto de aspectos que "hipotéticamente" constituyen aquella particularidad por la que se intenta distinguir o diferenciar una persona de otra o a un grupo humano de otro. La identidad se configura como una ficción metodológica que otorga una fisonomía a una persona, a un grupo o un país. (Larraín 2001)

Tal como se ha señalado en III.2.1, el comentarista de arte Antonio Romera, en su libro "Asedio a la pintura chilena" (1969), incorporó a la historiografía del arte nacional dos conceptos que permiten establecer criterios generales y particulares para abordar el análisis de la pintura nacional, a saber, las $<<$ constantes $>>$ y las $<<$ claves $>>$. Las constantes permiten apreciar las direcciones que sigue fielmente la pintura. Las claves son aquellos signos que van señalando la tónica, a lo largo del desarrollo histórico, de la pintura nacional. Las constantes permanecen, las claves cambian.

Romera establece cuatro componentes que son constantes: Paisaje, Color; influjo francés, Carácter. Por su parte las claves son, en cierto modo, las mutaciones estilísticas en las que a veces intervienen también las diversas polarizaciones hacia una determinada clase de temas. Ellas serían: Exaltación, realidad, sentimiento, razón plástica.

No es objeto de este estudio entrar a polemizar la pertinencia, objetividad o multidimensionalidad de estas constantes y claves. Sin embargo, se ha establecido un criterio que incluya aquellos aspectos que siendo objetivables hayan sido señalados por el crítico Romera, en ese sentido se ha utilizado el concepto de "dimensión", por su pertinencia y precisión. Se entiende por dimensiones, a los componentes de una pintura, que le otorgan cuerpo, es decir unidad y totalidad. Los componentes que se abordan aquí son: los aspectos formales, materiales y los aspectos temáticos. 
Se establecen dimensiones en dos planos, el primero comprende el plano denotativo de la obra en lo relacionado con la dimensión formal-material y la temática. En un segundo plano, se considera lo connotativo con dimensiones referidas al sentido de la obra, lo referencial, lo contextual. Entendiendo que las claves que establece Romera corresponden a un nivel de apreciación y calificación estrictamente personal e interpretativo, se desmarca de la relación arte-identidad y cultura por lo que no aporta a este estudio.

A continuación se exponen las unidades de recolección, de ellas se desprenden, en primer lugar las unidades de análisis, seleccionadas de acuerdo a la presencia, en ellas, de elementos o bien connotaciones en relación con la idiosincrasia identitaria nacional. En segundo lugar una visión panorámica de las tendencias ya sean de género o estilísticas en la pintura chilena. En un tercer lugar veremos algunas de las características que presentan los desplazamientos y la práctica expansiva del campo de la pintura. En cuarto lugar la muestra nos plantea una serie de caminos a posibles investigaciones futuras ya sean referidas a lo estético propiamente tal o bien en lo que a aspectos sociológicos o socio-políticos en la práctica pictórica en nuestro país.

Las obras

Las obras seleccionadas para el presente estudio es el resultado del seguimiento de la producción pictórica, período 2000-2015, de 180 artistas nacionales seleccionados con relación a los parámetros mencionados anteriormente en I.3.5. Fueron sometidos al estudio un total de 540 pinturas, las que se presentan en fichas por autor. 


\section{Magdalena Atria}

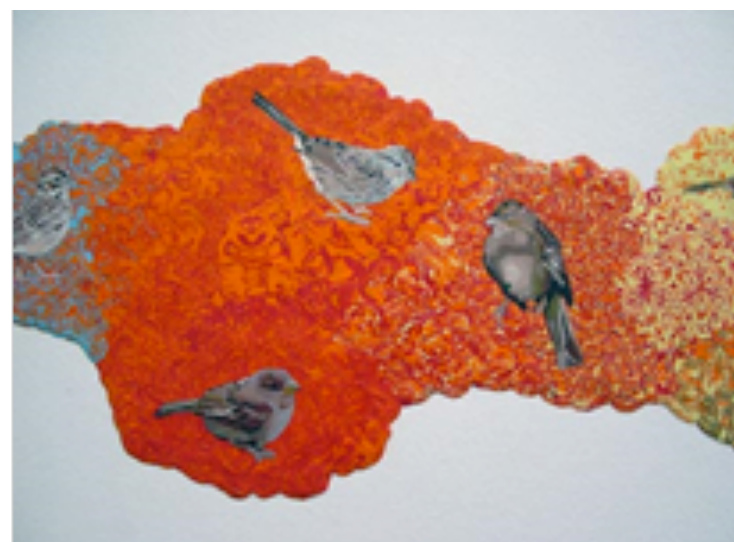

Contra la naturaleza 2004 (detalle) plastilina al muro, (5 x $2.50 \mathrm{mts}$,

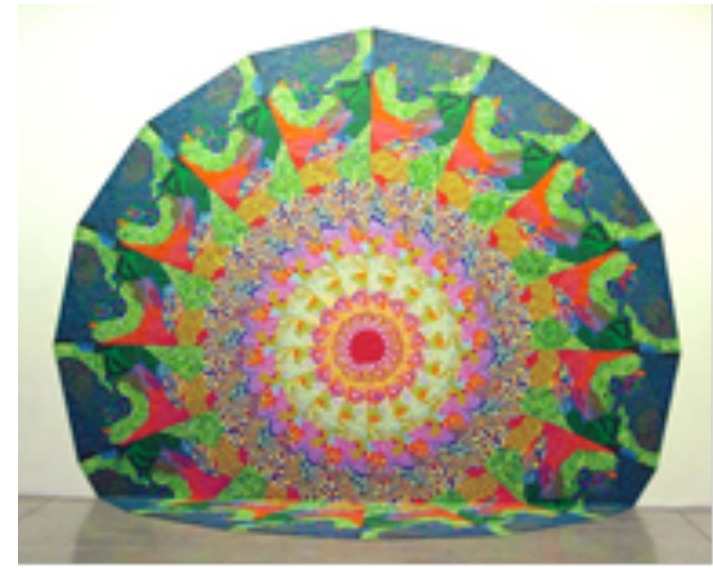

Desde niño ya engañaba a sus amigos(2004)

Plastilina al muro $4 \mathrm{mt}$. de diam

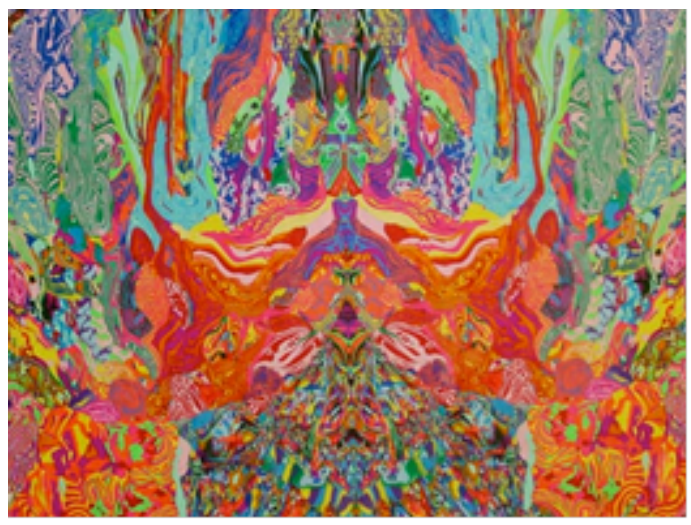

"Love and Space" 2013 plastilina en muro

http://www.artistasplasticoschilenos.cl/658/w3-article-40395.html http://www.xsgaleria.cl/portfolio/magdalena-atria/ 


\section{Carolina Fresno}

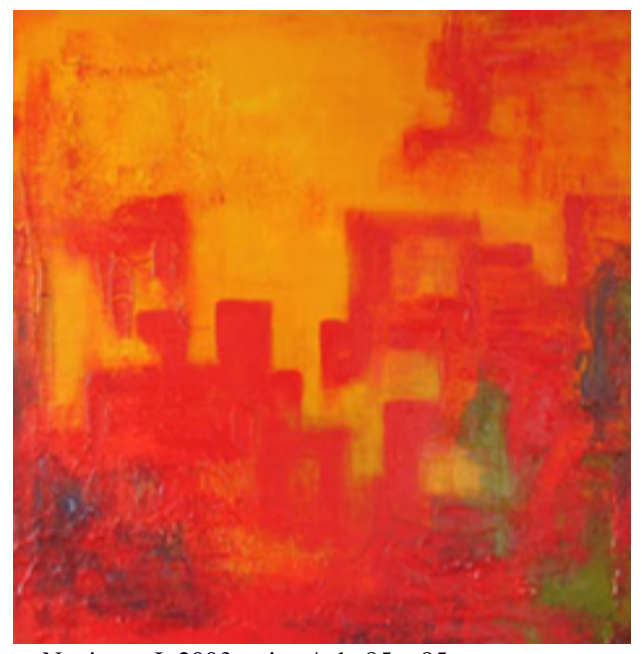

Nociones I 2003, mixta/tela 85 x $85 \mathrm{cms,}$

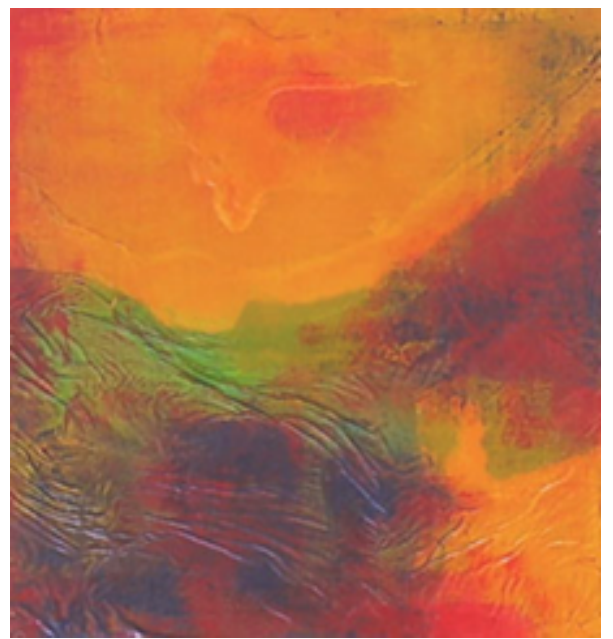

Serie Nuveau III 200320 x $20 \mathrm{~cm}$. técnica mixta/

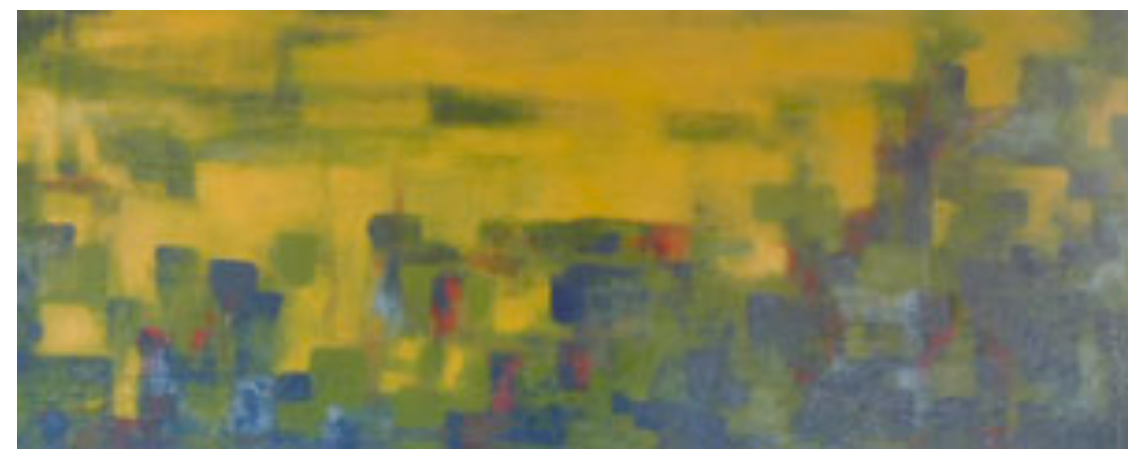

Taller II 22003 mixta/madera 100 x $50 \mathrm{~cm}$

http://www.portaldearte.cl/artistas_visuales/fresno_maria.html 


\section{Consuelo Lewin}

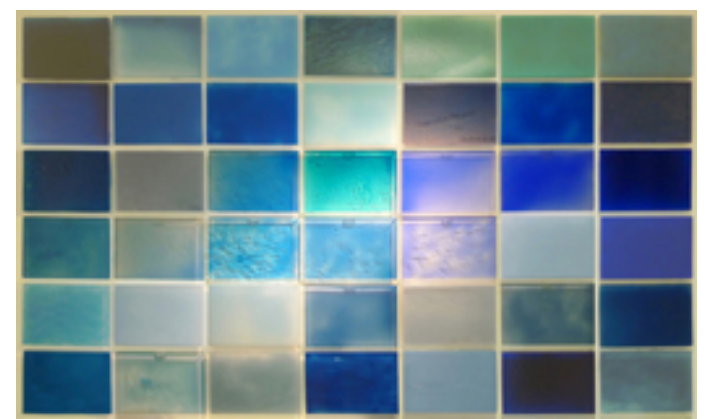

“Blue” 2007, Fotografía, acrílico, resina pigmentada, 120 x $210 \mathrm{~cm}$.

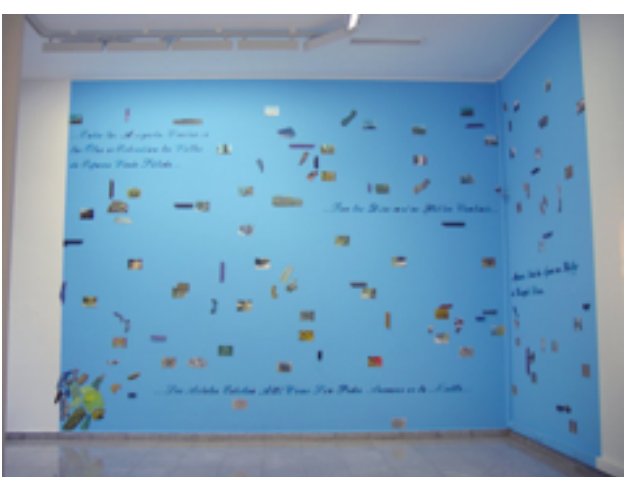

"Fragmentos de un viaje utópico" 2005.

Óleo, fotografías color, resina pigmentada, 800 × $400 \mathrm{~cm}$.

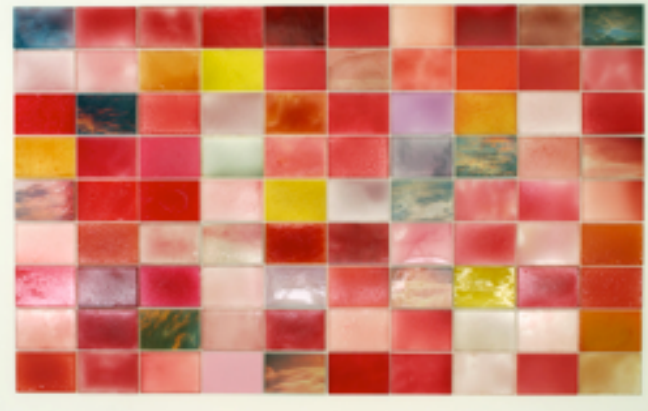

"Resplandor", 2007, fotografías, resina pigmentada sobre módulos de acrílico, 180 × $300 \mathrm{~cm}$.

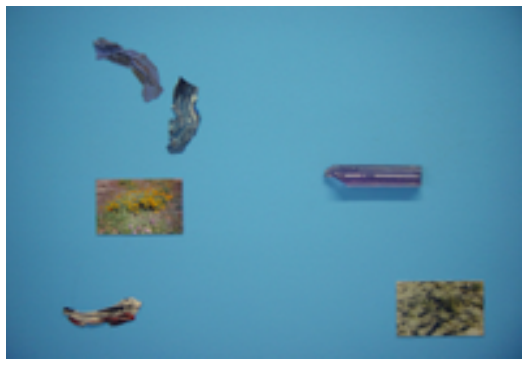

"Fragmentos de un viaje utópico" 2005 (Detalle) 
$N^{\circ} 4$ ficha

\section{Denisse Blanchard}

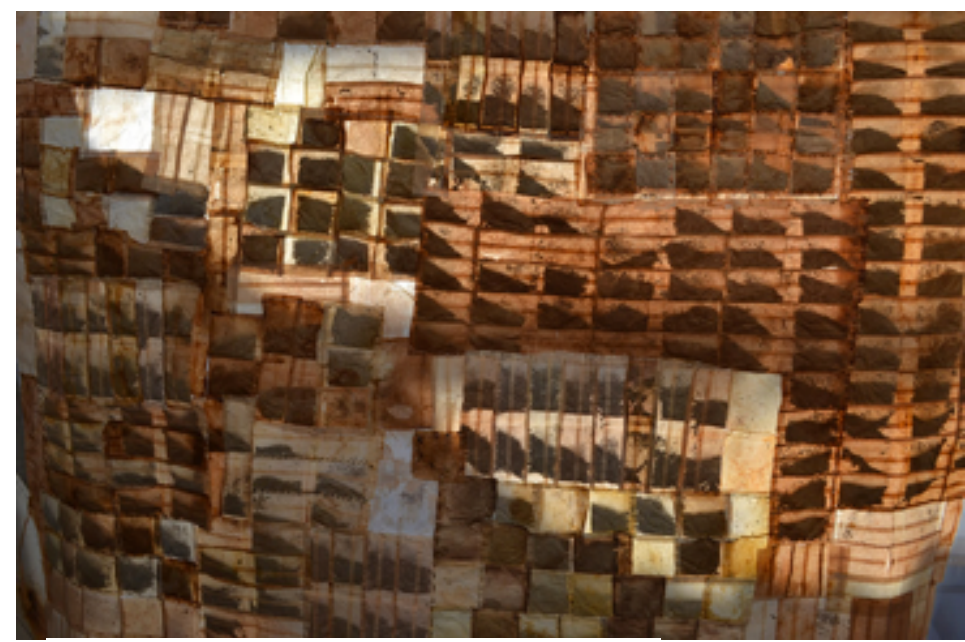

“Orient Express" proyecto, 2013 Bolsas de Té

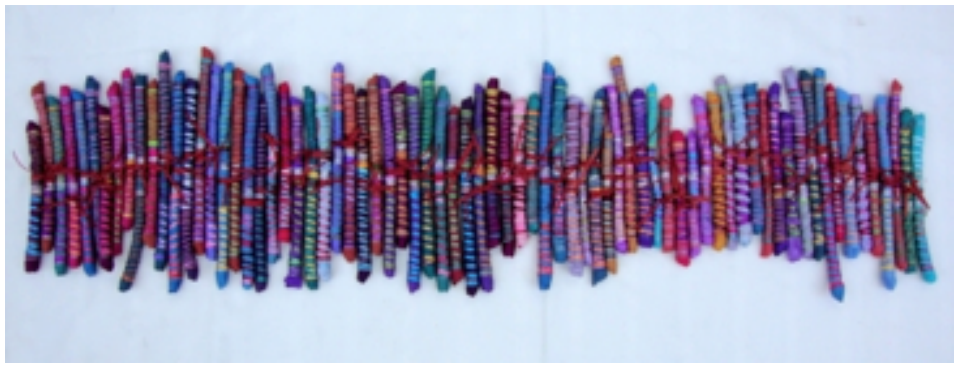

"Formados" 2010, hilos enrrollados y unidos con amarras
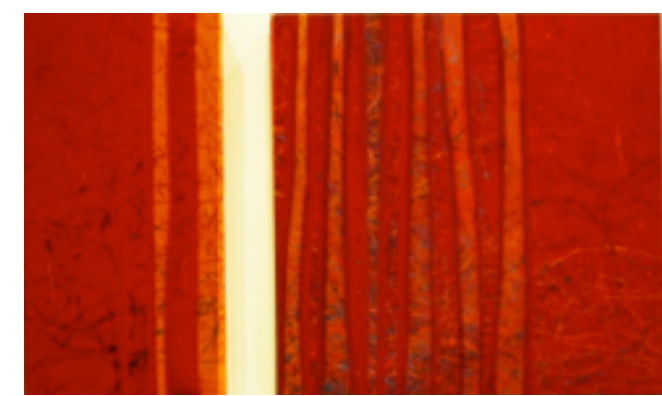

"Re puntadas" 2010, Puntada collage 80x100cm

www.deniseblanchard.cl

www.flickr.com/photos/deniseblanchardart 


\section{$N^{\circ} 5$ ficha}

\section{Felix Lazo}

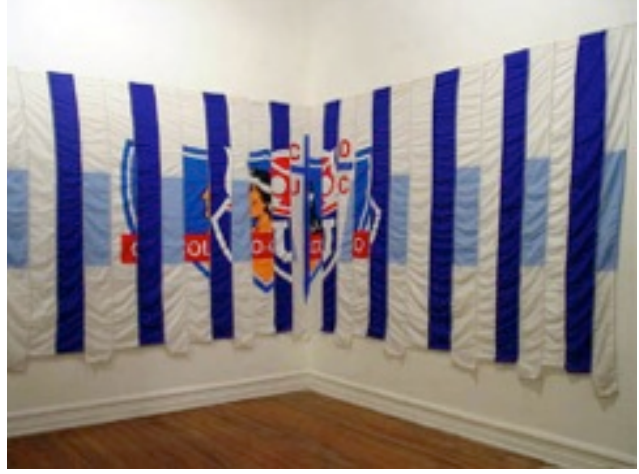

"Madre" Félix Lazo 2001 Impreso en poliéster. E Hilo de seda, 9x2,5 mt.

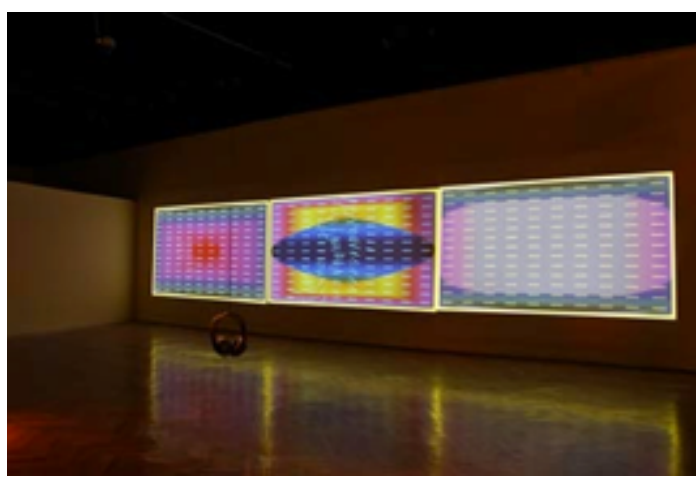

Sistemas Autopoiéticos [999], 2015 Instalación interactiva audiovisual

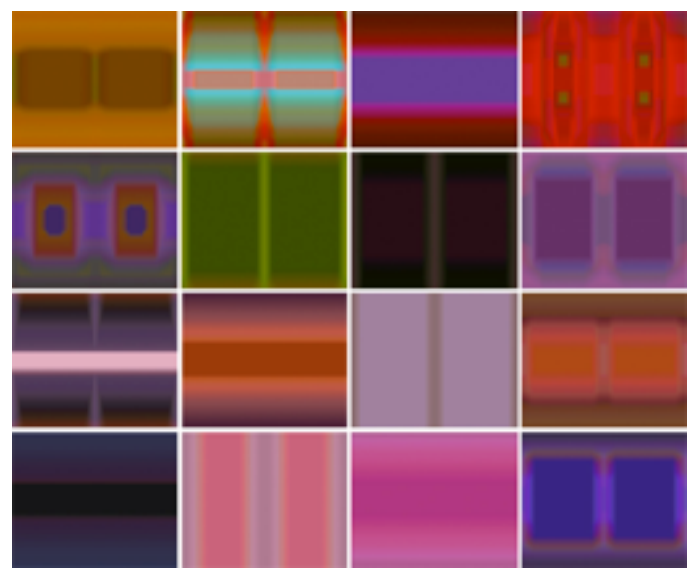

“instant Rothko", 2007, software, duración indefinida.

http://www .artistasplasticoschilenos.cl/658/w3-article-39620.html

http://www.lazo.cl/

http://galeria13.cl/portfolio_category/pintura/page/3/ 
$N^{\circ} 6$ ficha

\section{Francisca Sutil}

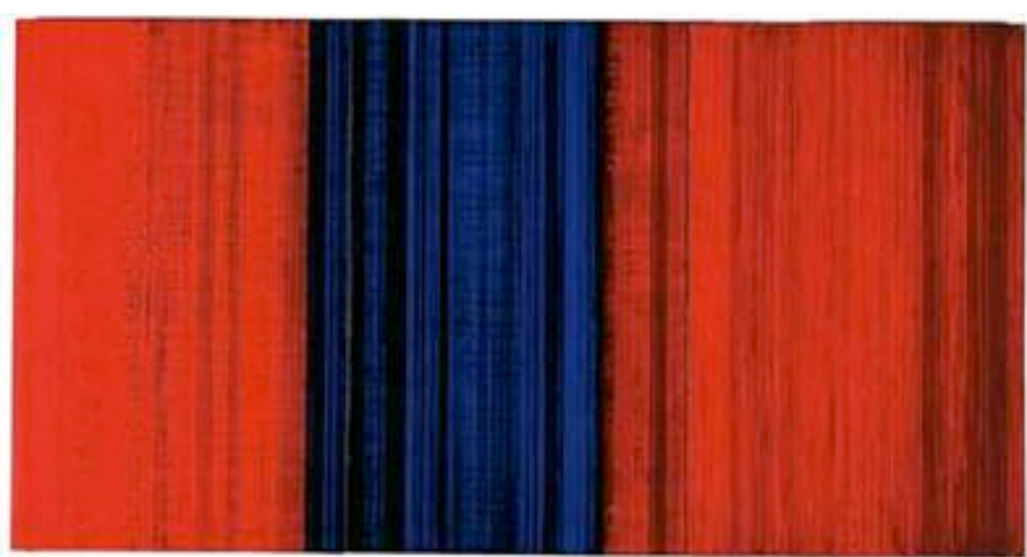

"RESONANCIA No. 12" 2005 pigmento, gesso, oil / lino montado en madera.

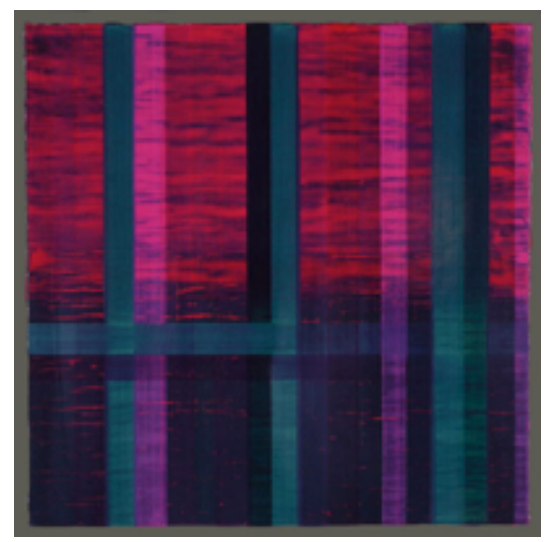

INTERLUDIO Nº 28 / 2009

Gesso pigmentado y óleo sobre lino / madera

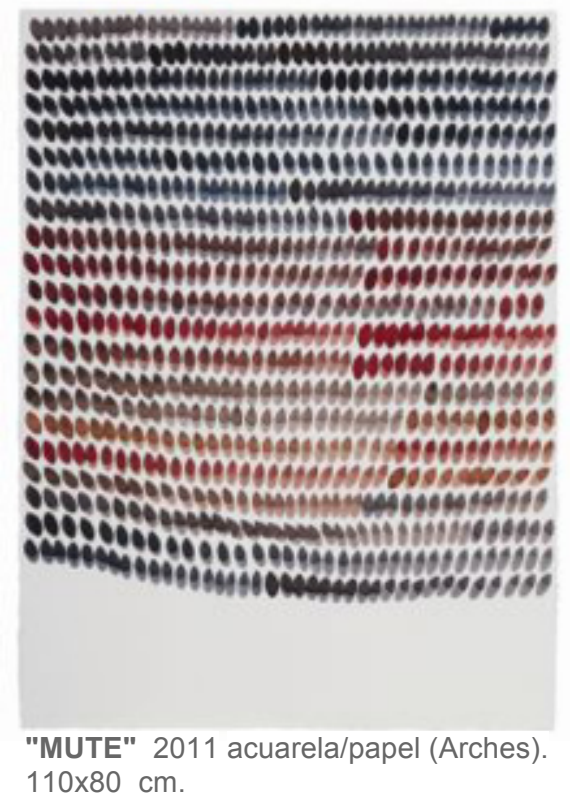

http://www.franciscasutil.cl/

http://www.artistasplasticoschilenos.cl/658/w3-article-40135.html 
$N^{\circ} 7$ ficha

\section{Susana Cox}

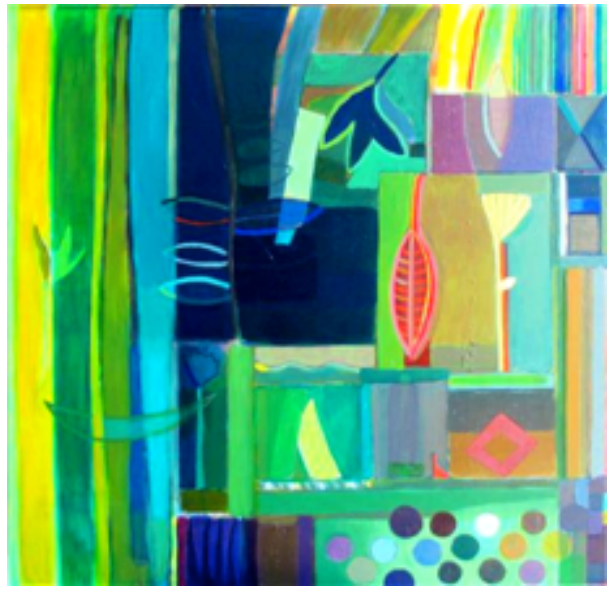

S/T 2008 Oleo/tela 1.10 x 1.05 mts.

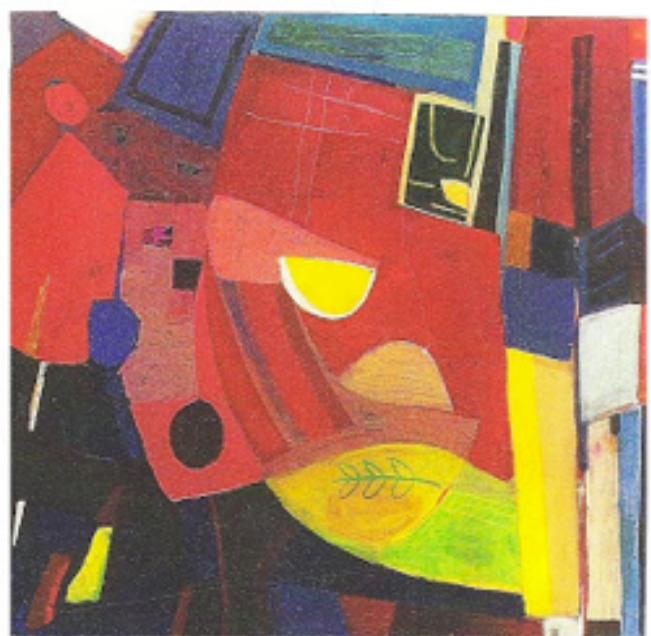

S/T 2008 Oleo/tela 1.10 x $1.05 \mathrm{mt}$

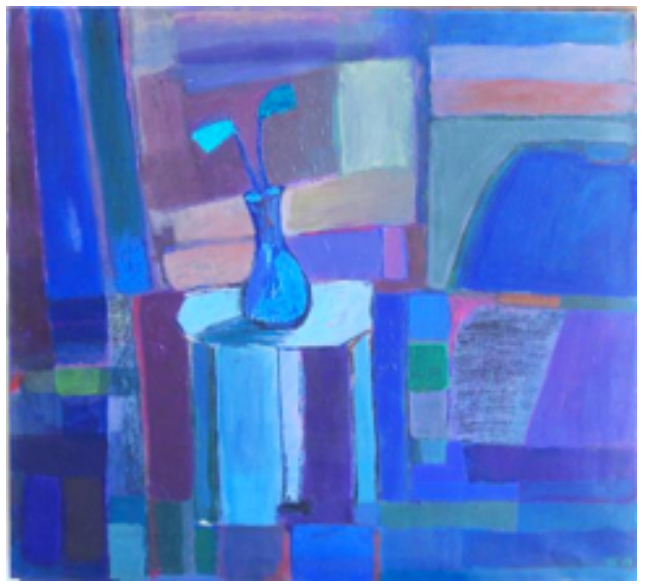

S/T 2008 Oleo/tela 1.10 x $1.05 \mathrm{mt}$

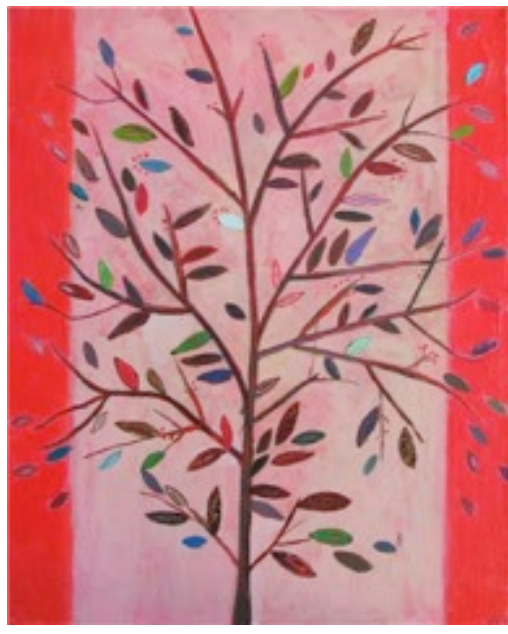

S/T 2008 mixta/tela 50 x $70 \mathrm{~cm}$.

http://susanacox.blogspot.com/

http://www .artistasplasticoschilenos.cl/658/w3-article-39785.html 
$N^{\circ} 8$ ficha

\section{Antonella Gallegos}

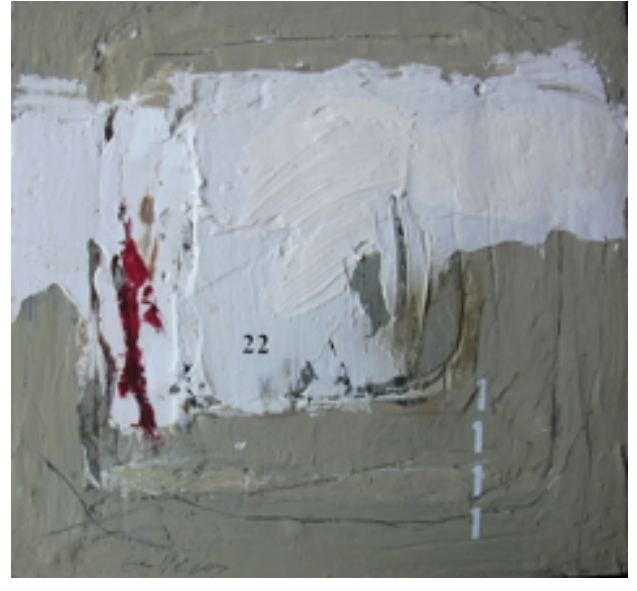

"Fragmentos" 2007 mixta/tela 1x1 mt.

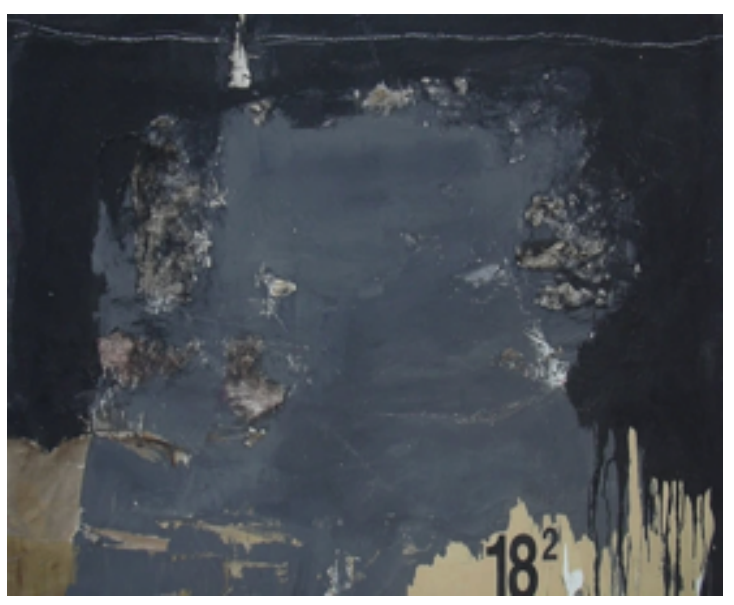

“Casa" 2007 mixta/tela 1,20x1 mt. Mixta/tela

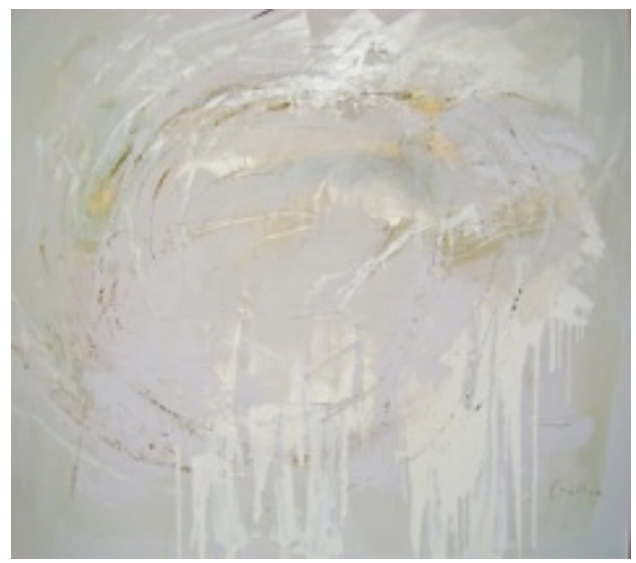

"Espera" 3 / 3 2008, mixta/tela 1x1 mt.

http://espacio.fundaciontelefonica.cl/blog/2015/04/13/antonella-gallegos-altar/

http://www.portaldearte.cl/artistas_visuales/gallegos_antonella.htm

http://revista.escaner.cl/node/233

http://apech.es.tl/ESPA\%D1A-EN-EL-CORAZ\%D3N.htm 
$N^{\circ} 9$ ficha

\section{Claudio Herrera}
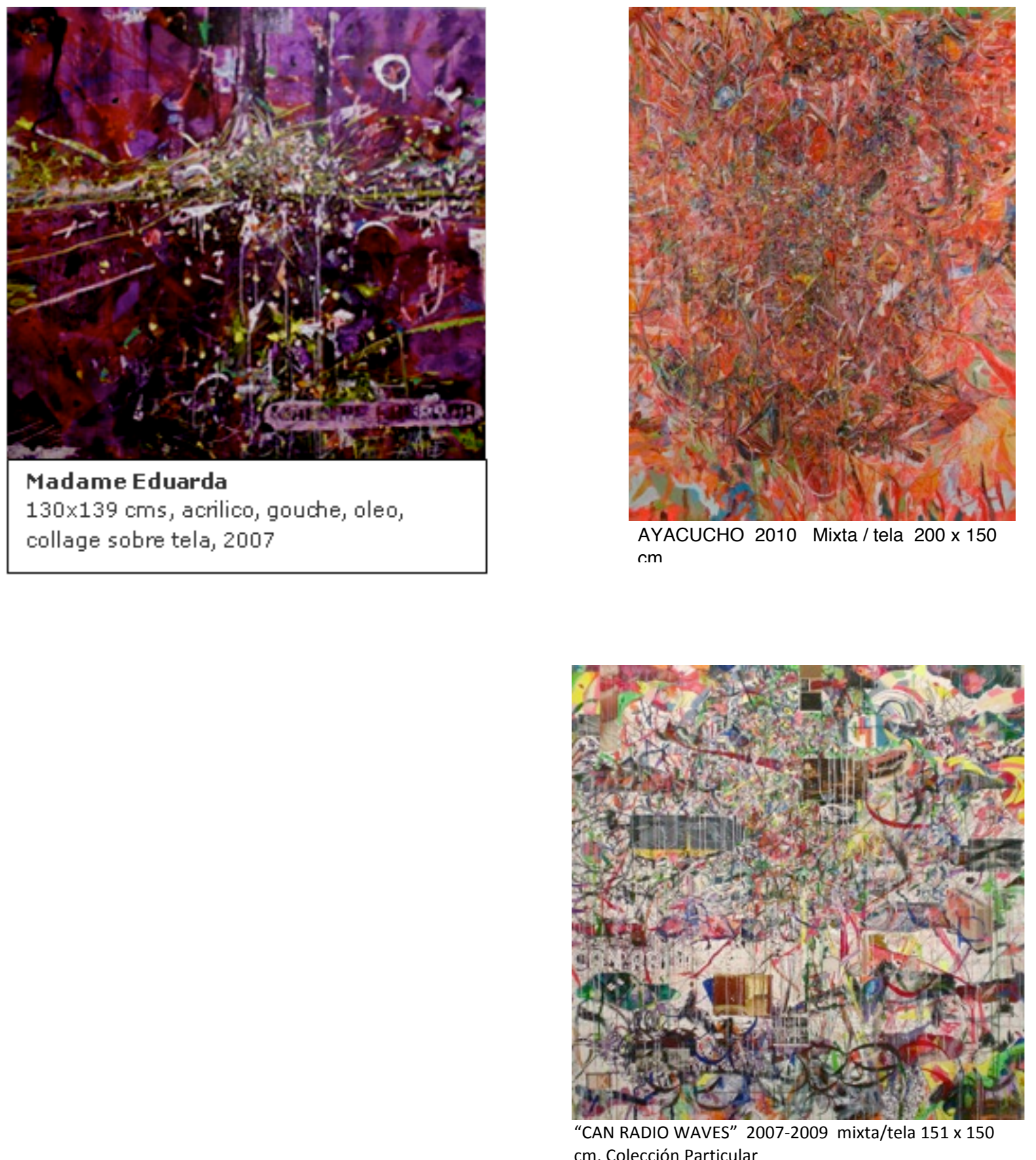

http://www.artistasplasticoschilenos.cl/

http://www.artishock.cl/2011/09/la-oscura-vida-radiante/ 
$N^{\circ} 10$ ficha

\section{Francisco Corcuera}

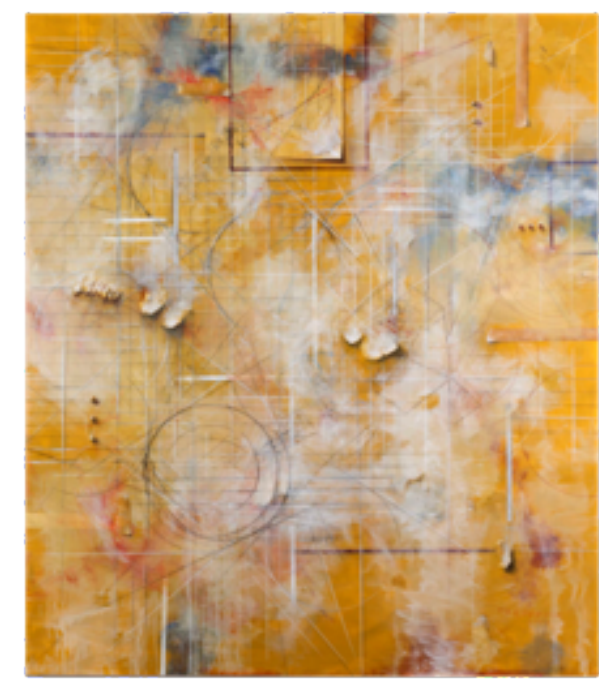

S/T V, 2012 acrílico y lápiz/tela, $190.5 \times 200 \mathrm{~cm}$

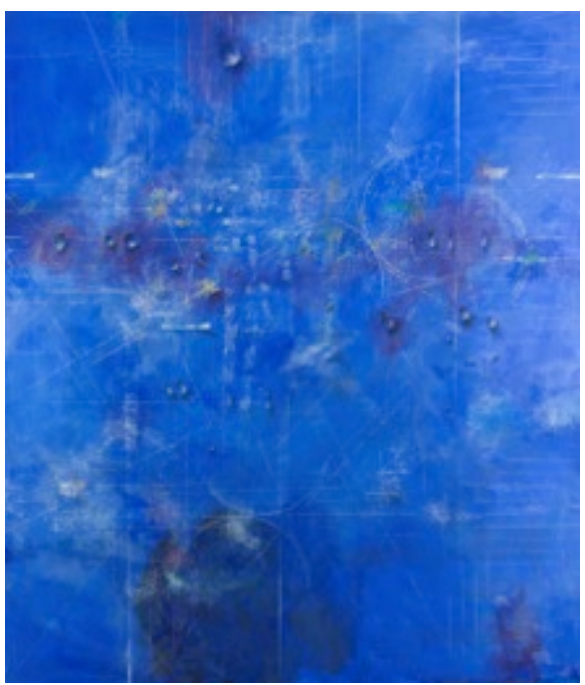

S/T VIII, 2006. Oleo, acrílico/ tela, 190.5 x $220 \mathrm{~cm}$

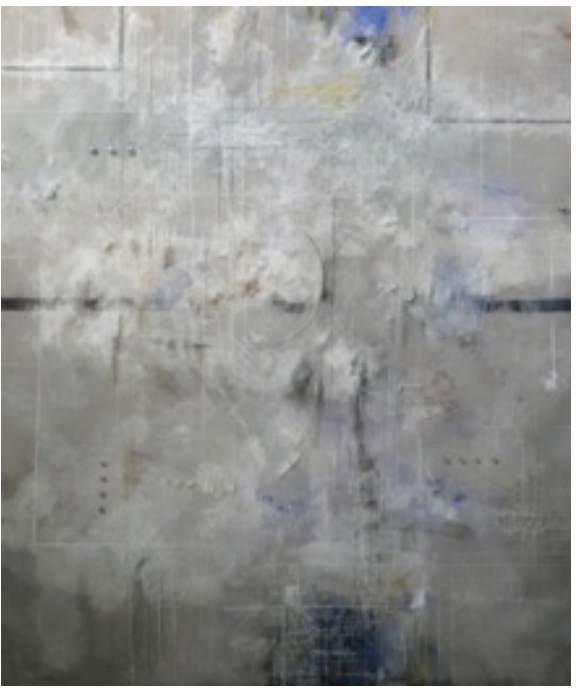

S/T VI, 2012. Oleo, acrílico/ tela, 190.5 x $220 \mathrm{~cm}$

http://www.artistasplasticoschilenos.cl/658/w3-article-40476.html http://www.cosas.com/casas/francisco-corcuera-exposicion-individual/ 
$N^{\circ} 11$ ficha

\section{Josefina Fontecilla}

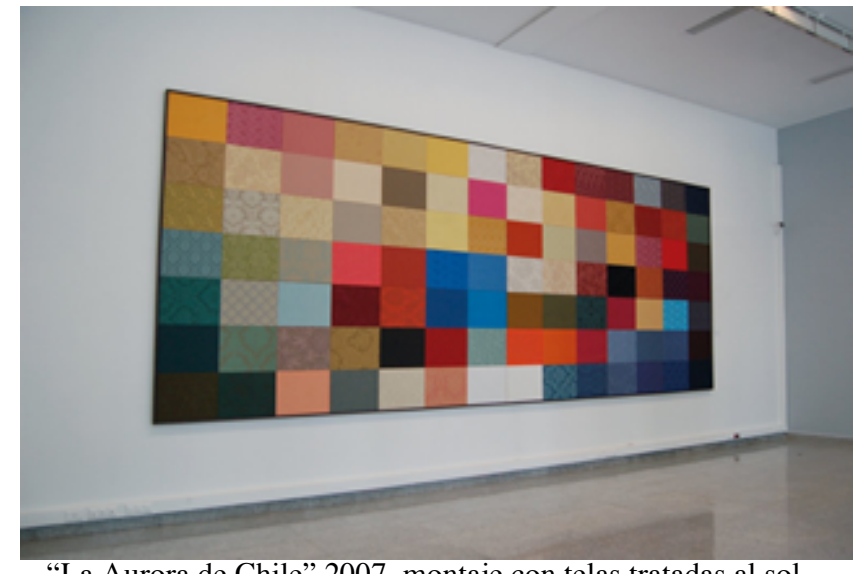

"La Aurora de Chile" 2007, montaje con telas tratadas al sol, $1,5 \times 5 \mathrm{mt}$.

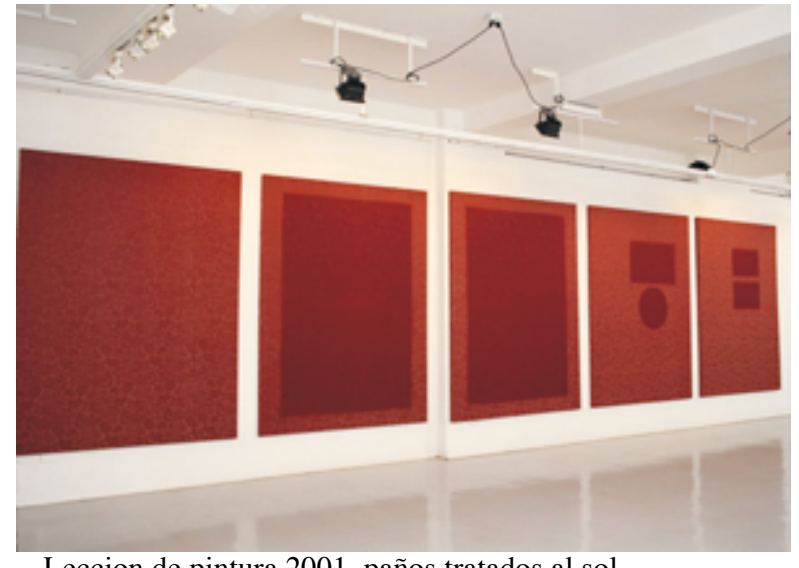

Leccion de pintura 2001, paños tratados al sol

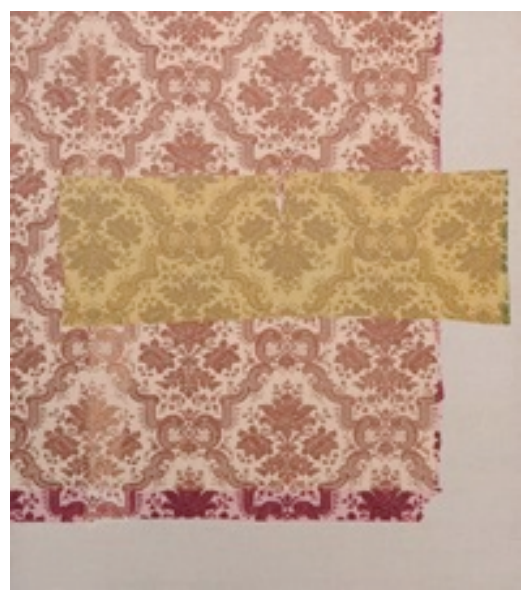

Lirios II 2014 Oleo/ tela $270 X 170 \mathrm{C} / \mathrm{U}$

http://www.artistasplasticoschilenos.cl/658/w3-article-39625.html\#exposiciones

http://www.galeriapready.cl/\#! josefina-fontecilla/cwxf

https://www.facebook.com/media/set/?set=a.254162561434287.1073741828.254152638101946\&type=3 


\section{Fernando Cifuentes}
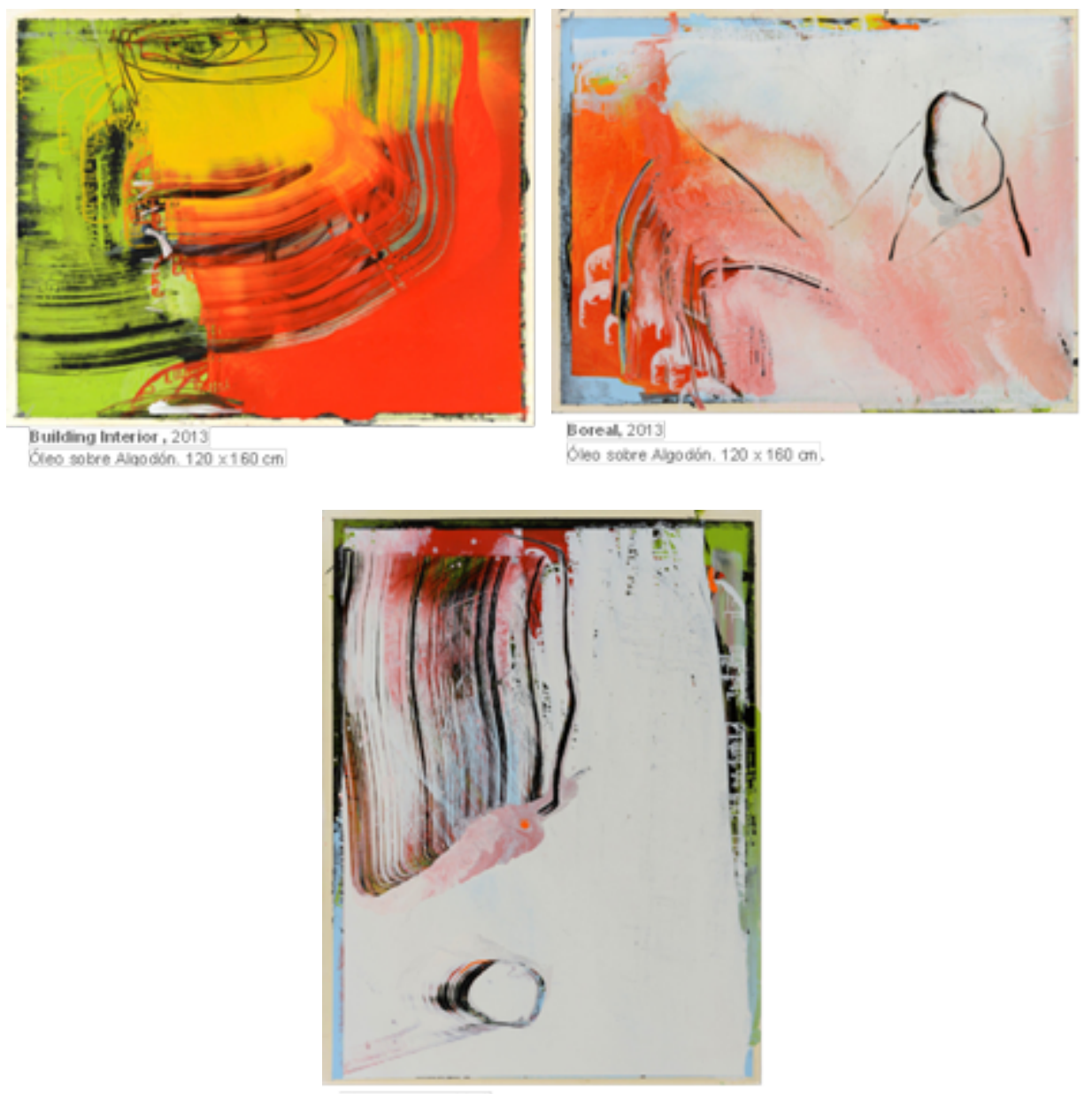

Mek Jagger, 2013

Óleo sobre Algodon, $160 \times 120 \mathrm{~cm}$

http://www.cifuentessoro.cl/

http://www.artistasplasticoschilenos.cl/658/w3-article-39672.html 
$N^{\circ} 13$ ficha

\section{Francisco Bustamante Gubbins}

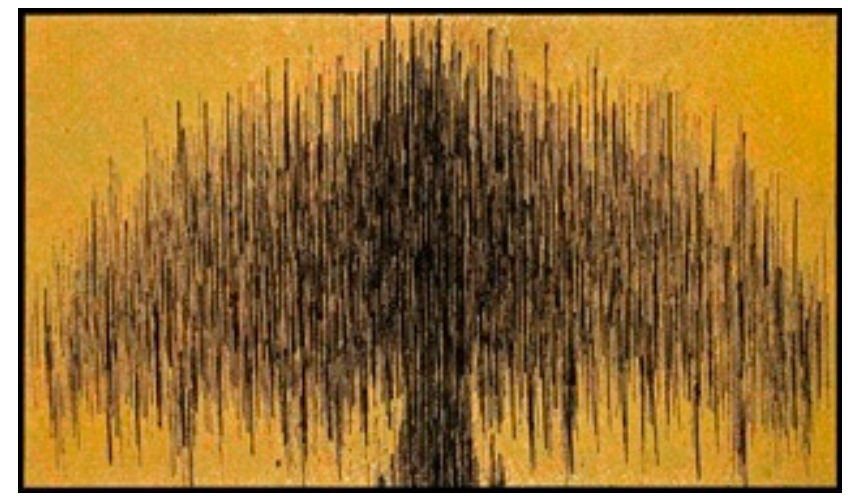

S/T 2005 Láminas doradas y óleo/tela 125 x $250 \mathrm{~cm}$. Colección Particular

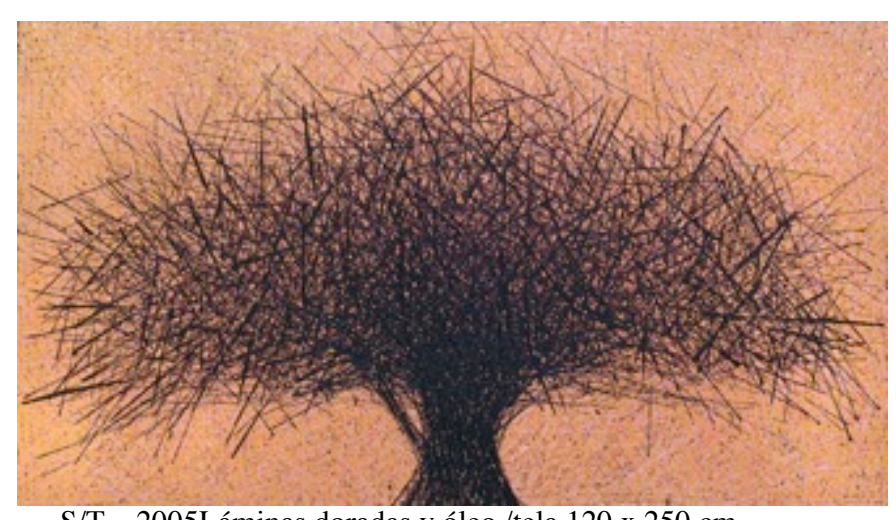

S/T 2005Láminas doradas y óleo /tela 120 x $250 \mathrm{~cm}$. Colección Particular

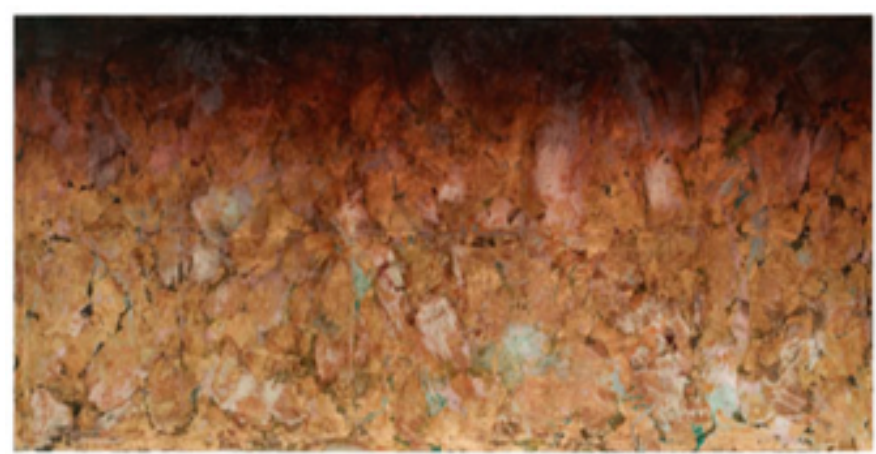

Sin Título 2004 Láminas doradas y óleo/ tela 130 x $500 \mathrm{~cm}$. Colección Particular

http://www.bustamantegubbins.com/

http://www.artistasplasticoschilenos.cl/658/w3-article-40062.html 
$N^{\circ} 14$ ficha

\section{Leonardo Godoy}

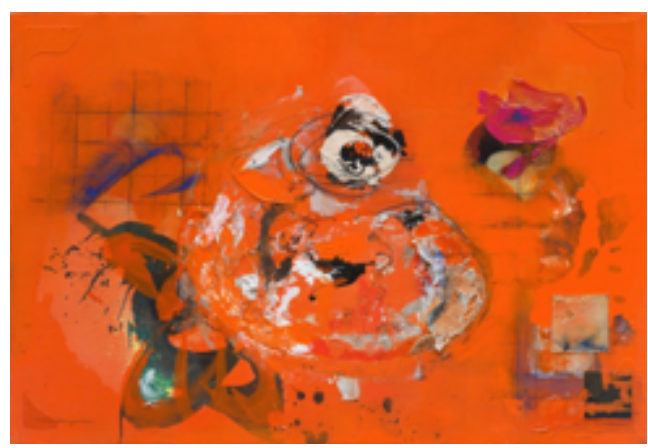

La difracción de la luz 2008195 x 130cm. Tec. mixta sobre

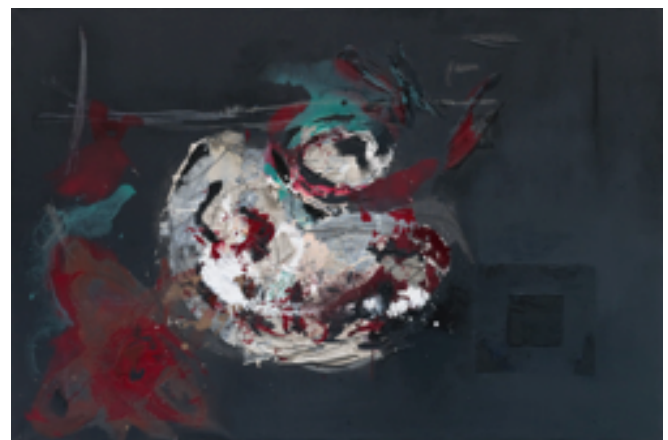

El palpitar de los cuerpos 2008195 x 130cm. Tec. mixta sobre

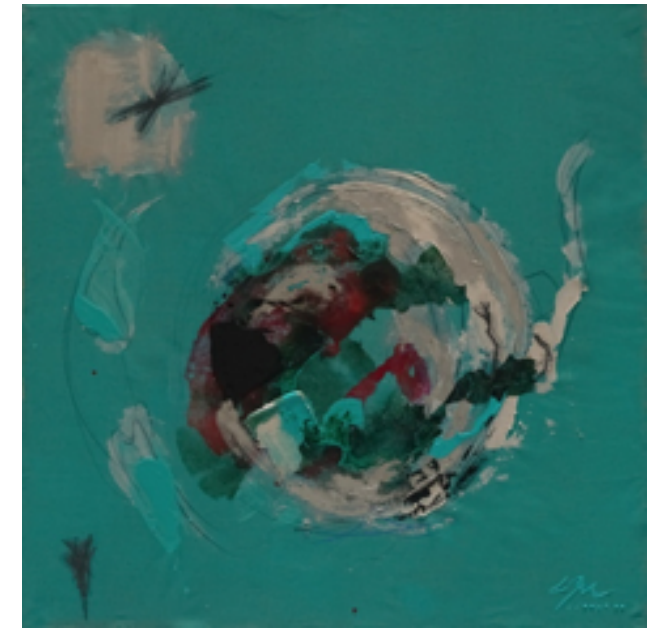

Transposición de los mundos 2008150 x 150cm. Tec. Mixta/ lino

http://leogm.com/

http://www.artistasplasticoschilenos.cl/658/w3-article-39731.html 
$N^{\circ} 15$ ficha

\section{Miguel de Lanú}
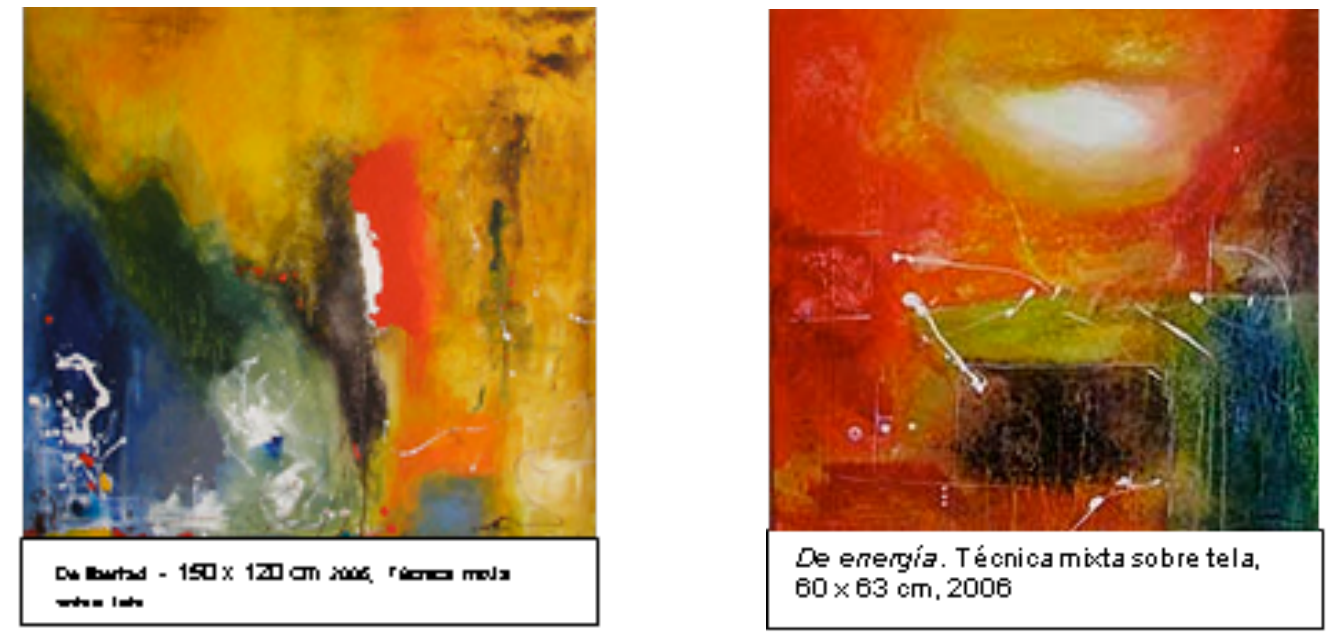

De energía. Técnica mixta sobre tela, $60 \times 63 \mathrm{~cm}, 2006$

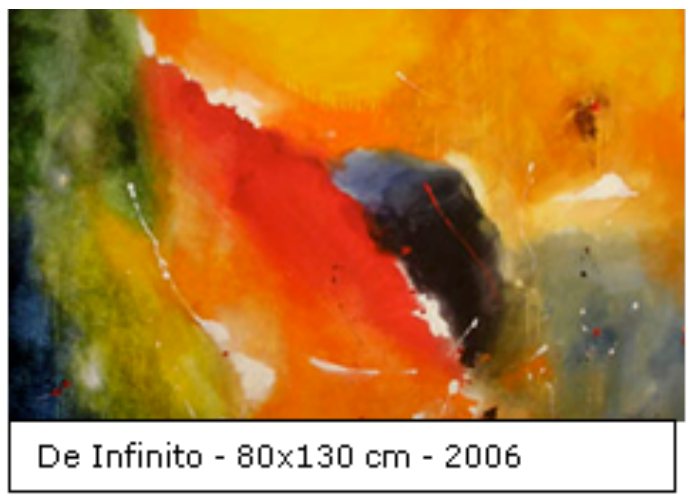

www.delanu.cl

http://www.portaldearte.cl/artistas_visuales/delanu_miguel.html 


\section{Marcel Solá}

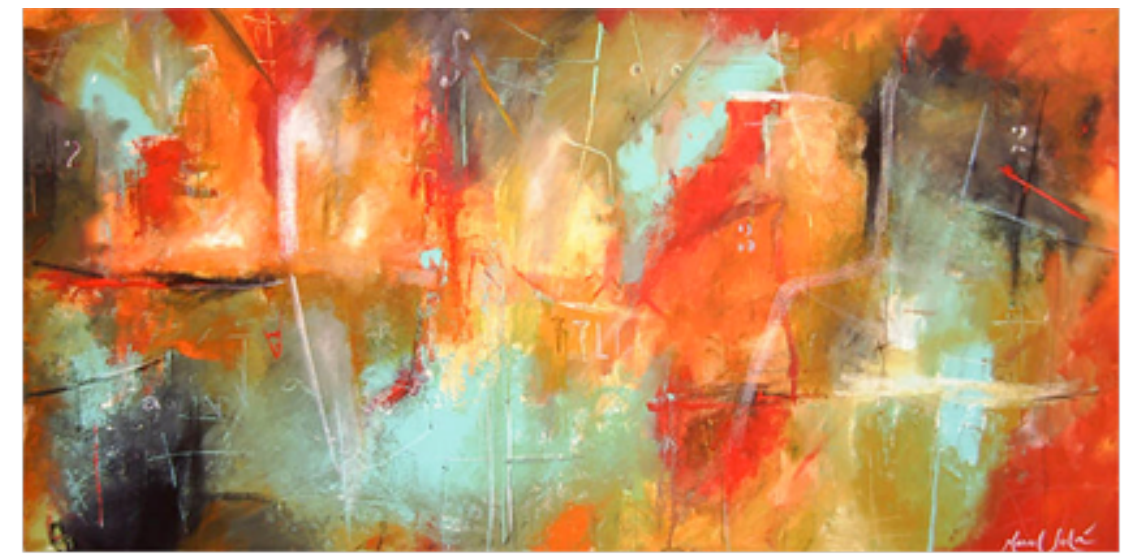

SilencioDeBach, 2007, acrílico Sobre Tela

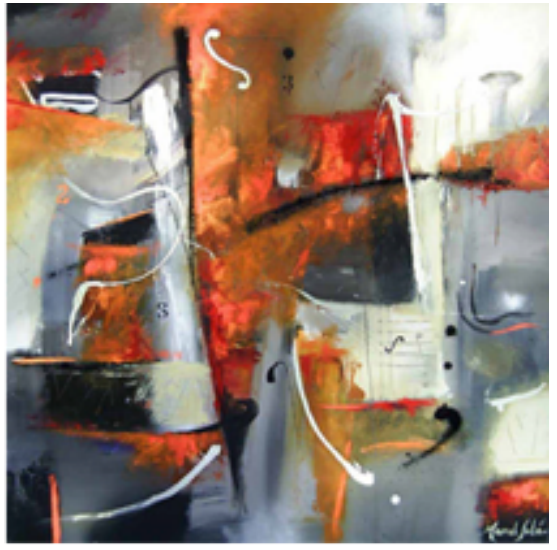

Gesto desdela música. FA, 2006

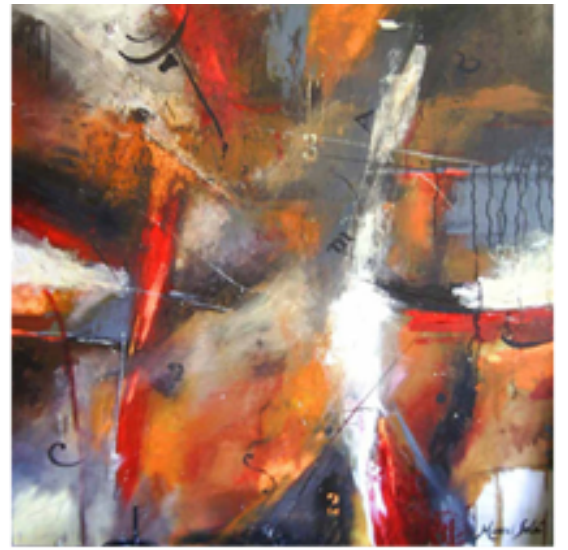

Gesto desde la música. SOL 2006

http://www.saatchiart.com/marcelsola http://marcelsola.blogspot.com/ 
$N^{\circ} 17$ ficha

\section{Paca Jiliberto}

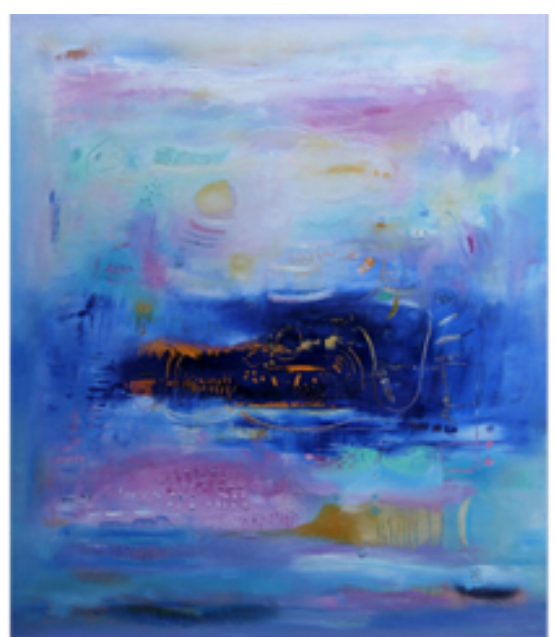

En el océano, 2012, oleo/tela (90k70 cm)

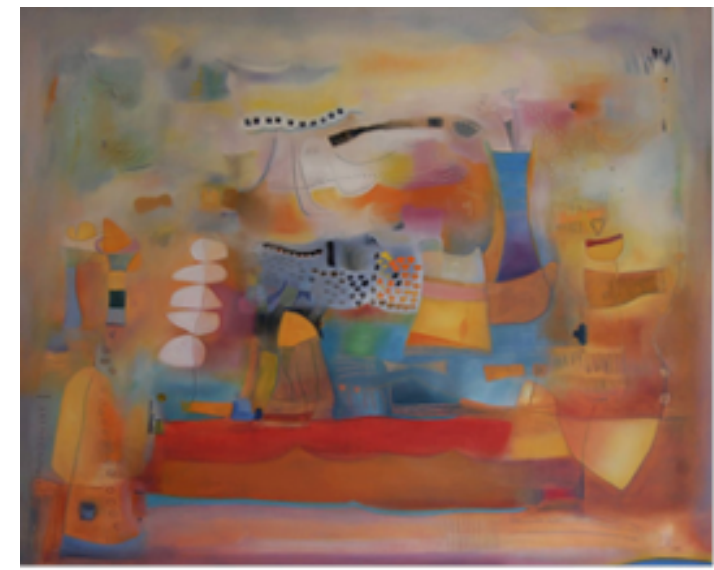

Hec ho todo de Trigo,2004 if oleoftela

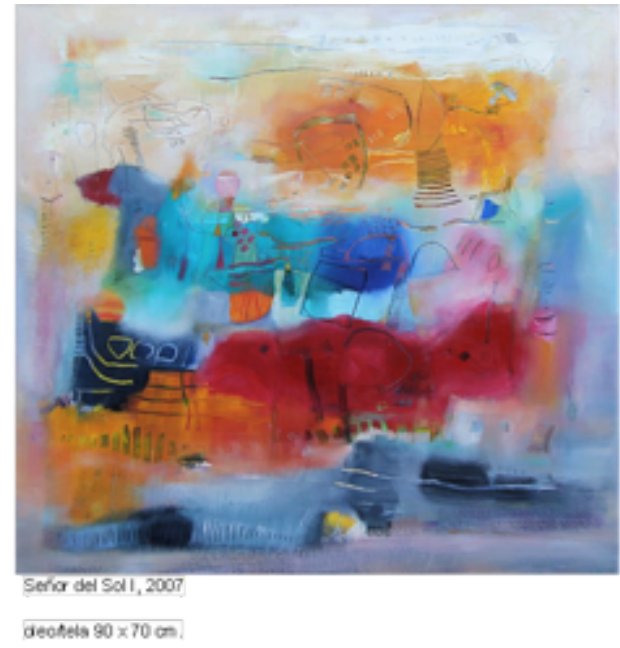

www.pacajiliberto.cl/

http://www.artistasplasticoschilenos.cl/658/w3-article-39684.html 


\section{$N^{\circ} 18$ ficha}

\section{Cristian Abelli}

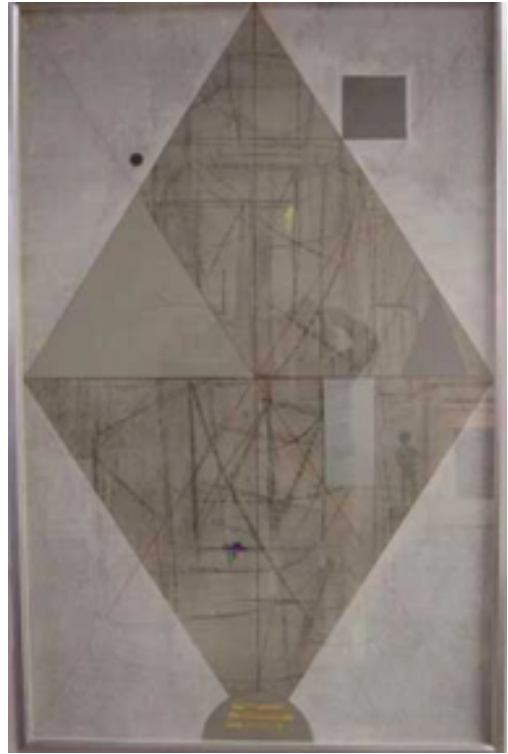

Composición $\mathrm{V}$ con acento y pausa 2006 Tela / tabla-mixta $101 \times 161 \mathrm{~cm}$

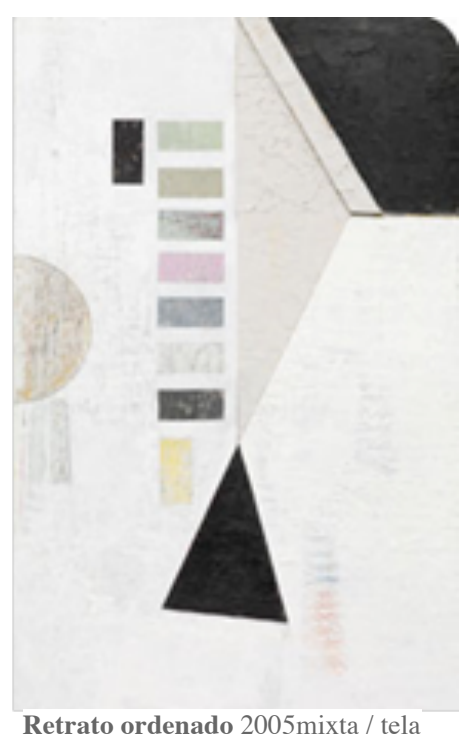
$161 \times 101 \mathrm{~cm}$

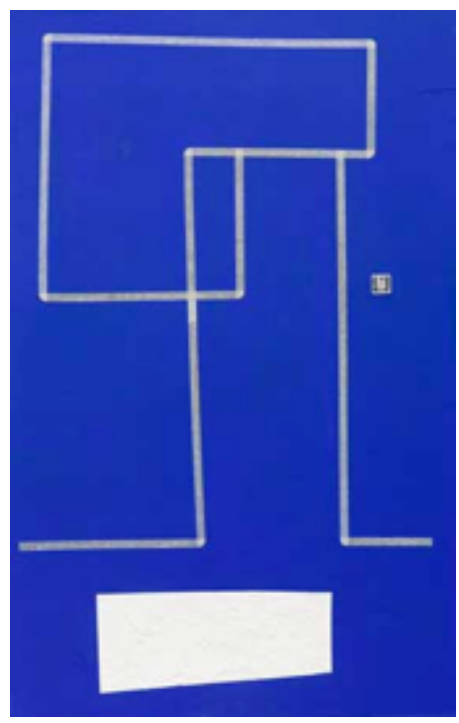

Tono azul 2005 mixta/ tela $161 \times 101$

http://www.artistasplasticoschilenos.cl/658/w3-article-40387.html

https://www .artnexus.com/ArtistHome. aspx? ArtistId=44282\&GalleryId=7212 


\section{Alamiro Carrasco}

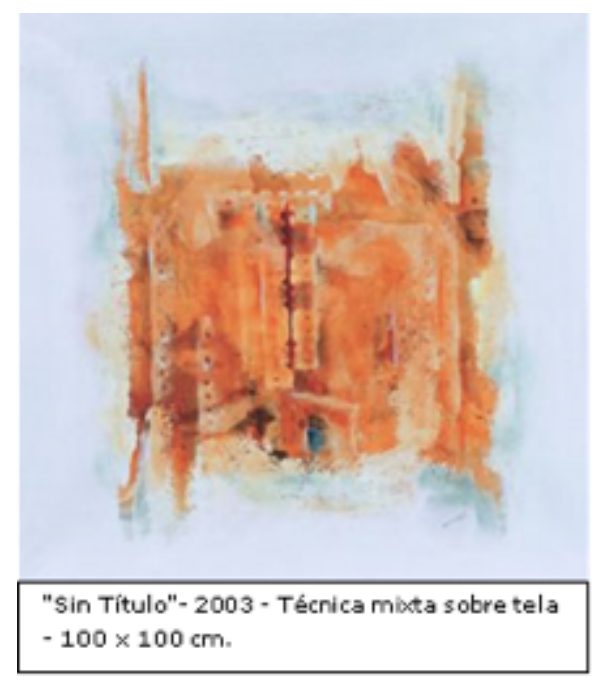

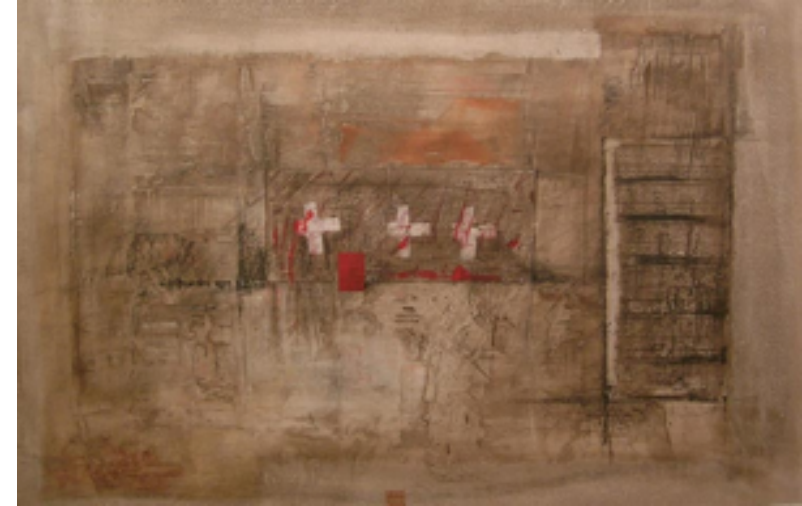

Tres cruces 2006 mixta tela $100 \times 150 \mathrm{~cm}$

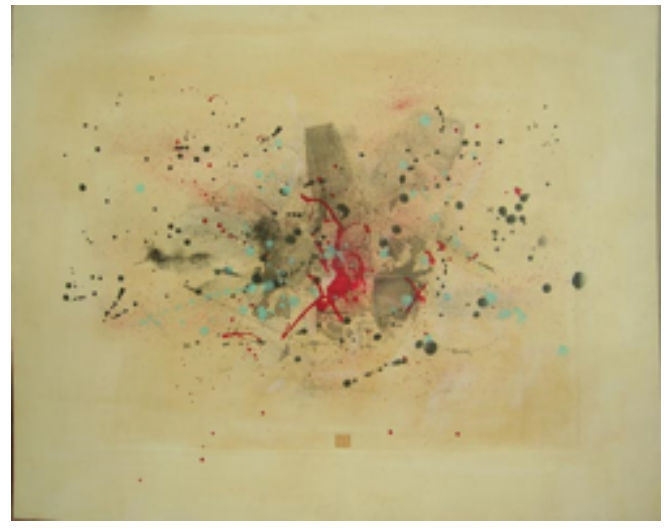

s/t 2005 mixta tela $100 \times 120 \mathrm{~cm}$

www.janetteosses.cl/artistas-1/alamiro-carrasco

www.galeriasalataller.cl/carrasco-alamiro 


\section{Andrés Vio}

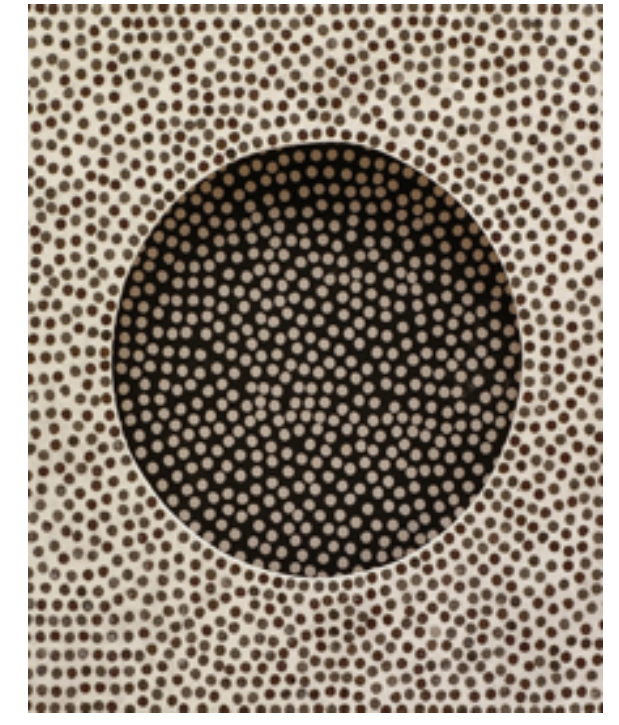

$\mathrm{S} / \mathrm{T}$ - madera y papel de diario $-40 \times 40 \times 10 \mathrm{~cm}$ http://rtandresvio.blogspot.com/

www.andresvio.cl

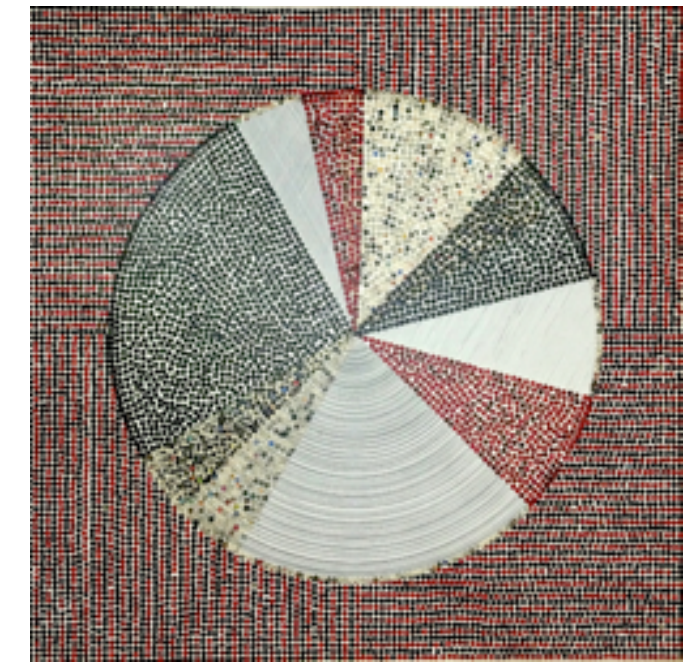

S/T 2014 Pintura y papel de diario / tela. 80 x $80 \mathrm{~cm}$.

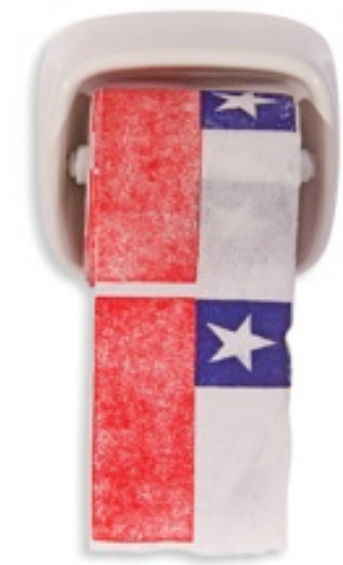

Variables, 
$N^{\circ} 21$ ficha

\section{Camilo Yañes}

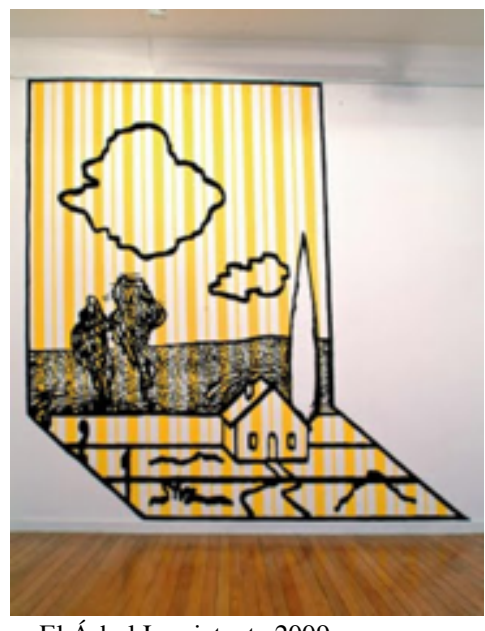

El Árbol Inquietante 2009

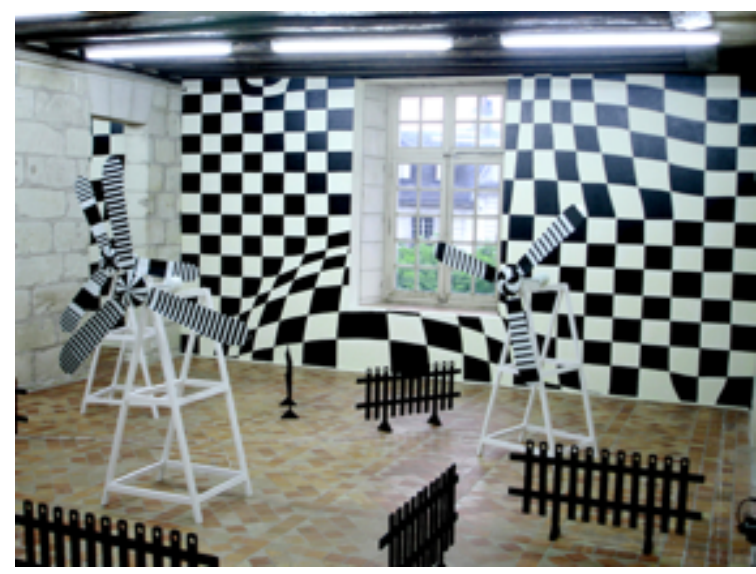

"Flashback Collection" 2008 instalación-objetos /pintura

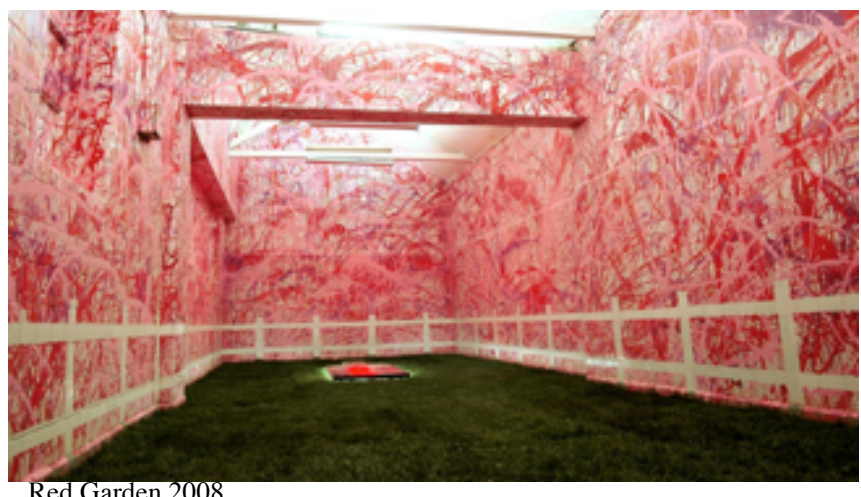

$\underline{\text { www.cy.cl }}$

http://www.artistasplasticoschilenos.cl/658/w3-article-40514.html 


\section{Ciro Beltrán}

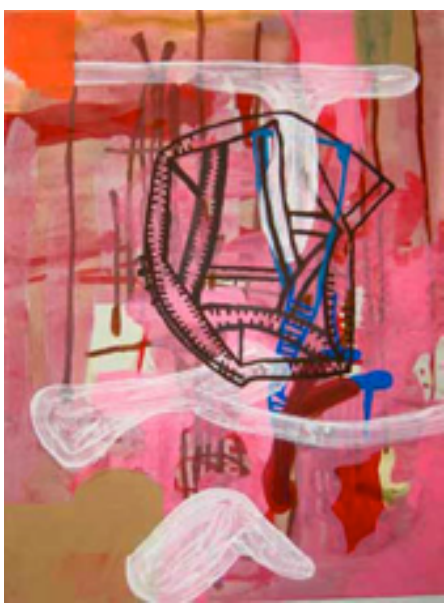

Una periferia circular, 200. .acrílico / tela, $98 \times 75 \mathrm{~cm}$

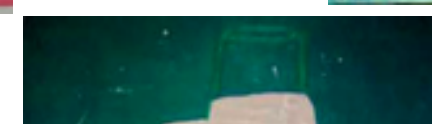

hes paralelas, 2003 /tela, $160 \times 125$,

www.cirobeltran.com

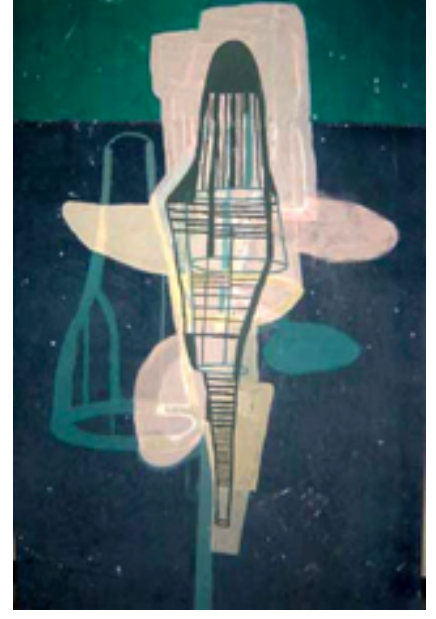

Pintura sobre alfombra $N^{\circ} 24,2000$ acrílico /alfombra, $300 \times 190 \mathrm{~cm}$.

www.artistasplasticoschilenos.cl/658/w3-article-40401.html

http://www.scielo.cl/scielo.php?script=sci_arttext\&pid=S0718-04622003048800010 
$N^{\circ} 23$ ficha

\section{Andrés Díaz}
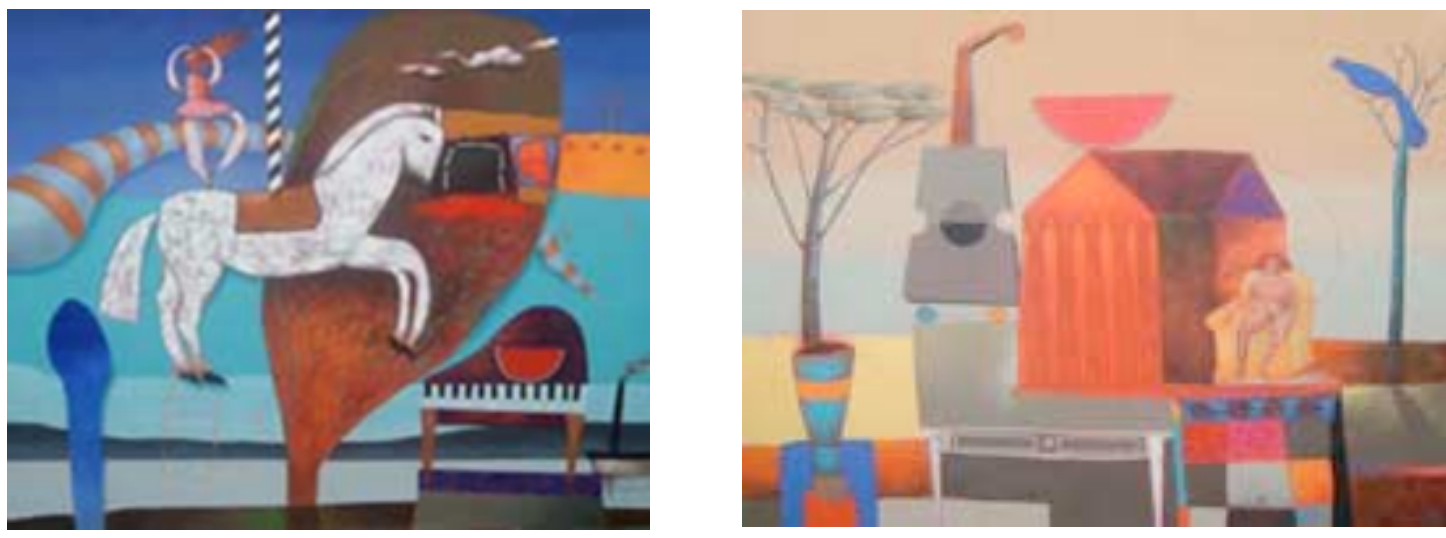

"a la hora de tu viaje" $2004-2005$ serie de 20 pinturas oleo/tela120x100 cm Y 100X100 CM.

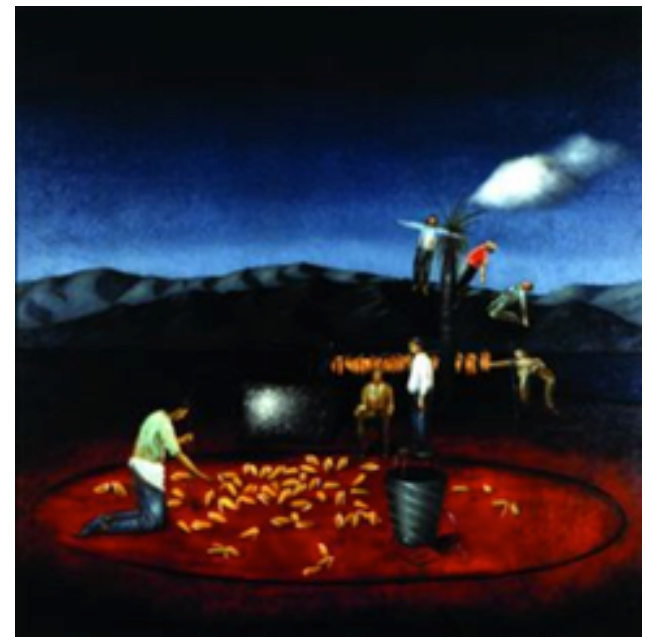

http://diario.elmercurio.com/detalle/index $. \mathrm{asp} ? \mathrm{id}=\{\mathrm{cc} 2 \mathrm{fd} 226-70 \mathrm{bc}-4 \mathrm{c} 0 \mathrm{a}-\mathrm{ab6e}-\mathrm{ea} 56 \mathrm{a} 9 \mathrm{e} 768 \mathrm{e} 1\}$

http://www.portaldearte.cl/agenda/pintura/2007/andres_diaz.html

http://www.portaldearte.cl/agenda/pintura/2005/andres_diaz.htm 
$N^{\circ} 24$ ficha

\section{Daniela Gasic}

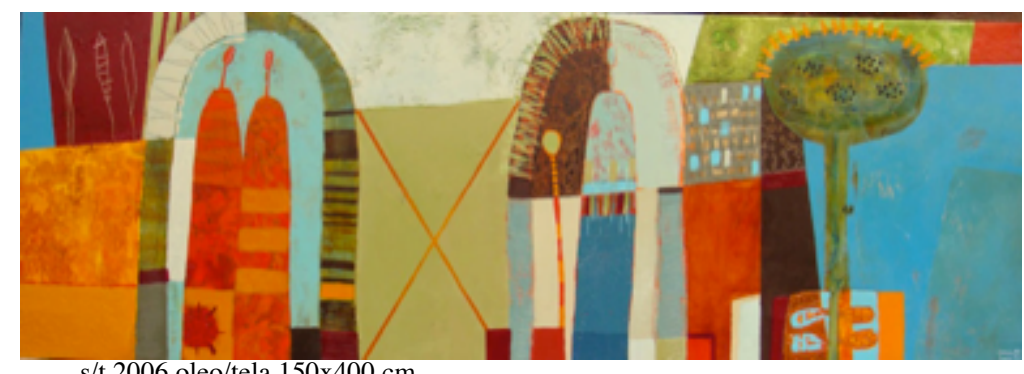

s/t 2006 oleo/tela $150 x 400 \mathrm{~cm}$

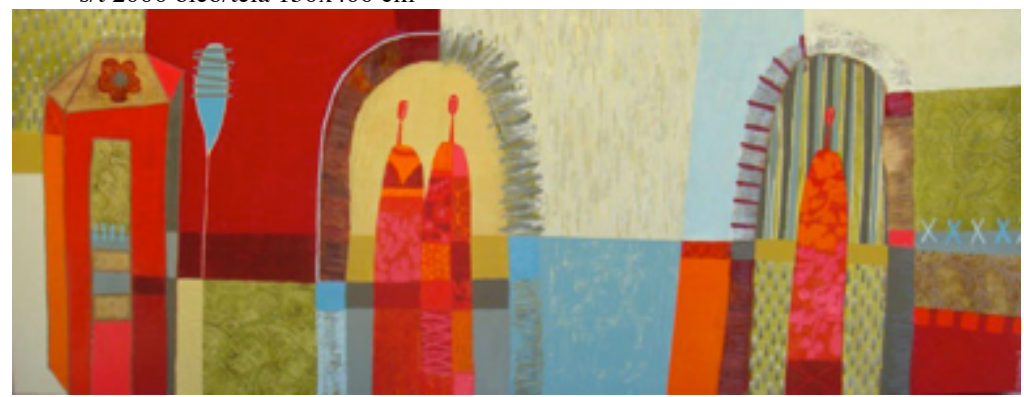

s/t 2006 oleo/tela $150 \times 400 \mathrm{~cm}$

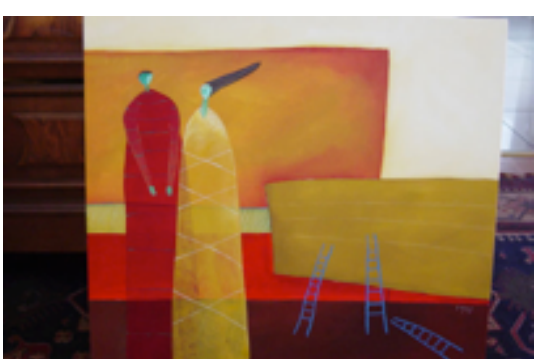

s/t 2008 oleo/tela $100 \times 150$

www.microescala.cl/socias.htm

http://www.acontemporaneo.cl/galeria4.html

www.portaldearte.cl

http://www.acontemporaneo.cl/ 


\section{$N^{\circ} 25$ ficha}

\section{Francisca Castaño}

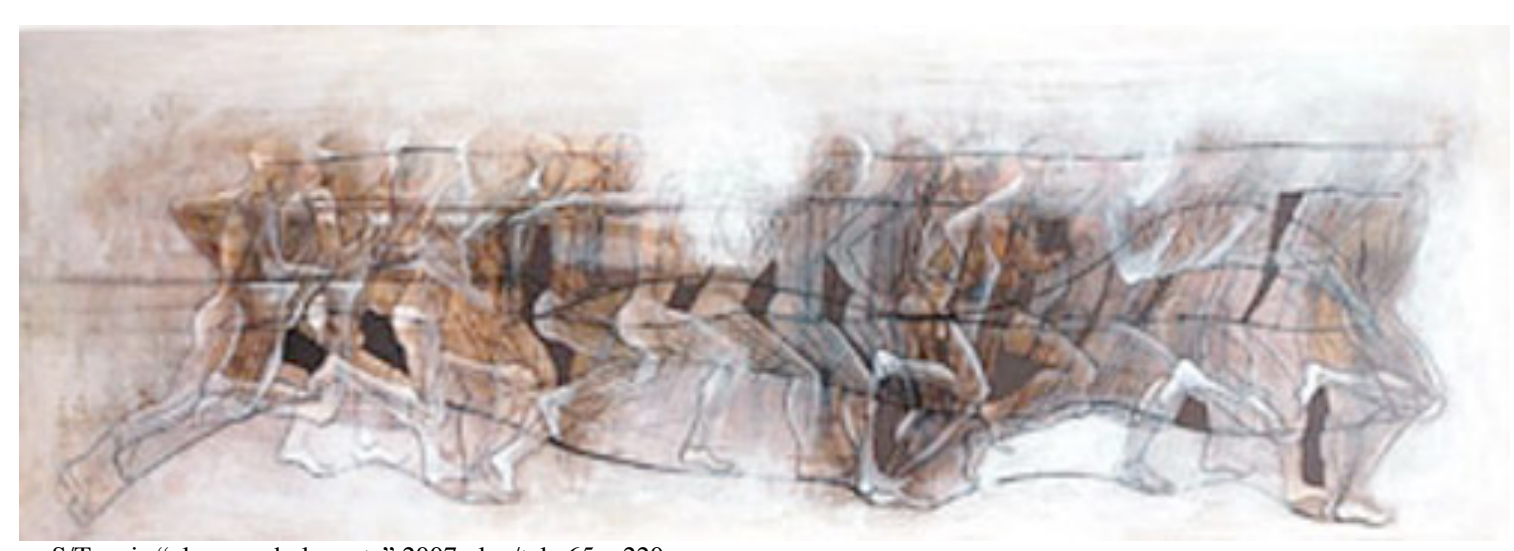

S/T serie "alcanzando la meta" 2007 oleo/tela 65 x 220
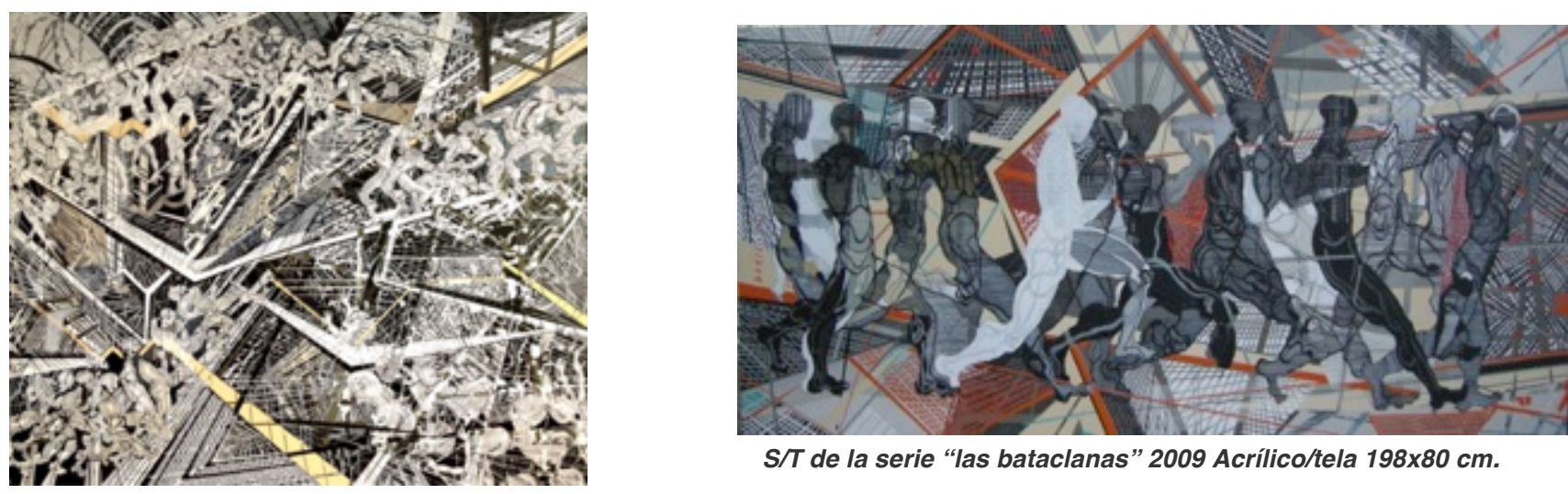

S/T de la serie "las bataclanas" 2009 Acrílico/tela 198x80 cm.

$\mathrm{S} / \mathrm{T}$ dela serie "alcanzando la meta" 2008 Acrílico/tela 120x150 cm

www.franciscacastano.com/Contacto.html

www.artfacts.net/es/artista/francisca-castao-66523/perfil.html 
$N^{\circ} 26$ ficha

\section{Francisco Moran}

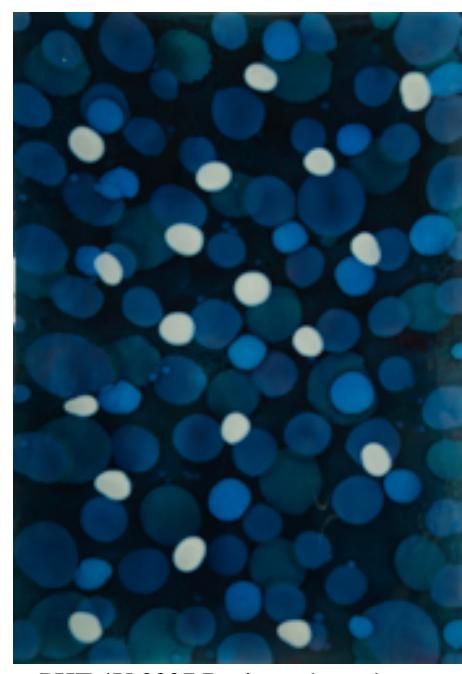

PHT 4U 2007 Resina sobre tela

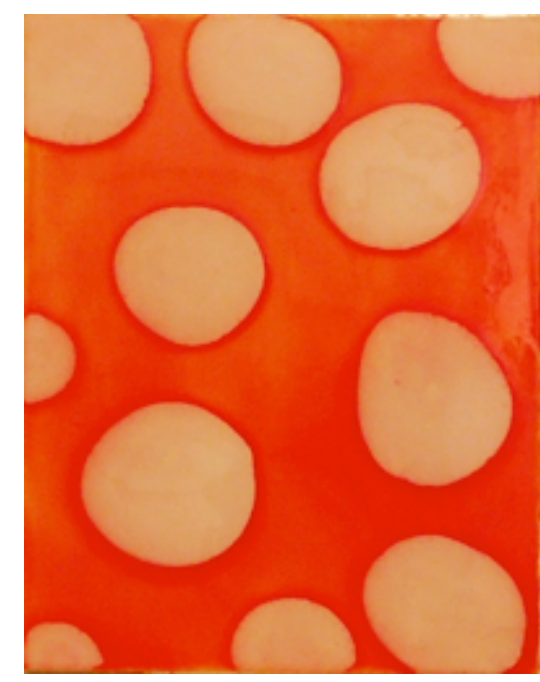

PHT 7R 2008 Resina 76 x $61 \mathrm{~cm}$

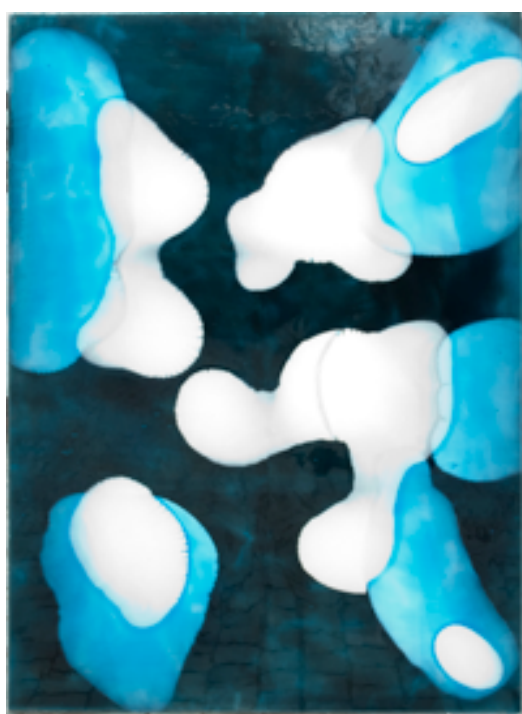

A7976 PHT1E 2008 Resina tela 180 x

http://rtfranciscomoran.blogspot.com/

http://www .arteinformado.com/guia/f/francisco-moran-48599

http://www.portaldearte.cl/agenda/pintura/2008/francisco_moran.html 


\section{Giancarlo Bertini}

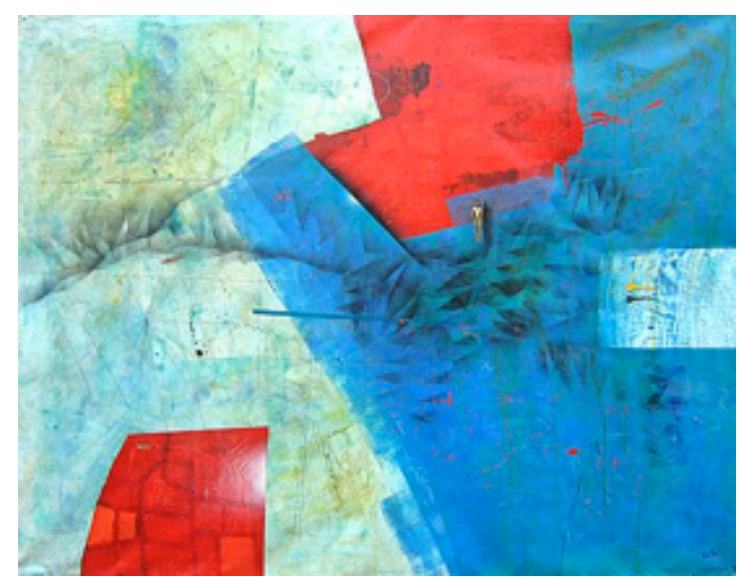

"The Big Bang" 2013 oleo/tela 55x74 pulgadas

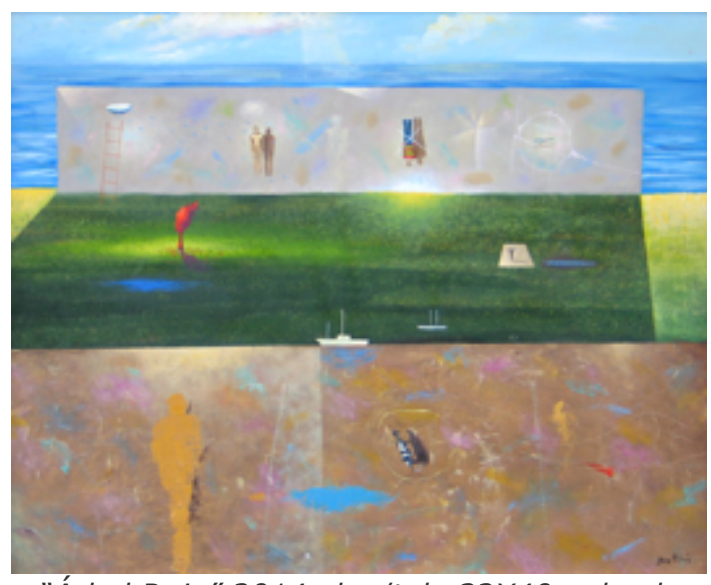

"Árbol Rojo" 2014 oleo/tela 32X40 pulgadas

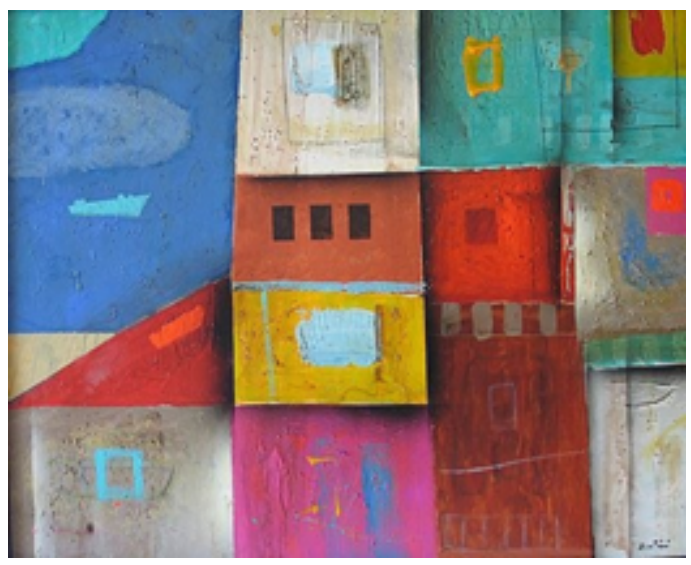

"Casas en la colina" oleo/tela 30x39 pulgadas

http://www .artistasplasticoschilenos.cl/658/w3-article-40177.html www.giancarlobertini.cl/index.php/25-giancarlo-bertini https://gallerybergelli.wordpress.com/2011/07/02/219/ 


\section{$N^{\circ} 28$ ficha}

\section{Jorge Gerrero}
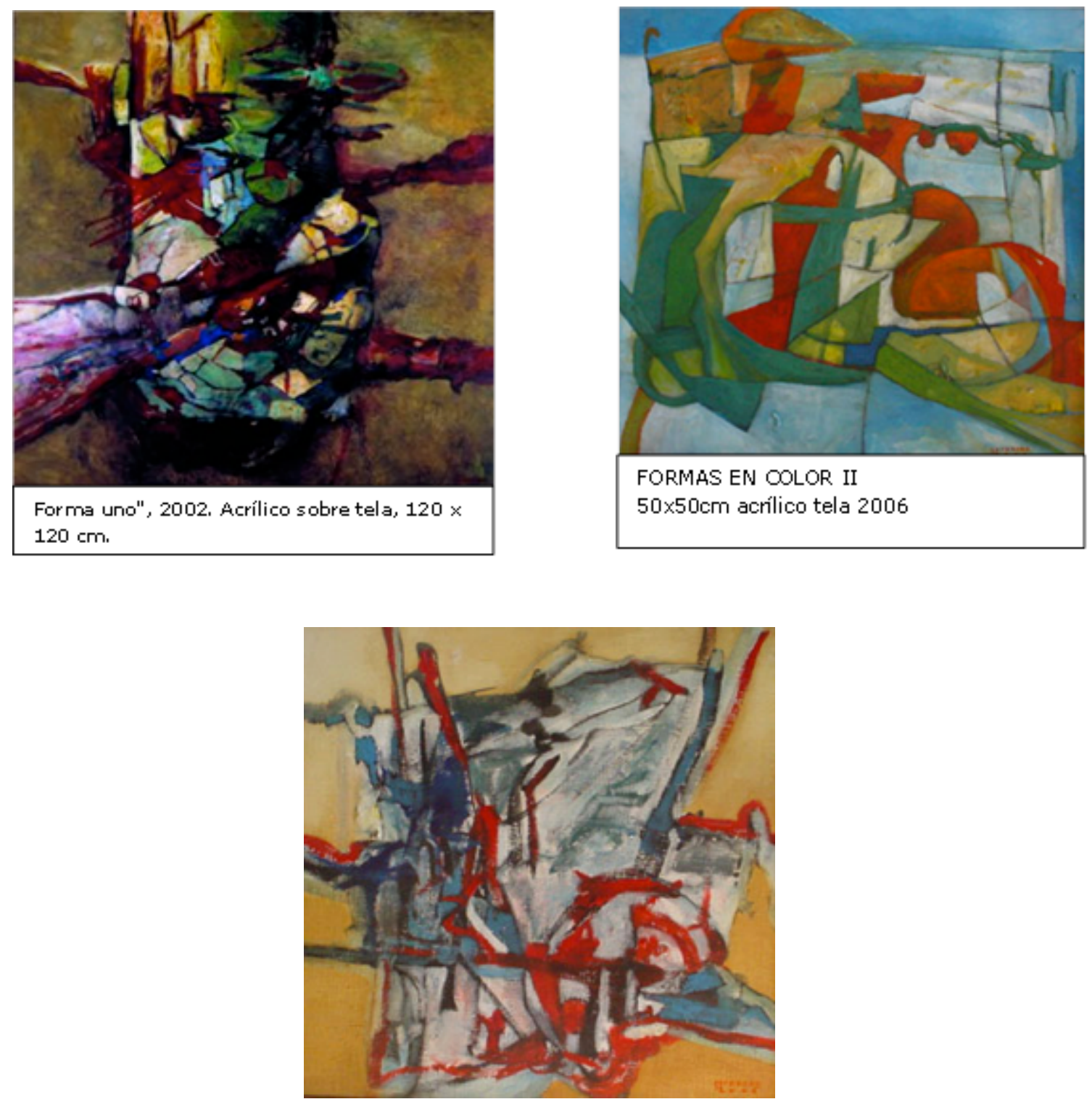

“FORMAS EN COLOR I” 2006 50x50 cm acrílico

www.artistasplasticoschilenos.cl/658/w3-article-39790.html www.galeriasalataller.cl/guerrero-jorge/

http://www.portaldearte.cl/artistas_visuales/guerrero_jorge.html 


\section{$N^{\circ} 29$ ficha}

\section{Manuel Torres}

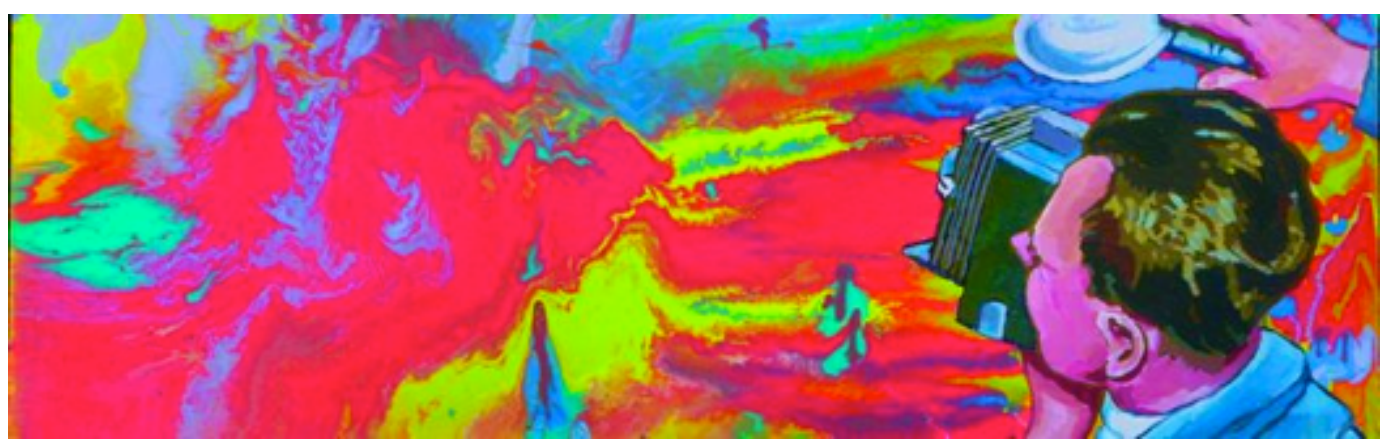

"Head of fish II" 2010 esmalte/madera 30x90cm.

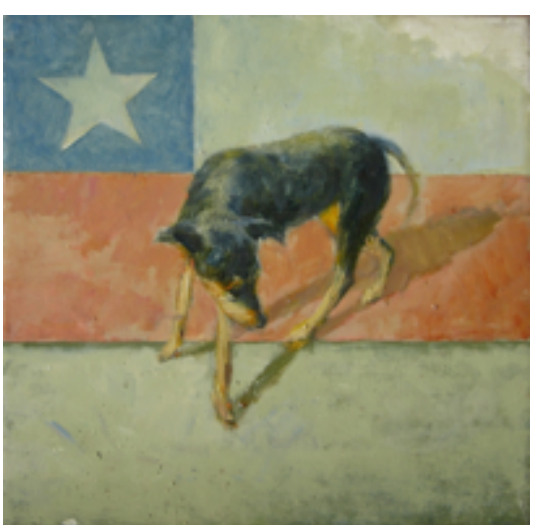

S/T, Manuel Torres 2008 óleo/tela 30x30 $\mathrm{cm}$

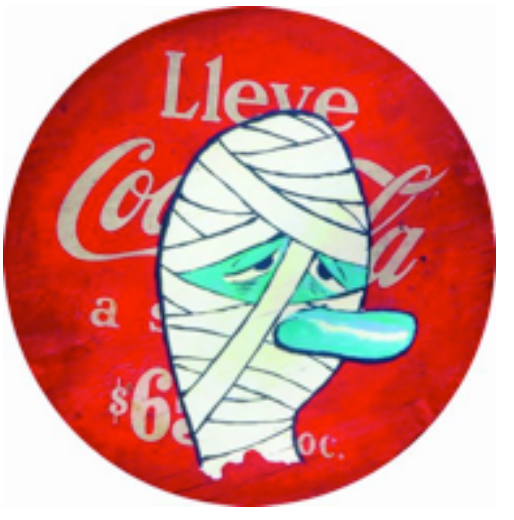

“arqueología” 2010 esmalte/madera 35 cm. diámetro

www.artistasplasticoschilenos.cl/658/w3-article-39714.html

http://galeriagm.cultura.gob.cl/coleccion_artista/m/74

http://revista.escaner.cl/node/3183 
$N^{\circ} 30$ ficha

Oscar Concha
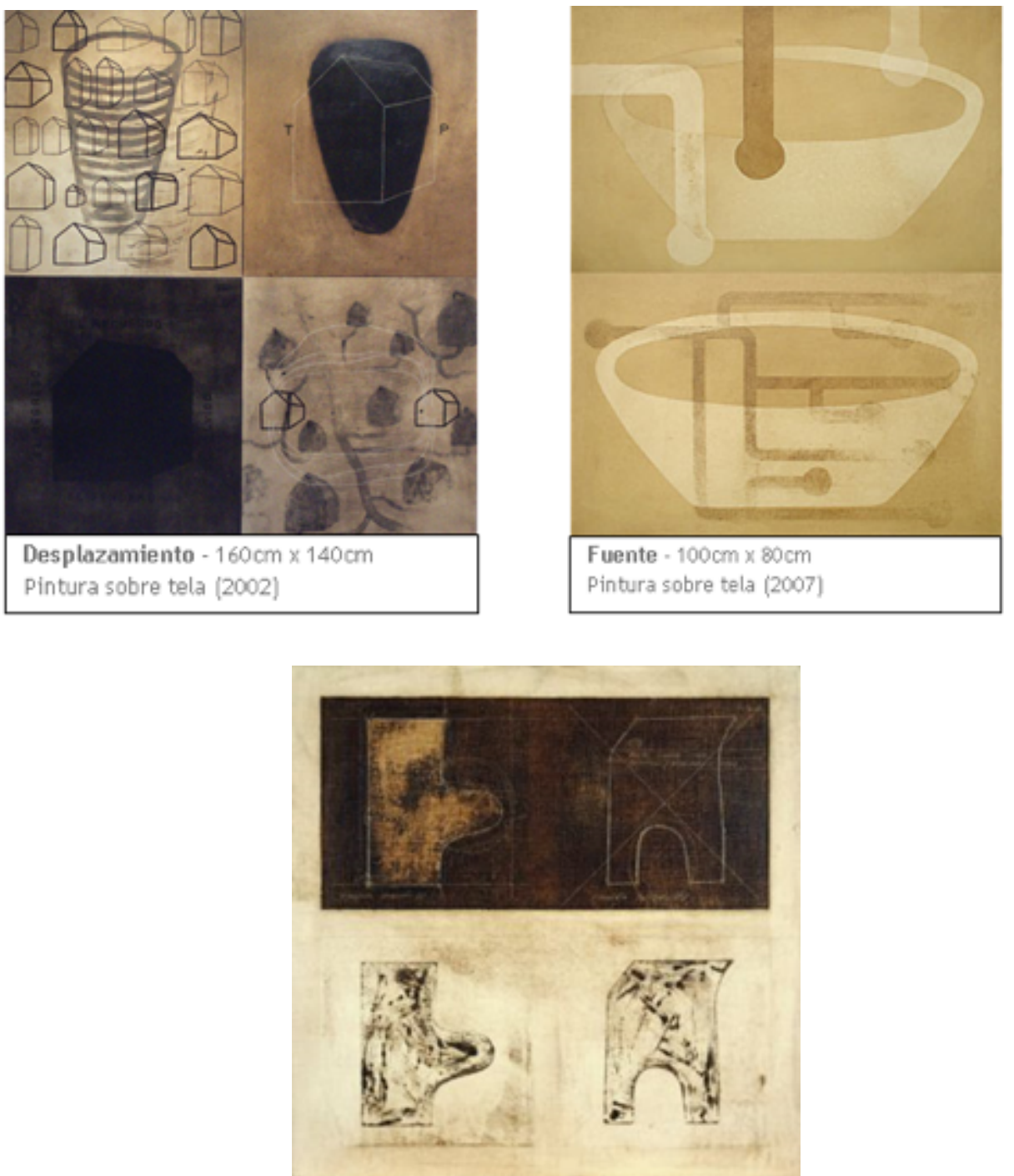

S/T 2009 acrílico/tela 1x1mt.

http://www.artistasplasticoschilenos.cl/658/w3-article-39803.html\#obra http://www.galeriasalataller.cl/concha-oscar/ http://rtoscarconcha.blogspot.cl/ 


\section{$N^{\circ} 31$ ficha}

\section{Pablo Jansana}

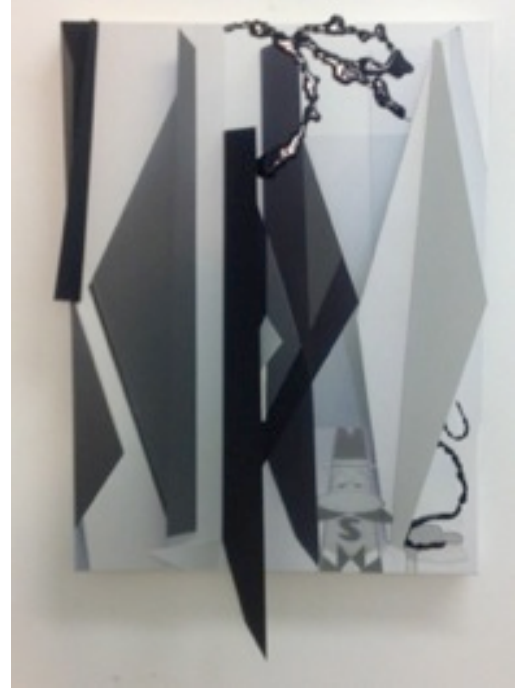

Nostalgia and Affection 3 (Bialetti Express), 2014 Epson Ultrachrome 4880 inyección en papel de algodón, aluminio, esmalte, panel de madera 61 x 46 $\mathrm{x} 13 \mathrm{~cm}$.

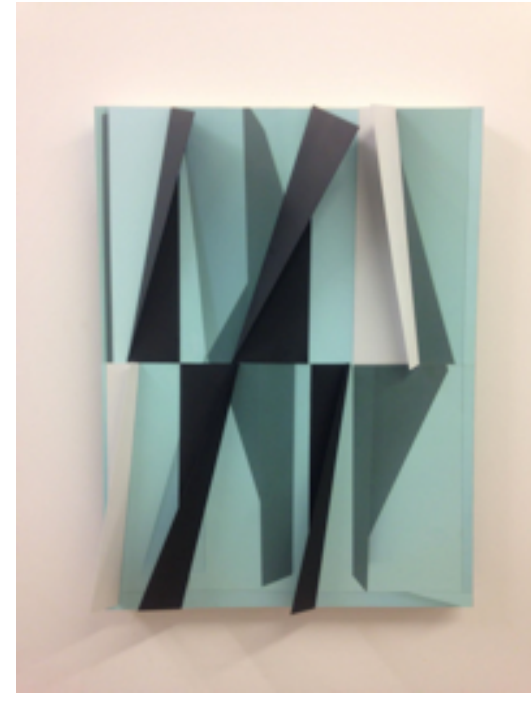

Nostalgia and Affection 4 (Bialetti Express), 2014 Epson Ultrachrome 4880 inyección en papel de algodón, aluminio, esmalte, panel de madera $61 \times 45.5 \times 15 \mathrm{~cm}$

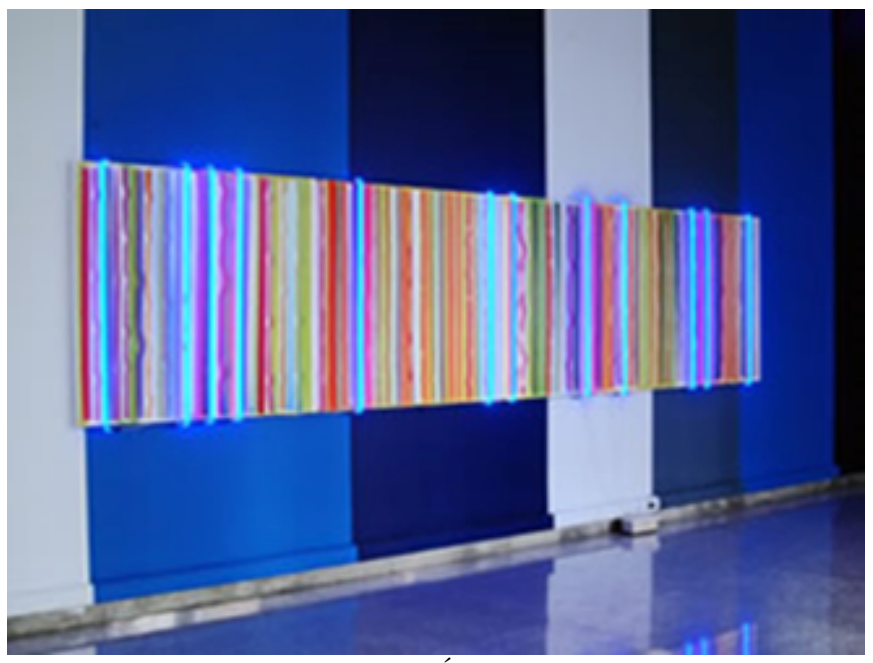

"Los secretos de la luz del día" 2005 Óleo/ lino y neón 5,2 x 1,3 m.

http://rtpablojansana.blogspot.com/

www.pablojansana.com

http://www.salagasco.cl/sala_expo_orden.html 
$N^{\circ} 32$ ficha

\section{Pamela Bozinovic}
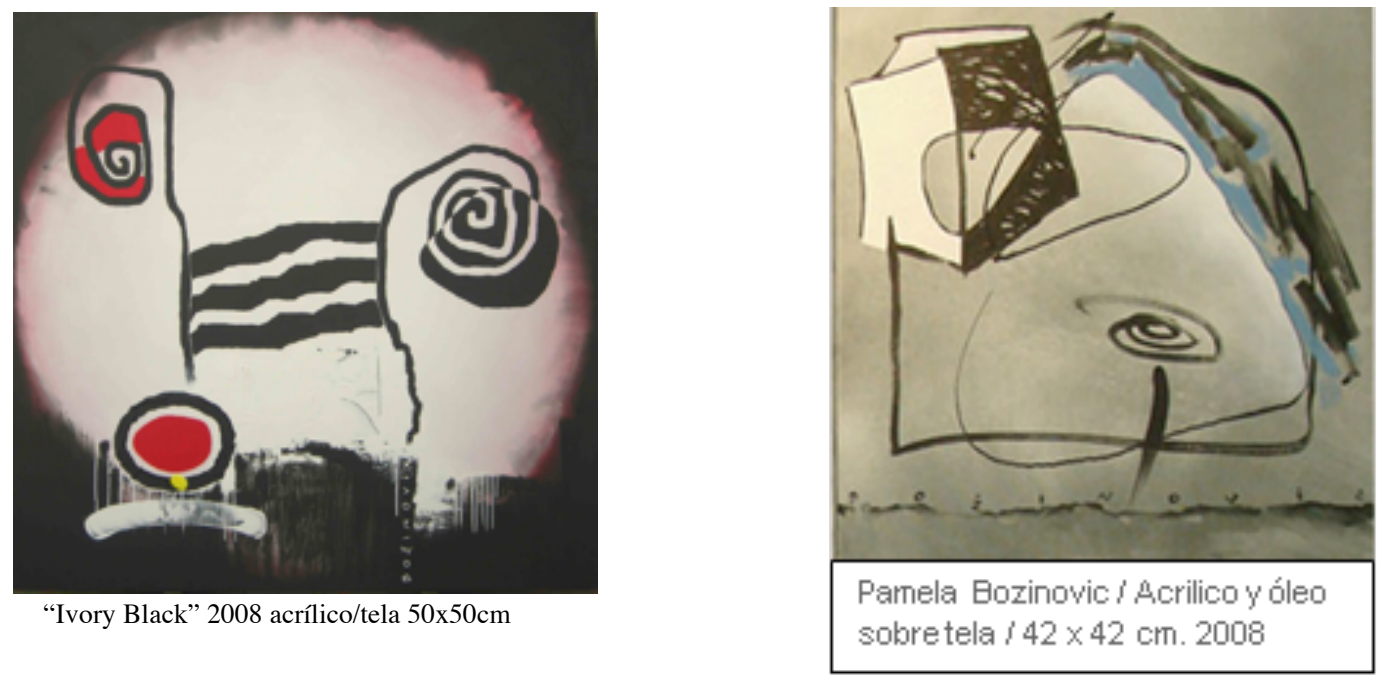

"Ivory Black" 2008 acrílico/tela 50x50cm

Pamela Bozinovic íAcrilico yóleo

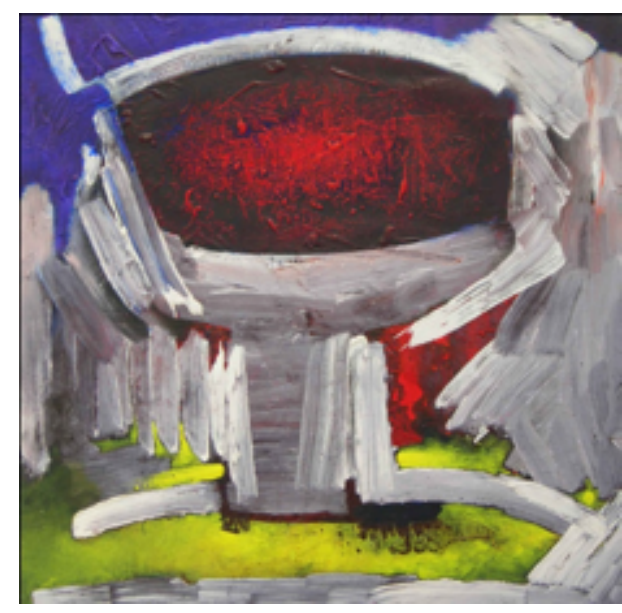

S7T 2010 oleo, mixta/tela $1 x 1 \mathrm{mt}$.

www.artistasplasticoschilenos.cl/658/w3-article-39749.html

www.galerialasala.cl/.../pamela-bozinovic-ymarcelo-vergara-ivory-black/ 


\section{Patricio Court}
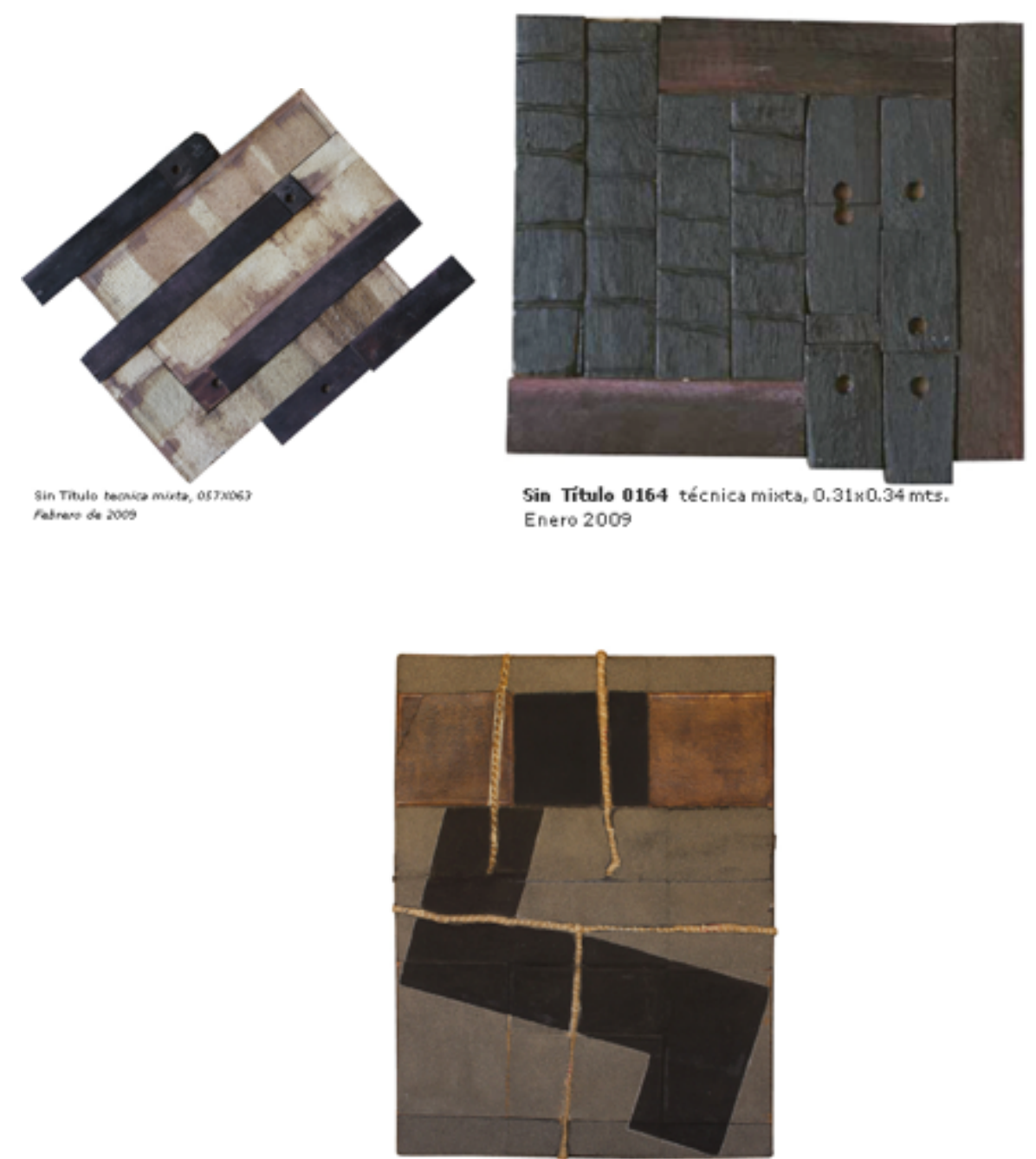

S/T 2009 mixta, 132x099 cm.

http://www.artfacts.net/es/artista/patricio-court-1777/artwork/sin-ttulo-0164-26589.html www.artistasplasticoschilenos.cl/658/w3-article-39547.html 


\section{Pablo Laglois Vicuña}

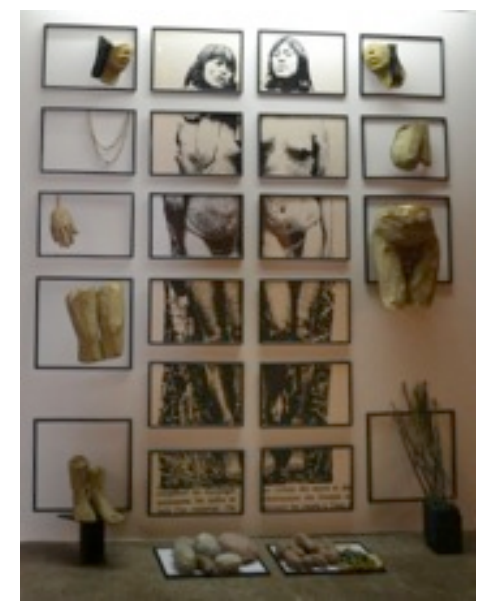

“de la serie Misses”, 2012

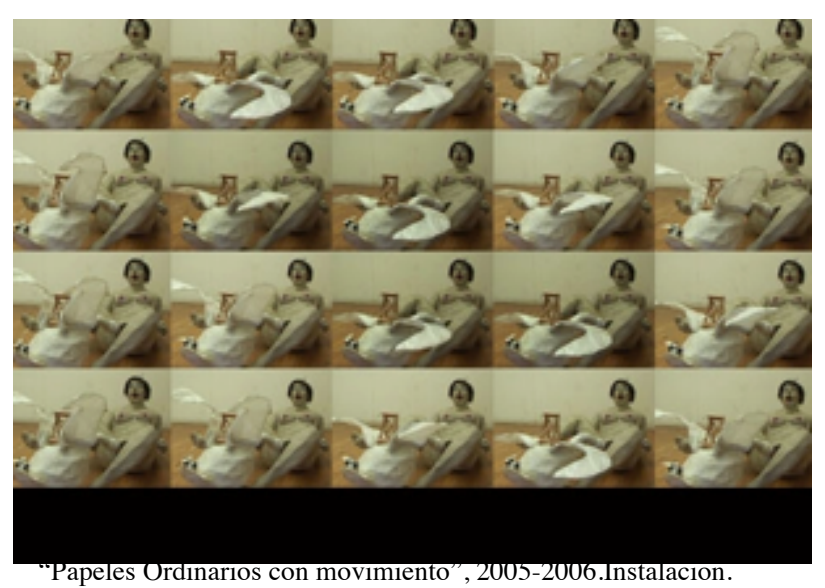

Plastilina, cabello natural, papel. Ed. Única. Medidas variables.

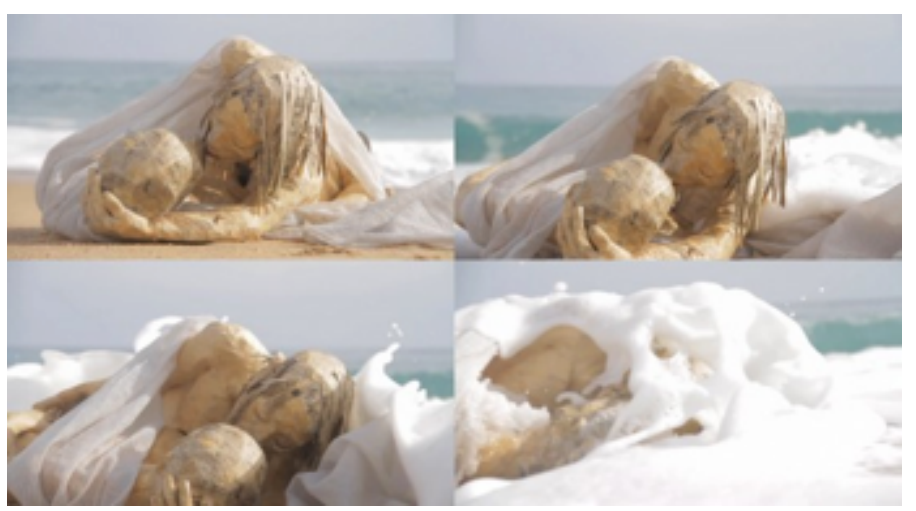

“Papeles sádicos”, 2012

http://www.arteycritica.org/criticas-de-arte/tinta-corrosiva-y-papel-que-se-deshace-la-retrospectiva-a-langloisvicuna-en-m100/

http://www.artistasplasticoschilenos.cl/658/w3-article-40064.html\#obra http://www.galeriaafa.com/?portfolio=que-dice-1-mayo 


\section{Rodrigo Galecio}

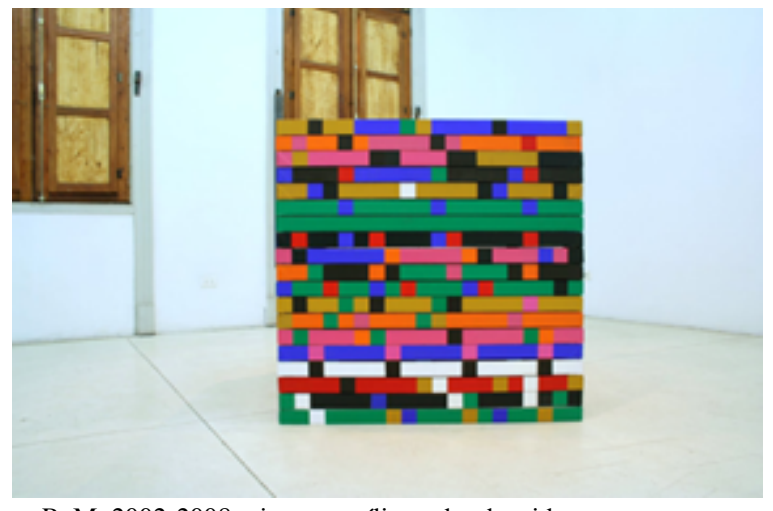

RaM, 2002-2008, pintura acrílica sobre bastidor

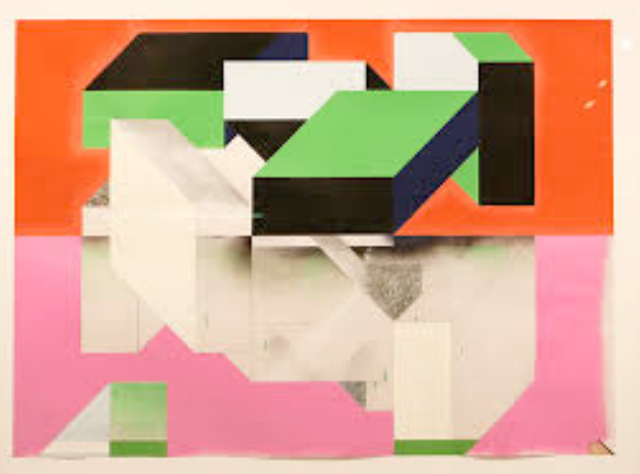

Apocalipsis Nau - mixta/ papel, 70 x 108 cm, 20132014

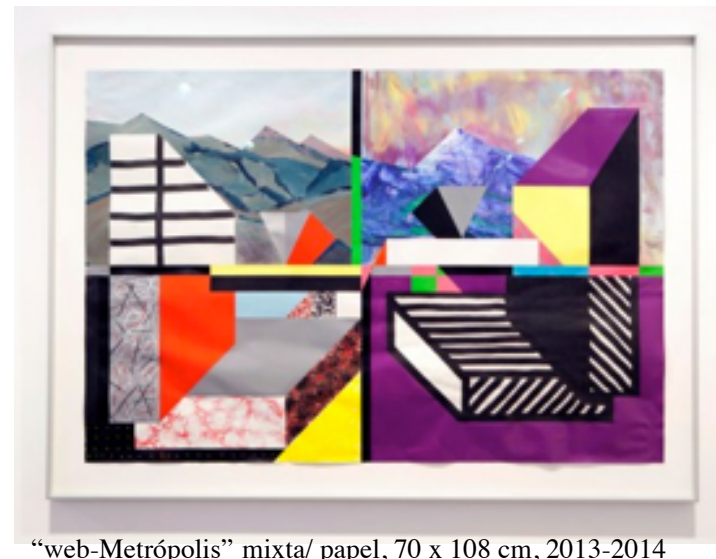

“web-Metrópolis" mixta/ papel, 70 x 108 cm, 2013-2014

http://www.artistasplasticoschilenos.cl/658/w3-article-40149.html HTTP://TALLERBLOC.CL/TUTORES/RODRIGO-GALECIO/ 
$N^{\circ} 36$ ficha

\section{Rubén Fernández}
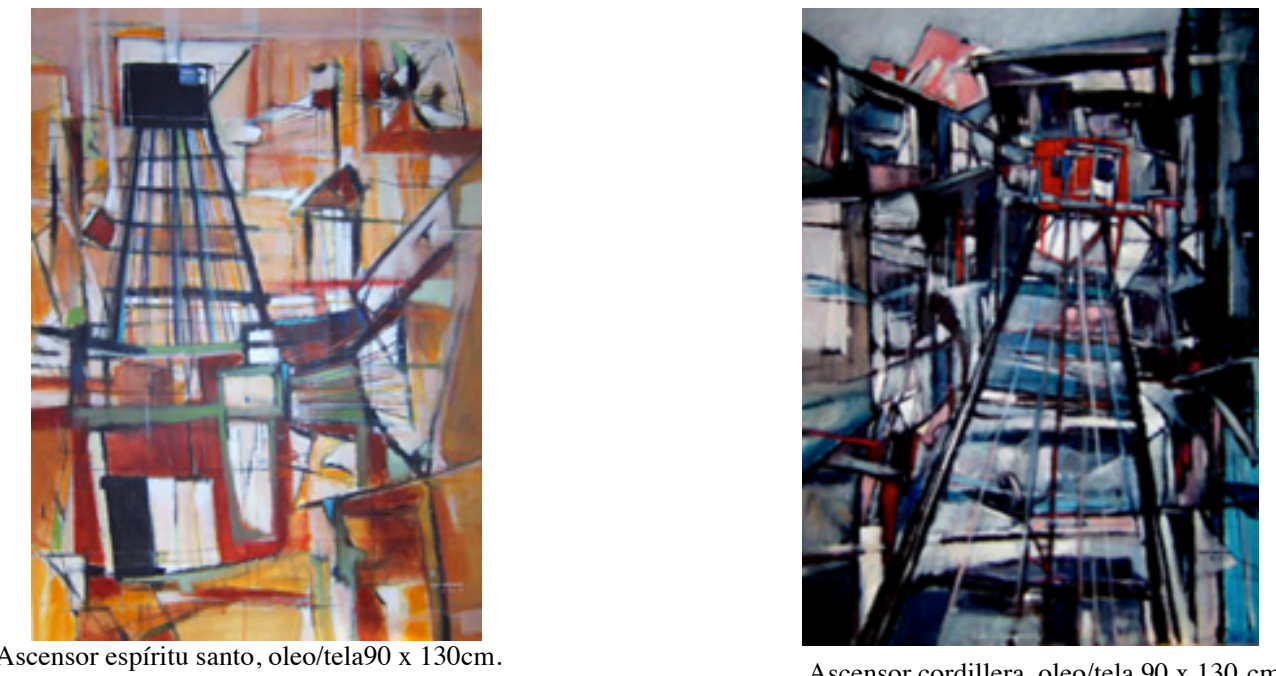

Ascensor cordillera, oleo/tela 90 x $130 \mathrm{~cm}$.

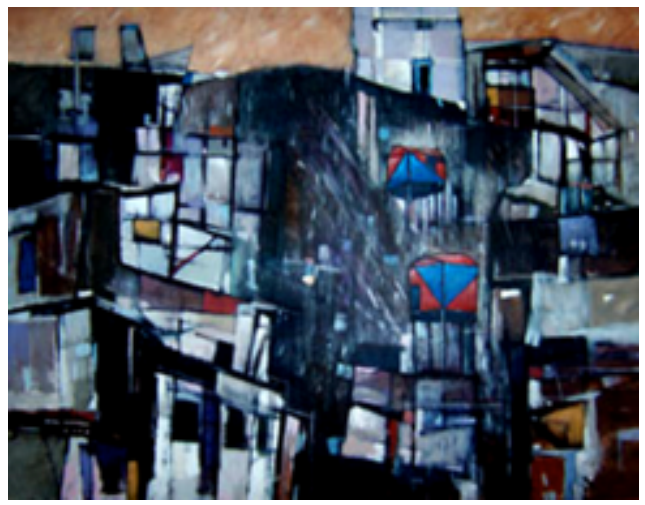

Ascensor Larraín, 2008 oleo/tela 83,5 x 108 cm.

www.artistasplasticoschilenos.cl/658/w3-article-39811.html www.portaldearte.cl/artistas_visuales/fernandez_ruben.html 


\section{$N^{\circ} 37$ ficha}

\section{Samy Benmayor}

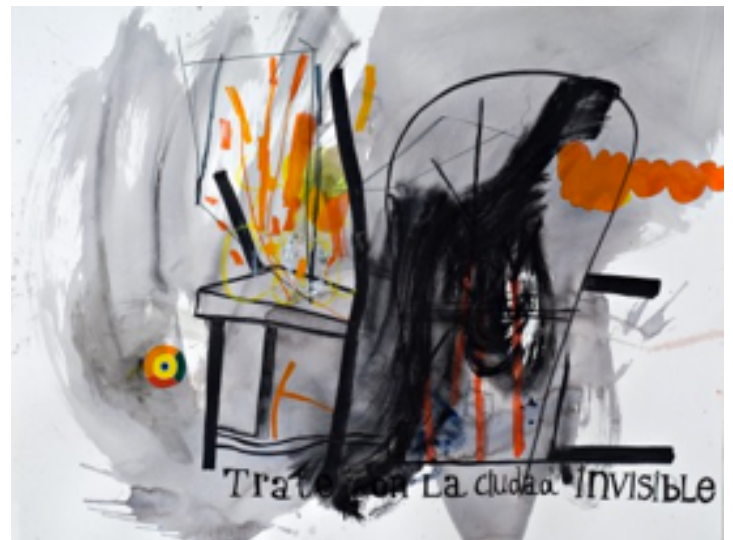

"La ciudad invisible" Acrílico y acuarela / papel 75 x 105

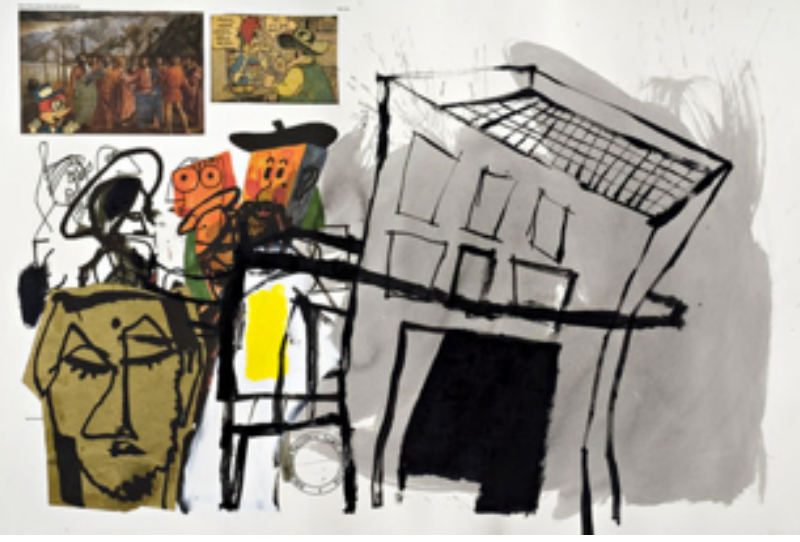

The Witness, 2007 Acrílico y tinta/impresión digital 31 x 47

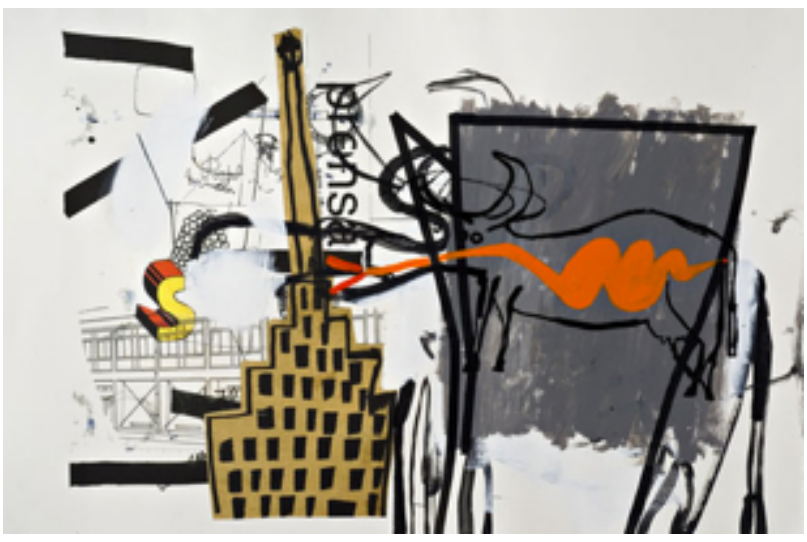

"The Illuminated Cow" 2007 Acrílico, y tinta/impresión digital 31 $\mathrm{x} 47$ pulgadas

http://samybenmayor.com/

http://www .artistasplasticoschilenos.cl/658/w3-article-40329.html\#obra 
$N^{\circ} 38$ ficha

\section{Ximena Mandiola}
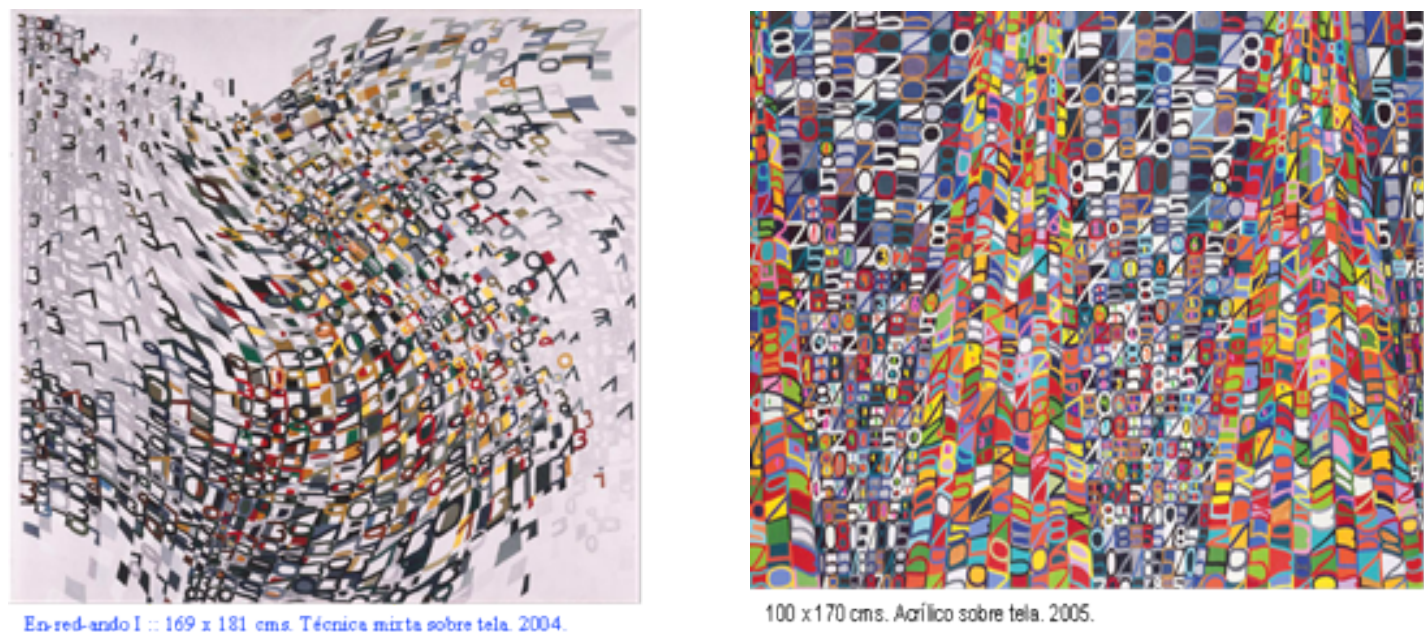

$100 \times 170$ cns. Agrilloo sobre tela. 2005

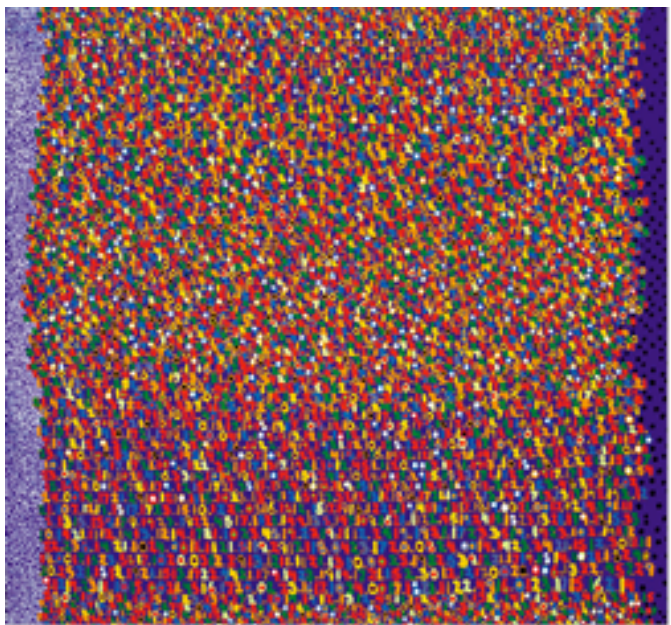

Tiempo Fugaz :: $120 \times 110 \mathrm{cms}$.

Acrílico sobre tela. 2001. 
$N^{\circ} 39$ ficha

\section{Ximena Velazco}

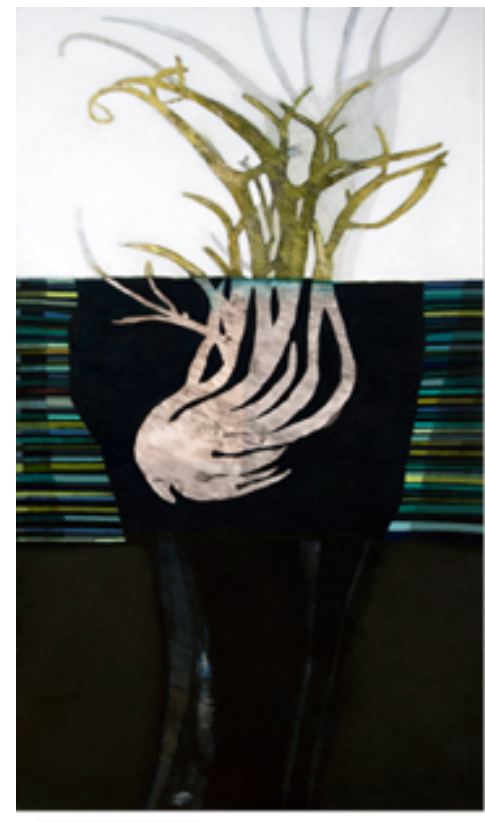

Sin titulo, 2013

Acrilico sobre tela, $100 \times 200$ cns

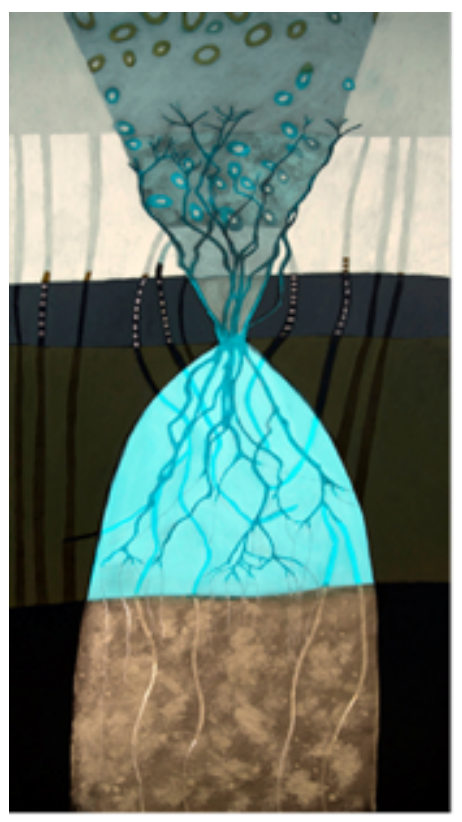

Sin titulo, 2013

Oleo sobre tela, $100: 200 \mathrm{cms}$

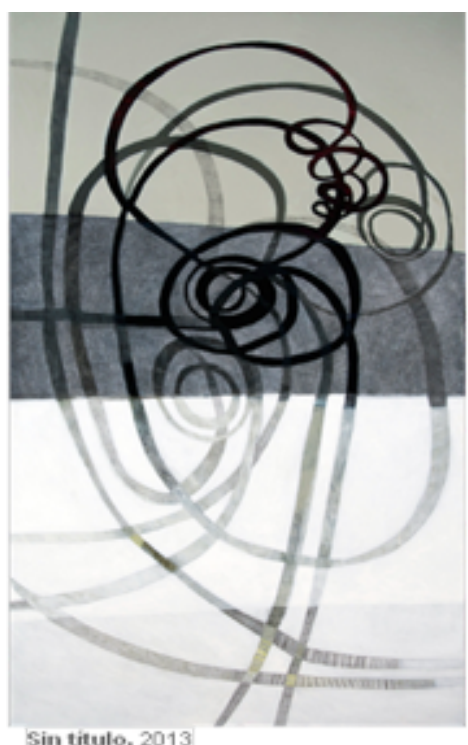

Acrilico sobre tela, $200 \times 100 \mathrm{cms}$. 


\section{Alejandra Cigarroa}

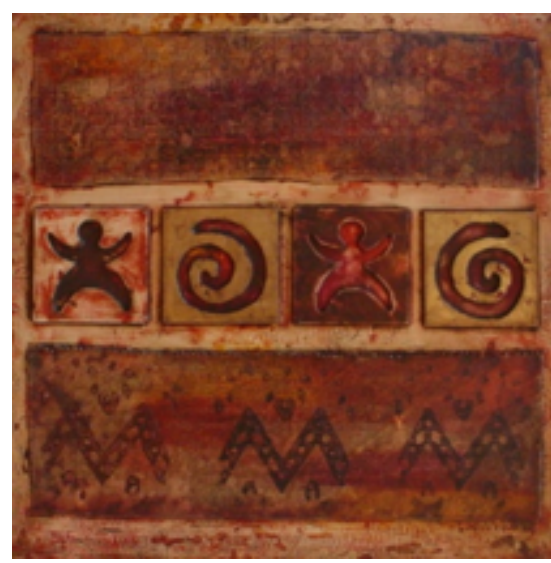

TEXTIL I 2006 mixta/tela 50x50 cm

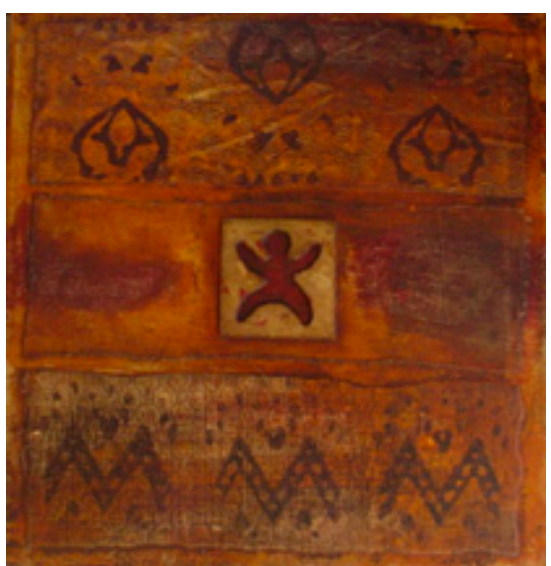

“TEXTIL II” 2006 mixta/tela 50x50 cm

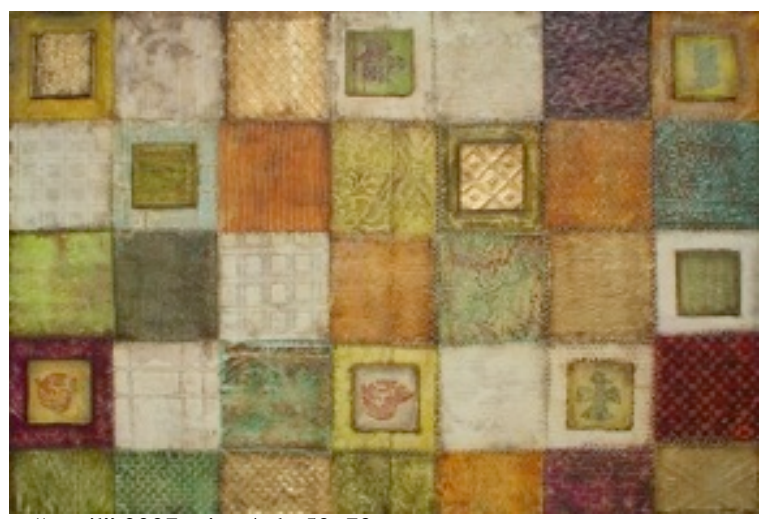

“textil” 2007 mixta/tela $50 \times 70 \mathrm{~cm}$.

http://www.artistasdelatierra.com/artistas/PORTALDEARTE/blog-44.html

http://www.portaldearte.cl/artistas_visuales/cigarroa_alejandra.html

https://picasaweb.google.com/salablanco/AlejandraCigarroa?feat=flashslideshow \#5242294155407247890 
$N^{\circ} 41$ ficha

\section{Loreto Corvalán}

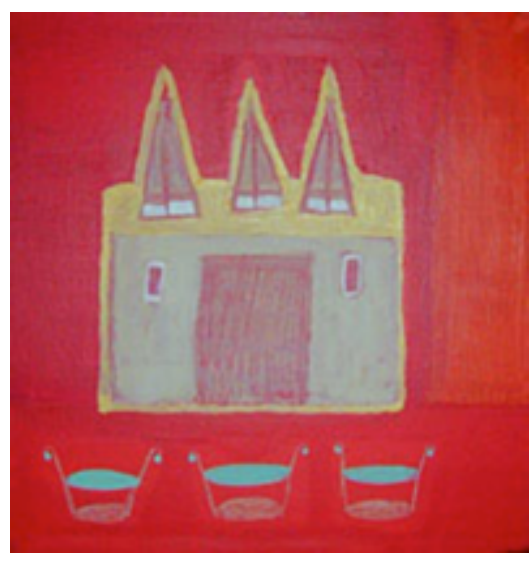

S/T 2005 oleo/tela 150x150 CM.

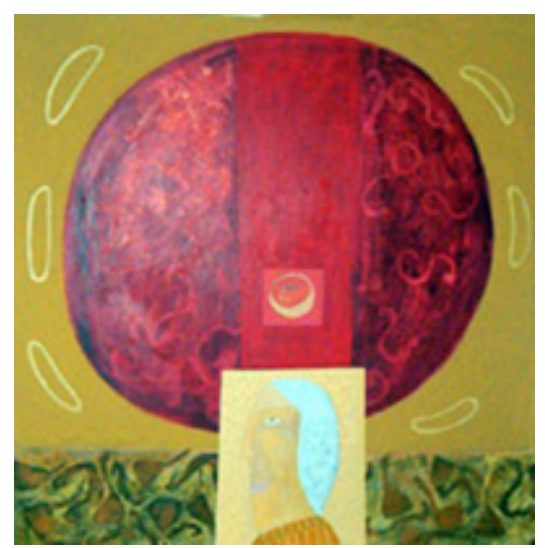

S/T 2005 oleo/tela 150x150 CM

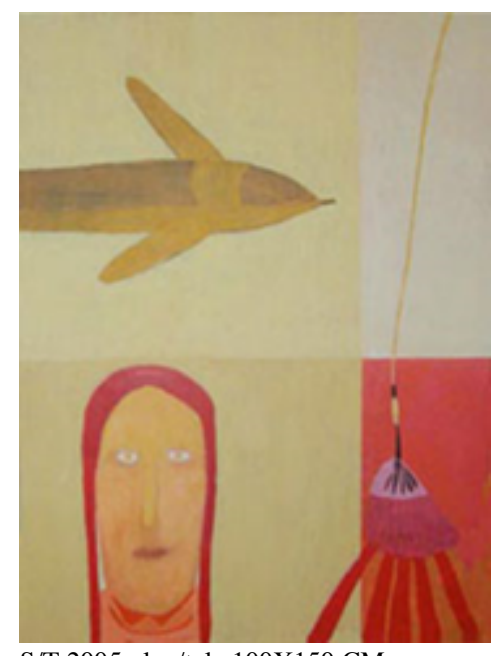

S/T 2005 oleo/tela 100X150 CM.

http://loretocorvalan.free.fr

http://www.lagaleria.cl

http://www.sieterayas.cl 
$N^{\circ} 42$ ficha

\section{Luis Cuello}
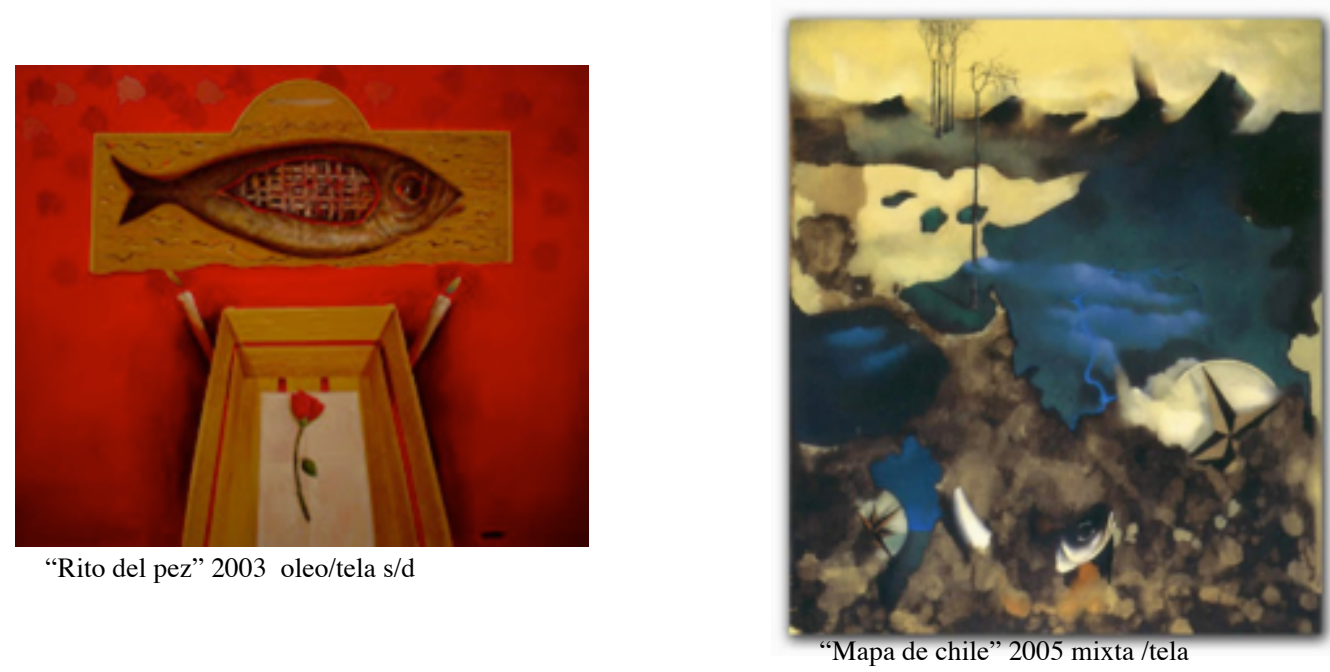

"Rito del pez" 2003 oleo/tela s/d

"Mapa de chile" 2005 mixta/tela

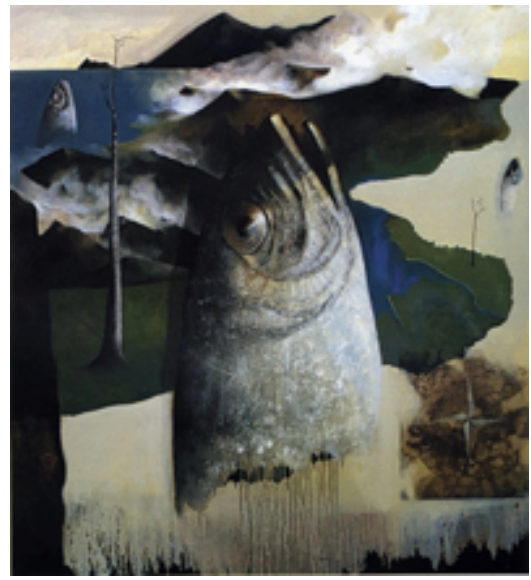

"El pez nuestro" 2006 oleo/tela s/d

http://cuellomadariaga.blogspot.com/

http://www.granconcepcion.com/pintura-grafica-dibujo-exposicion/ 
$N^{\circ} 43$ ficha

\section{Matías Movillo}

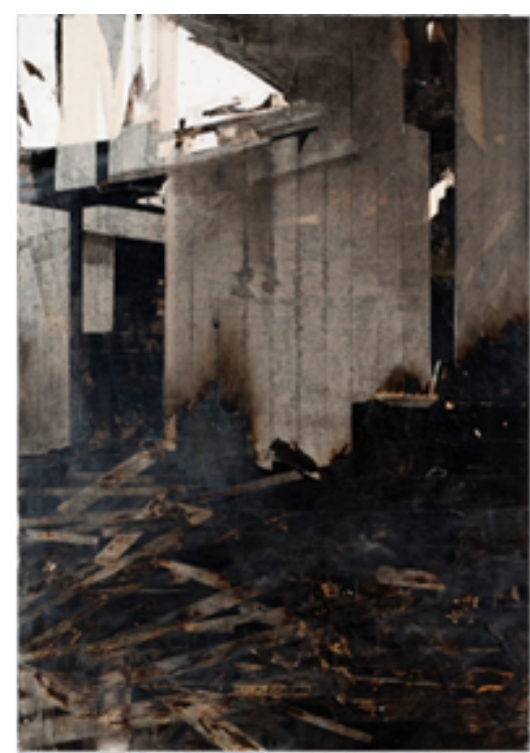

"19nicion"

2011 Cinta de enm ascarar, acrílico y fuego sobre madera. $100 \times 70 \mathrm{~cm}$.

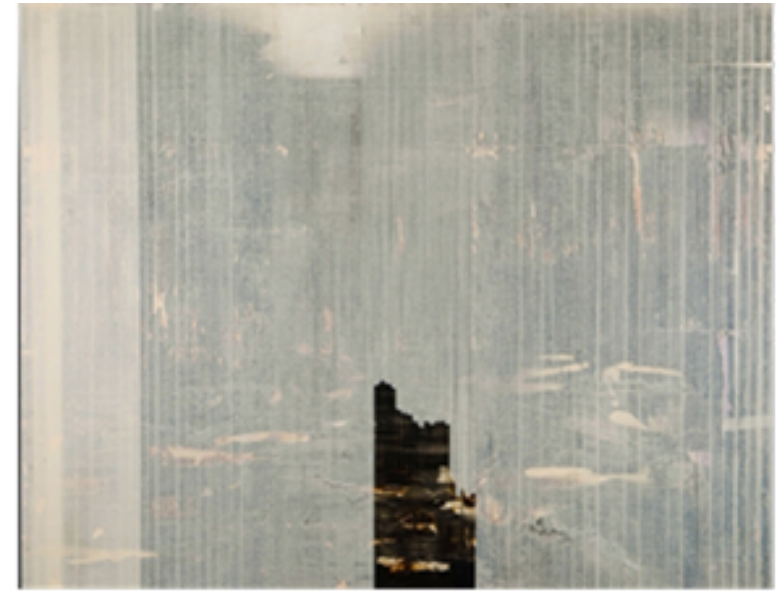

"Latencia"

2013 Cinta de enm ascarar, acrilico y tuego sobre m adera. $192 \times 211 \mathrm{~cm}$

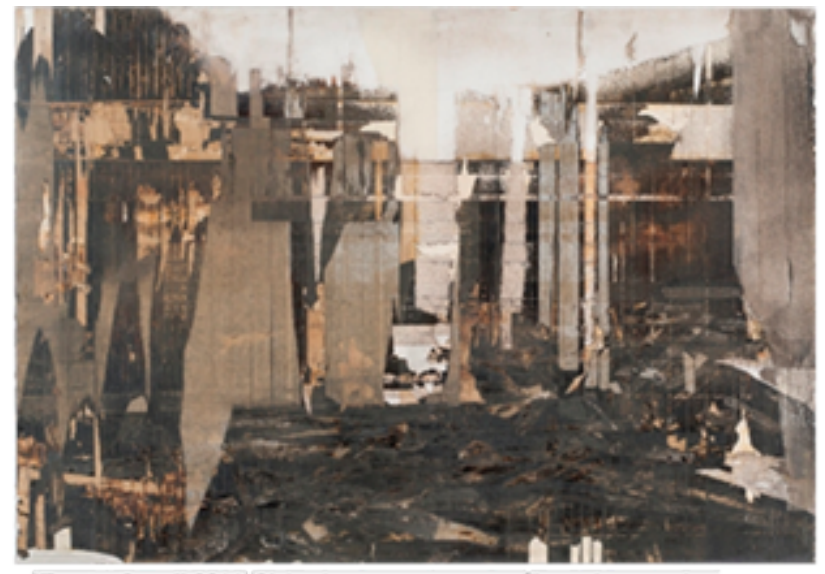

"Purto Cero" 2011 Cinta de enm ascarar, acrilico y fuego sobre madera. $100 \times 70 \mathrm{~cm}$.

http://www.artistasplasticoschilenos.cl/658/w3-article-39696.html\#obra

http://www.latercera.com/noticia/cultura/2013/06/1453-527874-9-el-paso-del-realismo-a-la-abstraccion-dematias-movillo.shtml 


\section{$N^{\circ} 44$ ficha}

\section{Jorge Tacla}

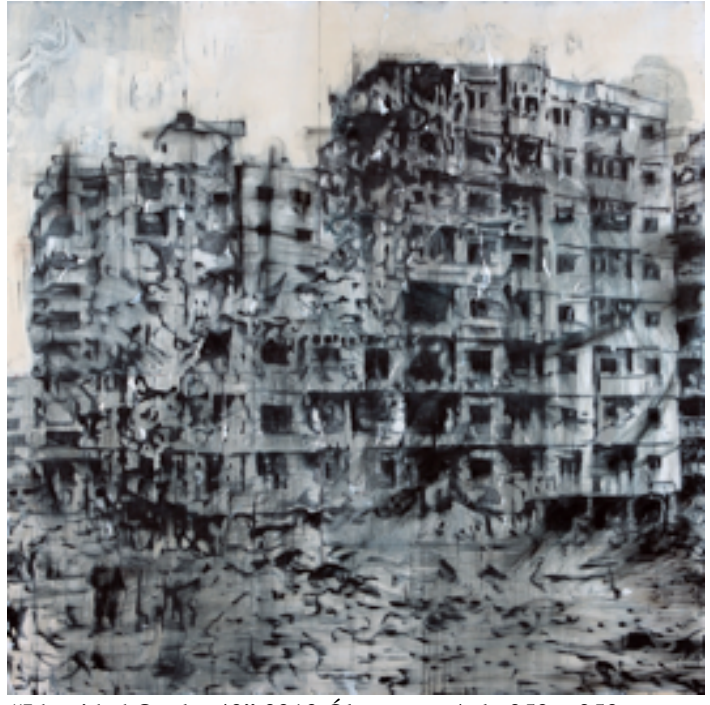

"Identidad Oculta 40" 2013 Óleo y cera/tela 250 x $250 \mathrm{~cm}$

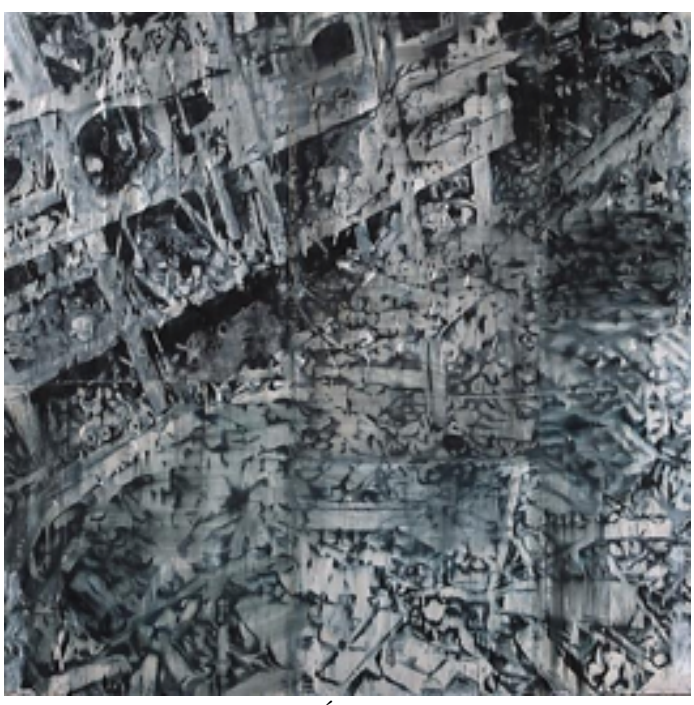

Identidad Oculta 39” 2013 Óleo y cera/tela 250 x $250 \mathrm{~cm}$

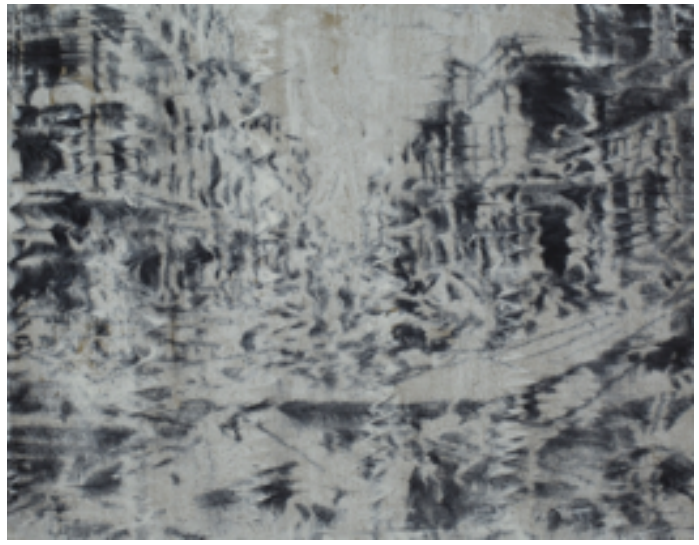

“Identidad Oculta 56”, 2014. oleo, cera/tela 33 x $40.6 \mathrm{~cm}$.

www.jorgetacla.com/

www.artistasplasticoschilenos.cl/658/w3-article-40311.html 
$N^{\circ} 45$ ficha

\section{Sebastián Maquieira}
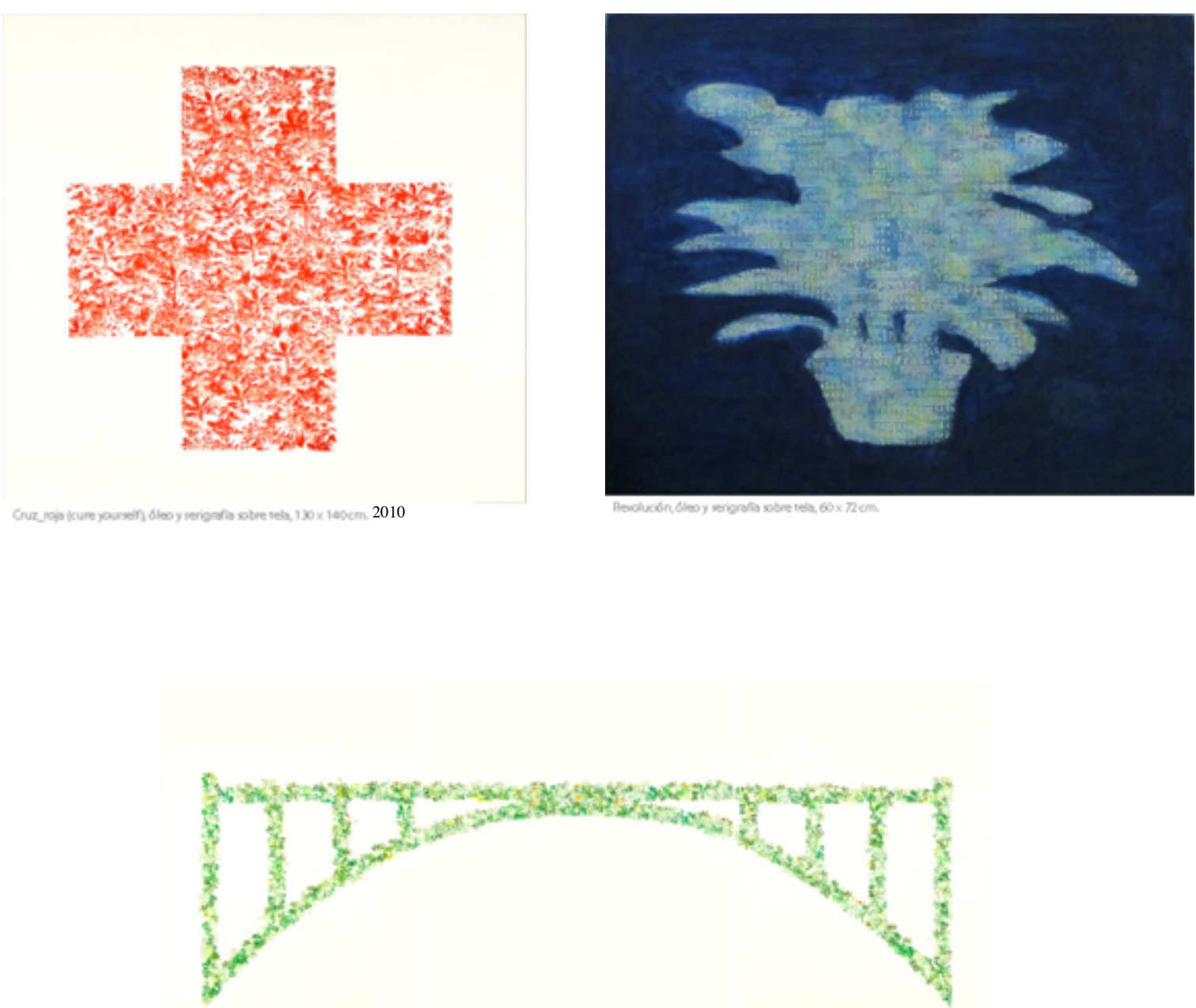

http://www.sebastianmaquieira.cl/resonancias.html http://rtsebastianmaquieira.blogspot.com/ 


\section{$N^{\circ} 46$ ficha}

\section{Pablo Langlois Prado}
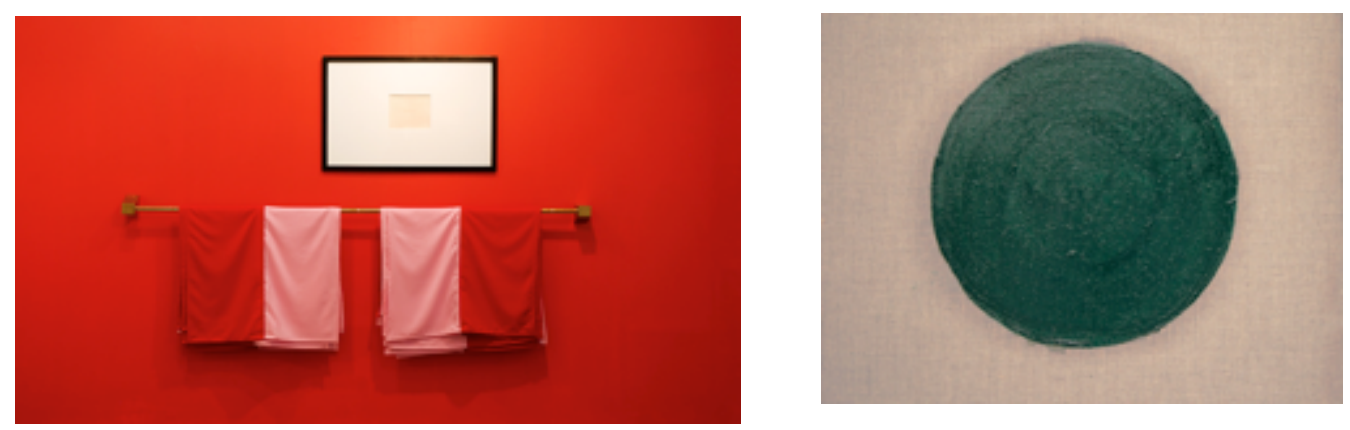

“Viridian y rojo saturno" instalacion 2013

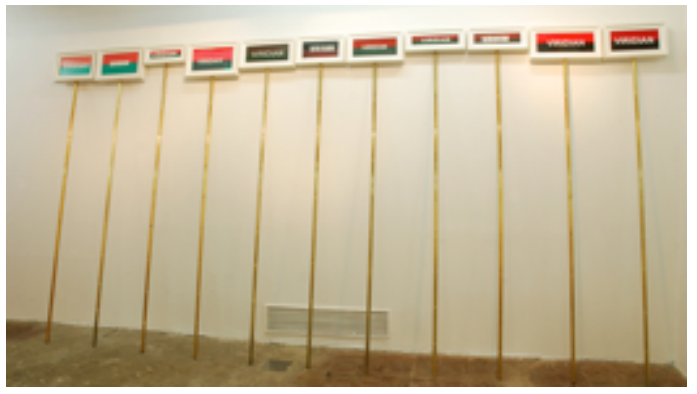

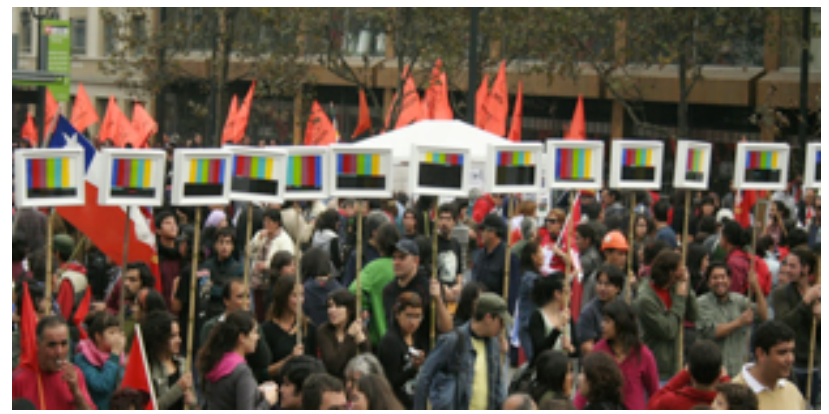

"Uniones de papel precariedad forzada" Pablo Langlois 2012

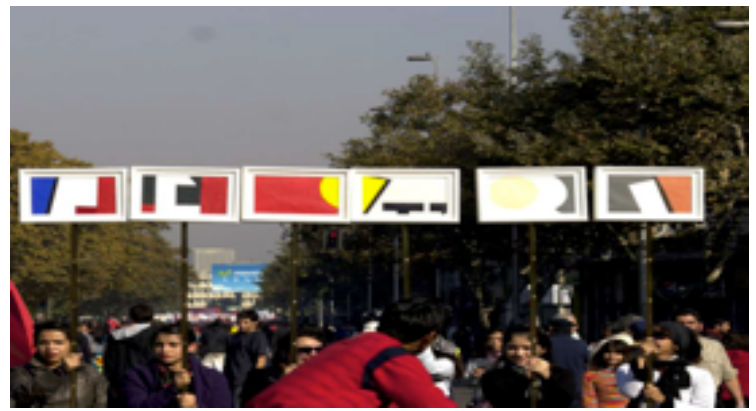

¿qué dice? Pablo Langlois, 2011

http://www .artistasplasticoschilenos.cl/658/w3-article-40064.html

http://rtpablolanglois.blogspot.com/

http://www.galeriaafa.com/?portfolio=pablo-langlois 
$N^{\circ} 47$ ficha

\section{Alex Chellew}

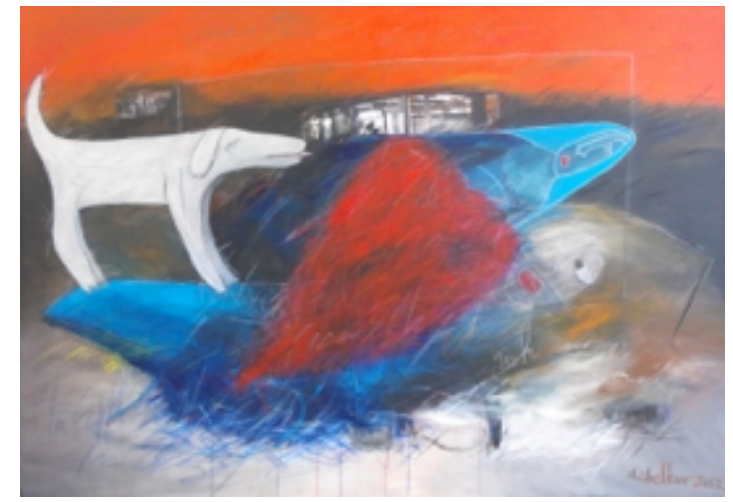

"Después de Vichuquen" 2012 Oleo, imagen digital/tela $150 \times 200 \mathrm{~cm}$.

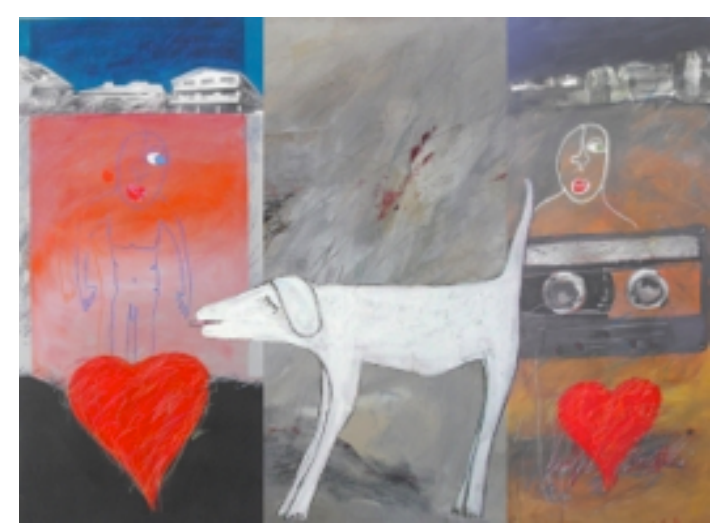

"Perro y personajes" 2012 oleo, imagen digital/tela $50 \times 70 \mathrm{~cm}$.

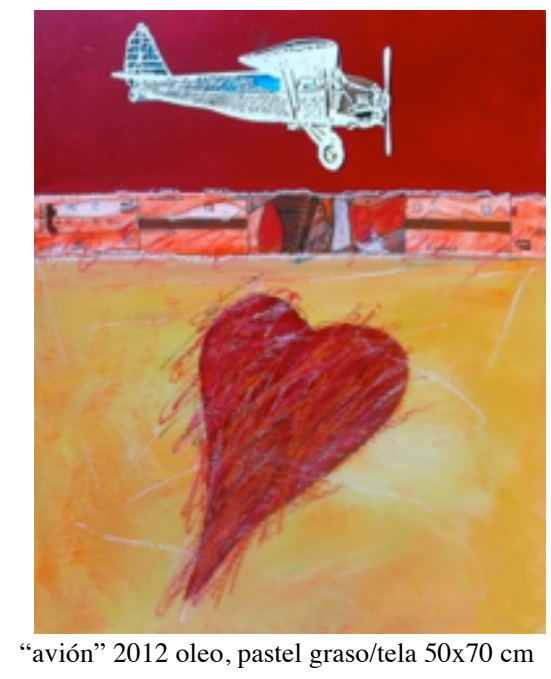

www.artistasplasticoschilenos.cl/658/w3-article-45657.htm

http://alex-chellew.artenlinea.com/ 


\section{Bruna Truffa}
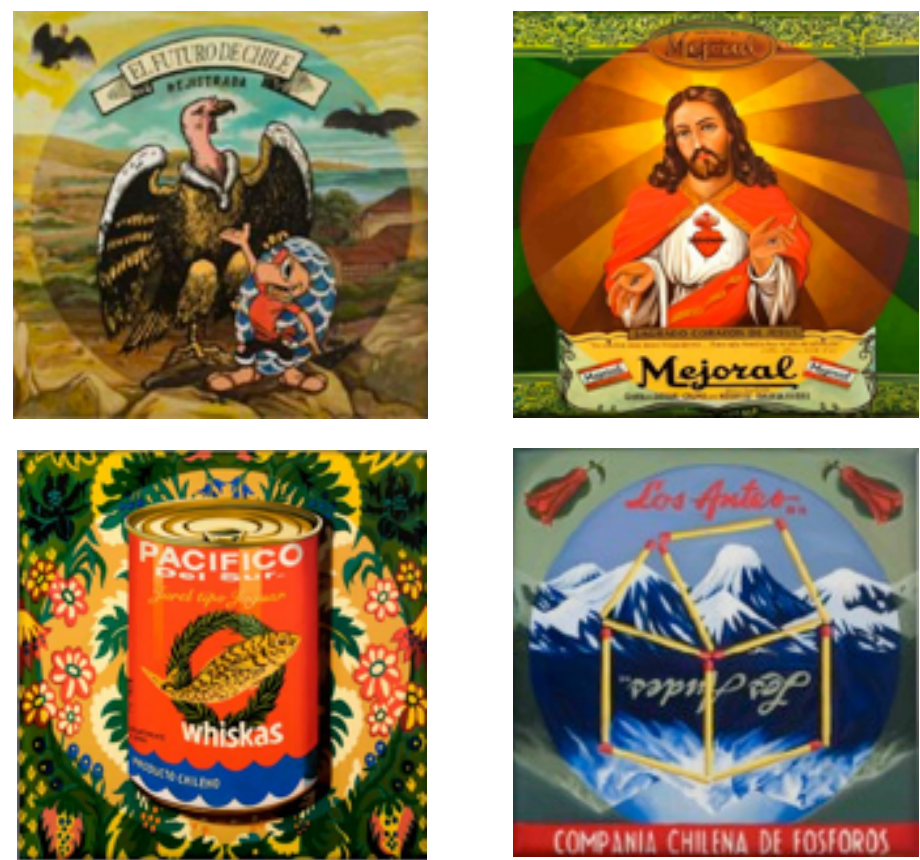

"Memorice" 2005 serie de obras de 1x1 mt. Oleo/tela donde recurre a La caja de fósforos Los Andes, el tarro de Jurel San José, la publicidad de Klenzo y los vinos Santa Rita se mezclan con tapices andinos, paisajes de Claudio Gay y los cuadros geométricos de Matilde Pérez

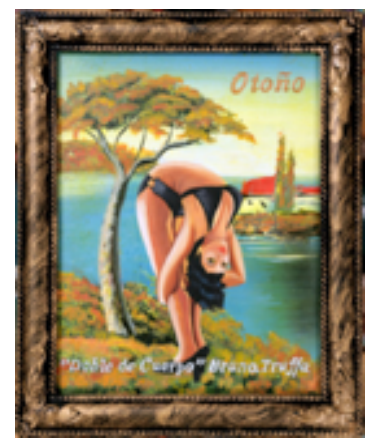

"doble de cuerpo" 2005 .

Óleo/madera $34 \times 24 \mathrm{cms}$

De la serie territorio doméstico.

http://rtbrunatruffa.blogspot.com/ www.brunatruffa.com/ 


\section{Carlos Bogni}
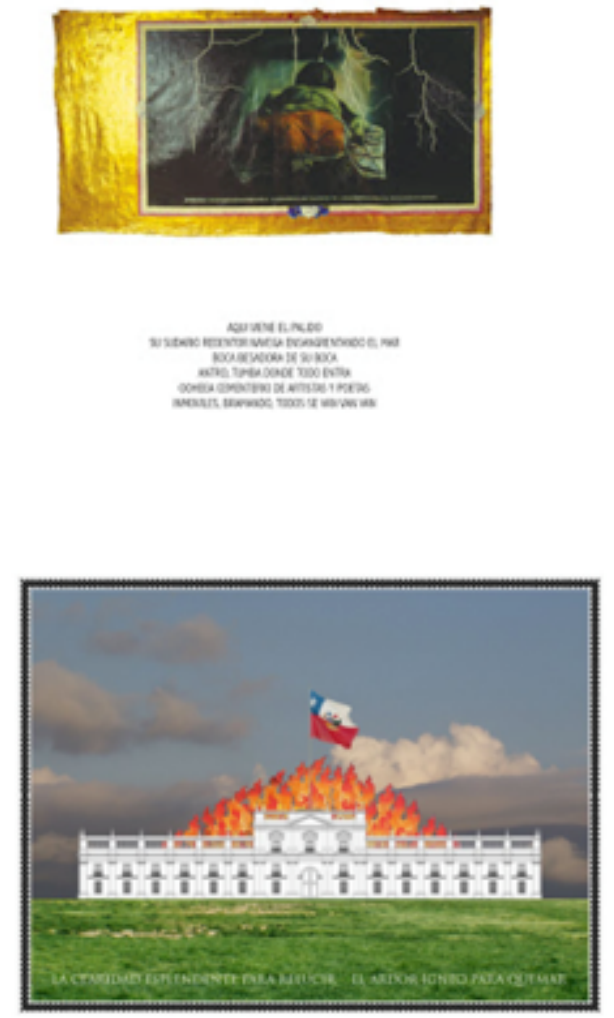

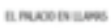
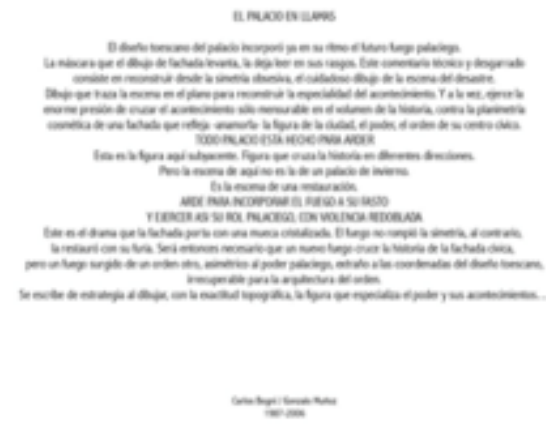

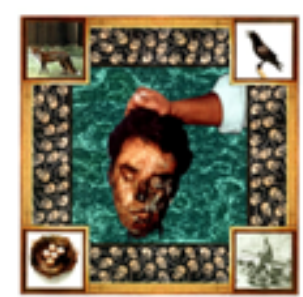

m.
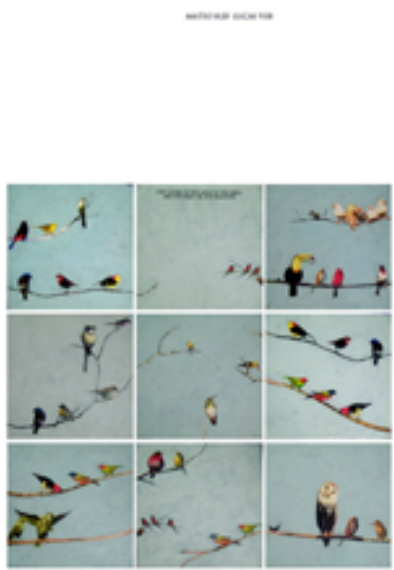

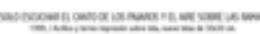

http://www.artistasplasticoschilenos.cl/658/w3-article-39556.html www.portaldearte.cl/autores/bogni.htm 


\section{$N^{\circ} 50$ ficha}

\section{Juan Dávila}

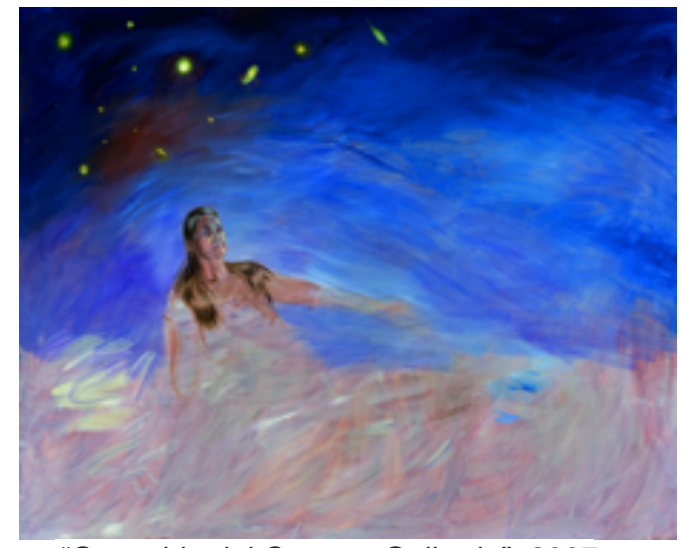

“Guacolda del Carmen Gallardo”, 2007

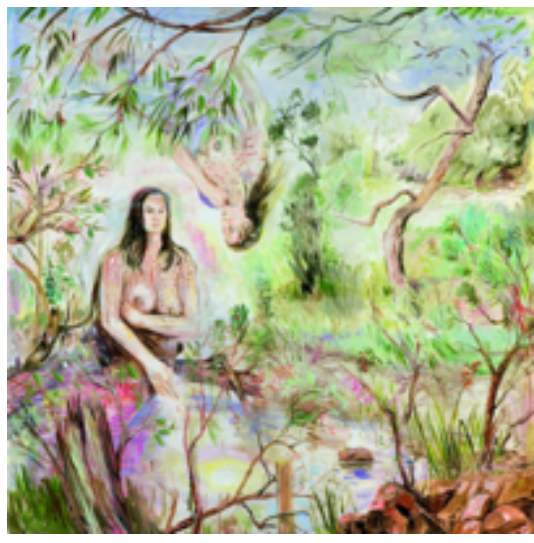

"Woman by the River Yarra", 2008, oleo/tela

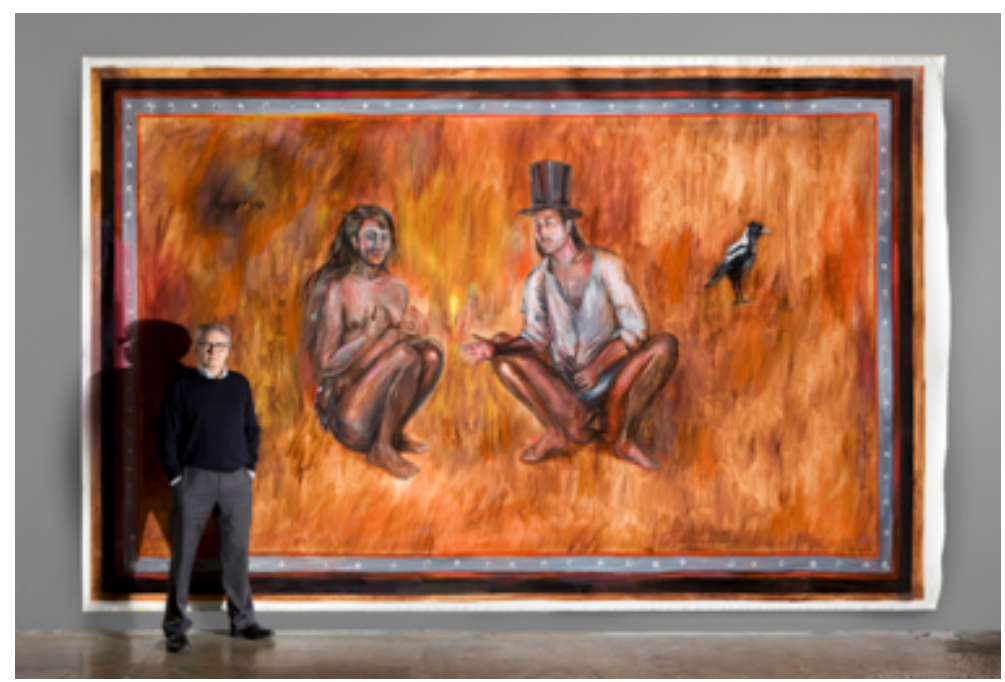

S/T 2011, oleo/tela 3x5 mt.

www.portaldearte.cl/autores/davila.htm

www.artistasplasticoschilenos.cl/658/w3-article-39682.html http://www.artfacts.net/en/artist/juan-dvila-59901/profile.html 


\section{$N^{\circ} 51$ ficha}

\section{Arturo Duclos}

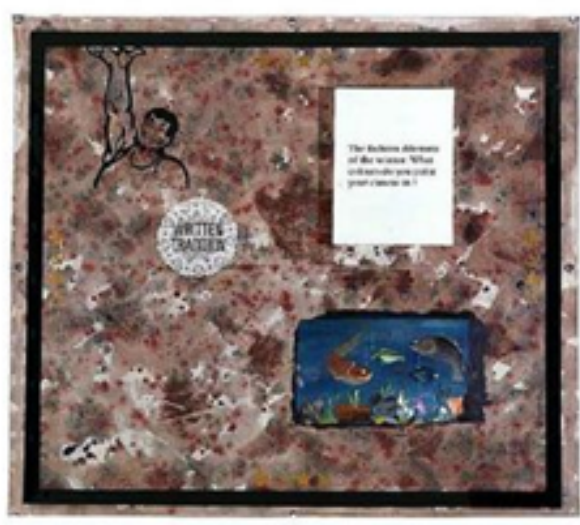

"tradicion escrita" 2U0J mixta/tela, $51 \times 5 / \mathrm{cm}$

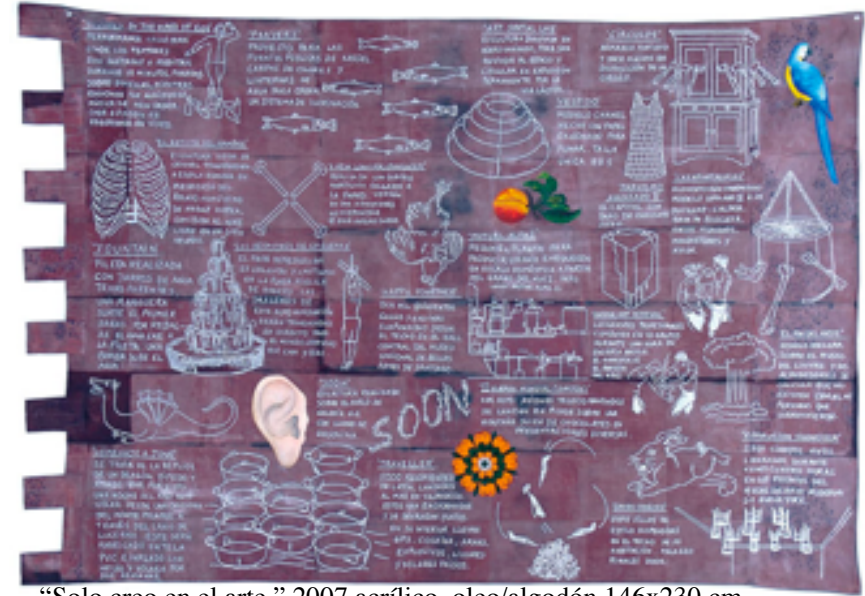

"Solo creo en el arte " 2007 acrílico, oleo/algodón 146×230 cm

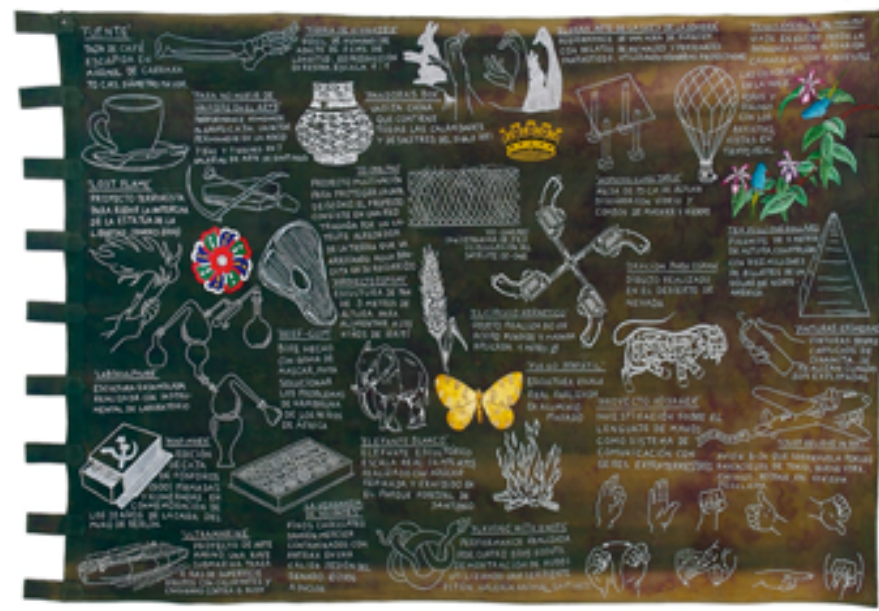

“Solo creo en el arte 2" 2007 acrílico, oleo/algodón 146x230cm

www.artistasplasticoschilenos.cl/biografia.aspx?itmid $=730$

http://www.premioaltazor.cl/arturo-duclos/

http://www.latinamericanart.com/es/obras-de-arte/arturo-duclos-i-just-believe-in-art-3.html http://www.dpmgallery.com/exhibiciones/i-just-believe-in-art 
$N^{\circ} 52$ ficha

\section{Eugenio Tellez}

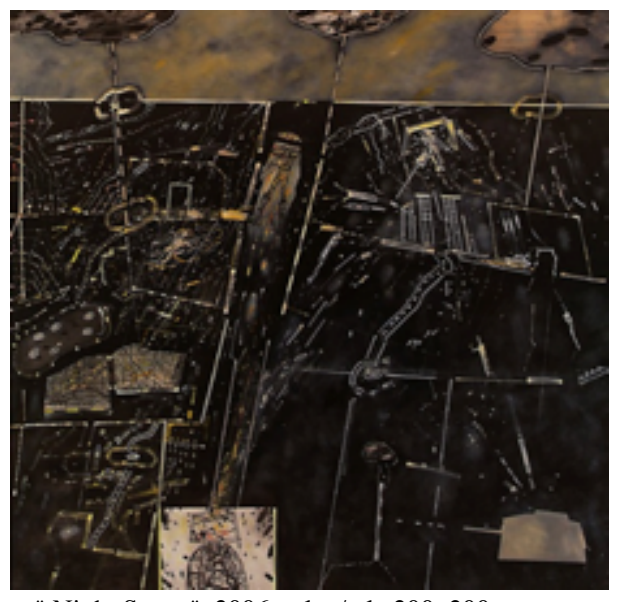

" Night Scape" 2006, oleo/tela 200x200cm

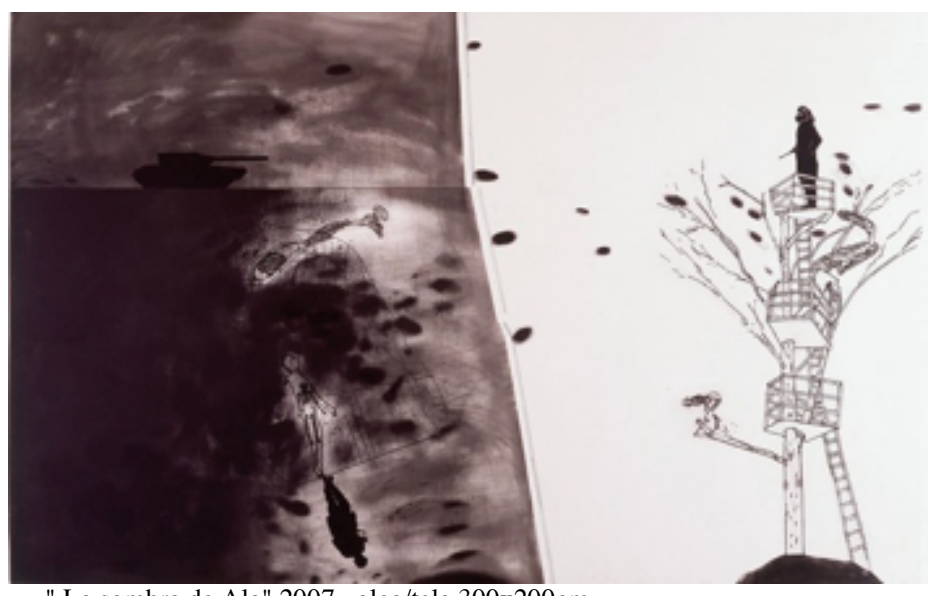

" La sombra de Ala" 2007, oleo/tela 300x200cm

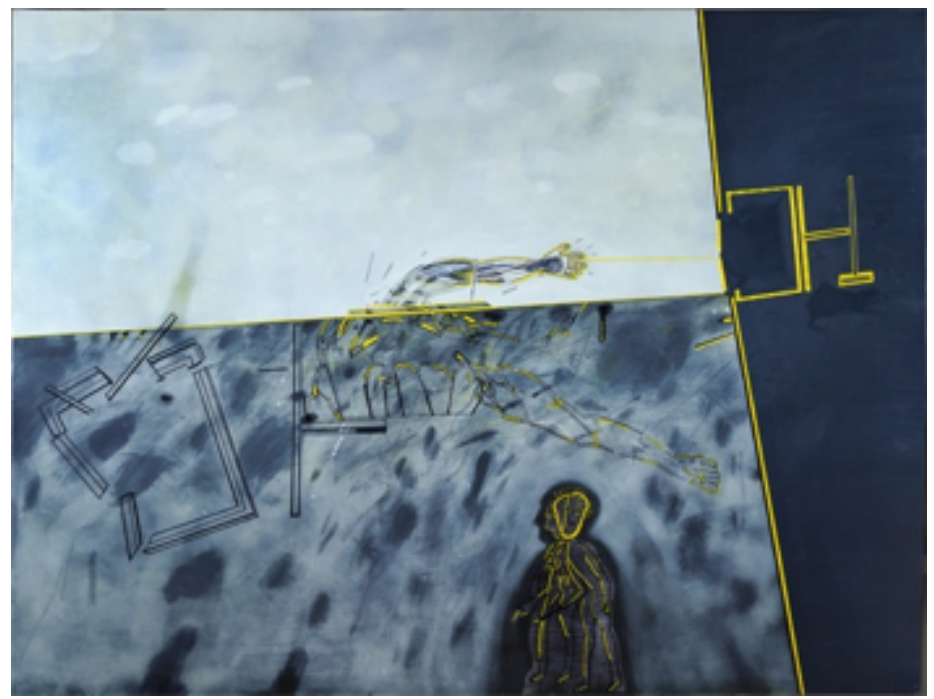

" Paysage désarticulé " 2011 oleo/tela, 200/150cm

http://www.portaldearte.cl/autores/tellez.htm

http://eugeniotellez.com/paintings/2006--night-scape--200200cm.html

http://eugeniotellez.com/paintings/2011--paysage-desarticule-.html\#previous-photo 
$N^{\circ} 53$ ficha

\section{Juan Enrique Gabler}
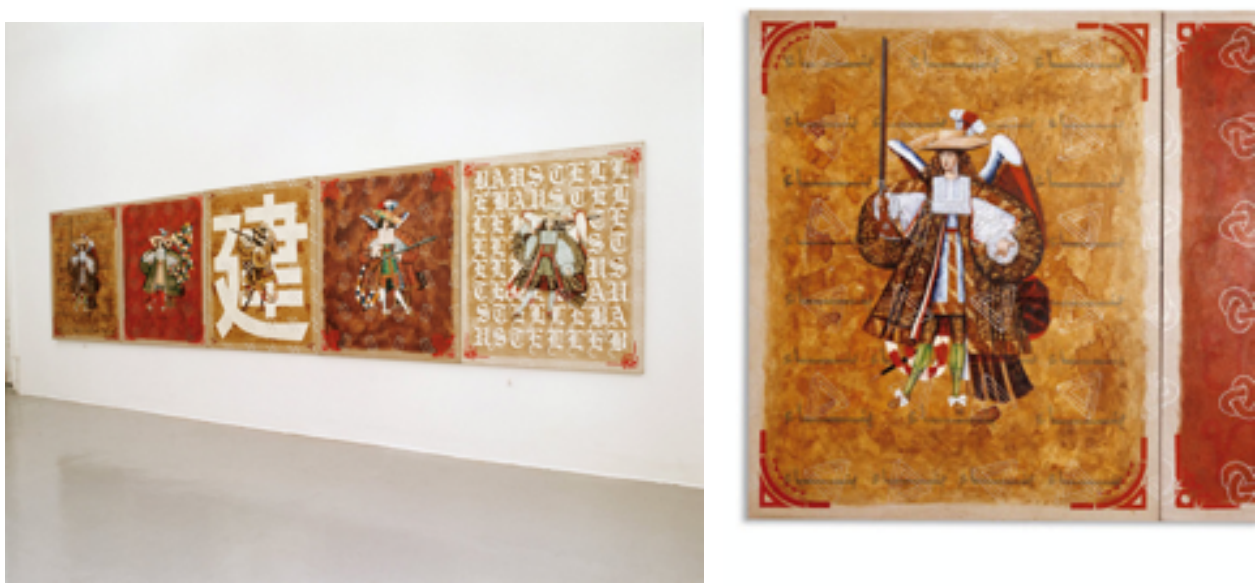

Serie propaganda Fide, 2000 mixta/tela C/u $165 \times 135 \mathrm{~cm}$.

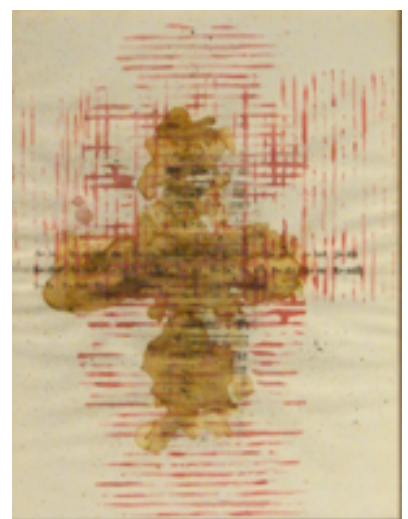

"Cruz" 2008 Técnica mixta/ papel, 34x44 cm.

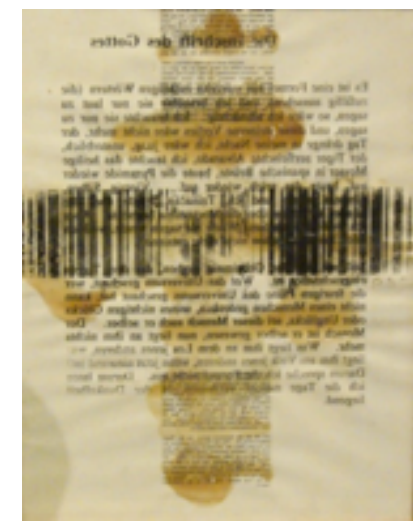

"Señal de la cruz" 2008, mixta/papel $34 \times 44 \mathrm{~cm}$.

http://www.artistasplasticoschilenos.cl/658/w3-article-39755.html\#exposiciones

http://rtjuanenriquegabler.blogspot.com/ 


\section{$N^{\circ} 55$ ficha}

\section{Gonzalo Díaz}
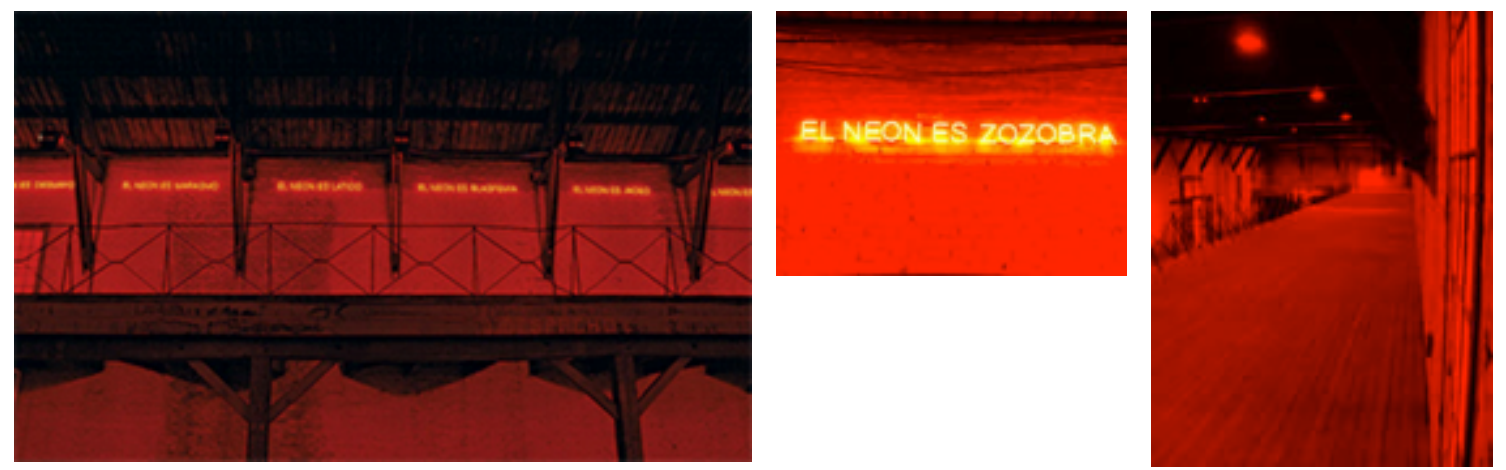

Rubrica enviroment en centro de arte matucana 100, 2003 (detalles)
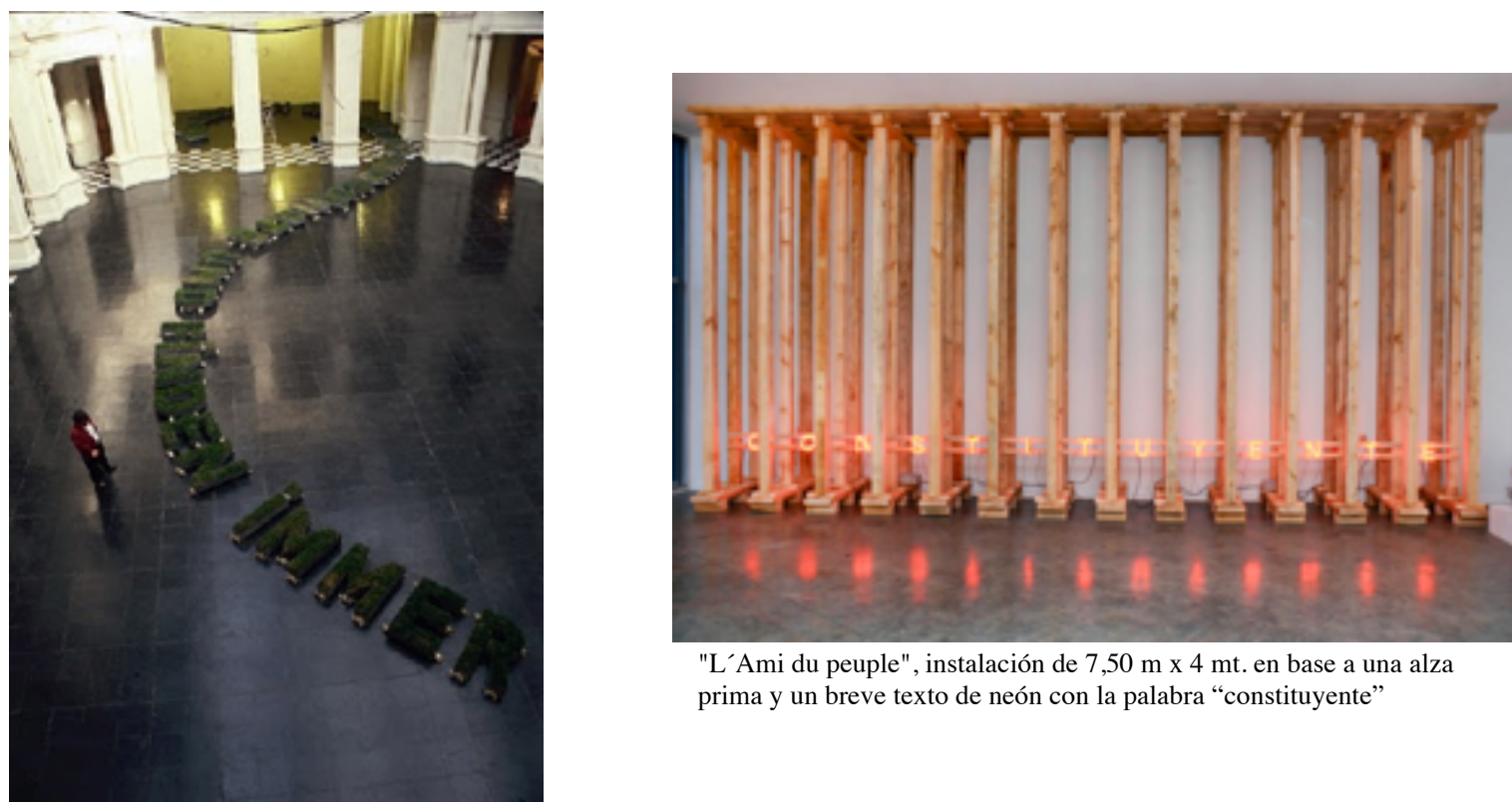

"L’Ami du peuple", instalación de 7,50 m x 4 mt. en base a una alza prima y un breve texto de neón con la palabra "constituyente"

"Tratado del entendimiento humano" 2008 letras emplazadas en el suelo del hall central del Museo de Arte Contemporáneo, MAC, formando el texto "Wir suchen überall das Unbedingte, und finden immer nur Dinge" a lo largo de unos 55 metros. 
$N^{\circ} 56$ ficha

\section{Judith Jorquera}

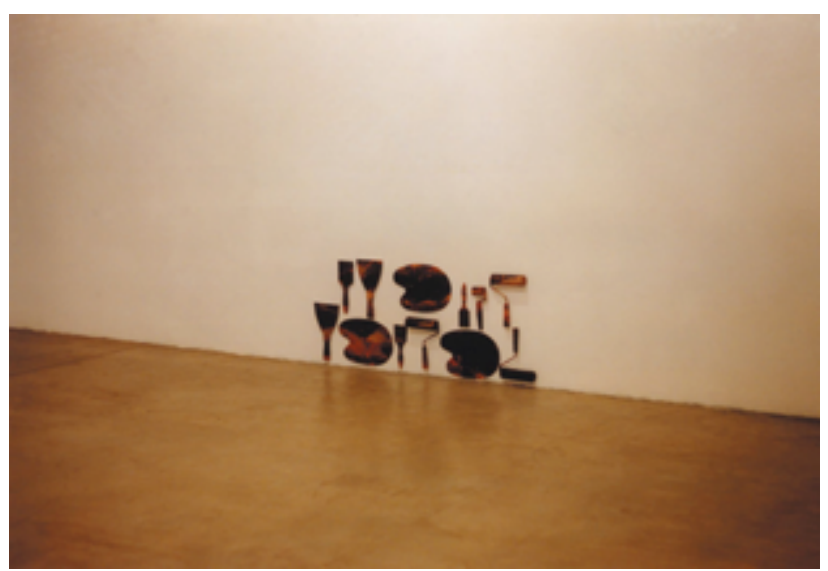

S/T 2002 objetos de taller forrados con imagen de paisaje dimens. variables

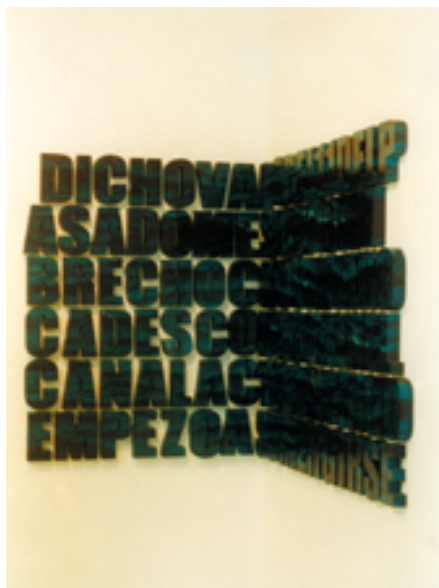

S/T 2002, oleo/letras de madera 130x90 cm.

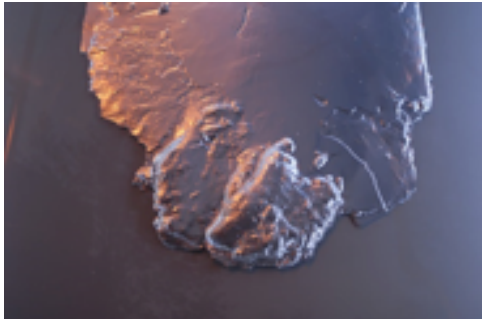

"Ultramarina"2013(detalle) resina sobre panel.

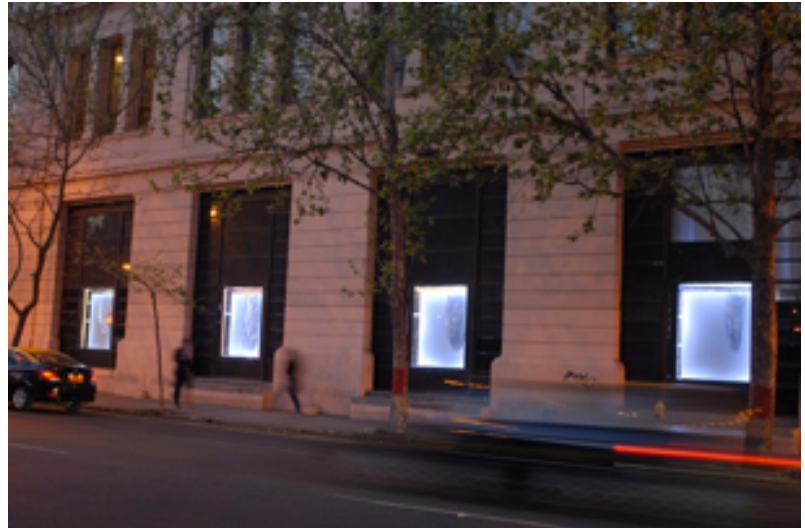

"Ultramarina" 2013 intervención en vitrinas medidas variables

www.arteallimite.com/eventos/ultramarina

http://www.biobiochile.cl/2013/10/14/artista-visual-petrifica-el-colapso-del-progreso-sobre-ventanales-deavenida-balmaceda-en-el-ccem.shtml 
$N^{\circ} 57$ ficha

\section{Alejandra Wolff}

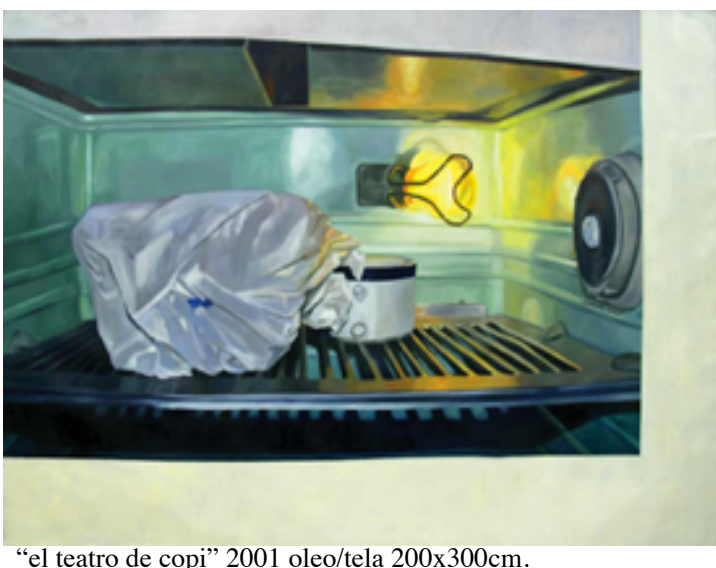

"el teatro de copi" 2001 oleo/tela 200x300cm.

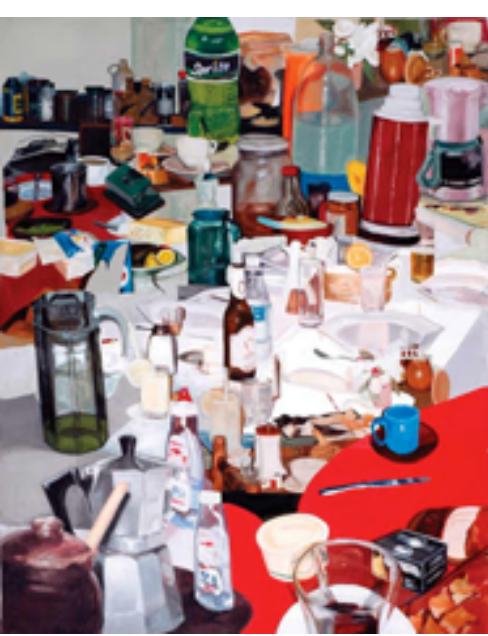

"sobremesa" 2006 mixta/papel 245x215 $\mathrm{cm}$.

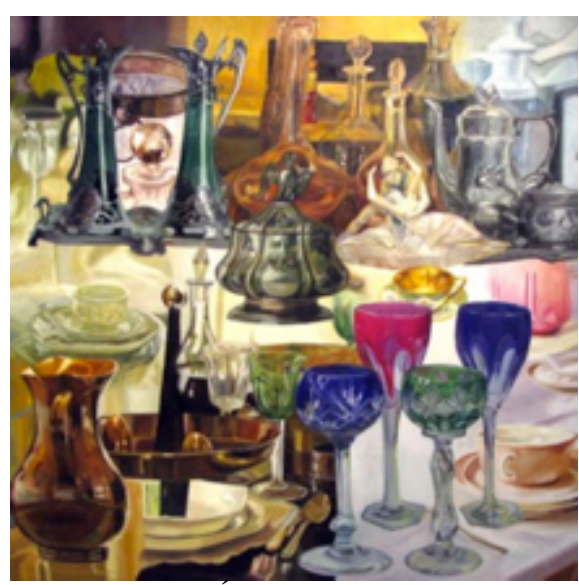

"Banquete" 2008 Óleo sobre tela, 100X100 cms,

www.artistasplasticoschilenos.cl/658/w3-article-40515.html www.portaldearte.cl/autores/wolff.htm

http://rtalejandrawolff.blogspot.cl/ 
$N^{\circ} 58$ ficha

\section{Benito Rojo}
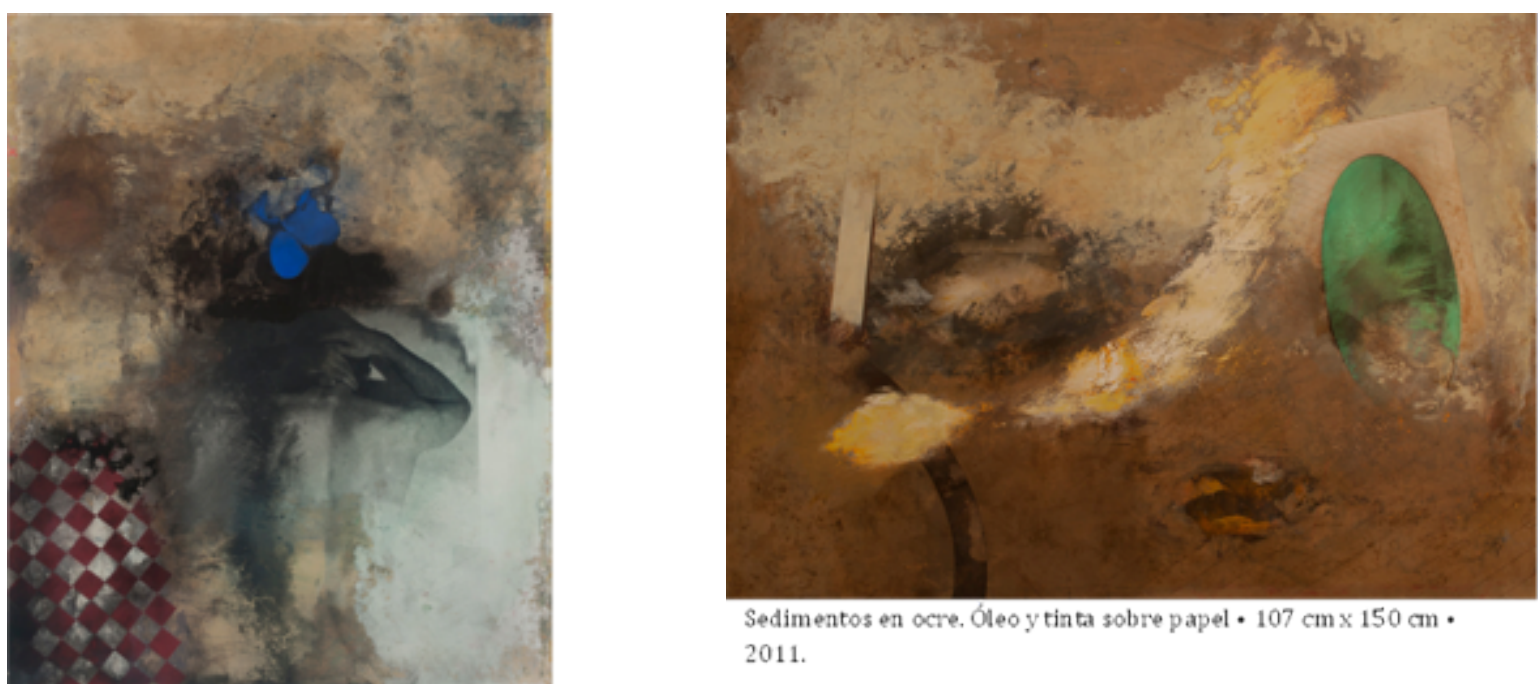

Sedimentos en ocré, Óleo y tinta sobre papel $107 \mathrm{~cm} \times 150 \mathrm{~cm}$. 2011

Fonmato carta en ocre. Oleo y tima sobce pupel • $80 \mathrm{~cm} \times 100$ $\mathrm{cm} \cdot 2011$

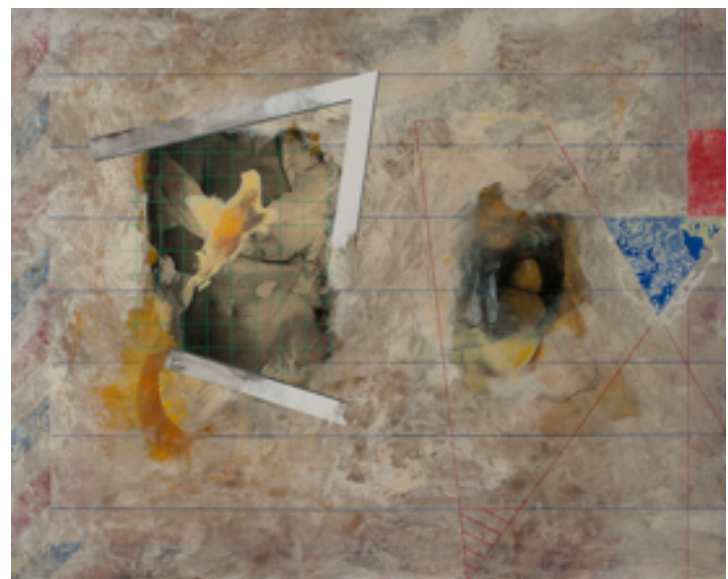

"Sedimento formato carta". 2011, Acrílico y tinta/ tela • $160 \mathrm{~cm} \times 200 \mathrm{~cm}$ 


\section{Ismael Frigerio}
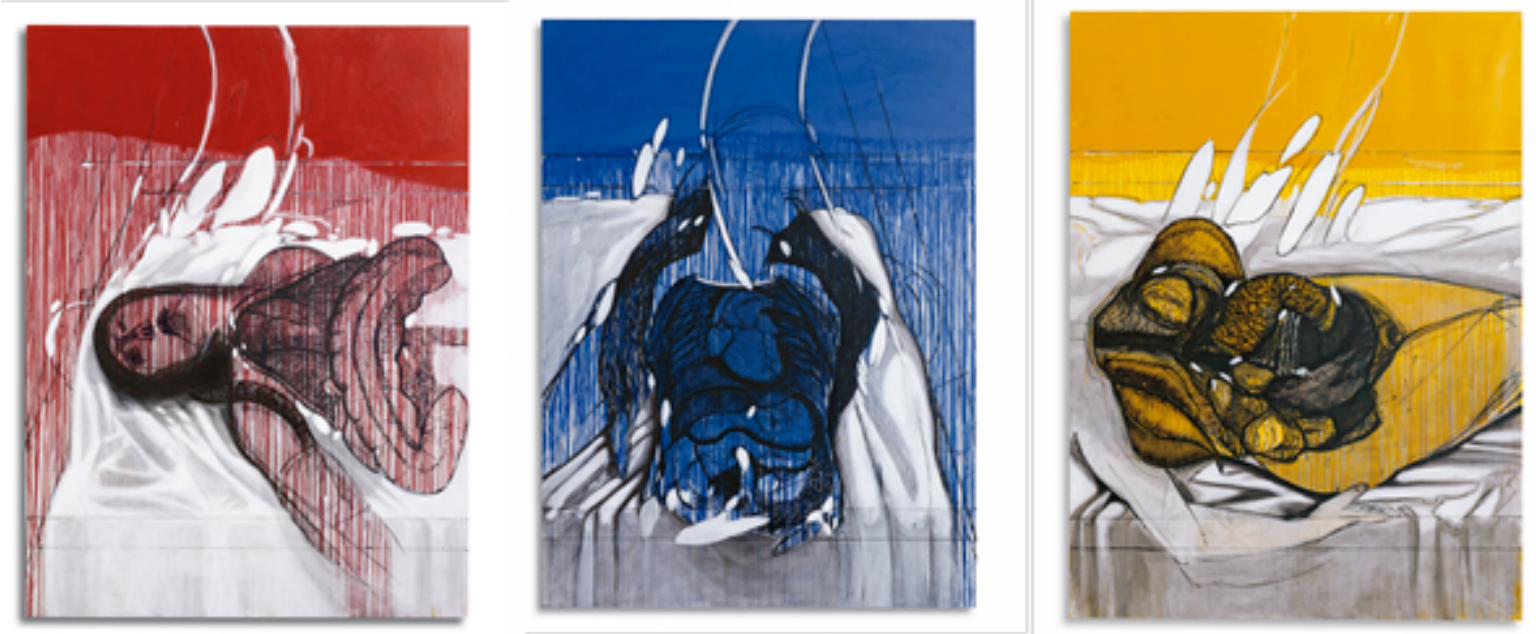

Zona de construcción, técnica mixta, 2003.

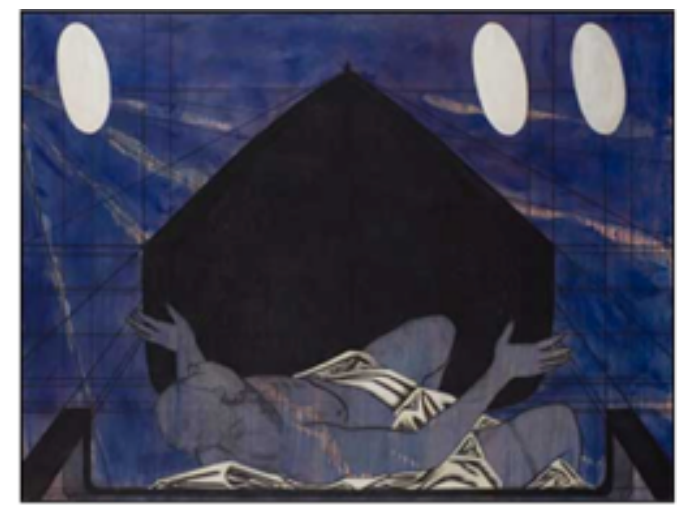

De la serie Sombras de la Modernidad 2009 Technique: Mixed media $58.5 \times 78$ Inches

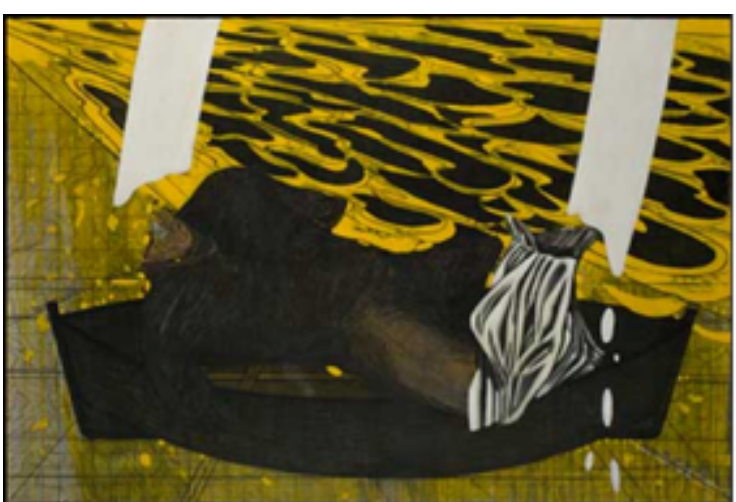

De la serie Sombras de la Modernidad 2009 Mixed media $60.06 \times 85.8$ Inches

www.artistasplasticoschilenos.cl/658/w3-article-40418.html http://www.galeriapready.cl/\#! ismael-frigerio/c9sb 
$N^{\circ} 60$ ficha

\section{Matías Vergara}
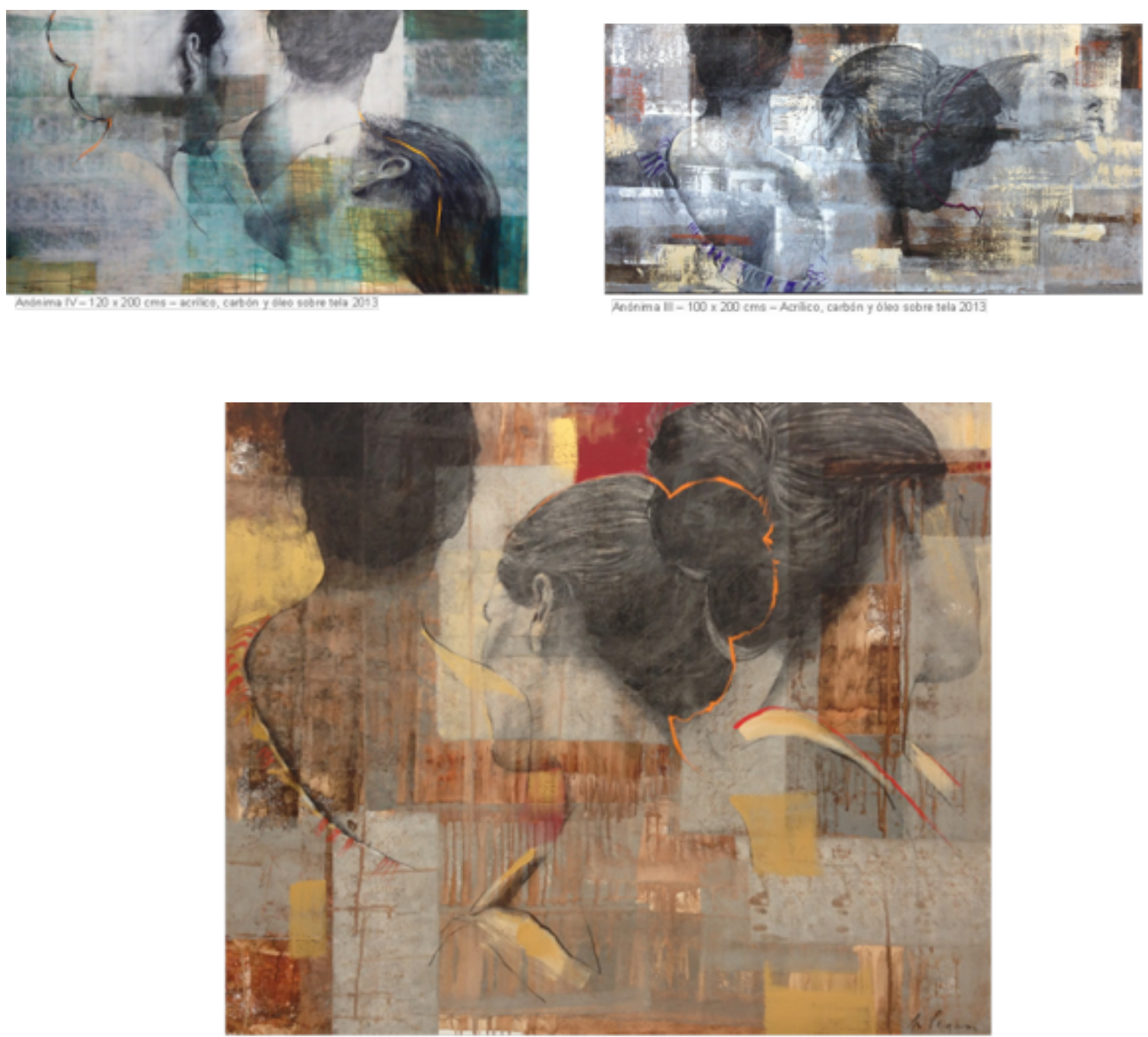

Anónima I - $140 \times 170 \mathrm{cms}$ - Acrilico, carbón y óleo sobre tela 2012

http://matiasvergara.cl/

http://www.galeriaartespacio.com/\#!matias-vergara/c9yj 
$N^{\circ} 61$ ficha

\section{Rene Poblete}

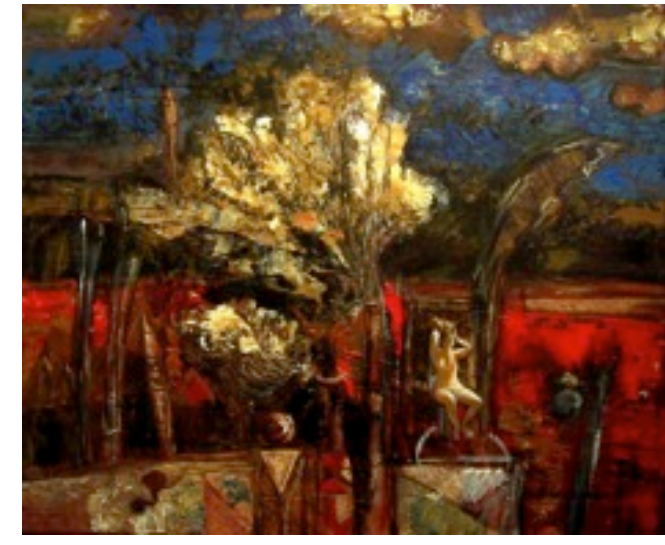

"Sin pareja" 2004. Acrílico/tela. 50 x 60 cm

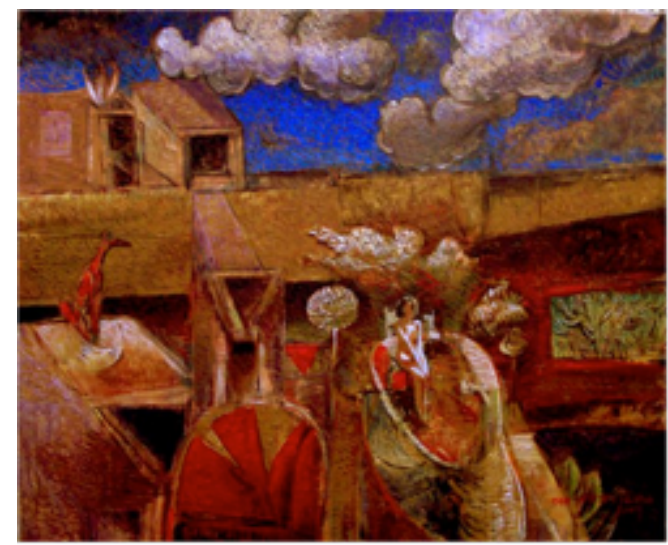

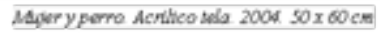

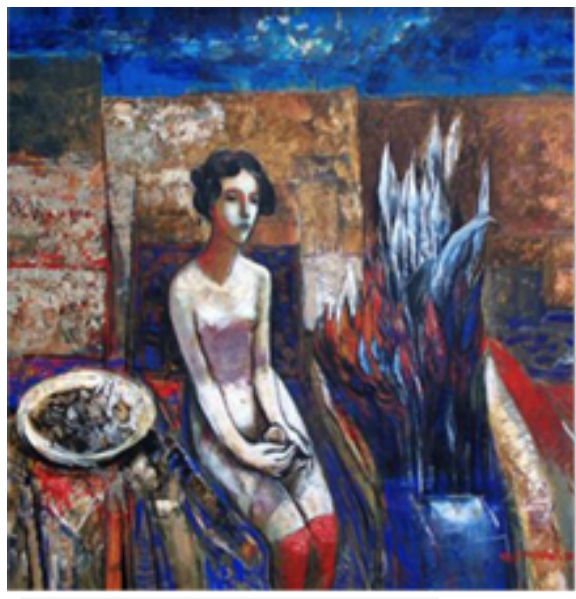

Mesery planta Acribco tela. $2004.120 \times 150 \mathrm{~cm}$

www.artistasplasticoschilenos.cl/658/w3-article-39649.html

www.culturallascondes.cl/home2/rene-poblete-urquieta.html 


\section{Rodrigo Vega}
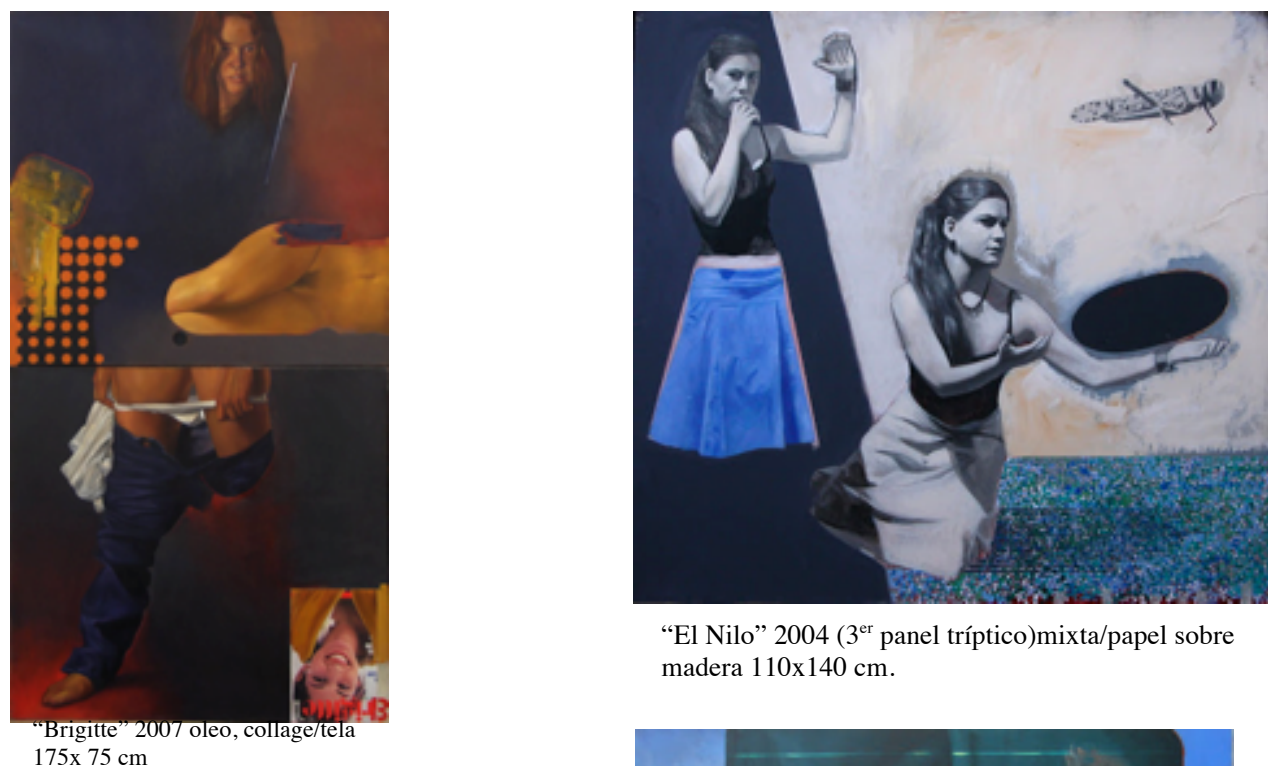

"El Nilo" 2004 ( $3^{\text {er }}$ panel trí́ptico)mixta/papel sobre madera $110 \times 140 \mathrm{~cm}$.

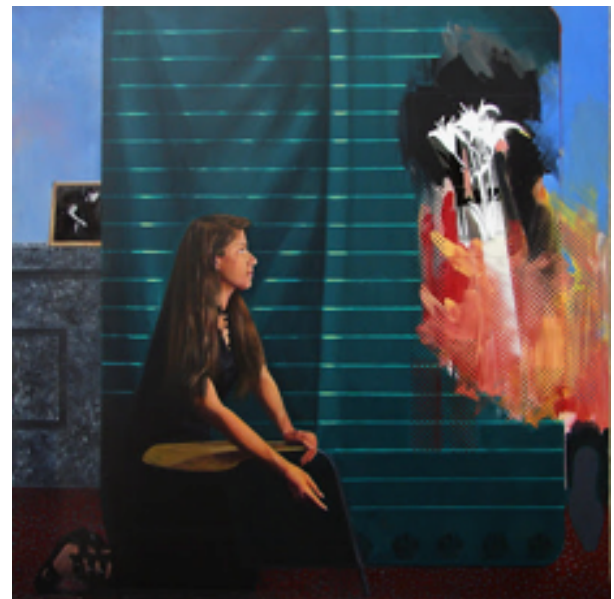

"Anuncio" 2005-2006, Acrílico fotografía/tela 150x150 $\mathrm{cm}$

http://rtrodrigovega.blogspot.com/

http://www.artistasplasticoschilenos.cl/658/w3-article-39873.html\#exposiciones 
$N^{\circ} 63$ ficha

\section{Adrián Gouet}

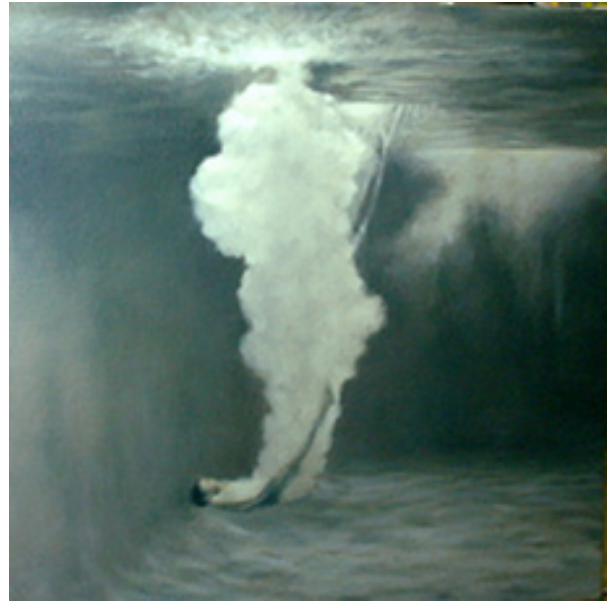

"Estado vegetal 3" 2009 oleo/tela 116x122cm

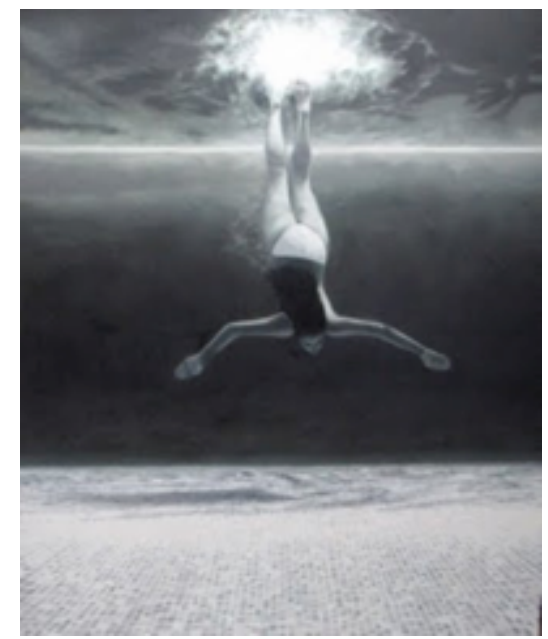

“Estado vegetal 2" 2009 oleo/tela 116x122cm

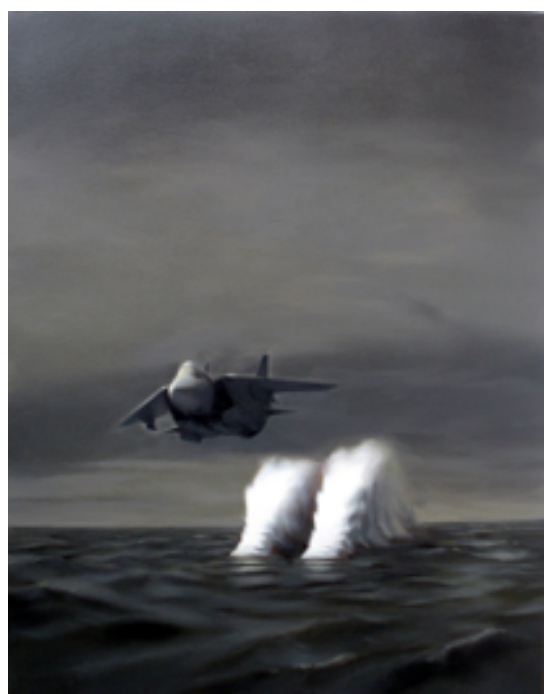

"F-24 Tomcat" 2008 oleo/tela 110x90 cm.

http://rtadriangouet.blogspot.com/2009/10/blog-post.html/ http://www.mutt.cl/otros/adrian-gouet/ 
$N^{\circ} 64$ ficha

\section{Catalina Abbot}
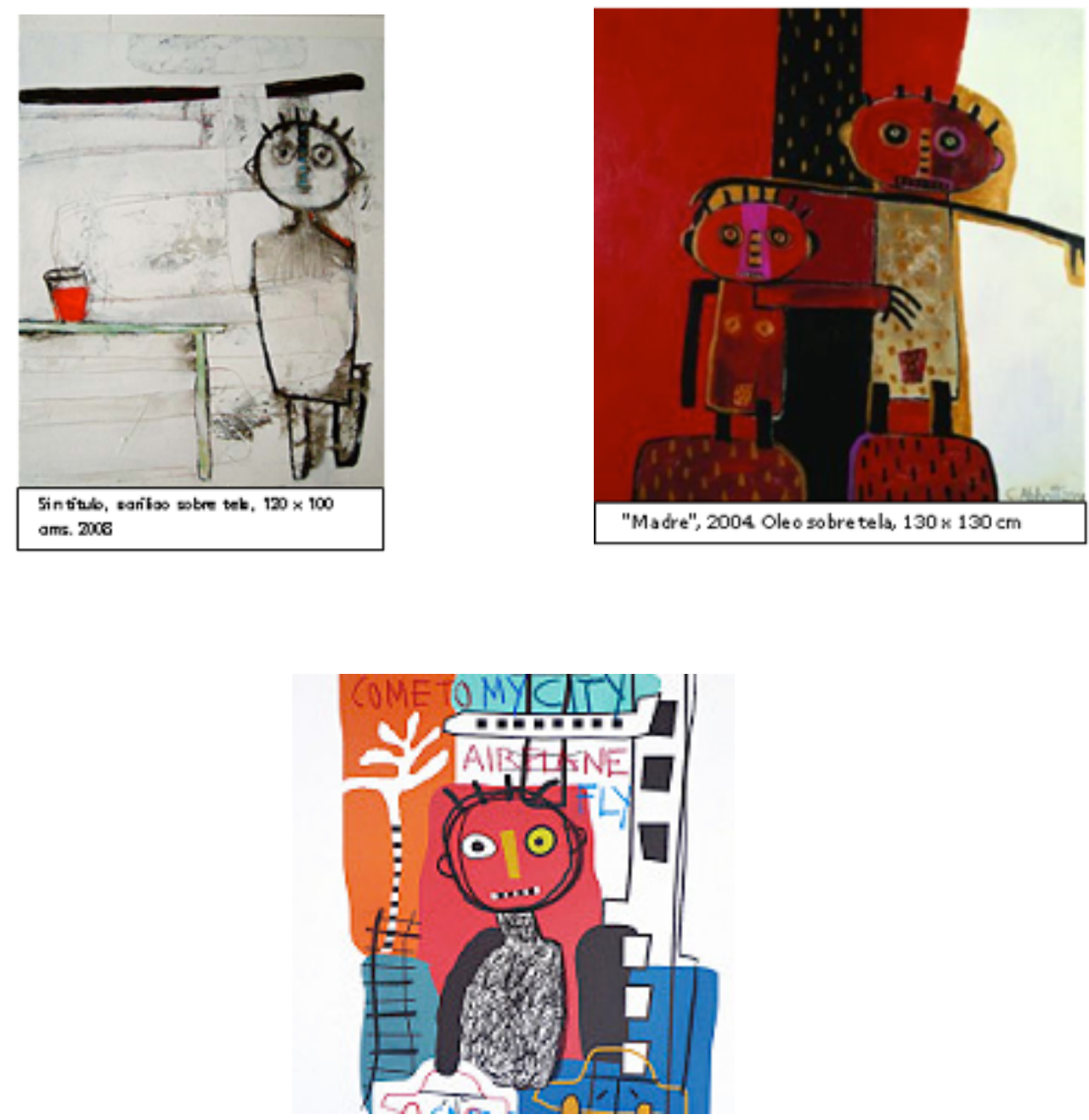

S/T, 2009 Impresión digital intervenida $57 \times 76 \mathrm{~cm}$.

www.ququ.cl/artistas.htm

www.bazared.cl/products/view/1715 
$N^{\circ} 65$ ficha

\section{Claudia Kemper}

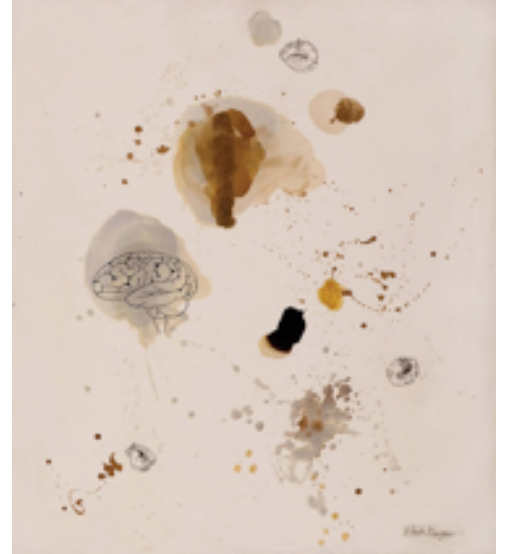

“el pensamiento" 2012 mixta/lino

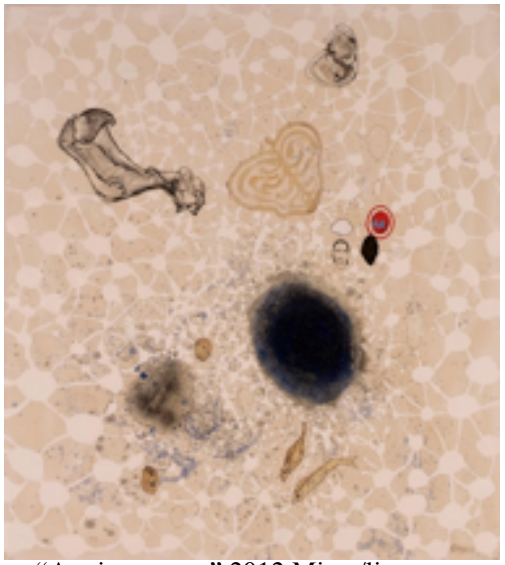

“Agujero negro" 2012 Mixta/lino

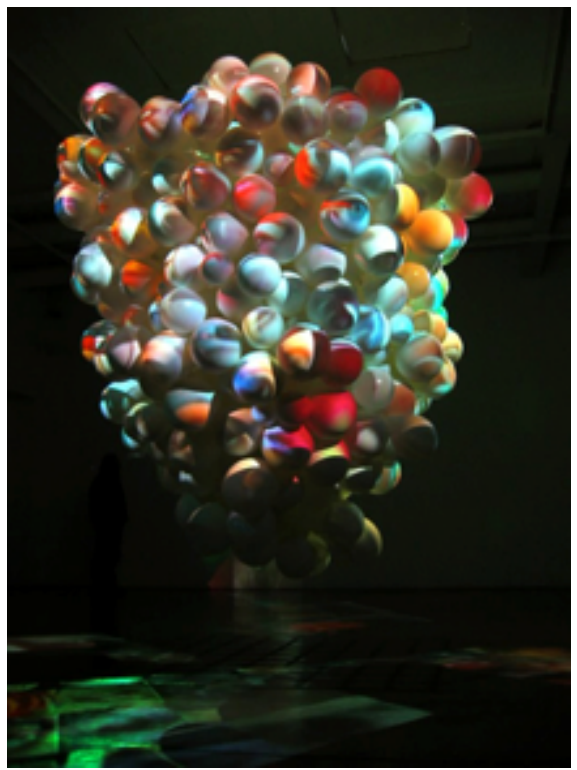

Video Instalación, cuatro proyecciones sobre globos inflados y audio. 2005

http://rtclaudiakemper.blogspot.com/ http://www.klaudiakemper.com/ 
$N^{\circ} 66$ ficha

\section{Marcela Trujillo}

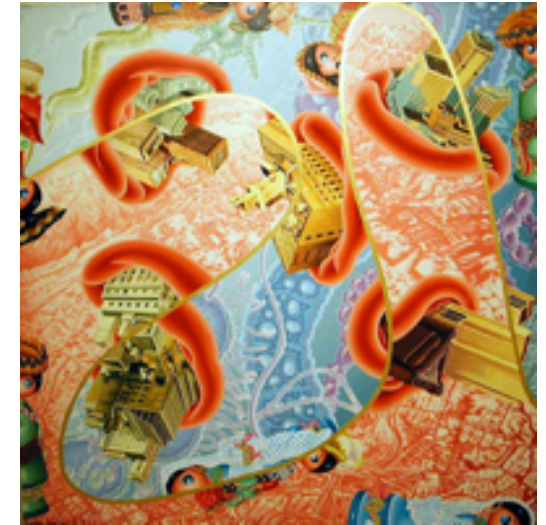

"Damas de sangre" 2009 mixta/tela 1x1

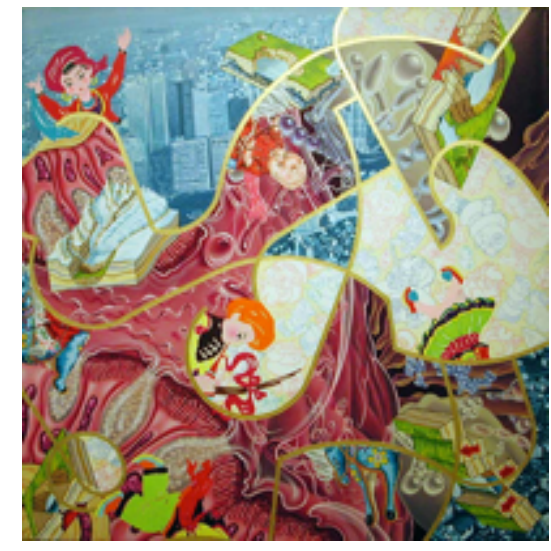

“Trompas y vesiculas” 2009 mixta/tela 1x1 mt.

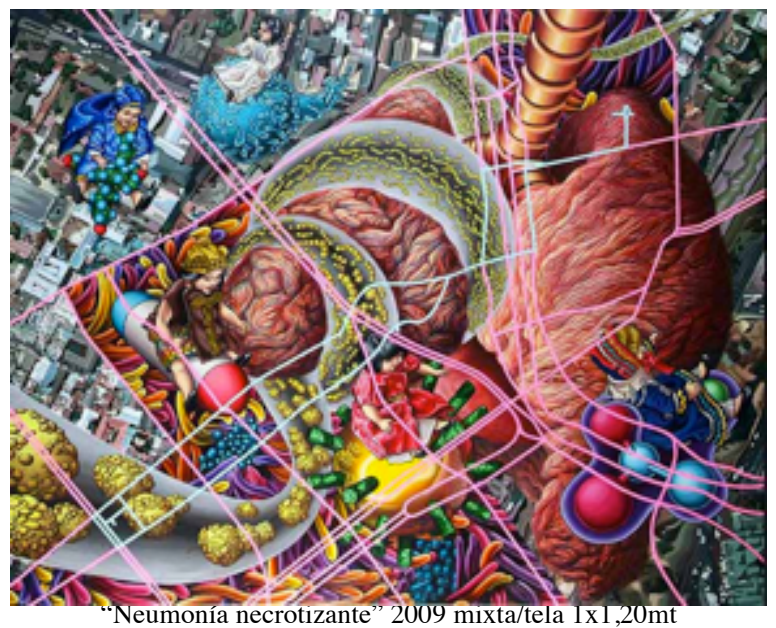

www .artistasplasticoschilenos.cl/658/w3-article-39514.html

http://www.premioaltazor.cl/marcela-trujillo/ 
$N^{\circ} 67$ ficha

Norton Maza

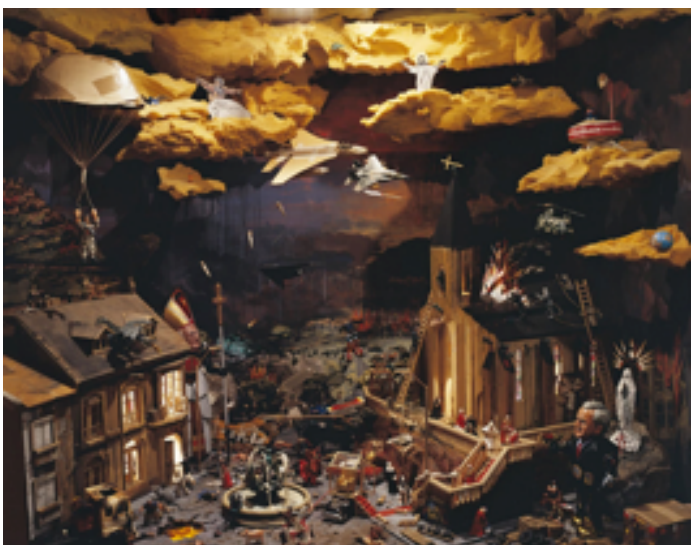

"La avalancha del caos", Photography, 68 x $53 \mathrm{~cm}$ maquetas a escala, construidas con elementos residuales, encontrados, producidos, pintados, apropiados

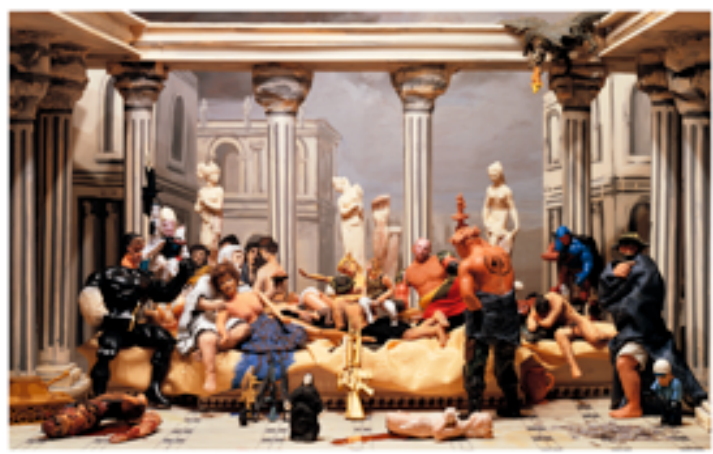

"La junta de la decadencia", Photography, 88 x $54 \mathrm{~cm}$.

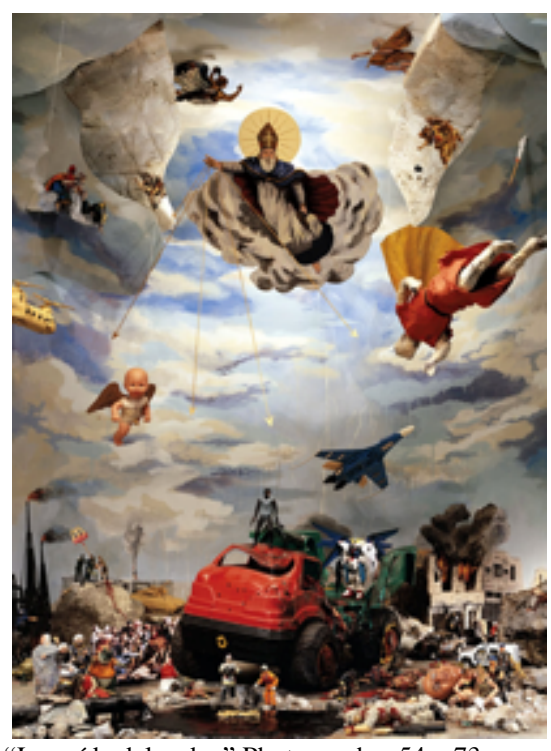

"La caída del orden" Photography, 54 x $73 \mathrm{~cm}$.

http://rtnortonmaza.blogspot.com/

http://nortonmaza.com/ 
$N^{\circ} 68$ ficha

\section{Víctor Hugo Bravo}
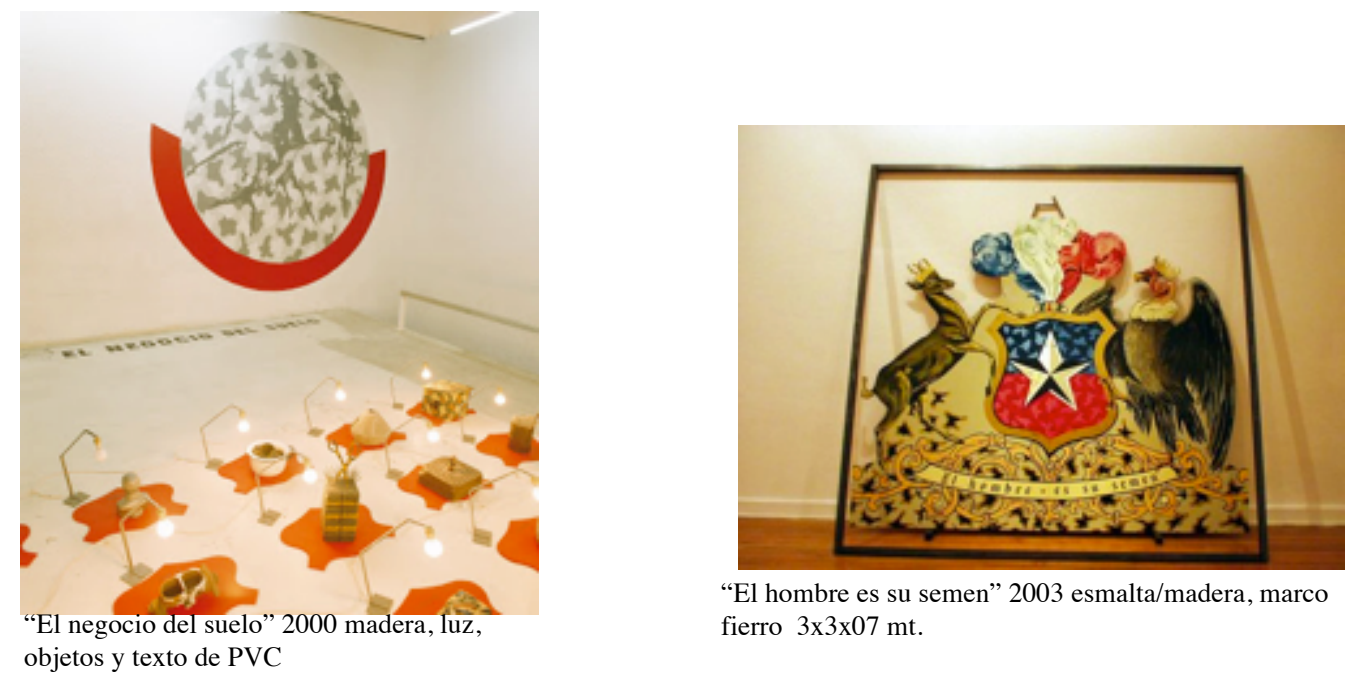

"El hombre es su semen" 2003 esmalta/madera, marco fierro $3 \times 3 \times 07 \mathrm{mt}$.

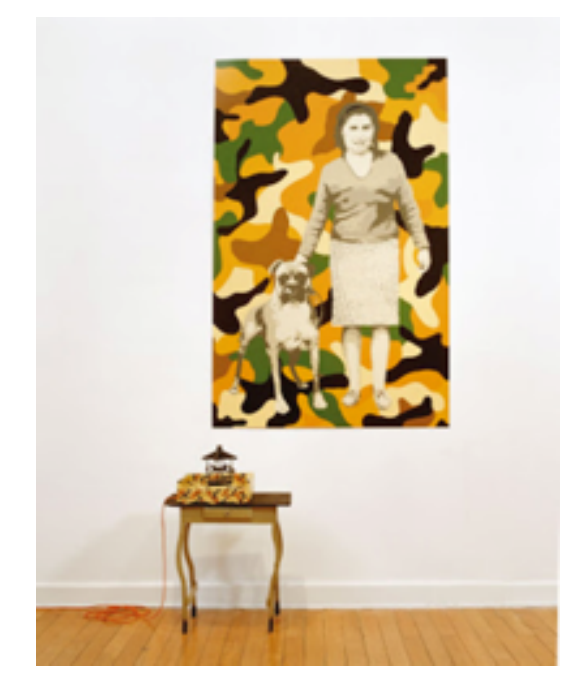

"Eras como te soñabas" 2003 esmalte/madera, objetos, dimensiones variables

http://victor-bravo.blogspot.com/

www.artistasplasticoschilenos.cl/658/w3-article-40088.html

http://www.premioaltazor.cl/victor-hugo-bravo/ 
$N^{\circ} 69$ ficha

\section{Ximena Cousiño}

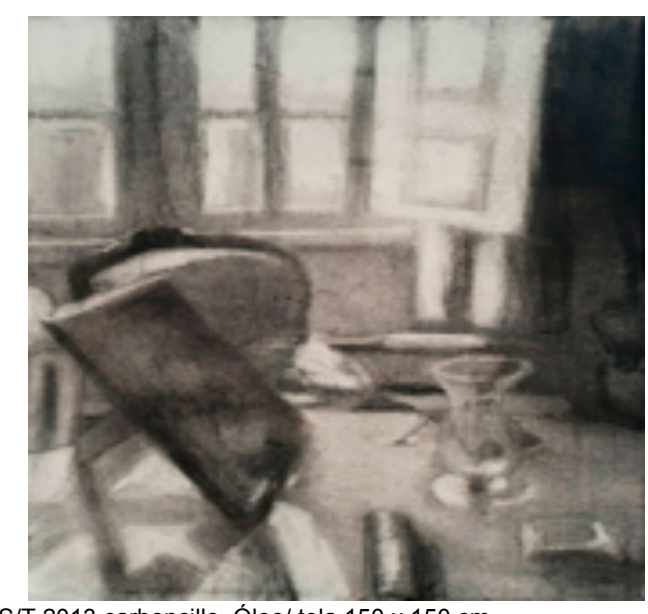

S/T 2013 carboncillo. Óleo/ tela 150 x $150 \mathrm{~cm}$.

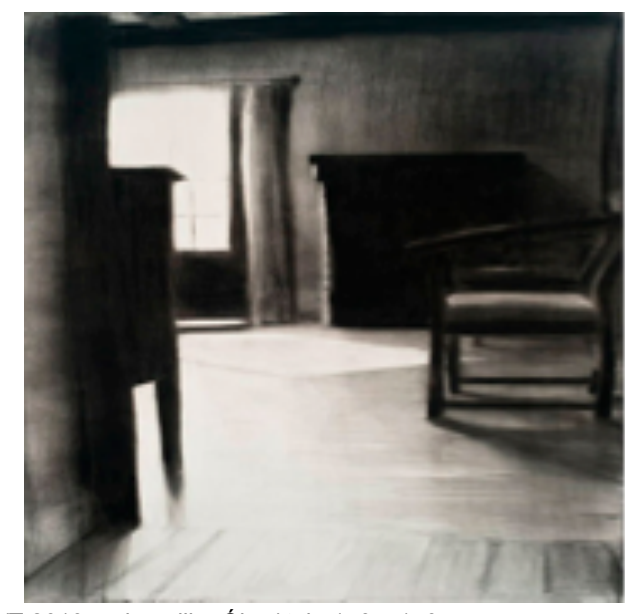

S/T 2013 carboncillo. Óleo/ tela 150 x $150 \mathrm{~cm}$.

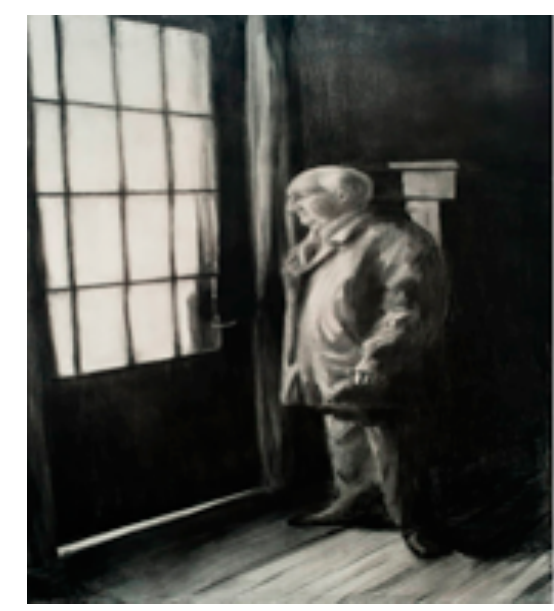

S/T 2013 carboncillo. Óleo/ tela 150 x $150 \mathrm{~cm}$.

www.ximenacousino.cl/CV.html

www.artistasplasticoschilenos.cl/658/w3-article-39588.html 
$N^{\circ} 70$ ficha

Adolfo Bimer

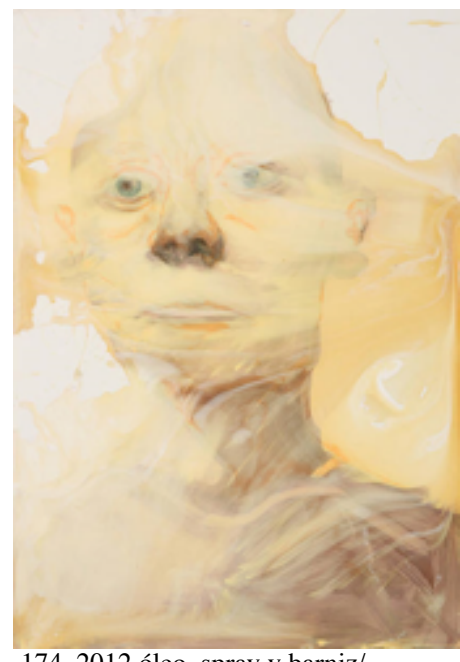

174, 2012.óleo, spray y barniz/ foamboard, $84 \times 122 \mathrm{cms}$,

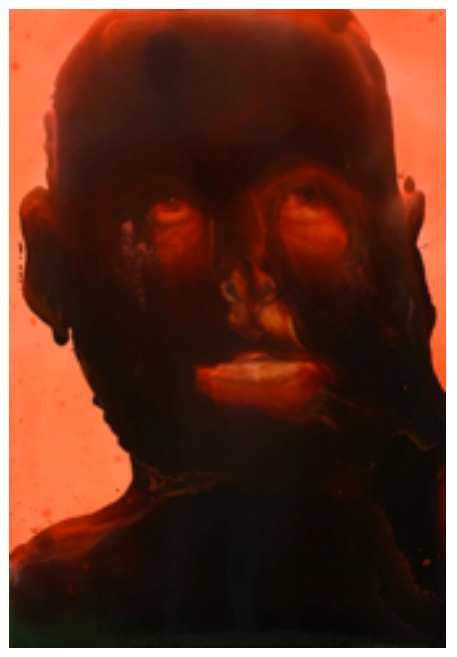

187, 2012. óleo, spray y barniz /foamboard, 84 x $122 \mathrm{cms}$,

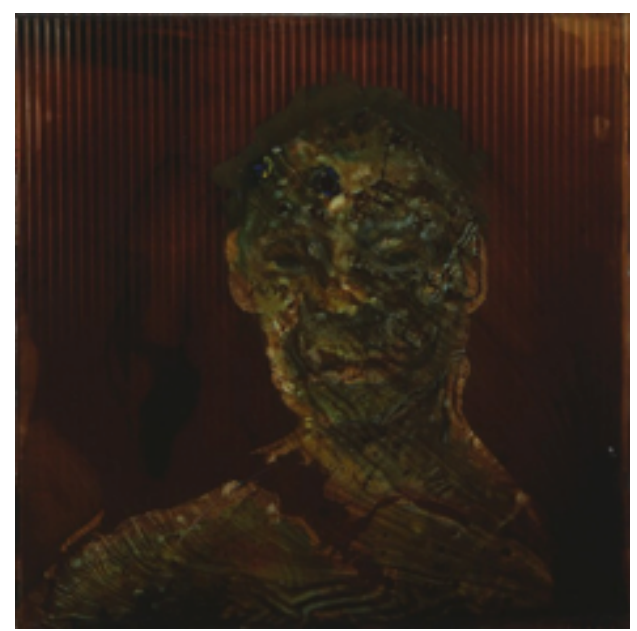

211,2013 . óleo, spray y barnices/ policarbonato, 35 x $39 \mathrm{cms}$,

http://www.galeriapready.cl/\#!adolfo-bimer/cp2t http://adolfobimer.blogspot.com/ 


\section{Fernando Allende}

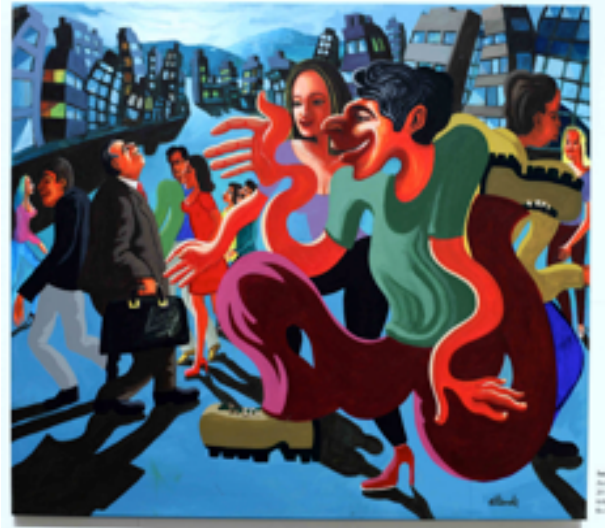

"Día de semana", 2011, acrílico/tela 90x70 cm.

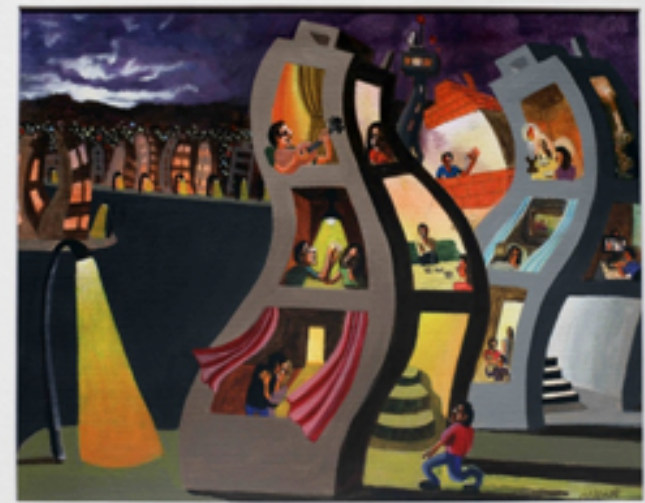

"Fin de semana 2", 2013 acrílico /papel. 50x70 cm

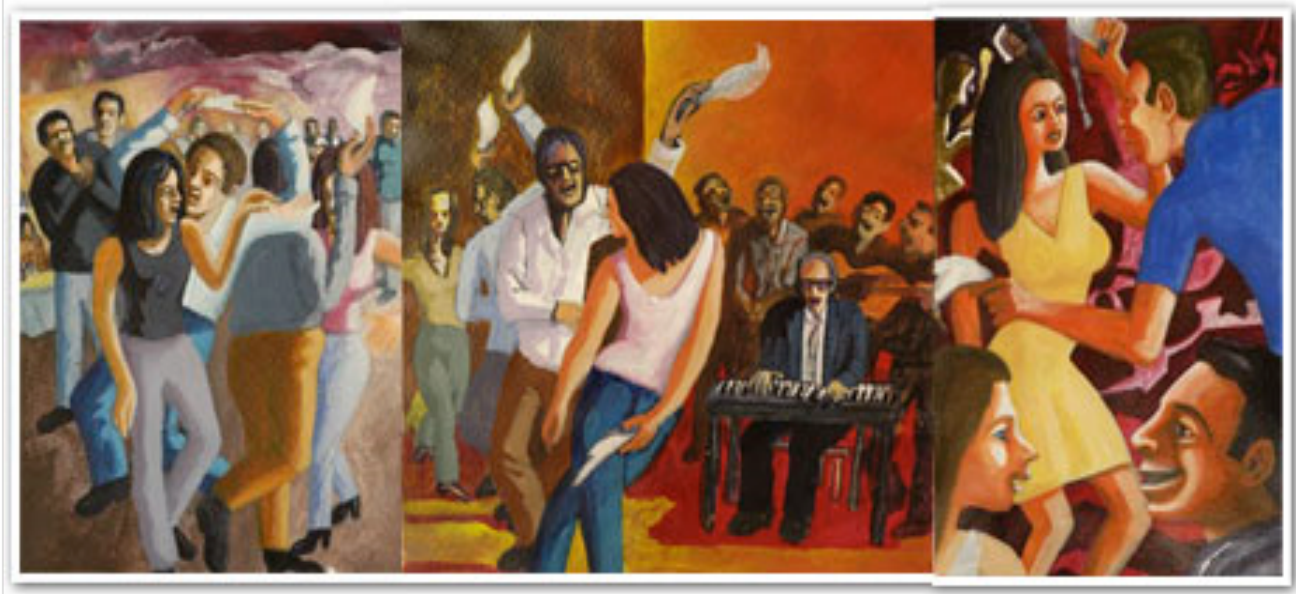

Fig.: 44"cueca brava", 2013 acrílico/tela 90x120cm. 


\section{Antonio Guzmán}
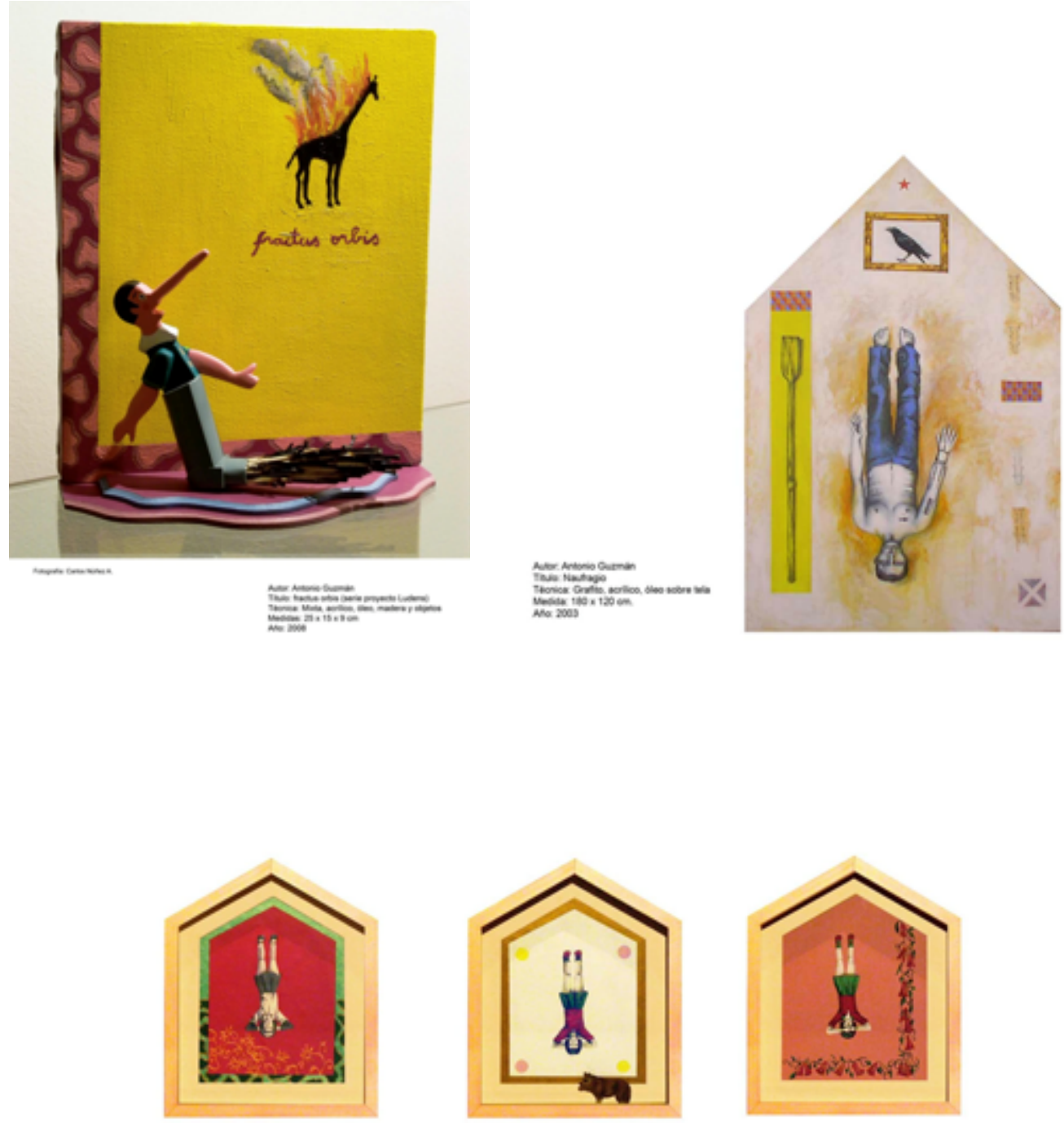

Nor Anons Cuenta

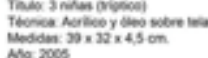

http://rtantonioguzman.blogspot.com/

http://antonioguzmanartesvisuales.blogspot.com/ 
$N^{\circ} 73$ ficha

\section{Alejandro Arrepol}
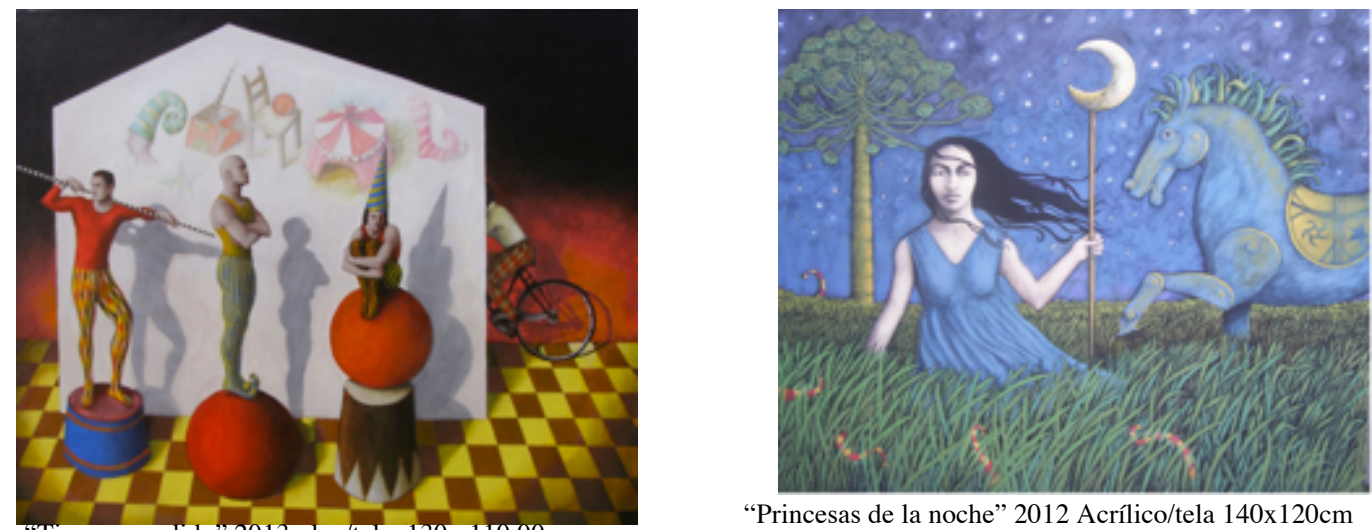

“Princesas de la noche” 2012 Acrílico/tela 140x120cm

"Tiempo perdido" 2013 oleo/tela $130 \times 110.00 \mathrm{~cm}$

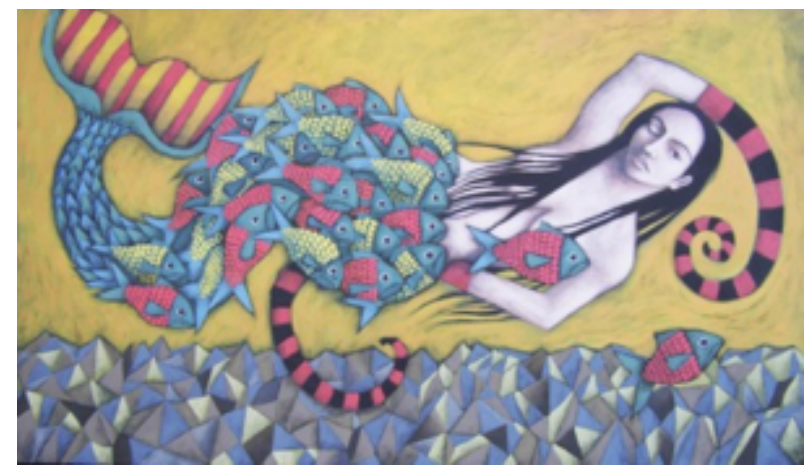

"La pincoya" 2012 Acrílico/tela 130 x 75cm

www .arteallimite.com/galeria/artistas/alejandro-arrepol-172

http://www .estimarte.com/?cmod=bioshome\&iartist=e732727203284984d0f2ee6bff988a1b\&artista=ArrepolAlejandro\&id $=3810$ 


\section{Carlos Maturana (Bororo)}

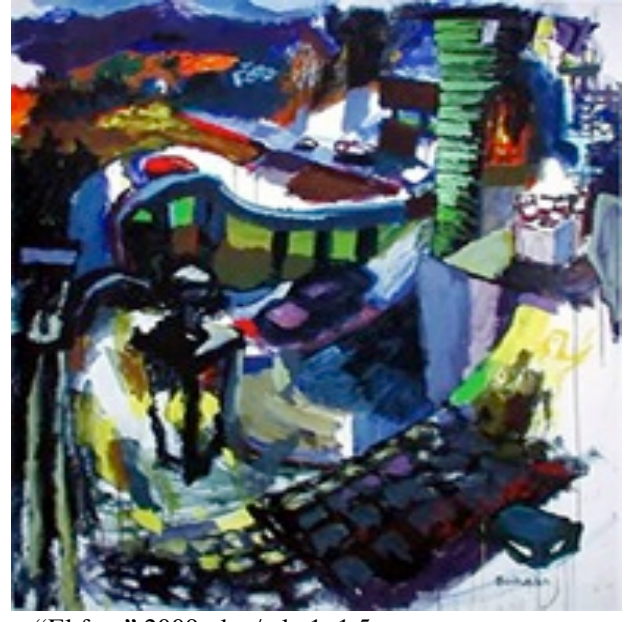

"El faro" 2009 oleo/tela 1x1,5 mt

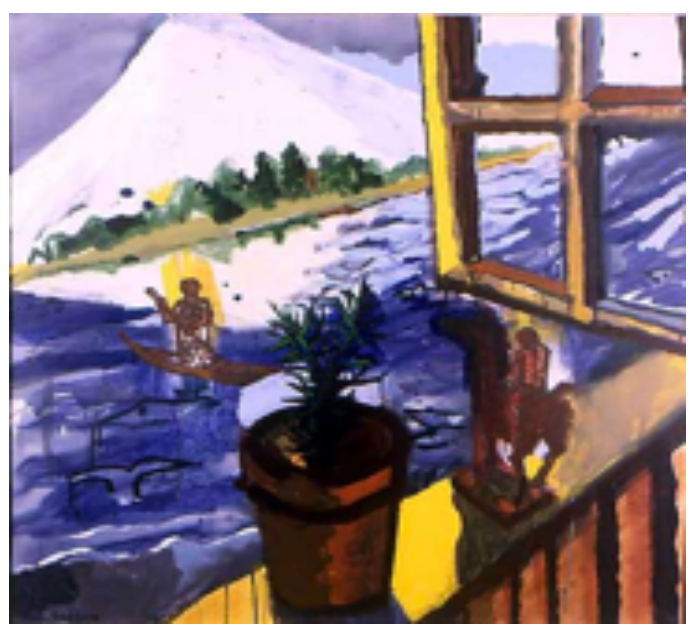

“Amor en Pucón” 2008 oleo/tela 1x1 mt.

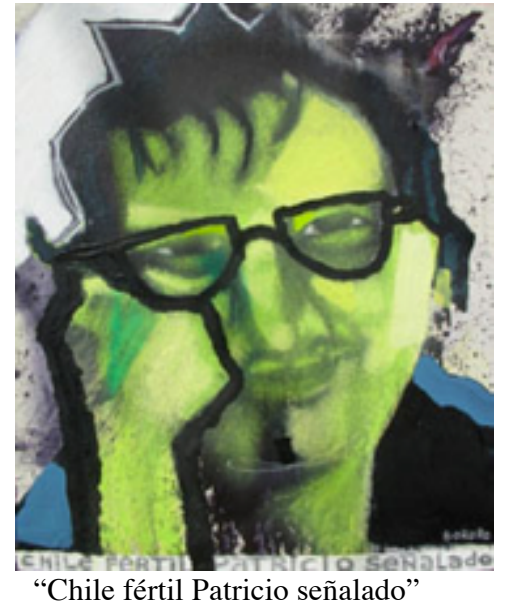

Bororo 2006 mixta/ tela, 50x $60 \mathrm{~cm}$.

http://bororo.cl/

www.artistasplasticoschilenos.cl/658/w3-article-40328.html http://www.portaldearte.cl/autores/bororo.htm 
$N^{\circ} 75$ ficha

\section{Cesar Gabler}

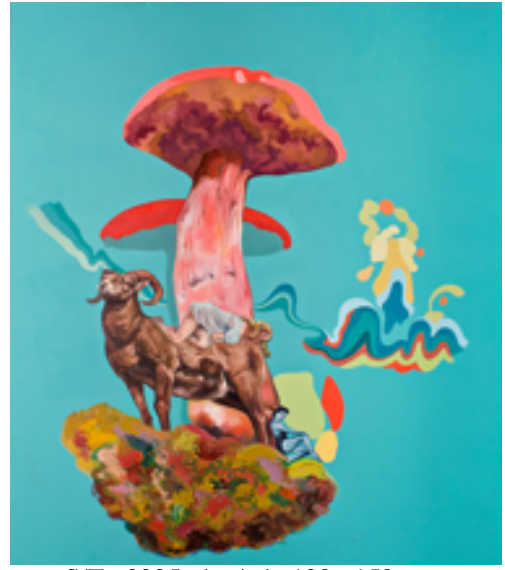

$\mathrm{S} / \mathrm{T}, 2005$ oleo/tela 100x $150 \mathrm{~cm}$.

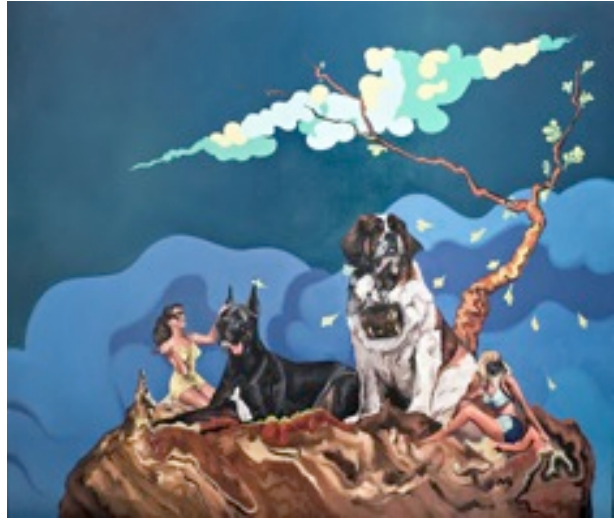

"Bonsai" 2008 oleo/tela 150x180 cm.

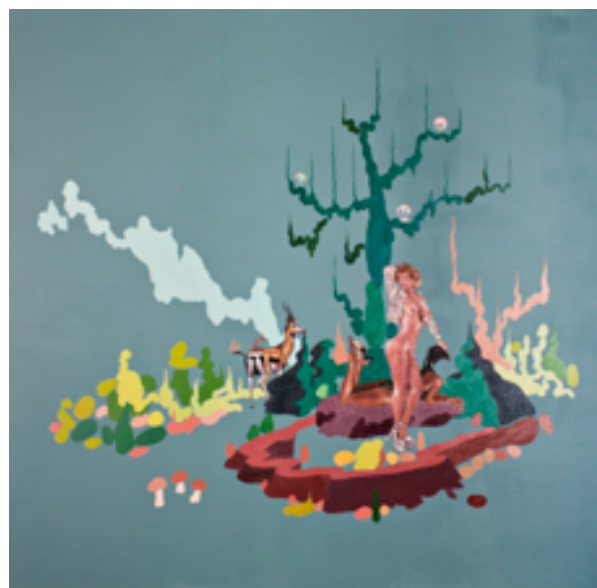

"Árboles Madres",2008. Óleo/tela, 180x180 cm.

http://rtcesargabler.blogspot.com/

www.artishock.cl/tag/cesar-gabler/

www.portaldearte.cl/agenda/pintura/2008/cesar_gabler.html 


\section{Diego Hernández}

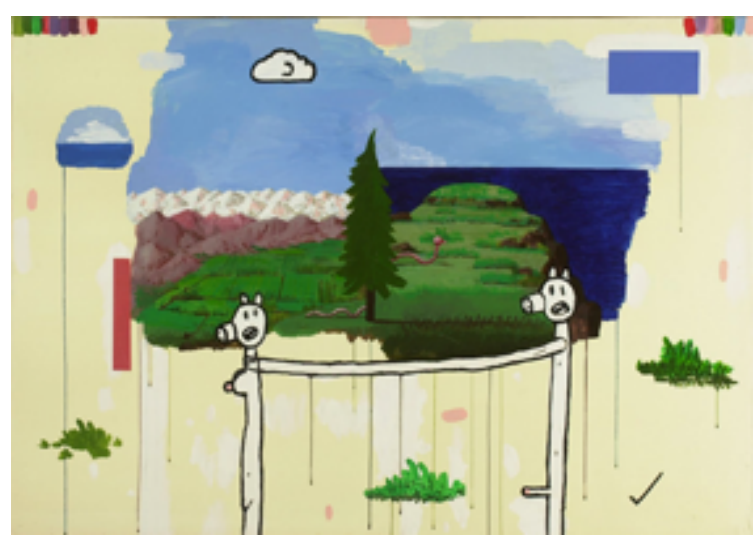

"Pigs" 2003, acrilico/tela 100x150 cm.

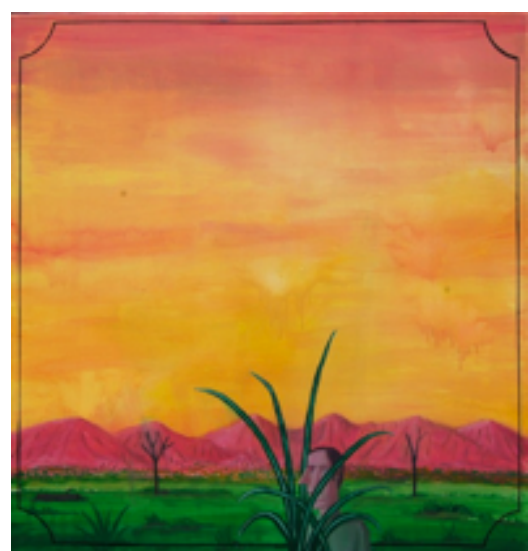

"Volver a esos campos", 2013, acrílico/ tela, 120 x 120 $\mathrm{cm}$.

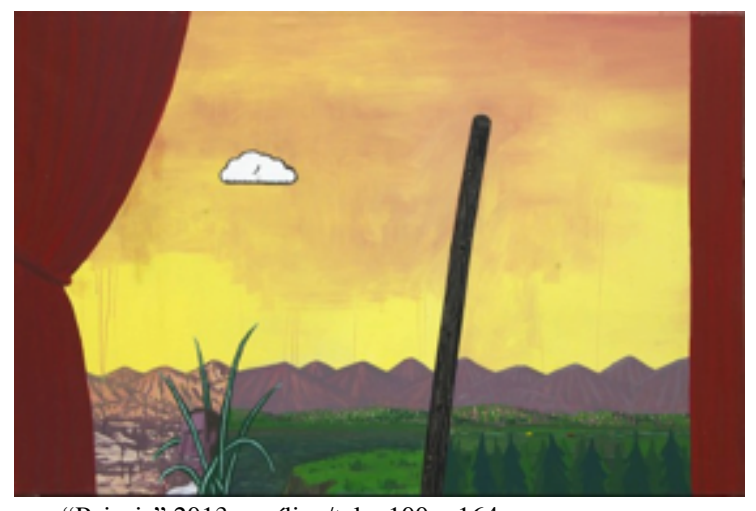

"Paisaje" 2013, acrílico/tela, 100 x 164 cm

http://rtdiegohernandez.blogspot.com/

http://www .artishock.cl/2013/12/un-hueso-duro-de-roer-sobre-la-pintura-de-diego-hernandez/ http://www.premioaltazor.cl/diego-hernandez/ 


\section{$N^{\circ} 77$ ficha}

\section{Gonzalo Cienfuegos}

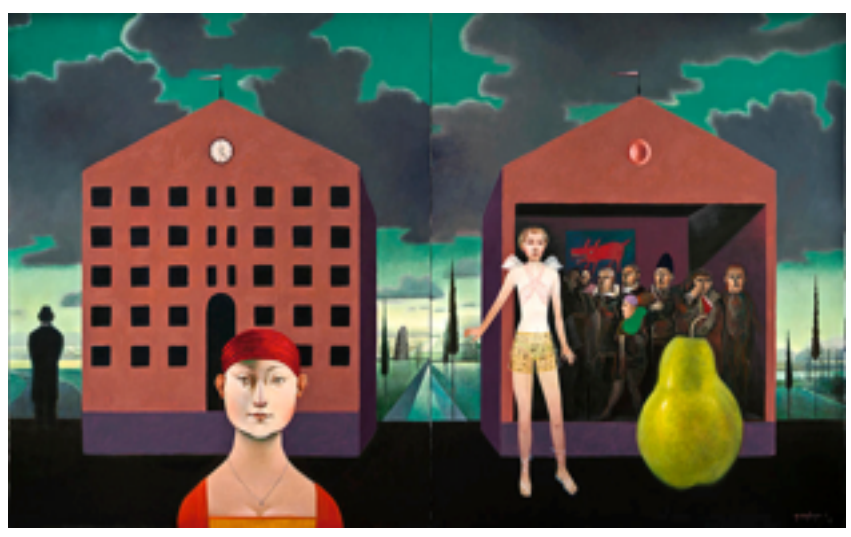

Anunciación X, 2012 Oleo sobre tela, 120 x 140 cm c/u (díptico)

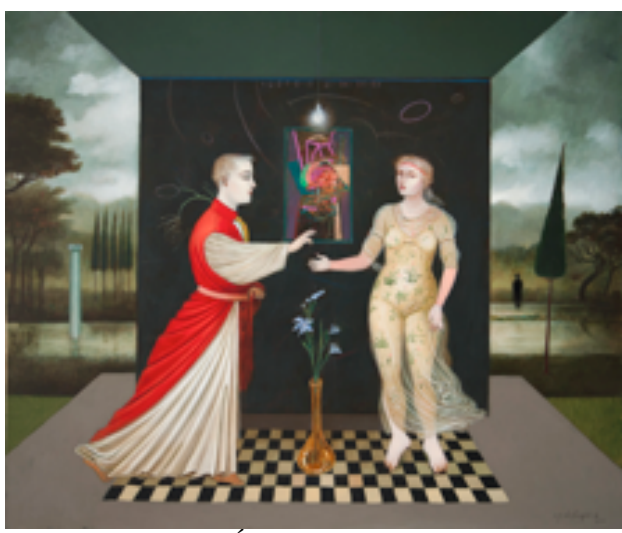

Anunciación VII, Óleo/tela, 120 x 140 cm, 2012

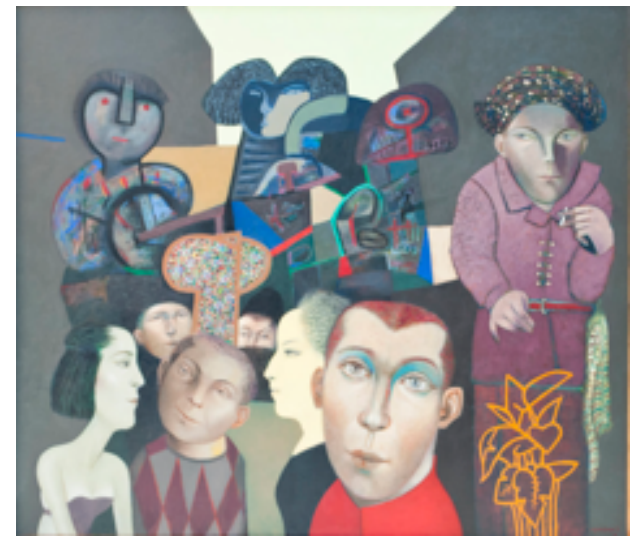

Manifiesto Social, 2014, Oleo sobre tela, 120 x $140 \mathrm{~cm}$

Www.gonzalocienfuegos.com/

www.artistasplasticoschilenos.cl/658/w3-article-40074.html

www.portaldearte.cl/autores/cienfuegos.htm 
$N^{\circ} 78$ ficha

\section{Ignacio Gana}

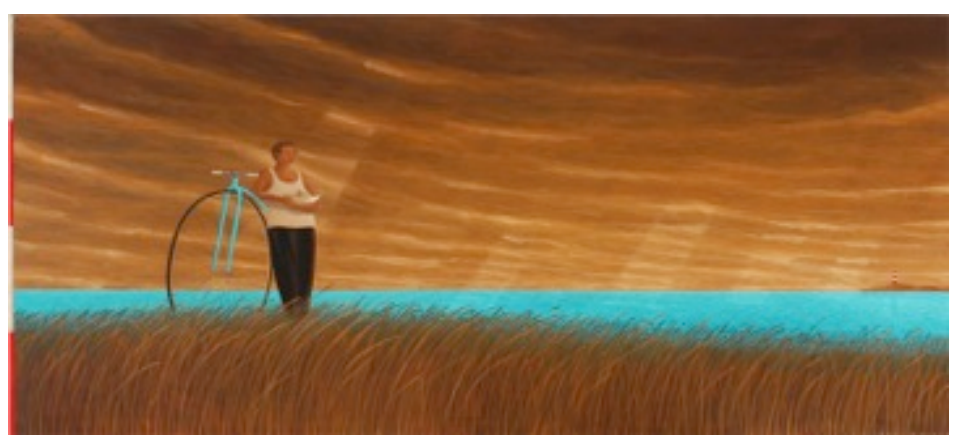

"El viaje” 2012 oleo/tela
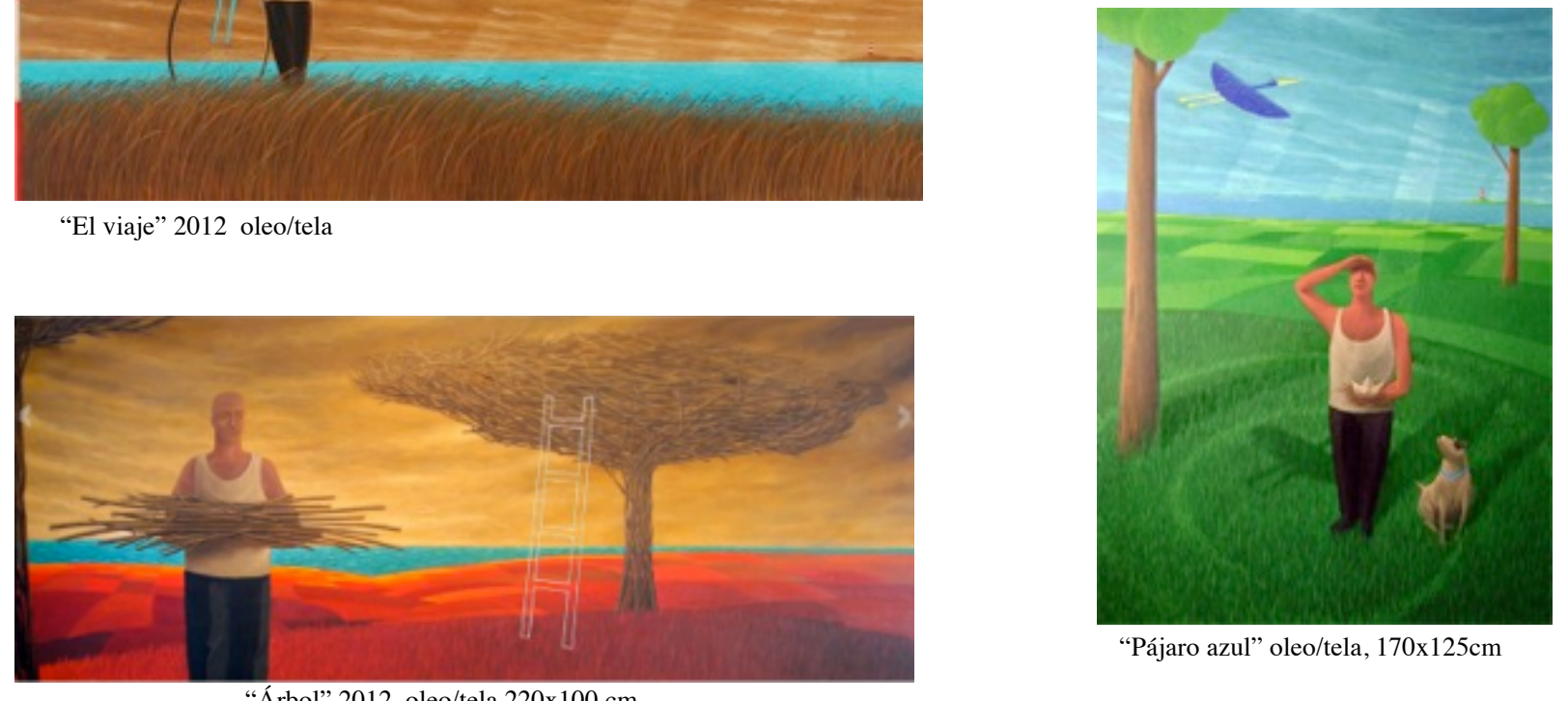

"Pájaro azul" oleo/tela, 170x125cm

“Árbol” 2012 oleo/tela 220x100 cm

www.galerialasala.cl/exposiciones/ignacio-gana-2/

www.ignaciogana.cl/

http://www.artistasplasticoschilenos.cl/658/w3-article-40089.html 


\section{Jorge Opazo}
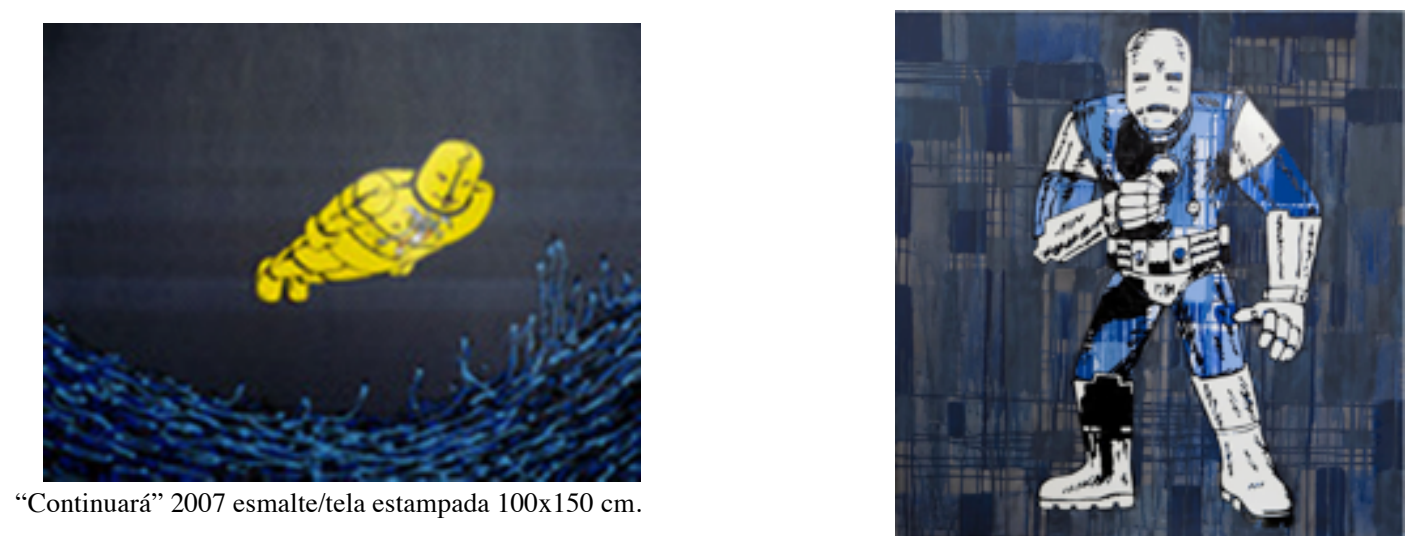

S/T, 2008 Acrílico y esmalte/tela 95 x 95

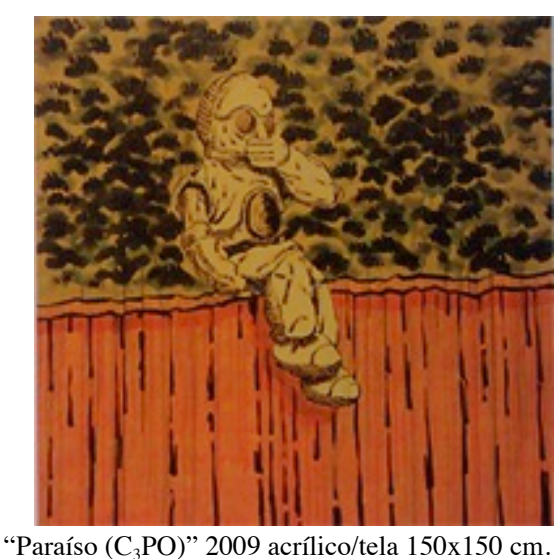

www.artistasplasticoschilenos.cl/658/w3-article-40312.html http://www.jorgequien.com/ 


\section{$N^{\circ} 80$ ficha}

\section{Leonardo Casas}

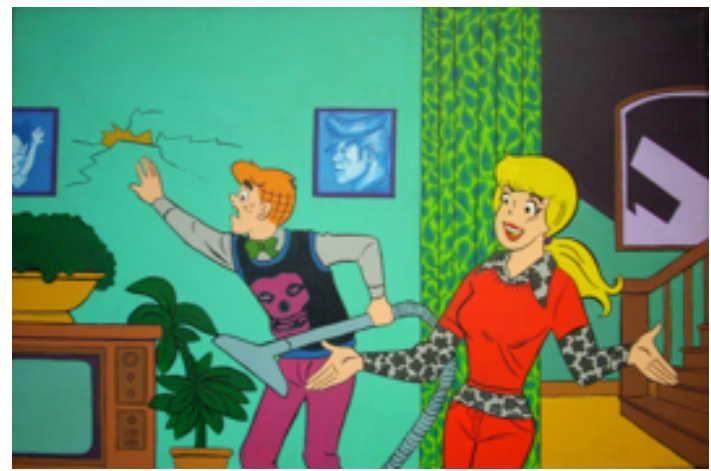

“Súper bien!” 2009 acrílico/tela 50x80 cm.

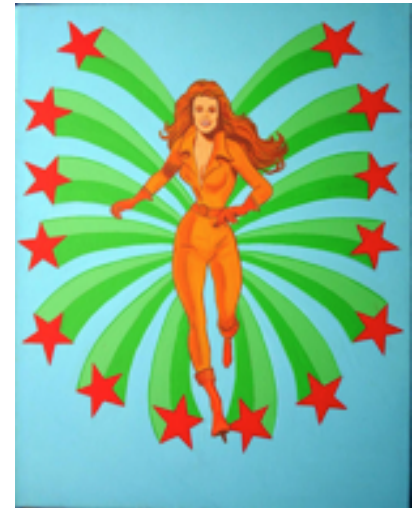

“Tracy ninfa del templo" 2009 acrílico/tela 50x40 cm.

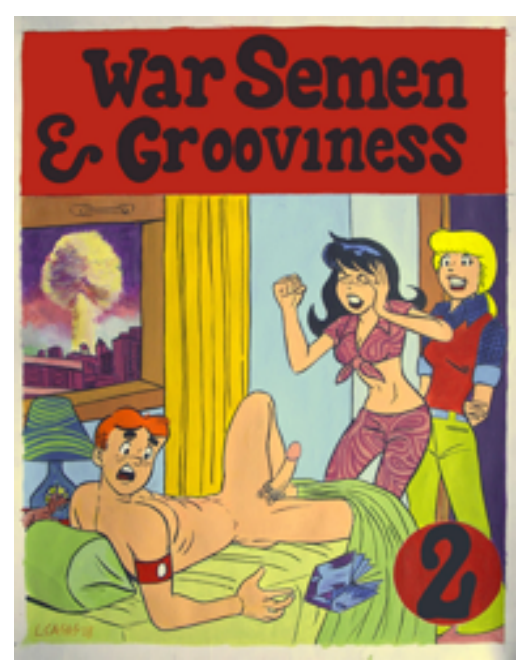

Nuclear Anxiety” 2008 acrílico/papel 65X45 cm

http://leonardocasas.blogspot.com/

http://www.artistasplasticoschilenos.cl/658/w3-article-40252.html\#biografia 


\section{María Elena Cárdenas}

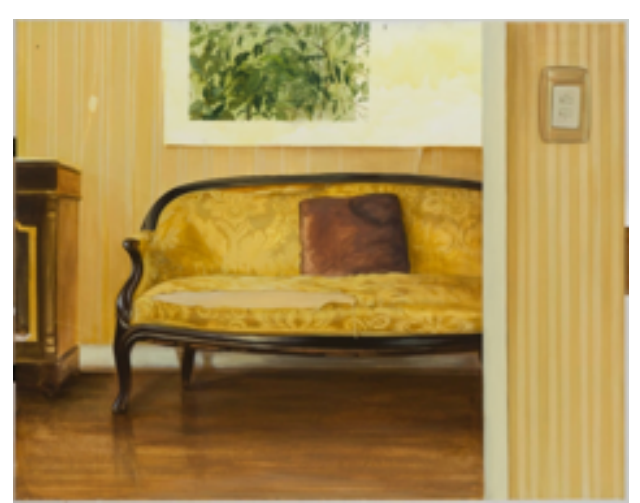

S/T. 2014 Óleo sobre tela 140 x $110 \mathrm{~cm}$.

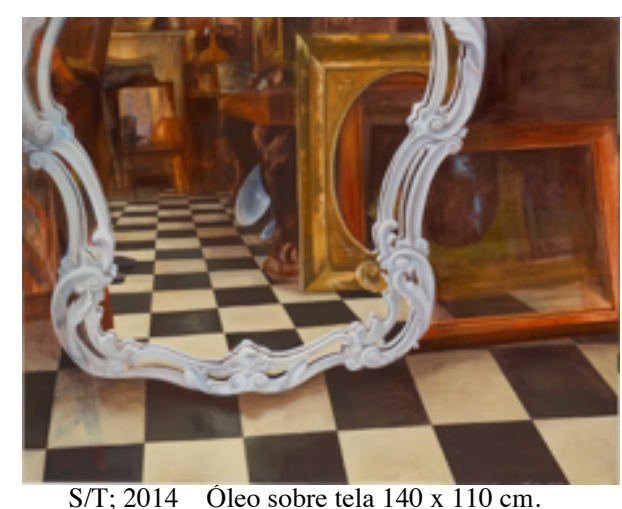

S/T; 2014 Óleo sobre tela 140 x $110 \mathrm{~cm}$.

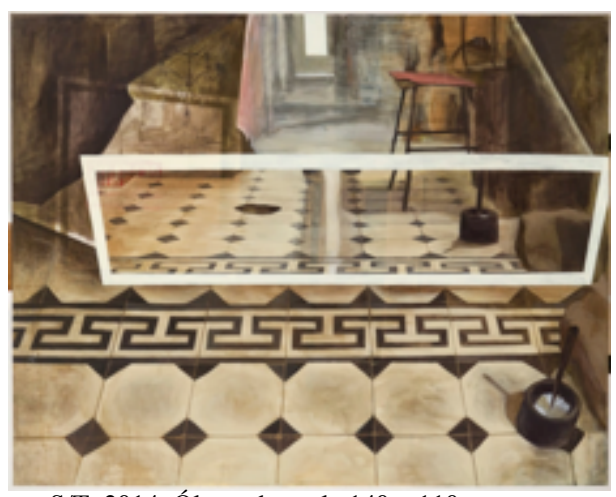

S/T. 2014 Óleo sobre tela $140 \times 110 \mathrm{~cm}$

http://mariaelenacardenas.blogspot.com/

www.artistasplasticoschilenos.cl/658/w3-article-40022.html

http://www.bohemiasantiaguina.cl/pintura-de-camara-maria-elena-cardenas-y-manuel-torres/ 


\section{$N^{\circ} 82$ ficha}

\section{Mario Ibarra}

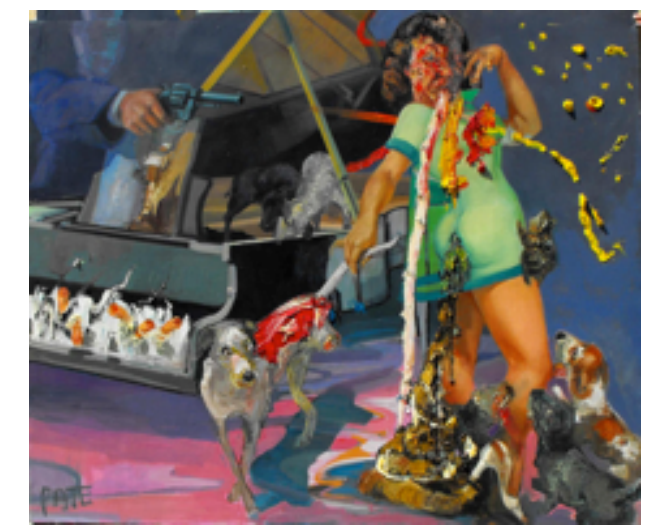

Café descontrol” 2007 oleo/lienzo 130x155 cm.

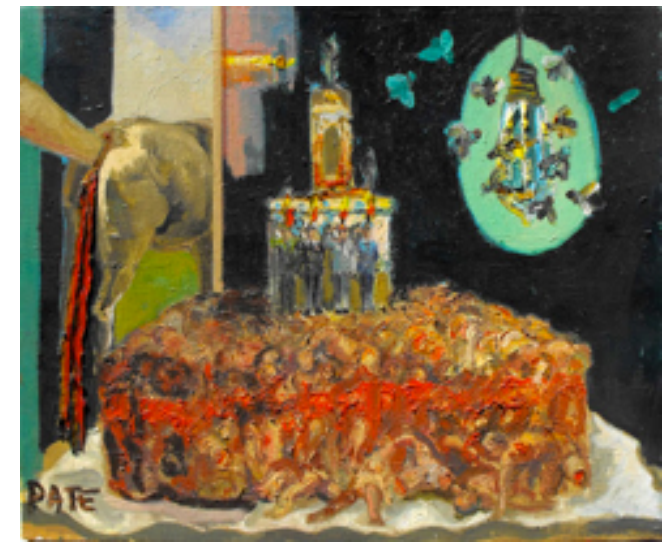

“Torta de detenidos desaparecidos" 2000 oleo/tela 50x60cm.

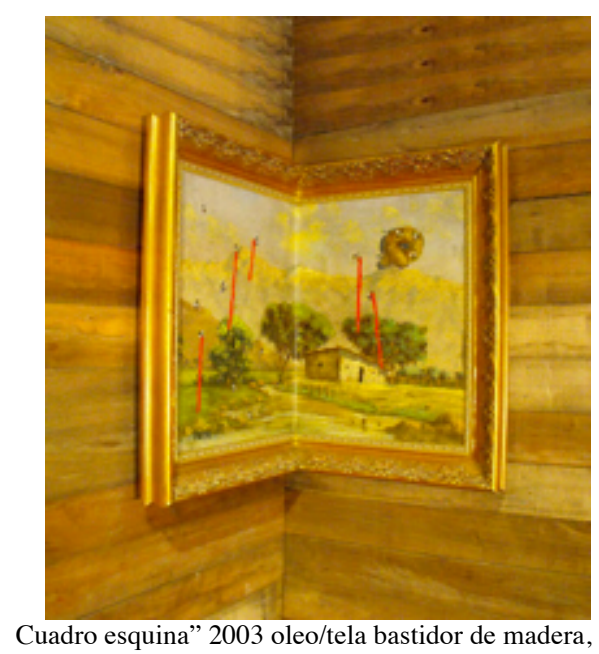

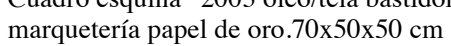

http://sitiopatekong.blogspot.com/

http://rtmarioibarra.blogspot.com/

http://mario-ibarra-catalan.artenlinea.com/ 


\section{Pablo Ferrer}

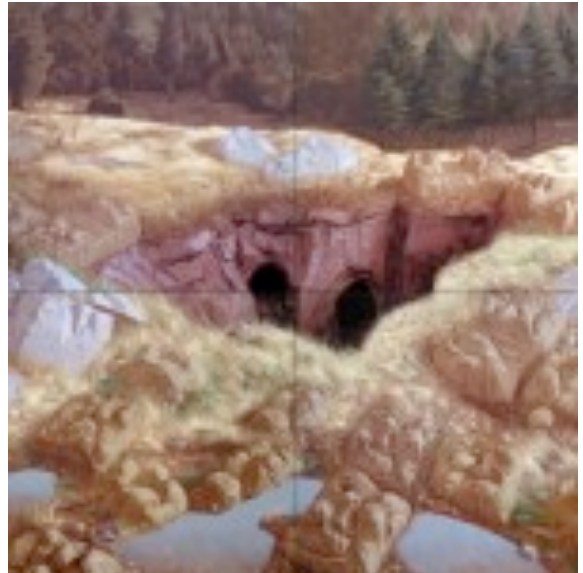

"Excavación”. 2009 Óleo y esmalte sobre 4 telas.

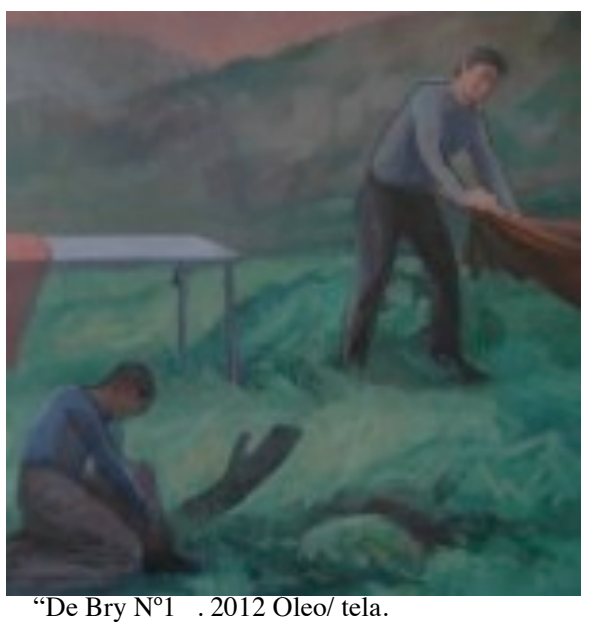

"De Bry N¹ . 2012 Oleo/ tela.

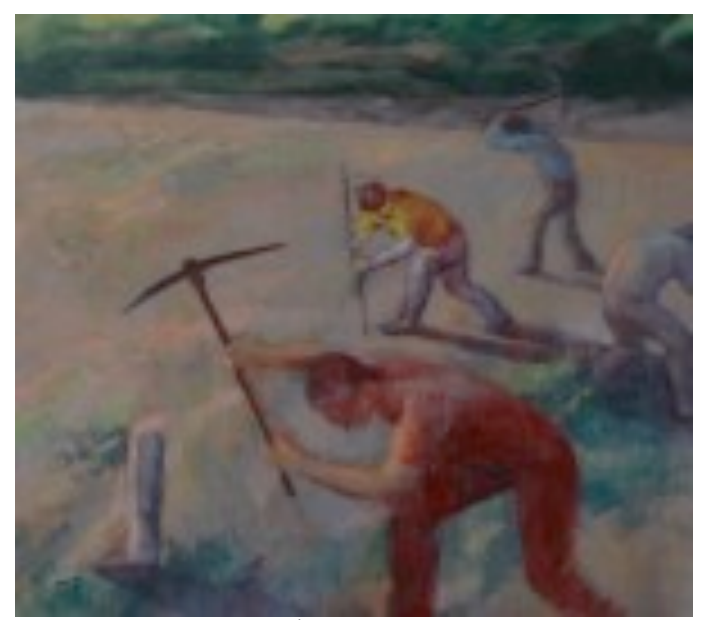

“De Bry N4 . 2012 Óleo/tela.

www.artistasplasticoschilenos.cl/658/w3-article-40268.html www.espaciohache.cl/pablo-ferrer/

http://www.artes.uchile.cl/noticias/42000/los-fantasticos-personajes-de-pablo-ferrer-cobran-vida-en-ortopedia 
$N^{\circ} 84$ ficha

\section{Vasco Bazco}

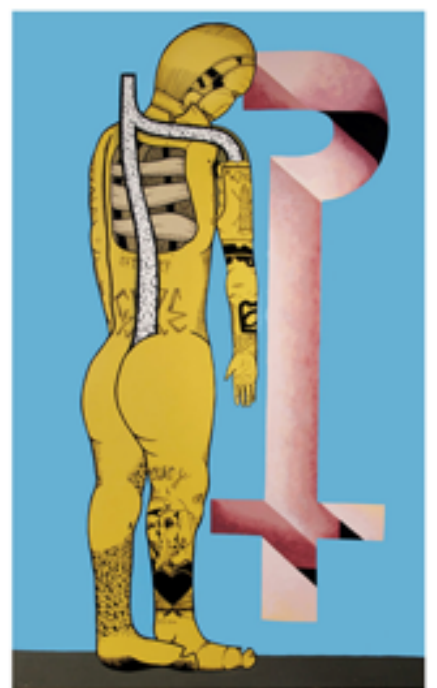

S/T 2008 Acrílico, esmalte al agua/madera $100 \times 150 \mathrm{~cm}$.

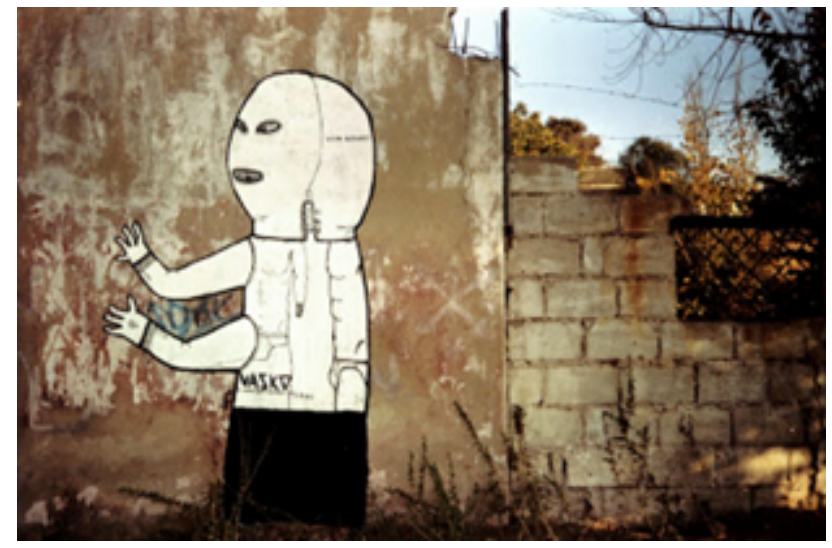

S/T 2002 látex/muro Concón

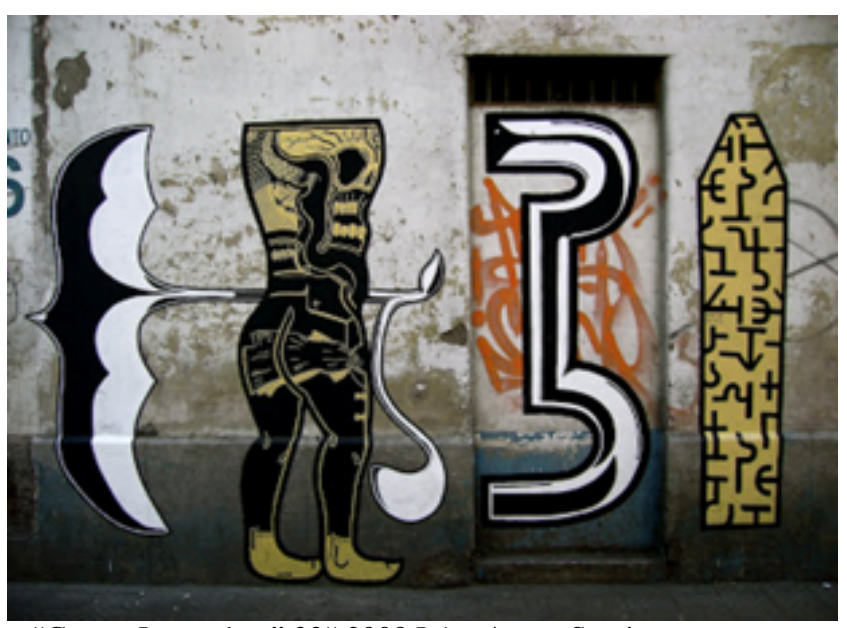

“Cuatro Le madass” 32“ 2008 Látex/muro Santiago

http://basco-vazko.blogspot.com/

https://www.flickr.com/photos/basco/ 


\section{Jorge González Lohse}

LOS OCHO DIAS DE LA SEMANA. Políptico de 200x 400 cms. técnica mixta/tela. 2008.
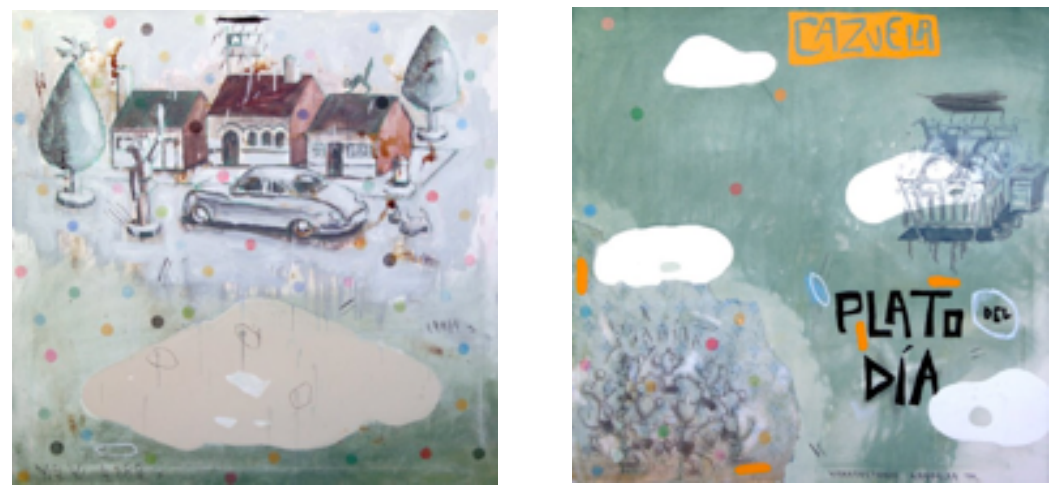

“Abecedario". 2 piezas de 29 pinturas de tec. mixta/tela. de $50 x 50 \mathrm{~cm}$. (detalle)

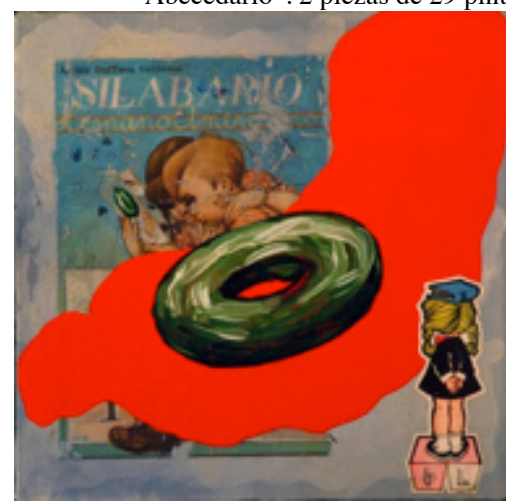

"Silabario" 2005 (detalle) mixta/tela

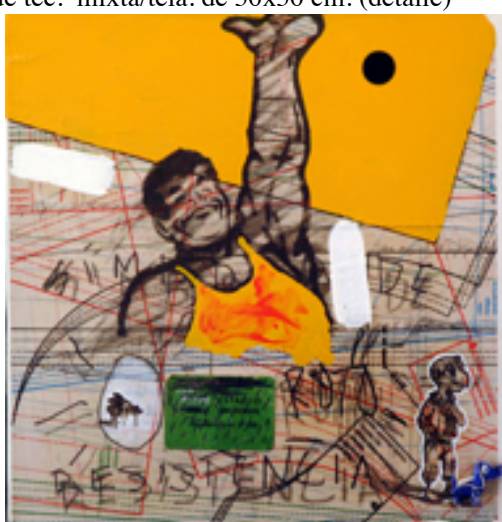

"Roto"2005 mixta/tela 500x50

http://pintorchileno7.blogspot.com/ 
$N^{\circ} 86$ ficha

\section{José Luis Villablanca}
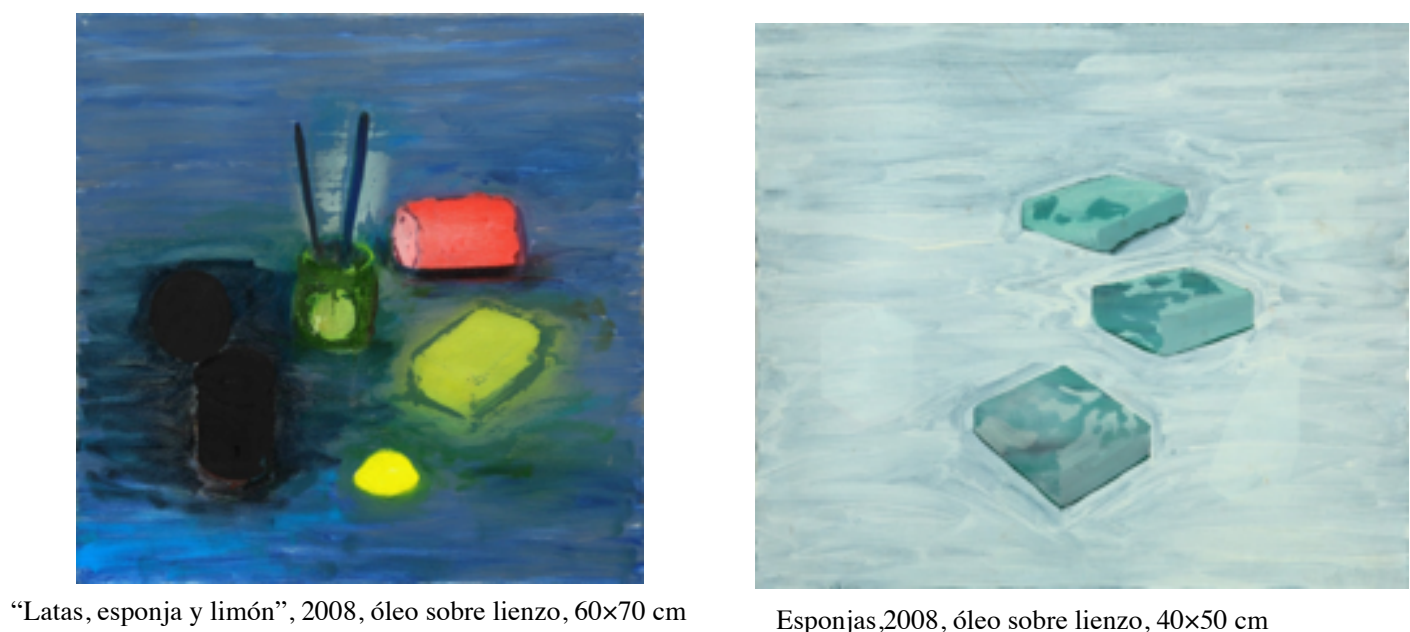

Esponjas,2008, óleo sobre lienzo, 40×50 cm

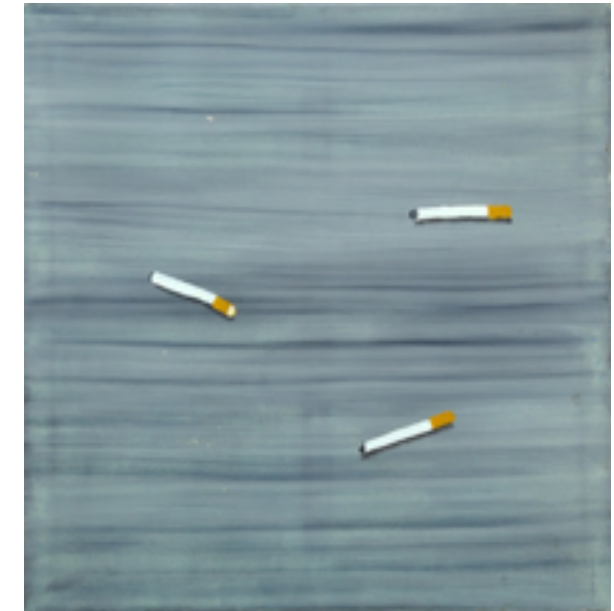

3 cigarrillos, 2008, óleo sobre lienzo, $60 \times 70 \mathrm{~cm}$

http://galeriagm.cultura.gob.cl/coleccion_artista/j/83

http://www.artishock.cl/tag/jose-luis-villablanca/ 


\section{Omar Gatica}

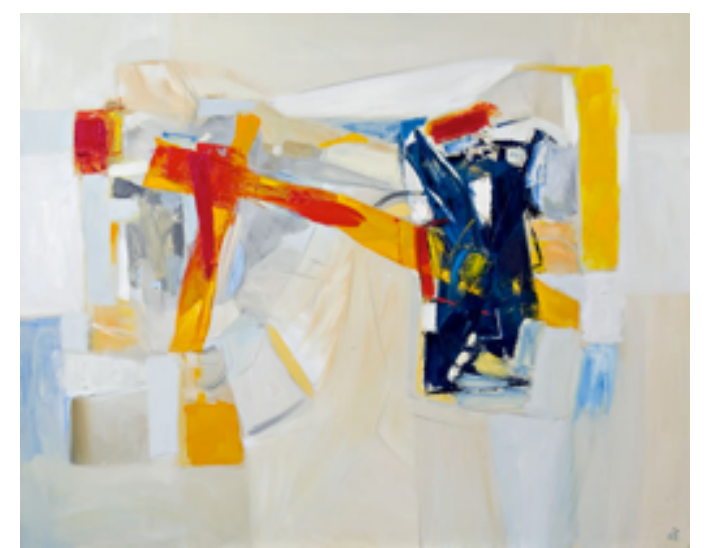

"Paisaje 4" 2007-Oleo/tela 120x150 cm.

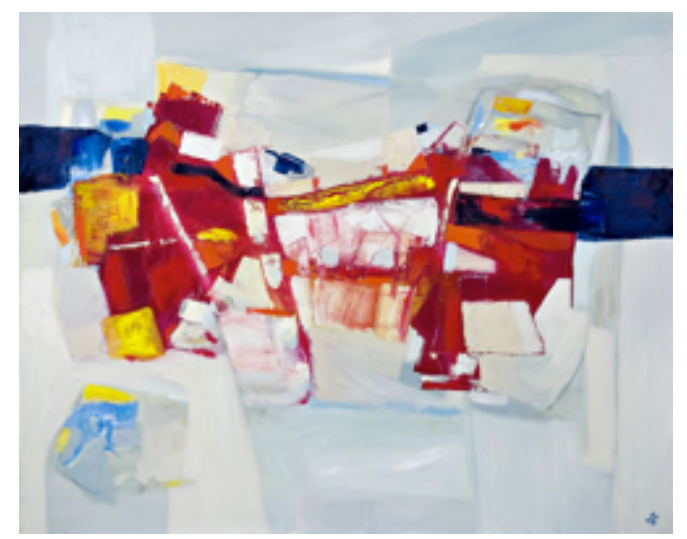

"El Torrente del Tiempo" 2007 oleo/tela 120x150cm.

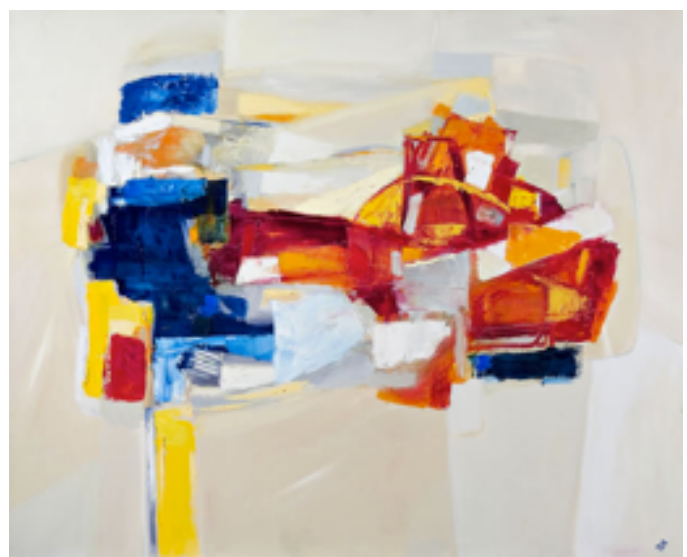

"Paisaje 5" 2007, Oleo/tela -130x160 cm.

www.artistasplasticoschilenos.cl/658/w3-article-40330.html www.portaldearte.cl/autores/gatica.htm

http://www.premioaltazor.cl/omar-gatica/ 
$N^{\circ} 88$ ficha

\section{Rodrigo Cabezas}
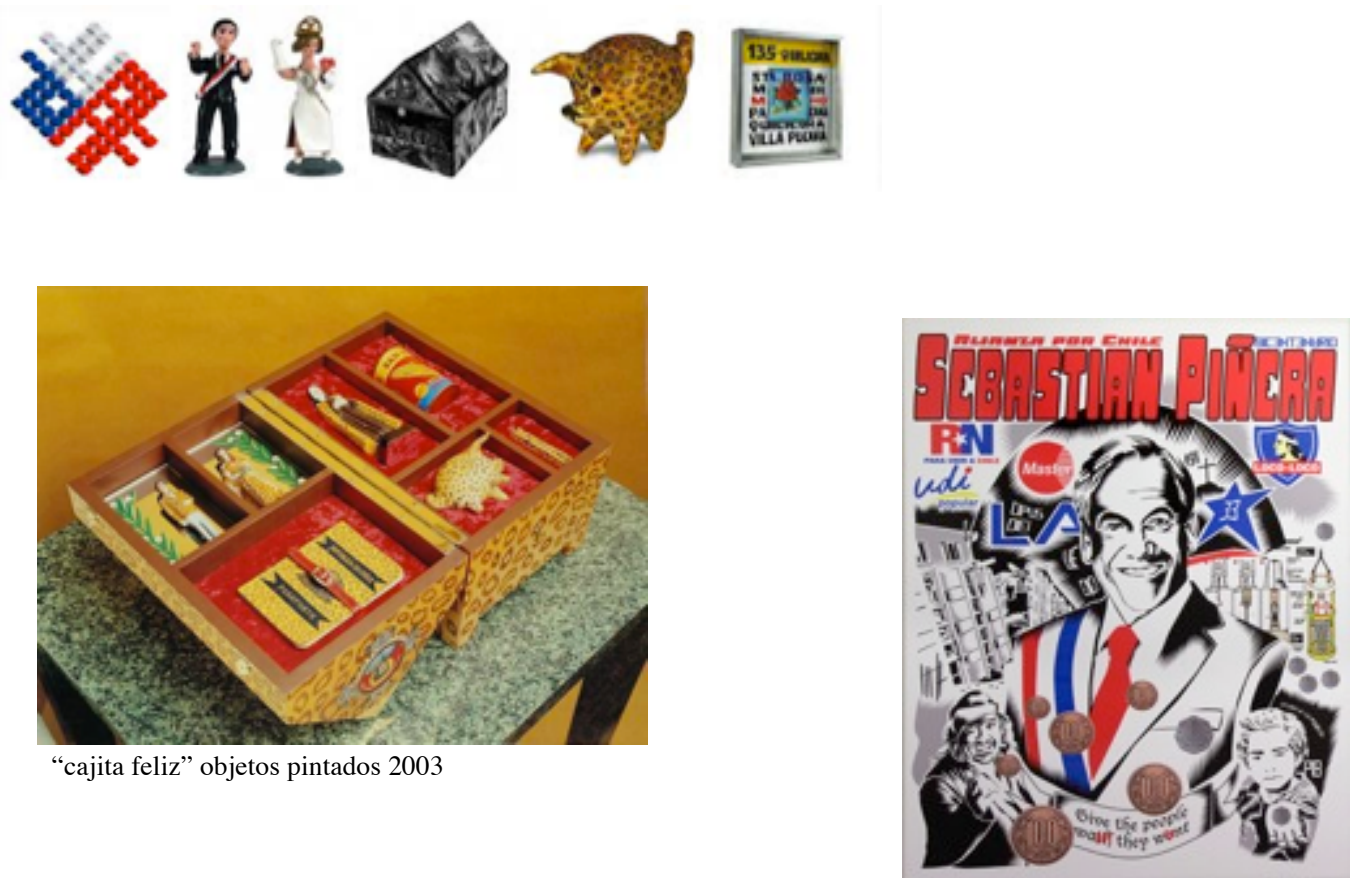

Sebastian piñera, 2010/2011

Impresión digital/tela 100X130

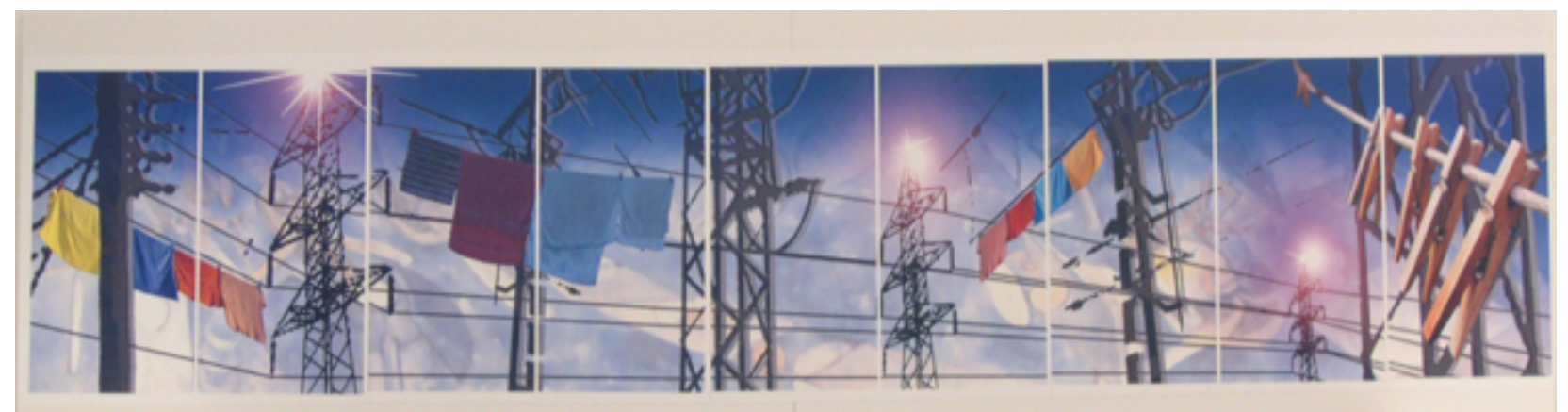

"Las Tres Marías" 2008 // 2 x11 metros de largo.

Museo de Arte de las Américas octavo piso del edificio dela Secretaría General(GSB) ONU

http://www.ecured.cu/index.php/Rodrigo_Cabezas_Mardones

http://www.galerialasala.cl/exposiciones/rodrigo-cabezas-headhunter-2/

http://blog.rodrigocabezas.com/?p=132 


\section{Carmen Aldunate}

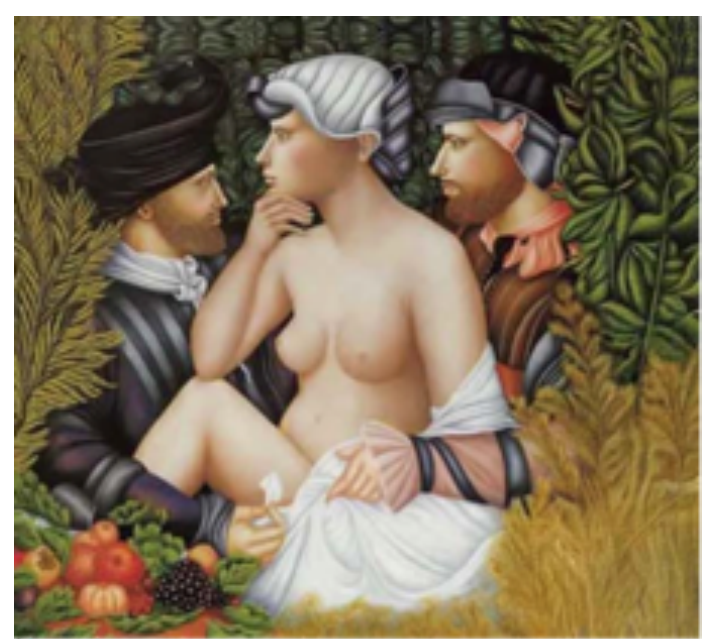

Thingulacion del follawe, Oleo sotre tela $2014,120 \times 90 \mathrm{cms}$

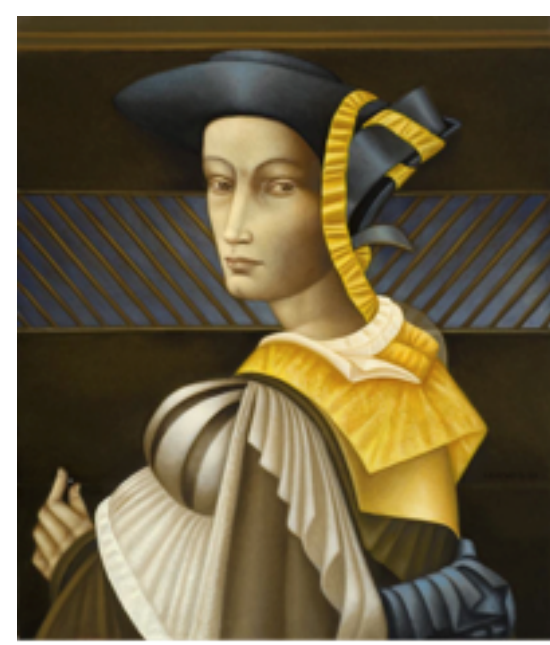

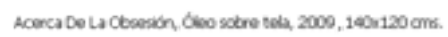

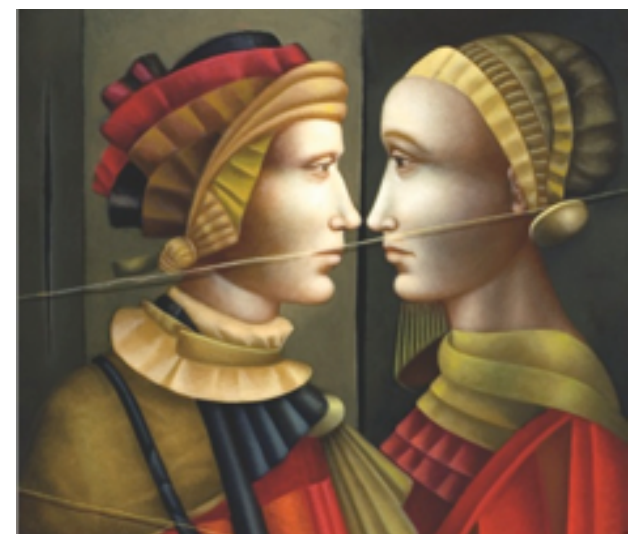

"Hasta que la muerte nos separe" 2009, óleo/tela $140 \times 120 \mathrm{~cm}$,

www.artistasplasticoschilenos.cl/658/w3-article-40315.html

www.portaldearte.cl/autores/aldunate.htm

http://www.rmm.cl/index_sub2.php?id_contenido=15377\&id_seccion=6031\&id_portal=730 
$N^{\circ} 90$ ficha

\section{Víctor Alegría}

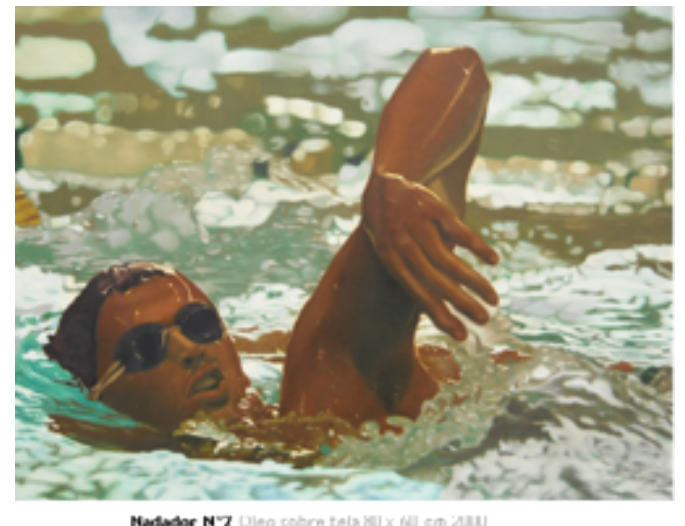

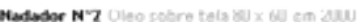

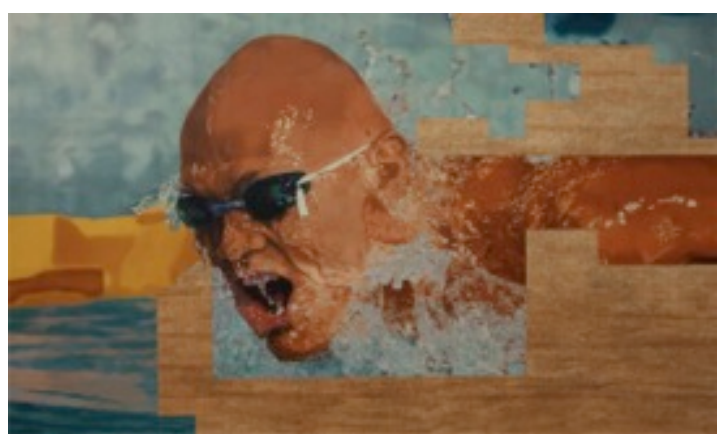

"Nadador N³" 2002 Óleo/tela 132 x $80 \mathrm{~cm}$

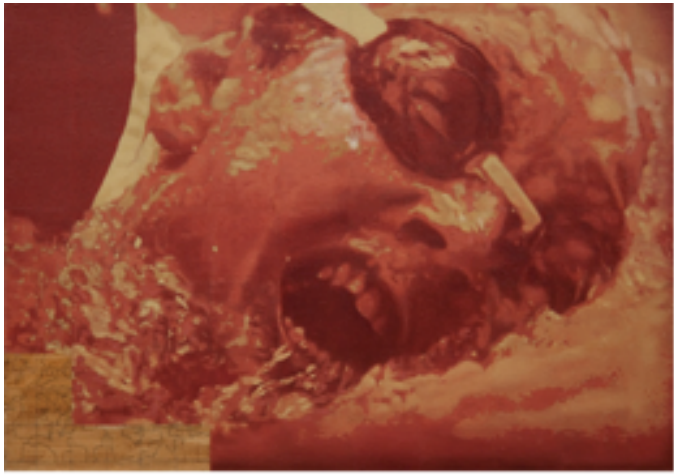

Madador $\mathrm{N}^{-4}$ UVeo sobre tela41 $\times 28 \mathrm{~cm}$ 2014

www.victoralegria.cl/

www.artistasplasticoschilenos.cl/658/w3-article-40313.html 


\section{Soledad Alsina}

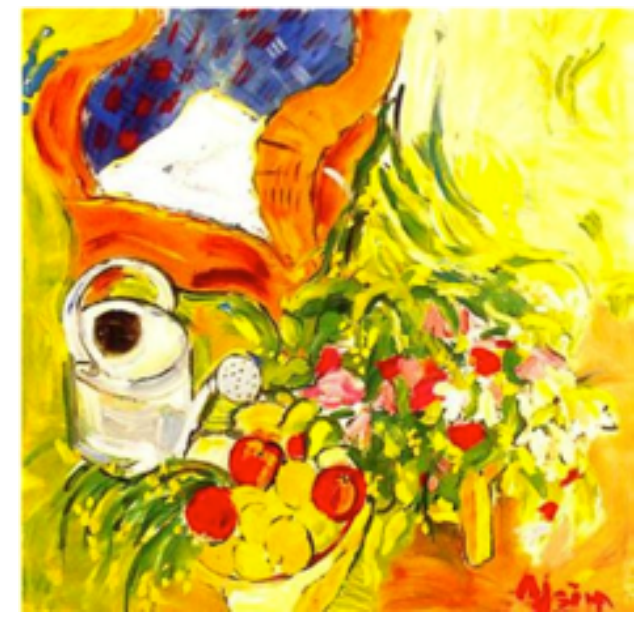

Balancín con flores 2006 óleo/tela 160x180 / colección particular

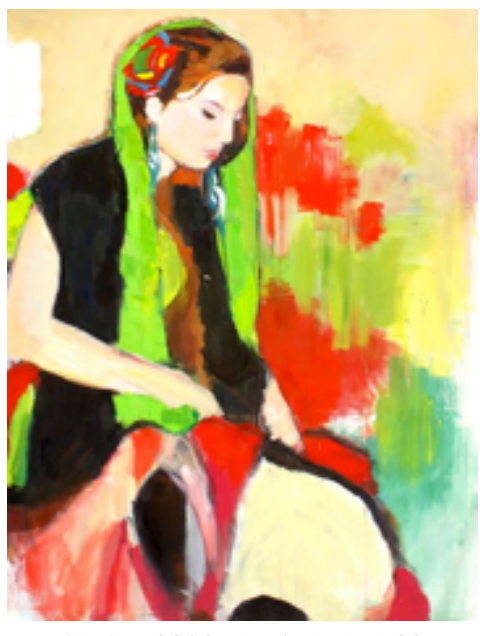

Bailarina 2008 oleo/tela 1x1,30 mt.

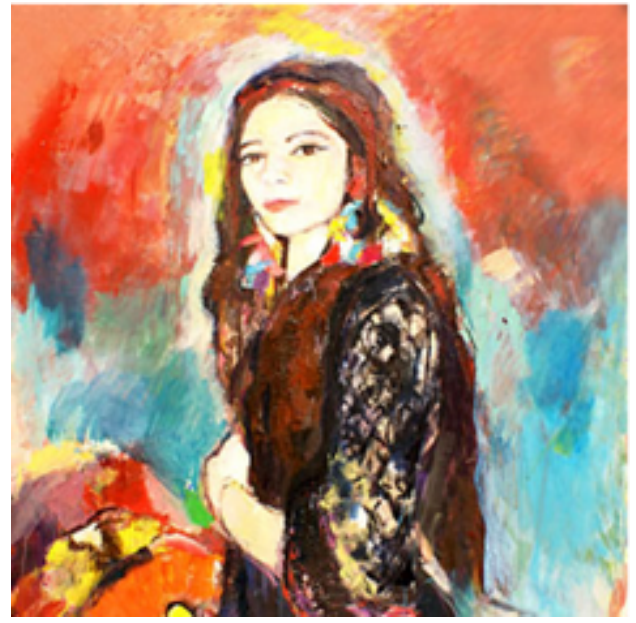

RETRATO 2008 (detalle)óleo/tela 1x1,30 mt.

www.artistasplasticoschilenos.cl/658/w3-article-39725.html

www.portaldearte.cl/autores/alsina.htm

http://www.lascondes.cl/cultura/hall_salsina.html

http://artealsina.wix.com/sol\#!obras 
N92 ficha

\section{Cristóbal Anwandter}
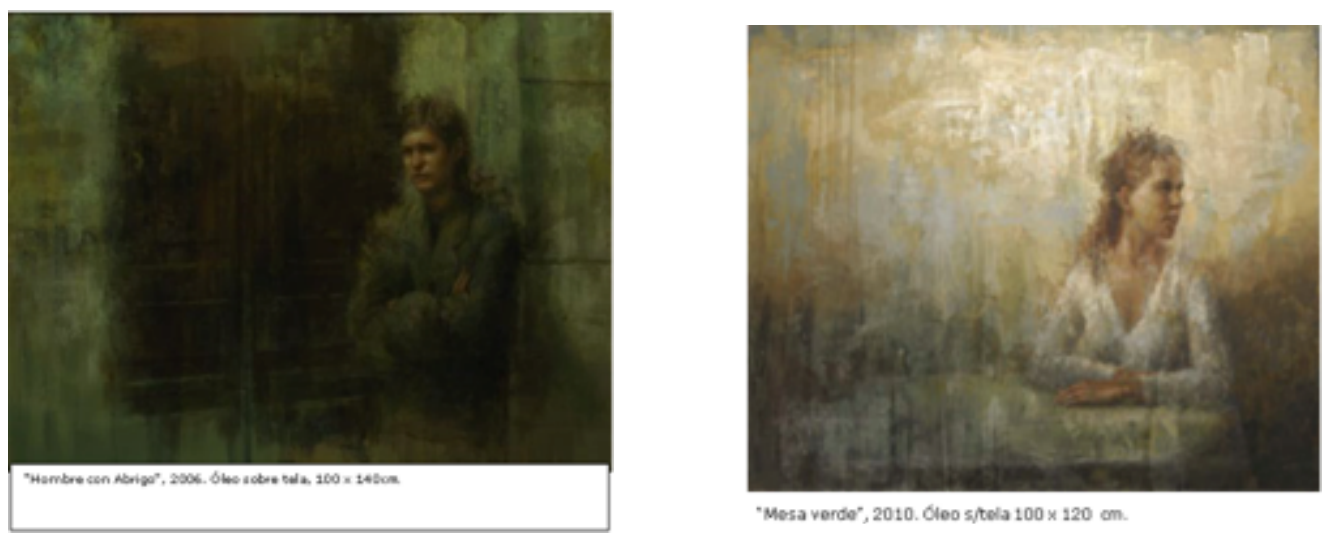

"Mesa verde", 2010. Oleo s/twla $100 \times 120 \mathrm{om}$

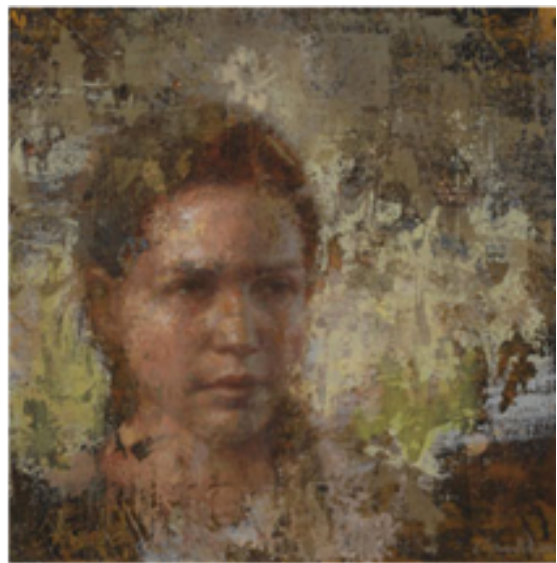

"Mourk" ol eo s/tels, $100 \times 100 \mathrm{~cm}, 2011$

www.cristobalanwandter.com/

http://www.portaldearte.cl/artistas_visuales/anwandter_cristobal.html 
$N^{\circ} 93$ ficha

\section{Claudia Peña}
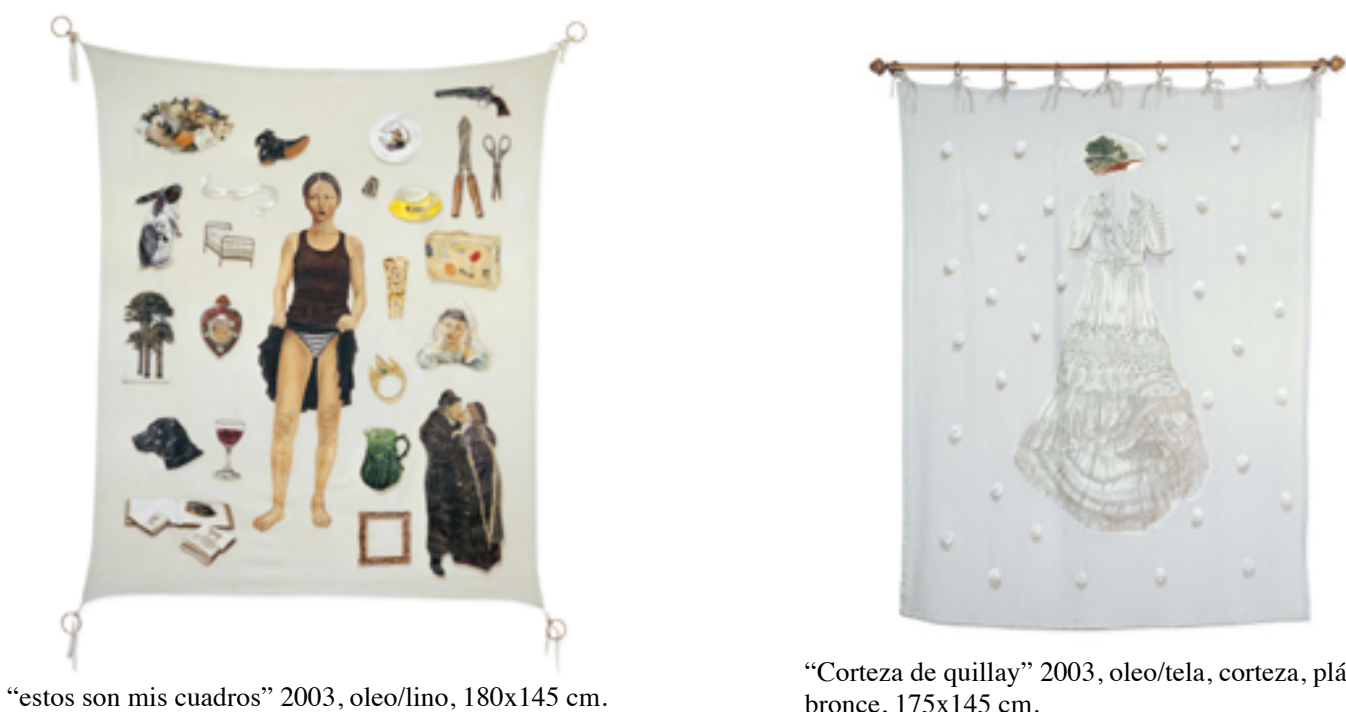

"Corteza de quillay" 2003, oleo/tela, corteza, plástica y bronce, $175 \times 145 \mathrm{~cm}$.

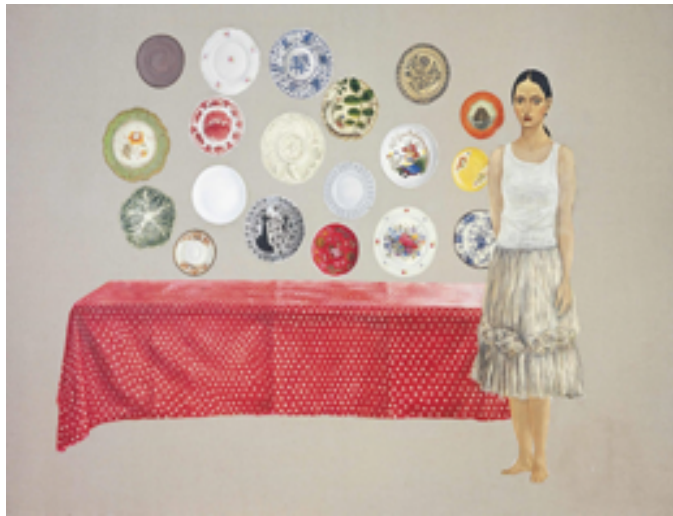

“¡a almorzar” 2003 oleo/tela 140x200 cm.

http://rtclaudiapena.blogspot.com/

http://claudiapenasalinas.com/

www.arteallimite.com/galeria/artistas/claudia-pena-795 


\section{Eduardo García de la Sierra}

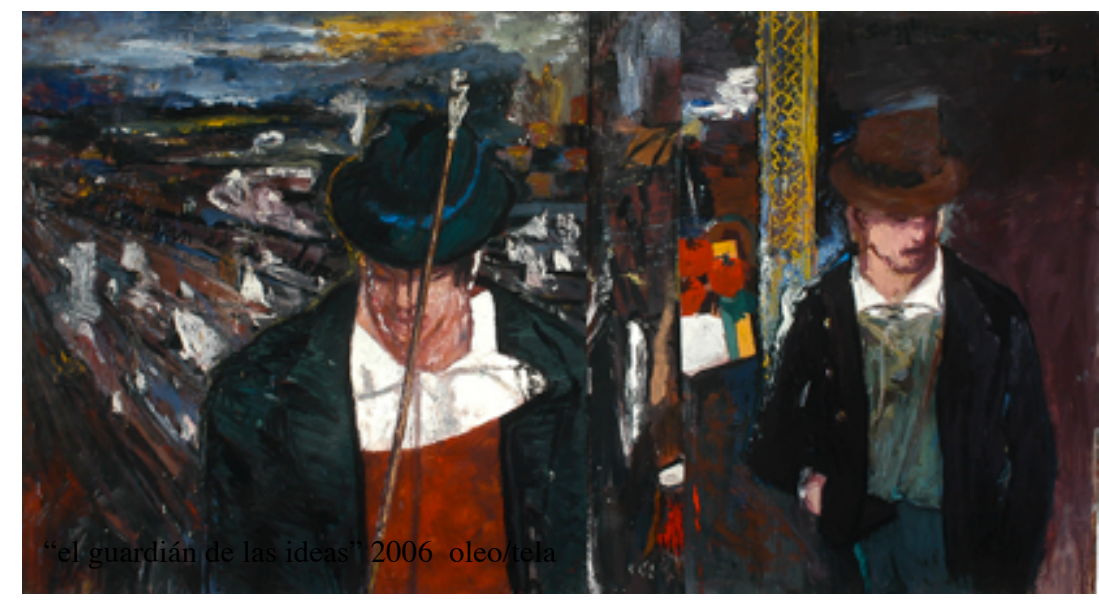

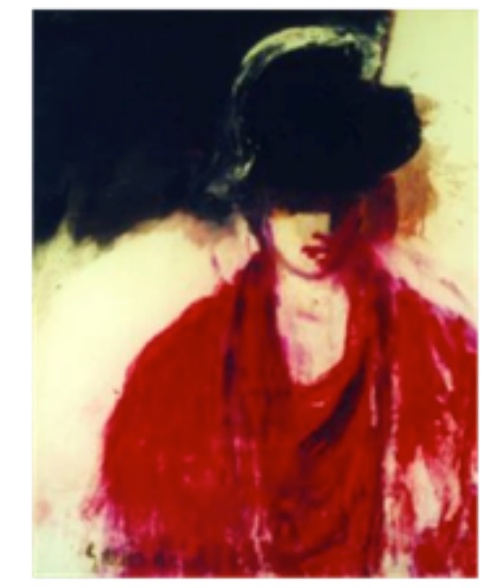

Sin Título", 2001 . Óleo sobre tela, $100 \times 180 \mathrm{~cm}$

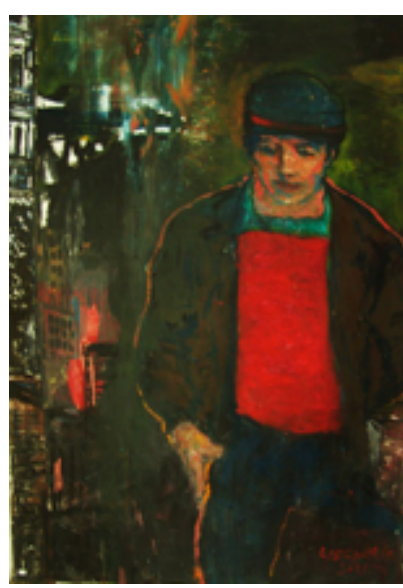

S/T, 2004 Oleo/tela 152x $98,5 \mathrm{~cm}$.

www.artistasplasticoschilenos.cl/658/w3-article-40496.html

http://galeria13.cl/portfolio/eduardo-garcia-de-la-sierra/ 
$N^{\circ} 95$ ficha

\section{Felipe Christensen}

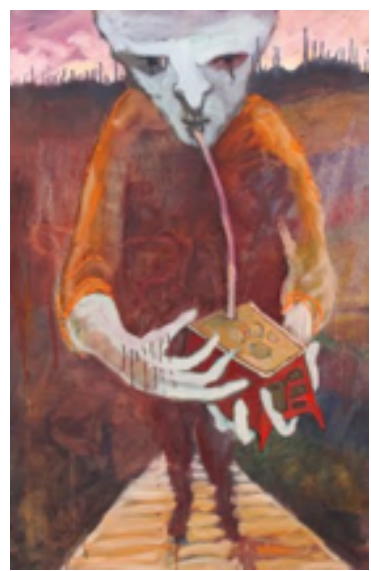

"MATECIANURO" 2006 Oleo/Tela 64,3

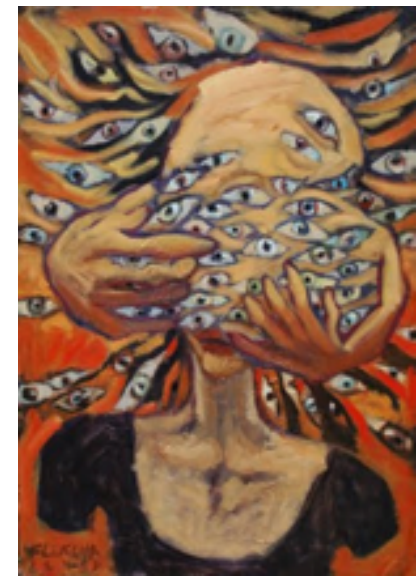

"Insoportable autocensura" imposible" 2006 oleo/tela

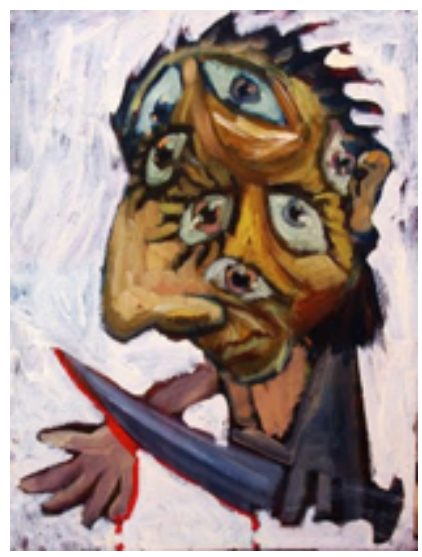

Latinoamérica Cortándose las Venas" $2006(\mathrm{O} / \mathrm{T})$ $43,5 \times 55 \mathrm{~cm}$

http://elojodelsurpoesia.blogspot.com/2009/08/muestra-del-pintor-chileno-felipe.html 

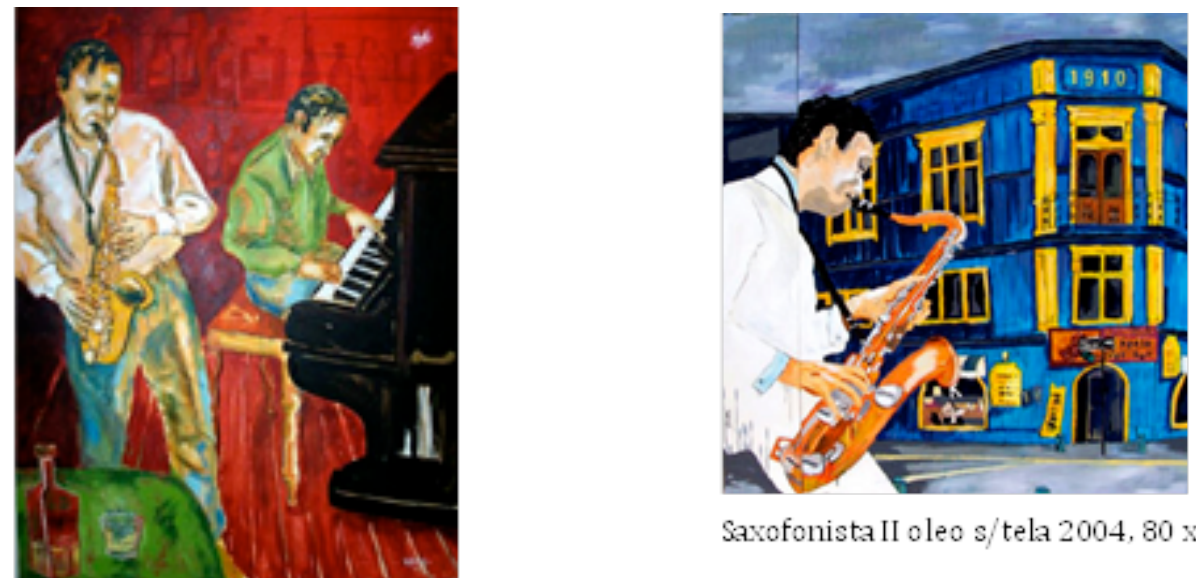

Saxofonista II oleo s/tela 2004, $80 \times 80$

Saxofonista interior, abeo s/tela $2004.100 \mathrm{x} 80 \mathrm{~cm}$.

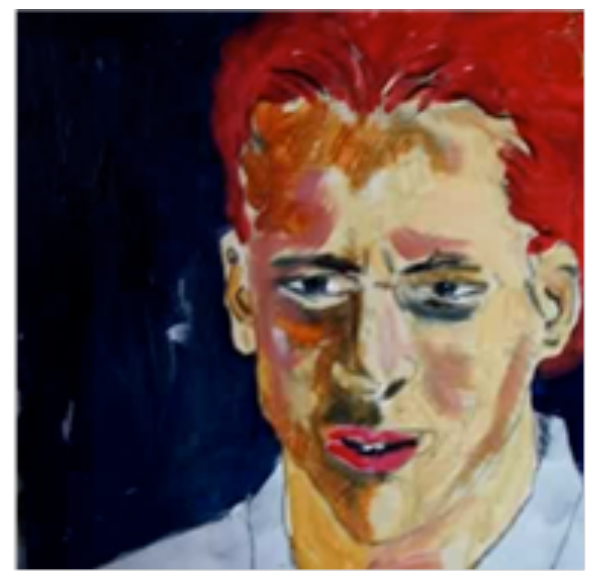

Mirada Duda oleo s/tela $200580 \times 90 \mathrm{fcm}$.

www.portaldearte.cl/artistas_visuales/urbina_jose.html http://www.escaner.cl/escaner66/entrevista.html 


\section{$N^{\circ} 97$ ficha}

\section{Matías Camus}
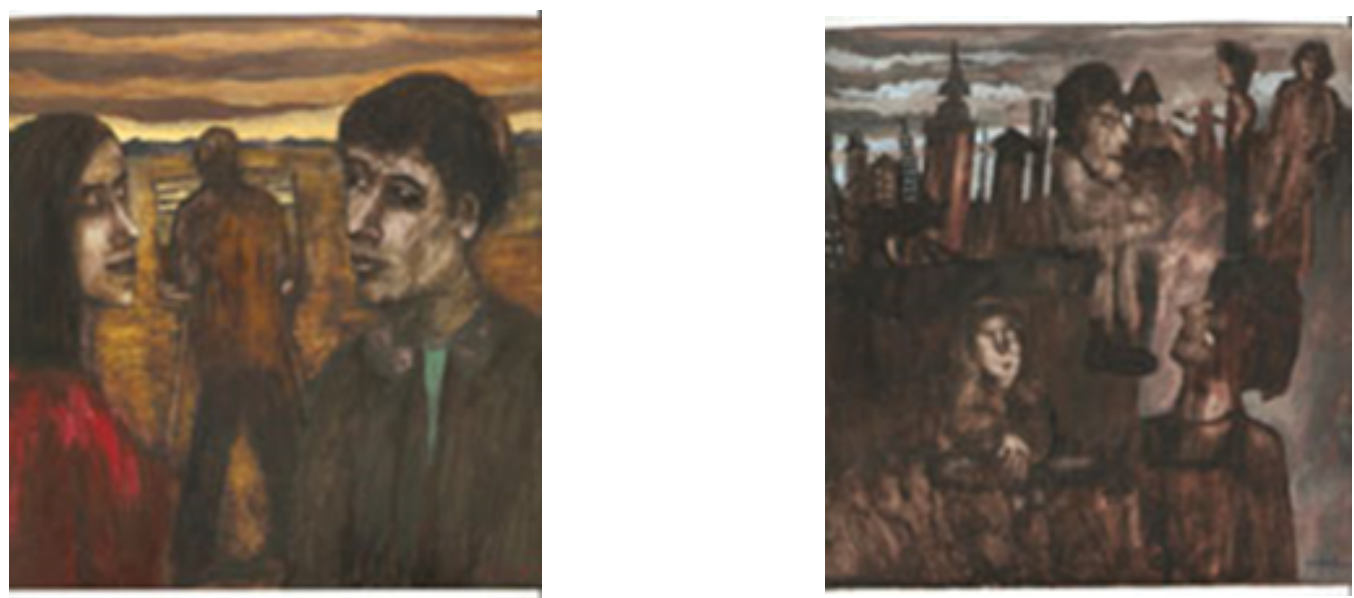

Exposición "Viajando en el Mismo Lugar" 2008, serie de pinturas oleo/tela 50x50 cm.

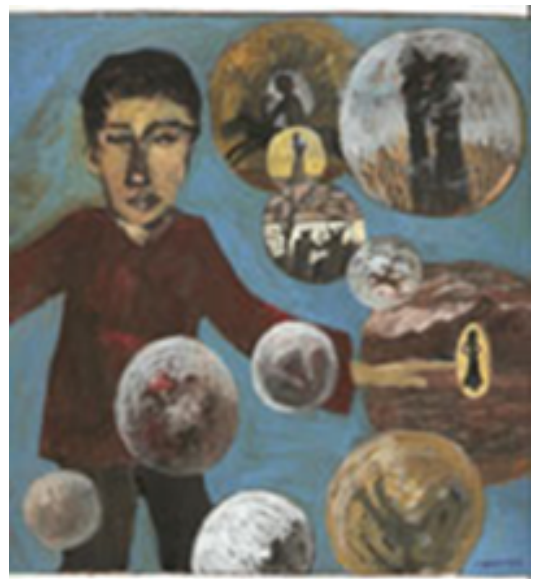

www.galerialasala.cl/exposiciones/matias-camus-21-caprichos/

http://diario.elmercurio.com/detalle/index .asp?id=\{43c426da-f80c-4310-8399-e3871b980217\} 


\section{$N^{\circ} 98$ ficha}

\section{Natalia Babarovic}
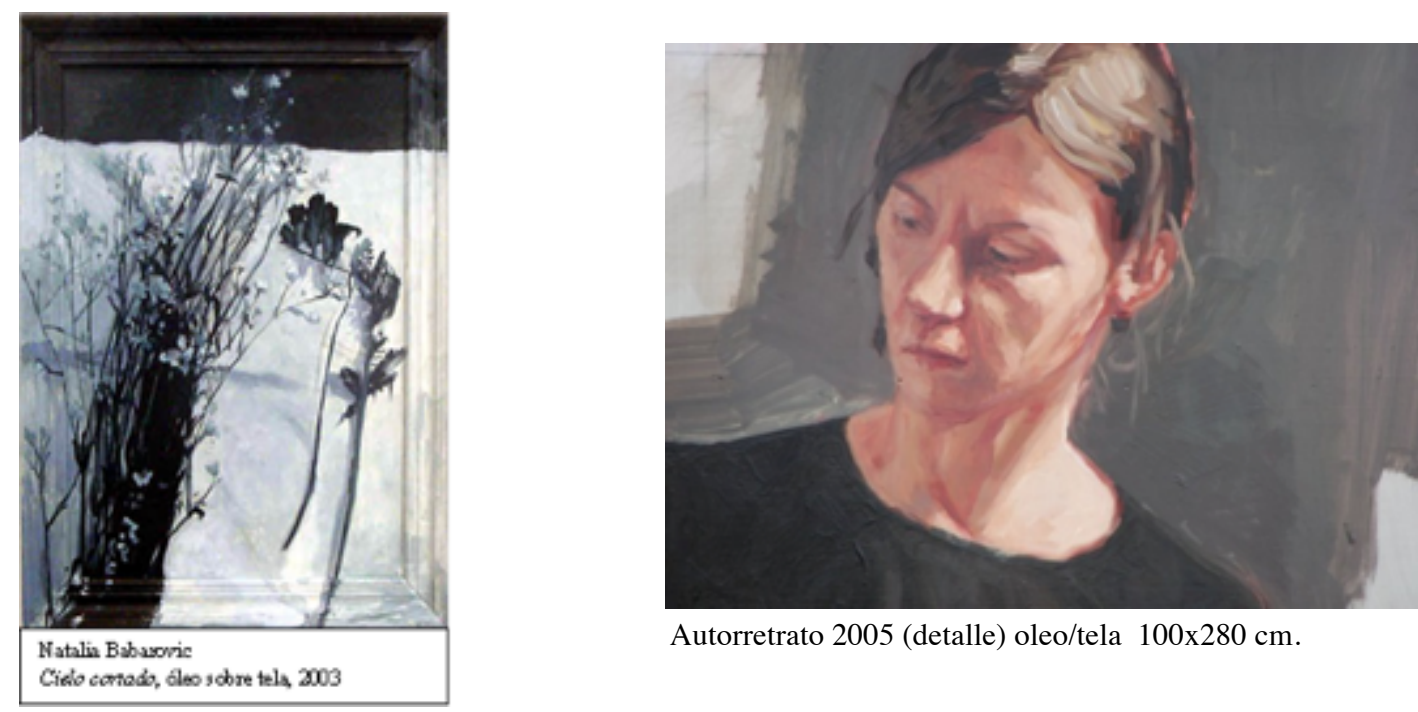

Autorretrato 2005 (detalle) oleo/tela $100 \times 280 \mathrm{~cm}$.

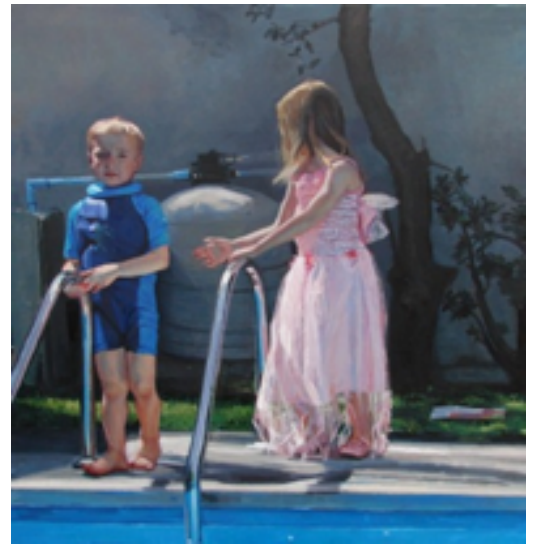

Modern Art I (2013) oleo/tela $200 \mathrm{~cm}$ x $241 \mathrm{~cm} \mathrm{I}$

http://www.nataliababarovic.cl/

www.artistasplasticoschilenos.cl/658/w3-article-40025.html

http://www.portaldearte.cl/autores/babarovic.htm

http://www.xsgaleria.cl/portfolio/natalia-babarovic/ 
N99 ficha

\section{Pablo Serra}

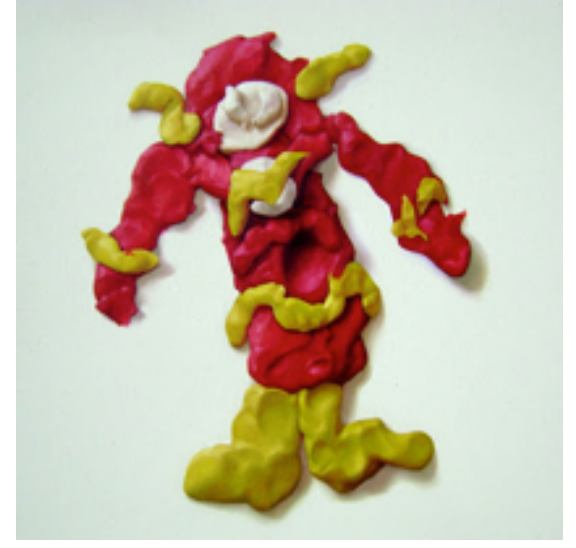

Flash 2010 trama offset con plastilina

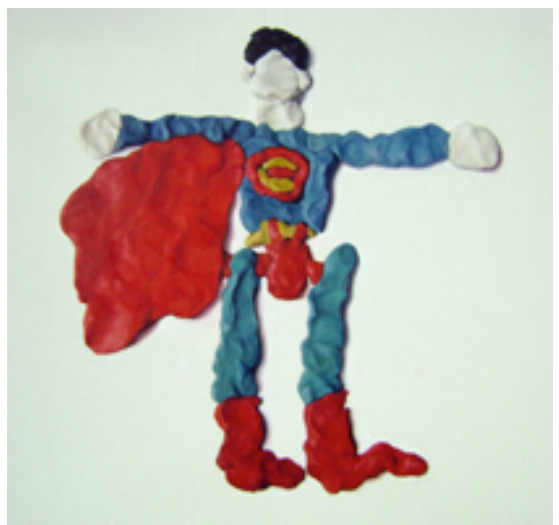

Supermán 2010 trama offset con plastilina

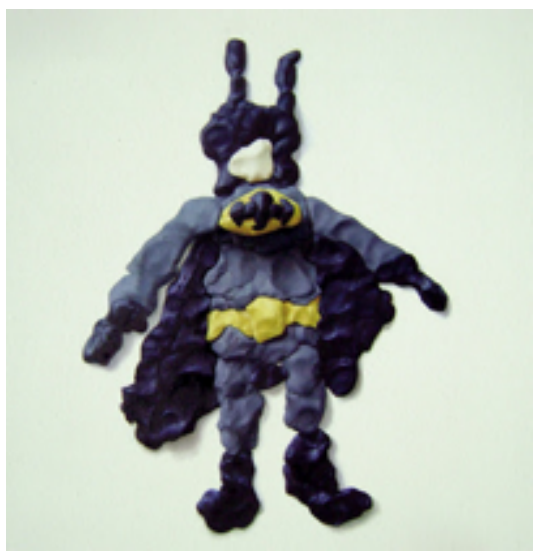

Batman 2010 trama offset con plastilina

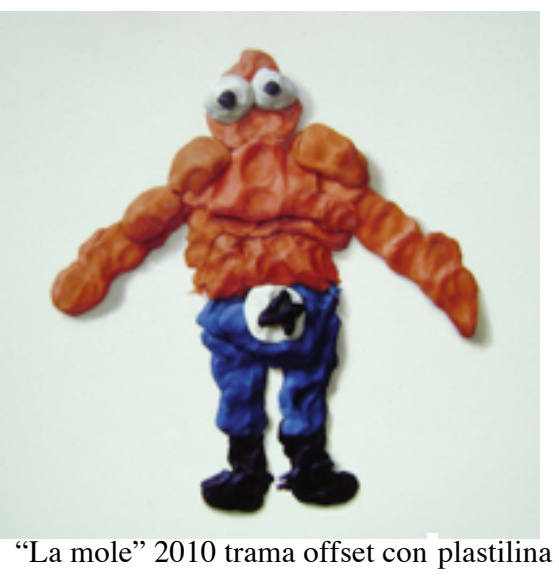

http://pablo-serra.artenlinea.com/

www.galeriapready.cl/\#!pablo-serra/c13z7

www.arte-sur.org/es/artistas/pablo-serra-marino-2/ 


\section{Patricia Ossa}

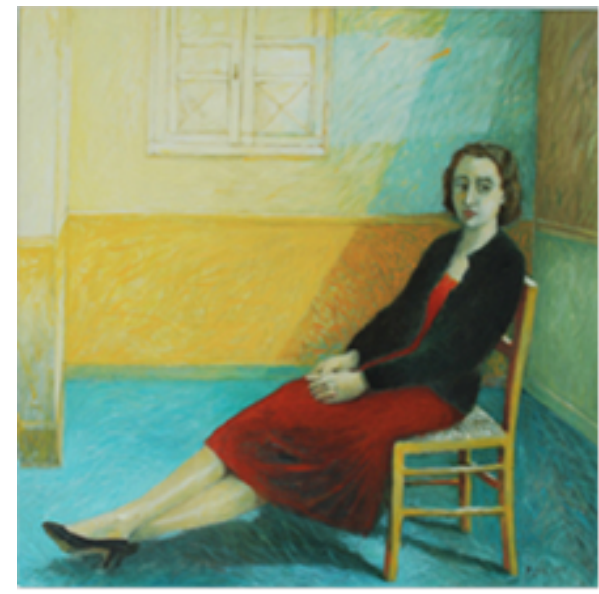

Sin Titulo Oleo sobre tela $90 \times 90 \mathrm{cms}$

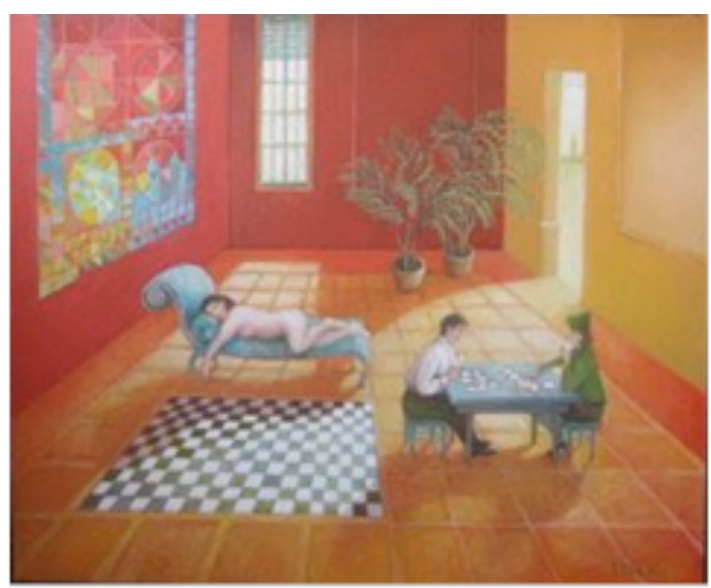

óleo $120 \times 902007$

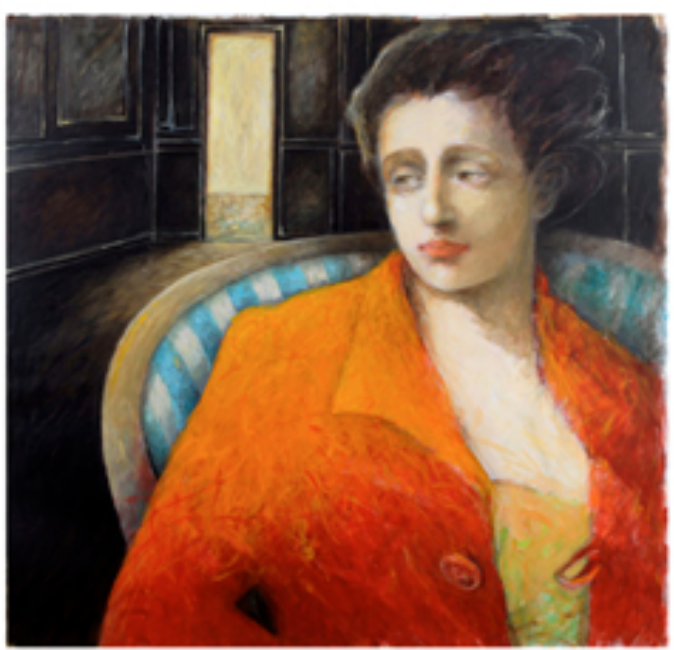

Oleo sobre tela $90 \times 90$ cms 2008

www.artistasplasticoschilenos.cl/658/w3-article-40351.html

http://www.galeriaceciliapalma.cl/obra-detalle.html/obra.id/174/patricia-ossa-sin-titulo 


\section{Roser Bru}

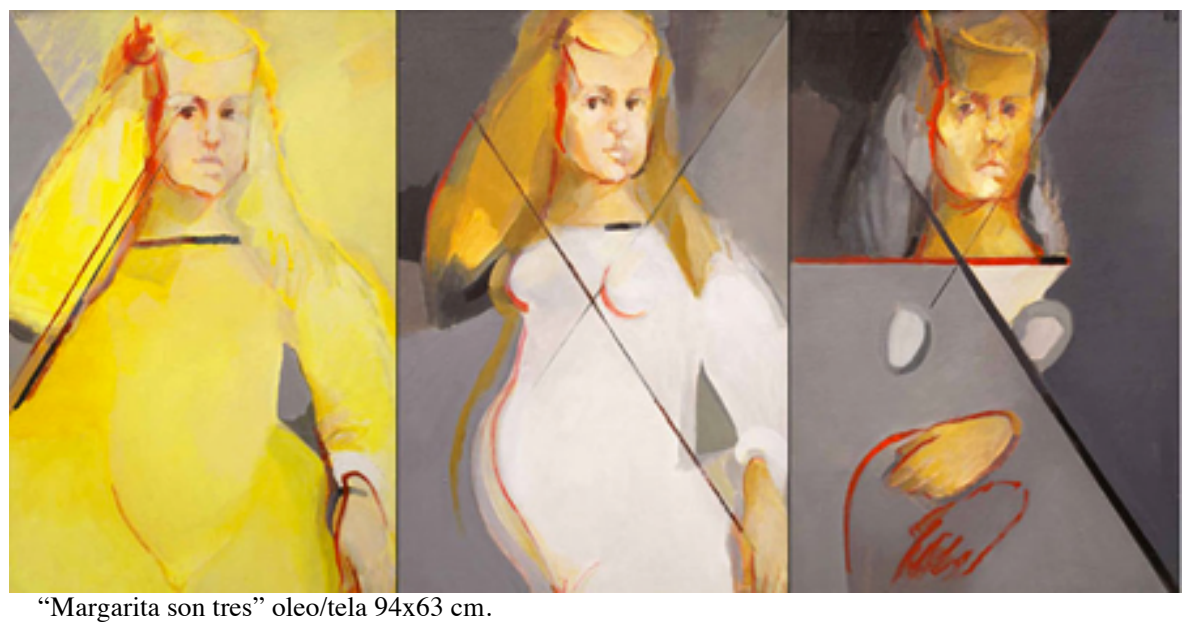

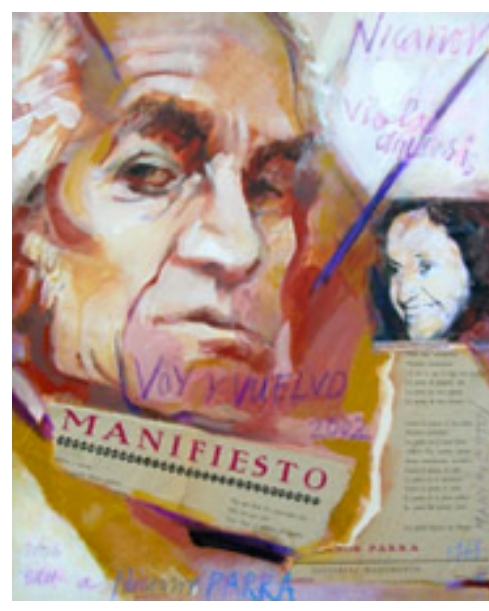

Fig.: 1 "Voy y vuelvo" Roser Bru 2002 mixta /tela 50x $60 \mathrm{~cm}$

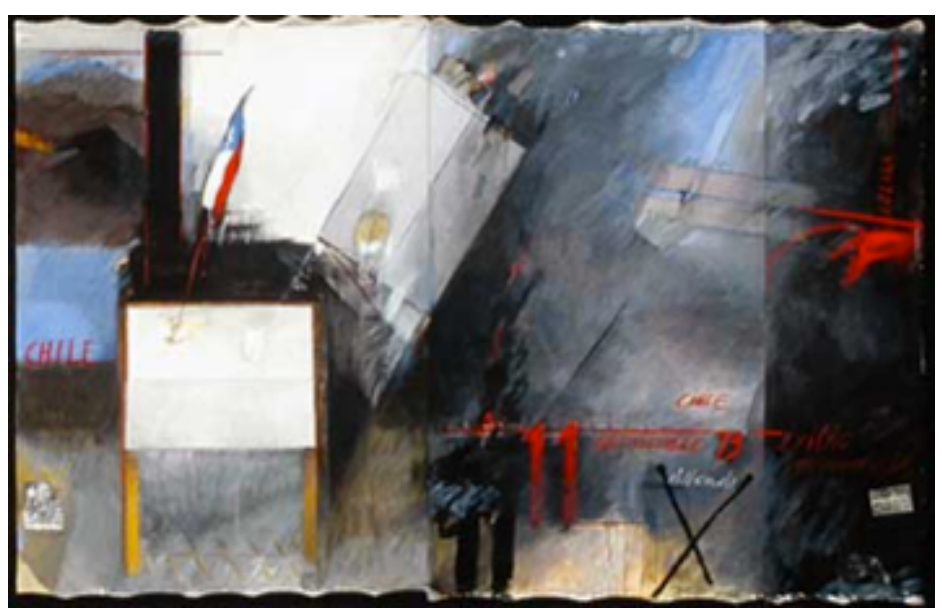

Fig,:25 "historia personal" (detalle) Roser Bru, 2003 acrilico/tela $1,60 \times 5 \mathrm{mt}$.

http://www.roserbru.com/main.htm

www.artistasplasticoschilenos.cl/658/w3-article-40136.html 
$N^{\circ} 102$ ficha

\section{Tatiana Lastarria}

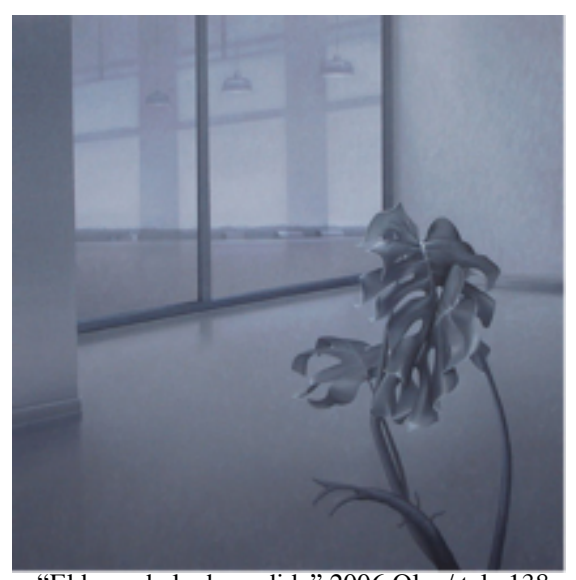

"El beso de la despedida" 2006 Oleo/ tela 138 x $138 \mathrm{~cm}$

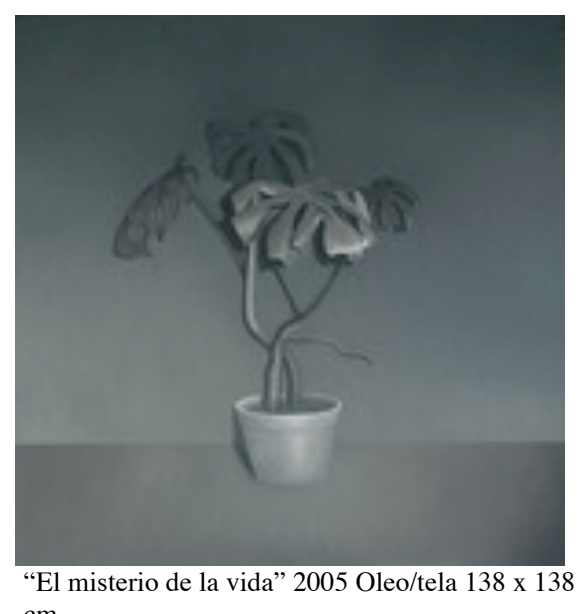

$\mathrm{cm}$.

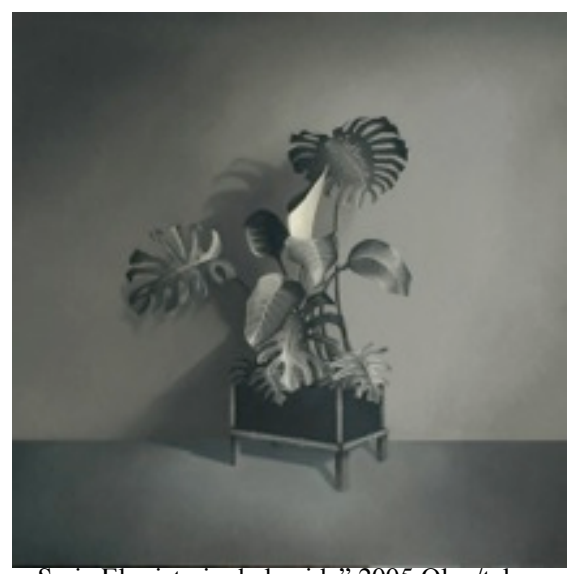

Serie El misterio de la vida" 2005 Oleo/tela $138 \times 138 \mathrm{~cm}$.

www.artistasplasticoschilenos.cl/658/w3-article-40066.html http://www.agendaconce.cl/2014/613/exposicion-cancion-de-amor-de-tatiana-lastarria-pinacoteca-udecconcepcion 
$N^{\circ} 103$ ficha

\section{Francisco Álvarez}

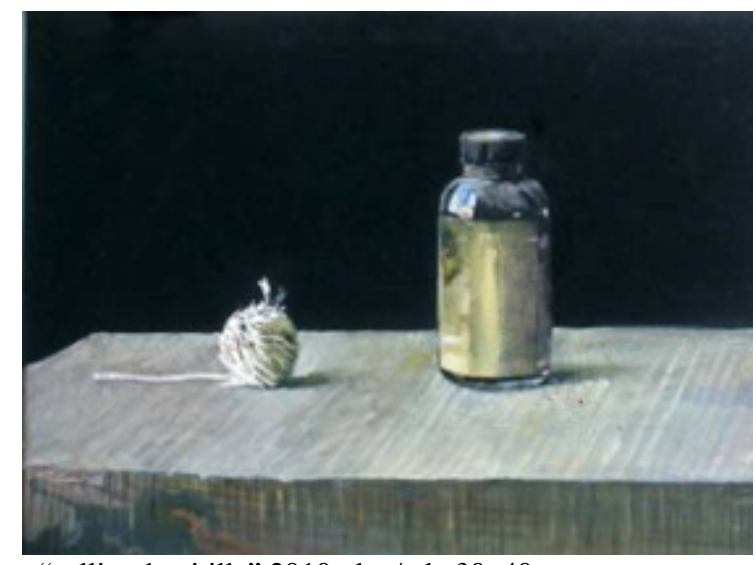

"rollito de pitilla" 2010 oleo/tela 30x40 cm

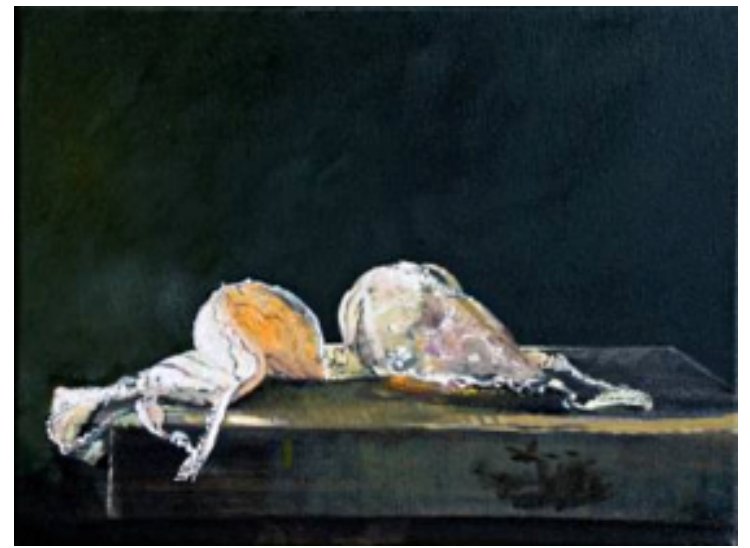

"recuerdo" 2008 oleo/tela 30x40 cm.

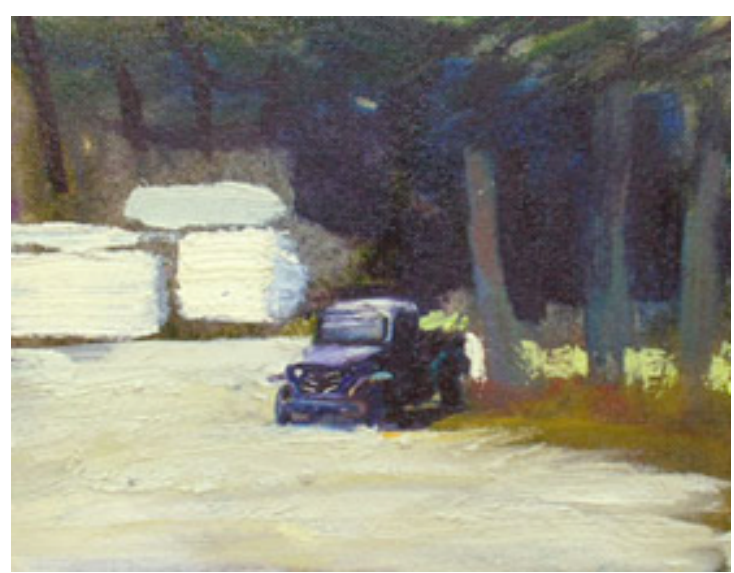

"Jeep" 2007 Óleo/tela 17 X 22 cm.

http://www.saatchiart.com/account/artworks/480620

www.artistasplasticoschilenos.cl/658/w3-article-39727.html www.portaldearte.cl/artistas_visuales/alvarez_francisco.html 


\section{Josefina Guilisasti}

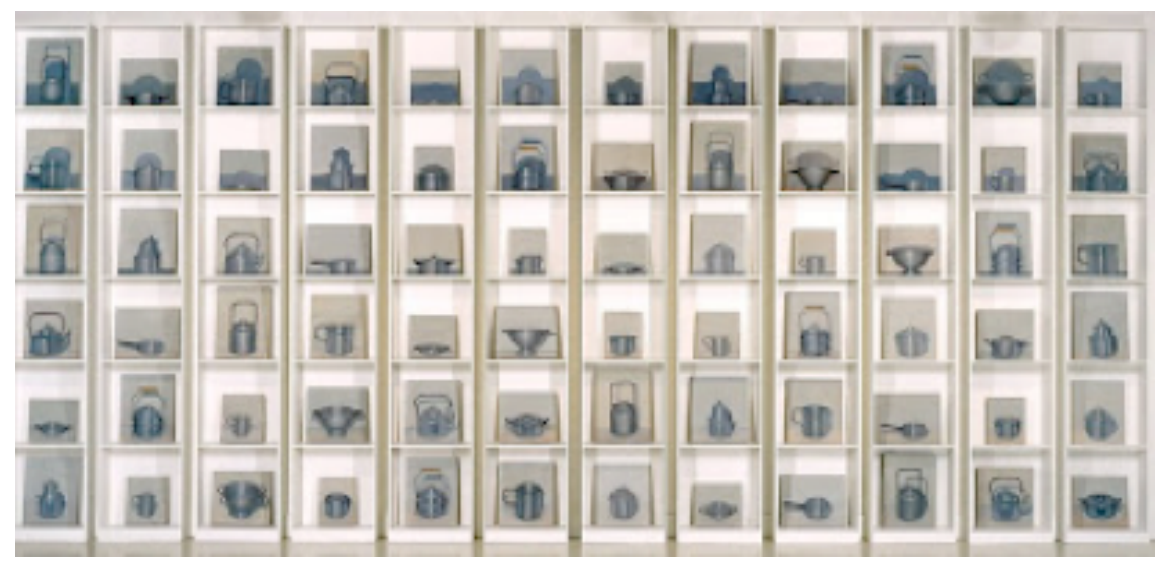

La Vigilia-(2001) 72 pinturas de objetos oleo/tela

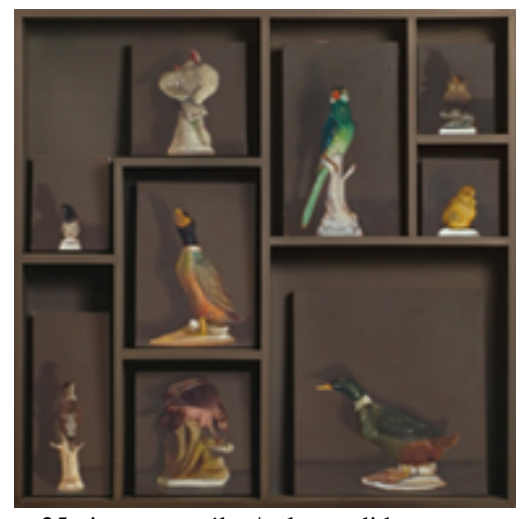

25 pinturas en óleo/ tela, medidas variables montadas en 16 módulos de madera. Medidas: 110x110 cms.

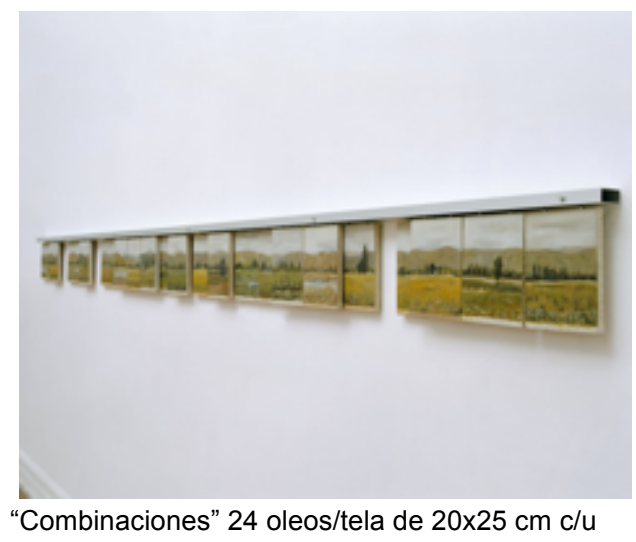
$484 \mathrm{~cm}$

www.josefinaguilisasti.cl/

http://rtjosefinaguillisasti.blogspot.com/

http://www.galeriaafa.com/?portfolio=obras-de-josefina-gilisasti 
$N^{\circ} 105$ ficha

\section{María Paz García}

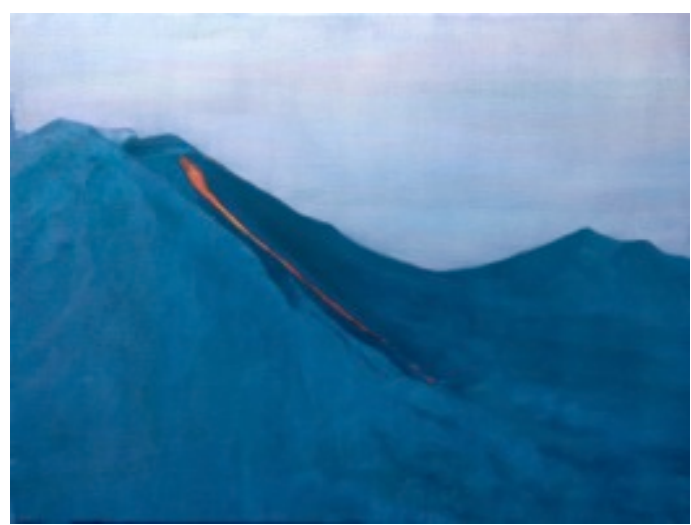

S/T, 2013 oleo/tela 150x190 cm.

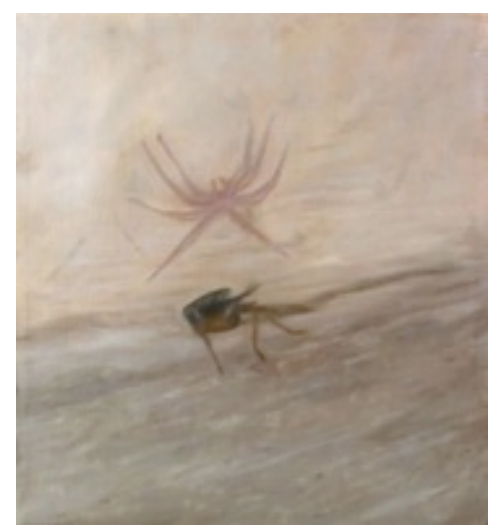

$\mathrm{S} / \mathrm{T}, 2012$ oleo/tela $37 \times 50 \mathrm{~cm}$

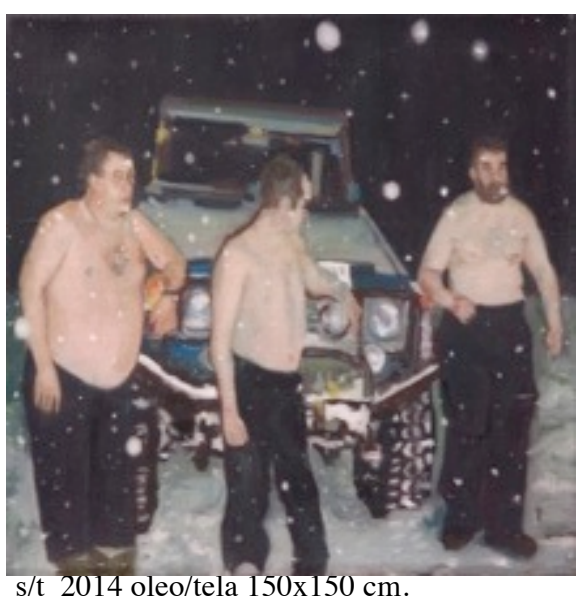

www.artistasplasticoschilenos.cl/658/w3-article-39742.html

www.portaldearte.cl/autores/garcia1.htm

http://mariapazgarcia.com/

http://3.bp.blogspot.com/_yOxrkh3g1Ds/StzyC01FQOI/AAAAAAAACQ8/MZR5qPZlkk0/s1600-h/31.jpg 
$N^{\circ} 106$ ficha

\section{Patrick Hamilton}

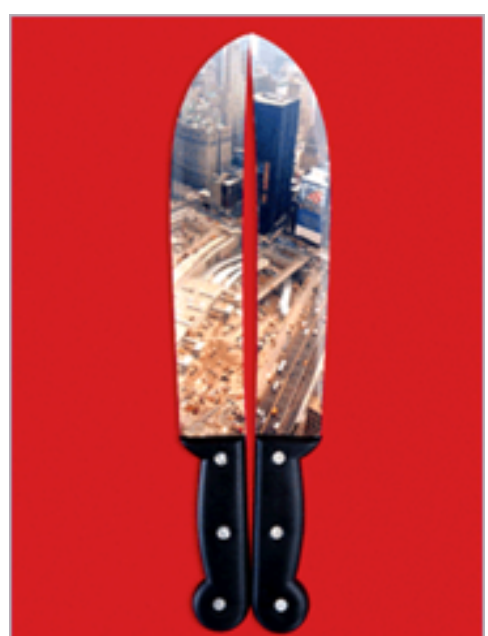

Machetes 3, 2004 mixta/madera

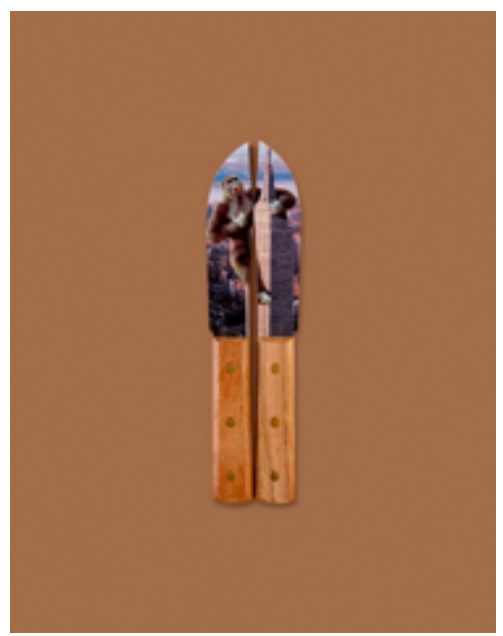

King Kong, 2004 mixta madera

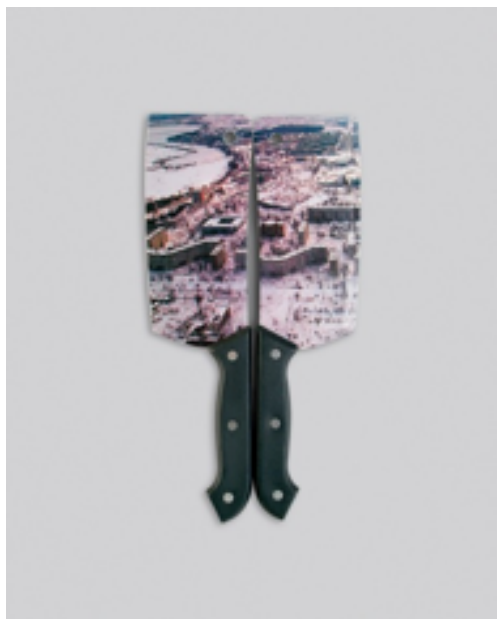

Machetes 5, 2004 mixta madera

www.artistasplasticoschilenos.cl/658/w3-article-39592.html http://www .artishock.cl/2015/03/progreso-la-primera-individual-de-patrick-hamilton-en-espana/ http://www.mac.uchile.cl/exposiciones/otrositio/expoemergentes2.html 
$N^{\circ} 107$ ficha

\section{Rosario Carmona}
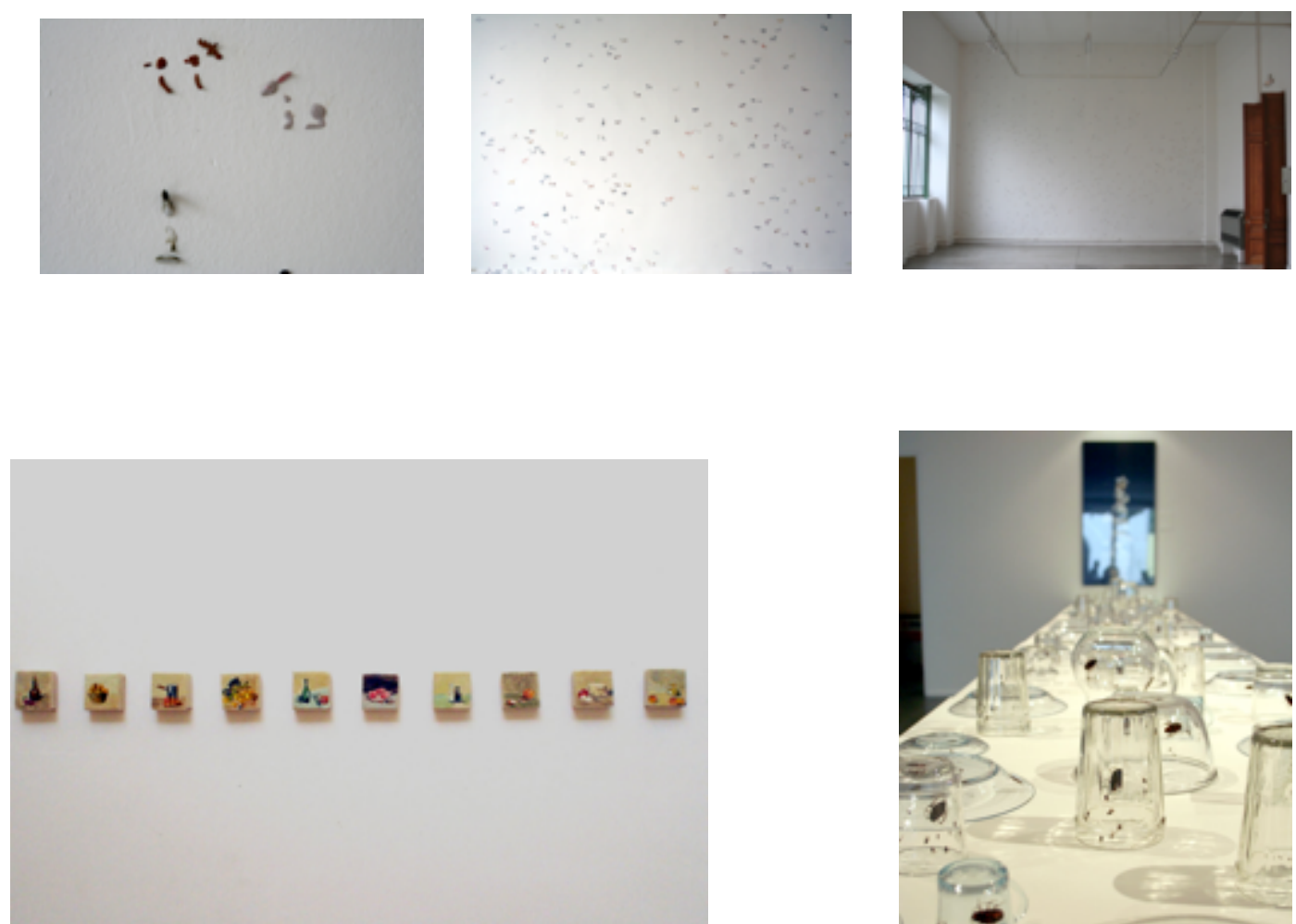

Habito de una disciplina estéril 2008 (detalle) 800 pinturas oleo/tela de $2 \times 2 \mathrm{~cm}$

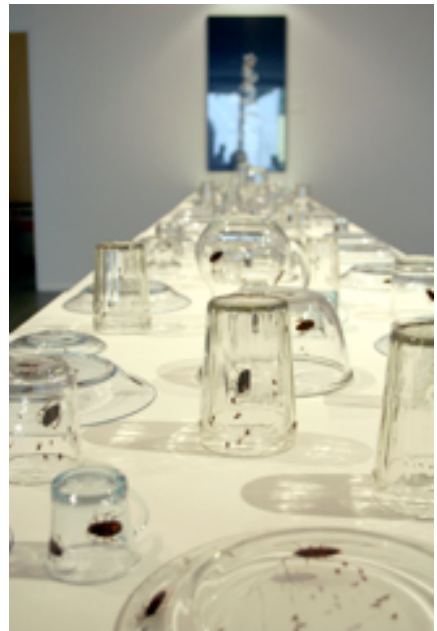

"Es mejor que me vaya" 2009 oleo sobre objetos de vidrio

https://rosariocarmona.wordpress.com

http://rosario-carmona-yost.artenlinea.com/

www.artishock.cl/tag/rosario-carmona/

www.artdiscover.com/es/artistas/rosario-carmona-id2775 
$N^{\circ} 108$ ficha

\section{Ximena Cristi}

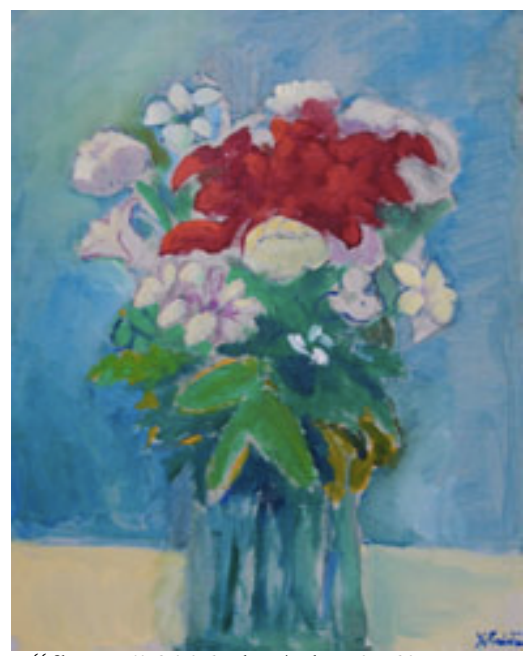

“florero" 2006 oleo/tela 50x60cm

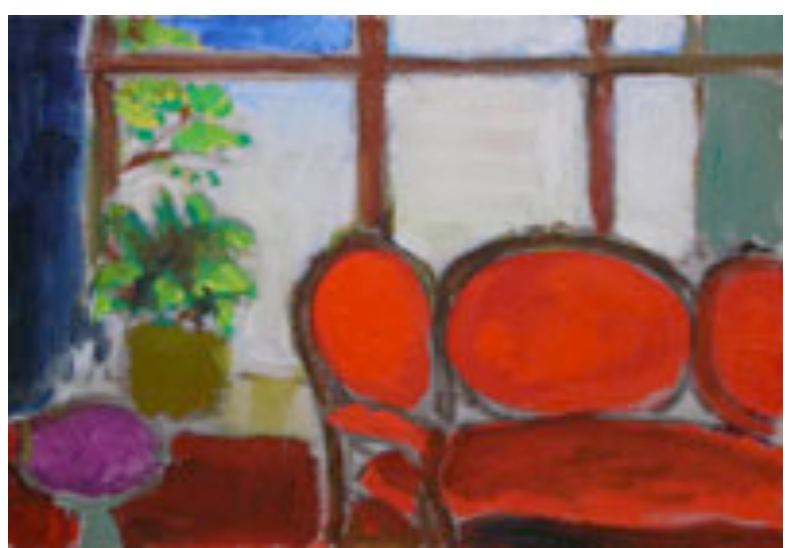

“Sillón rojo", 2006 oleo/tela 70x50 cm

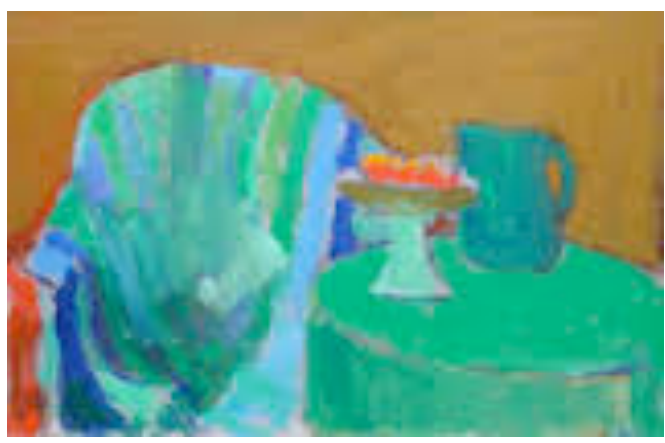

"Interior" $2006 \mathrm{oleo} /$ tela $55 \times 70 \mathrm{~cm}$

www.artistasplasticoschilenos.cl/658/w3-article-40220.html

www.portaldearte.cl/entrevistas/cristi.htm

http://www.premioaltazor.cl/ximena-cristi-2/ 


\section{María Victoria Polanco}

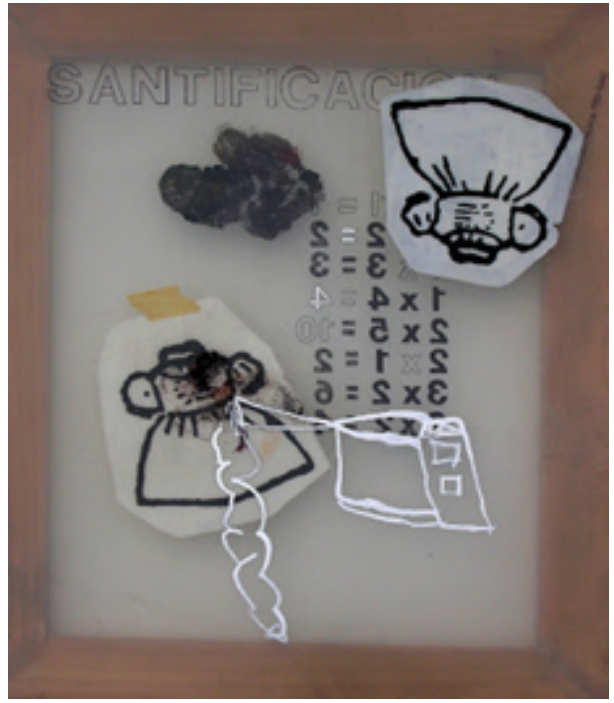

"Santificación" 2005 mixta/plástico collage $35 \times 25 \mathrm{~cm}$

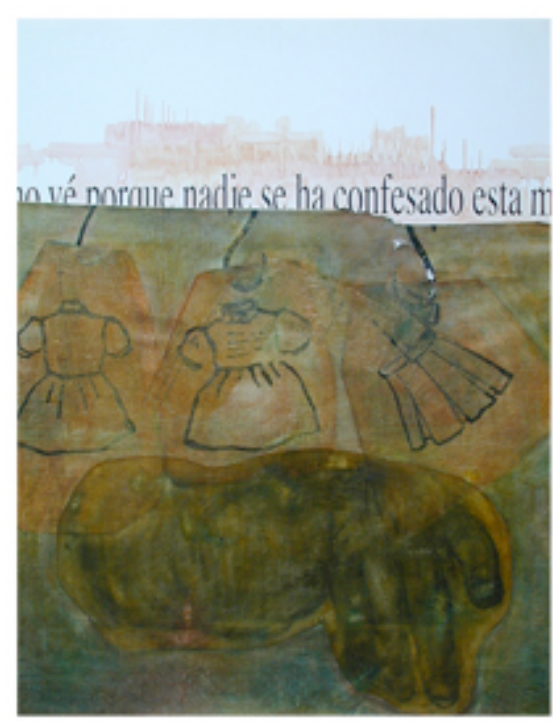

"Dios no ve porque nadie se ha confesado" 2005 Óleo/tela y PVC - 110 x $90 \mathrm{cms}$.

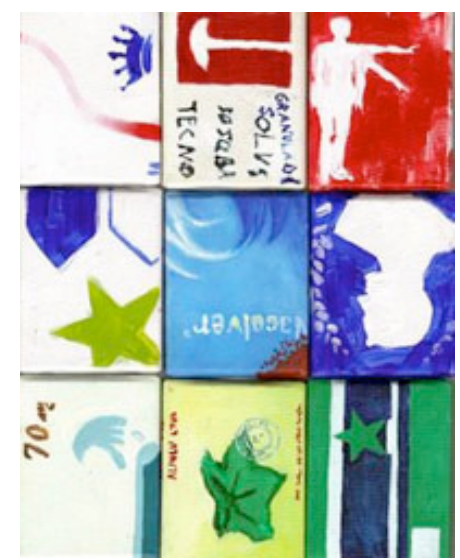

"La salud de chile" 2008 serie oleo/tela formatos variables

www.artistasplasticoschilenos.cl/658/w3-article-39813.html www.galeriabucci.cl/ficha.asp-id_art=16.htm www.portaldearte.cl/agenda/pintura/2008/maria_victoria.html 
$N^{\circ} 110$ ficha

\section{Rodrigo Canala}

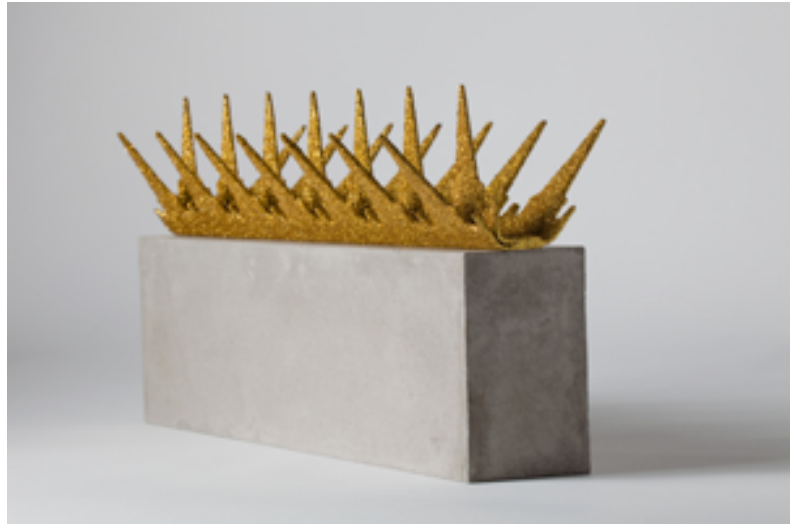

"Corona" 2006 defensa recubierta con escarcha metalica, tornillos, concreto. 20x44x $13 \mathrm{~cm}$.

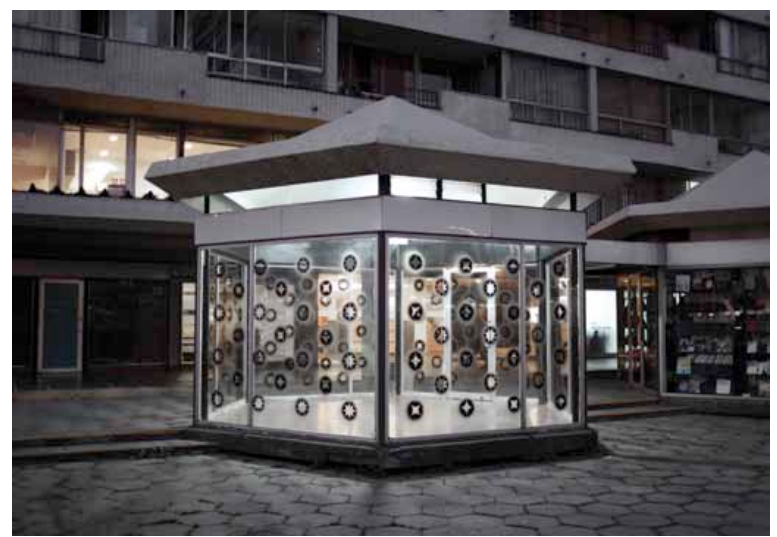

"Diamante hueco" 2011 Pintura spray negra sobre vidrio (exterior) Dimensiones variables

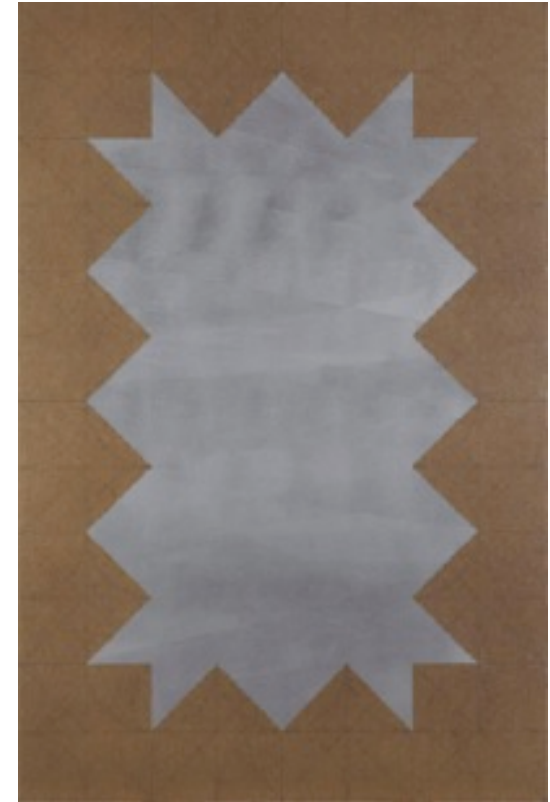

Escudo, espejo, estandarte \#2 (serie), 2012-2011, Esmalte sintético, tinta rotulador / madera prensada, $156 \times 106 \mathrm{~cm}$

www .canala.cl/

www .artistasplasticoschilenos.cl/biografia.aspx $?$ itmid $=838$

www.galeriapready.cl/\#!rodrigo-canala/ctsp

http://tallerbloc.cl/tutores/rodrigo-canala/ 


\section{Virginia Álvarez}

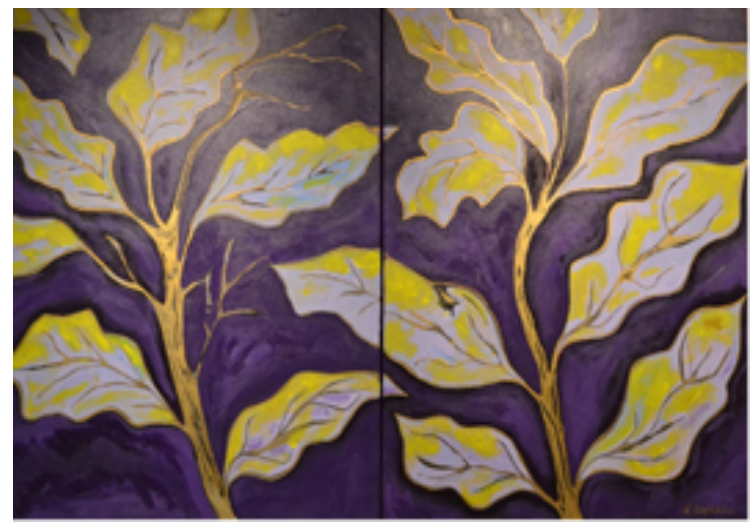

"Fotosíntesis" 2014 acrilico/tela

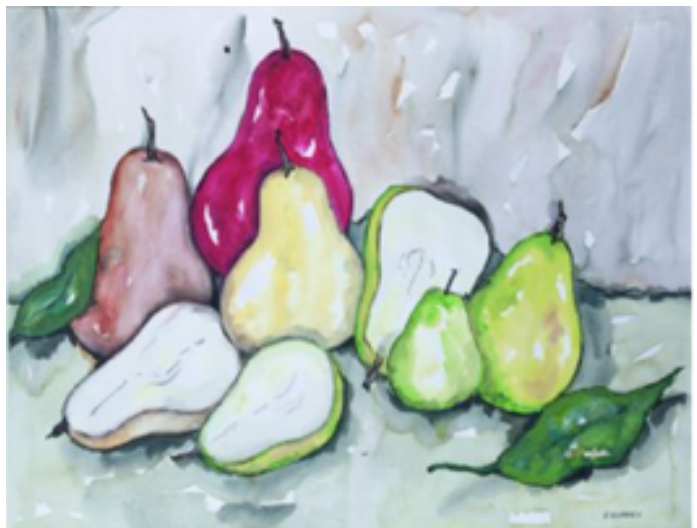

“Peras" 2004 Acuarela, 70 x 90 cm.

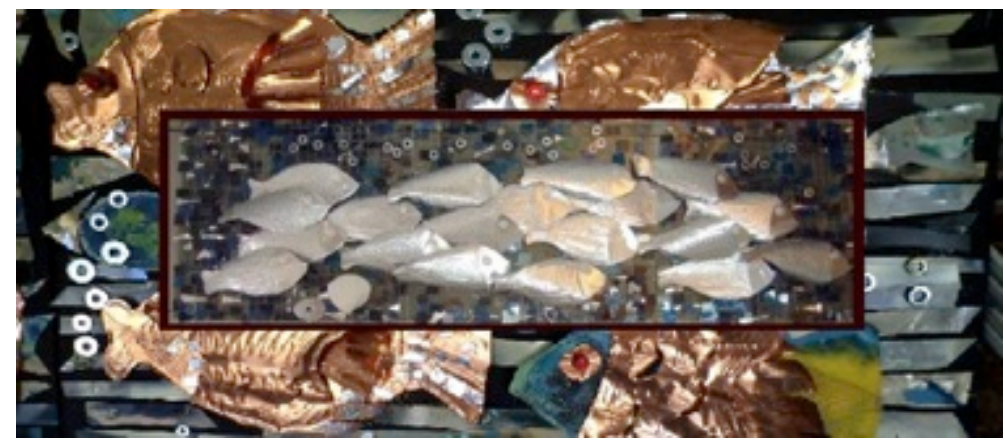

"Peces" 2014 mixta, collage/tela 50x100 cm.

http://virginiaalvarezebner.com/

http://www.ccuenelarte.cl/coleccion/pintura/peras-2004/ 


\section{$N^{\circ} 112$ ficha}

\section{Mónica Bengoa}
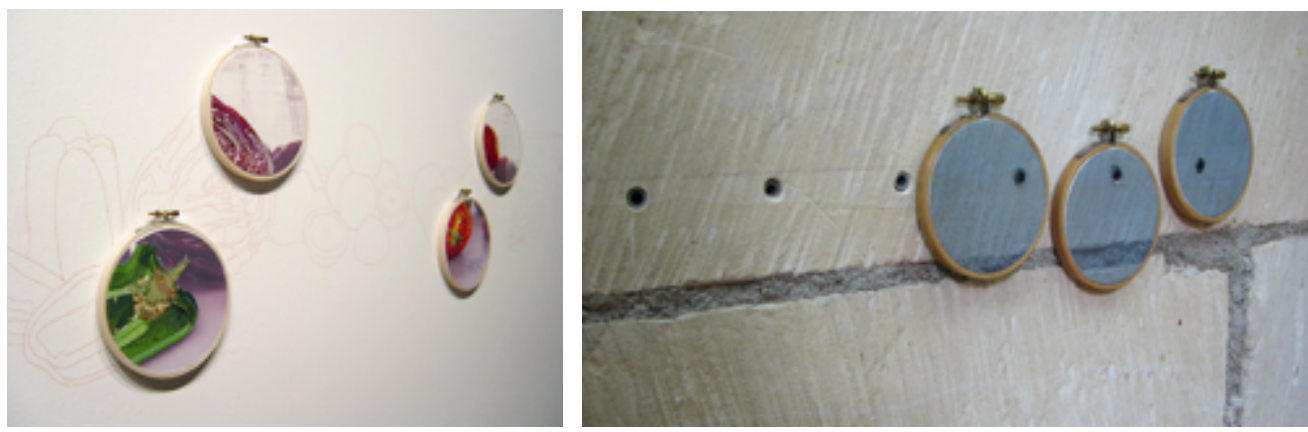

2005 Dibujo al muro y bordado a mano sobre transfer fotográfico en tela de algodón $13,7 \mathrm{~cm}$. c/u Maleta de madera de 61 x 42 x $15 \mathrm{~cm}$. Medidas totales 463 x $84 \mathrm{~cm}$.

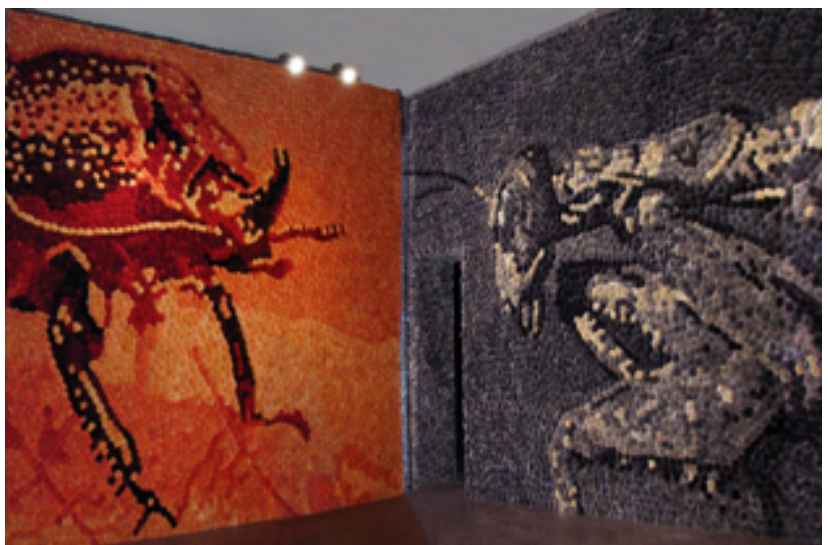

"some aspects of color in general and red and black in particular" 2007 Instalación de cuatro murales de 28.000 flores naturales de cardos teñidos $4,5 \times 6,5 \times 6 \mathrm{~m}$

http://monicabengoa.cl/

http://www.premioaltazor.cl/monica-bengoa/

http://www.portaldearte.cl/autores/bengoa.htm

http://60watts.cl/2014/06/artes-visuales-monica-bengoa-2/ 


\section{$N^{\circ} 113$ ficha}

\section{Paul Fuguet}
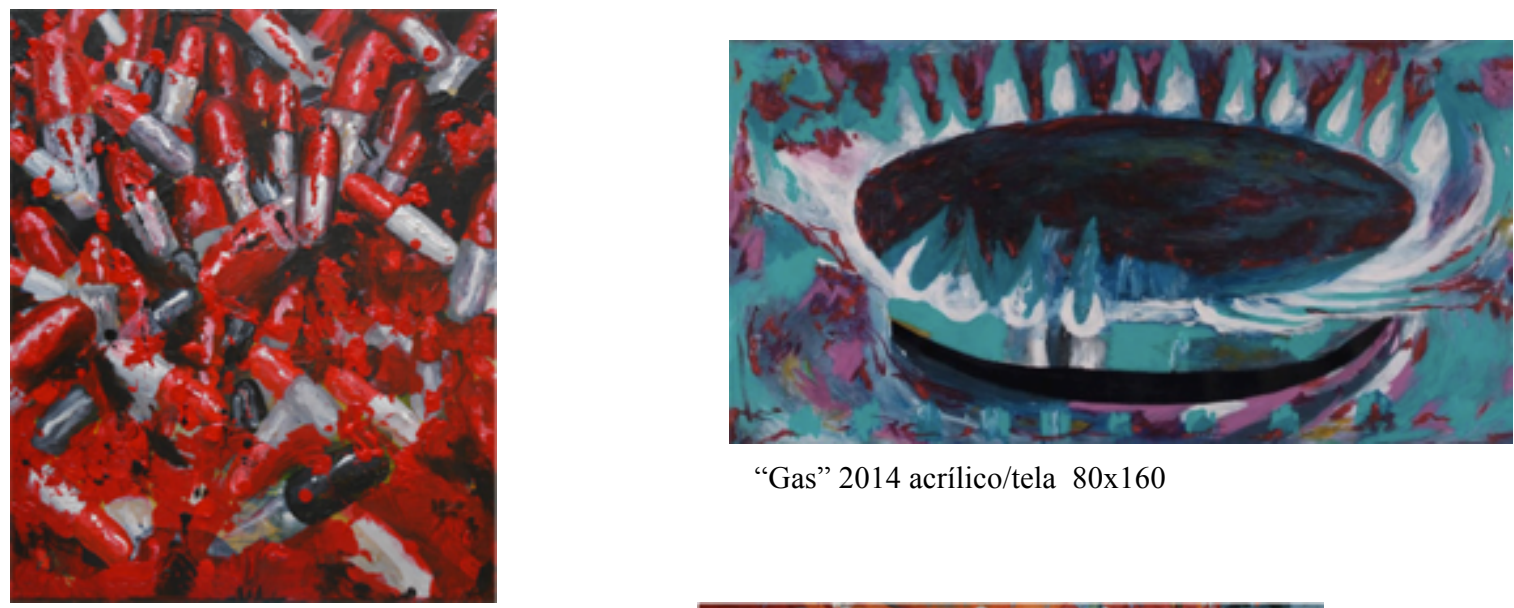

“Gas" 2014 acrílico/tela 80x160

“Briggid” 2007, Acrílico/ tela120cm*105cm

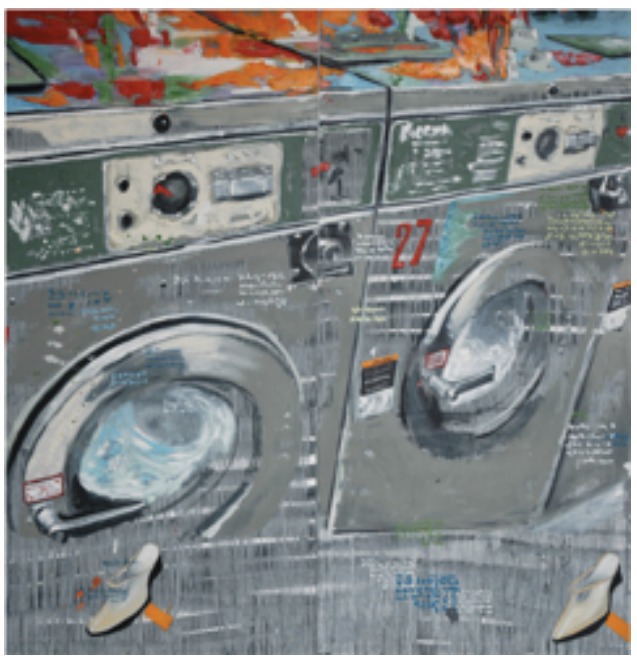

“Laundry Poet" 2005 Oleo / tela 170x210cm

http://paulfuguet.com/

http://www.cultura.gob.cl/agenda-cultural/paul-fuguet-se-presenta-en-lima-con-\%E2\%80\%9Ccandyloop\%E2\%80\%9D/ 
$N^{\circ} 114$ ficha

\section{Francisco Schwemberg}

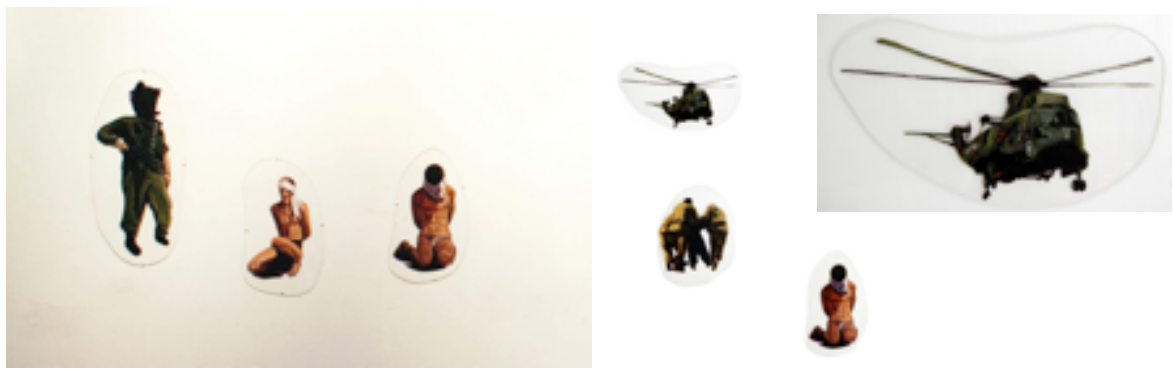

El Origen. 2010 Óleo sobre

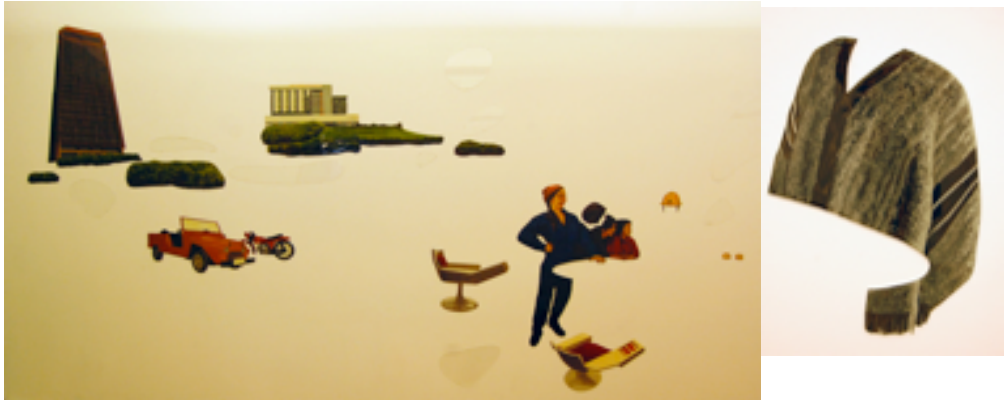

Fragmentos para una vía chilena al realismo
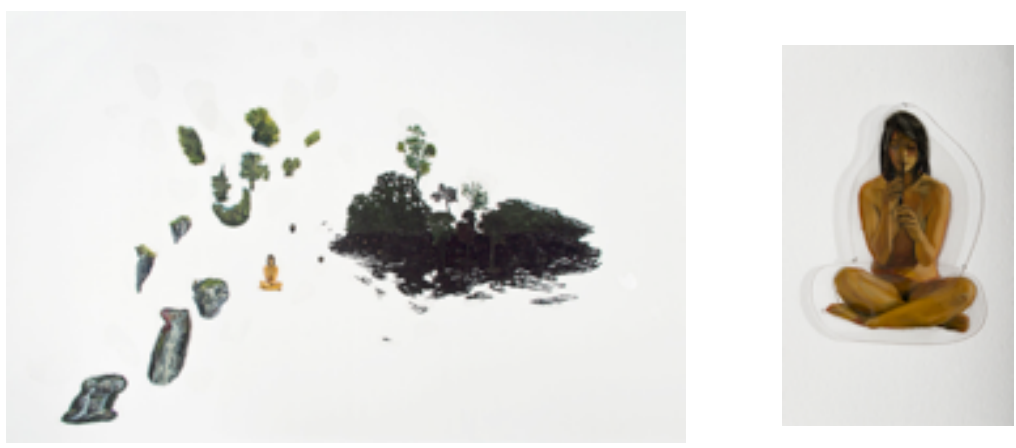

Trapananda, 2012 - 2015. Óleo, pigmento y

http://franciscoschwember.cl/presentacion/

http://artes.uc.cl/index.php/noticias-artes-uc/1107-arte-muestra-dialogos-del-reconocimiento-en-mac-de-valdivia.html 
$N^{\circ} 115$ ficha

\section{Julia San Martin}
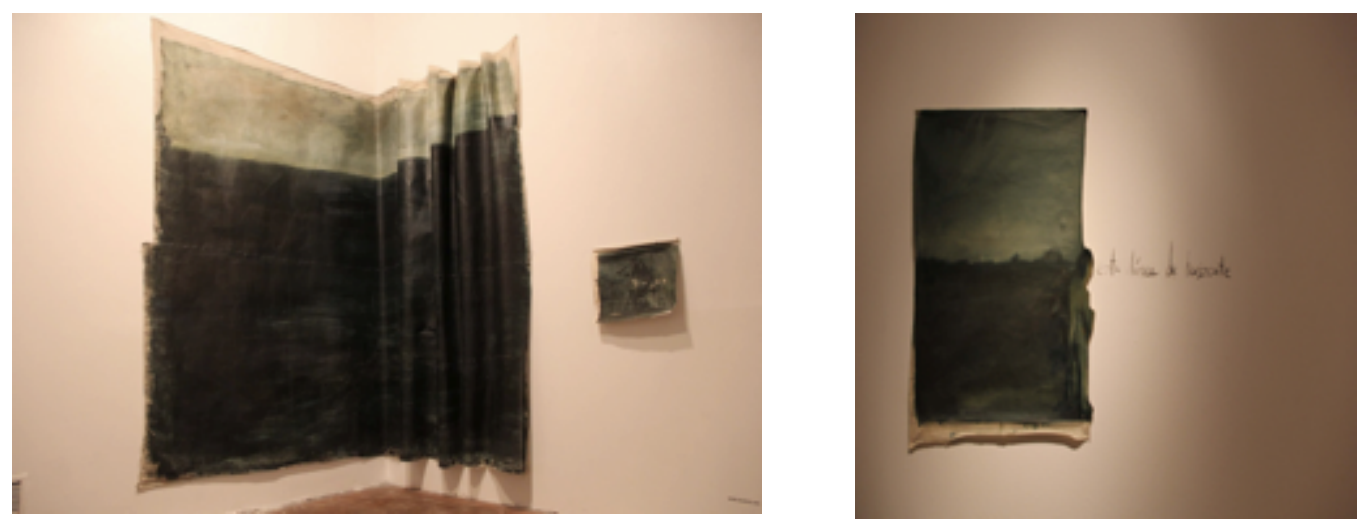

"Exposición 59" 2012 serie pintura, tinta /papel dimensiones variables

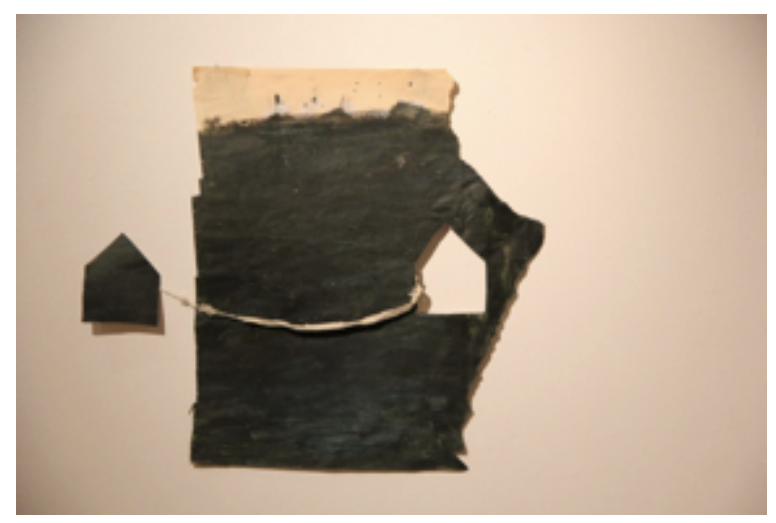

www .artistasplasticoschilenos.cl/658/w3-article-40214.html

www .artishock.cl/2013/12/julia-san-martin-desde-el-otro-lado/

http://www .galeriaafa.com/?portfolio=exposicion-59 


\section{María Luisa Stewart}

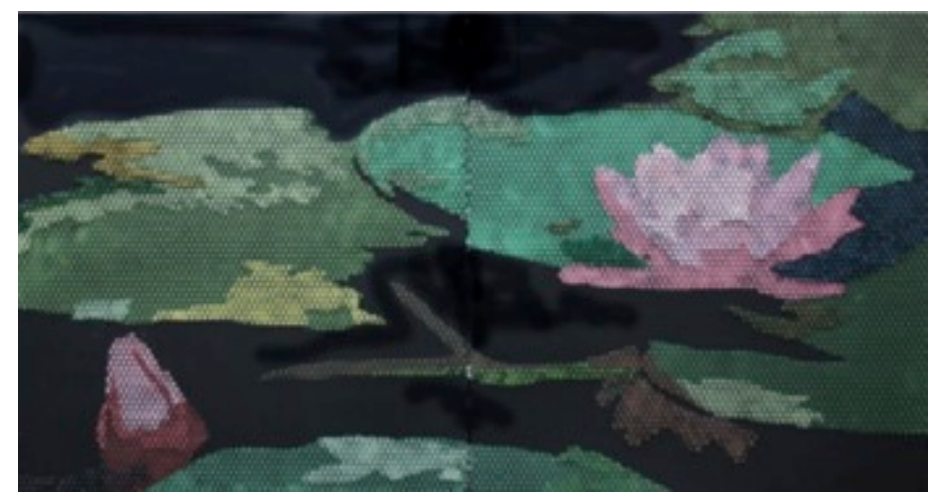

“Lotus Flower" 2010 pasta acrílico/tela 200x100 cm.

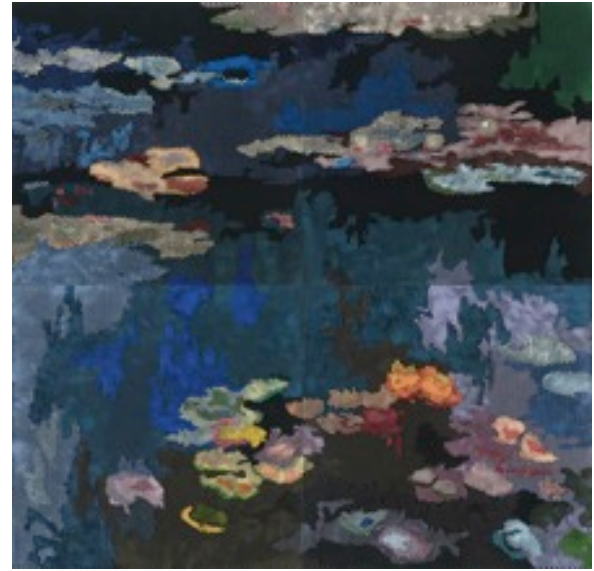

"Black Pond" 2009 acrílico, pasta/tela 196x204 cm.

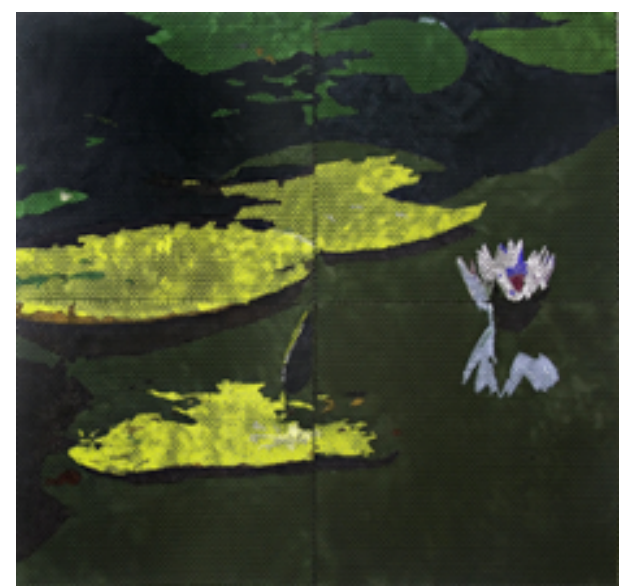

"PONDS" 2007 pasta, acrílico/madera 100x100

http://www .arte-sur.org/es/artistas/malu-stewart-2/

www.artistasplasticoschilenos.cl/658/w3-article-39891.html

www.malustewart.cl/

www.arte-sur.org/es/artistas/malu-stewart-2/ 


\section{$N^{\circ} 117$ ficha}

\section{Fernando Prats}

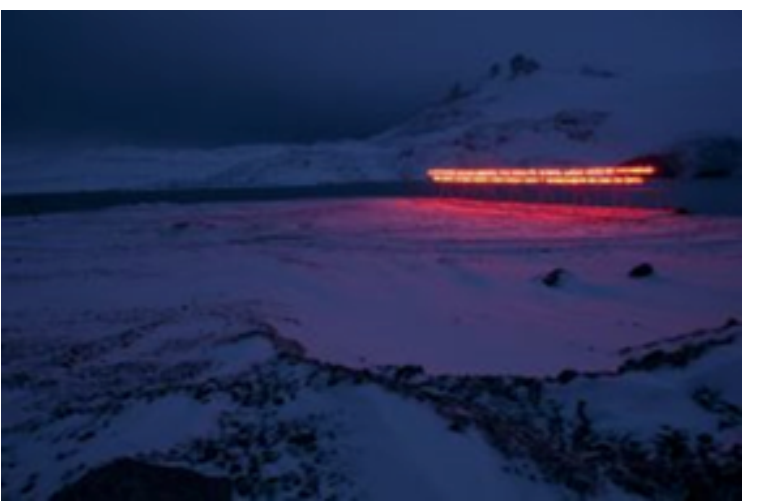

Del Cardener a la Antártida, 2001-2002. Instalación en la antartida

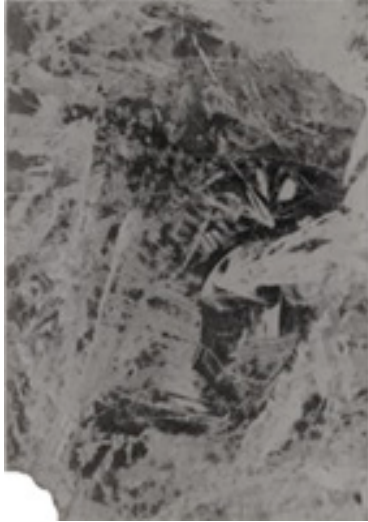

"Salar de Atacama" 2006, Humo y costra de sal sobre papel, video, $4 \mathrm{~min}$. $45 \mathrm{~s}$.

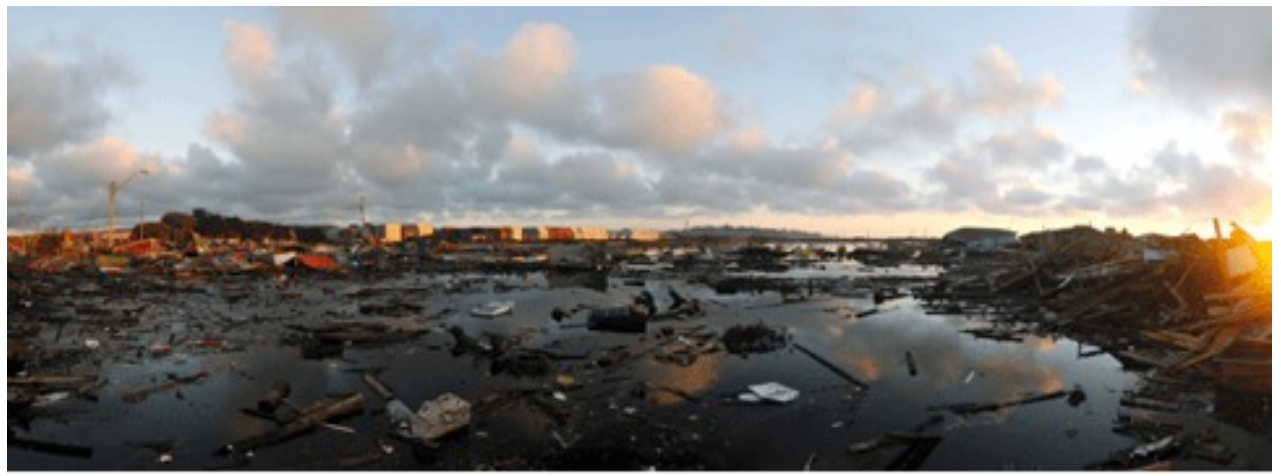

Llolleo, 2011. Vídeo HD, blu-ray, 2 min 15 s.

http://rtfernandoprats.blogspot.com/

http://www.fernandoprats.cl/

http://www.galeriapready.cl/\#!fernando-prats/c1nop 
$\mathrm{N}^{\circ} 118$ ficha

\section{Rodrigo Zamora}

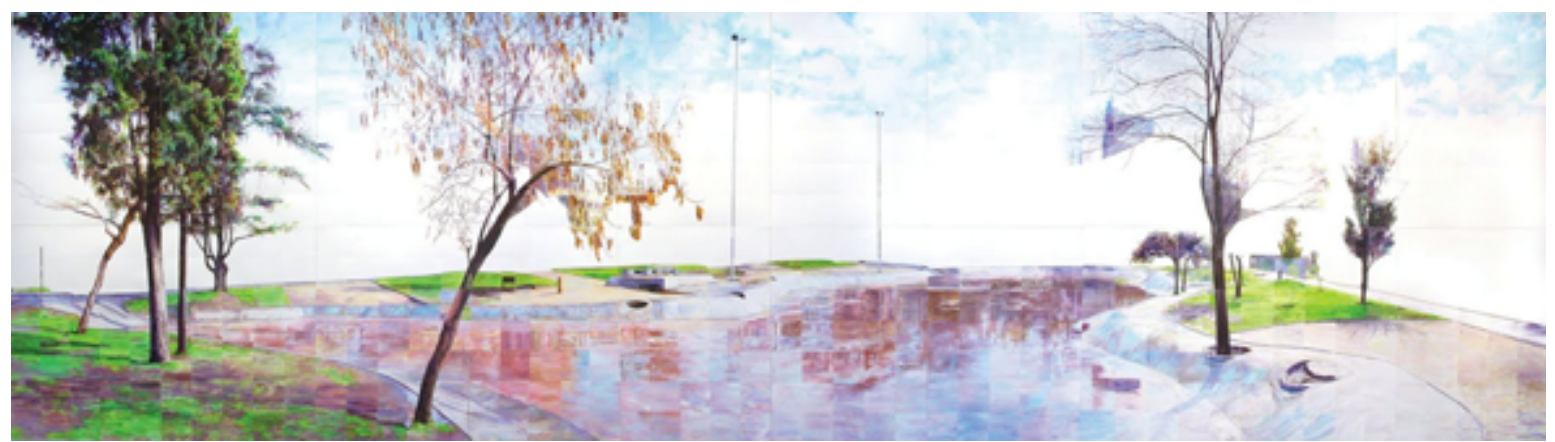

Serie Ventana (2004-2005). acuarela / papel

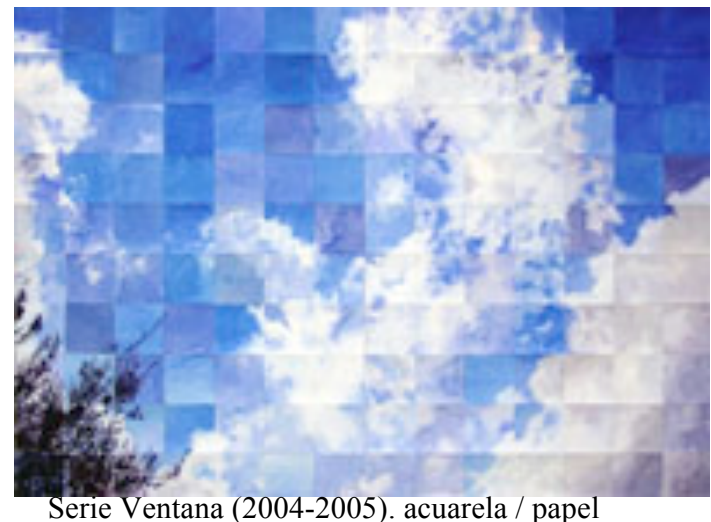

Serie Ventana (2004-2005). acuarela / papel

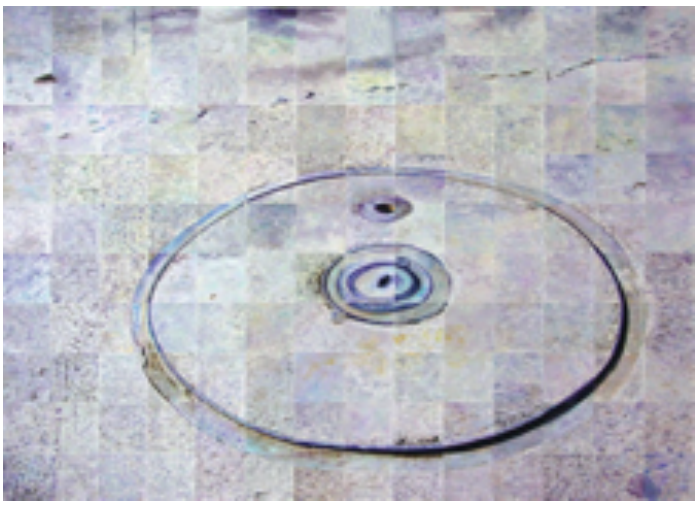

Serie Objeto Público (2004-2005). Acrílico/ papel

http://www.galeriapready.cl/\#!rodrigo-zamora/c1u21

http://rtrodrigozamora.blogspot.com/

http://www .arteallimite.com/galeria/artistas/rodrigo-zamora-764 


\section{Cristian Silva}

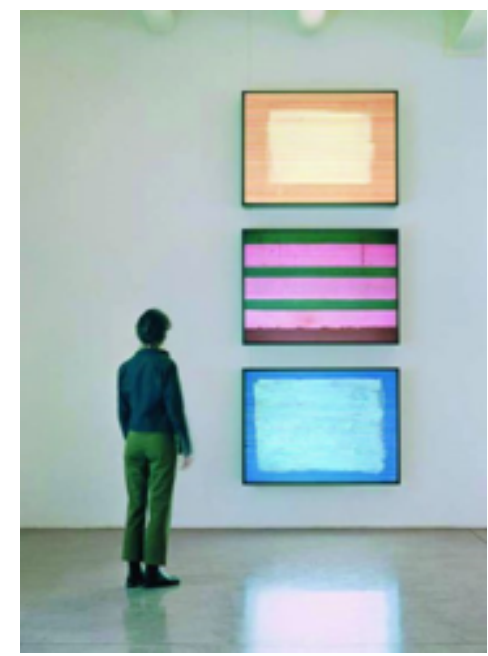

El color local 2002 ampliaciones fotográficas Duratrans y cajas de luz

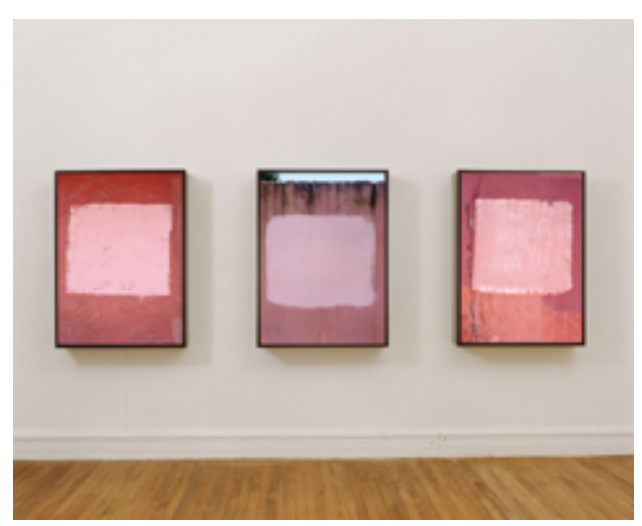

The Chilean abstrac painting" 2002 duratrans y cajas de luz $94 \times 128 \mathrm{~cm}$ c/caja.
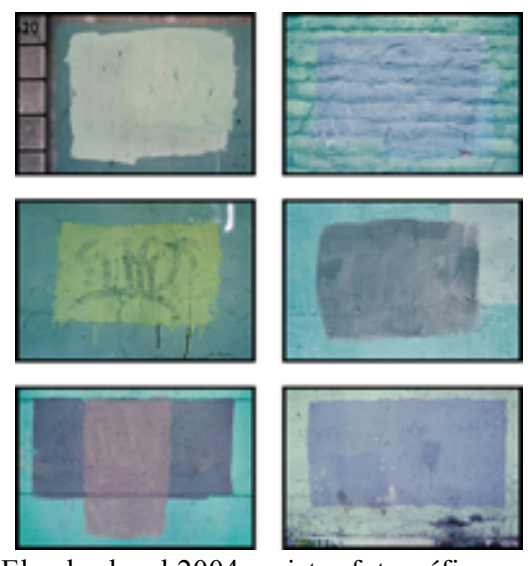

El color local 2004 registro fotográfico

www.artistasplasticoschilenos.cl/658/w3-article-39704.html http://rtcristiansilva-avaria.blogspot.com/

http://www .artishock.cl/2014/05/cristian-silva-avaria-mind-the-gap/ 


\section{José Caerols (Yisa)}

Intervenciones en muro pintura industrial 2009 dimensiones variables
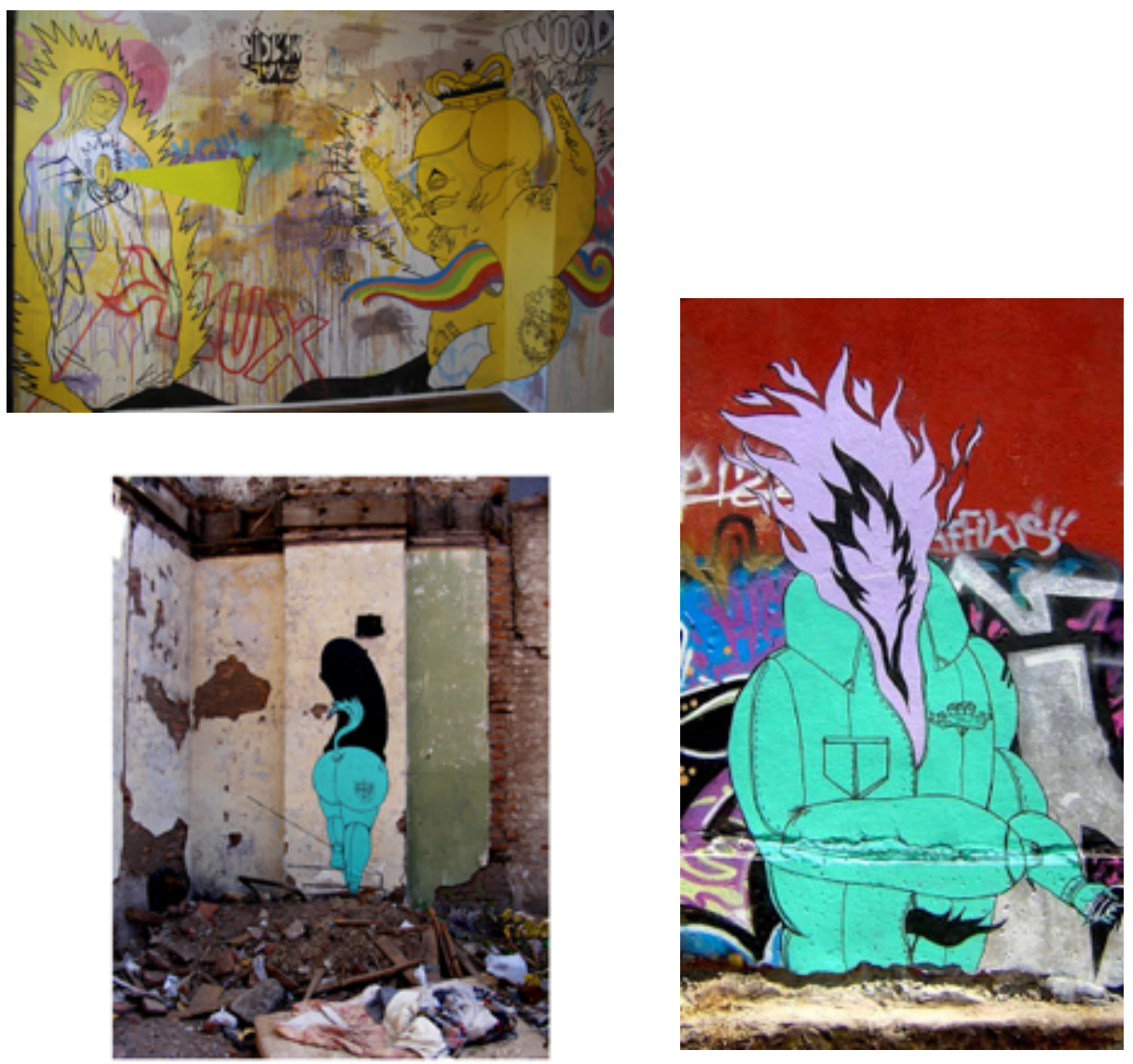

http://rtjoseyisa.blogspot.com/

http://yizas.blogspot.com/

http://www.artishock.cl/2011/06/yisa/ 
$N^{\circ} 121$ ficha

\section{Sebastián Leyton}

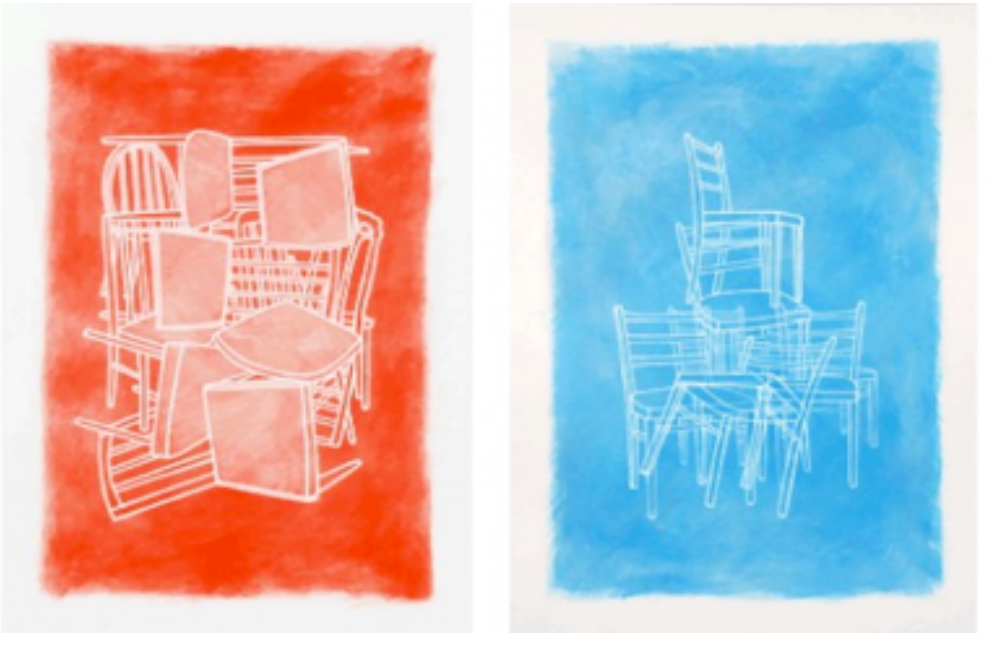

“Barricadas” 2013 acrílico/ papel

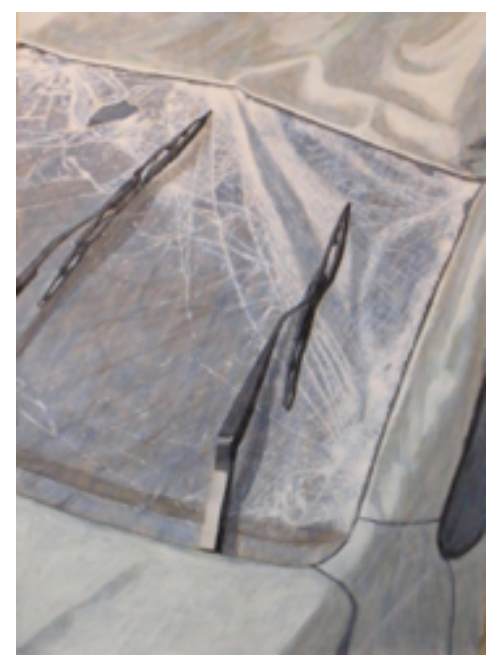

http://rtsebastianleyton.blogspot.com/

http://www.sebastianleyton.cl/

www.artistasplasticoschilenos.cl/658/w3-article-40457.html

http://www.arslatino.com/es/actualidad/461-exposicion-de-sebastian-leyton-se-inaugura-en-el-centro-deextension-uc 


\section{Álvaro Oyarzun}

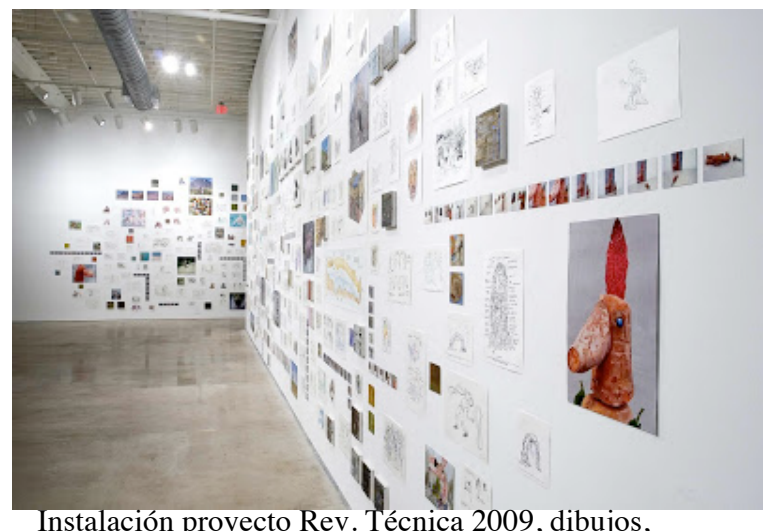

Instalación proyecto Rev. Técnica 2009, dibujos, pinturas, fotos, recortes. Dimensiones variables.

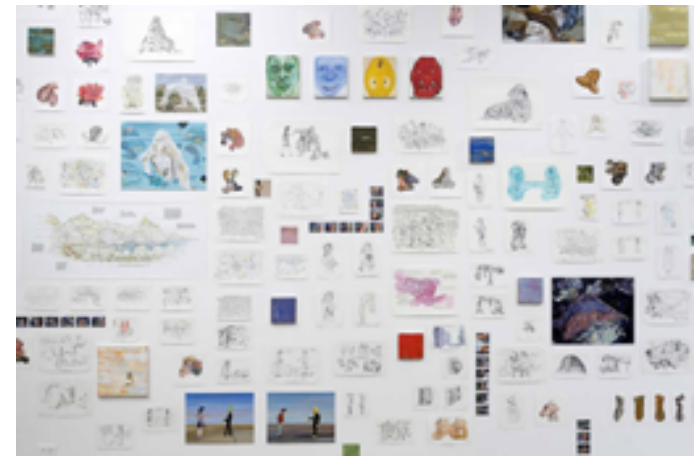

Detalle Instalación proyecto Rev. Técnica 2009, dibujos, pinturas, fotos, recortes.

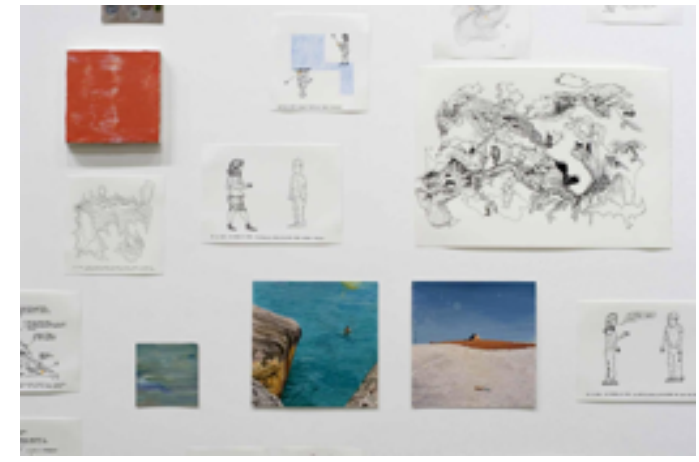

Detalle Instalación proyecto Rev. Técnica 2009, dibujos, pinturas, fotos, recortes.

http://rtalvarooyarzun.blogspot.com/

www.artistasplasticoschilenos.cl/658/w3-article-40334.html www.xsgaleria.cl/portfolio/alvaro-oyarzun/ 


\section{Daniela Montecinos}

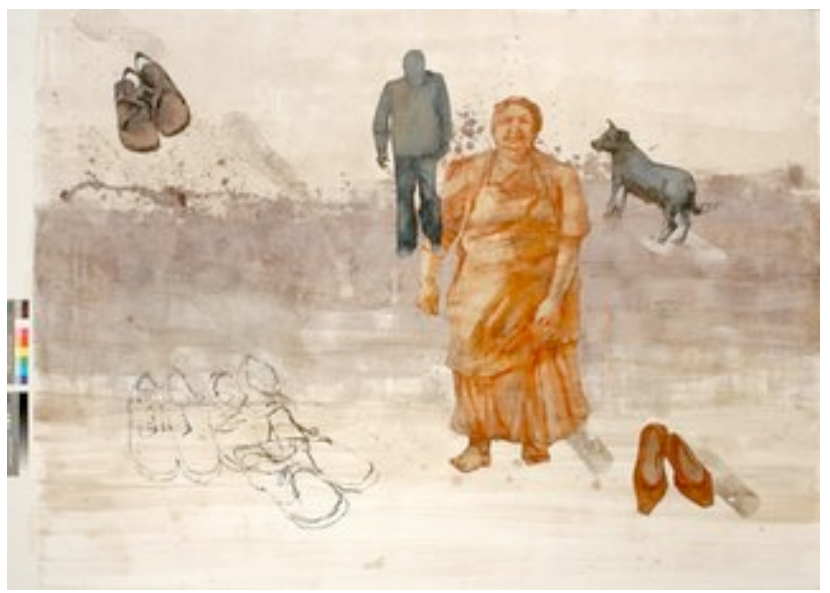

dias diferentes, 2005 oleo y collage/tela $120 \times 170 \mathrm{~cm}$. (serie "La Vega"

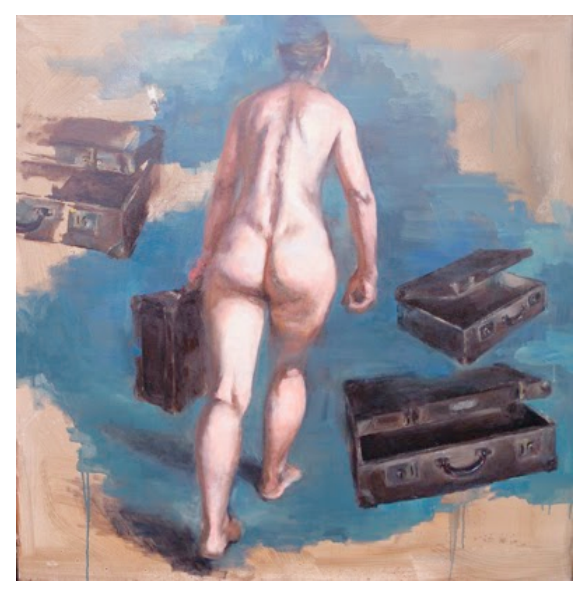

Sleepwalker, 2013 oleo/tela 100 x $100 \mathrm{~cm}$,

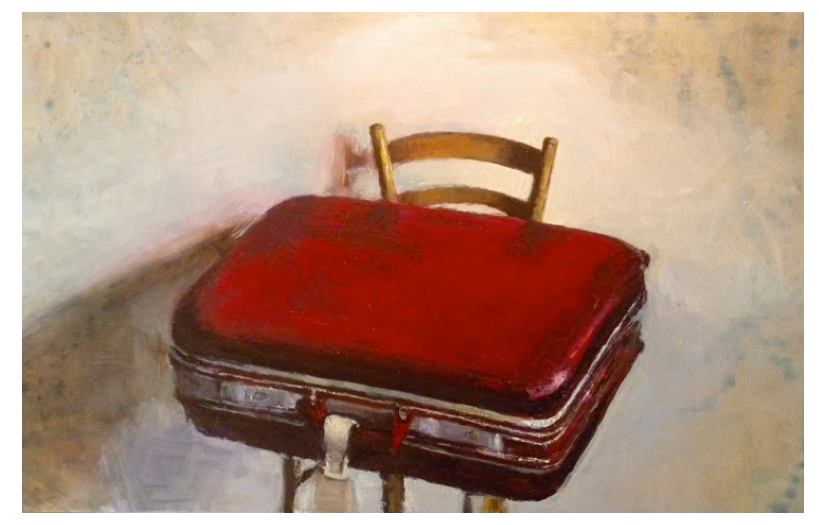

El Viaje I, 2014 oleo/tela, 50 x $80 \mathrm{~cm}$,

http://danielamontecinos.blogspot.com/

http://www.portaldearte.cl/artistas_visuales/montecinos_daniela.html

http://www.perrerarte.cl/wp/daniela-montecinos-en-chile-cohabitan-lo-feroz-y-lo-tierno 


\section{Patricia de Israel}
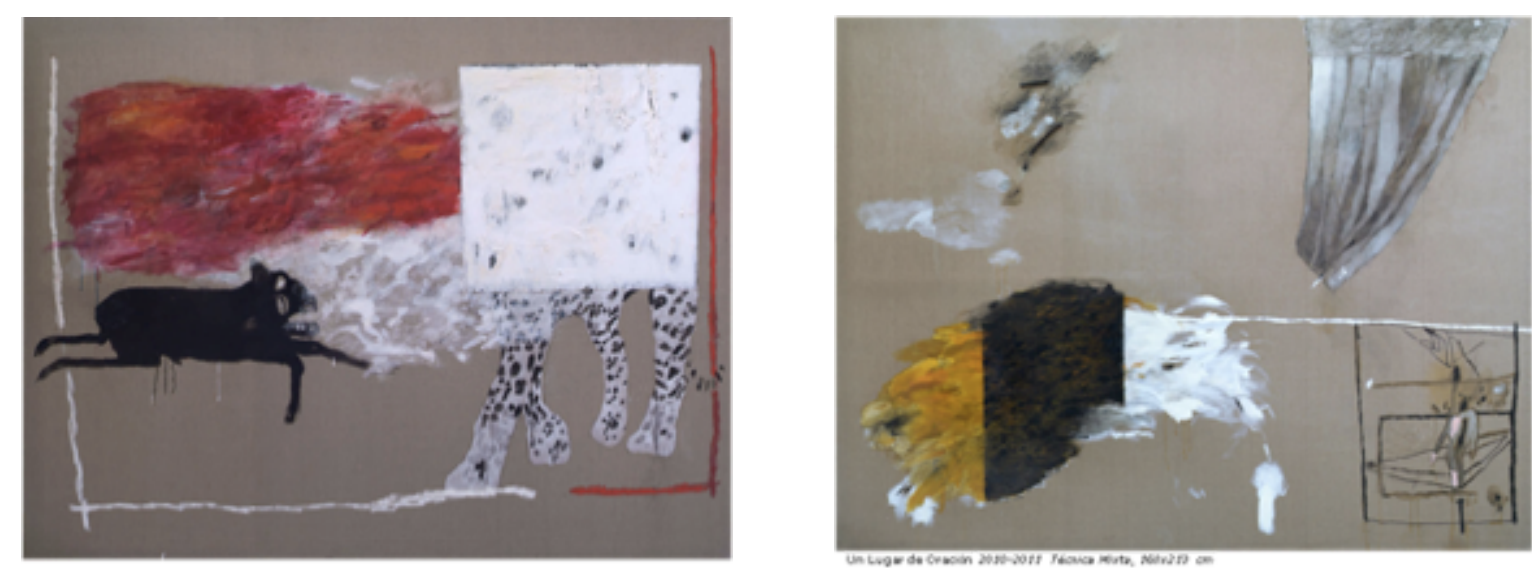

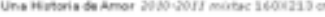

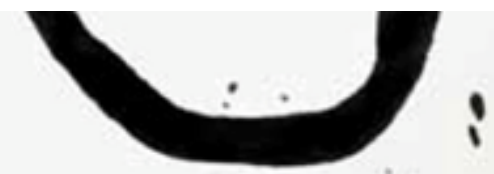

$\therefore \rightarrow$
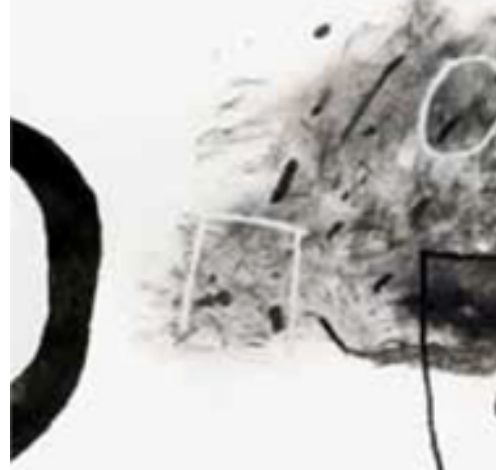

Sin Titulo 2011 Mixts sobre lino, 200x200 cms

www.artistasplasticoschilenos.cl/658/w3-article-40424.html

http://www.latercera.com/multimedia/galeria/2011/11/683-29859-7-vea-las-obras-de-patricia-israel.shtml www.portaldearte.cl/autores/israel.htm 
$N^{\circ} 125$ ficha

\section{Patricio Rueda}
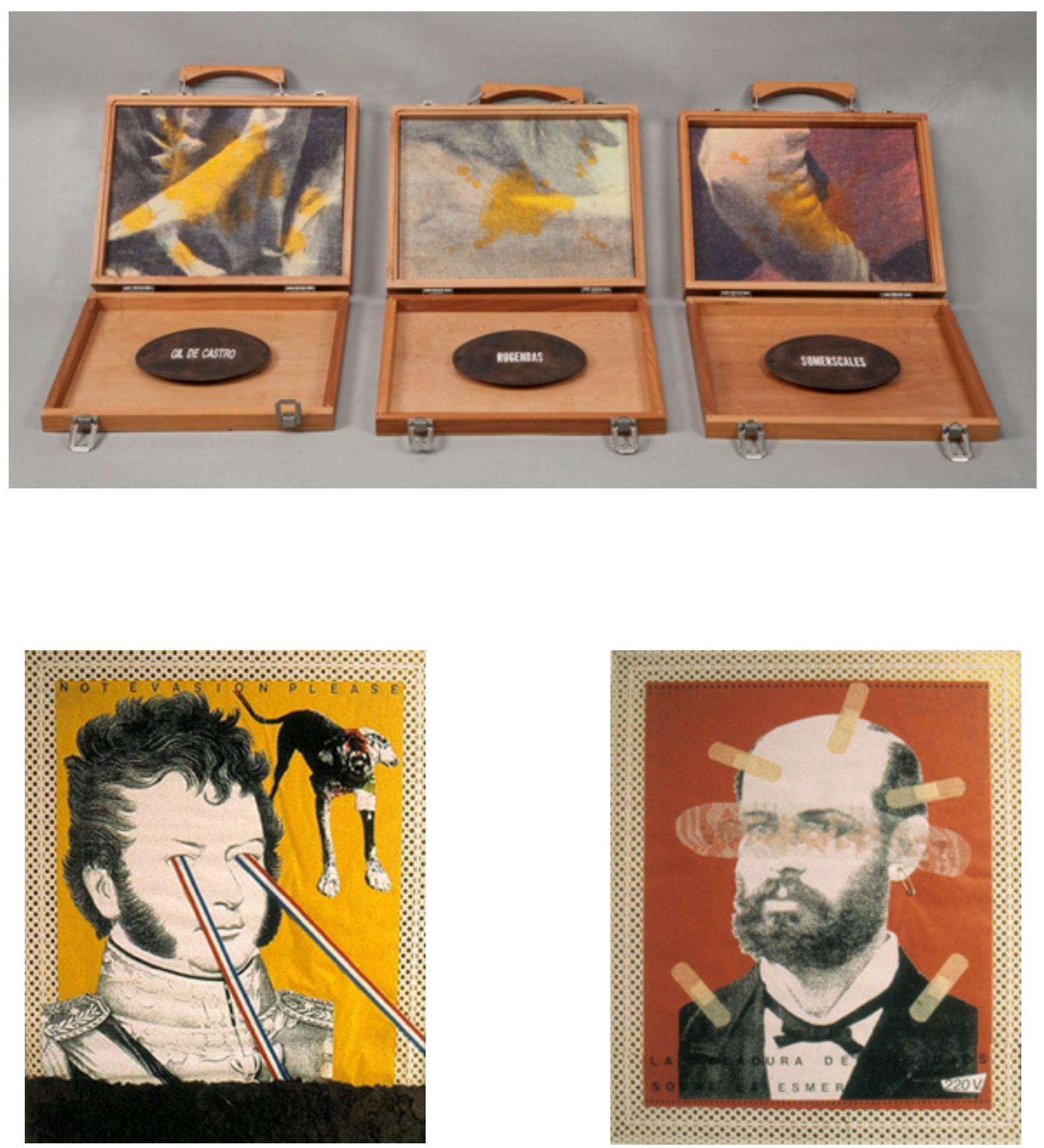

http://rtpatriciorueda.blogspot.com/

www.artistasplasticoschilenos.cl/658/w3-article-39886.html http://galeriagm.cultura.gob.cl/coleccion_artista/p/65 
$N^{\circ} 126$ ficha

\section{Voluspa Jarpa}
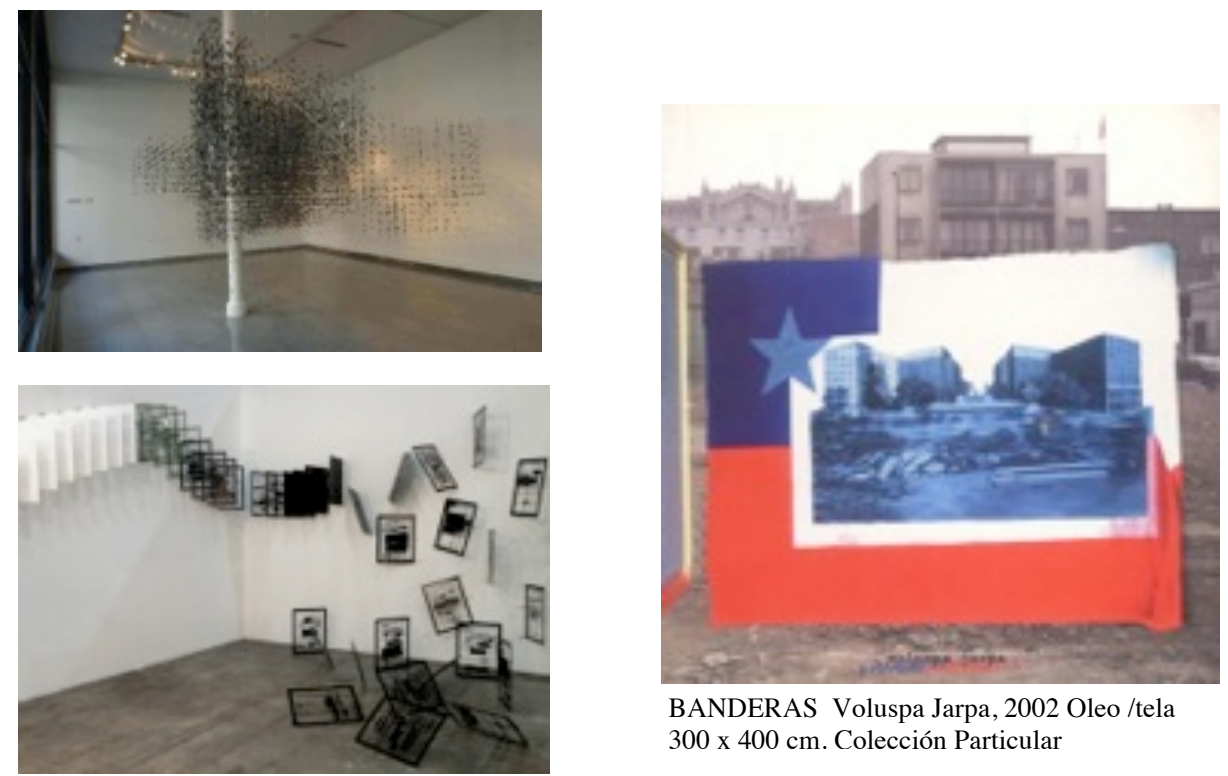

BANDERAS Voluspa Jarpa, 2002 Oleo /tela 300 x $400 \mathrm{~cm}$. Colección Particular
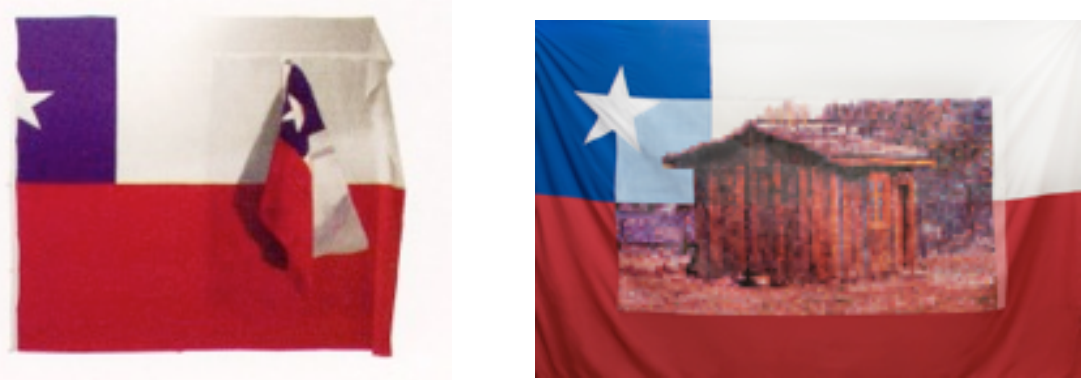

DE LA SERIE HISTORIA ORIVADA HISTORIA PUBLICA 2001-2002 Oleo / bandera chilena 300 x $300 \mathrm{~cm}$ (Colección de Arte Contemporáneo Galería Gabriela Mistral)

www.artistasplasticoschilenos.cl/658/w3-article-40498.html

http://www.portaldearte.cl/autores/jarpa_voluspa.htm

http://galeriaisabelaninat.cl/artista/voluspa-jarpa/

http://www.latercera.com/noticia/cultura/2014/11/1453-603576-9-voluspa-jarpa-concibo-el-arte-como-portador-deconocimiento.shtml 


\section{Catalina Donoso}
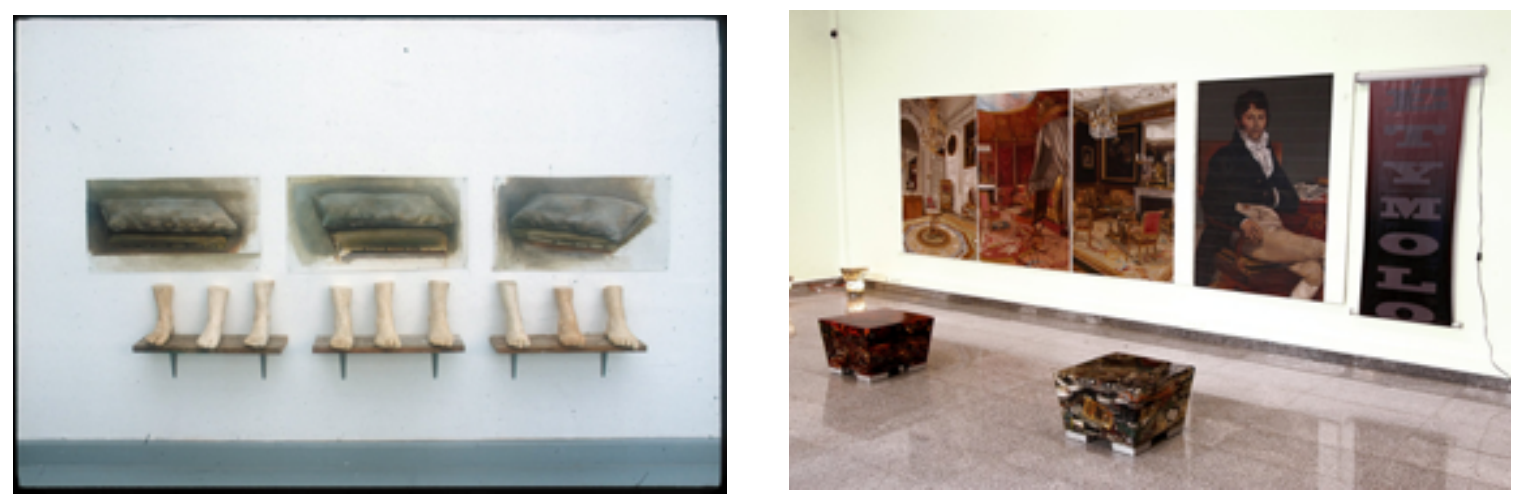

Proyecto Revisión Técnica 2009 "El imperio de Catalina” instalación: pintura e impresión en tela y objetos, dimensiones variables
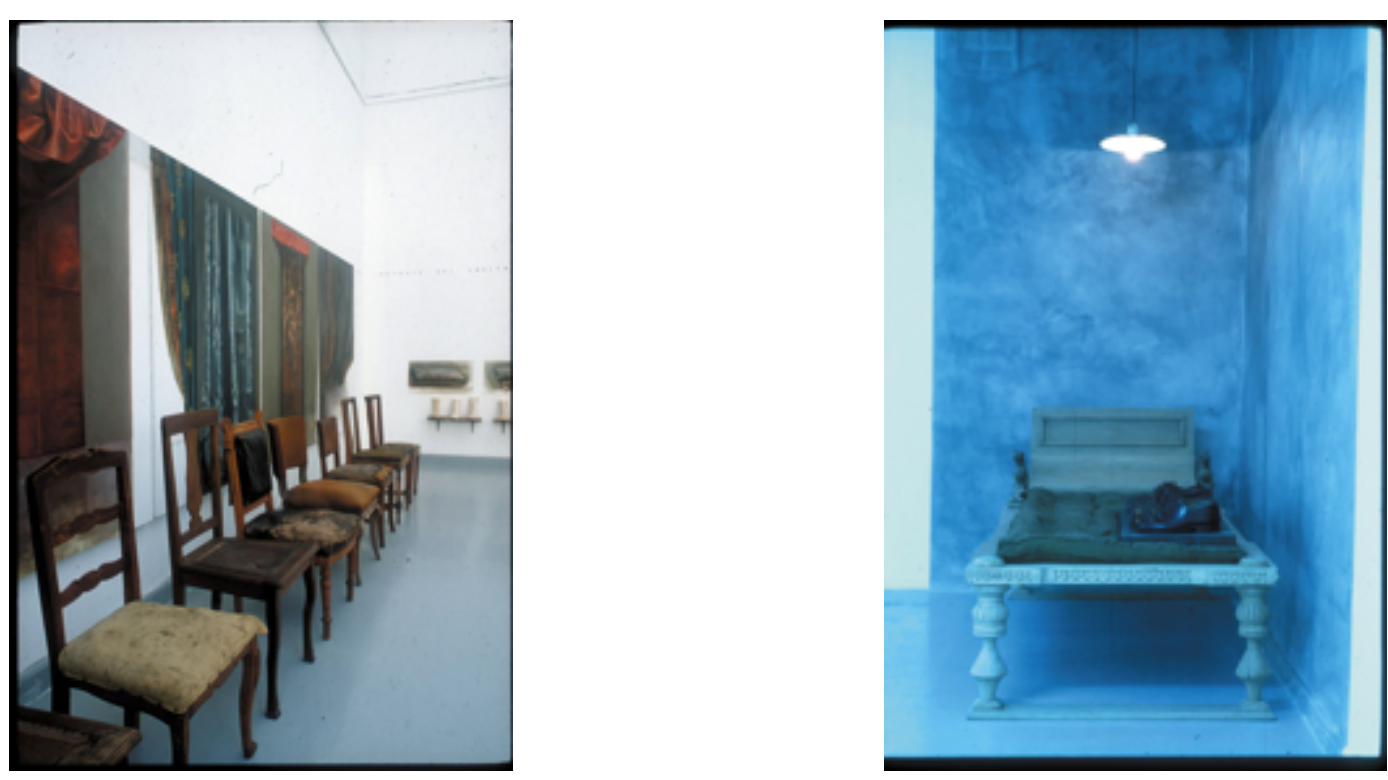

www.artistasplasticoschilenos.cl/658/w3-article-39753.html

http://www.arteallimite.com/galeria/artistas/catalina-donoso-435

http://galeriagm.cultura.gob.cl/coleccion_artista/c/16 


\section{Sonia Etchart}

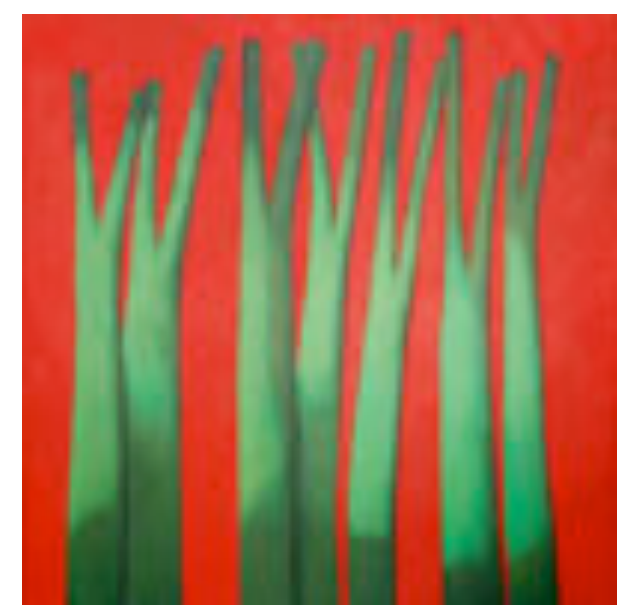

SE:C7 - 2006, oleo/tela 148x148 cm -

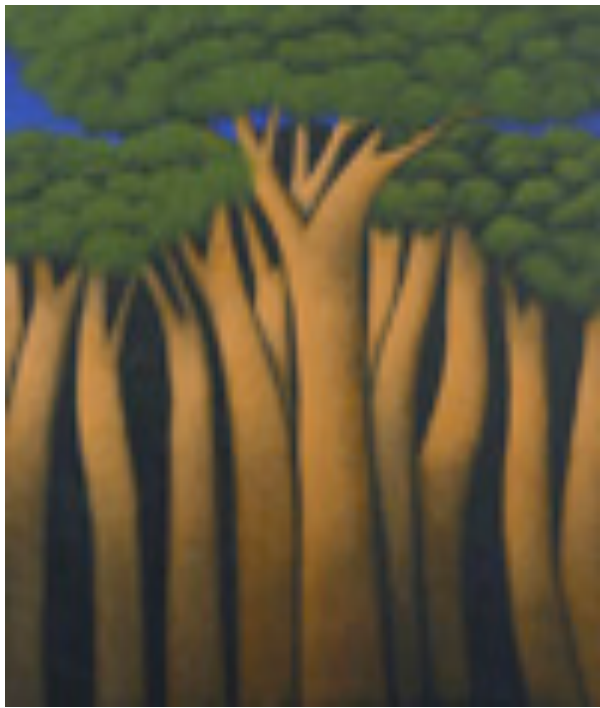

SEC6 2006 oleo/tela 80x100cm.

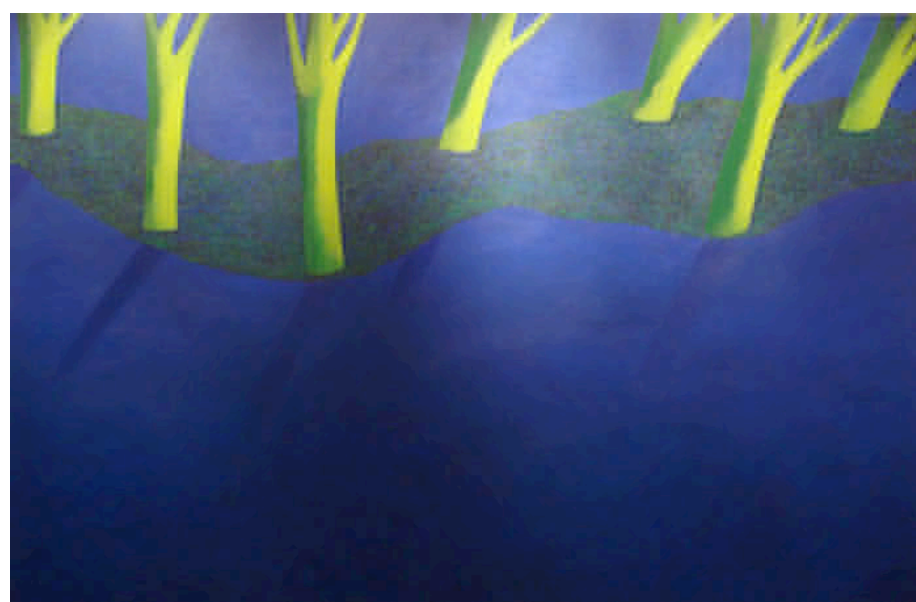

"SE-C4 Azul" 2008, oleo/tela 80x100 cm. 
$N^{\circ} 129$ ficha

\section{Carmen Gloria Cucurella}

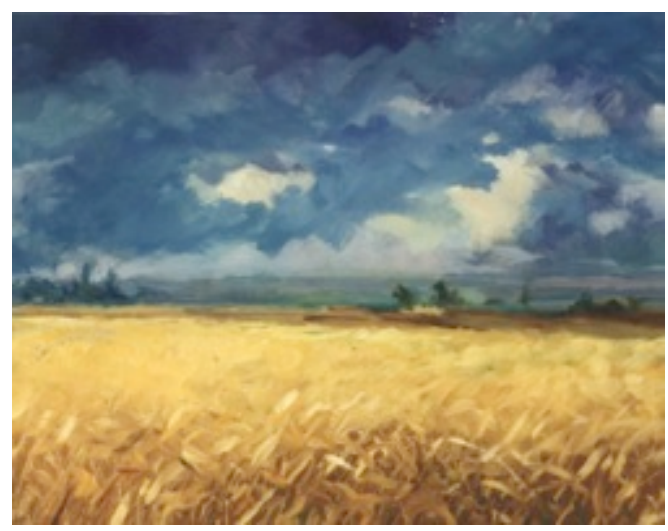

“Campo de trigo y cielo" 2014 oleo/tela 70x90 cm.

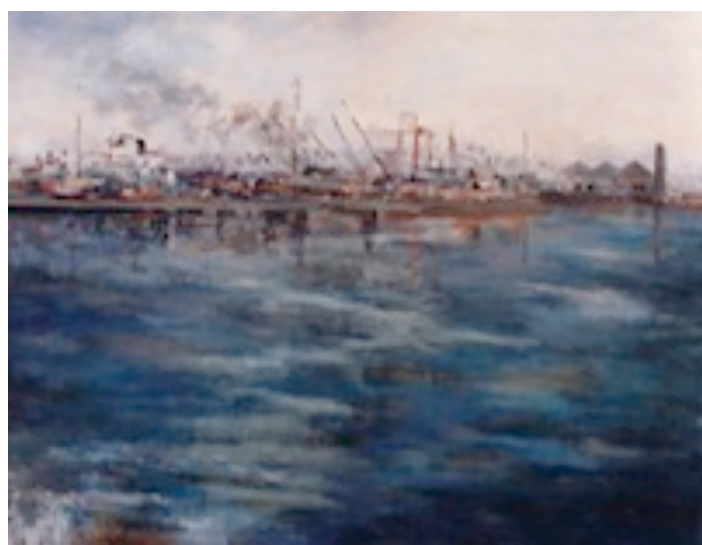

Puerto de San Antonio"

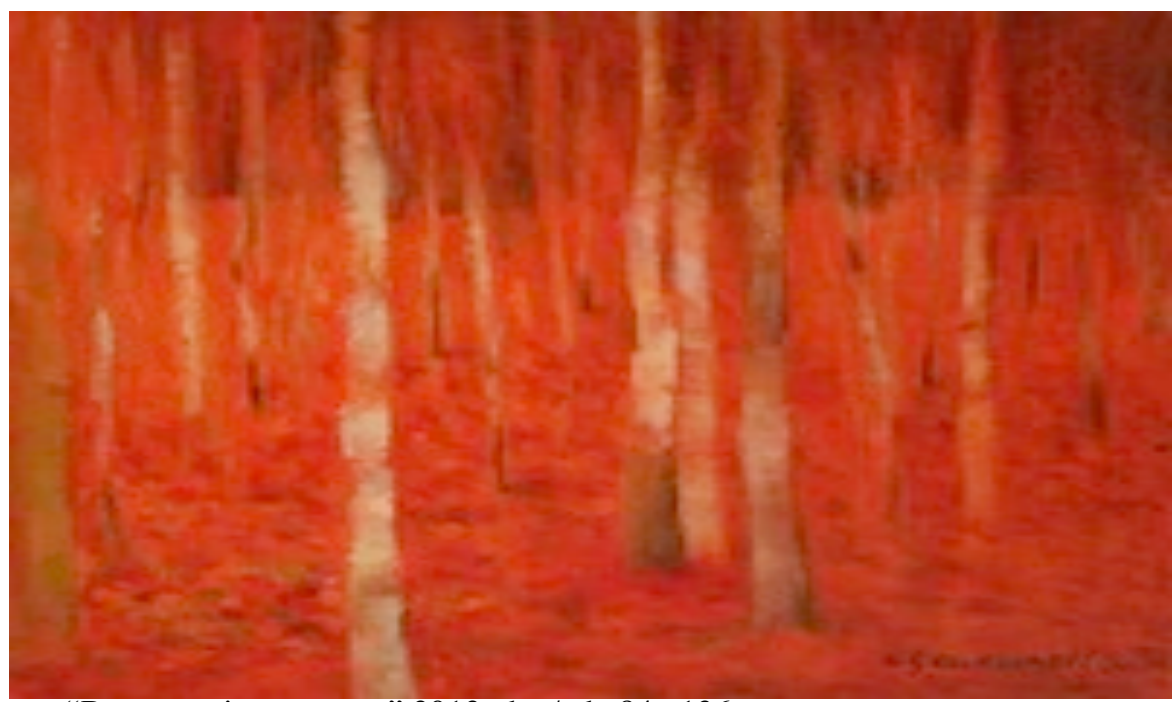

“Bosque rojo y margen” 2012 oleo/tela 84x 136 cm.

www.carmengloriacucurella.cl

http://www.cayomecenas.com/mecenas 1175.htm

$N^{\circ} 130$ ficha 


\section{Axel Ekdahl Escobar}

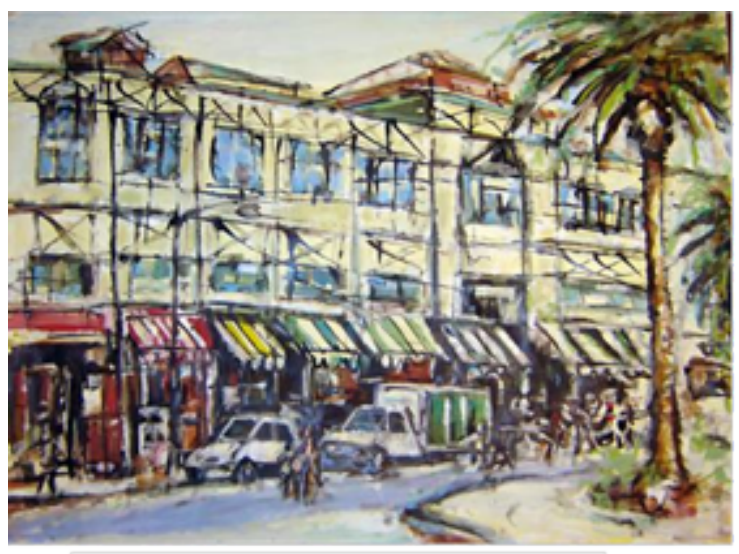

- Moxta s'papel 2010

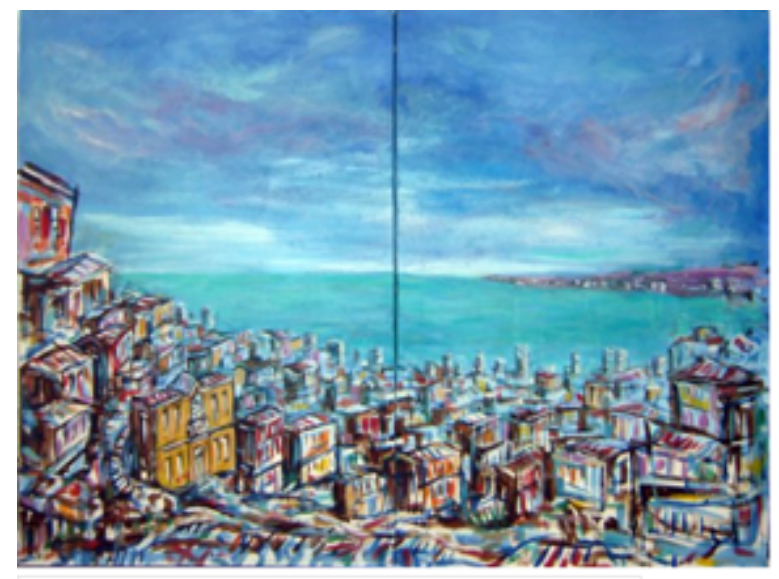

Diptico, deo acrilico SI tela, 135 × $90 \mathrm{cms} 2010$

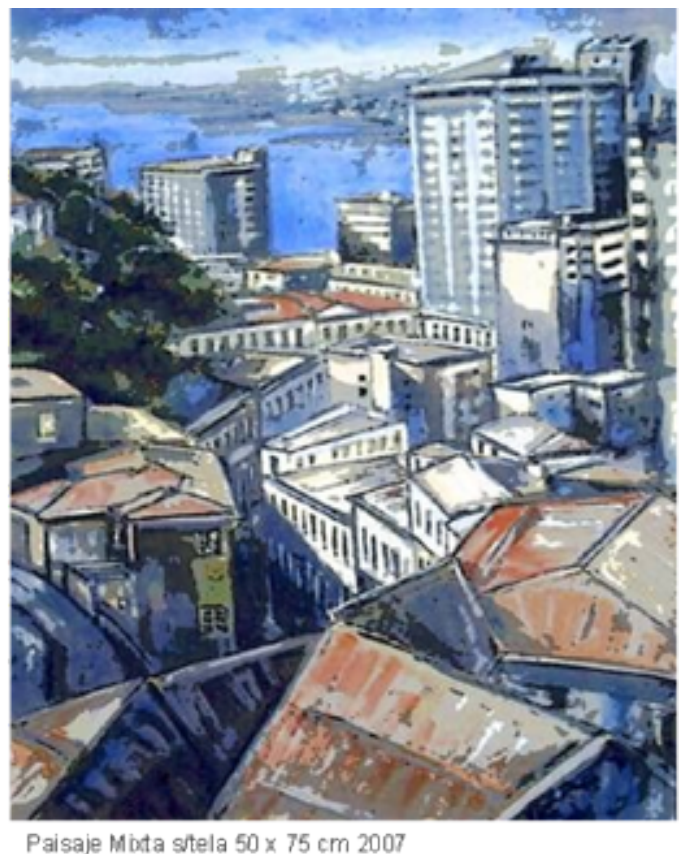

Paisaje Mbłta sttela $50 \times 75 \mathrm{~cm} 2007$

http://axelekdahl.artelista.com/

http://www.moving-art.net/painting/artists/Chile/Axel_Ekdahl.aspx?sflang=es 


\section{Francisco Moya}
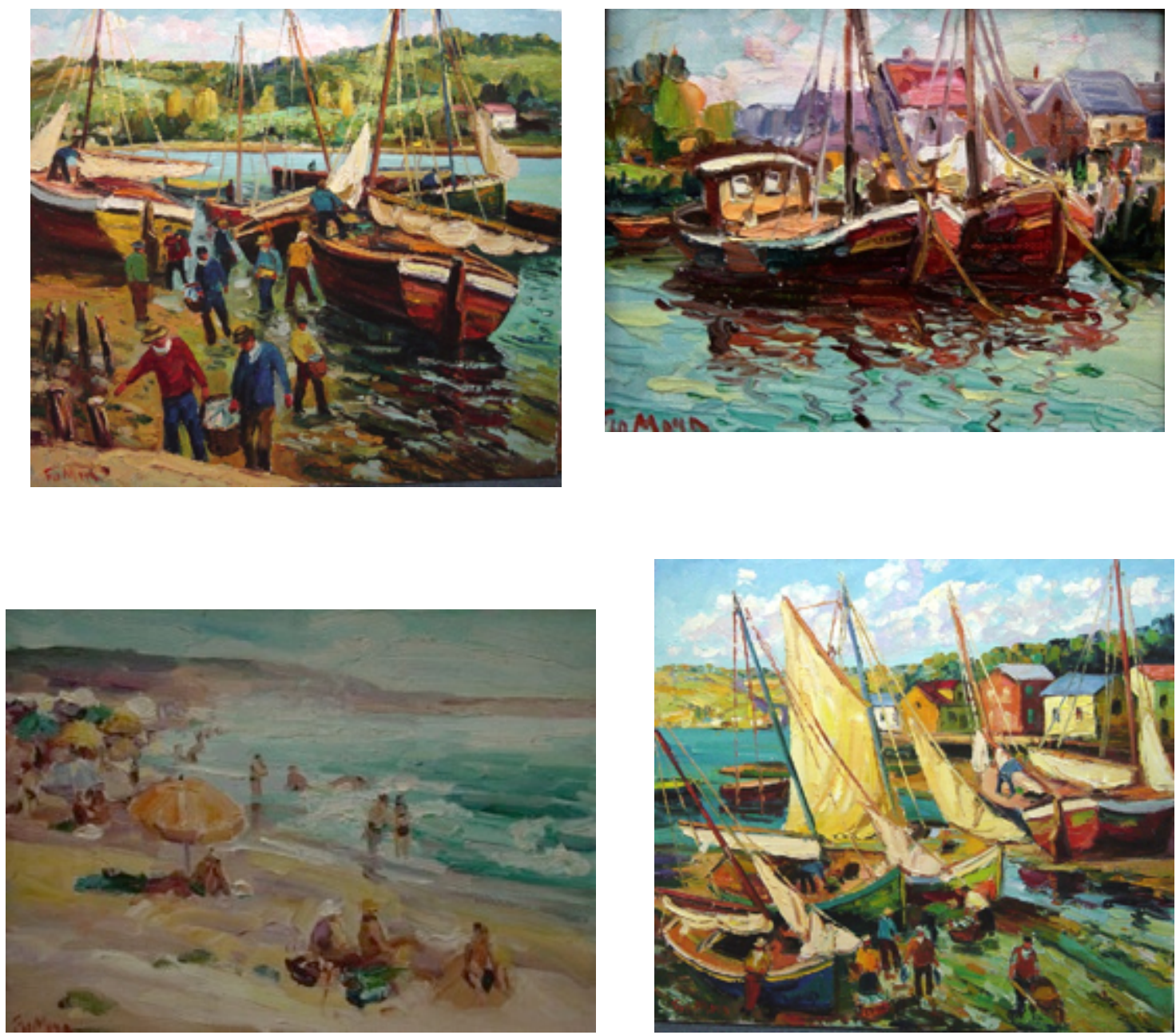

http://frayco.blogspot.com/2012/02/francisco-moya.html 
$N^{\circ} 132$ ficha

\section{José Basso}

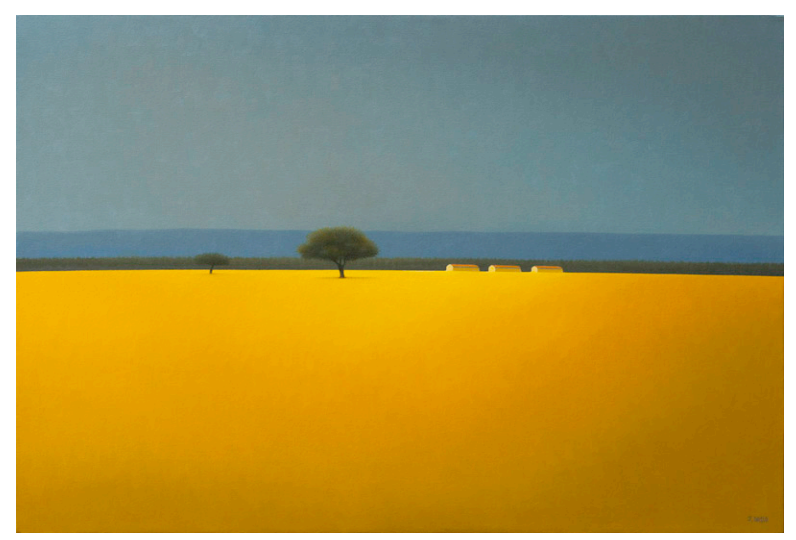

s/t V” 2012 oleo/tela 72x102 cm

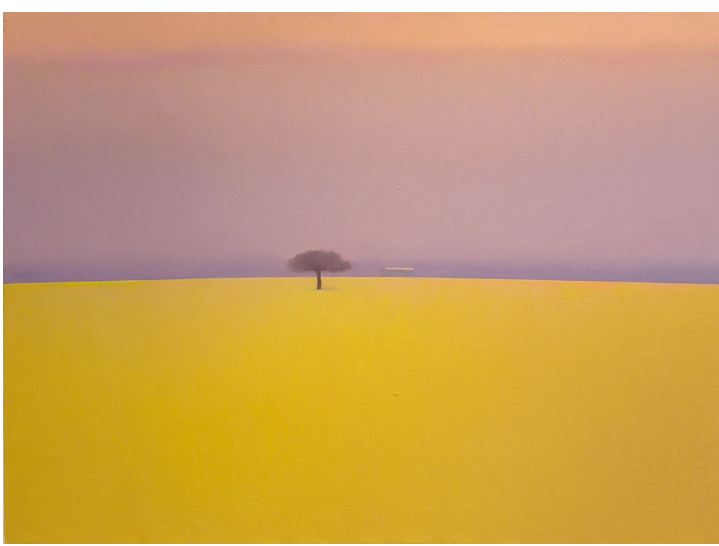

s/t II" 2012 oleo/tela $80 \times 100 \mathrm{~cm}$

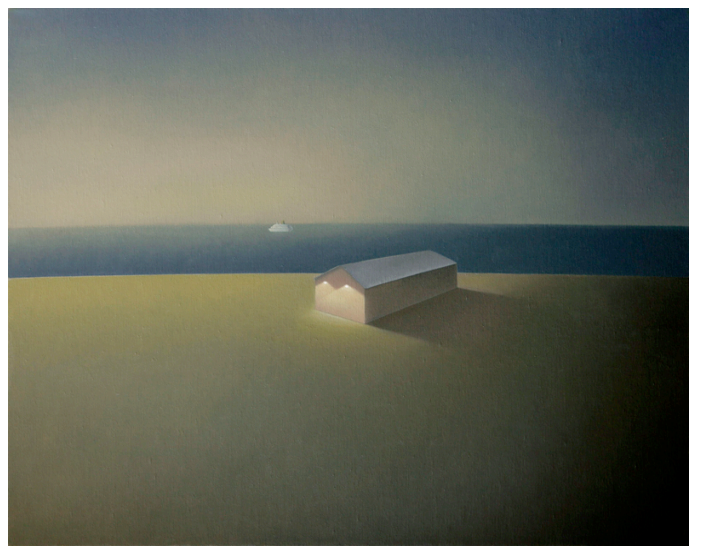

“antiguo galpon del puerto" 2013 oleo/tela 72x102

www.artistasplasticoschilenos.cl/658/w3-article-40086.html www.josebasso.com/

www.portaldearte.cl/autores/basso.htm

http://www.josebasso.com/Breve\%20Biografia\%20de\%20Jose\%20Basso.htm 


\section{Pablo Dominguez}
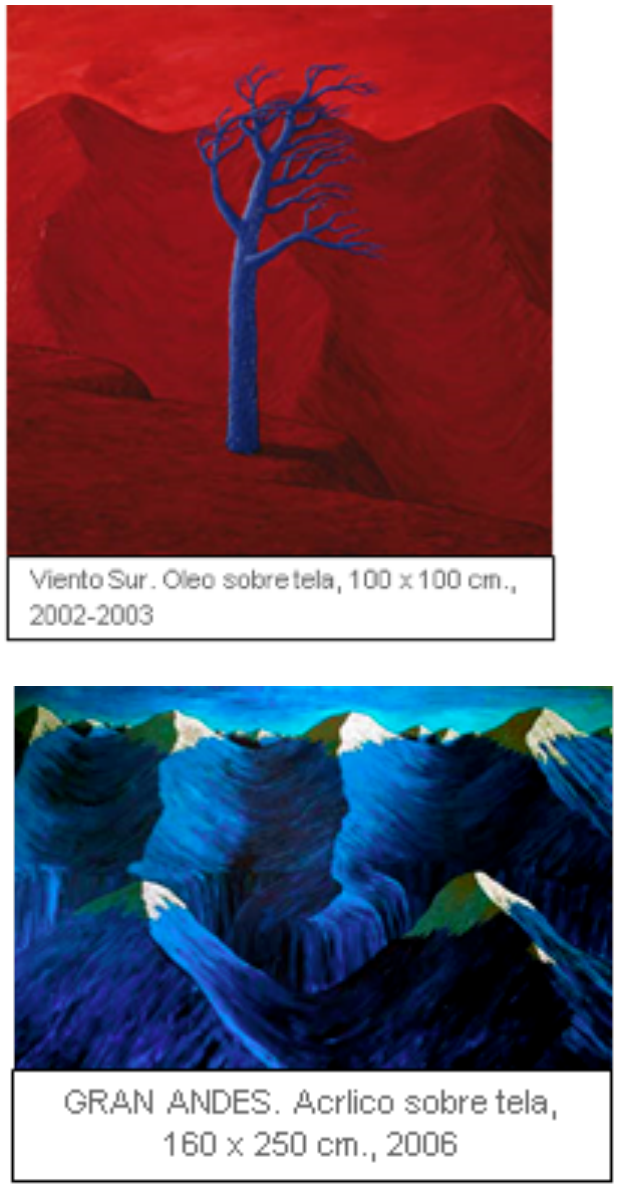
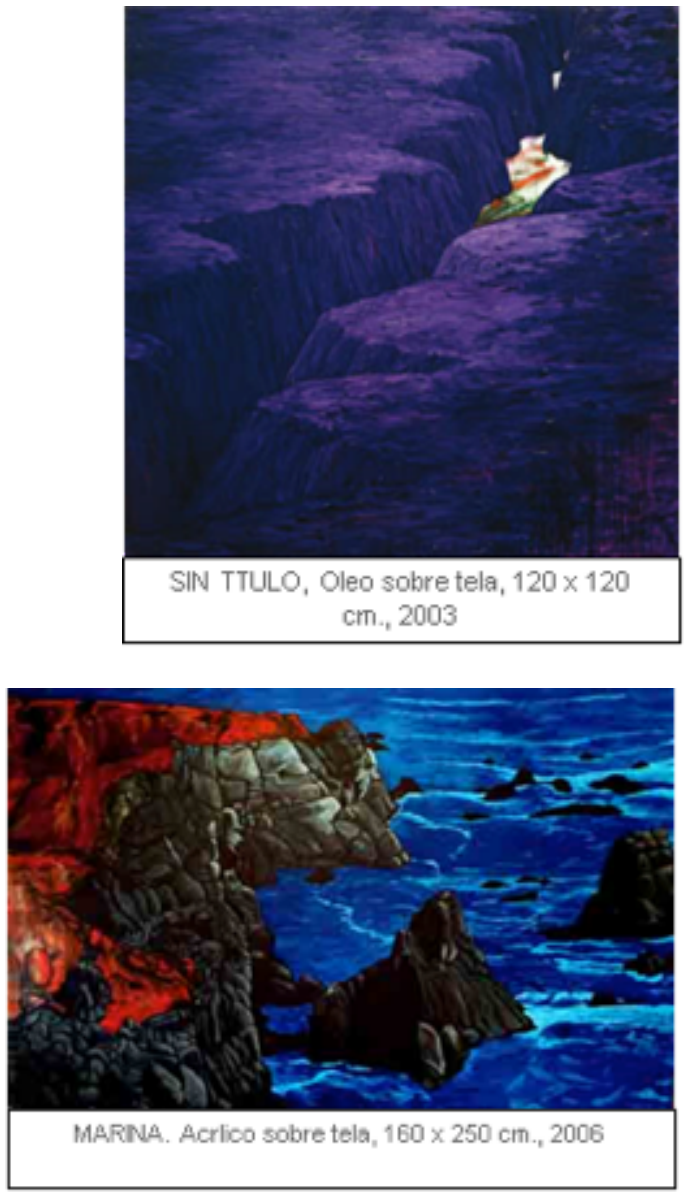

Ç

www.artistasplasticoschilenos.cl/658/w3-article-40013.html

www.portaldearte.cl/autores/dominguez $1 . h t m$ 


\section{$N^{\circ} 134$ ficha}

\section{Roberto Geisse}
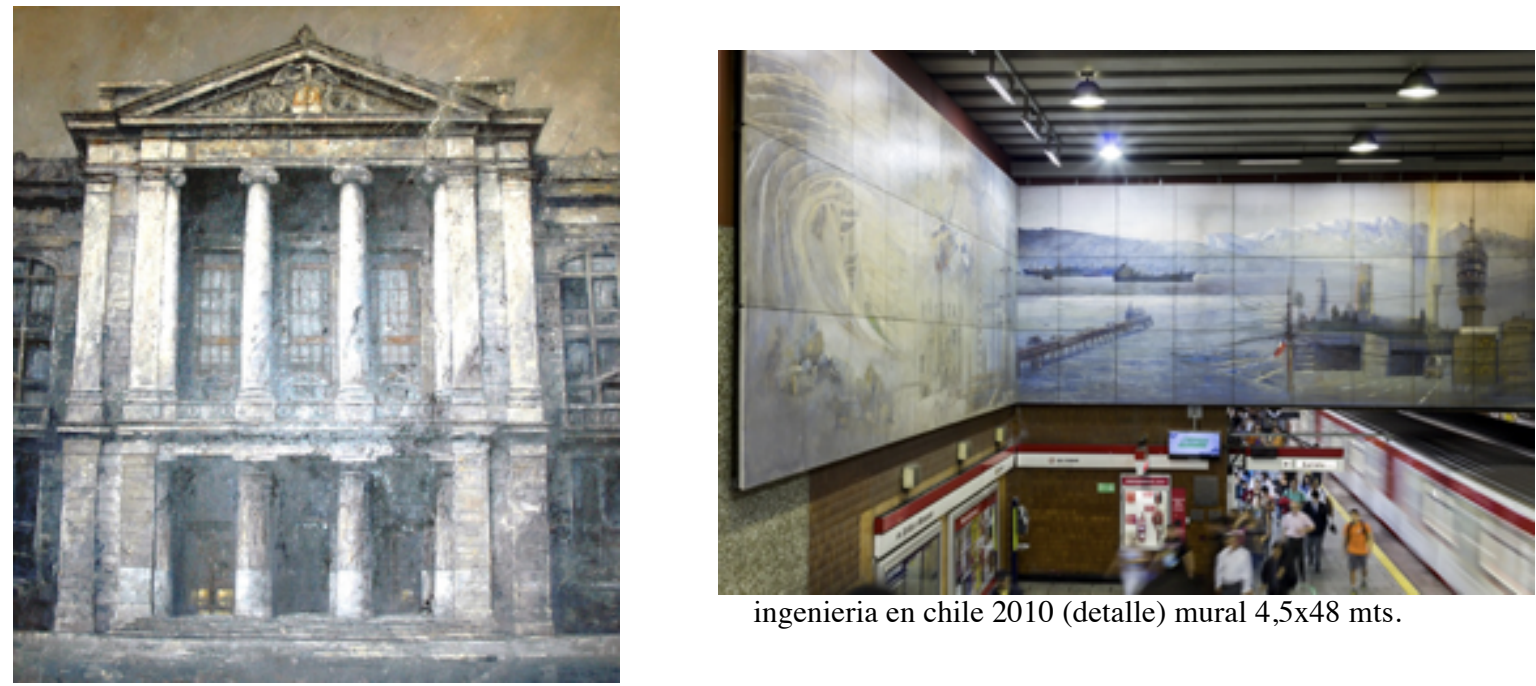

ingenieria en chile 2010 (detalle) mural 4,5x48 mts.

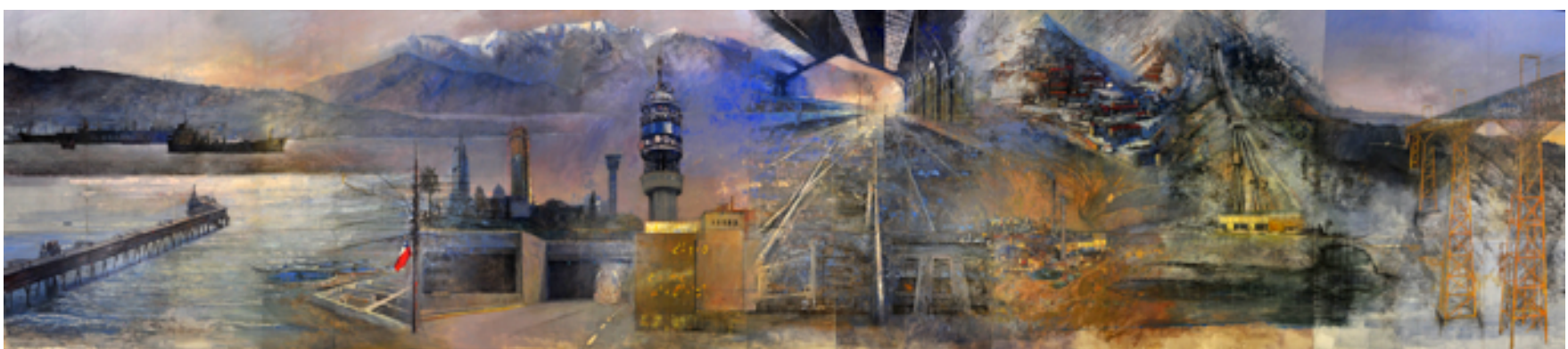

en MetroArte de 220 metro cuadrados, (Roberto Geisse 2010) 48 metros de largo por 4,5 metros de altura), se retratan más de 31 escenas que recorren Chile de norte a sur y que en su conjunto reflejan el aporte y el legado de la ingeniería en nuestro país. Entre ellas destaca una mina a tajo abierto, una instalación salitrera, imágenes de trabajadores mineros, un observatorio astronómico, líneas de transmisión eléctrica, la dársena de Valparaíso, un muelle para descarga de graneles, autopistas urbanas, edificios y torres emblemáticas de la Región Metropolitana, una estación de ferrocarriles, una central hidroeléctrica, el acueducto del Malleco, una planta de tratamiento de aguas, una industria siderúrgica, una empresa de explotación petrolera, una imagen del Banco Central en reconocimiento a la ingeniería comercial, entre otras

http://www.plataformaurbana.cl/archive/2015/01/09/arte-y-ciudad-mural-de-la-ingenieria-chilena-en-metro-estacioncentral/mural-de-la-ingenieria-chilena-robert

www .artistasplasticoschilenos.cl/658/w3-article-40419.html

www.metrosantiago.cl/minisitio/ingenieria-chilena/ 
$N^{\circ} 135$ ficha

\section{Carlos Altamirano}

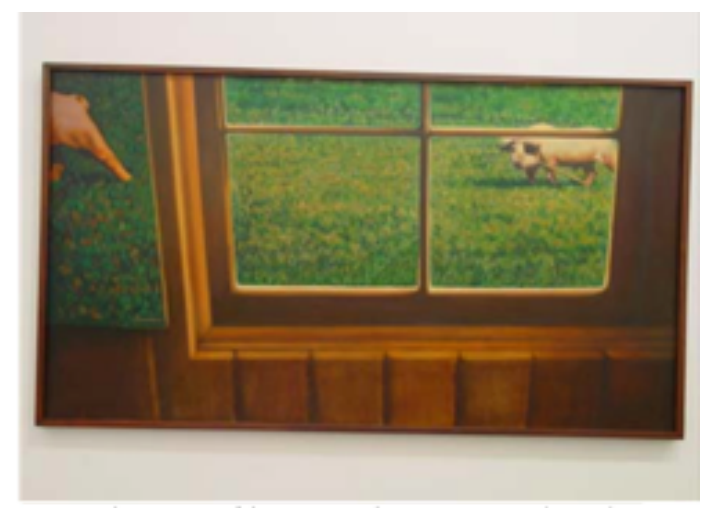

Un euadro en que faita pintar algunas casas, óleo sobre tela. 2003.

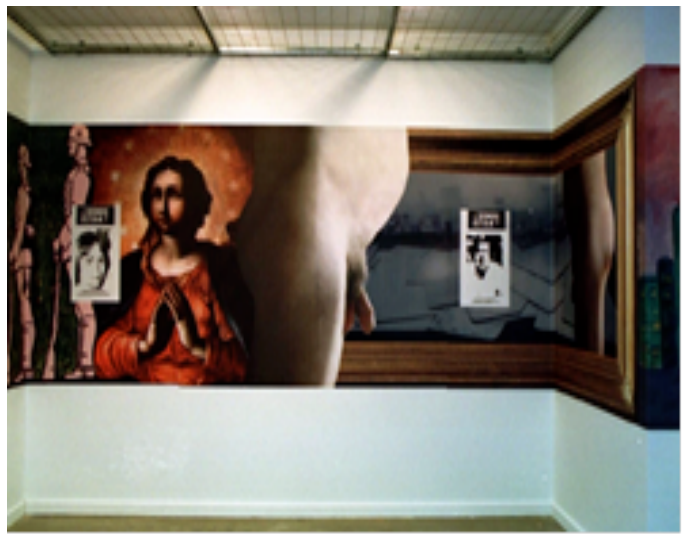

“retratos" (detalle) Obra completa, Carlos Altamirano, 2007.

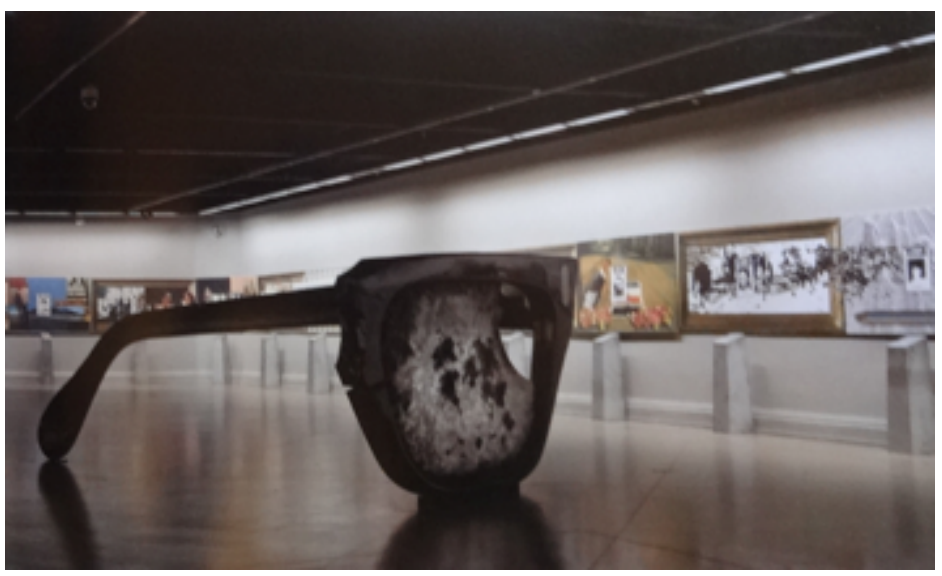

"retratos" (detalle) Obra completa, Carlos Altamirano, 2007.

www.artistasplasticoschilenos.cl/658/w3-article-40262.html

http://galeriagm.cultura.gob.cl/coleccion_artista/c/2

www.portaldearte.cl/autores/altamirano.htm 


\section{Carolina Barros}
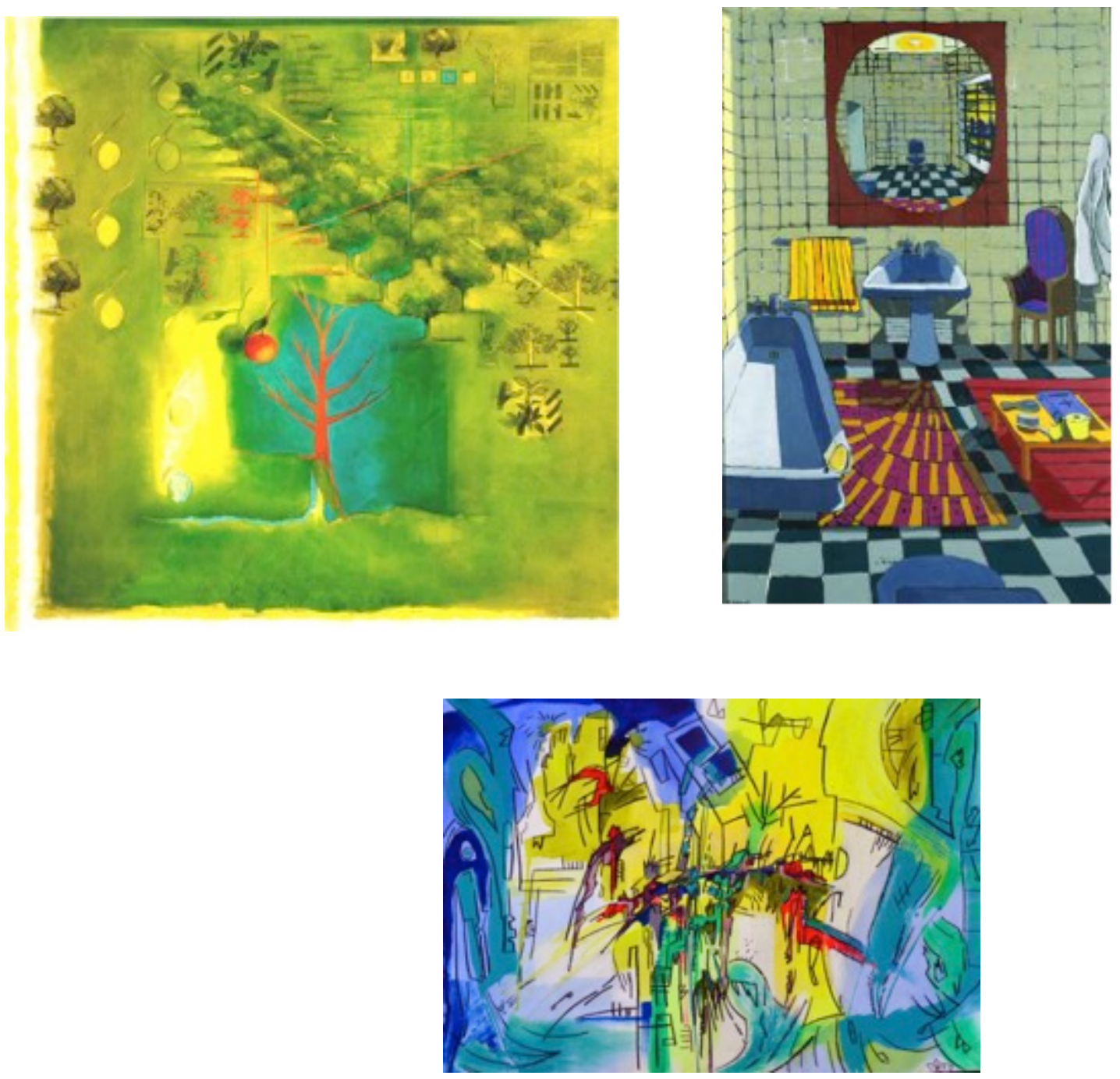

www.artistasplasticoschilenos.cl/658/w3-article-39761.html

http://www .arteallimite.com/galeria/artistas/maria-carolina-barros-577

https://corporacionculturalvina.wordpress.com/2011/12/13/xxxvi-salon-nacional-de-pintura-expone-a-susganadores-y-seleccionados/mencion-de-honor-artista-carolina-barros/ 


\section{Carolina Landea}
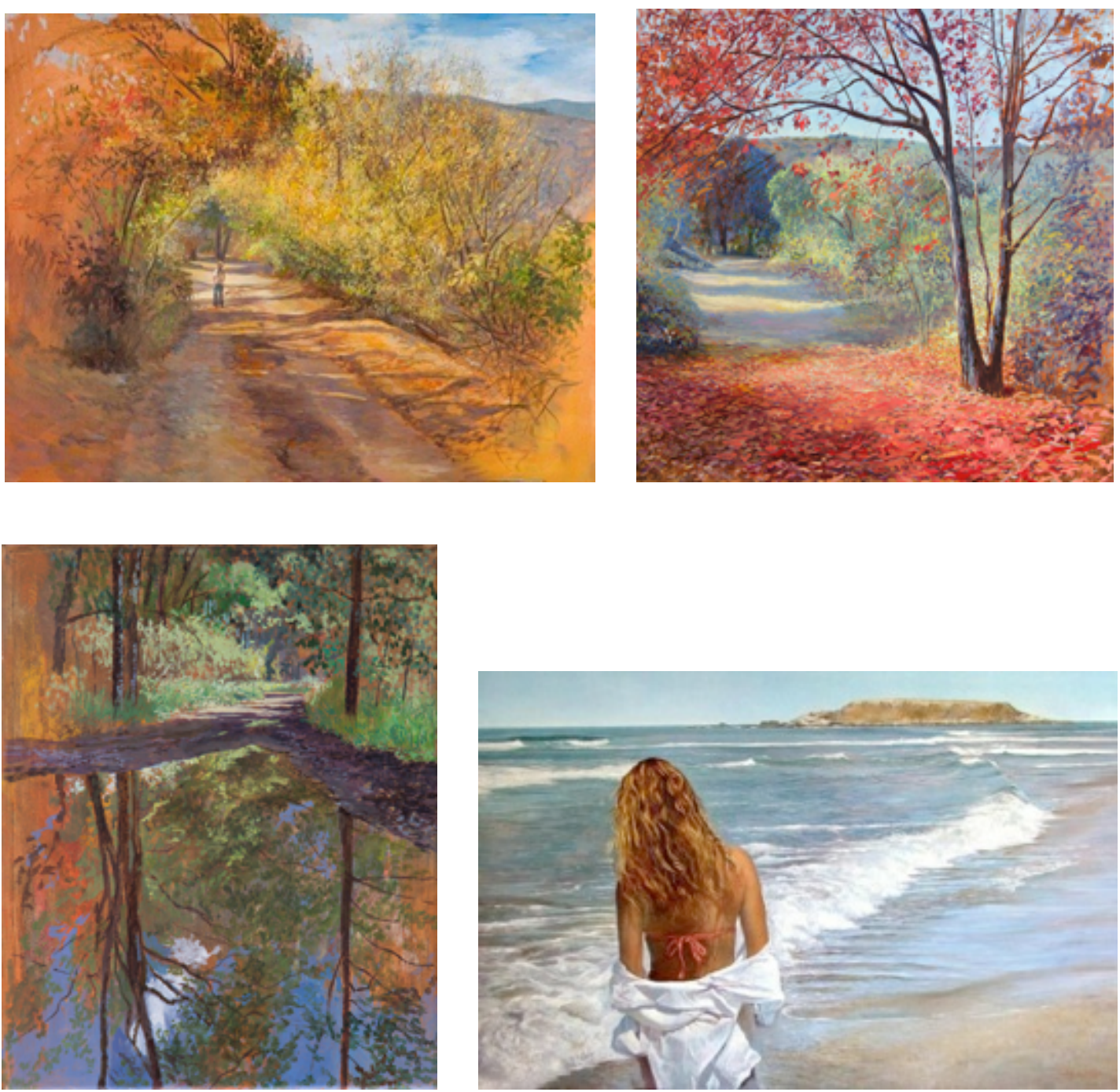

http://www.carolinalandea.com/

www.artistasplasticoschilenos.cl/658/w3-article-39633.html

www.portaldearte.cl/autores/landea $1 . h t m$

http://porelamoralarte.blogspot.com/2013/06/las-hermosas-pinturas-de-la-chilena.html 


\section{Felipe Cusicanqui}

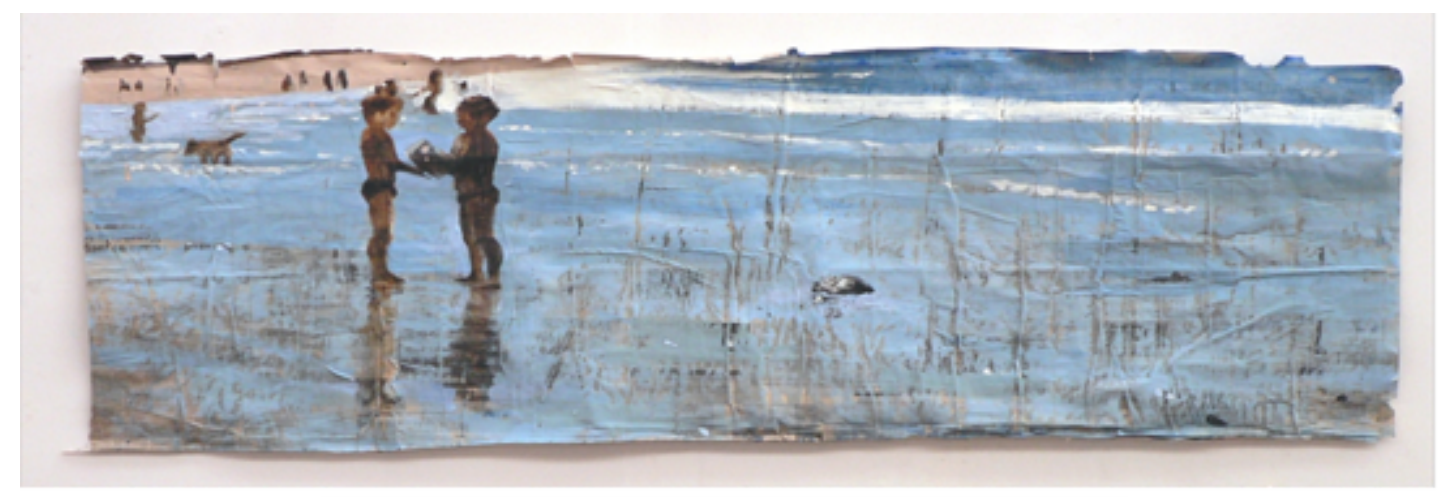

Playa I Acrilico y oleo sobre papel de diario encolado $180 \times 70 \mathrm{cms} 2007$
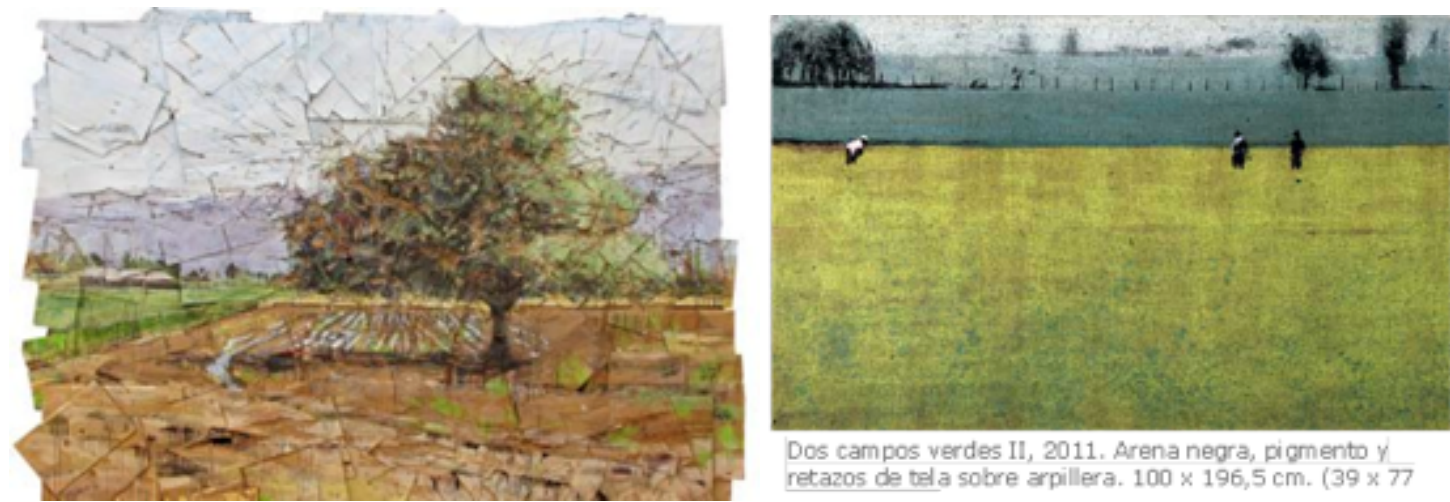

Dos campos verdes II, 2011. Arena negra, pigmento y retazos de tel a sobre arpillera. $100 \times 196,5 \mathrm{~cm}$. (39 ×77

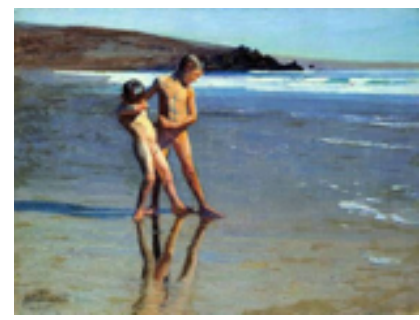

Chicos en la playa", s/f, Benito rebolledo (1880-1964) Oleo

http://www.galeriapready.cl/\#!felipe-cusicanqui/c21wq http://www.premioaltazor.cl/felipe-cusicanqui/

http://felipe-cusicanqui.artenlinea.com/

http://www.latercera.com/contenido/727_193810_9.shtml 


\section{$N^{\circ} 139$ ficha}

\section{Loreto Enríquez}

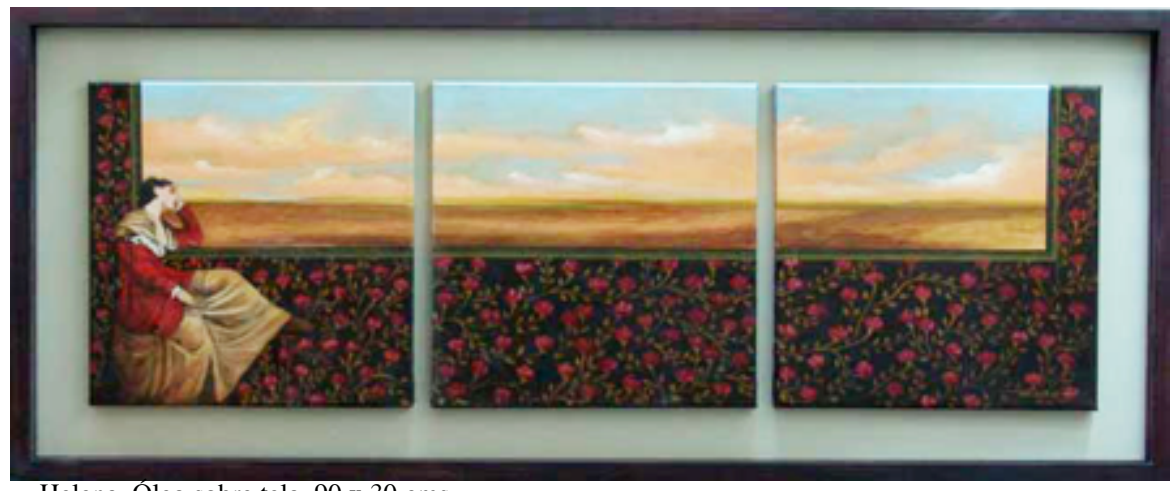

Helena, Oleo sobre tela, 90 × $30 \mathrm{cms}$

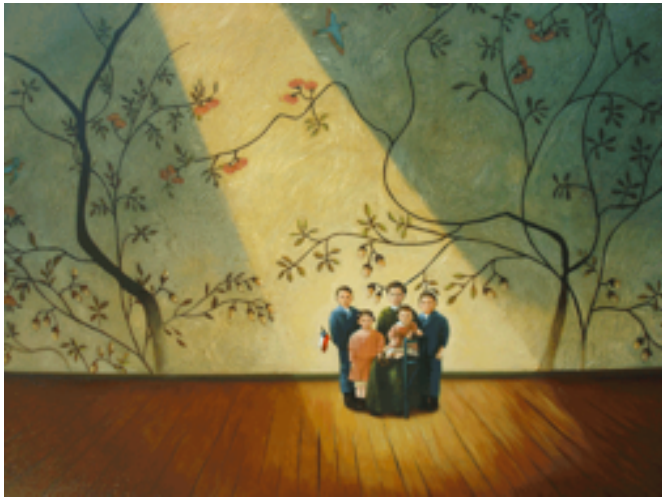

“familia” 2007 Óleo /tela, 120 × 100 cms.

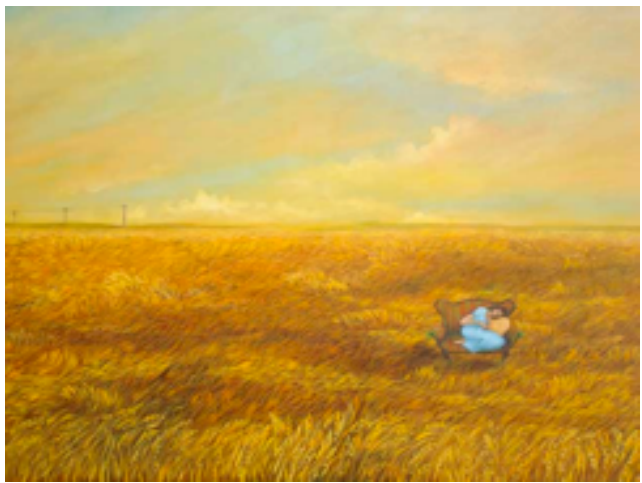

La siesta, 2007 Óleo/ tela, 160 × 120 cms.

www.loretoenriquez.com/

http://galeria13.cl/portfolio/ 
$N^{\circ} 140$ ficha

\section{Pablo Chiuminatto}
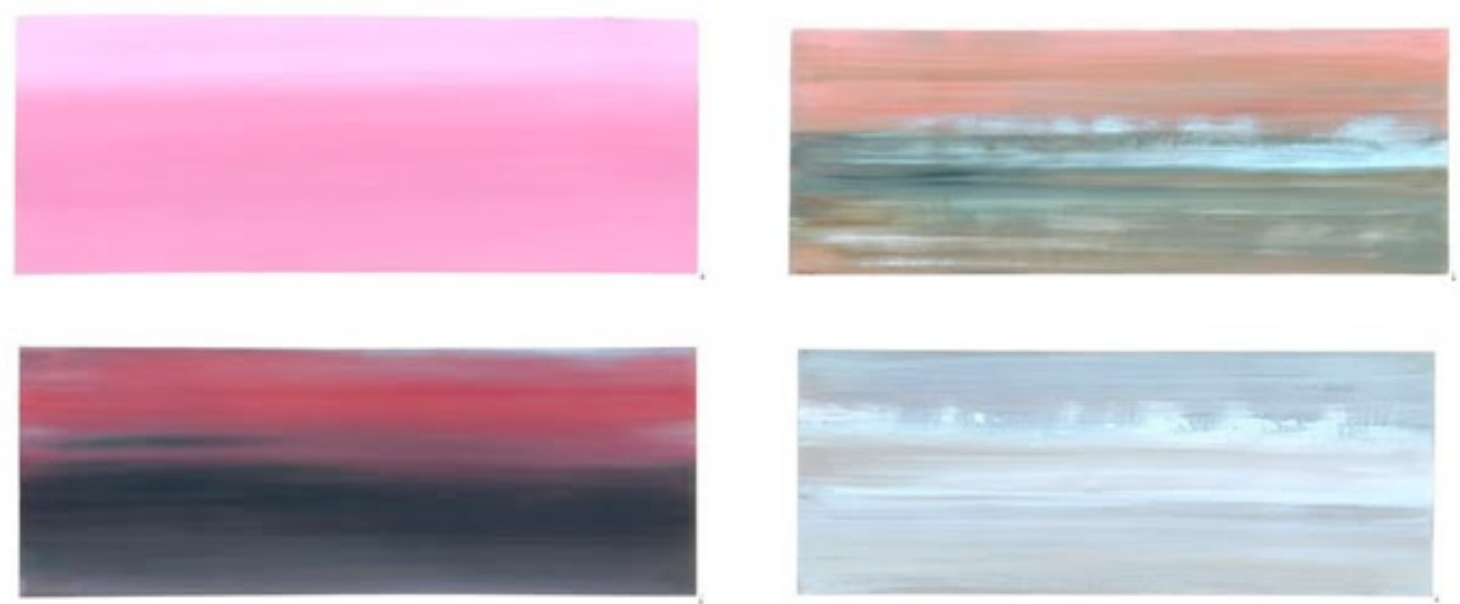

Serie Atlántico 2006 oleo/tela 50×100 cm

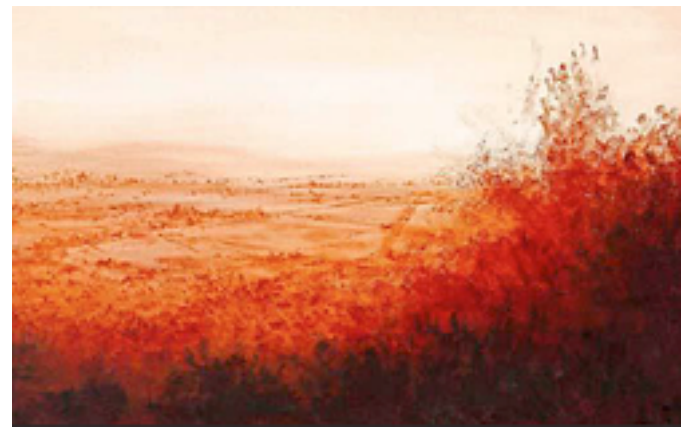

"paisaje chileno" 2015 oleo/tela

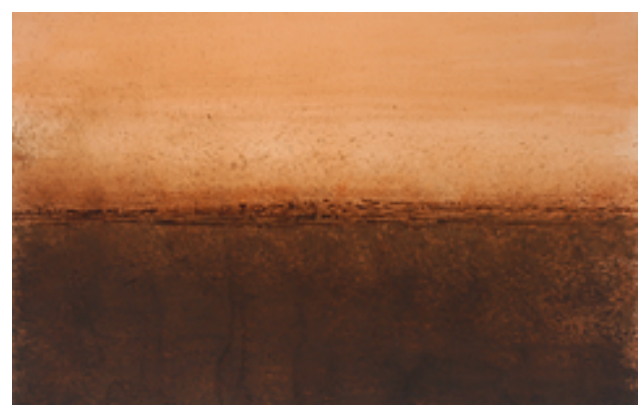

"paisaje de la infancia" 2007 oleo/tela $40 \times 70 \mathrm{~cm}$

http://pablochiuminatto.blogspot.com/

www.portaldearte.cl/autores/chiuminatto.htm

www.artistasplasticoschilenos.cl/658/w3-article-40385.html 


\section{$N^{\circ} 141$ ficha}

\section{Sebastián Garretón}
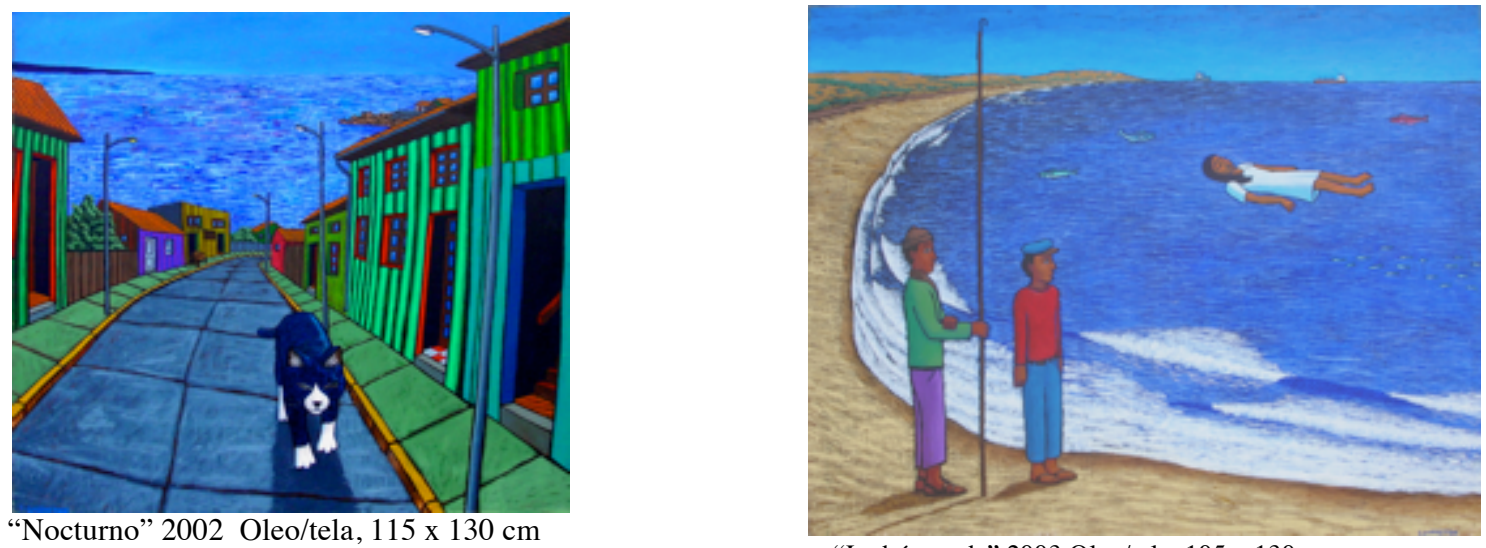

"La búsqueda" 2003 Oleo/tela 105 x 130

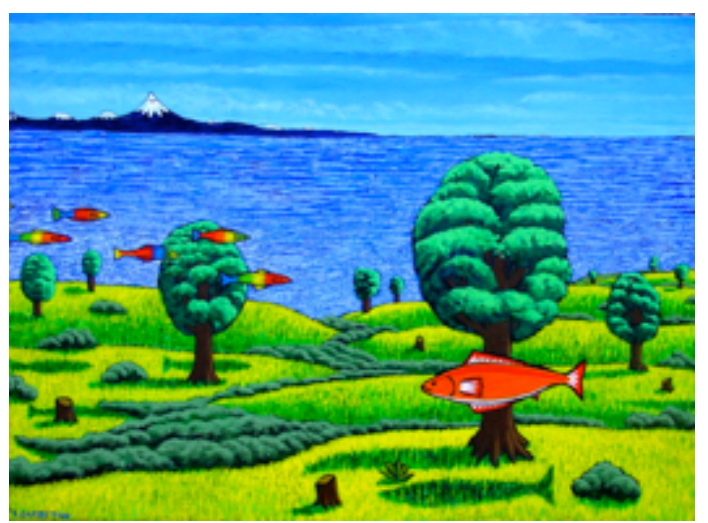

"Peces volando" 2002 Oleo/tela, 60 x $80 \mathrm{~cm}$.

http://www.albatique.com/Sebastian\%20Garreton\%20-\%200euvres\%20Originales.html http://www.rmm.cl/index_sub2.php?id_contenido=9662\&id_seccion=6031\&id_portal=730 http://revista.escaner.cl/

http://viveartechile.blogspot.cl/2010_02_01_archive.html 
$N^{\circ} 142$ ficha

\section{José Ignacio León}
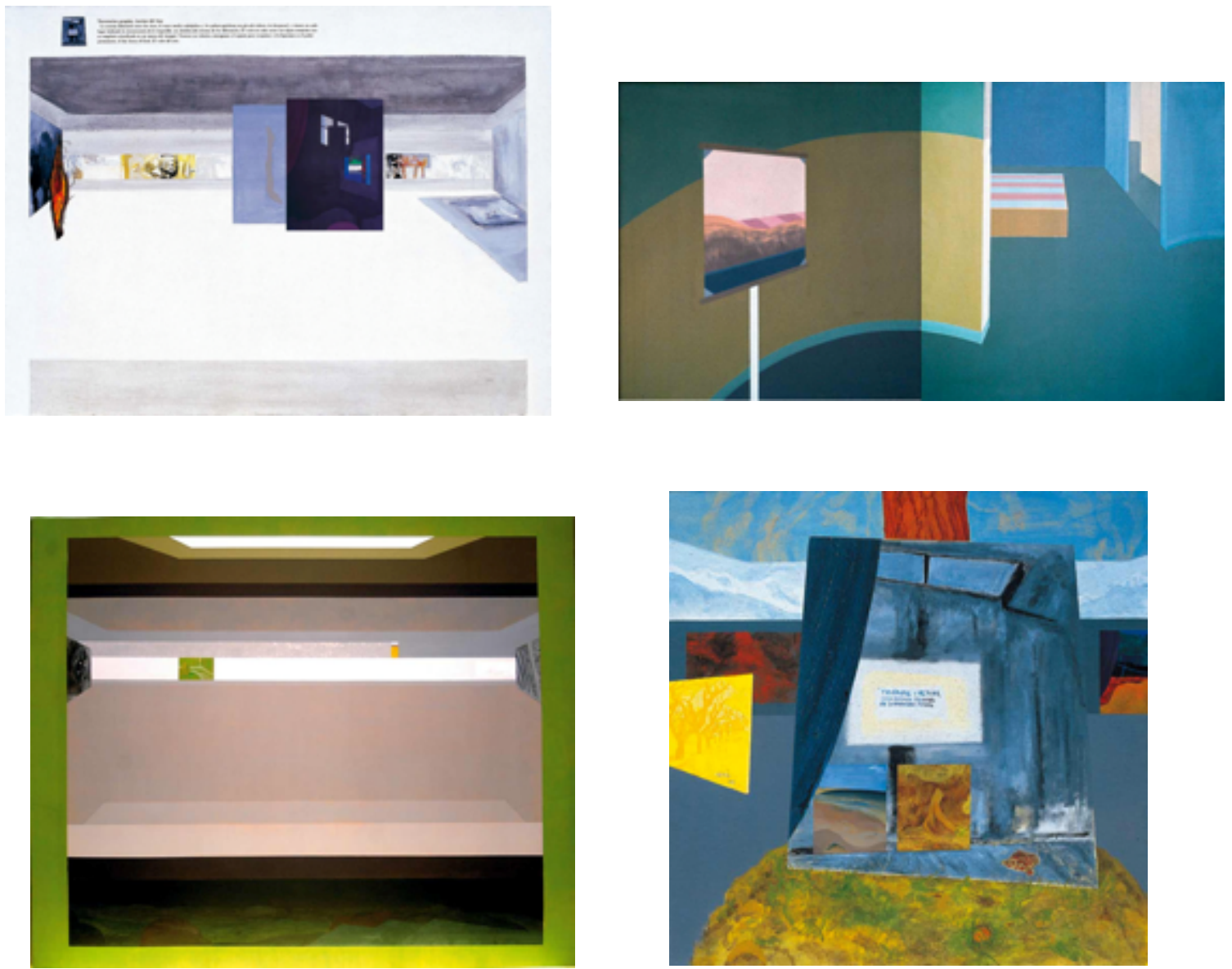

http://rtjoseignacioleon.blogspot.com/

www.artistasplasticoschilenos.cl/658/w3-article-39677.html

www.portaldearte.cl/autores/leon_jose.htm 


\section{Tatiana Álamos}
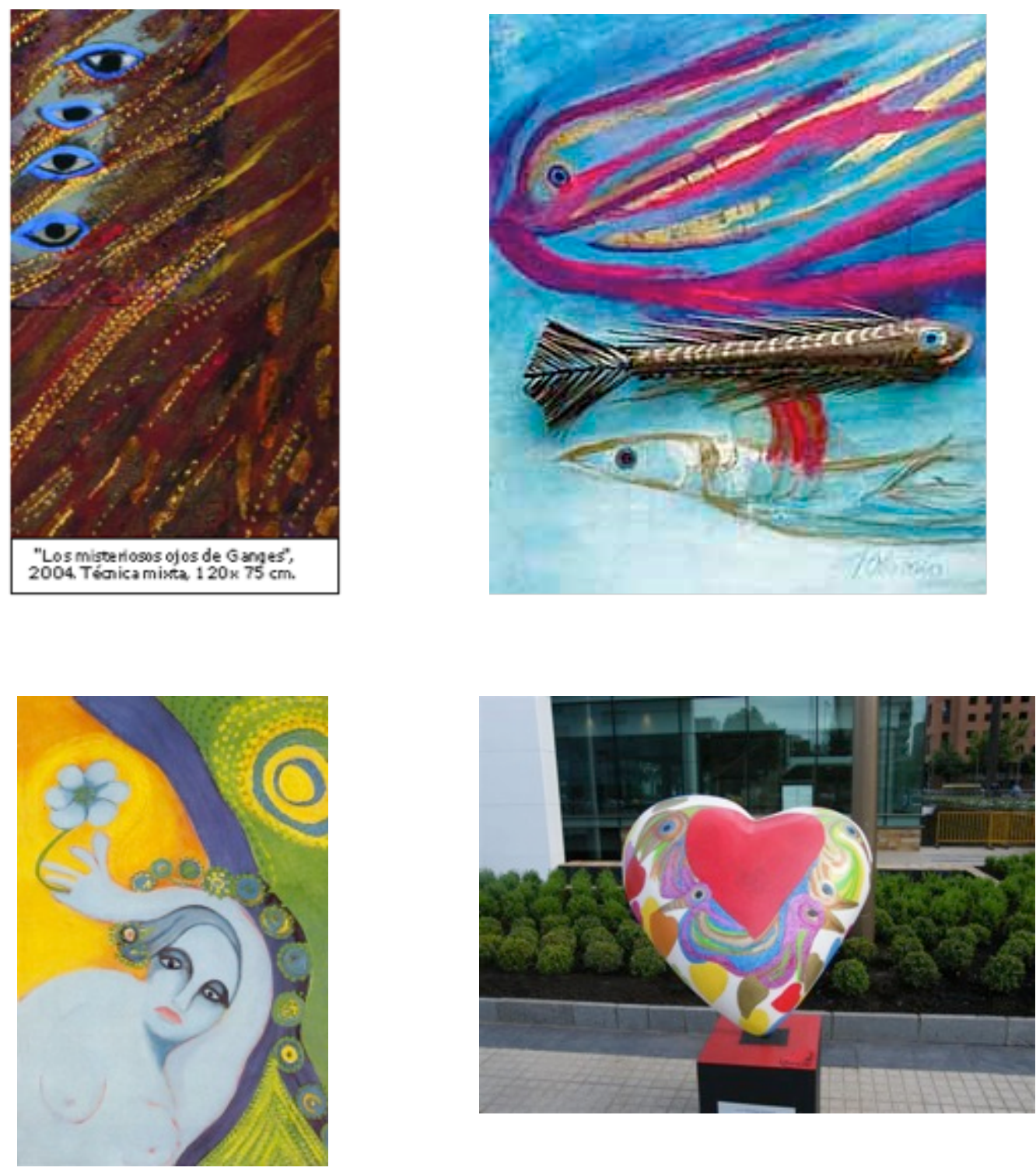

http://www.afteroffice.cl/2011/05/22/

https://www.flickr.com/photos/lapollera/4190106043

www.artistasplasticoschilenos.cl/658/w3-article-40391.html

www.portaldearte.cl/autores/alamos.htm 
$N^{\circ} 144$ ficha

\section{Patricia Claro}

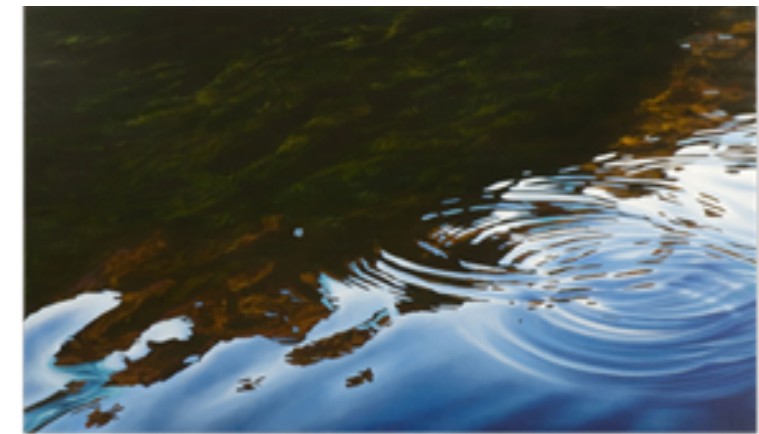

"Re-Corte de Agua",

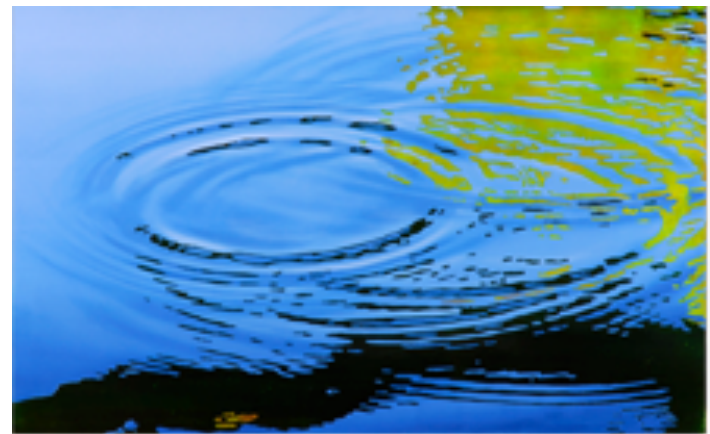

Distorsion $6.45 .15 " 60095 \mathrm{~cm}$ Oleo sobre

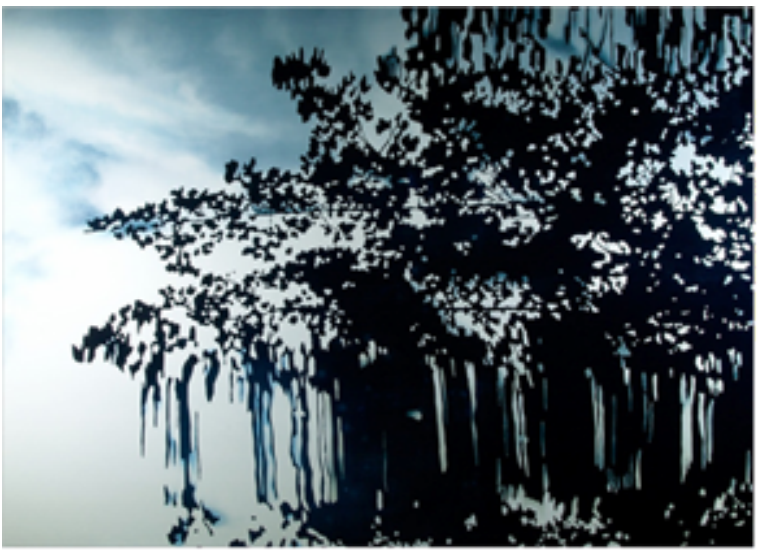

14hr45m36s óleo $130 \times 180$

http://www.patriciaclaro.com/

www.artistasplasticoschilenos.cl/658/w3-article-39898.html

http://www.latercera.com/noticia/cultura/2011/11/1453-406795-9-patricia-claro-presenta-sus-pinturas-y-videoen-galeria-animal.shtml 
$N^{\circ} 145$ ficha

\section{Paulina Beyer}

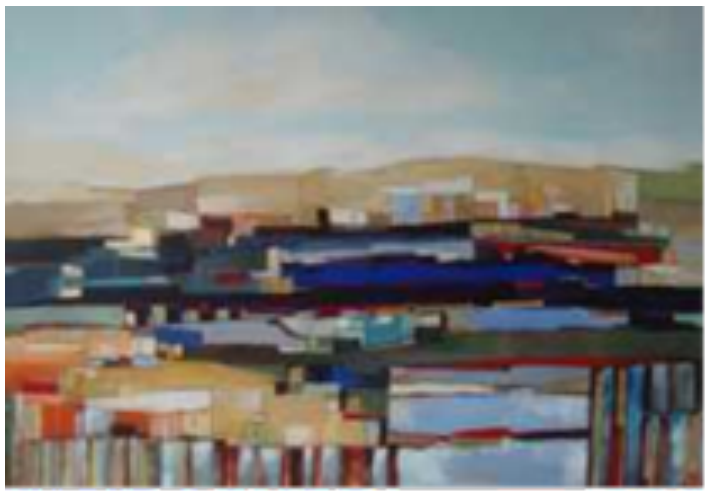

Sobre el Mar, acrilico Stela $70 \times 100 \mathrm{~cm}$. 2009

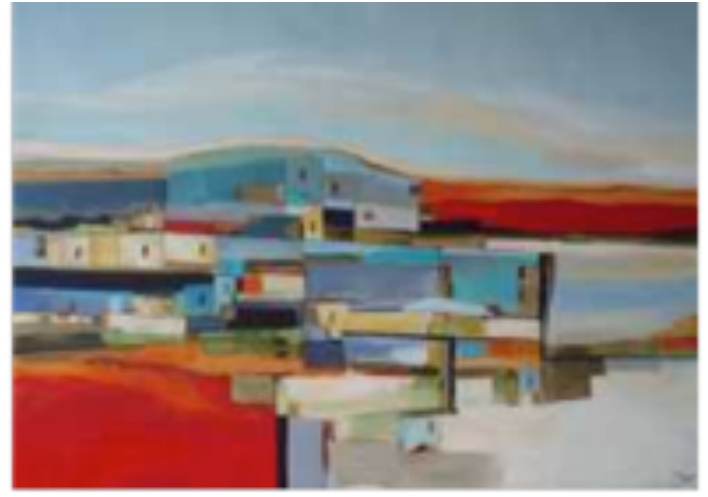

De Viista, Acrilico sobre tela, $70 \times 100 \mathrm{~cm}, 2009$

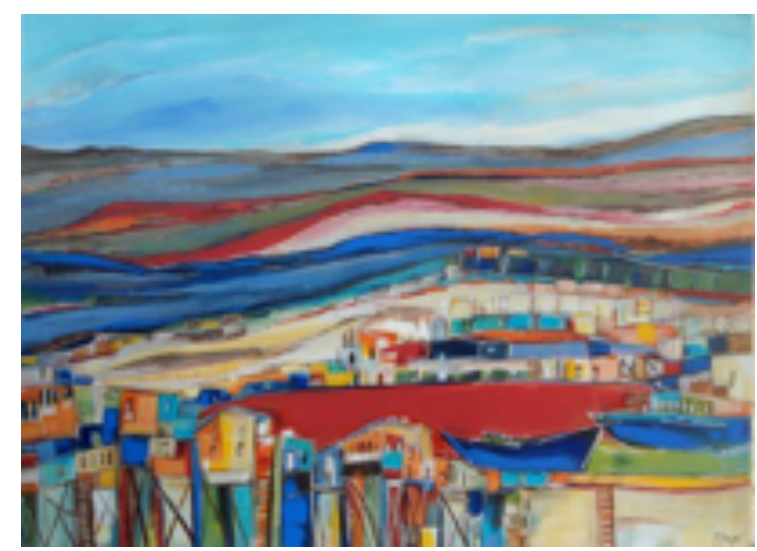

palafitos de castro 2014 mixta/tela $50 \times 70 \mathrm{~cm}$

http://www.paulinabeyer.cl/

http://www.portaldearte.cl/artistas_visuales/beyer_paulina.html http://www.revistasomos.cl/tag/paulina-beyer/ 
$N^{\circ} 146$ ficha

\section{Oscar Barra}
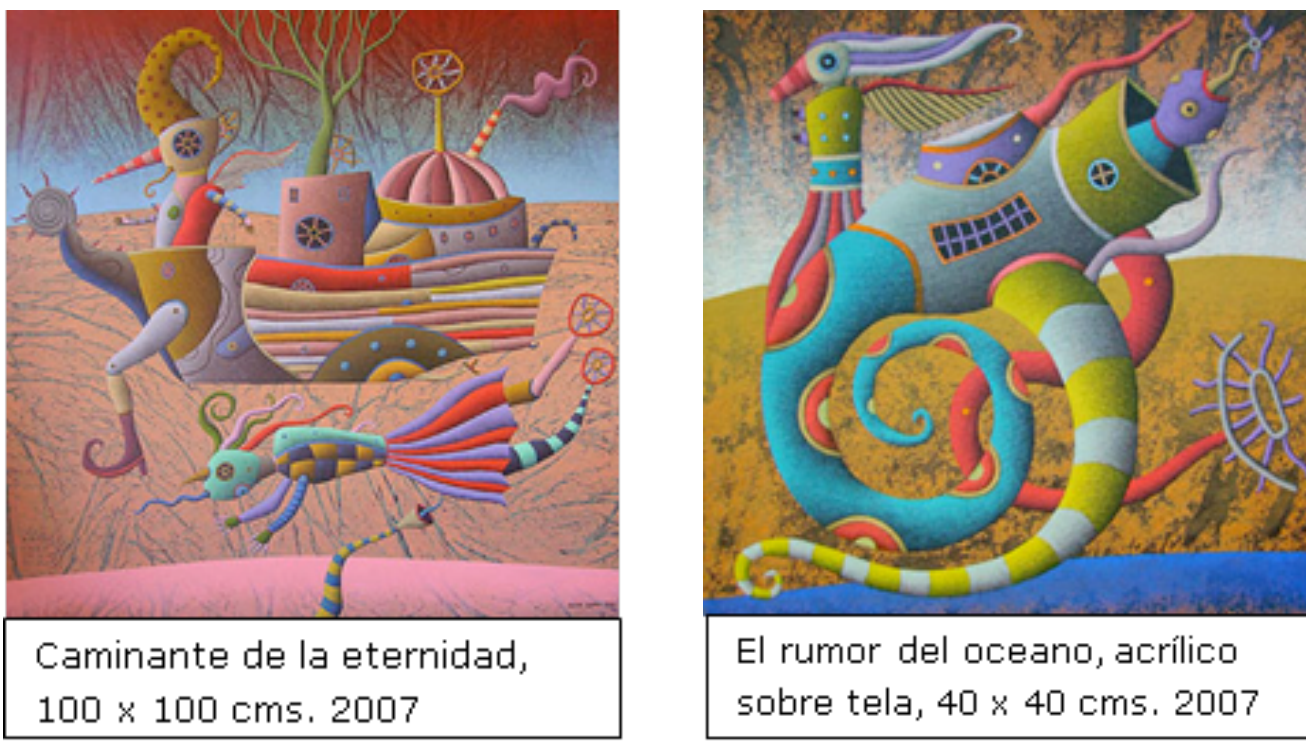

El rumor del oceano, acrílico sobre tela, $40 \times 40 \mathrm{cms} .2007$

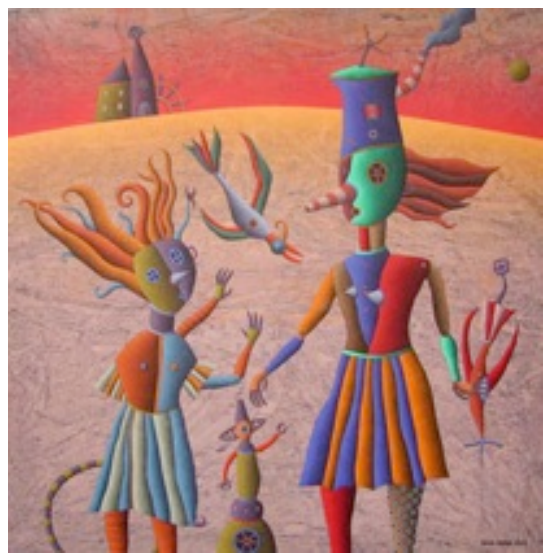

http://talleroscarbarra.blogspot.com/

http://oscarbarraobrasanteriores.blogspot.com/

www.portaldearte.cl/artistas_visuales/barra_oscar.html

www.artistasplasticoschilenos.cl/658/w3-article-40356.html 
$N^{\circ} 147$ ficha

\section{Ruperto Cádiz}
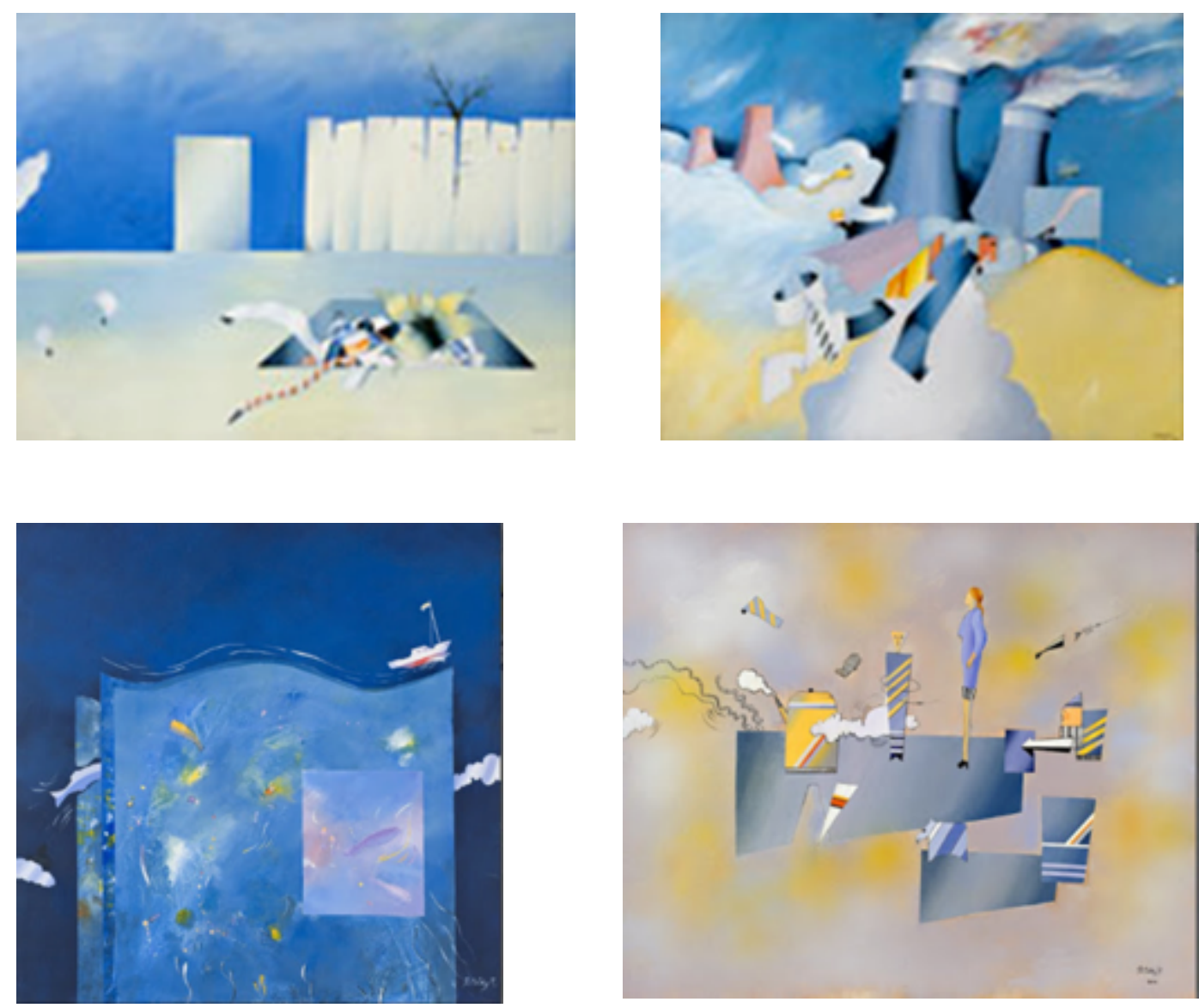

www.rupertocadiz.blogspot.com/ www.mnba.cl/617/w3-article-29909.html

http://arteayuda.cl/ruperto-cadiz-4/ 
$N^{\circ} 148$ ficha

\section{Amelia Errázuriz}

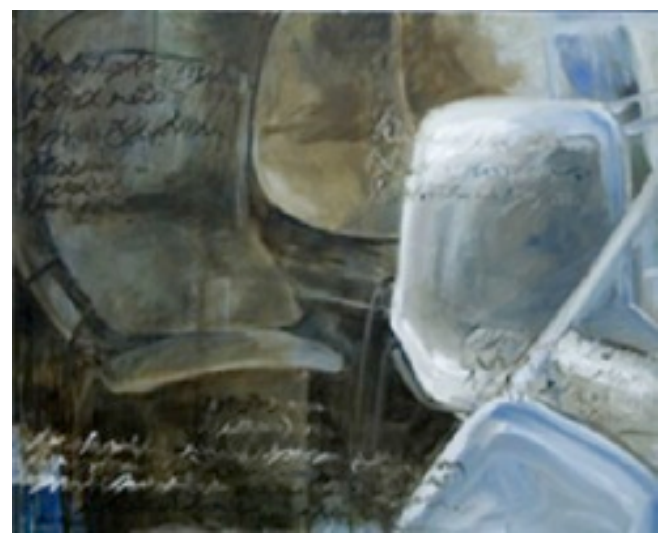

"Escritura blanca" 2008 mixta/tela 80x100 cm.

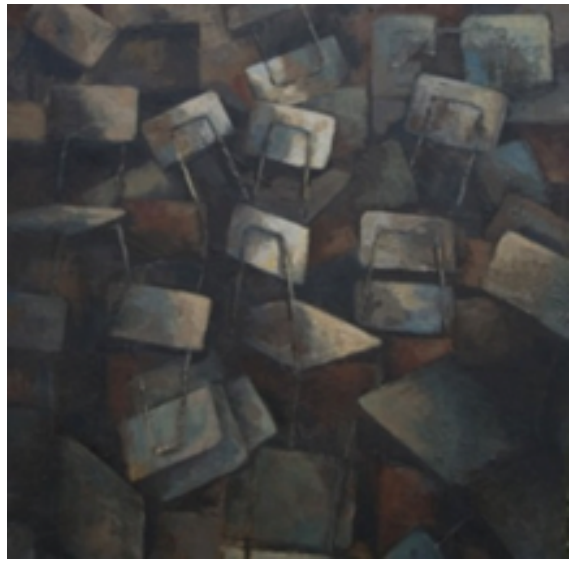

S/T 2008 mixta/tela 100x100 cm.

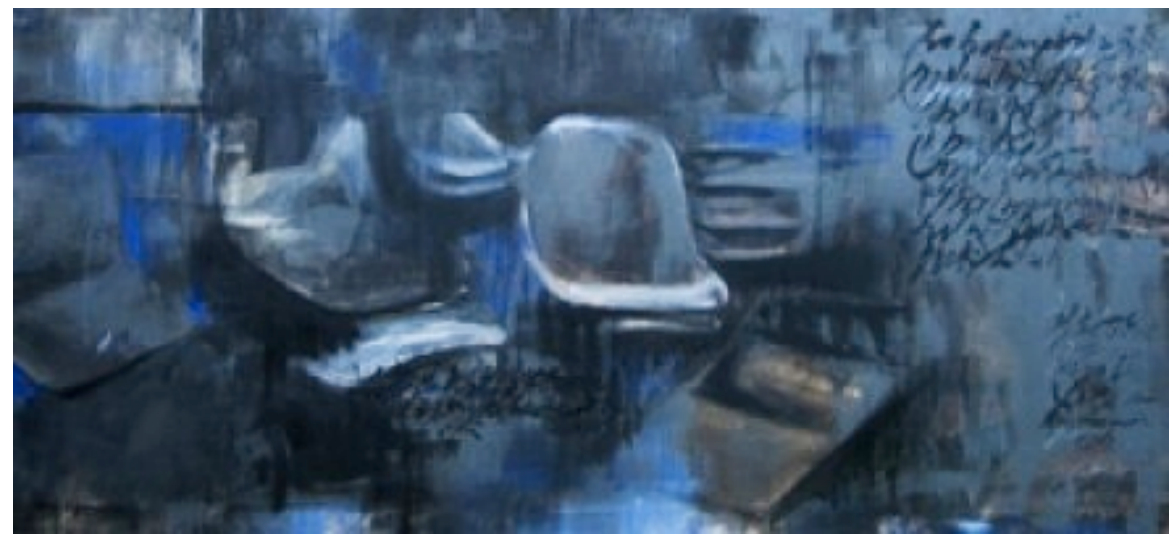

Escritura negra-azul 2008 oleo/tela $75 \times 150 \mathrm{~cm}$.

http://mocca.cl/es/detalle_artista.php?id=9

http://www.arteenlared.com/latinoamerica/mas-de-latinoamerica/la-artista-chilena-amelia-errazuriz-expone-enlima.html

www.arteallimite.com/galeria/artistas/amelia-errazuriz 
$N^{\circ} 149$ ficha

\section{Andrea Casanova}
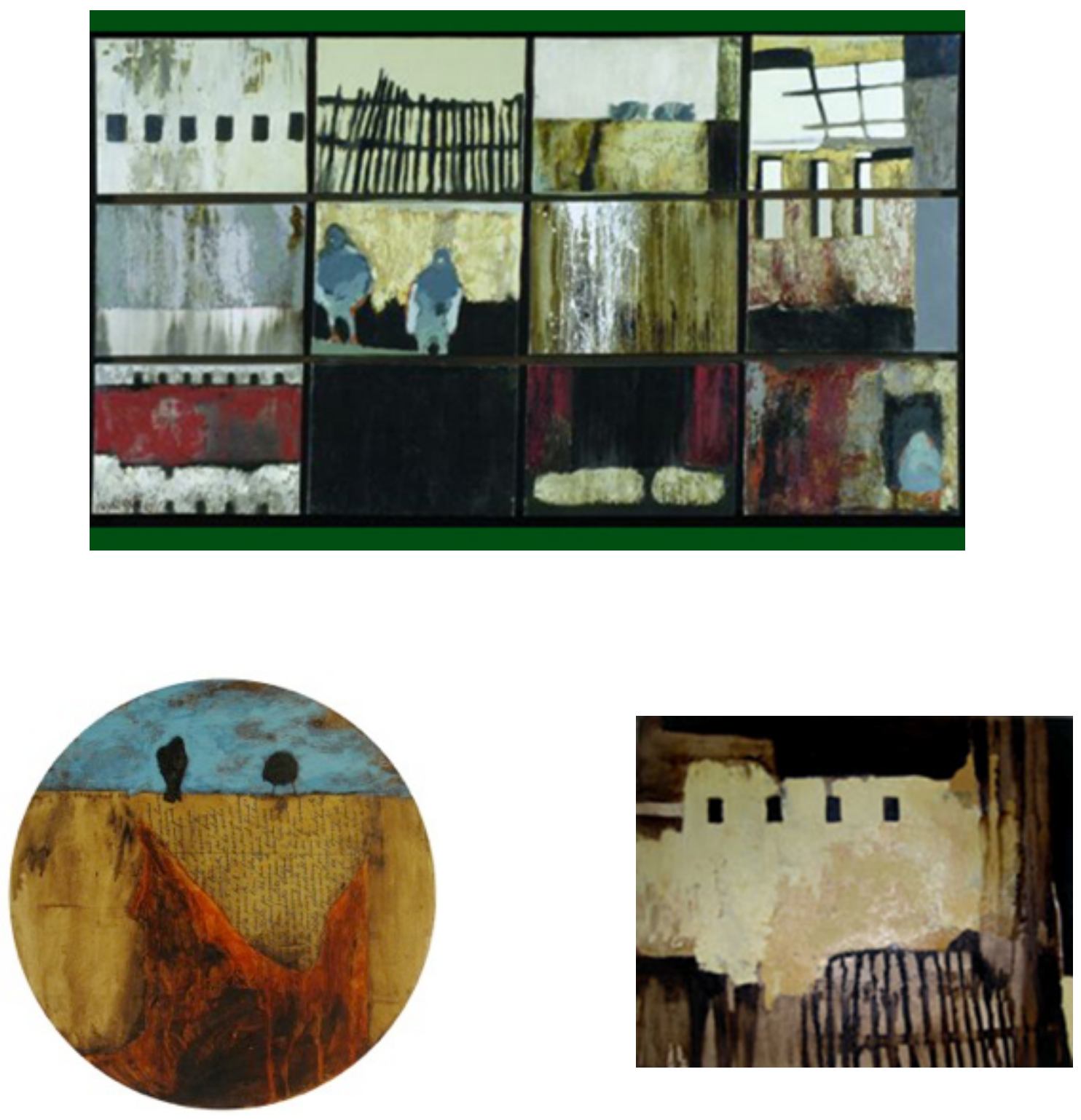

http://andreacasanova.cl/

http://www.galeriaceciliapalma.cl/obra-detalle.html/obra.id/1031/andrea-casanova-recuerdos-de-infancia 


\section{Carlos Araya (Carlanga)}

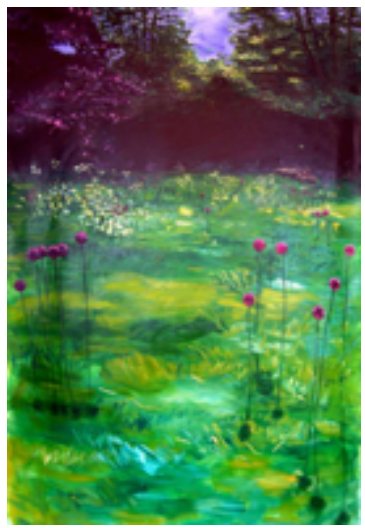

"Paysage bucolique 2 bis" oleo/tela

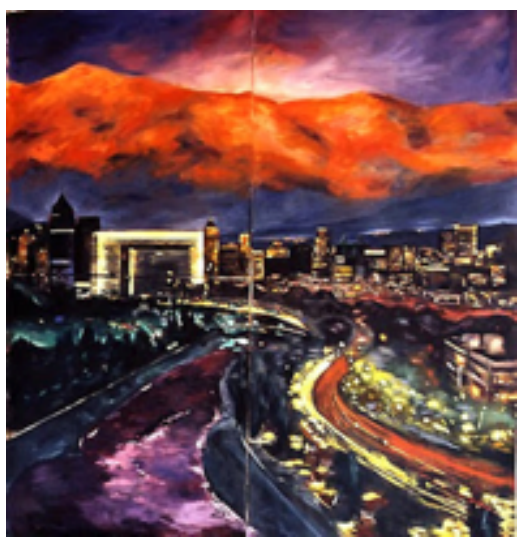

"Santiago" 2000, oleo/tela 250x250 cm.

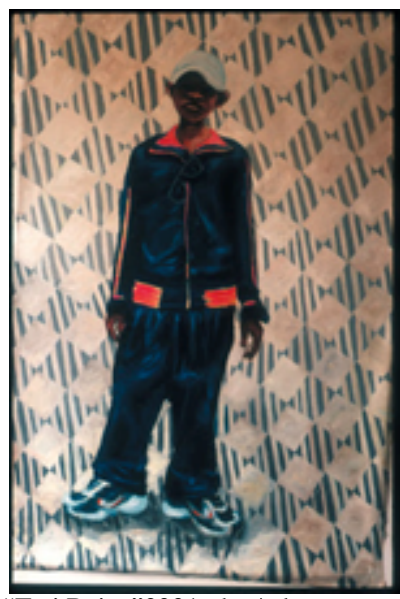

"Tati Beige"2001 oleo/tela $155 \times 105 \mathrm{~cm}$.

http://www.carlosaraya.com/fr/

www.artistasplasticoschilenos.cl/658/w3-article-40257.html http://www.klak.cl/portfolio/carlos-araya-carlanga-pintor/ 


\section{$N^{\circ} 151$ ficha}

\section{Carlos Eguiguren}

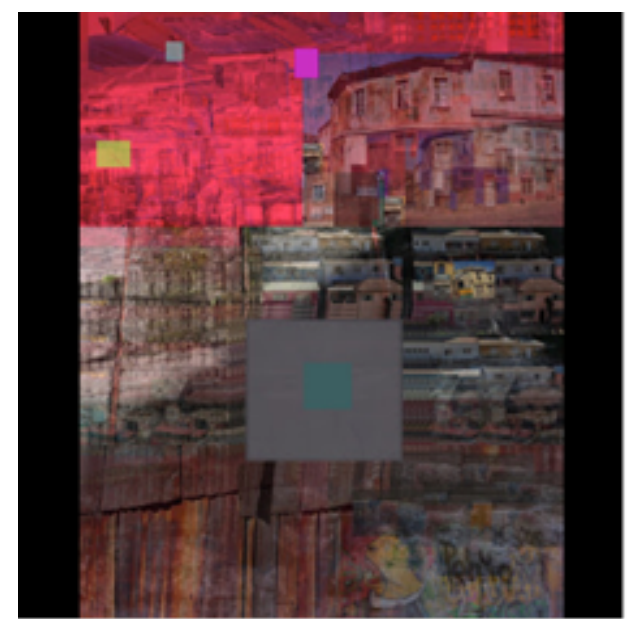

Manolo, mantenido ambicioso, Valparaiso $20081.25 \times 1.00 \mathrm{mts}$,

Imoreso en Lambda.

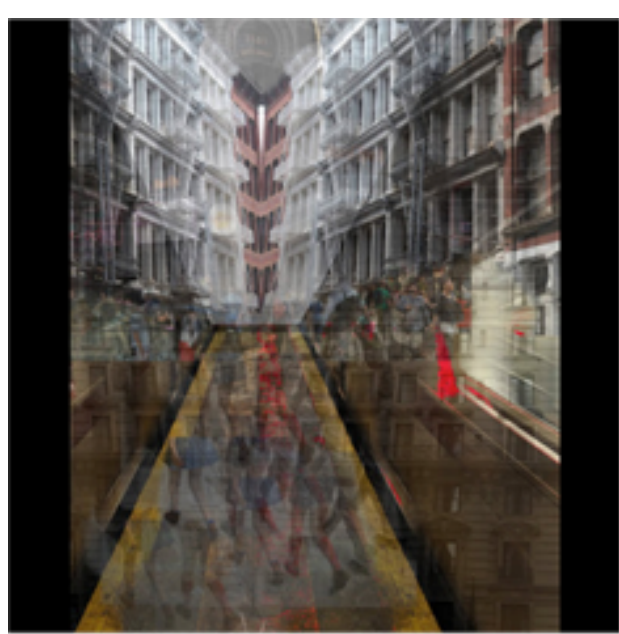

Walking (caminando), N.Y

Impresoln Lambda. 2009.

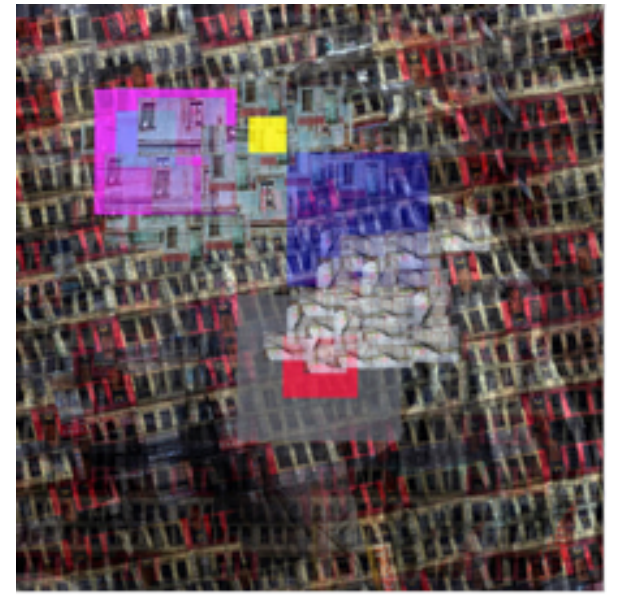

Ropos y Grises, Valparaiso

http://www.carloseguiguren.com/

www.mnba.cl/617/w3-article-29918.html

http://www.galeriaartespaco.com/\#!carlos-eguiguren/c11hn 
$N^{\circ} 152$ ficha

\section{Enrique Zamudio}

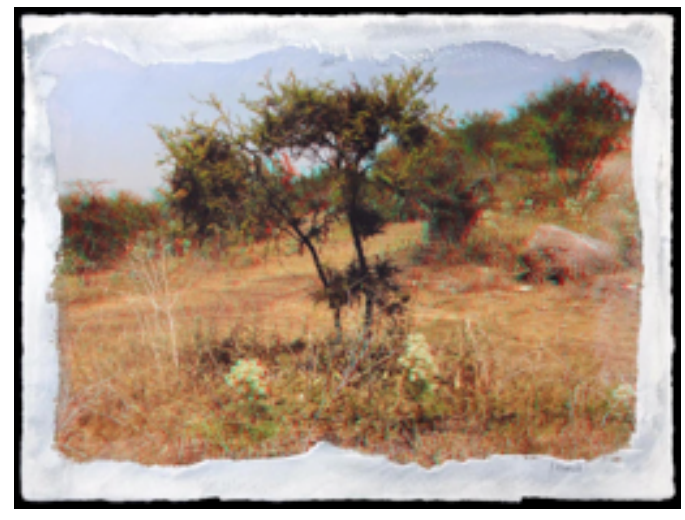

Serie Paisajes 3D, P. 142010

Fotografía estereoscópica, anáglifo digital, impresión inkjet 0.70 X 1.10

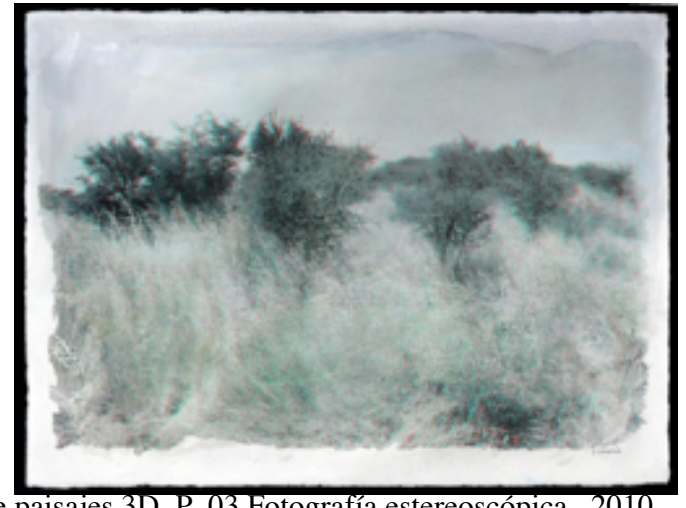

Serie paisajes 3D, P. 03 Fotografía estereoscópica, 2010 anáglifo, impresión inkjent $0,70 \times 1,10 \mathrm{mt}$

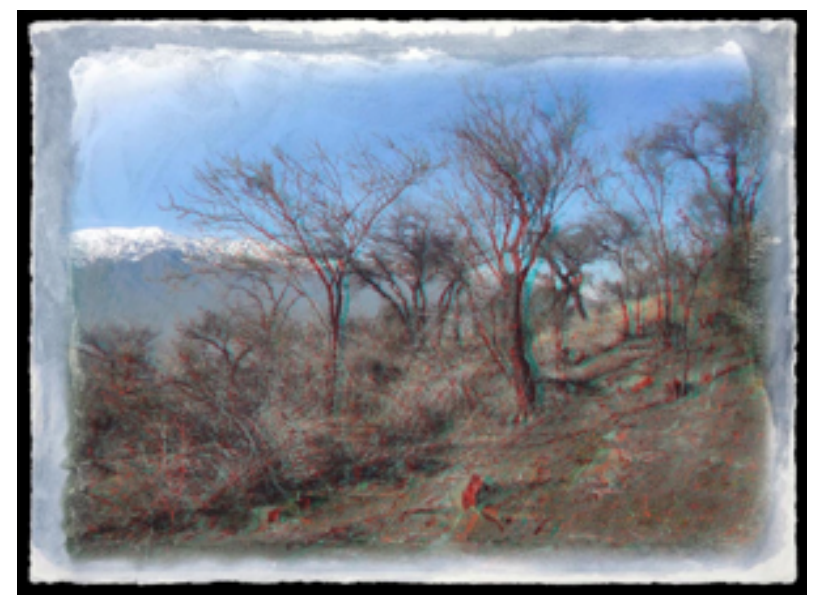

Serie paisajes 3D, P.10 Fotografía estereoscópica,

2010 anáglifo, impresión inkjent $0,70 \times 1,10 \mathrm{mt}$

http://rtenriquezamudio.blogspot.com/

http://enriquezamudio.cl/

www.artistasplasticoschilenos.cl/658/w3-article-40436.html

www.portaldearte.cl/autores/zamudio.htm 
$N^{\circ} 153$ ficha

\section{Silvia Gleisner}

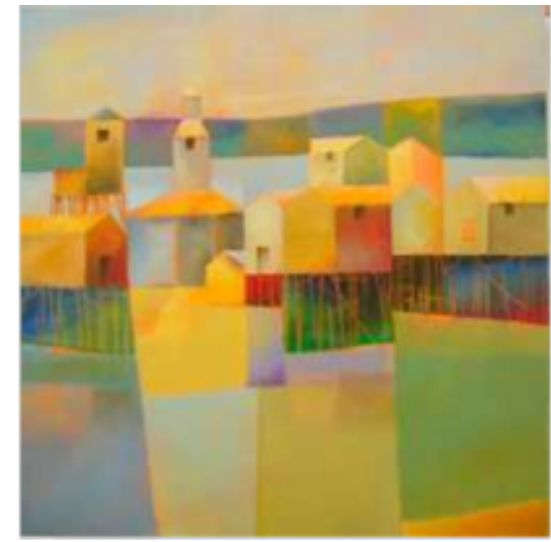

La lglesia junt o al Canal, Oleo sobre tela, $80 \times 60 \mathrm{~cm}, 2009$

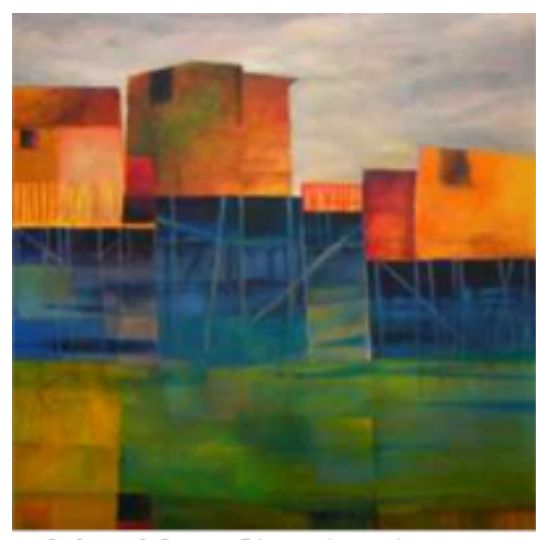

Sobre el Agua, Oleo sobre tela

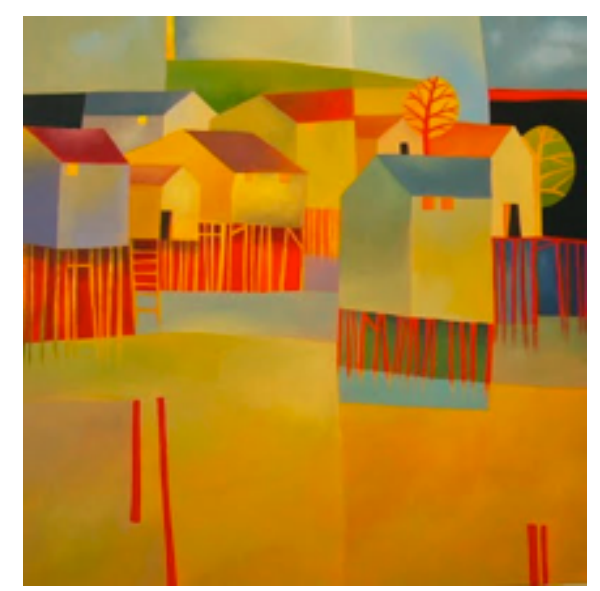

Palafitos en verano" 2007 oleo/tela 100x100 cm.

http://galerias.artelista.com/montecatinicl/artistas/silvia-gleisner-biografia.html www.portaldearte.cl/artistas_visuales/gleisner_silvia.html

www.arteallimite.com/archivos/curriculums/silvia-gleisner.pdf

http://isabelgutierrez.blogspot.com/2009/07/el-arte-que-me-inspira-los-lugares.html 


\section{José Balmes Parramón}
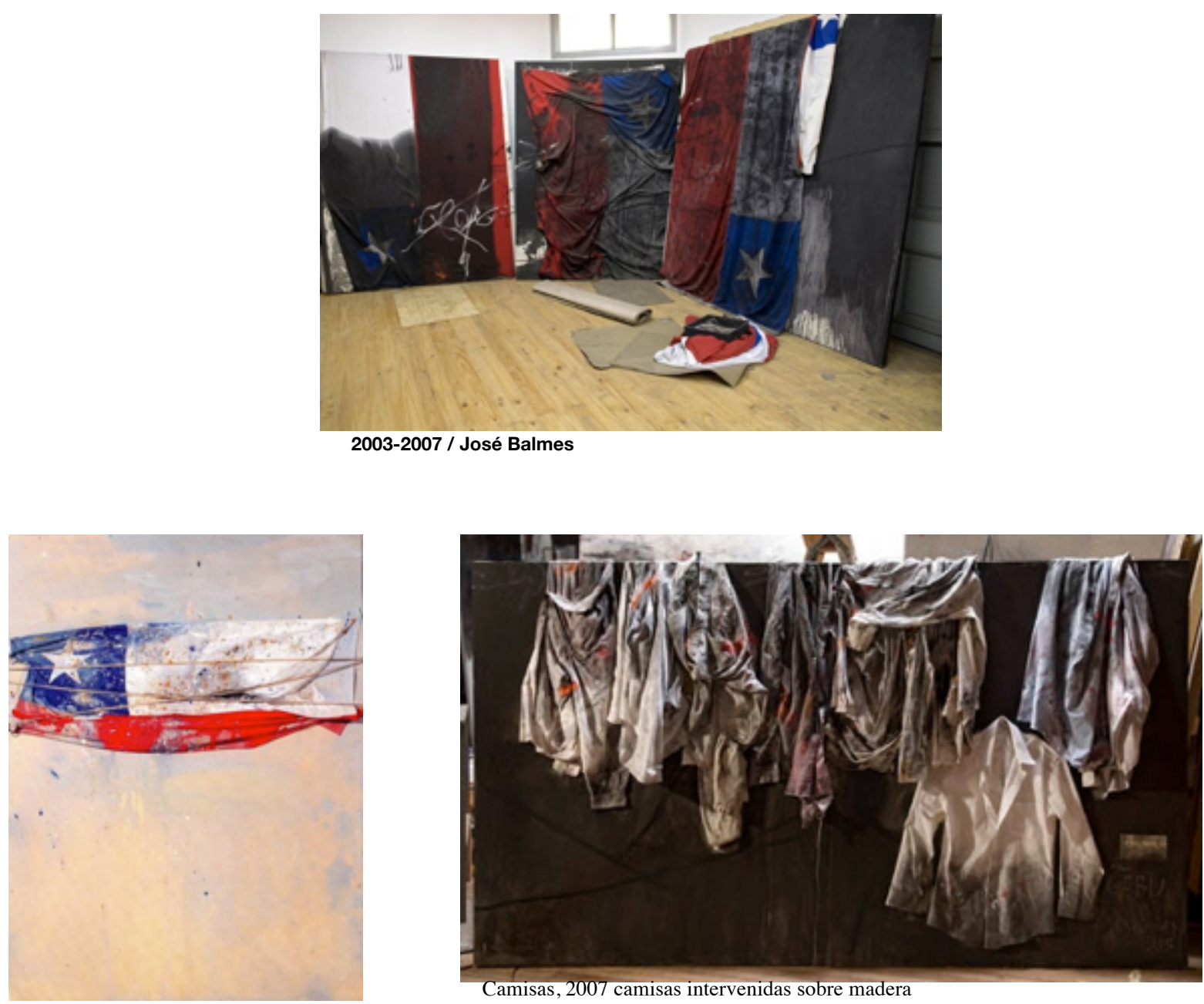

"Bandera" 2001 Bandera, oleo/madera

Camisas, 2007 camisas intervenidas sobre madera

www.artistasplasticoschilenos.cl/658/w3-article-39918.html

www.portaldearte.cl/autores/balmes.htm

http://hokidanock-art-studios.blogspot.com/2010/07/jose-balmes-parramon.html

http://www.latinartmuseum.com/balmes.htm 


\section{Margarita Echeñique}

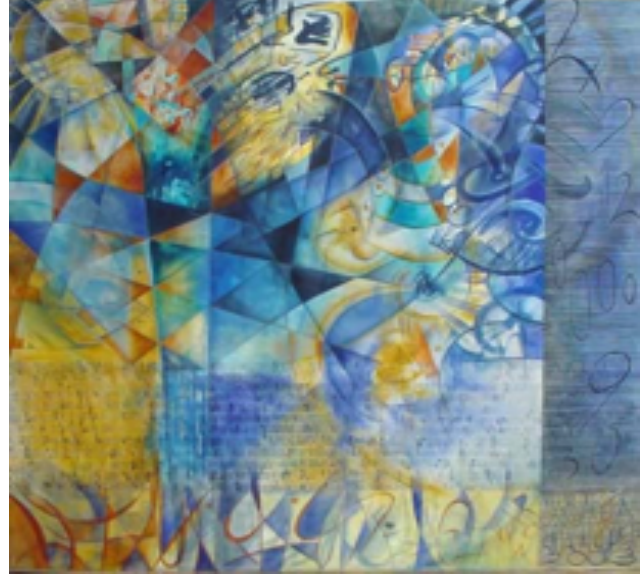

Anuncio, 2003. Acrílico / tela, 171 x $161 \mathrm{~cm}$.

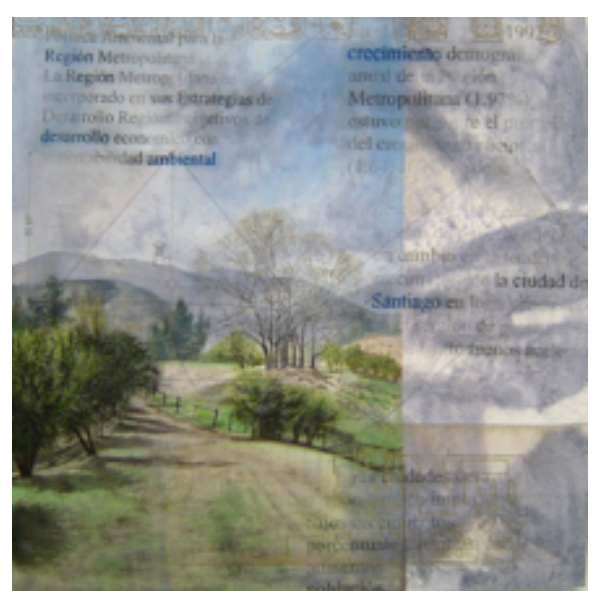

Vuelta I. 2004 Tinta acrílica / tela, 120,4 x 120,4 cm.

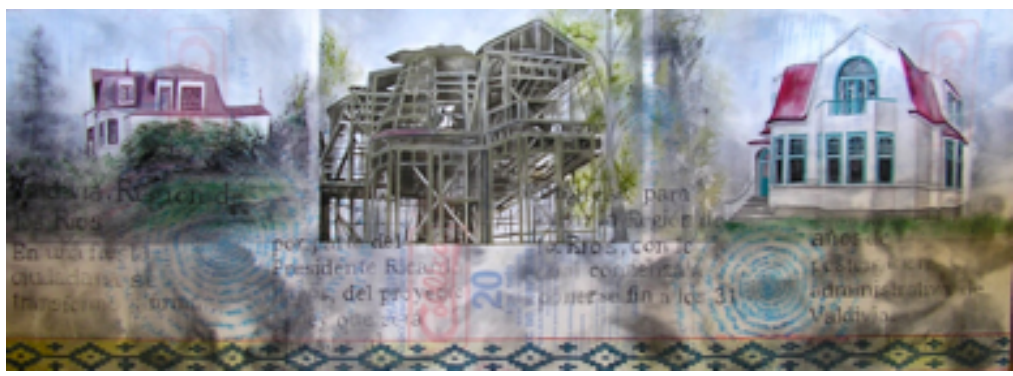

Conservación IV. 2006 Técnica mixta / tela. 72 x 200 cm.

http://margaritaecheniqueb.blogspot.com/ www.tallerartepicarte.blogspot.com/ 


\section{Luz María Benavente}
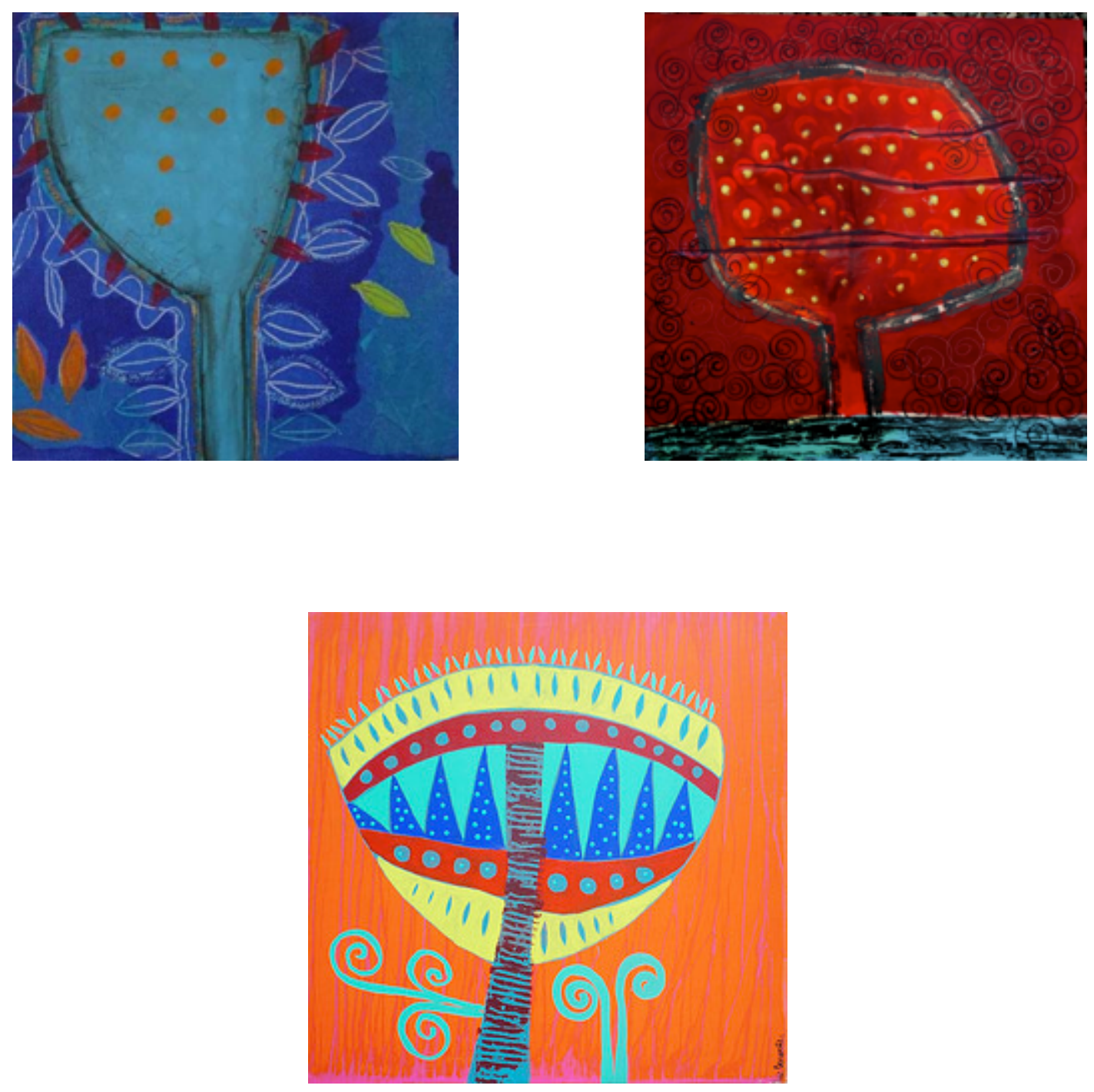

http://www.luzmaria.cl/

http://www .artdealers.cl/v1/artistas.php?tipo=6

https://es.pinterest.com/luzbenavente/ 


\section{Rodrigo Yañes}
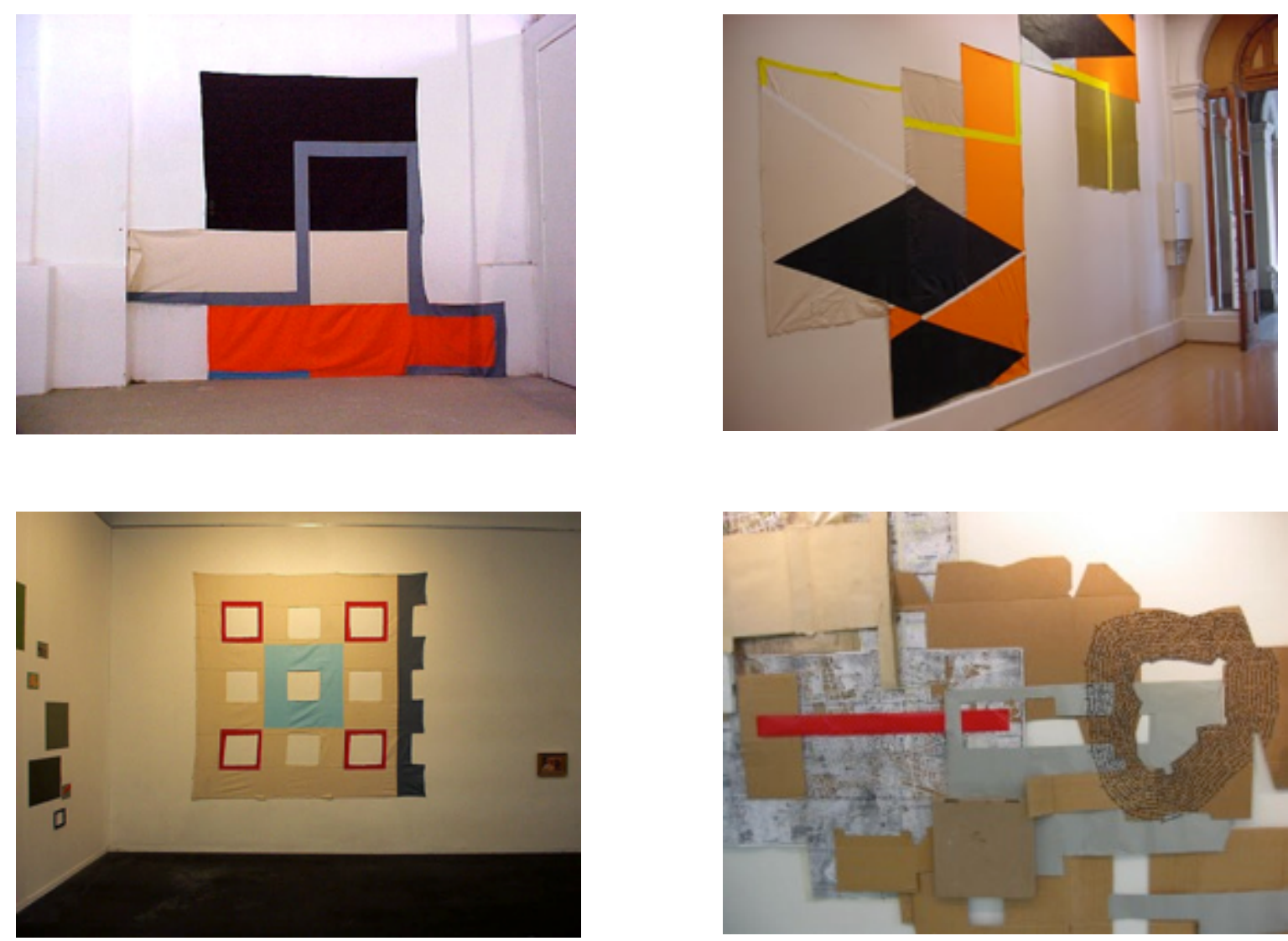

http://rtrodrigoyanes.blogspot.com/

http://rodrigoyanes.blogspot.com/

https://cajanegrartesvisuales.wordpress.com/rodrigo-yanes/

http://diario.elmercurio.com/detalle/index.asp?id=\{ede160d0-fbcc-4a80-b701-def534ab1f76 $\}$ 


\section{Claudio Correa}

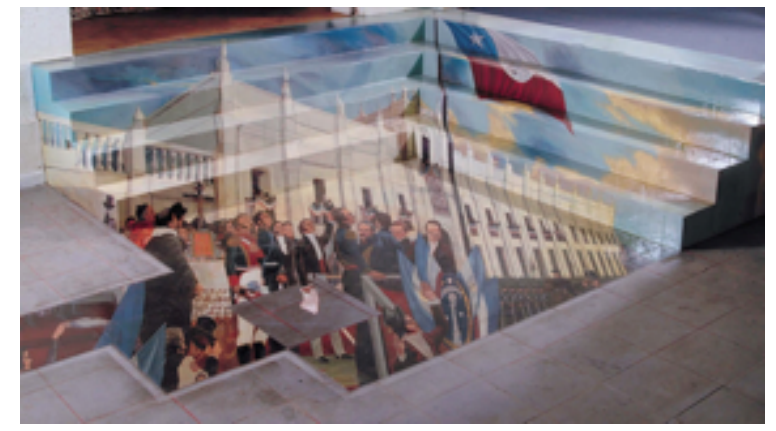

Declaración de Independencia" óleo/papel autoadhesivo. "anamorfosis" sobre el piso y parte la escalera de acceso a la terraza y parte del suelo.

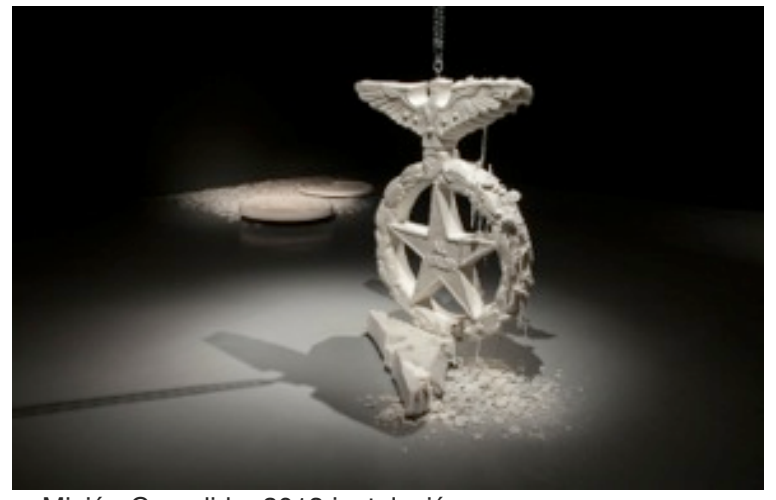

Misión Cumplida. 2013 instalación

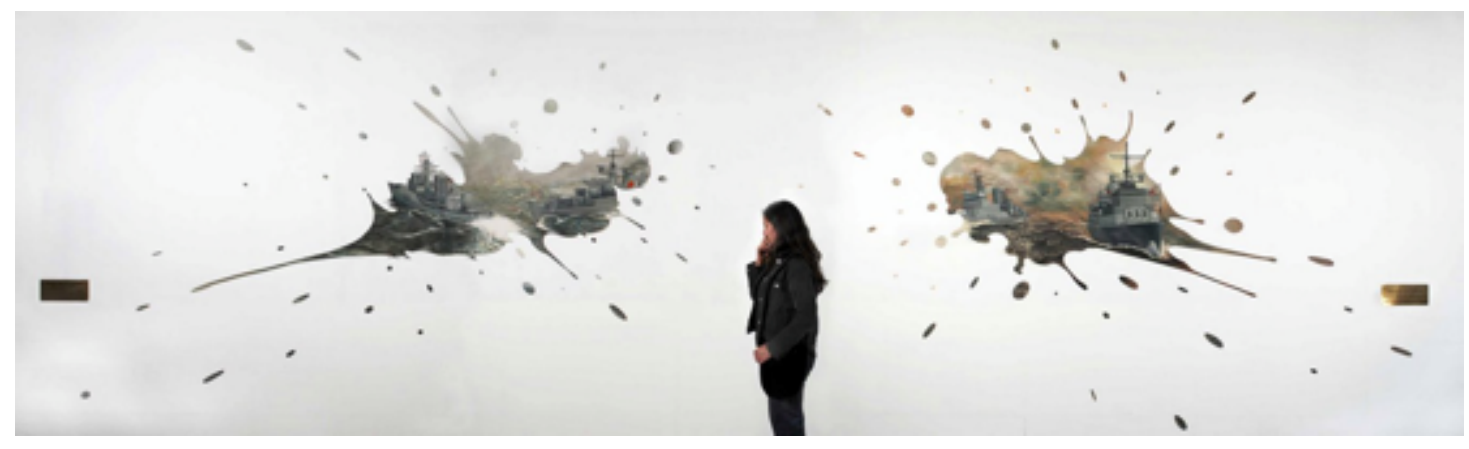

Combate chileno-japonés, 2002

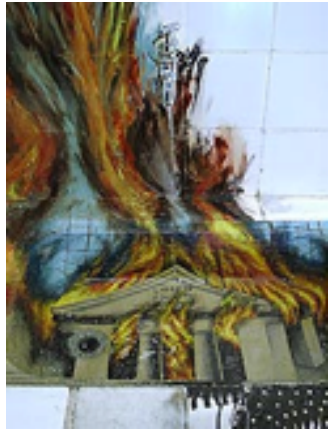

Autosuficiencia, 2003 (detalle)

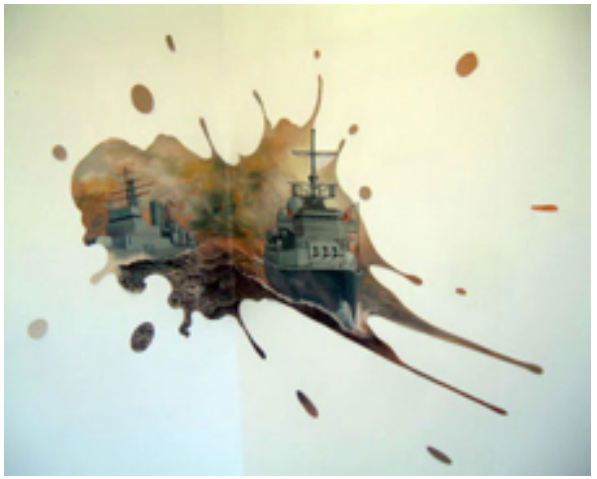

Combate chileno-japonés, 2002 (detalle)

http://www.galeriapready.cl/\#!claudio-correa/c6cp www.artistasplasticoschilenos.cl/658/w3-article-39802.html www.portaldearte.cl/autores/correa_claudio2.htm www.artishock.cl/tag/claudio-correa/

http://universes-in-universe.de/car/habana/bien8/cabana/e-tour-16.htm https://claudiocorreavassallo.wordpress.com/2014/09/15/dossier-de-obra/ 


\section{Enrique Matthey}
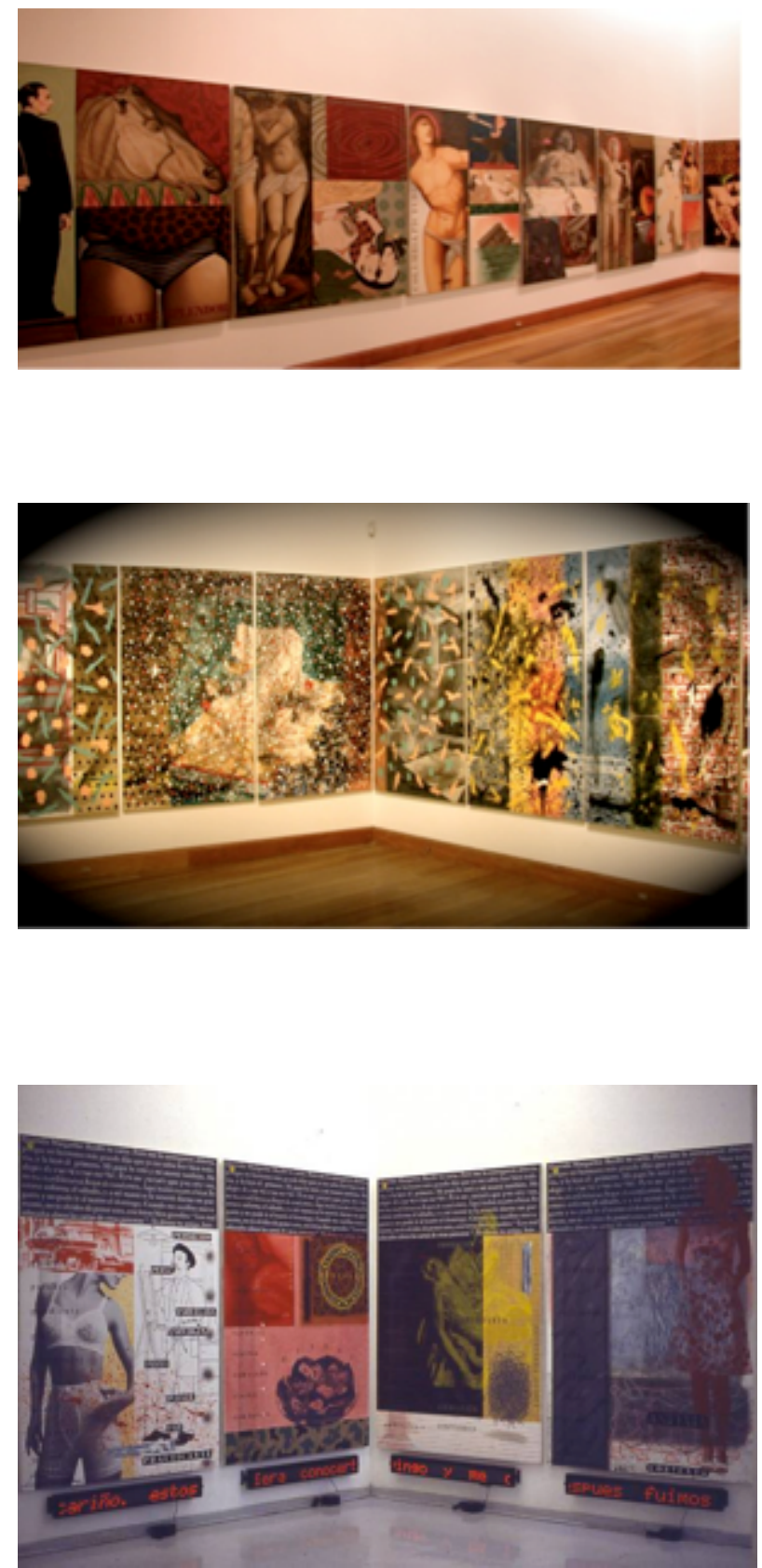

http://rtenriquematthey.blogspot.com/ www.artistasplasticoschilenos.cl/658/w3-article-39617.html

www.portaldearte.cl/autores/mathey.htm

http://galeriagm.cultura.gob.cl/coleccion_artista/e/38 


\section{Jorge Vilches}
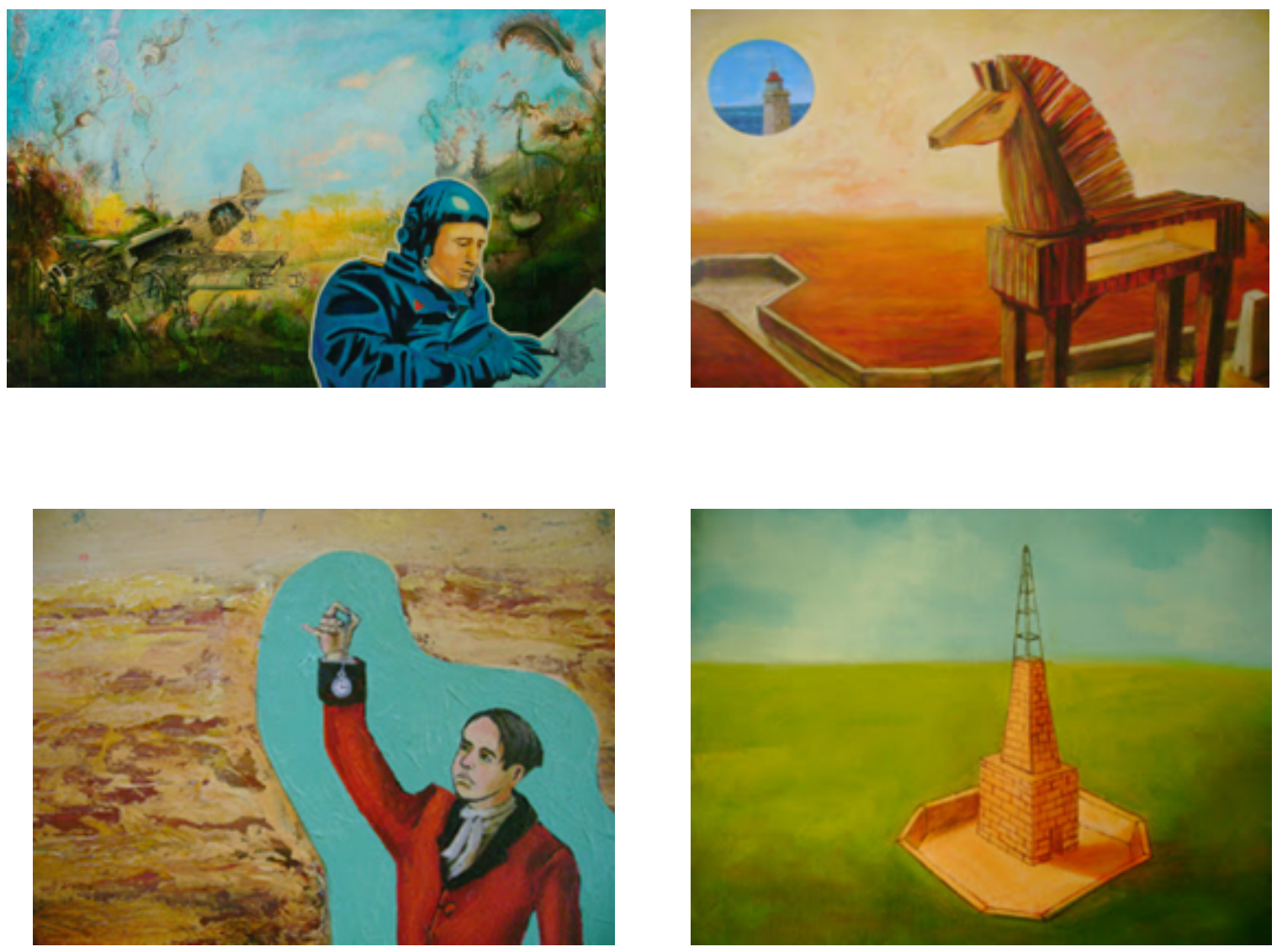

http://rtjorgevilches.blogspot.com/

http://www.biobiochile.cl/2013/07/29/tierra-de-nadie-la-nueva-exposicion-de-jorge-vilches-en-la-galeria-espora.shtml

http://www.culturallascondes.cl/home/la-mirada-pertinaz

https://www.flickr.com/photos/jorgevilches/sets/72157624638770199/ 


\section{Alejandro Quiroga Vial}
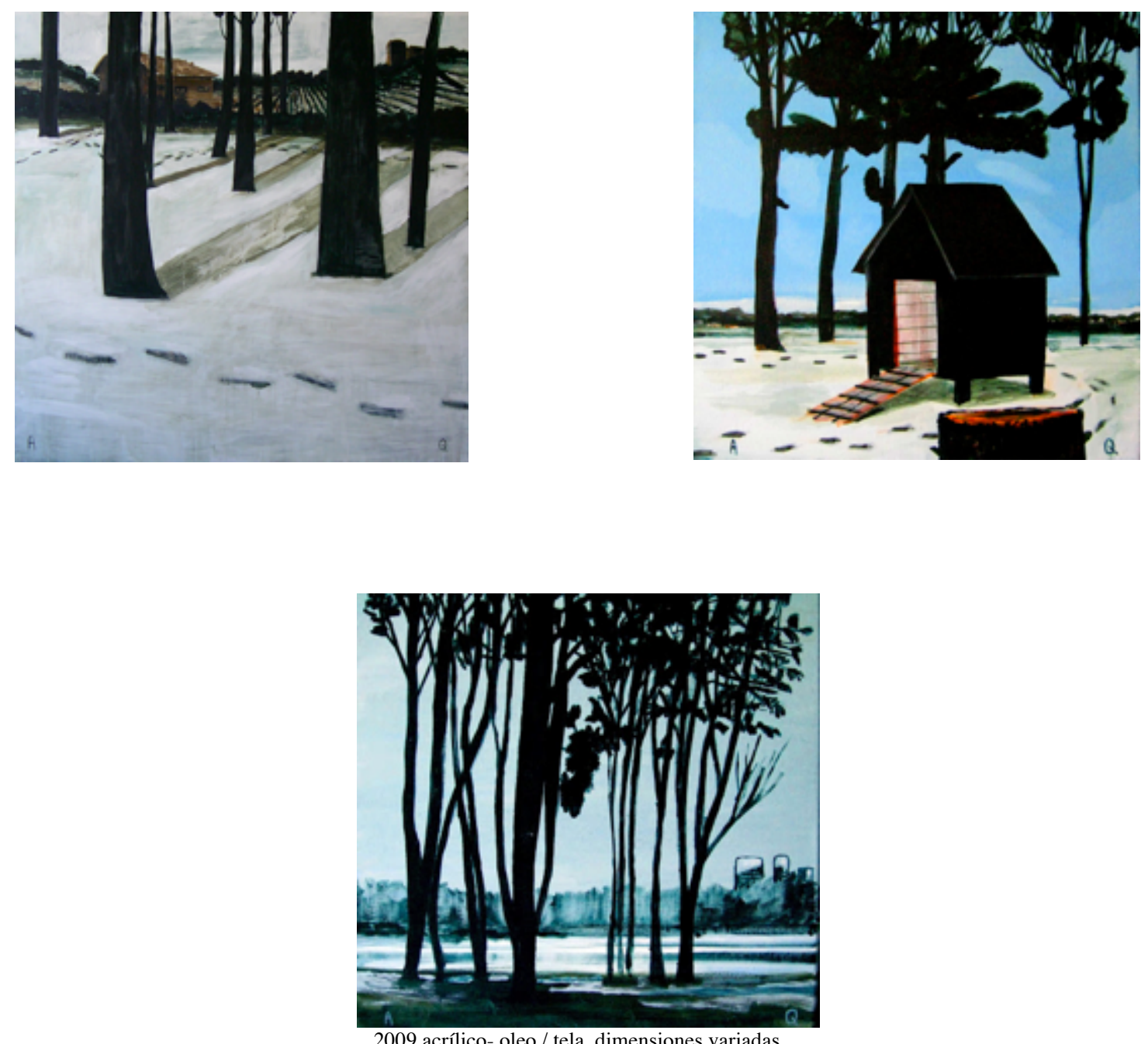

http://elcanoa.blogspot.cl/2009/07/pinturas-recientes-2009.html http://artenlinea.com/portfolios?page $=4$

http://www.portaldearte.cl/agenda/pintura/2005/

http://www.portaldearte.cl/agenda/pintura/2005/alejandro_quiroga.htmalejandro_quiroga.htm 
$\mathrm{N}^{\circ} 162$ ficha

\section{Muños de Marco}
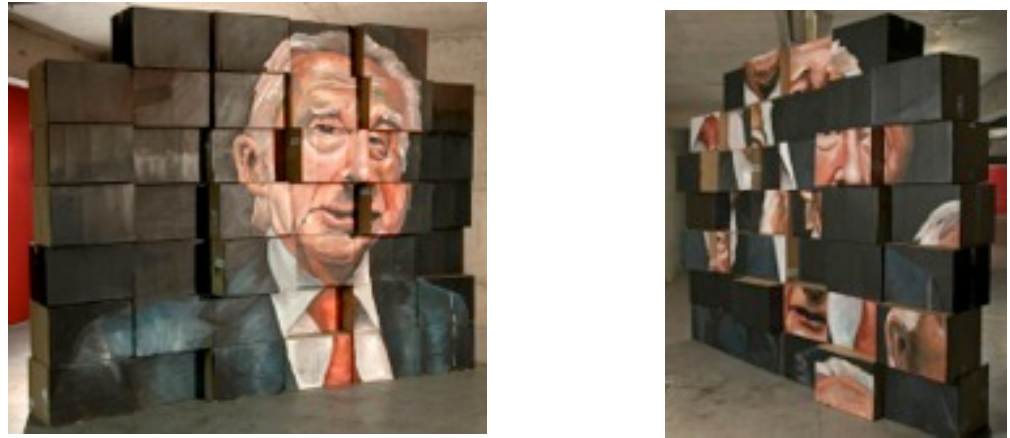

Muñoz de Marco, "Horst Paulmann” (2013), acrílico sobre 40 cajas de cartón, 300 x 250 cm.

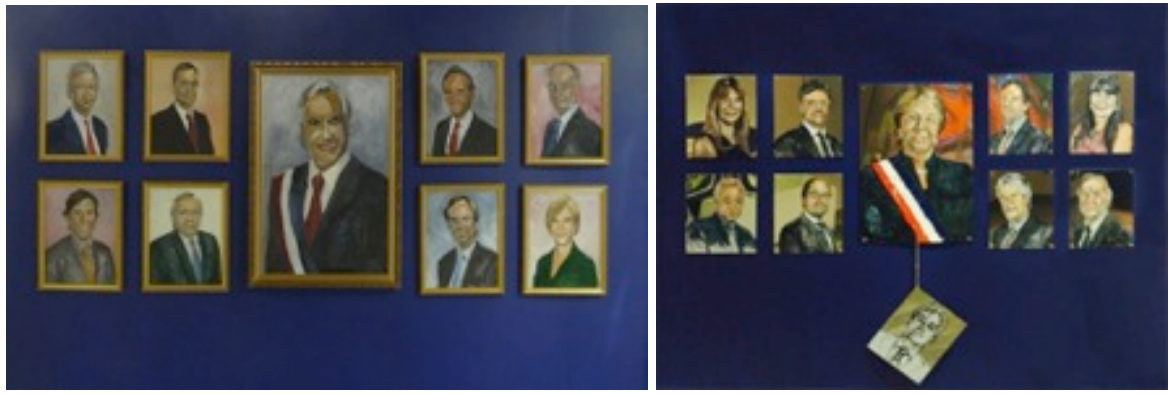

Gabinetes I y II, Muñoz de Marco, (2015), políptico de óleo/tela y oleo/acero.

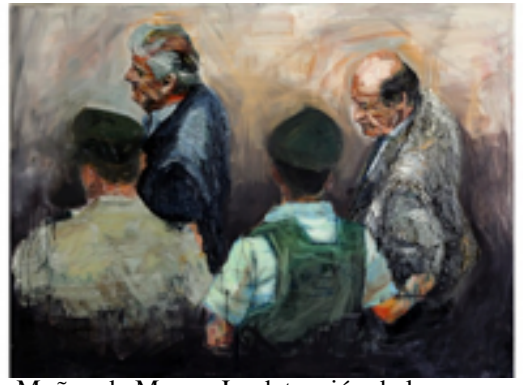

Muñoz de Marco, La detención de los Carlos (2015), óleo sobre tela, 90 × $70 \mathrm{~cm}$.

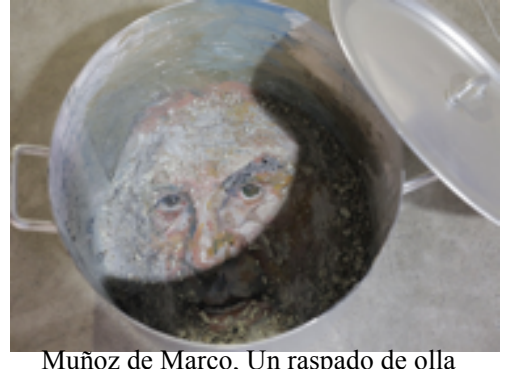

Muñoz de Marco, Un raspado de olla para Iván Moreira (2015), óleo sobre alıminin $80 \mathrm{~cm}$ diámetro

http://www.eldinamo.cl/cultpop/2015/04/11/munoz-de-marco-el-artista-chileno-que-retrata-a-los-poderosos-de-siempre/

http://www.balmacedartejoven.cl/2014/05/eris-choro-o-eris-paulmann-parte-ciclo-2014-en-la-galeria-balmaceda-arte-joven/ http://www.elmostrador.cl/cultura/2015/08/03/politicos-y-celebridad-la-exposicion-que-inquieta-a-frei-y-a-empresarios-chilenos/ 


\section{Ignacio Gumucio}

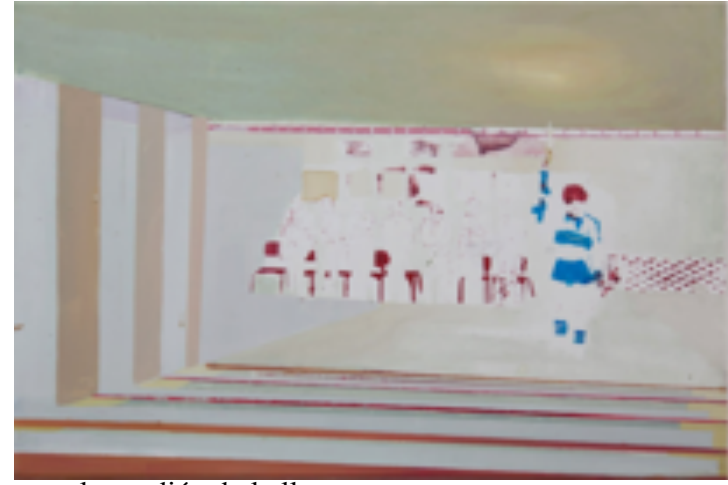

el guardián de la llama

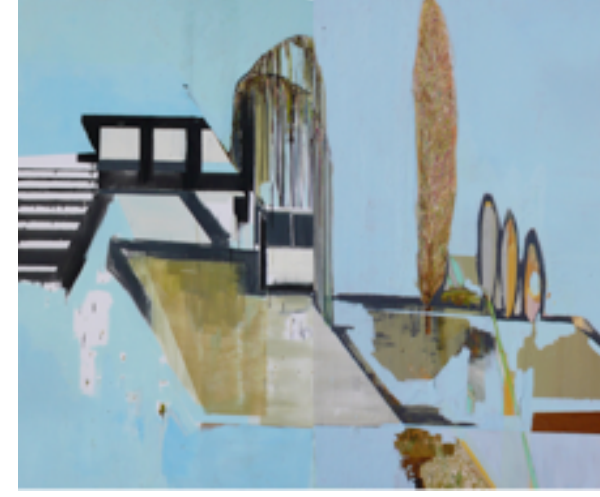

Árboles amigos”, 2012 mixta/tela

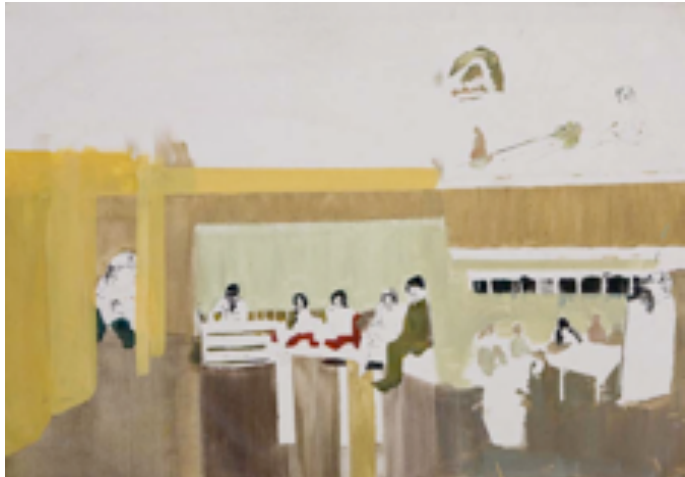

S/T 2012 mixta/tela

http://www.galeriaafa.com/?portfolio=obras-de-ignacio-gumucio http://www.mac.uchile.cl/exposiciones/otrositio/expoemergentes $1 . \mathrm{html}$ http://www.arte-sur.org/es/artistas/ignacio-gumucio-2/attachment/hg-copy-2/ 


\section{Iván Durán}
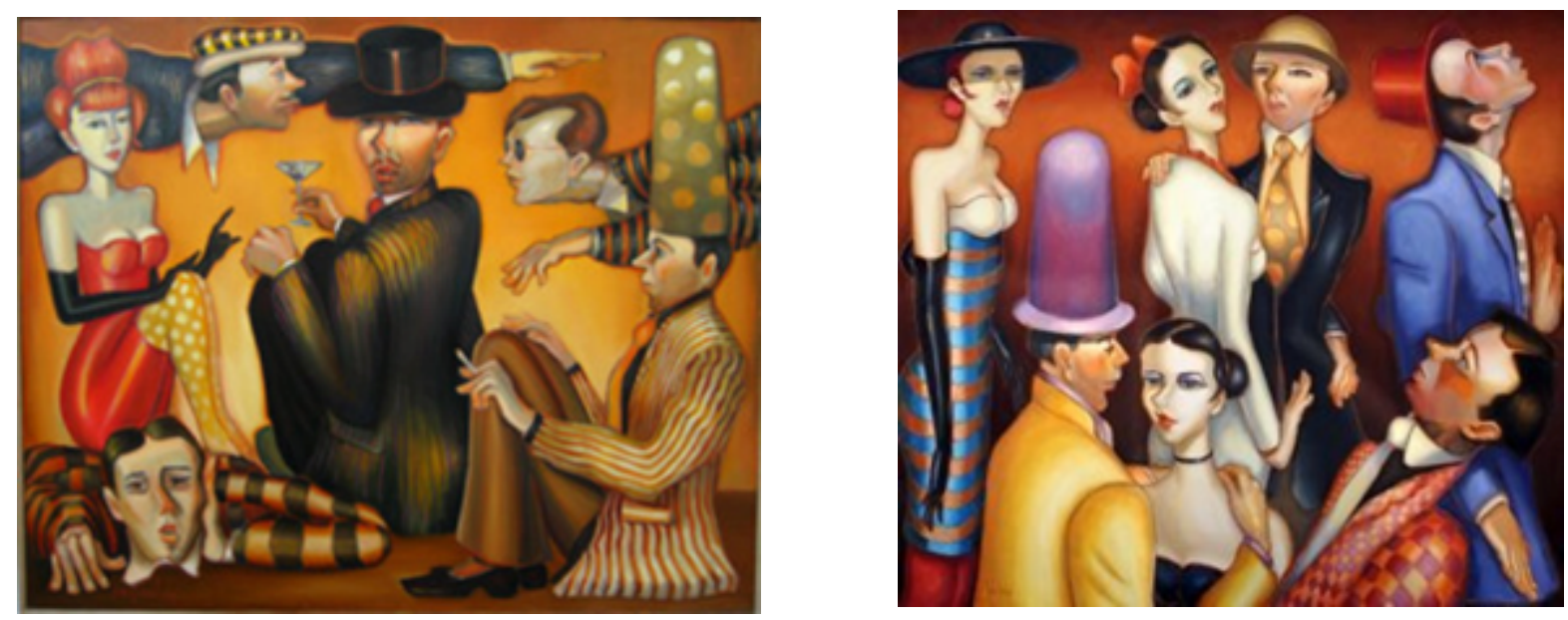

serie "estilos de vida/explorando el ego" 2007 oleo/tela dimensiones variables
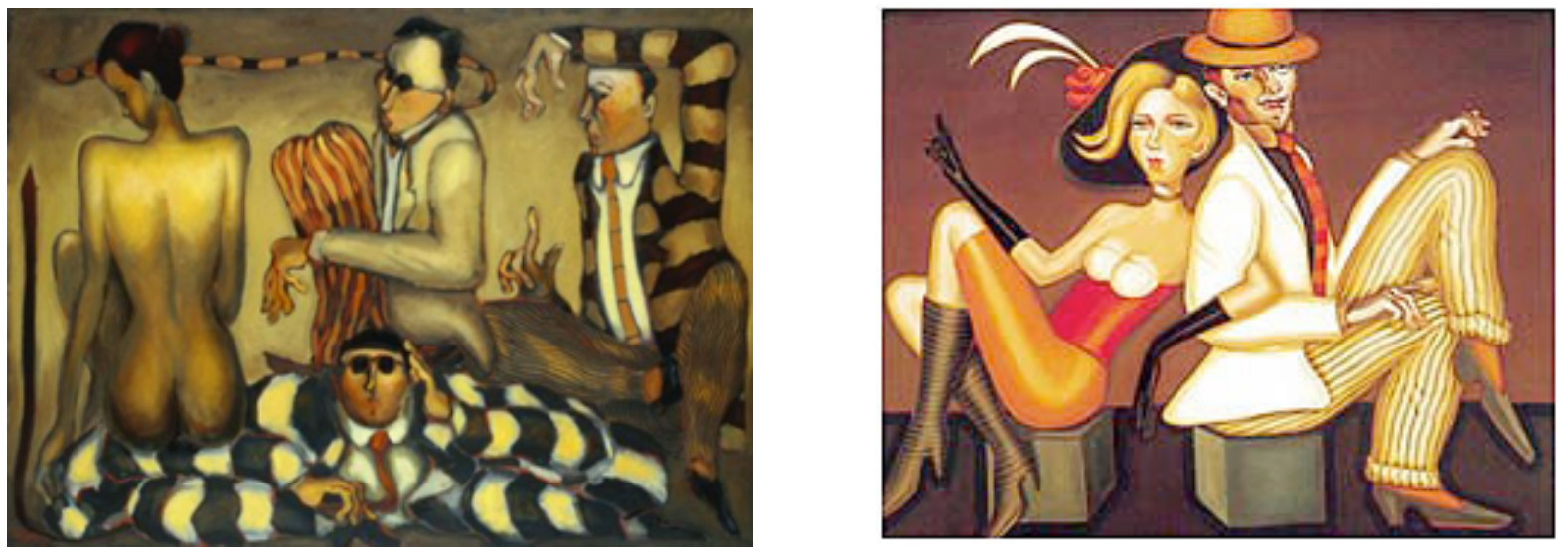

http://elembudo.cl/

www.portaldearte.cl/agenda/pintura/2008/ivan_duran.html www.estilosdevida.cl/2007/02/20/explorando-el-ego/ 
$N^{\circ} 165$ ficha

\section{Juan Martínez}

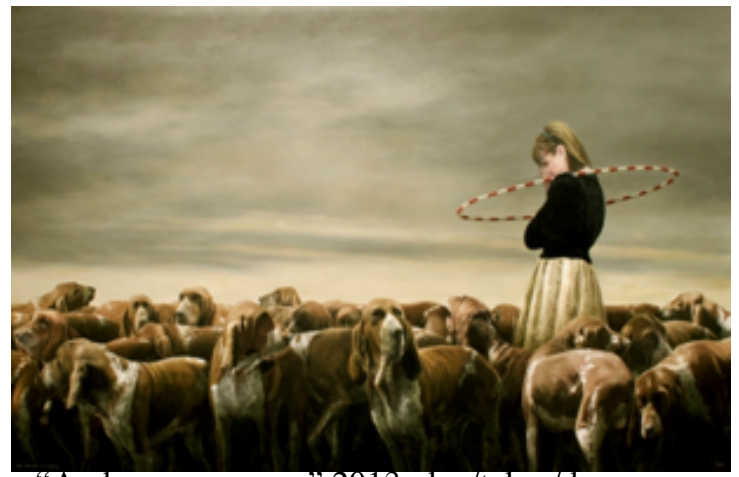

"Andrea con perros" 2013 oleo/tela s/d

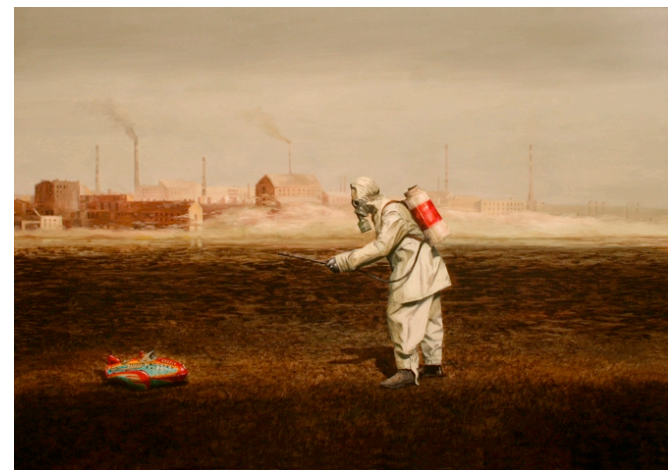

Fumigador y cohete 2014 oleo/ tela s/d

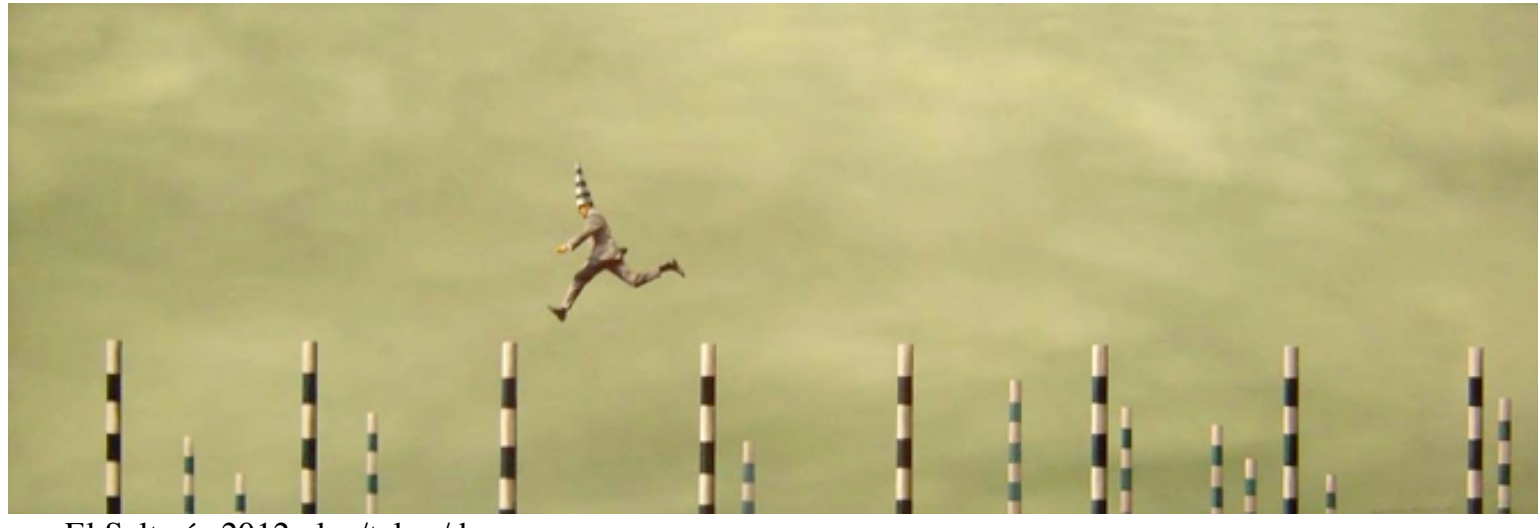

El Saltarín 2012 oleo/tela s/d

https://www.flickr.com/people/juan_martinez/

http://juan-martinez-bengoechea.artenlinea.com/

http://galeria13.cl/portfolio/juan-martinez/ 
$N^{\circ} 166$ ficha

\section{Nicolás Grum}
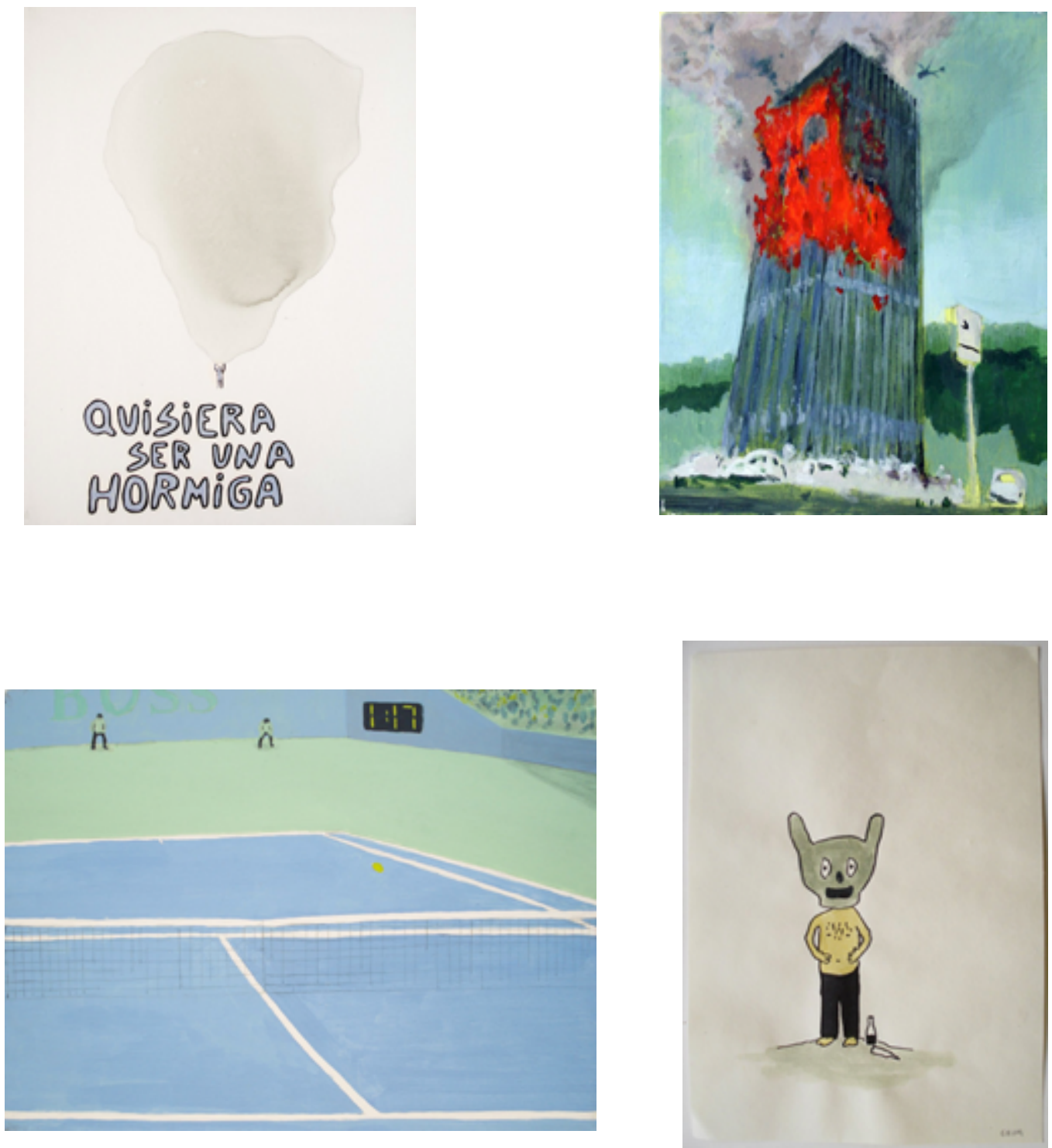

http://www.grum.cl/

http://1.bp.blogspot.com/_yOxrkh3g1Ds/SqDeWy2zxGI/AAAAAAAABXw/1xKOAfkx18E/s1600/temeroso2.jpg www.galeriapready.cl/\#!nicolas-grum/c1geu 
$N^{\circ} 167$ ficha

\section{Pilar Contardo}
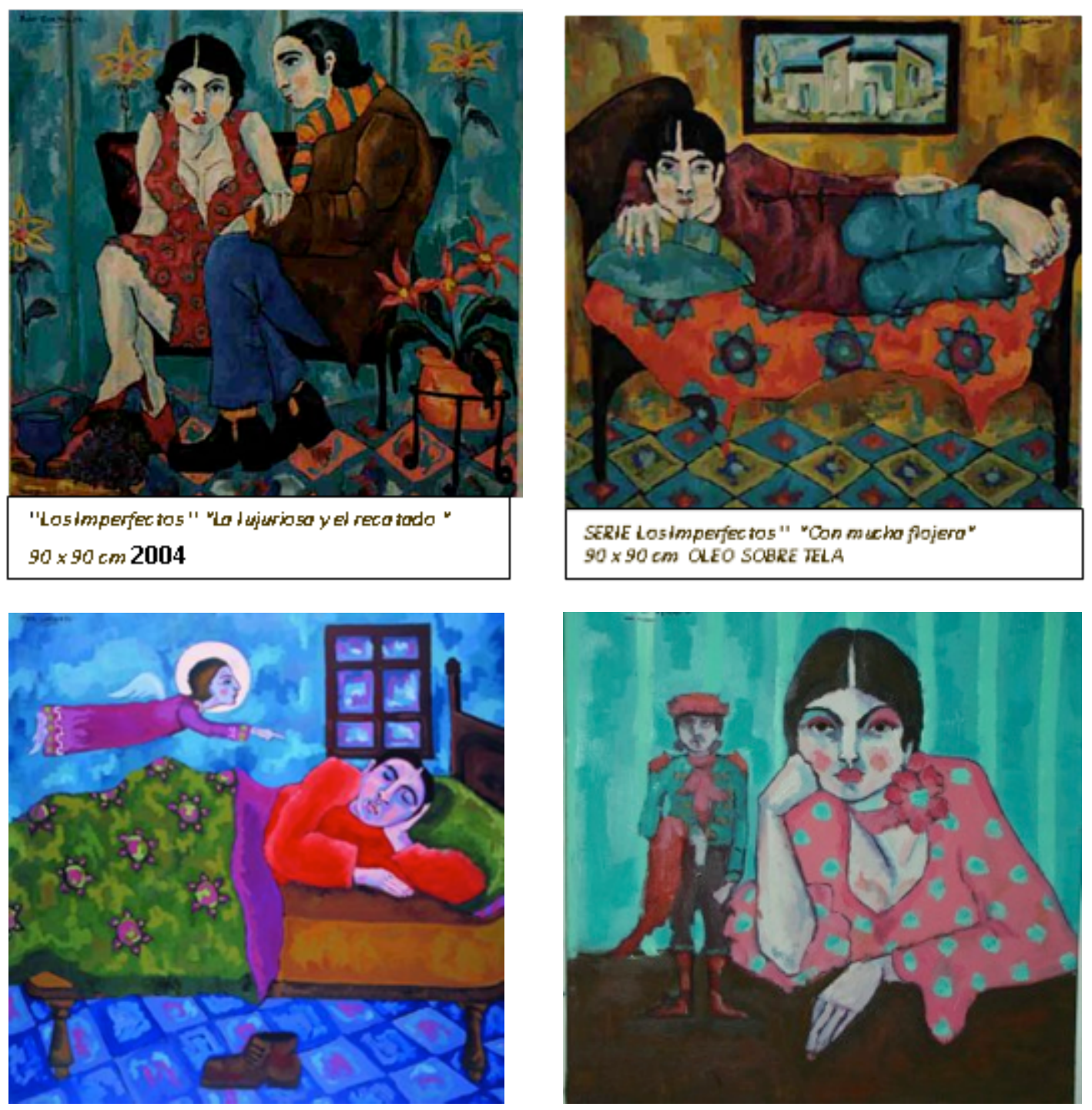

www.galerialasala.cl/exposiciones/pilar-contardo-los-de-la-noche-2/ www.revistainvitro.cl/contenido.php?art=323

http://lasala.wpchile.cl/wp-content/uploads/2013/01/CV-Pilar-Contardo.pdf 


\section{Sarjo Prem}
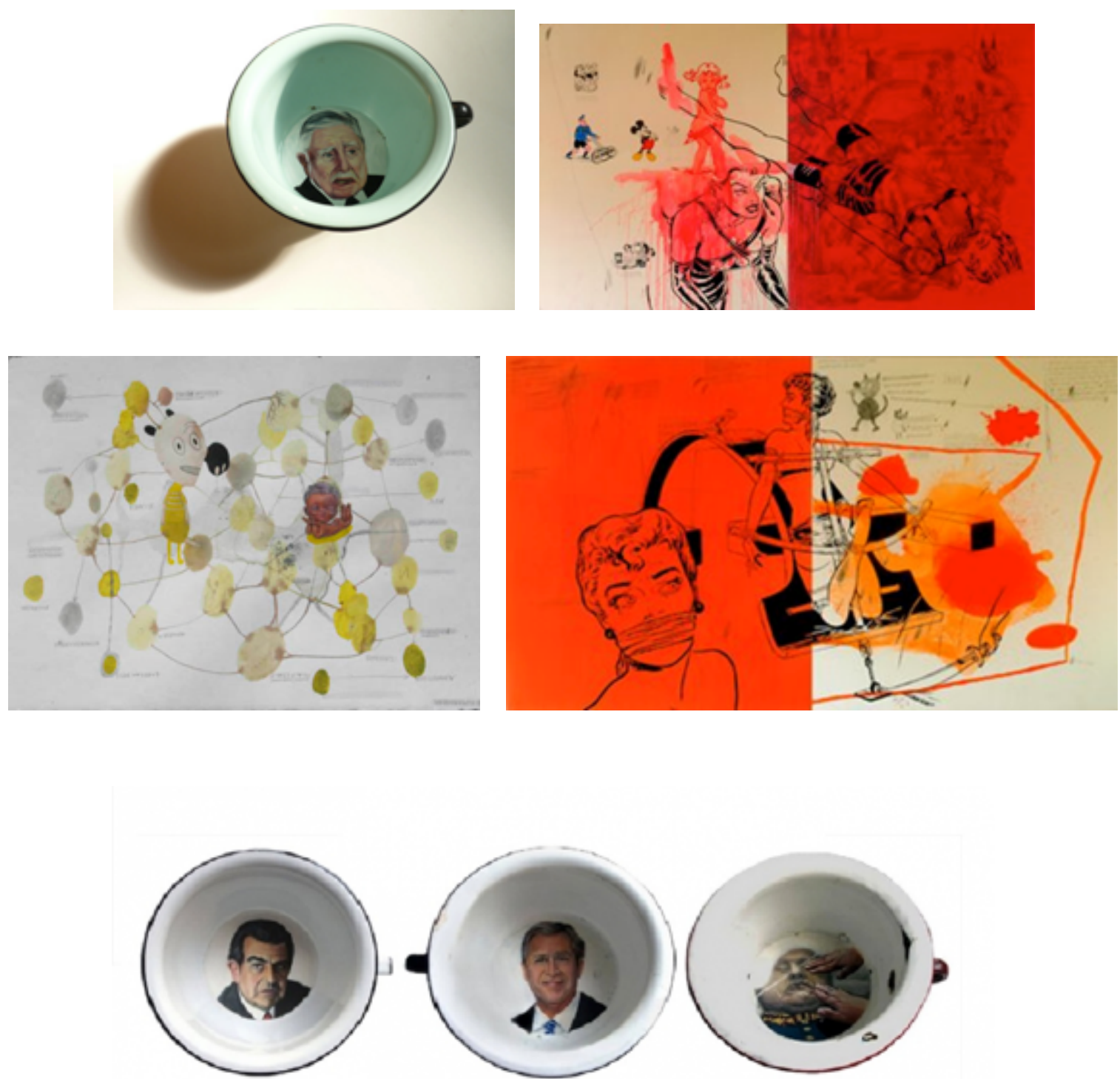

Estudio para Uroboros (de la serie "Hommo Corruptus"), 2008, óleo sobre fierro enlozado, $24 \mathrm{~cm}$ diámetro y $11 \mathrm{~cm}$ de profundidad. Colección Sauma Carvajal, Santiago de Chile.

http://rtsarjoprem.blogspot.com/

http://www .atlasiv.cl/post/anomalie-de-prem-sarjo www.sarjo.cl/ 


\section{Víctor Castillo}
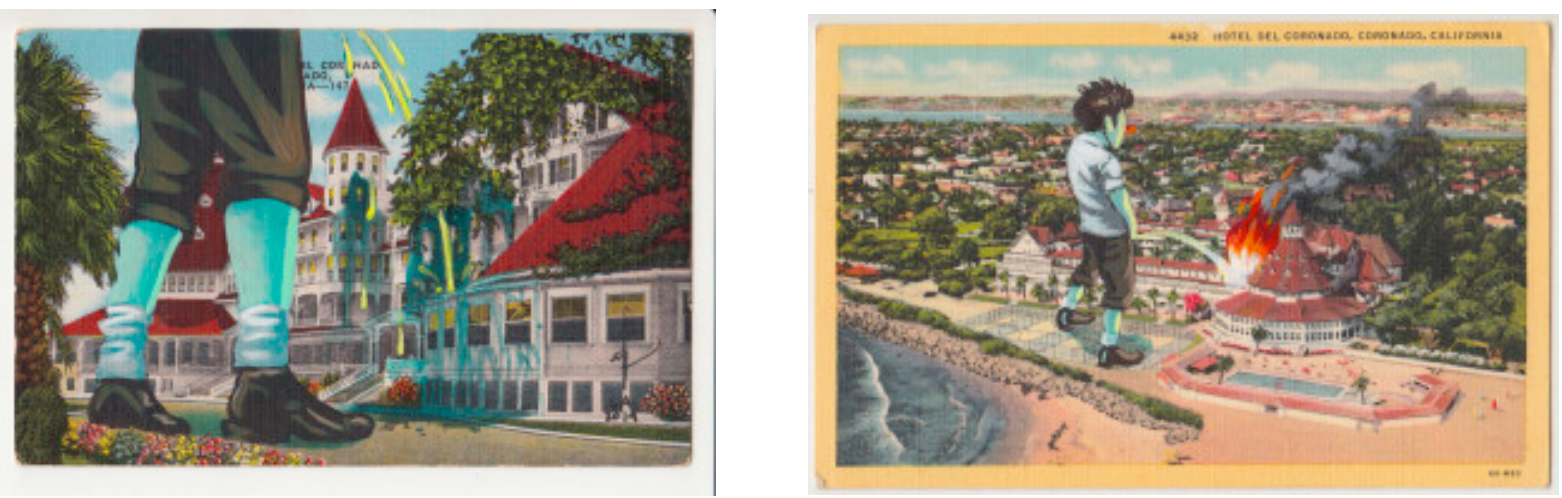

'Strange Fiction'. 2014 serie de pinturas en Acrílico / madera (72X50).

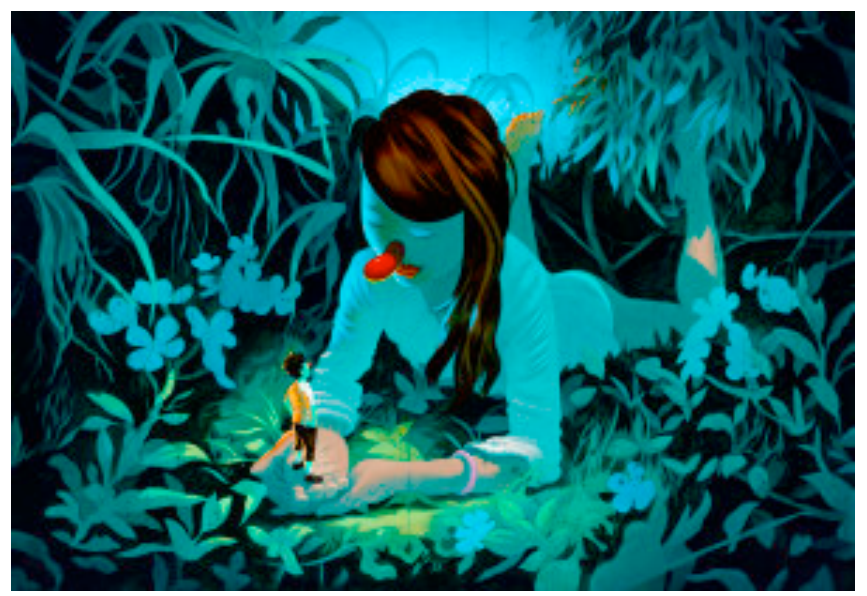

http://victor-castillo.com/

http://www.artishock.cl/dialogos/03_victor_castillo.html http://www.spacejunk.tv/v4/index.php?option=com_flexicontent\&view=items\&cid=53\%3Apreviouslyexhibited\&id=332\%3Avictor-castillo\&Itemid=2\&lang=es 


\section{José Pedro Godoy}

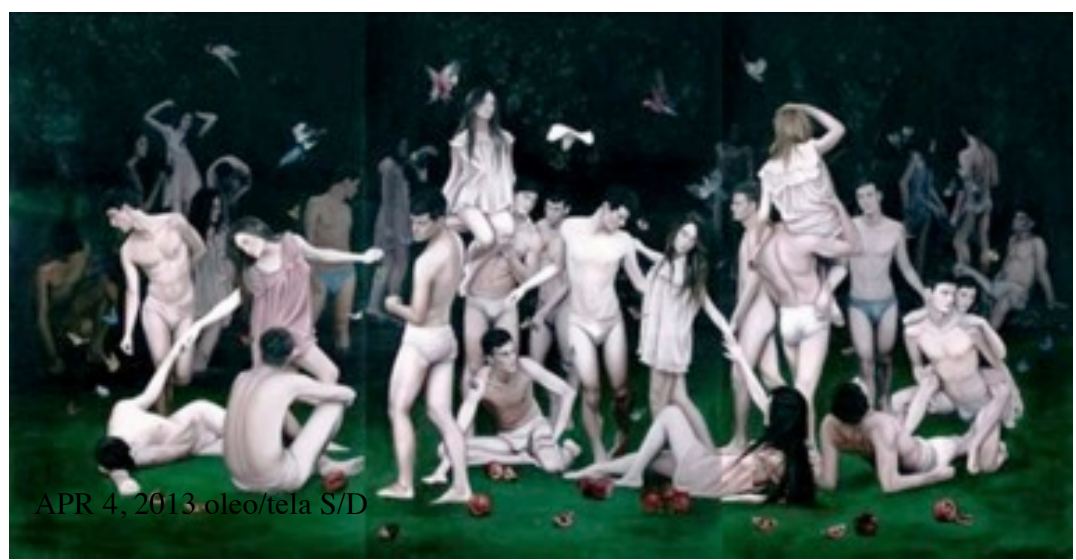

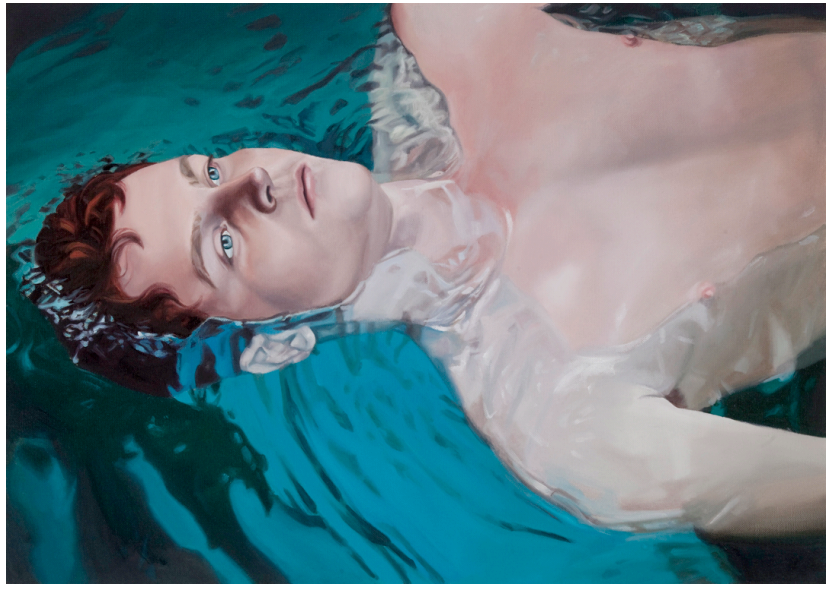

MAR. 92014 oleo/tela S/D

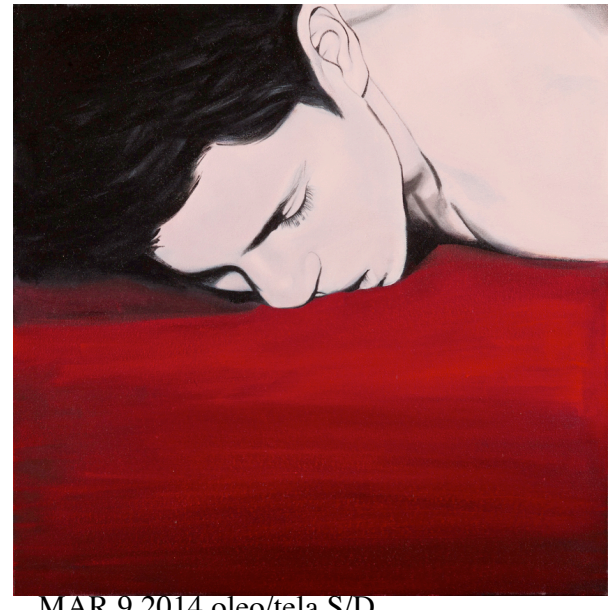

MAR.9 2014 oleo/tela S/D

http://josepedrogodoy.tumblr.com/

https://valebarahona.wordpress.com/2014/03/19/el-erotismo-gay-de-jose-pedro-godoy/

http://www.caras.cl/tag/jose-pedro-godoy/

www.artishock.cl/2012/08/jose-pedro-godoy/ 


\section{Maite Izquierdo}

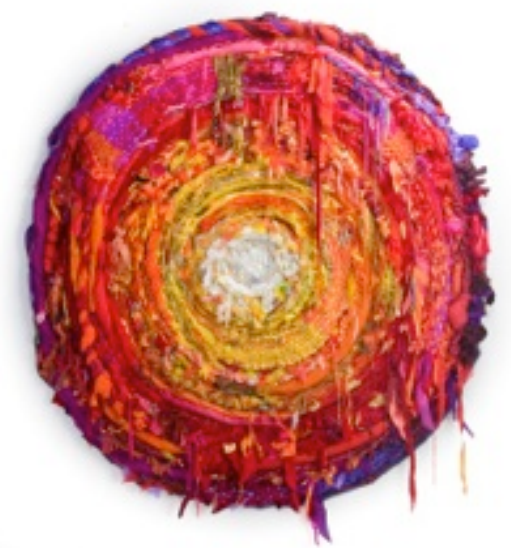

"Espiral Textil" 2012 tondo compuesto de múltiples materiales textiles, tejidos, trenzados o anudados,

www.caras.cl/tag/maite-izquierdo/

http://www.ellalabella.cl/maite-izquierdo

http://creadoenchile.cl/2014/11/14/arte-textil-maite-izquierdo/

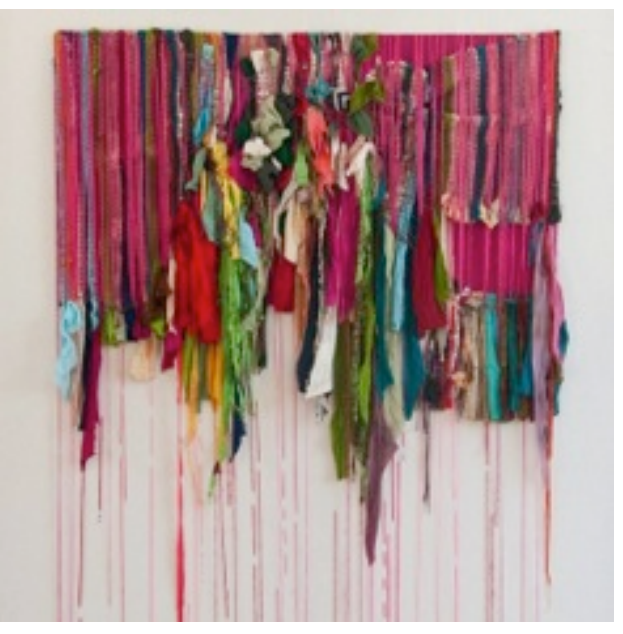

De la serie entre telas 2009-2012

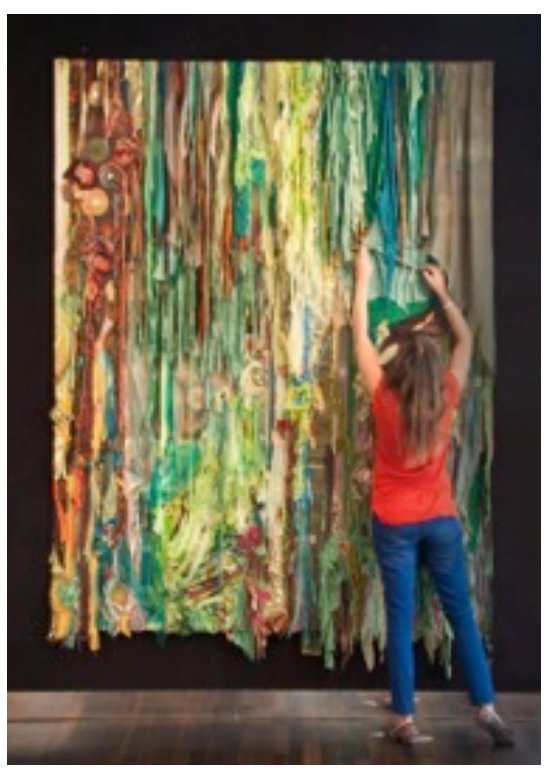




\section{$N^{\circ} 172$ ficha}

\section{Paz Castañeda}

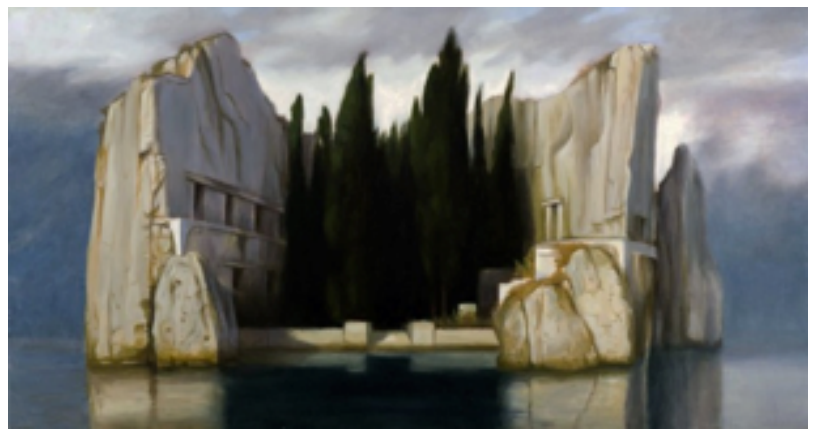

La Isla de los Muertos, óleo sobre tela, 80 x $150 \mathrm{cms}$.

Cortesía de la artista

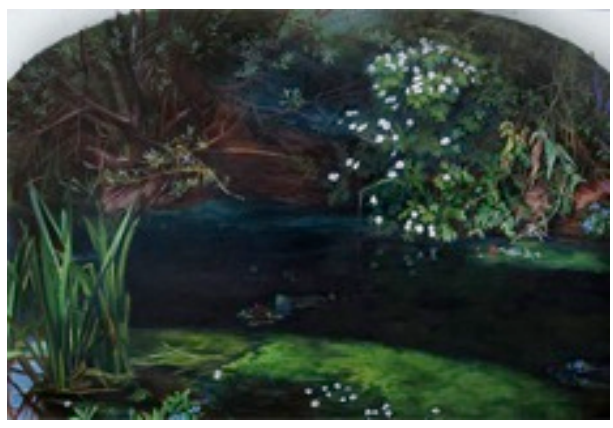

Ofelia, óleo sobre tela, 76 x $112 \mathrm{cms}$.

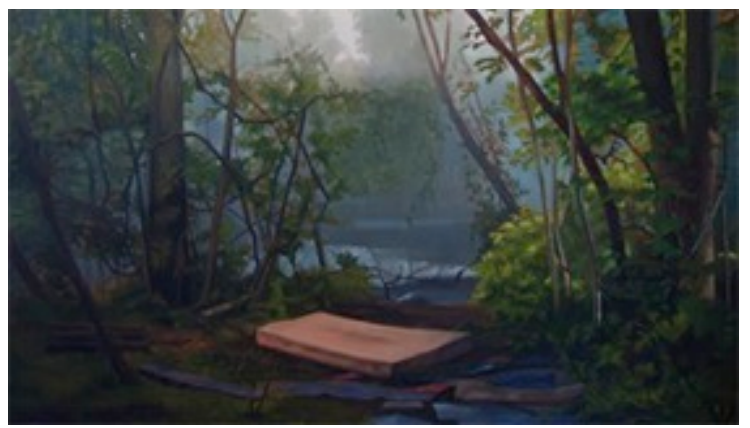

"Crewdson" 2006 oleo/tela 2.27 mt. x 1.93 mt.

www.artishock.cl/tag/paz-castaneda/

www.mac.uchile.cl/exposiciones/anteriores/.../otrautoretratos.html

http://www.elmostrador.cl/cultura/2014/07/18/artista-visual-paz-castaneda-hace-desaparecer-a-personajes-decuadros-famosos/

http://www.latercera.com/noticia/cultura/2014/07/1453-587832-9-brueghel-y-millais-a-traves-de-pazcastaneda.shtml 


\section{Ernesto Barreda}

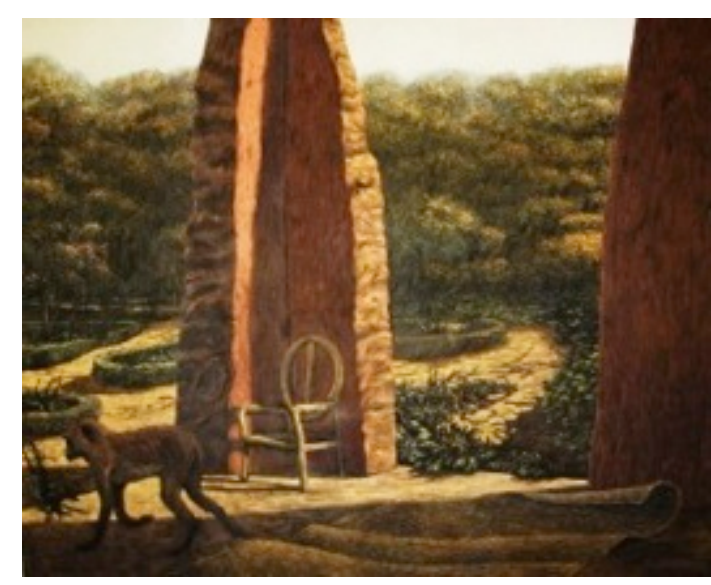

La Tarde 2000 oleo/tela $109.2 \times 139.7 \mathrm{~cm}$ )

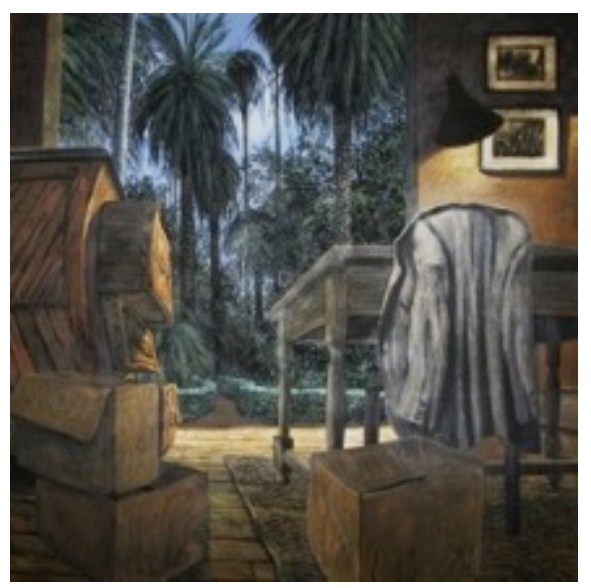

La Mudanza 2000 oleo/tela 139.7 x

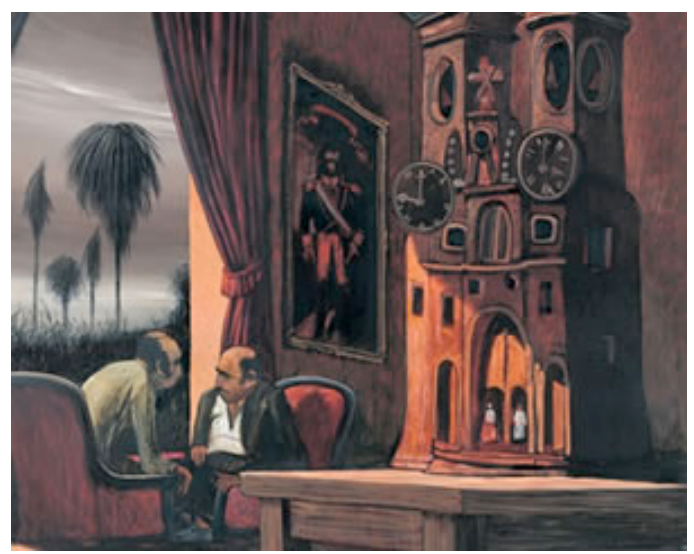

"Relaciones peligrosas" 2002 óleo s/ tela 1,40x1,40

http://www.salagasco.cl/sala_expo_hitos.html www.artistasplasticoschilenos.cl/658/w3-article-40400.html www.portaldearte.cl/autores/barreda.htm 


\section{Waldo Gomez}

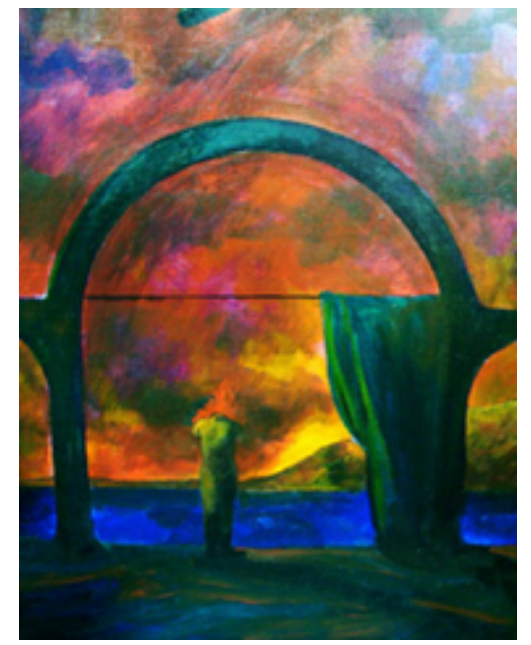

Paisaje, arco,” 2007 oleo/lona 50x60

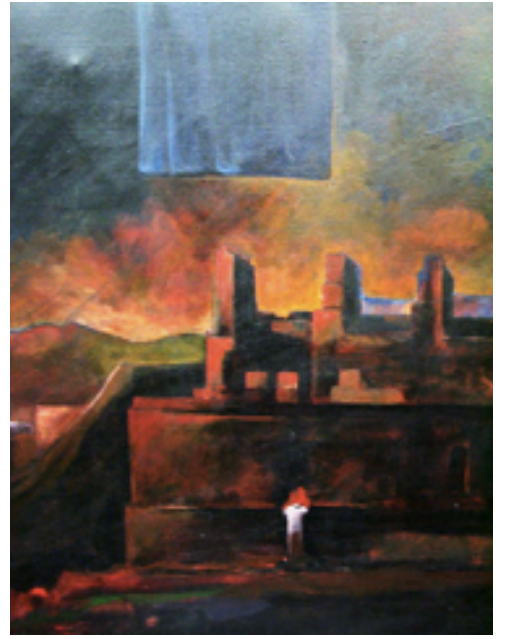

Ruina. 2007 Oleo / lona 40/50

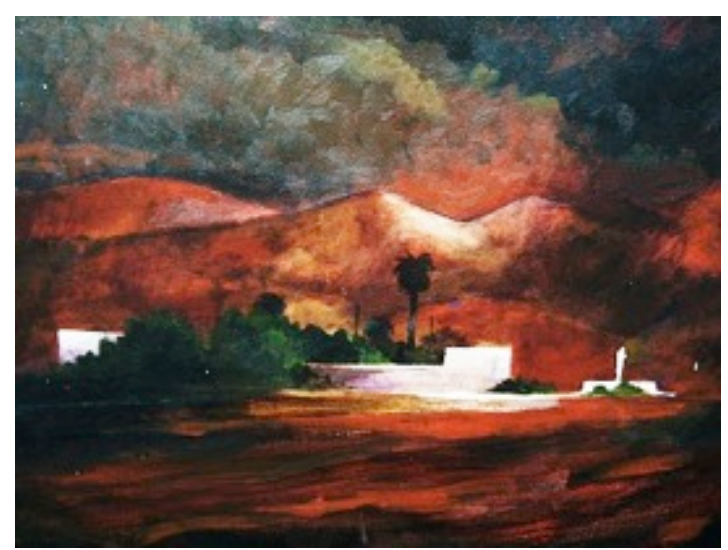

Ruina, desierto, 2008 oleo sobre lona 50/70 cms.

https://alenar.wordpress.com/2007/07/14/waldo-gomez-la-pintura-es-signo/

http://waldogomeza.blogspot.com/

http://rtwaldogomez.blogspot.com/ 
$N^{\circ} 175$ ficha

\section{Mariana Acuña}

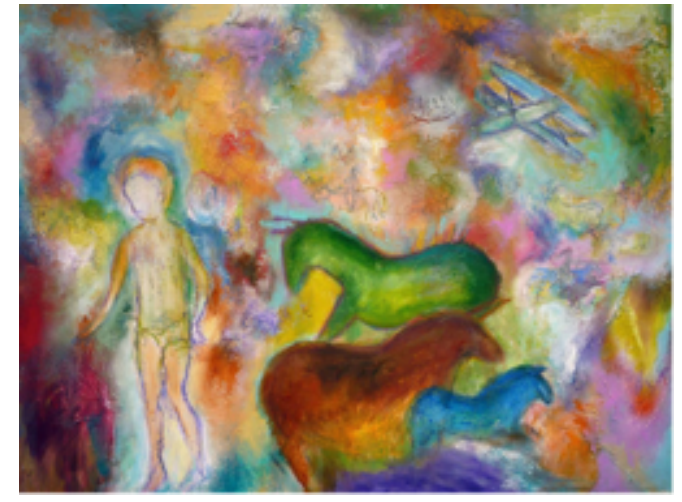

Beatitudine d'Infanzia” 2012 oleo, acrílico /tela $28 " \mathrm{n} 35.5^{\prime \prime}$

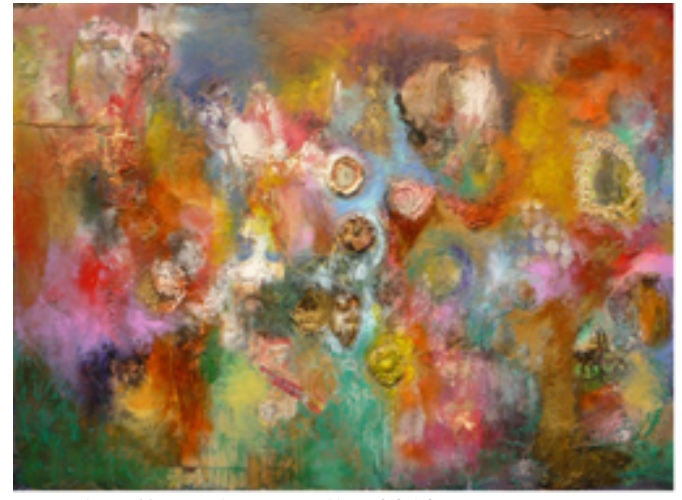

Me lo Dijeron las Estrellas 2013

Mixt</madera m 31.5" x 47"

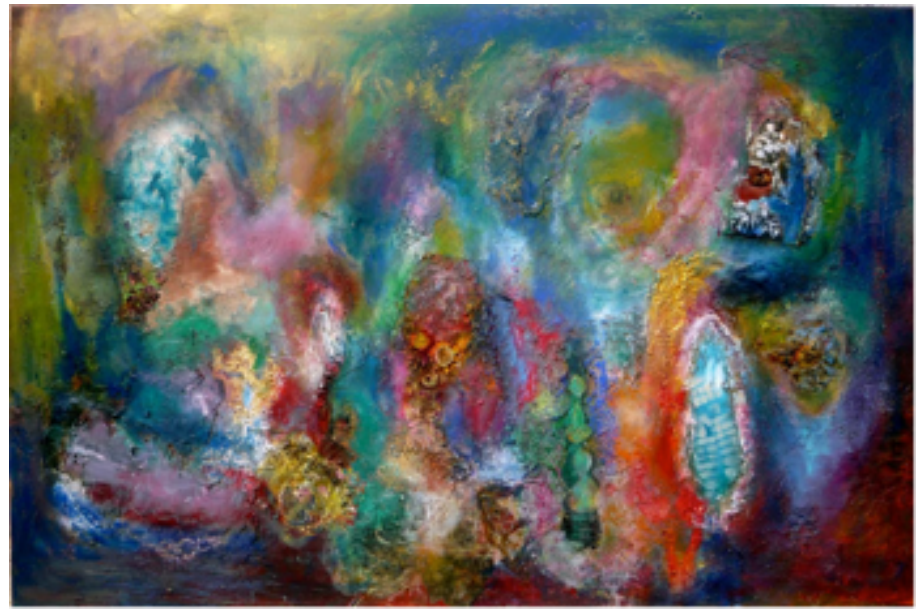

Canto a una Semilla. Homenaje a Violeta Parra Acrylic /tela 31.5" x 47"

http://www.agora-gallery.com/artistpage/Mariana_Acu\%C3\%B1a.aspx http://www.artistasplasticoschilenos.cl/658/w3-article-39723.html 


\section{Ricardo Araya}

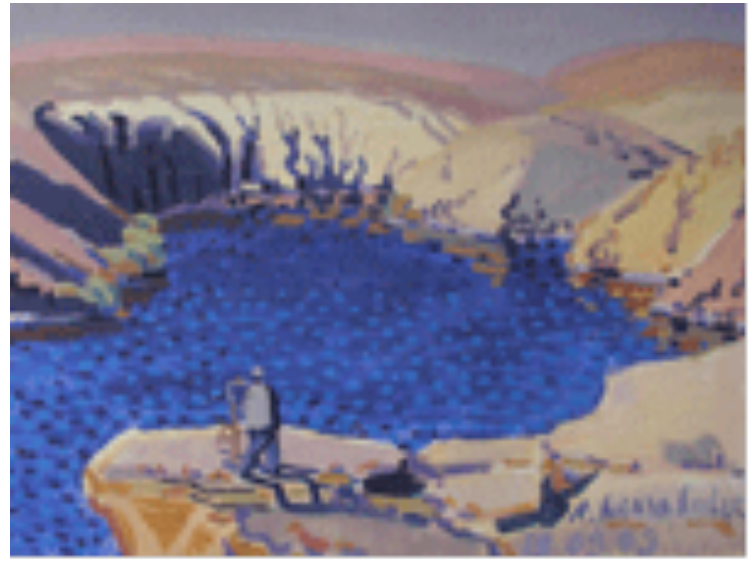

"tranque Sloman rio Loa", 2010 oleo/tela $40 \times 30 \mathrm{~cm}$

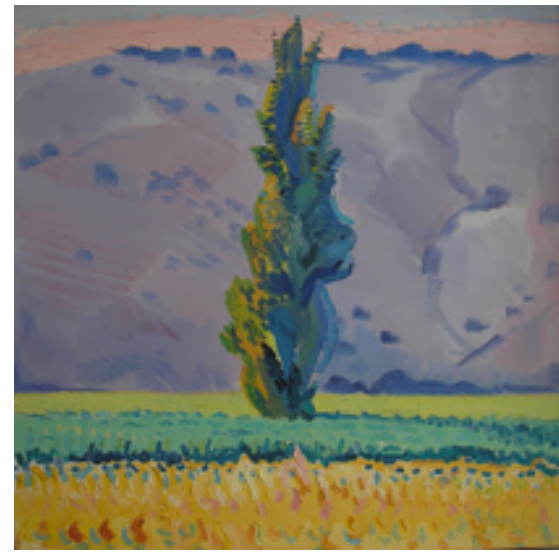

Álamo cerro y viña, 2007 oleo/tela 80x80 cm

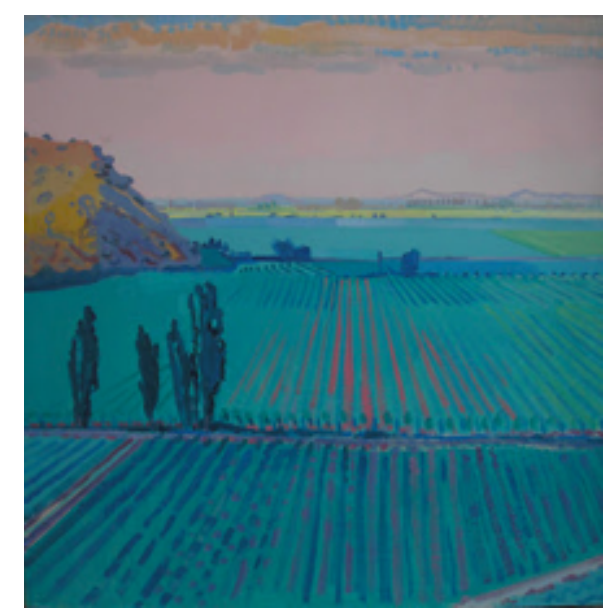

Comienzos del verano, 2007 óleo/tela $80 \times 80 \mathrm{~cm}$

http://taloaraya.blogspot.com/2010/05/pinturas-viaje-bolivia.html http://diario .elmercurio.com/detalle/index $. a s p ? i d=\{8657298 \mathrm{e}-5359-493 \mathrm{~d}-\mathrm{b} 783-8316 \mathrm{ed} 7 \mathrm{db} 4 \mathrm{a} 6\}$ http://www.mercuriovalpo.cl/site/edic/20040404001141/pags/20040404012657.html 
$N^{\circ} 177$ ficha

\section{Víctor Pavez}

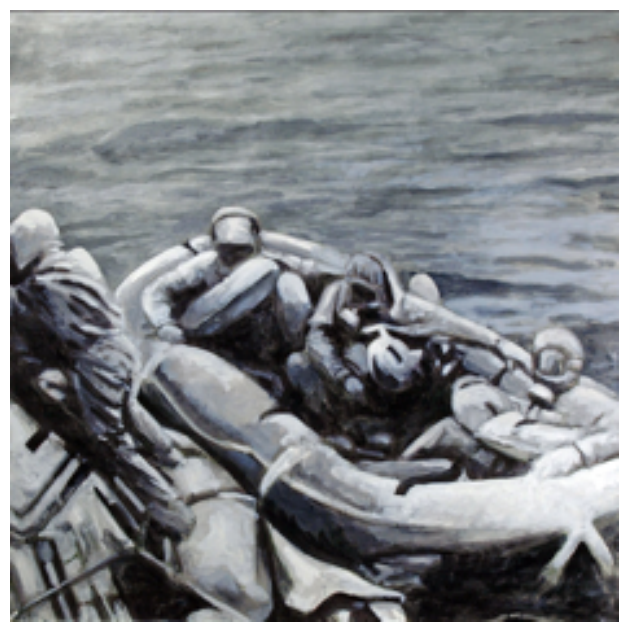

Proyec. Rev. Tec. 2009 Oleo/tela S/D.

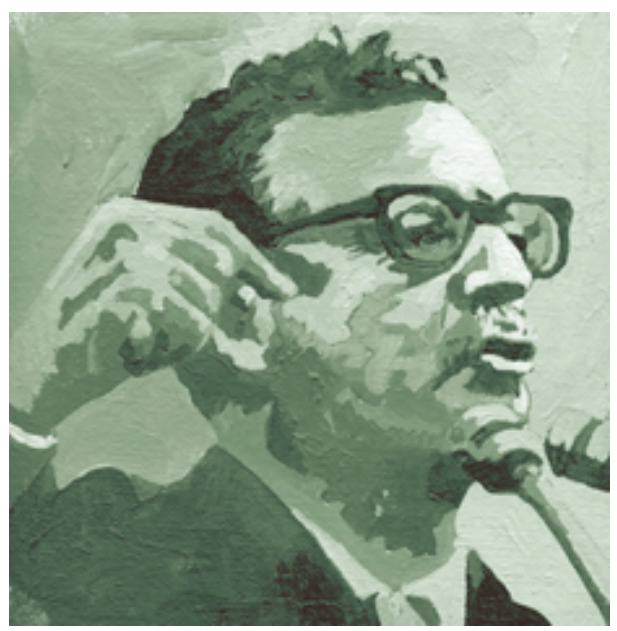

Allende 2009 Oleo/Tela S/D proyecto Rev. Tec.

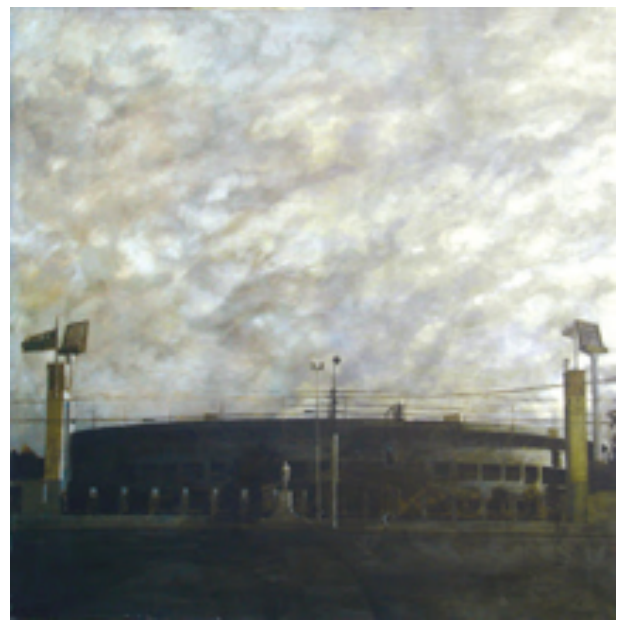

campo de deportes" 2009 óleo/tela s/d

http://victor-manuel-pavez.artenlinea.com/

http://rtvictorpavez.blogspot.com/

www.artistasplasticoschilenos.cl/658/w3-article-39838.html 
$N^{\circ} 178$ ficha

\section{Gastón Laval}

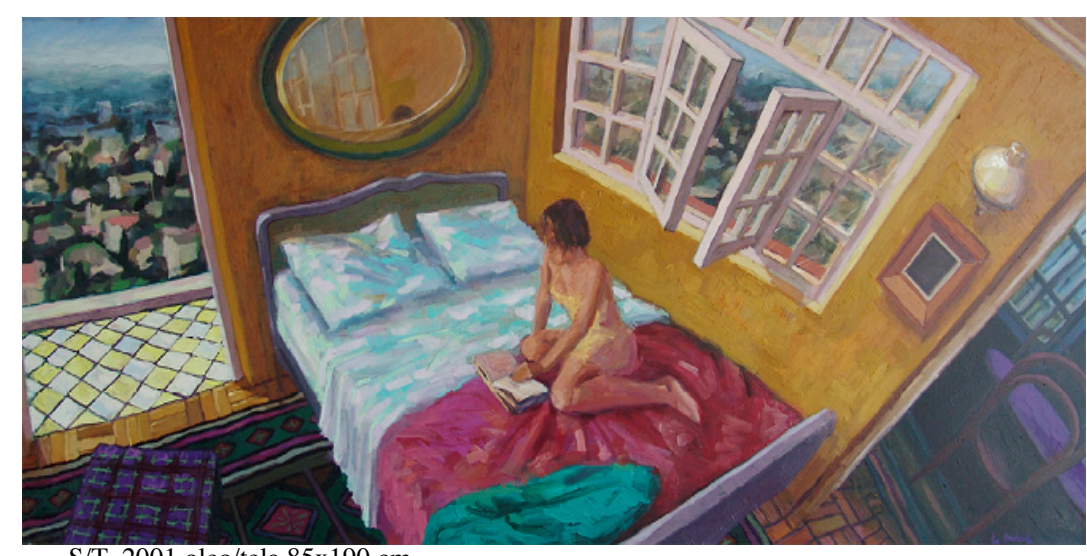

S/T 2001 oleo/tela $85 \times 190 \mathrm{~cm}$

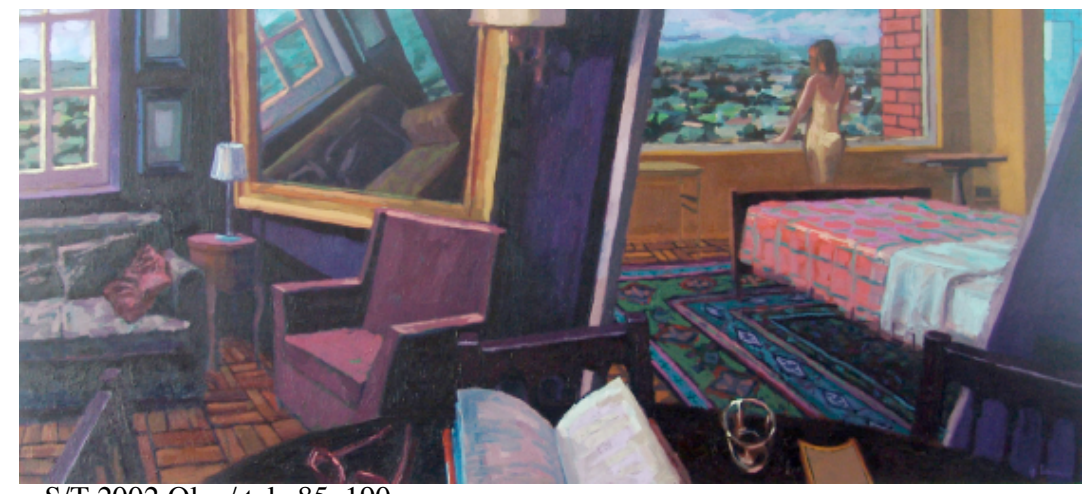

S/T 2002 Oleo/ tela $85 \times 190 \mathrm{~cm}$

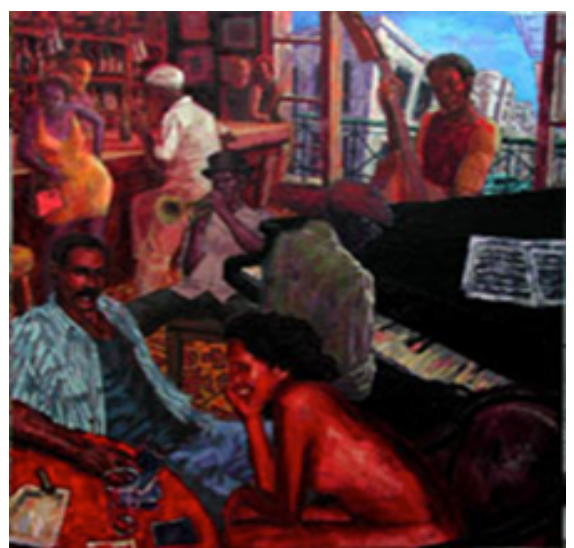

De la serie "Habana (Habana Blues)" 2006 oleo/ tela S/D

http://www.mac.uchile.cl/exposiciones/taller_san_ignacio/gaston_laval.htm http://rtgastonlaval.blogspot.com www.artistasplasticoschilenos.cl/658/w3-article-40467.html http://galeria13.cl/portfolio/gaston-laval/ 
$N^{\circ} 179$ ficha

\section{José Luis Aravena}
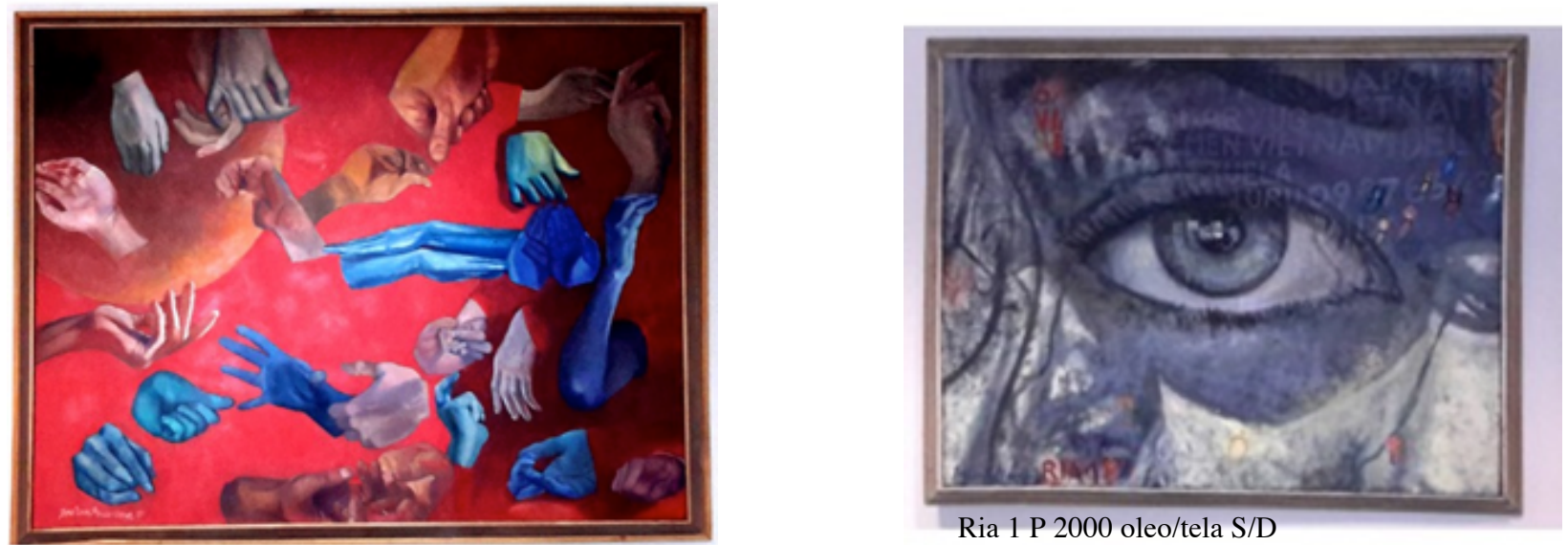

“musas" 2000 oleo/tela 80x100 cm.cm.

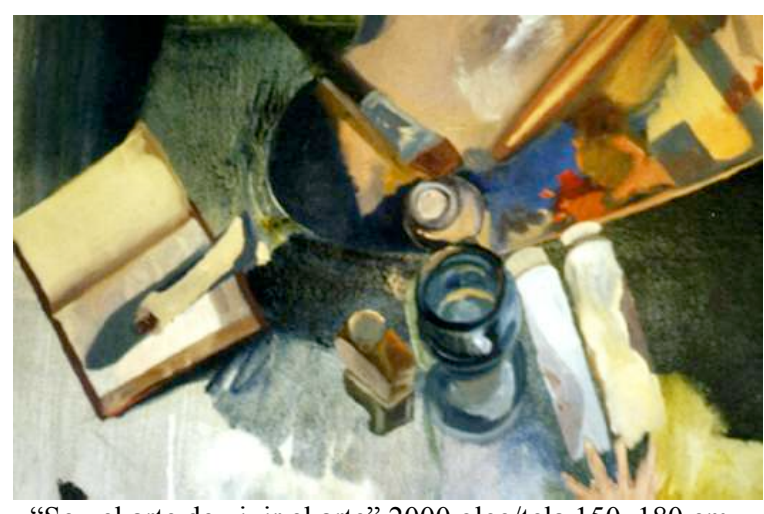

"Soy el arte de vivir el arte" 2000 oleo/tela 150x180 cm.

http://www.joseluisaravena.cl/biografia.html

http://www tandemsantiago.cl/cursos-idiomas-santiago-

chile/news/2010/11/jose_luis_aravena.php?listview $=556$ 


\section{Francisco Cansino}

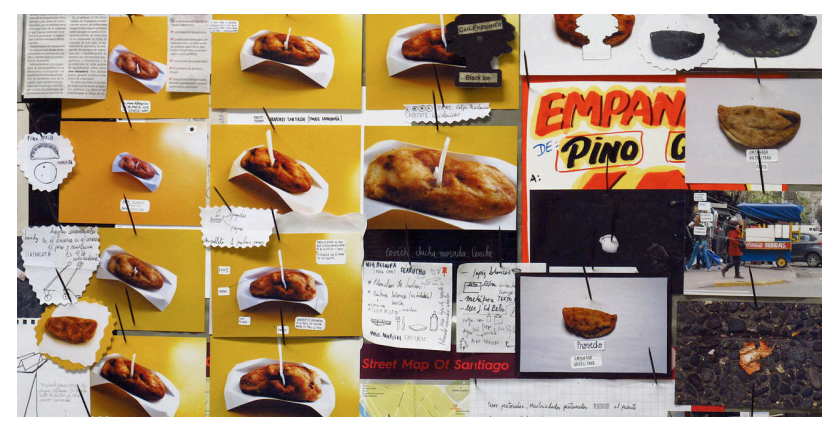

Mural cancha 112014 (detalle)

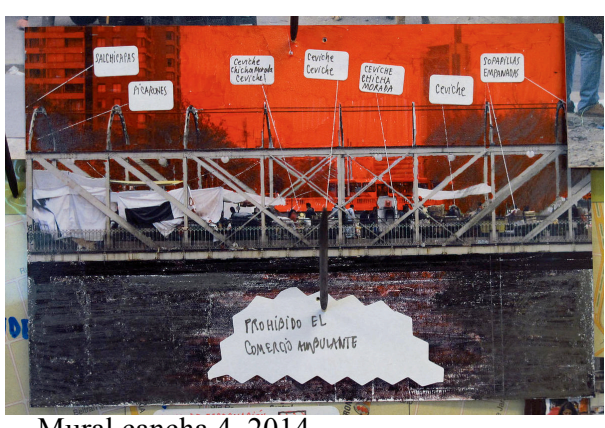

Mural cancha 4, $20 \overline{14}$

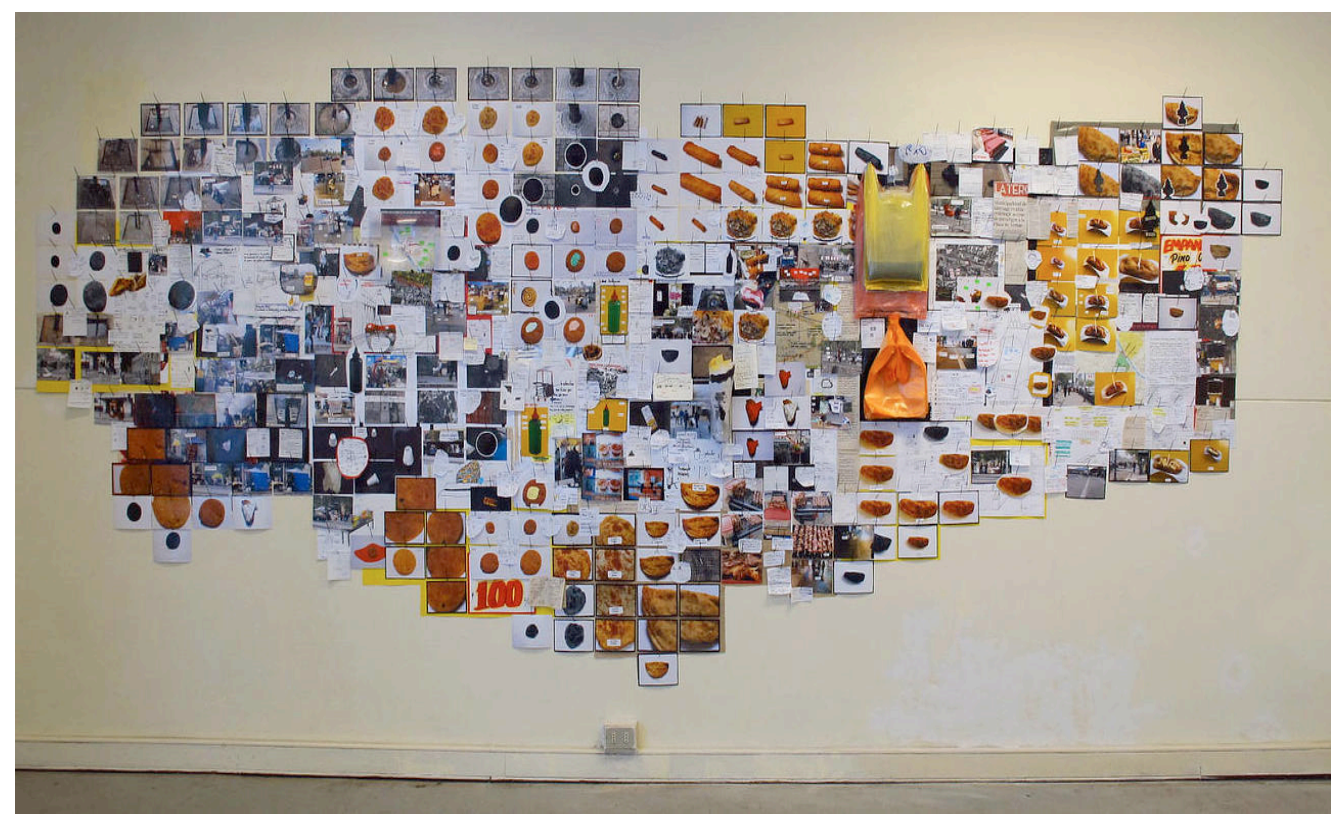

Mural 9, proyecto "Borde Rio" 2014 estudio visual sobre los diferentes tipos de carros de comida que se instalan en la ribera del río Mapocho y sobre los puentes Padre Hurtado. La Paz. Los Carros v Recoleta.

http://www.franciscojaviercancino.com/\#! about/c24vq

http://www.artishock.cl/2014/10/mapocheros-segunda-residencia-cancha/ 


\section{V.4. ANÁLISIS DE LAS OBRAS.}

La pregunta de investigación es el eje que estructura el presente estudio, la recolección de la información se lleva adelante a partir de un procedimiento según criterios que se establecen a partir la búsqueda, señalamiento y registro, de aspectos vinculados a la idiosincrasia nacional que estén presentes en las obras pictóricas referidas. El análisis de los datos se realiza utilizando una estrategia que permite estudiar las obras pictóricas de manera, más o menos objetiva, sistemática, a la vez que posibilita el agrupar los contenidos en dimensiones, categorías y subcategorías basada en la secuencia que establece Michael J. Parsons (2002).

\section{V.4.1 Dimensiones en la pintura chilena.}

Quizás por efectos de la globalización, la producción artística nacional recupera su mirada hacia el interior. Una búsqueda identitaria a través de recursos tecnológicos provenientes del mundo globalizado. El peso de la globalización implica tratar de contrarrestar fuerzas que pueden anular la identidad. Las obras actuales presentan ciertas características que las distinguen y permiten su comprensión desde comprender el contexto nacional en el que se han producido y al cual hacen referencia; entendiéndolas como producto de las reflexiones que los artistas han realizado respecto al quienes somos, instalados en el escenario en que la globalización de las comunicaciones tiende a desdibujar las territorialidades o especificidades identitarias. Ello nos plantea realizar una revisión de aquellos aspectos y características consideradas como propias y que muestran las producciones nacionales actuales.

\section{V.4.1.1 Dimensión Forma materia.}

Esta dimensión se asocia, por un lado, a los elementos constituyentes de la imagen pictórica propiamente tal, en su carácter modal, partiendo en primer lugar por el soporte que le da forma y dimensiona a la obra ya sea en tela, madera, cuero, entre otros, que determinan el campo de acción del pintor y separa el "espacio plástico" del espacio físico o ajeno a la obra, pero que es donde se instala. Por el otro lado, nos encontramos, en el campo la pintura, con otro tipo de materialidades y soportes que salen de lo bidimensional y sitúan la obra en la tridimensionalidad o bien en la virtualidad. Ello nos obliga a considerar la obra pictórica más allá del cuadro y su resolución tradicional y observar aquellas producciones que 
obedecen o bien a desplazamientos del soporte, al cambio de materialidad, como aquellas que se proyectan en un espacio tridimensional o virtual.

Podemos señalar que en la práctica pictórica en Chile, encontramos la pintura realizada con materiales diversos, no necesariamente pintura (al óleo) y sobre gran diversidad de soportes que contemplan lo bidimensional (tela, madera, muro, poliéster, muro espacio público) lo virtual (internet, vídeo, proyecciones, tecnologías, sistemas audio visuales), y lo tridimensional (sobre objetos, objetos, instalaciones).

Las características formales en la pintura hoy en Chile nos hablan de la multiplicidad de recursos en sus connotaciones descriptivas y sensibles como posibilidades de determinación de contenidos.

\section{V.4.1.2 Dimensión temática.}

Tal como se ha señalado en III.2.1.2, esta dimensión se asocia a la parte más literaria de la estructura visual de una obra. El tema es la apariencia y su relación con la manera en que nombramos aquello que vemos y va desde un simple punto, línea o color, hasta la estructuración compleja de un relato, una anécdota o una historia.

En este trabajo, se analizan algunos ejes temáticos que se consideran recurrentes en la historia de la "pintura chilena"

Un ejemplo de ello se presenta en el ciclo "Colección en Viaje" (2010), con el que se conmemoraron los cien años de la inauguración del edifico del MNBA. Allí se presentó las obras que componen la Colección de Arte Chileno, desde una perspectiva que trasciende el enfoque cronológico, entregando, según su curador Ramón Castillo, una visión que extiende y enriquece el análisis de las obras, así como de los contextos y procesos relacionados con su producción. La propuesta consiste en presentar, en el catálogo (2009), la colección con relación a ejes temáticos, en rigor siete. En este trabajo se ha optado por una estrategia similar y se han sintetizado, en beneficio de la investigación, en cuatro ejes temáticos que los incluyen: Retrato(s), Objeto (emblemático), Paisaje (entorno) y Escenas (cultura popular). Este último eje contempla: Imaginario Religioso; Narración Histórica; fiestas y ritos populares. 
Revisemos en las unidades de análisis los cuatro ejes temáticos en la pintura chilena:

\section{a.- El retrato}

El retrato tiene su punto de partida en el inicio de la república, con José "Mulato" Gil de Castro $^{19}$, con una pintura de 1821 a Bernardo O'Higgins "Director Supremo". Retrata, en primera instancia a los protagonistas de la independencia.

"En un principio, el retrato tuvo como objetivo enaltecer a la persona, no cualquiera era pintado. Luego adquirió un matiz más sicológico y rescató a personajes anónimos", (Castillo, 2010, p.2)

La pintura retrato, a través de la representación mimética y modelado académico de luz y sombra, va mostrando en Chile, a personajes, hombres y mujeres destacados en los planos políticos, culturales o económicos y también, a personajes anónimos del mundo rural. Asimismo da cuenta de una sociedad que va ampliando su transversalmente poder de adquisición y de auto-representación, los retratos configuran una cartografía en la que se reconocen las redes de amistad y poder, los afectos y aversiones de los artistas.

Asimismo, está presente en algunas obras, la mirada crítica de sensibilización social, inspirada en el "miserabilismo" europeo, cuyo objetivo era sensibilizar a la burguesía, mostrando crudamente imágenes de personas que dan cuenta de la situación de extrema pobreza o miseria en que viven, como efecto de la migración del campo a la ciudad durante el siglo XIX, como lo muestra la pintura de Celia Castro en 1889 (Fig.: 1).

A principios del siglo $\mathrm{XX}$, se producen cambios significativos en la concepción del retrato, ellos impulsados por el artista Camilo Mori ${ }^{20}$ (Fig.:2), quien se aleja de la representación clásica y propone una mirada más contemporánea, expresada en dos obras que se han convertido en iconos populares y ya son parte del imaginario nacional en la medida que se reiteran en varias obras de artistas posteriores.

\footnotetext{
${ }^{19}$ José Gil De Castro y Morales, también llamado El Mulato Gil, pintor. Nació en Lima, Perú el $1^{\circ}$ de septiembre de 1785 y falleció en la misma ciudad en 1837. De origen humilde y mestizo. Avecindado en Chile hacia el año 1810 para cumplir con deberes militares. Instaló su taller en la actual calle Victoria Subercaseaux de Santiago, a los pies del cerro Santa Lucía. En 1816, es nombrado Maestro Mayor del Gremio de Pintores. Permanece en Chile hasta 1825.

${ }^{20}$ Pintor chileno. Nació en Valparaíso el 24 de septiembre de 1896 y murió en Santiago el 7 de diciembre de 1973. En 1923 participó en la creación del Grupo Montparnasse junto a Luis Vargas Rosas, José Perotti, Enriqueta Petit y Julio Ortiz de Zárate, quienes renovaron el medio cultural chileno, difundiendo la autonomía de los medios plásticos y una pintura Más vanguardista, cercana a los postimpresionistas y fauvistas.
} 


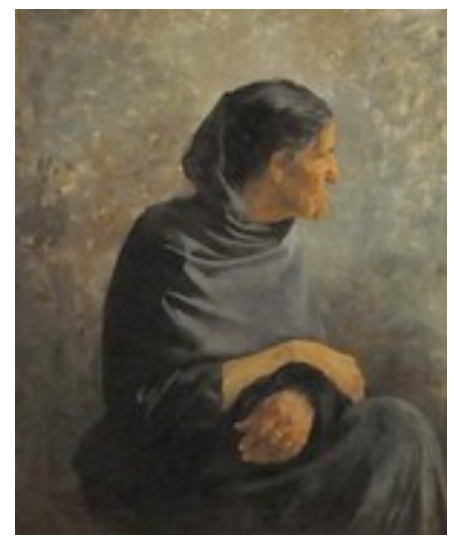

Fig. 1 "VIEJA," 1889

Celia Castro, Oleo/tela, $82 \times 66 \mathrm{cms}$.

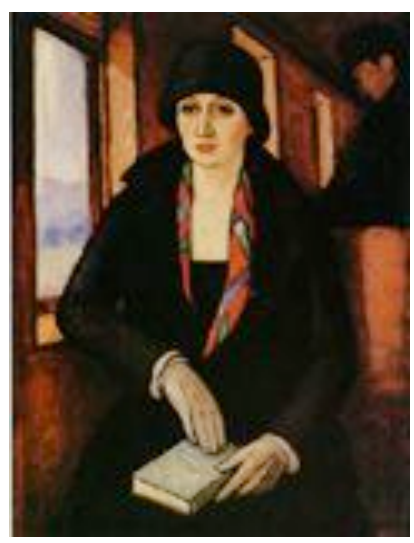

Fig. 2- "La Viajera," 1928 Camilo Mori, Oleo/tela $100 \times 70 \mathrm{cms}$.

La historia de la pintura chilena durante la segunda mitad del siglo XX estuvo marcada principalmente por la búsqueda de nuevas expresividades plásticas y por la creciente vinculación del artista con su contexto político y social, elementos que, a lo largo del período, no sólo disputaron el centro del quehacer artístico, sino que lograron en diversas ocasiones convivir y complementarse, y que relegaron la pintura retrato, a un plano de pintura de carácter intimista hasta finales del siglo $\mathrm{XX}$ en que el retrato es reconsiderado y es un pretexto para abordar problemáticas socio políticas o bien cuestiones propias del lenguaje pictórico.

En ese sentido podríamos observar características de la pintura retrato en Chile hoy con relación a personajes que de algún modo son emblemáticos, ya sea por que son o han sido socialmente destacados; políticos, representativos de nuestra diversidad cultural, mitológicos, caricaturescos, simbólicos, en general aquellos que de algún modo constituyen o representan parte de nuestro imaginario. Con relación a la pintura, se pueden señalar tres tipos de retratos: personajes emblemáticos (héroes, políticos, religiosos, retratos Simbólicos); personajes desconocidos o anónimos (vendedores, lavanderas, gente de pueblo); familiares del pintor.

Un retrato se proyecta a retener, atrapar o preservar una apariencia bajo cuyas formas está contenida, imaginada, alterada o negada la identidad de alguien. Un retrato, o una serie de éstos es también una galería del poder, vehículo de cuestiones históricas, políticas, trascendentes o cotidianas de aquello que Ramón Castillo (2009) llama "álbum familiar" individual o colectivo de una comunidad o de un país. A partir del siglo $\mathrm{XX}$, se logra observar cómo este género fue alejándose de lo meramente fisionómico para convertirse en un medio expresivo de problemáticas afectivas, ideológicas, sicológicas, económicas, socioculturales y conceptuales. 
Dos exposiciones durante la década pasada que, dada su línea curatorial y la dimensión de convocatoria, dan indicios de la recuperación de este género en la pintura nacional, a saber:

"Retratos de Sociedad" (2006) en Galería de Arte Cecilia Palma en Santiago de Chile, presenta el retrato y autorretrato, como género pictórico. El espejo y reflejo entre los propios artistas de la escena local actual y sus referentes internacionales en la pintura. 50 artistas exponen retrato(s) y/o autorretrato(s) en pintura y técnica mixta. (Fuente: Galería de Arte Cecilia Palma).

"Lecciones de ego" (2008) en Corporación Cultural de Las Condes se exponen retratos y autorretratos de 42 artistas chilenos con obras desde Rugendas a nuestros días. Las obras expuestas fueron recopiladas a través de una labor curatorial y no obedecen a solicitudes expresas para la muestra. Por el contrario, todas las pinturas y dibujos se realizaron por inquietud personal de sus autores, de tal modo que nos entregan una visión auténtica de la imagen que los pintores chilenos, del pasado y presente, quieren proyectar. (Fuente: http://www.portaldearte.cl/agenda/pintura/2008/pintores_chilenos.html)

Una tercera exposición en 2015, convocó a artistas nacionales y extranjeros a retratar personajes del ámbito de la política chilena actual. La muestra "Política y Celebridad" en la Galería del Centro Cultural de Matucana 100, reunió a más de 40 artistas chilenos y extranjeros que abordaron la relación entre esos dos mundos, resumiendo cinco exposiciones en torno al poder y la fama. La curatoría estuvo a cargo de Paco Barragán. De esta muestra se tomaron aquellas obras que se vinculan al imaginario nacional.

(Fuente: http://www.m100.cl/archivo/politica-y-celebridad-cinco-exposiciones-de-fama-ypoder)

A continuación se presentan cuatro tipologías resumen de personajes, objetos, paisajes y escenas, que figuran en el imaginario colectivo ya sea por haber sido motivo de diversos retratos en la historia de la pintura chilena o bien por ser emblemáticos o por su carácter simbólico en la imaginería popular, de tal modo que su presencia en la pintura se considera como propio de la idiosincrasia e identidad nacional. 


\begin{tabular}{|c|c|c|}
\hline Retratos & Tipología & Características \\
\hline \multirow{7}{*}{$\begin{array}{l}\text { Personajes } \\
\text { emblemáticos }\end{array}$} & Políticos & Reconocidos \\
\hline & Religiosos & Emblemáticos \\
\hline & Personajes simbólicos & Del imaginario nacional. \\
\hline & El huaso & $\begin{array}{l}\text { Con vestimenta típica (Personaje típico, de la zona } \\
\text { central, del campo chileno con sombrero, poncho, } \\
\text { faja y espuelas). }\end{array}$ \\
\hline & La nana chilena & $\begin{array}{l}\text { Antiguamente llamada "la empleada" empleo de raíz } \\
\text { colonialista. }\end{array}$ \\
\hline & El roto chileno & $\begin{array}{l}\text { El adjetivo sustantivado roto, que adoptó una } \\
\text { connotación clasista en el siglo XIX, ha sido usado } \\
\text { para denominar en Chile, en general, a la persona de } \\
\text { origen urbano y pobre. En Chile desde comienzos del } \\
\text { siglo XX, el roto ha sido considerado una figura de } \\
\text { identidad nacional y arquetipo de la chilenidad. }\end{array}$ \\
\hline & Condorito & $\begin{array}{l}\text { Condorito es un cóndor (ave que constituye el } \\
\text { emblema nacional) antropomorfo que personifica y } \\
\text { caricaturiza positivamente a la imagen del chileno de } \\
\text { clase humilde, "roto chileno". Su aspecto } \\
\text { corresponde a una mezcla entre humano y cóndor } \\
\text { aunque carece casi por completo de plumaje excepto } \\
\text { una cola compuesta por un puñado de plumas rojas } \\
\text { bajo su espalda y un pequeño collar de plumillas } \\
\text { blancas que rodea la base de su cuello y que } \\
\text { usualmente da la impresión de ser parte de su } \\
\text { camiseta. }\end{array}$ \\
\hline \multirow{4}{*}{$\begin{array}{l}\text { Desconocidos } \\
\text { anónimos }\end{array}$} & Vendedores & Callejeros \\
\hline & Lavanderas & Campesinas \\
\hline & Gente de pueblo & Vagabundos \\
\hline & Músicos y bailadores & De la calle \\
\hline $\begin{array}{l}\text { Amigos } \quad y / o \\
\text { familia del artista }\end{array}$ & Reconocibles & De sociedad \\
\hline Familiares & Álbum de familia & De sociedad \\
\hline
\end{tabular}

Hallazgos:

De los 180 artistas que componen la muestra, el 41,7\% de ellos ha incursionado en el retrato y un $35,6 \%$ presenta, en su producción pictórica del último tiempo, retratos que se vinculan al imaginario local. Se seleccionan, a modo de ejemplo, diez de los retratos que han sido expuestos a público en alguna de las exposiciones mencionadas, con el propósito de señalar, en estos, aquellos elementos o rasgos que se consideran propios de la idiosincrasia nacional. Asimismo se ha tomado en consideración retratos que representan a personajes vinculados a la identidad nacional. Connotados, quizás, por su participación, ya sea en lo político, lo cultural, lo religioso, lo policial, la farándula televisiva, el espectáculo, por su rol histórico, o bien por su cualidad de personaje emblemático. De los retratos en su mayoría $(99,8 \%)$ lo ha hecho estableciendo una relación de semejanza fisionómica entre el referente y su 
retrato. Por lo que su vinculación con el imaginario nacional se fundamenta, en una primera instancia, en la connotación del retratado, es decir en el plano connotativo-simbólico del referente. Sin embargo, además, algunos artistas le otorgan a la imagen, una función denotativa a través de la incorporación de significantes ya sean lingüísticos, plásticos, icónicos, o bien simbólicos. Confiriendo a la imagen una significación simbólica con relación al imaginario nacional, tal como lo muestran los ejemplos siguientes.

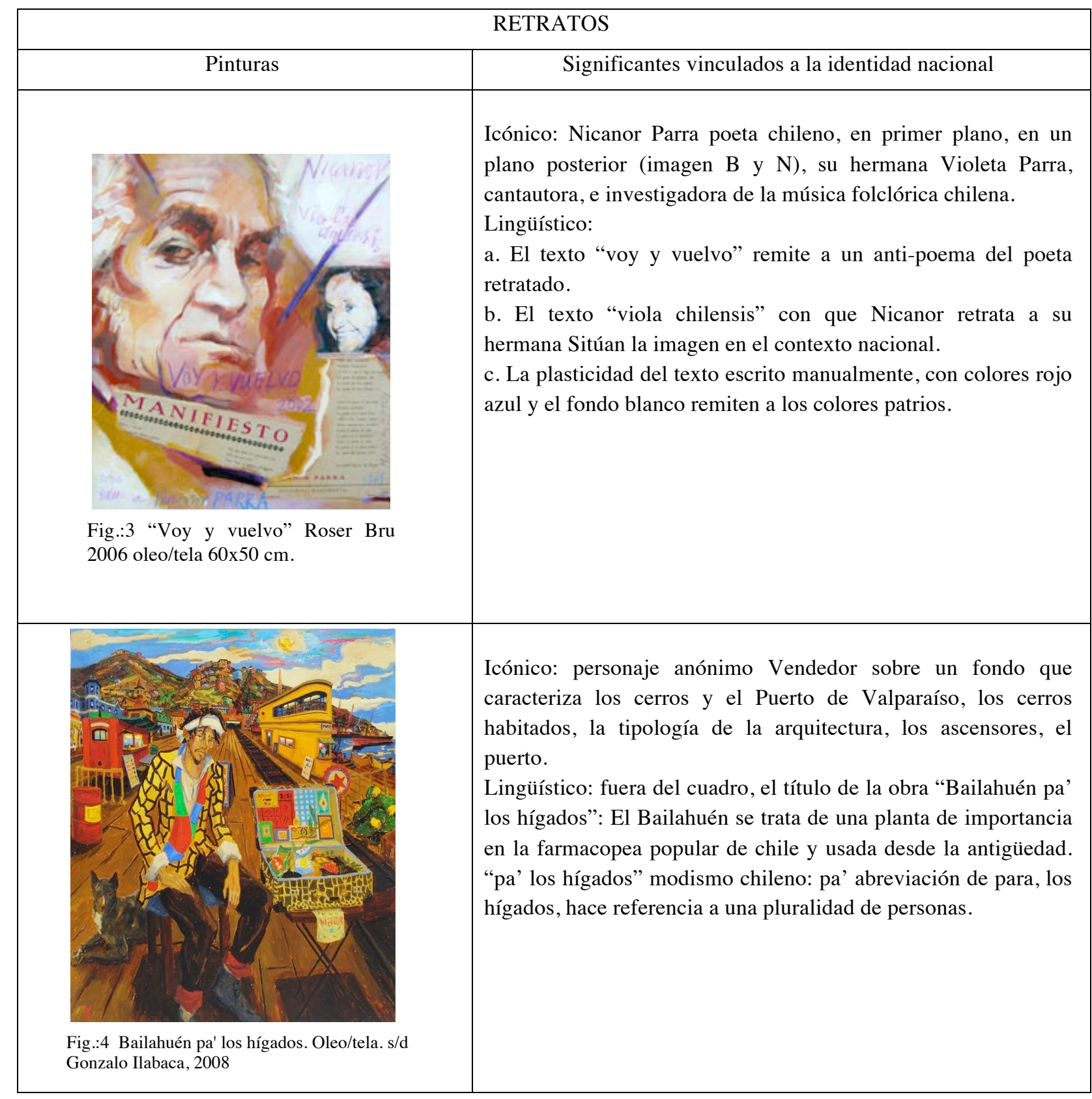




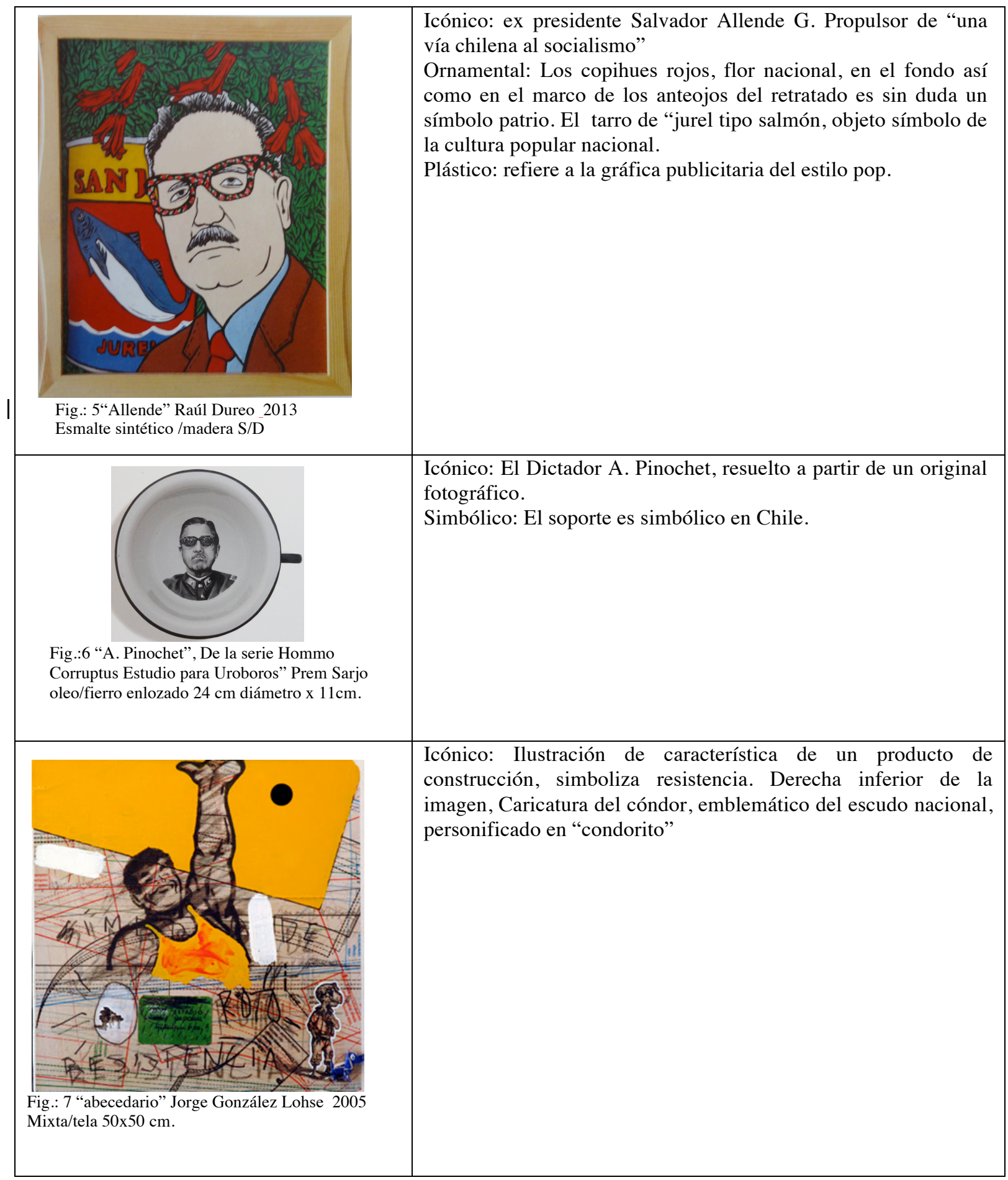




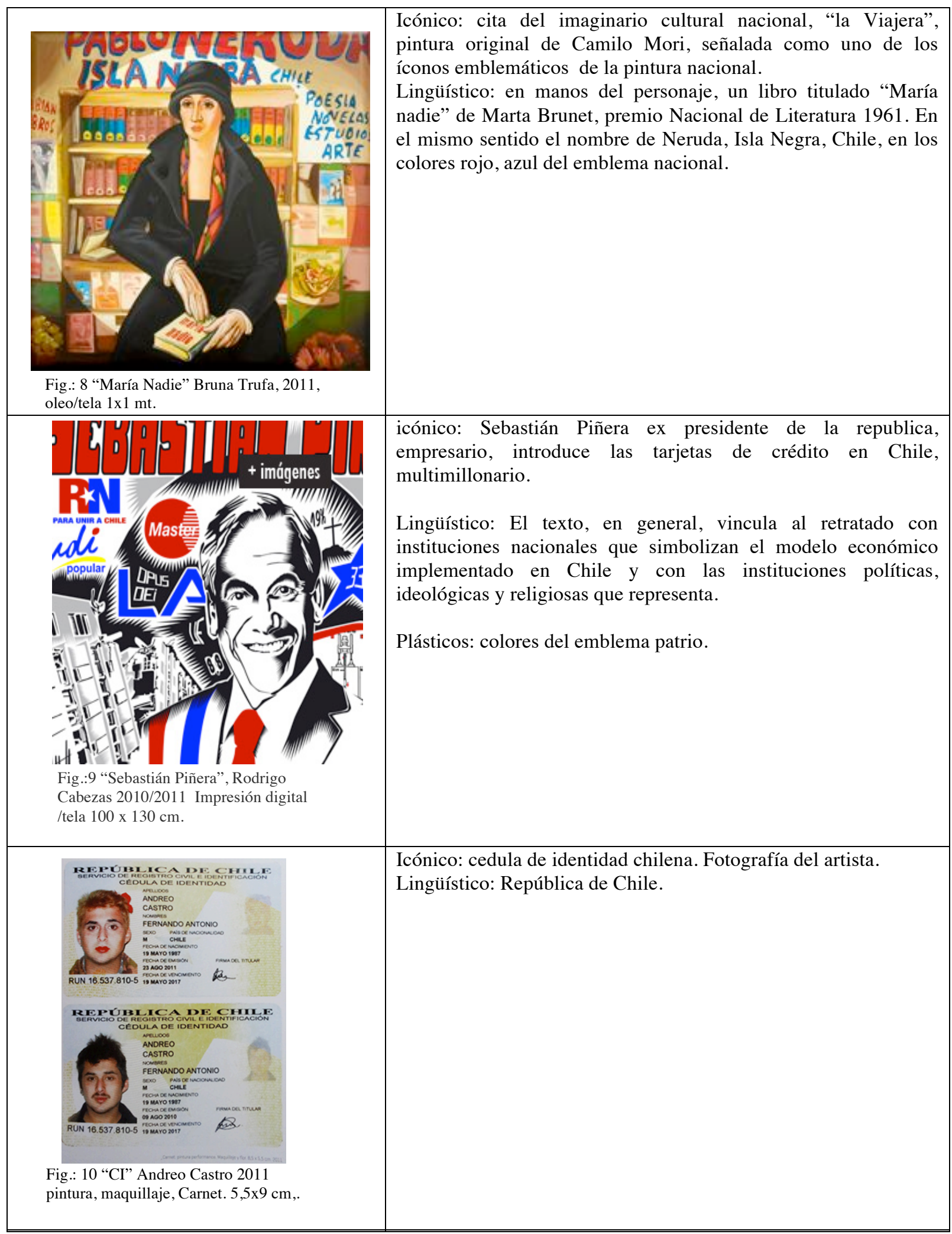




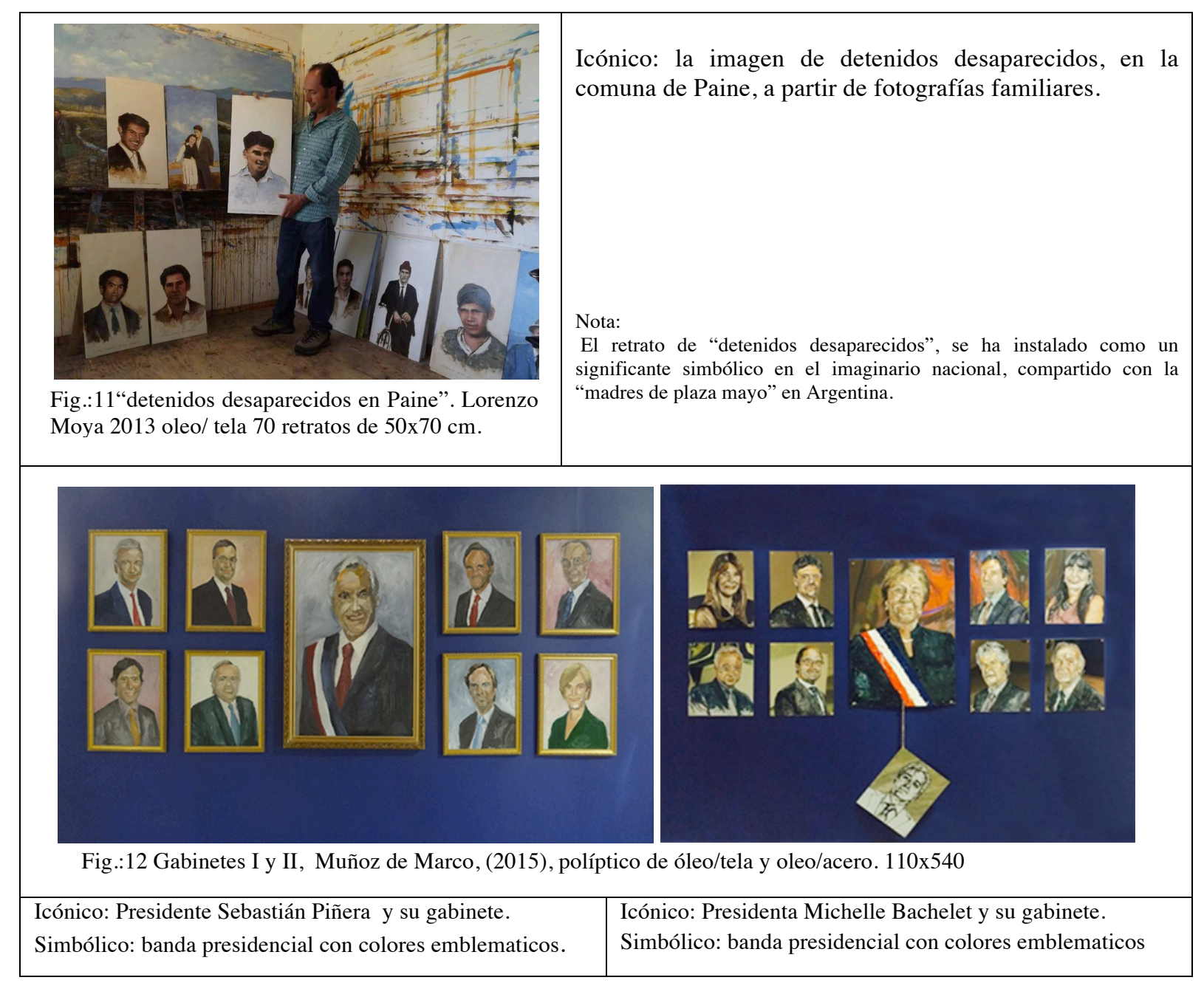

Distinguimos al menos seis tipos de retratos;

a) Aquellos que provienen de trabajos iniciados en los 90 se proyectan al 2005 (aproximadamente) los cuales tratan temas relativos a la dictadura derechos humano, personajes políticos, detenidos desaparecidos.

b) Aquellos que retratan personalidades de sociedad y del mundo de la cultura.

c) Otra tipología refiere el retrato a pequeñas narrativas que vinculan al retratado con un imaginario.

d) El retrato como cita a la historia de la pintura.

e) Retrato de personaje político.

f) El retrato político.

g) Retrato como cuestión de género 
b) El objeto.

La temática centrada en el objeto, tratada por un 12,2\% de los artistas seleccionados, asume que el pintor alude a lo histórico, lo cotidiano, lo costumbrista y popular, a través de un estudio y observación minuciosa y detallada que se detiene, en un primer plano, en el o los objetos.

Algunos artistas $(13,6 \%)$ asumen la temática con un tratamiento más experimental, lo que lo aleja de las enseñanzas académicas.

Los esfuerzos por crear obras que reflejen coherencia con la mirada personal frente al objeto cotidiano, se expresan también en las propuestas visuales $(59 \%, 1 \%)$ de quienes desarrollaron la abstracción y la síntesis como estrategia formal de creación.

Algunos se desprenden casi completamente del modelo real, otros, se quedan con aquel para construir una especie de realidad paralela, marcada por el simbolismo $(36,6 \%)$ y una poética personal, solo posible dentro del contexto de la obra.

Objetos que son característicos en Chile

Cabe decir que señalar objetos "típicos chilenos" no deja de ser riesgoso, dado que lo que se identifica como típico hoy pudiera no serlo mañana. Del mismo modo aquello que se señala o identifica como propio del chileno, no tiene por qué serlo para quien mire desde fuera $\mathrm{y}$, por el contrario lo que al ojo extranjero le parece como muy chileno, a veces, a nosotros no nos llama la atención como tal. A propósito de la celebración del bicentenario, el diario "El Mercurio (19 de Sept. 2010 bicentenario), publica entrevistas realizadas a personalidades destacadas de distintas áreas de la cultura, con la intensión de recabar información sobre los objetos que consideraban típicos y con un sesgo identitario.

Como se comprenderá esta nominación tiene el carácter ilustrativo documental, más que la intención de fijar una lista determinada de objetos chilenos ${ }^{21}$

\footnotetext{
21 a) Juan R. Couyoumdjian, historiador Licenciado en Historia con mención en Filosofía, Pontificia Universidad Católica de Chile. Doctor en Historia, Universidad de Londres.

b) José Pérez de Arce Músico, estudia composición musical en la Universidad de Chile, Santiago, investigador especialista en música prehispánica e indígena americana.

c) Sonia Montesino Profesora Titular de la Facultad de Ciencias Sociales, Licenciada en Antropología de la U. de Chile y Doctora en Antropología de la Universidad de Leidenen, Holanda.

d) Hernán Rodríguez; Arquitecto; historiador; ex Director del Museo Histórico Nacional y creador de su archivo fotográfico.

e) Verónica Waissbluth. Periodista de la Universidad Católica, especializándose en Estética y cursando un año de Historia del Arte en la Universidad Hebrea de Jerusalén.

f) Guillermo Tejeda; Licenciado en Artes por la Universidad de Chile.-Profesor en la Escola Massana y la Escola Elisava en Barcelona,.
} 


\begin{tabular}{|c|c|c|}
\hline Ámbito & Nominación & Descripción \\
\hline \multirow[t]{8}{*}{ Utilería } & $\begin{array}{l}\text { Gredas de Pomaire y } \\
\text { Quinchamalí }\end{array}$ & $\begin{array}{l}\text { En especial el cerdo-alcancía de tres patas. Similar al Piggi } \\
\text { Bank inglés }\end{array}$ \\
\hline & $\begin{array}{l}\text { El guatero: o bolsa de agua } \\
\text { caliente. }\end{array}$ & $\begin{array}{l}\text { Objeto que obedece, sin duda al influjo de la cordillera, a los fríos } \\
\text { andinos, y a un tipo de casa que jamás es calefaccionada de manera } \\
\text { integral. }\end{array}$ \\
\hline & El copihue rojo & Flor nacional. \\
\hline & La choca. & $\begin{array}{l}\text { Es el tarro de conserva que sirve para beber líquidos calientas o para } \\
\text { calentar la comida. Representa la invención y reemplazo de objetos } \\
\text { que, desde la pobreza, transforman y resignifican algo destinado a } \\
\text { otros fines en una nueva materialidad concreta y discursiva. }\end{array}$ \\
\hline & Los símbolos patrios; & La bandera, el escudo nacional, Banda presidencial. \\
\hline & Mates coquimbanos, & $\begin{array}{l}\text { En Chile se fabricó un tipo especial de mate llamado coquimbano por } \\
\text { ser un producto de la Región de Coquimbo, con plata de baja ley } \\
\text { extraída desde el mineral de Chañarcillo. Se caracterizan por } \\
\text { su pequeño tamaño, por tener escasos adornos de motivos vegetales } \\
\text { o geométricos, hechos con cobre o bronce plateado. }\end{array}$ \\
\hline & Caja de fósforos "los andes" & $\begin{array}{l}\text { Pequeña caja de cerillos cuya etiqueta es una imagen de la cordillera } \\
\text { de los andes. Se ha convertido en un Ícono nacional. }\end{array}$ \\
\hline & Estribos de madera tallada. & $\begin{array}{l}\text { El estribo chileno de factura artesanal y de carácter representativo } \\
\text { folklórico, está hecho de madera, caucho o suela. En los tres casos se } \\
\text { impone la forma trapezoidal, si lo observamos lateralmente, y la } \\
\text { cónica o piramidal, desde un punto de vista frontal; dándole una } \\
\text { proyección plana. }\end{array}$ \\
\hline \multirow[t]{8}{*}{ Vehículos } & $\begin{array}{l}\text { *indígenas canoeros del } \\
\text { extremo Sur de Chile. }\end{array}$ & $\begin{array}{l}\text { En 1970, el Gobierno de Salvador Allende, propuso fabricar dentro } \\
\text { de Chile un automóvil de orientación económica que pudiera } \\
\text { satisfacer las carencias del mercado y que estuviese concebido con } \\
\text { un sentido altamente utilitario. la Citroën FAF (Facile à } \\
\text { Frabriquer/Financer), cuya producción duró desde el año } 1972 \text { hasta } \\
1974 .\end{array}$ \\
\hline & $\begin{array}{l}\text { Citroën modelo } 2 \mathrm{CV} \\
\text { o "Citroneta", 1964, }\end{array}$ & $\begin{array}{l}\text { llamado Citroneta con carrocería particular de Chile, montada } \\
\text { en nuestro país. }\end{array}$ \\
\hline & Motocicleta "Motochi” & $\begin{array}{l}\text { "Motochi", primera motocicleta diseñada y fabricada en el país. } \\
\text { Iniciativa privada en tiempos del gobierno de Salvador Allende }\end{array}$ \\
\hline & El triciclo repartidor. & $\begin{array}{l}\text { Los chilenos hemos contado con una rede de repartos a domicilio en } \\
\text { base a personajes con canastos, bicicletas, camionetas, carretones } \\
\text { con o sin caballos, que se han encargado de traer alimentos, leche, } \\
\text { hielo, periódicos, balones de gas, etc. El triciclo, sin embargo, es } \\
\text { silencioso, humano, contundente, amigable. }\end{array}$ \\
\hline & $\begin{array}{l}\text { Los ascensores de los } \\
\text { cerros de Valparaíso. }\end{array}$ & $\begin{array}{l}\text { Son una parte esencial de esa ciudad de Chile. Debido a lo empinado } \\
\text { de los cerros porteños, por lo que los ascensores cumplen con la } \\
\text { función de comunicar rápidamente la parte alta de la ciudad con } \\
\text { el plano. funcionan a partir del año } 1883 \text {. }\end{array}$ \\
\hline & $\begin{array}{l}\text { Tejidos y figuras de } \\
\text { Rari de crin }\end{array}$ & $\begin{array}{l}\text { Rari es conocido en Chile por sus figuras de artesanía en crin, } \\
\text { artesanía única en el mundo. Las artesanas trabajan el crin de caballo } \\
\text { de color natural o teñido, y también combinado con el ixtle, fibra } \\
\text { vegetal proveniente de México }\end{array}$ \\
\hline & la joyería mapuche. & $\begin{array}{l}\text { La orfebrería mapuche, de carácter simbólico-religioso se ha } \\
\text { mantenido a través del tiempo elaborando infinidad de piezas de } \\
\text { utilidad práctica, o de expresión estética y espiritual. }\end{array}$ \\
\hline & "Antu" televisor & $\begin{array}{l}\text { "Antú" primer televisor de la Industria de Radio y Televisión IRT, } \\
\text { fabricado enteramente en chile. Respuesta para una cultura material } \\
\text { del diseño y uso de productos chilenos. }\end{array}$ \\
\hline Objetos multiuso & El alambrito, & $\begin{array}{l}\text { Objeto clave para solucionar los desperfectos de alguna maquina, } \\
\text { electrodoméstico u otro. Metáfora de la invención chilena que } \\
\text { "salva" la precariedad tecnológica. }\end{array}$ \\
\hline \multirow[t]{4}{*}{ Instrumentos musicales } & Flauta de chino. & instrumento de origen prehispánico, del norte de Chile. \\
\hline & La trutruca mapuche. & $\begin{array}{l}\text { La trutruca o petranca es un aerófono del género de las trompetas, } \\
\text { difundido principalmente entre los mapuches de Chile y Argentina. }\end{array}$ \\
\hline & Guitarrón Chileno" & $\begin{array}{l}\text { Es el cordófono mestizo (generado por el cruce de tradiciones } \\
\text { españolas y locales) más complejo de toda América }\end{array}$ \\
\hline & El cultrún mapuche & $\begin{array}{l}\text { Es un membranófono ceremonial, con membrana atada, de golpe } \\
\text { directo, semiesférico (como el timbal), independiente. Mide } \\
\text { aproximadamente entre } 35 \text { y } 40 \mathrm{~cm} \text { de diámetro superior y una } \\
\text { altura de } 12 \text { a } 15 \mathrm{~cm} \text {. Es el instrumento musical más importante de } \\
\text { la cultura mapuche, utilizado por el/la machi (chamán, curandero/a, } \\
\text { hechicero/a) para los rituales religiosos y culturales }\end{array}$ \\
\hline
\end{tabular}




\begin{tabular}{|c|c|c|c|}
\hline \multirow[t]{5}{*}{$\begin{array}{l}\text { Vestimentas } \\
\text { accesorios }\end{array}$} & $\mathrm{y}$ & Espuela de huaso: & $\begin{array}{l}\text { Accesorio de la indumentaria típica del campo se adosa al talón de } \\
\text { la bota típica de la zona de Colchagua. "un tipo de pieza que } \\
\text { provoca, como tanta cosa del campo tradicional, el orgullo altivo de } \\
\text { unos y el sufrimiento de otros" }\end{array}$ \\
\hline & & Chalas condorito, & $\begin{array}{l}\text { sandalias tipo hawaianas rebautizadas por el personaje de la tira } \\
\text { cómica. En su versión popular (la palabra chala también se usa para } \\
\text { designar la hoja del maíz) son fabricadas con restos de neumáticos, } \\
\text { son llamadas "ojotas" y forman parte de la indumentaria del } \\
\text { trabajador agrícola. }\end{array}$ \\
\hline & & El pilucho & $\begin{array}{l}\text { Prenda de vestir interior para las guaguas, la palabra es una mezcla } \\
\text { castellano-mapuche (dic. Lenz) }\end{array}$ \\
\hline & & La manta de castilla & Manta de grueso y denso paño negro impermeable. \\
\hline & & $\begin{array}{l}\text { Manta de huaso; de doble } \\
\text { faz. }\end{array}$ & $\begin{array}{l}\text { Estilización del poncho mapuche, en reducido tamaño, netamente } \\
\text { ornamental y reversible, es la prenda con historia, de la vestimenta } \\
\text { del huaso, con historia más profunda }\end{array}$ \\
\hline \multirow[t]{11}{*}{ Comidas } & & La pancutra o pantruca & $\begin{array}{l}\text { Preparación de masa hecha de harina cocida en un caldo de hueso. } \\
\text { La pantruca forma parte de los viejos saberes culinarios chilenos. La } \\
\text { palabra es de origen quechua. }\end{array}$ \\
\hline & & el charquicán, & $\begin{array}{l}\text { Guiso a base de charqui de equino, papas, zapallo y verduras } \\
\text { cocidas. }\end{array}$ \\
\hline & & El mote con huesillos, & Bebida en base a huesillos secos y mote cocinado, \\
\hline & & El valdiviano, & $\begin{array}{l}\text { Caldo de carne (normalmente restos de asado), papas, cebolla y } \\
\text { verduras }\end{array}$ \\
\hline & & El completo palta & $\begin{array}{l}\text { Sándwich de vienesa con palta (avocado) y tomate, donde el } \\
\text { elemento típico estaría en lo atiborrado del relleno }\end{array}$ \\
\hline & & $\begin{array}{l}\text { La cazuela en cualquiera de sus } \\
\text { versiones. }\end{array}$ & $\begin{array}{l}\text { Es posible que la cazuela americana tenga un origen autóctono. } \\
\text { Los mapuches preparaban "corri achawal", suerte de caldo de ave } \\
\text { (pavo o gallina araucana) que lleva papas, zapallo, choclo o } \\
\text { chuchoca, porotos verdes, pimentones, quínoa, ají, hierbas silvestres. } \\
\text { Podía llevar carne de guanaco, pudú o huemul denominándose "corri } \\
\text { ilo". Probablemente por metonimia los españoles denominaron como } \\
\text { "cazuela" mientras se referían al recipiente mientras los mapuches se } \\
\text { referían al contenido. }\end{array}$ \\
\hline & & La empanada & $\begin{array}{l}\text { unidad alimenticia integral de la patria, producto ibérico y } \\
\text { latinoamericano, escaso en materia verde. }\end{array}$ \\
\hline & & $\begin{array}{l}\text { El vino de Chile y sus } \\
\text { posibles combinaciones, }\end{array}$ & $\begin{array}{l}\text { Antiguamente(incluso hoy) la clase media y baja consumían vinos de } \\
\text { baja calidad o de poco trabajo, por lo que había una tendencia a } \\
\text { realizar mezclas, que con el pasar del tiempo han adoptado nombres } \\
\text { propios y que el folclore nacional ha preservado junto a la imagen } \\
\text { del huaso campesino asiduo a la bebida, como ejemplos tenemos: El } \\
\text { Bigoteado, el Borgoña, la Cacha floja, la Chicha de uva, el } \\
\text { Chimbombo, la Chupilca, el Clery o Cleri, el Jote, el Melvin, el } \\
\text { Navegado, el Pipeño, el Ponche, el Terremoto, el Tsunami o } \\
\text { Maremoto, el Vino de la casa. }\end{array}$ \\
\hline & & Los porotos granados & $\begin{array}{l}\text { Los porotos granados son un plato típico de la cocina } \\
\text { campesina chilena, el cual consiste en porotos cocidos } \\
\text { con mazamorra o alternativamente pilco (granos de maíz), } \\
\text { cebolla, zapallo, tomate y ajo }\end{array}$ \\
\hline & & La marraqueta. & $\begin{array}{l}\text { llamado también pan francés, parece provenir su denominación de } \\
\text { Marrakech o Marruecos, que fue protectorado de Francia. En } 1991 \text { el } \\
\text { pintor José Balmes presenta una exposición de pinturas donde el } \\
\text { ícono protagónico era la marraqueta. En Balmes el pan tiene una } \\
\text { gran carga simbólica referida a lo social. }\end{array}$ \\
\hline & & el Jurel tipo Salmón; & $\begin{array}{l}\text { Hace algunas décadas en Chile se comercializaba pescado enlatado } \\
\text { etiquetado como "Salmón“, que en realidad era Jurel, Caballa y } \\
\text { otros pescados similares los que, sin tener nada de malo como } \\
\text { producto alimenticio, se hacían pasar por otro producto de mayor } \\
\text { prestigio. A raíz de esta "suplantación de identidad" del contenido, es } \\
\text { que las empresas fueron obligadas a indicar correctamente qué } \\
\text { pescado es el contenido de la conserva. Dictada la norma se } \\
\text { encuentra el resquicio y apareció el Jurel tipo Salmón, que se ha } \\
\text { convertido en símbolo del arribismo nacional. }\end{array}$ \\
\hline
\end{tabular}




\begin{tabular}{|l|l|l|}
\hline Vivienda & La ramada; & $\begin{array}{l}\text { Construcción frágil de ramas y palos para albergar a los } \\
\text { participantes de una celebración. Su origen y uso se marca en el } \\
\text { período colonial en los parlamentos con los mapuches. }\end{array}$ \\
\hline $\begin{array}{l}\text { Expresiones de } \\
\text { espiritualidad }\end{array}$ & $\begin{array}{l}\text { La ruca } \\
\text { máscaras del norte. }\end{array}$ & $\begin{array}{l}\text { Vivienda mapuche, construcción de una habitación de barro y } \\
\text { paja, de planta circular y fogón en el medio. }\end{array}$ \\
\hline & $\begin{array}{l}\text { Vinculado a la religiosidad popular del norte. } \\
\text { mapuche }\end{array}$ & $\begin{array}{l}\text { Ve hue o hito sagrado } \\
\text { rodeado por ramas de canelo -árbol sagrado mapuche- ubicadas } \\
\text { en fila y adornadas con banderas blancas, celestes, amarillas, } \\
\text { negras. En algunas ocasiones la cima tiene una representación } \\
\text { de un rostro humano. Simboliza la conexión con el cosmos. El } \\
\text { rehue es un símbolo de gran importancia que se usa en } \\
\text { celebraciones importantes como en el machitún, guillatún, We } \\
\text { Tripantu (año nuevo mapuche), entre otros. }\end{array}$ \\
\hline & $\begin{array}{l}\text { Construcción pequeña en espacio público, de carácter religioso, } \\
\text { instalada en el lugar de fallecimiento accidental de una persona } \\
\text { a modo de casa para su alma }\end{array}$ \\
\hline
\end{tabular}

Lo típico se relaciona con una reinterpretación o resignificación "chilena" de objetos que de algún modo se convierten en metáforas o alegorías de nuestra comunidad. Veamos el detalle de algunos ejemplos.

\begin{tabular}{|l|l|}
\hline \multicolumn{2}{|c|}{ Pintura objetos } \\
\hline Pinturas & \multicolumn{1}{|c|}{ Significantes vinculados a la identidad nacional } \\
\hline & $\begin{array}{l}\text { Icónico; emblema nacional, bandera chilena. } \\
\text { Plásticos: colores de la bandera. }\end{array}$ \\
\hline Fig.: 30 "Bilz y Pap" 2002 óleo, carboncillo/tela & \\
\hline $100 x 100 \mathrm{~cm}$. & \\
\hline
\end{tabular}




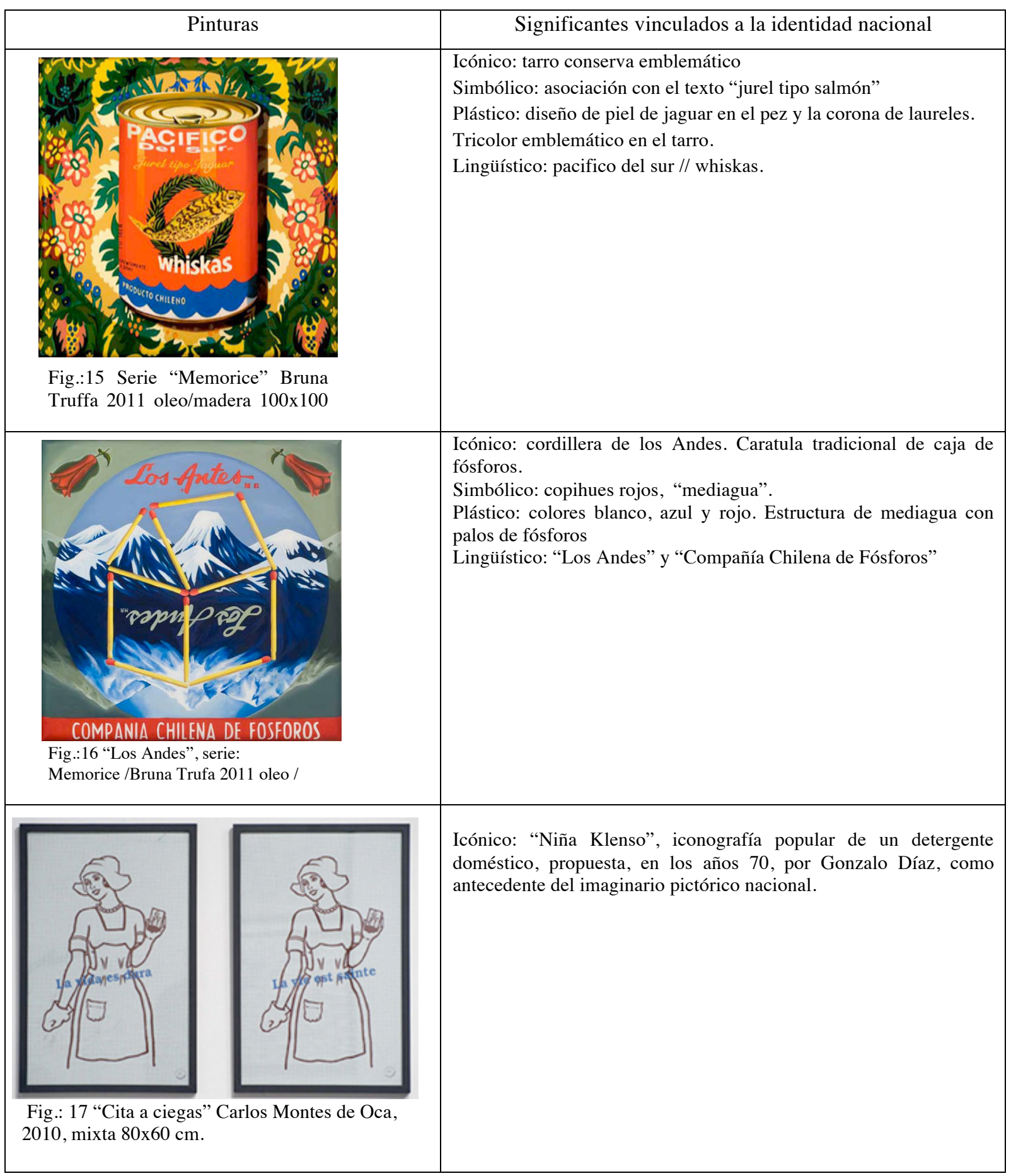




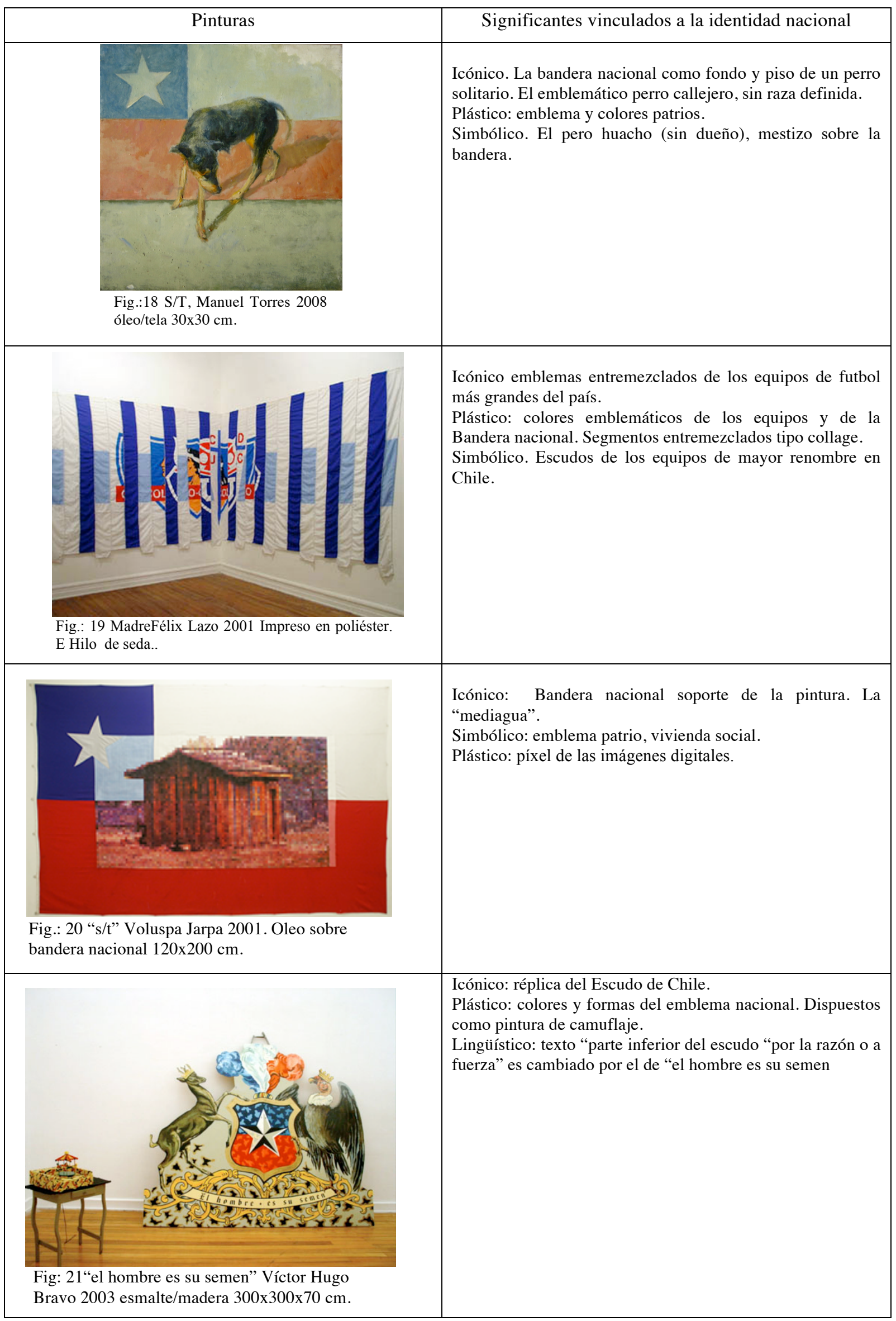




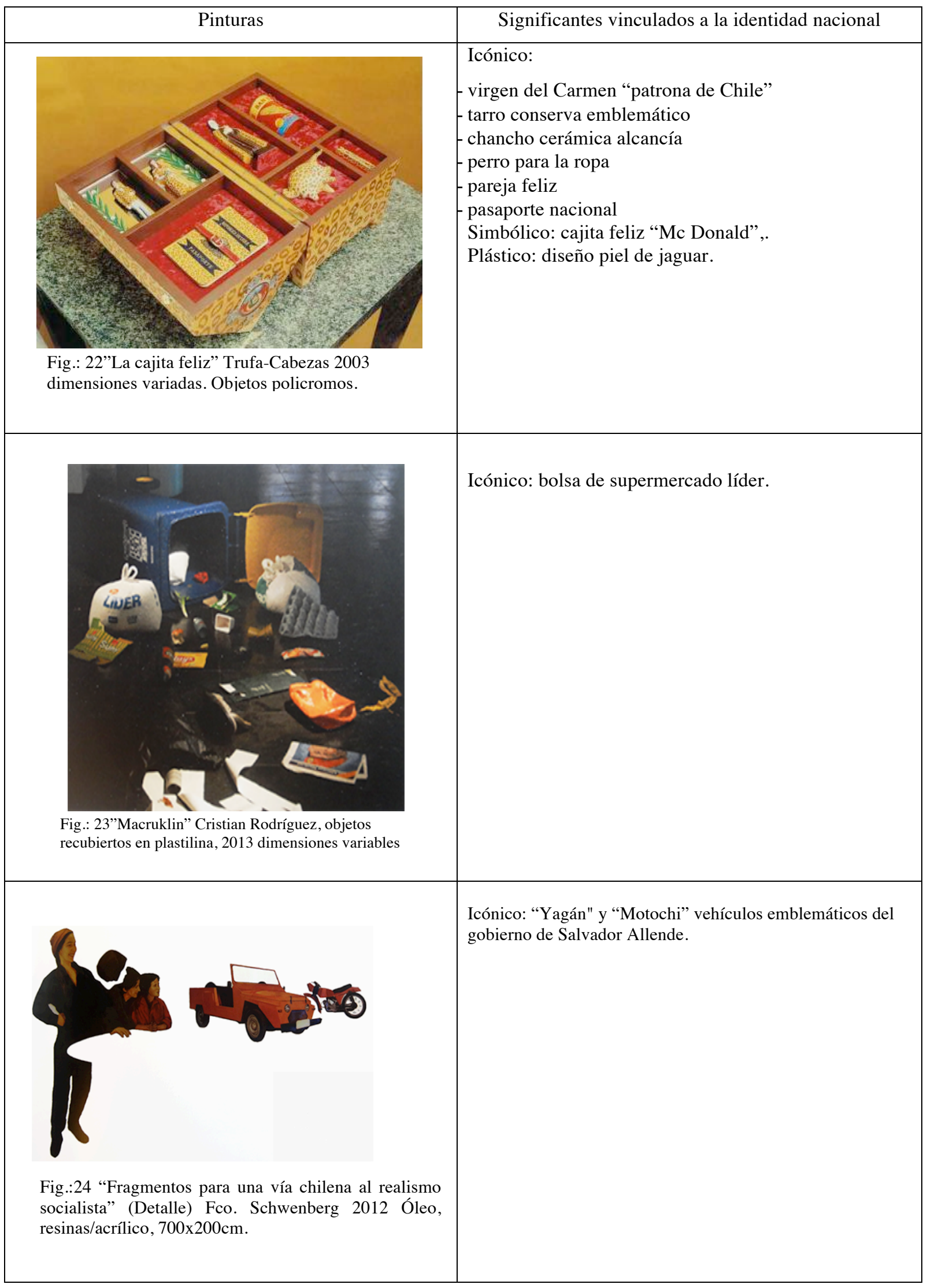


Del material revisado hemos distinguido diferentes por un lado el objeto representado y por otro el objeto soporte y con relación a su uso distinguimos:

a) El objeto emblemático, relativo a los emblemas nacionales, a saber la bandera, el escudo, la cinta tricolor, la banda presidencial, la flor nacional (el copihue rojo)

b) el objeto simbólico, cuya connotación obedece a significados otorgados por la comunidad y forman parte de la imaginería popular.

c) objetos históricos forman parte de la memoria colectiva.

d) objetos del cotidiano pertenecientes a la cultura popular, pero que sin embargo, son ya parte del imaginario. A saber la "pelela" (bacinica)

c) El paisaje

La toma de conciencia de la naturaleza como problema a resolver al interior de cuadro o más bien como un pretexto al interior del cuadro para abordar problemas de lenguaje, de forma o de la relación referente-referido, ha sido el motor de importante parte del trabajo sobre el paisaje en la pintura chilena. De hecho un 20,6\% de la muestra lo aborda, en alguna de sus formas. No hay duda que a principios del siglo XX los pintores de paisaje instalan por primera vez la idea de lugar y éste se sostiene cuando establecen conscientemente en sus procedimientos el cruce entre naturaleza y lenguaje. Hoy observamos una diversidad de propuestas que se instalan al interior del cuadro, como fuera de éste, unas más realistas apegadas a un modelo, ya sea mental o natural y otros que llevan lo visible del cuadro a un alejamiento de la representación, profundizando una especulación más bien lingüística que temática. (Galaz, 2003).

El paisaje chileno, sobre todo la costa porteña, y el valle central, es -según Galazrecurrente en la pintura chilena. En el último tiempo ha sido tomado como pretexto para tematizar los cambios lingüísticos a través de los cuales se vehicula la idea de paisaje, llama la atención el alto porcentaje (45\%) que lo refiere al paisaje imaginado. El 55\% lo hace con referencia a alguna localidad geográfica real. Pero, además, nos encontramos con propuestas pictóricas que tratan el tema como excusa para abordar problemas que van más allá del paisaje propiamente tal o como reconocimiento del lugar, abordando contenidos ya sea ecológicos o sociales vinculados al imaginario nacional. De ellos hemos tomado algunos ejemplos. 
Con relación tipología del paisaje chileno, vinculado a aspectos identitarios, hemos encontrado diversos tipos y caracterizaciones en cuanto a su ubicación geográfica, tal como lo describe el recuadro:

\begin{tabular}{|l|l|}
\hline Tipo Paisaje & Caracterización \\
\hline Rural & Zona central, desierto, sur austral, isleño, altiplano nortino. \\
\hline Montañés & Cordillera de la costa, Nahuel buta \\
\hline Cordillerano & Cordillera de los Andes, Volcanes y faldeos cordilleranos. \\
\hline Lacustre & Zona de los lagos, lago Chungará. \\
\hline Costero & Paisaje porteño, caletas, playas. \\
\hline Urbano & Ciudades y pueblos típicos, Valparaíso, Salitreras abandonadas. \\
\hline Imaginario & Vinculado a la imaginería nacional. \\
\hline Fuera del cuadro & El paisaje real como soporte de la acción o intervención pictórica. \\
\hline
\end{tabular}


Veremos, a continuación, algunos ejemplos extraídos de la muestra:

\begin{tabular}{|c|c|}
\hline \multicolumn{2}{|c|}{ PAISAJE } \\
\hline Pinturas & Significantes vinculados a la identidad nacional \\
\hline & $\begin{array}{l}\text { Icónico: la cordillera de los Andes, la bandera } \\
\text { nacional, el pan (marraqueta) sobre la mesa. } \\
\text { Lingǘstico: la palabra Chile manuscrita y repetida. El } \\
\text { apellido Allende en color blanco sobre una X símbolo } \\
\text { de la campaña del presidente Allende. }\end{array}$ \\
\hline \multicolumn{2}{|c|}{$\begin{array}{l}\text { Fig,:25 "historia personal" (detalle) Roser Bru, } 2003 \\
\text { acrilico/tela } 1.60 \times 5 \mathrm{mt} .\end{array}$} \\
\hline & Icónico: anamorfosis retrato del dictador Pinochet \\
\hline \multicolumn{2}{|c|}{$\begin{array}{l}\text { Fig.: } 26 \text { "Deep Chile" Hugo Cárdenas (detalle 1x0,9 mt) } \\
2003 \text { oleo/tela } 1 \times 7 \mathrm{mt} .\end{array}$} \\
\hline 8 & $\begin{array}{l}\text { Icónico: maqueta de casa inglesa, sobre planta de } \\
\text { mediagua } \\
\text { Plástico: rectángulo con color azul ultramar según } \\
\text { las dimensiones de una mediagua, en sitio eriazo } \\
\text { Valparaíso } \\
\text { Simbólico: sombra de mediagua en color azul } \\
\text { ultramar. }\end{array}$ \\
\hline $\begin{array}{l}\text { Fig.: "verosimilitud/ inverosimilitud" } \\
\text { Intervención con color azul ultramar s } \\
\text { una mediagua, en sitio eriazo Valparaís } \\
\text { rectángulo la maqueta de una casa ingle }\end{array}$ & \\
\hline
\end{tabular}




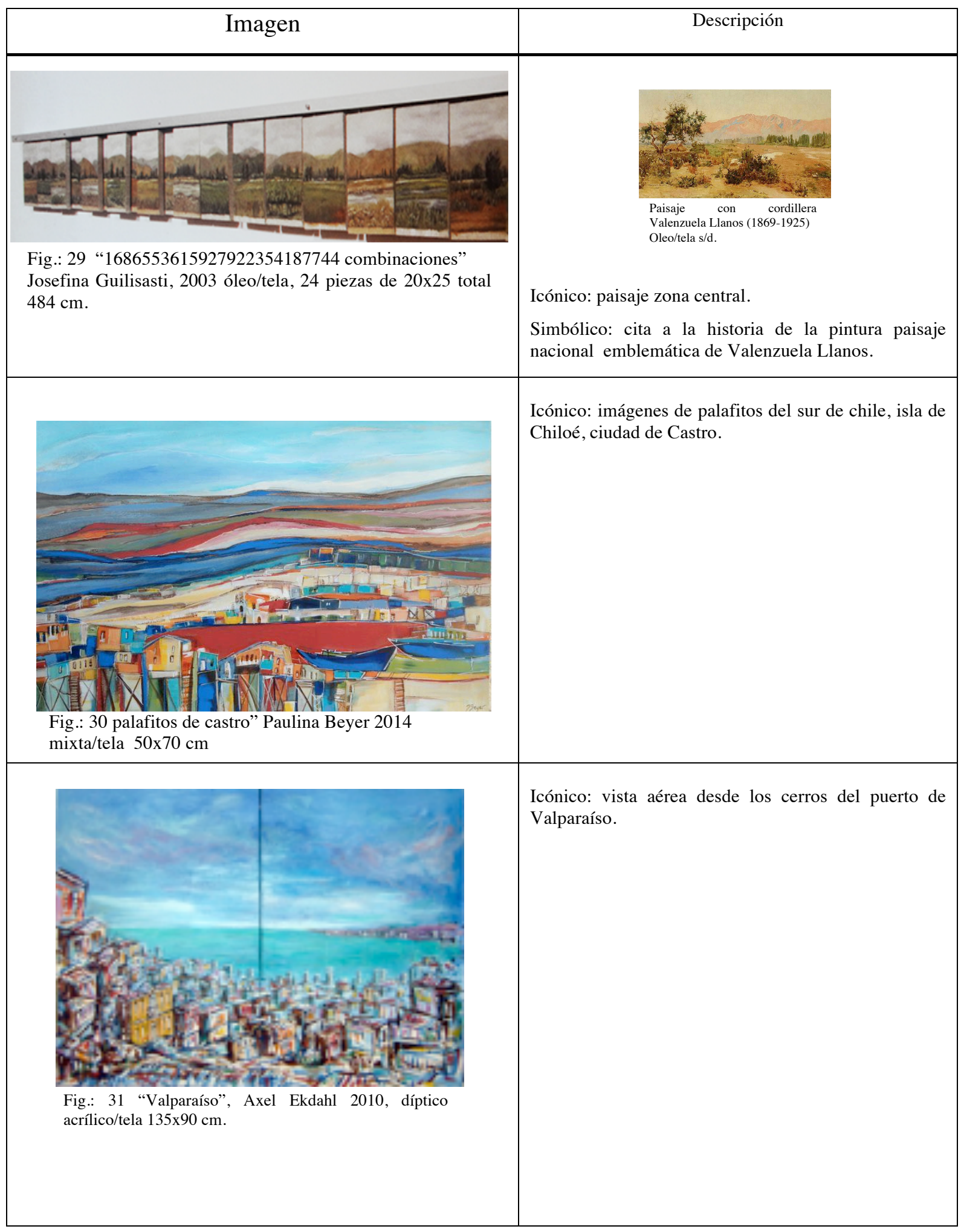




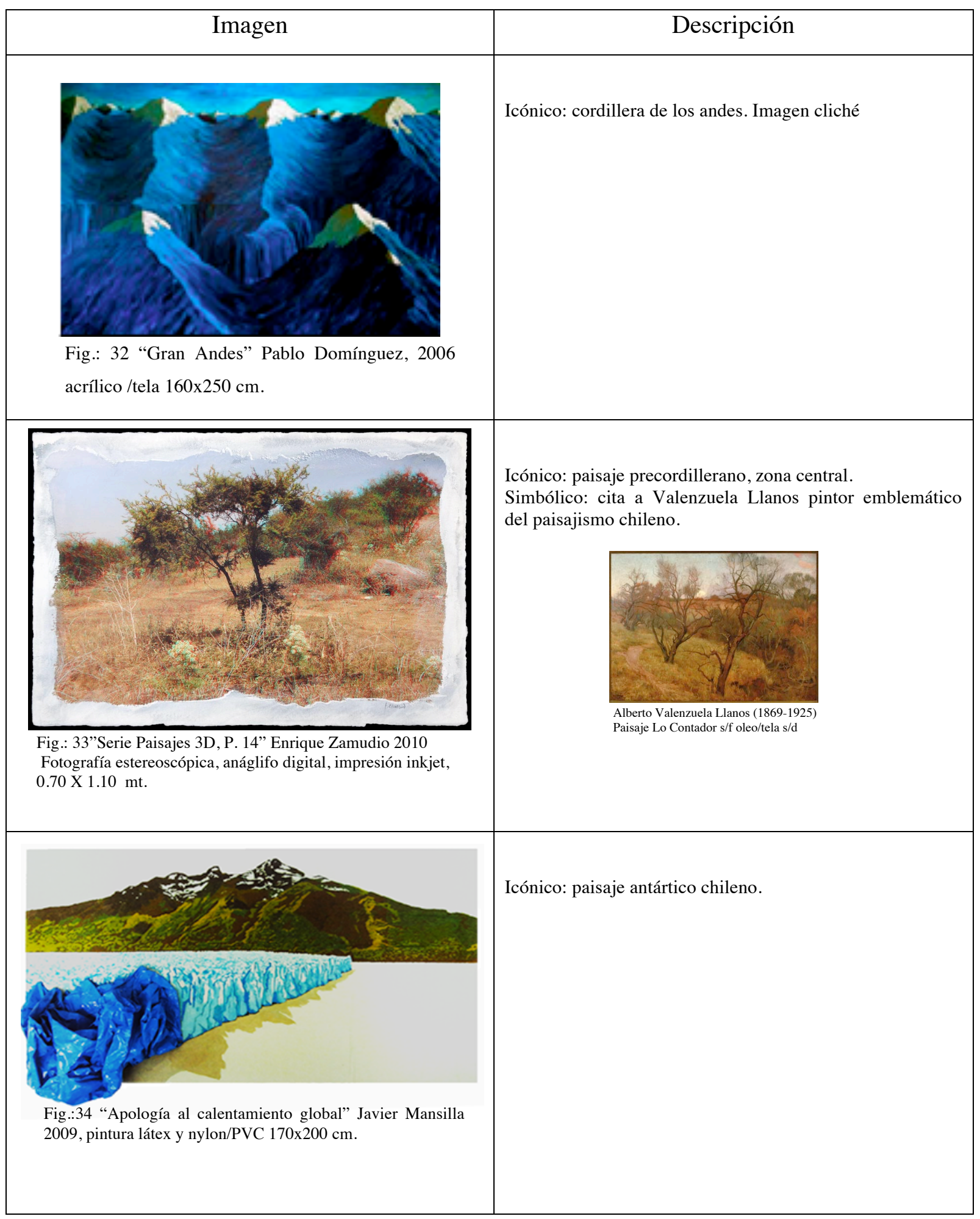




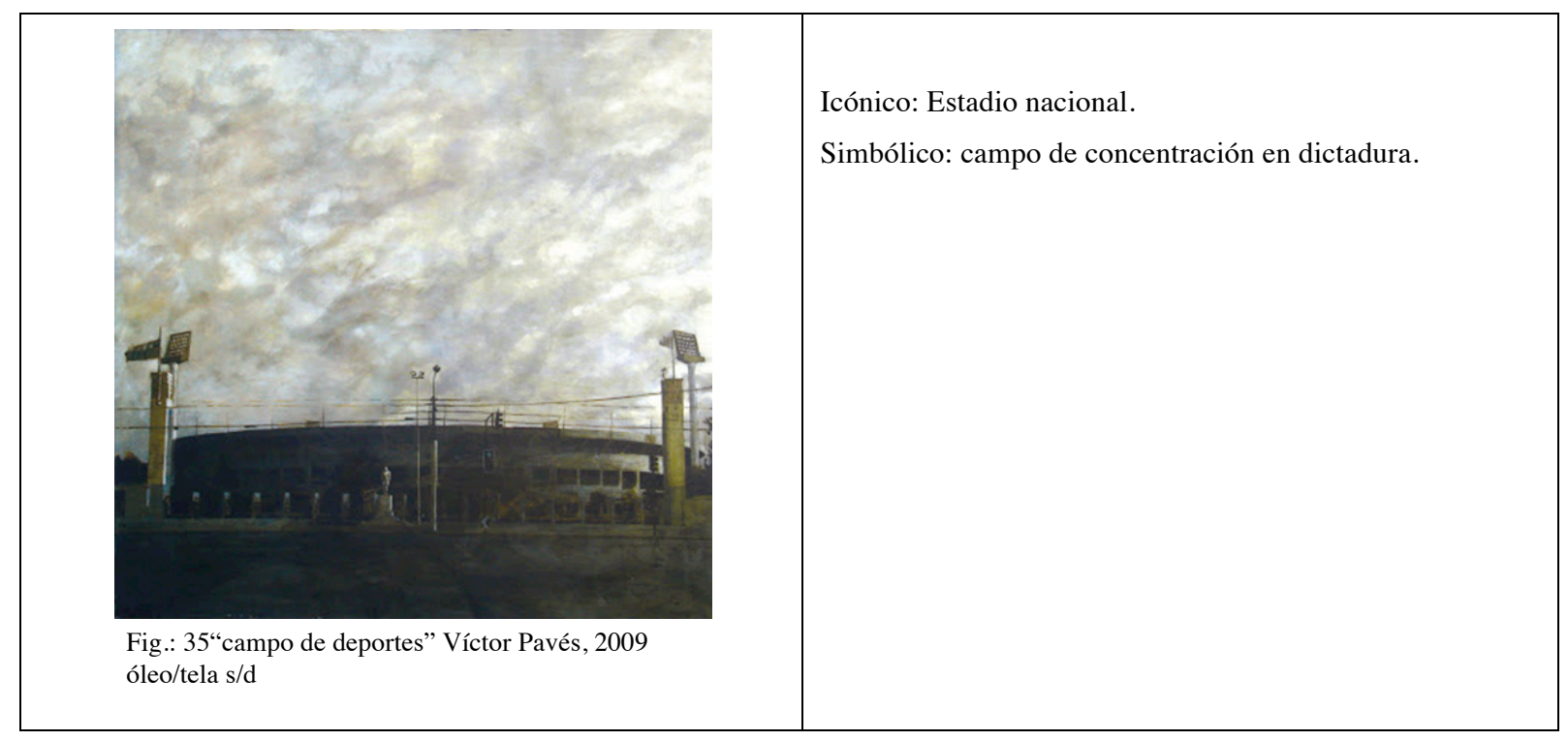

De los artistas 180 artistas encontramos recurrencia en el tratamiento y representación del paisaje en sus distintas especificidades:

Forestal: Como reconstitución de la memoria pictórica nacional como reconstrucción del territorio.

Urbano: resignificación del espacio urbano como re-visión del espacio social e identitario.

Costero: al igual que el paisaje forestal se propone un reconstitución de la memoria pictórica como autoreconocimiento.

Psicológico: a modo de reconstitución de la memoria individual a través de la evocación territorial.

Marino: a modo de evocación de la memoria colectiva histórica.

Cordillerano: a modo de cita de la iconografía popular, vinculados al imaginería popular. 
d) Escena.

Cuando aparece en la escena social la clase media, y cuando la actividad cultural se profesionaliza, en instituciones como la Universidad de Chile, el país empieza a descubrir y retratar las costumbres populares y los tipos campesinos chilenos, así como sus fiestas religiosas y profanas, un rico patrimonio con el que construye una identidad mirando hacia sus propias honduras.

Chile -como cualquier otro país- posee una cultura popular rica en expresiones ya sean religiosas, profanas, políticas o sociales. En su mayoría presentan características particulares con relación a las diferencias regionales y geográficas y otras vinculadas a la memoria colectiva nacional con relación a la independencia, las guerras, los desastres naturales o accidentales de gran impacto. Señalaremos las más populares y que perduran hasta el día de hoy, según el Centro Chileno de Cultura Folklórica ${ }^{22}$.

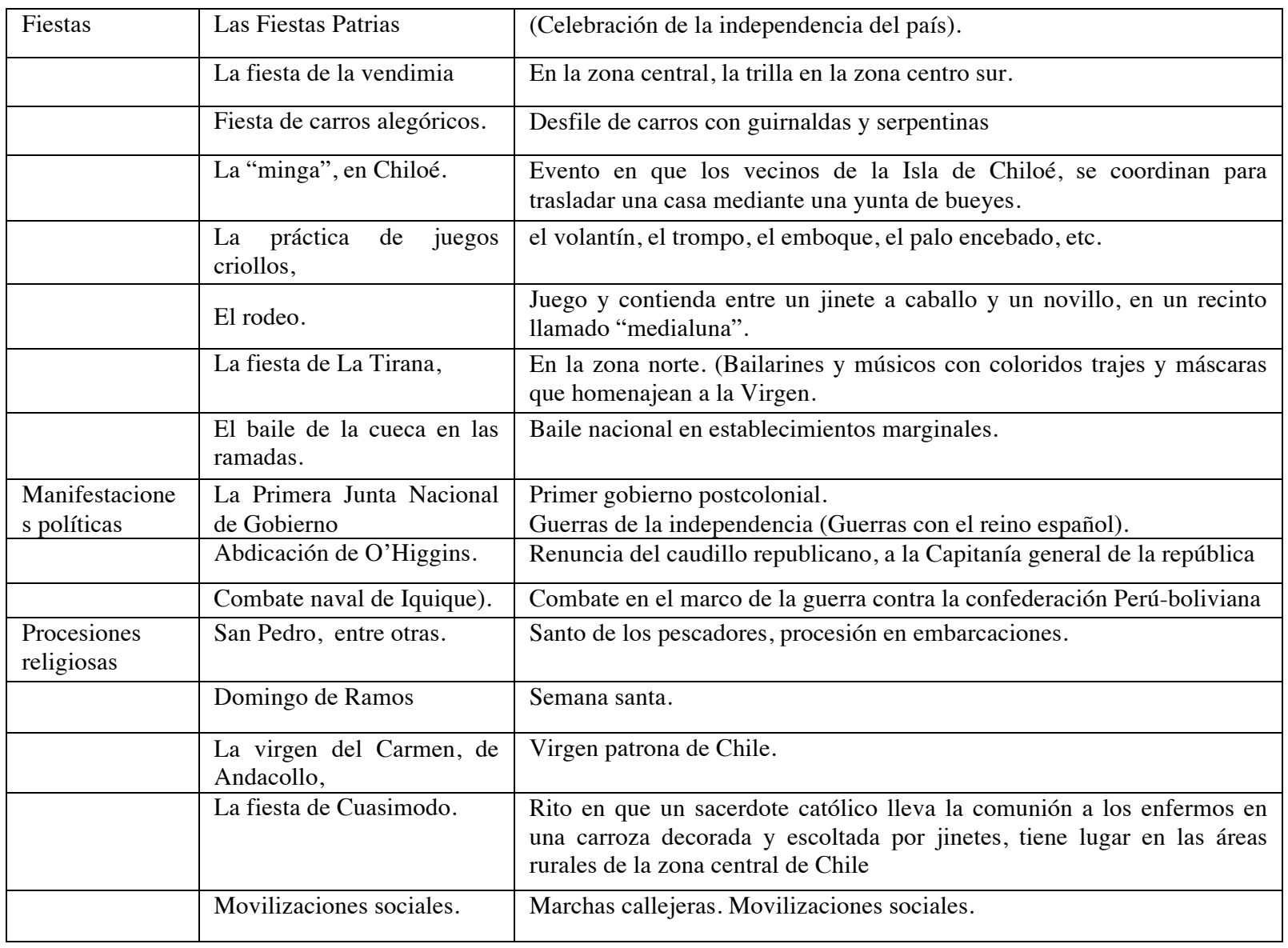

22 Centro Chileno de Cultura Folklórica ex Consejo Chileno de Cultura Tradicional y las Artes Populares, organización asociada a Dirección de Bibliotecas Archivos y Museos (DIBAM) del Consejo Nacional de la Cultura y las Artes (CNCA). Su función es aglutinar a varias organizaciones de folkloristas como el Sindicato de Folkloristas, la Agrupación Chilena R. Barros, ANFOLCHI, la AGEMPOCH, CHINCHINEROS, y otras, dándoles espacios escénicos para sus integrantes. 


\section{Hallazgos:}

Hemos constatado que un $36 \%$, de los artistas seleccionados, ha pintado escenas vinculadas al imaginario nacional, ya sea abordando temas socio-políticos, históricos o bien del cotidiano, otros como una forma de abordar aspectos relacionados con la celebración del bicentenario.

\begin{tabular}{|l|l|}
\hline Imagen & \multicolumn{1}{|c|}{ Descripción } \\
\hline & $\begin{array}{l}\text { Icónico: monumento al libertador B. O'Higgins } \\
\text { Lingǘstico. Fuera del cuadro titulo "bicentenario" }\end{array}$ \\
\hline & \\
\hline &
\end{tabular}




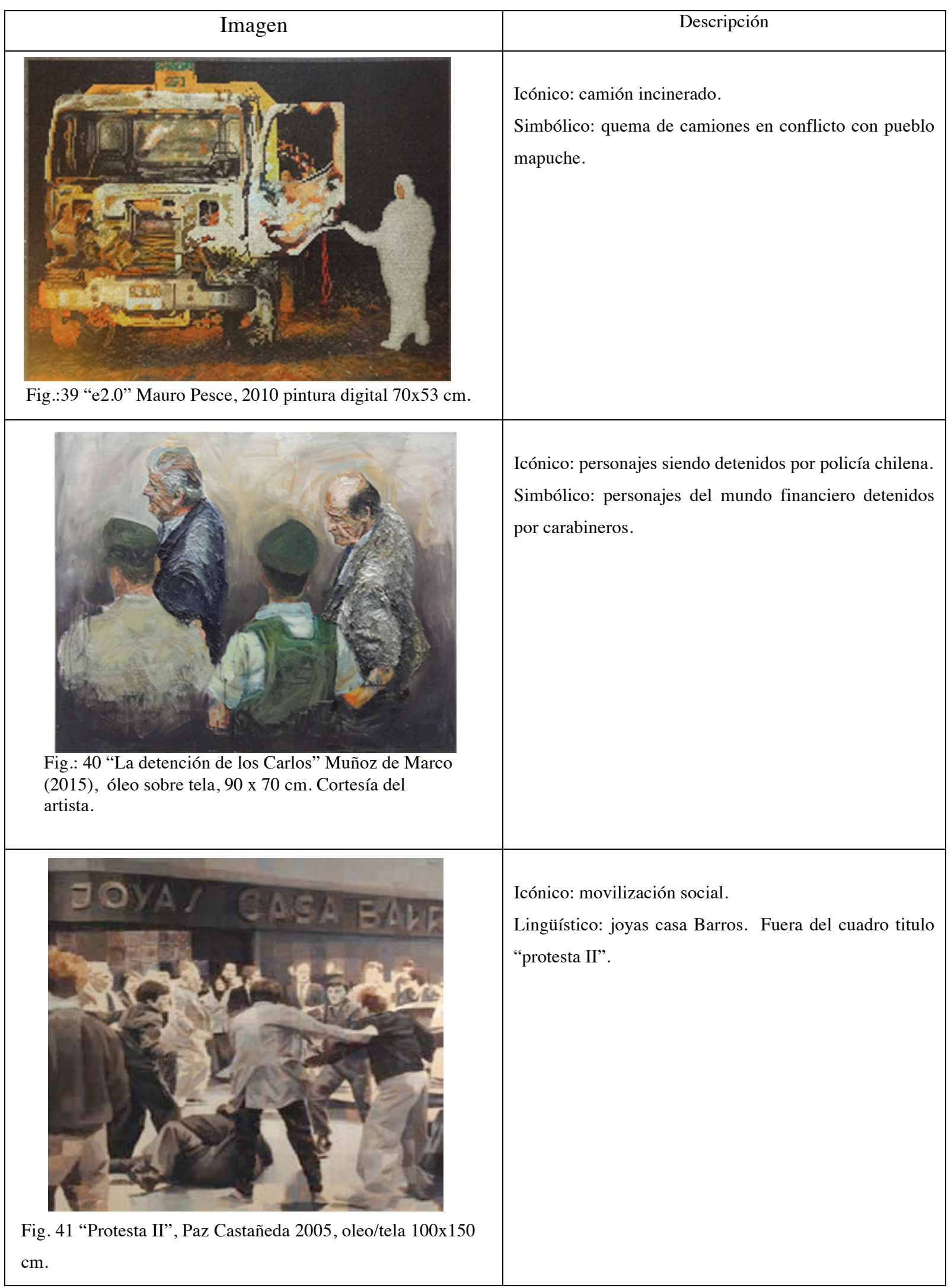




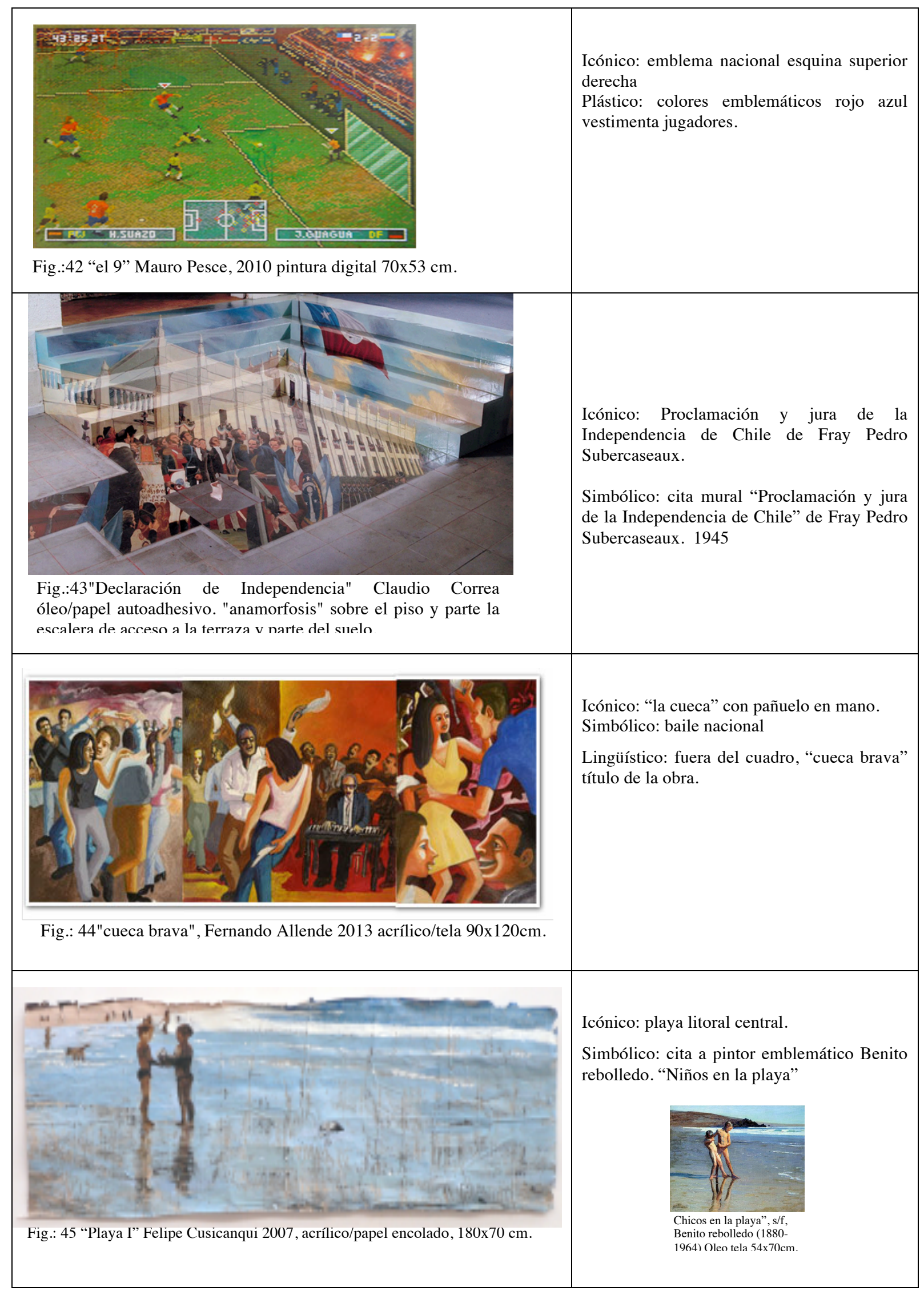

De los casos estudiados, el tema de la figura humana asociada a escenas de diversa índole vinculadas al imaginario la figura humana entre los cuales un alto porcentaje lo ha hecho representando escenas asociadas con: 
- Recreación/divertimiento, bailes, playa, fiestas.

- Represión, revueltas callejeras.

- Movilizaciones sociales.

- Conmemoraciones históricas.

\section{$\mathrm{N}^{\circ}$ 4. Análisis connotativo}

\section{4-a Dimensión sentido}

Si bien uno de los significantes de la imagen pictórica, en cuanto experiencia estética tradicionalmente ha estado dado, en parte, como se ha dicho, por el gesto pictórico o bien la huella de ese gesto y la trama matérica de la pintura propiamente tal, encontramos, en que la expansión del campo de la pintura, ha permitido la incorporación de significantes que bien pudiesen disputar con la pintura-materia su esencialidad en cuanto diagrama articulador de la imagen.

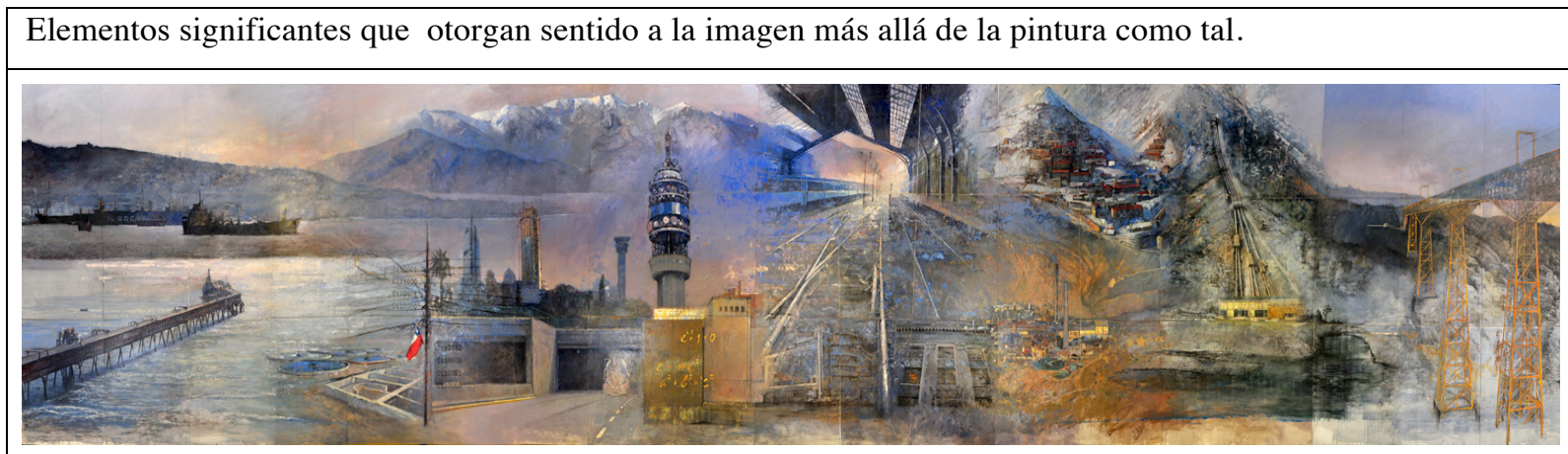

fig.: Fig 46 "Ingeneria en Chile" proyecto bicentenario, R Roberto Geisse (2010) en MetroArte de 220 metro cuadrados, (48 metros de largo por 4,5 metros de altura), mixta/madera

Icónico: 31 escenas que recorren Chile de norte a sur. Entre ellas destaca una mina a tajo abierto, una instalación salitrera, imágenes de trabajadores mineros, un observatorio astronómico, líneas de transmisión eléctrica, la dársena de Valparaíso, un muelle para descarga de graneles, autopistas urbanas, edificios y torres emblemáticas de la Región Metropolitana, una estación de ferrocarriles, una central hidroeléctrica, el acueducto del Malleco, una planta de tratamiento de aguas, una industria siderúrgica, una empresa de explotación petrolera, una imagen del Banco Central en reconocimiento a la ingeniería comercial. La bandera chilena.

El sentido de la imagen descansa en su narrativa, así como en la literalidad del signo icónico.

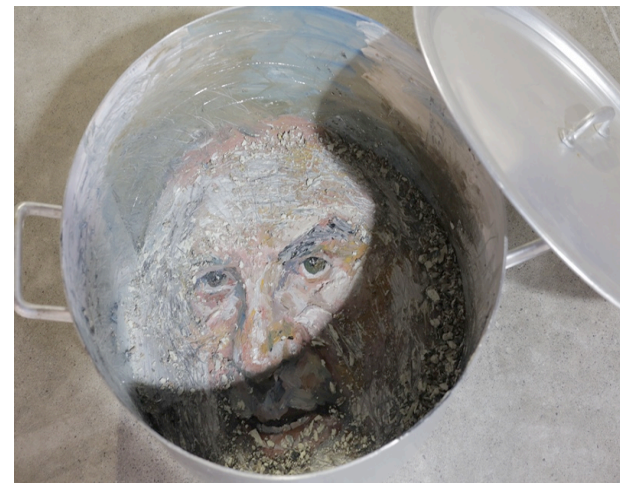

Fig.: 47 Muñoz de Marco, Un raspado de olla para Iván Moreira (2015), óleo sobre aluminio, $80 \mathrm{~cm}$ diámetro. Cortesía del artista.
El objeto como significante y soporte de la pintura. El sentido de la imagen surge en la relación literal entre objeto y pintura. 


\begin{tabular}{|c|c|}
\hline $\begin{array}{l}\text { Fig.: } 48 \text { "impertinencia y deseo" Voluspa Jarpa } 2001 \\
\text { Serie de } 5 \text { banderas de } 3 \times 4,5 \text { mts. En "informe/ } \\
\text { Balmes+Jarpa. }\end{array}$ & $\begin{array}{l}\text { Intervención "de sentido" a nivel de las imágenes } \\
\text { pintadas (imagen de mediagua, imagen de beso, imagen } \\
\text { de bandera). } \\
\text { La bandera chilena aparece cuestionada desde su forma } \\
\text { (fragmentaciones en el sentido horizontal y vertical de } \\
\text { sus proporciones), materialidad (bandera de frazada } \\
\text { gris de emergencia), identidad visual (bandera } \\
\text { enteramente blanca con texto) e }\end{array}$ \\
\hline $\begin{array}{l}\text { Fig.: "imaginario célebre" Álvaro López } \\
2000 \text { oleo/tela } 50 \times 50 \mathrm{~cm}\end{array}$ & $\begin{array}{l}\text { El pixel como significante plástico más allá del gesto } \\
\text { pictórico. }\end{array}$ \\
\hline $\begin{array}{l}\text { Fig: 49"Rubrica" Gonzalo Díaz } \\
\text { onnz inctalarión }\end{array}$ & $\begin{array}{l}\text { Color luz como significante plástico. } \\
\text { además de los neones, se valía de luces rojas para teñir } \\
\text { todo el recinto con ese color, asimismo el espacio } \\
\text { estaba cargado con el sonido a sottovoce de canciones } \\
\text { populares chilenas de los sesenta y ochenta, todas } \\
\text { "sampleadas" y distorsionadas electrónicamente }\end{array}$ \\
\hline $\begin{array}{l}\text { Fig.:50 "sombras virgenes" (detalle) Paul Fuguet } \\
2009 \text { figuras de yeso pintadas instalación. }\end{array}$ & $\begin{array}{l}\text { El objeto como soporte a la vez que significante } \\
\text { plástico }\end{array}$ \\
\hline
\end{tabular}




\section{Hallazgos.}

Los desplazamientos y la expansión del campo de la pintura obliga a construir el sentido de la imagen pictórica más allá del gesto u operación realizada con el material propiamente tal. Más bien el sentido de la imagen se construye a partir de las relaciones que se puedan establecer entre las distintas operaciones, dispositivos y elementos que constituyen la imagen y que operan como significantes articuladores de sentido.

En ese sentido podemos señalar, en las producciones pictóricas analizadas, imágenes cuyo sentido se construye a partir de la relación entre pintura y objeto, otras donde el objeto debe ser entendido como significante icónico-plástico, también aquellas donde la estructura narrativa de la imagen carga a ésta de sentido, y finalmente las que proponen lo pictórico de modo inmaterial a través de la virtualidad o la luz.

\section{4-b Dimensión referencial}

La práctica pictórica, en los últimos años se ha distanciado de los modelos previos, que de algún modo permitían la comprensión de la pintura a partir de referentes provenientes del mundo de la pintura. La práctica actual se presenta más desprejuiciada, se atreve a incursionar en un diversidad de propuestas que de algún transgreden las denominaciones tradicionales. La comprensión de obra pictórica obliga no solo al conocimiento del devenir histórico de la propia práctica y su contexto, sino también a la comprensión y conocimiento de aquellos elementos provenientes tanto de la cultura popular, como visual y medial, pertenecientes al cotidiano acontecer, tanto a nivel global como local.

Uno de los referentes estilísticos con mayor recurrencia en la obra que hemos seleccionado en cuanto a su vinculación con lo identitario tiene que ver con el pop art. Un alto porcentaje de los artistas, en general, no muestran filiaciones estilísticas en particular y de asumirla es meramente circunstancial. Las asociaciones o posibles filiaciones dicen relación con la temática abordada, en cuanto a lo señalado respecto al pop art, esta situación tiene su fundamento tanto en cuanto la imaginería popular ha sido el recurso utilizado como sinónimo de lo identitario.

\section{4-c Dimensión contextual}

El campo de expansión así como la noción de desplazamiento de lo pictórico va en paralelo con la incorporación y utilización de una diversidad de materiales; la intención es ampliar los límites de lo pictórico, incorporando lo objetual e induciendo nuevos procesos de reflexión y comprensión del hecho artístico, tanto en el campo perceptual como en el conceptual incorporando el espacio ocupado e intervenido como espacio que se activa y 
redefine en función de del sentido de la obra. Ello es observar el espacio de acogida con las posibilidades de intercambio o cruzamiento. Se desafía, de este modo, el carácter aurático, anulando los campos disciplinarios y el propio objeto pictórico en esta situación de expansión se encuentra en entredicho. Aunque es una tendencia en la escena del arte nacional no lo es en el plano del campo expandido de la pintura asociada a aspectos vinculados al imaginario o identidad chilena.-Señalamos A modo de ejemplo, señalamos algunos artistas que son parte de este estudio, puesto que su producción, en general, se inscribe en el campo de la pintura.

Se proponen, a modo de ejemplo, algunas intervenciones, que pudiesen considerarse campo expandido de la pintura, en los que la propuesta en "sitio específico" se inscribe en lo idiosincrático.

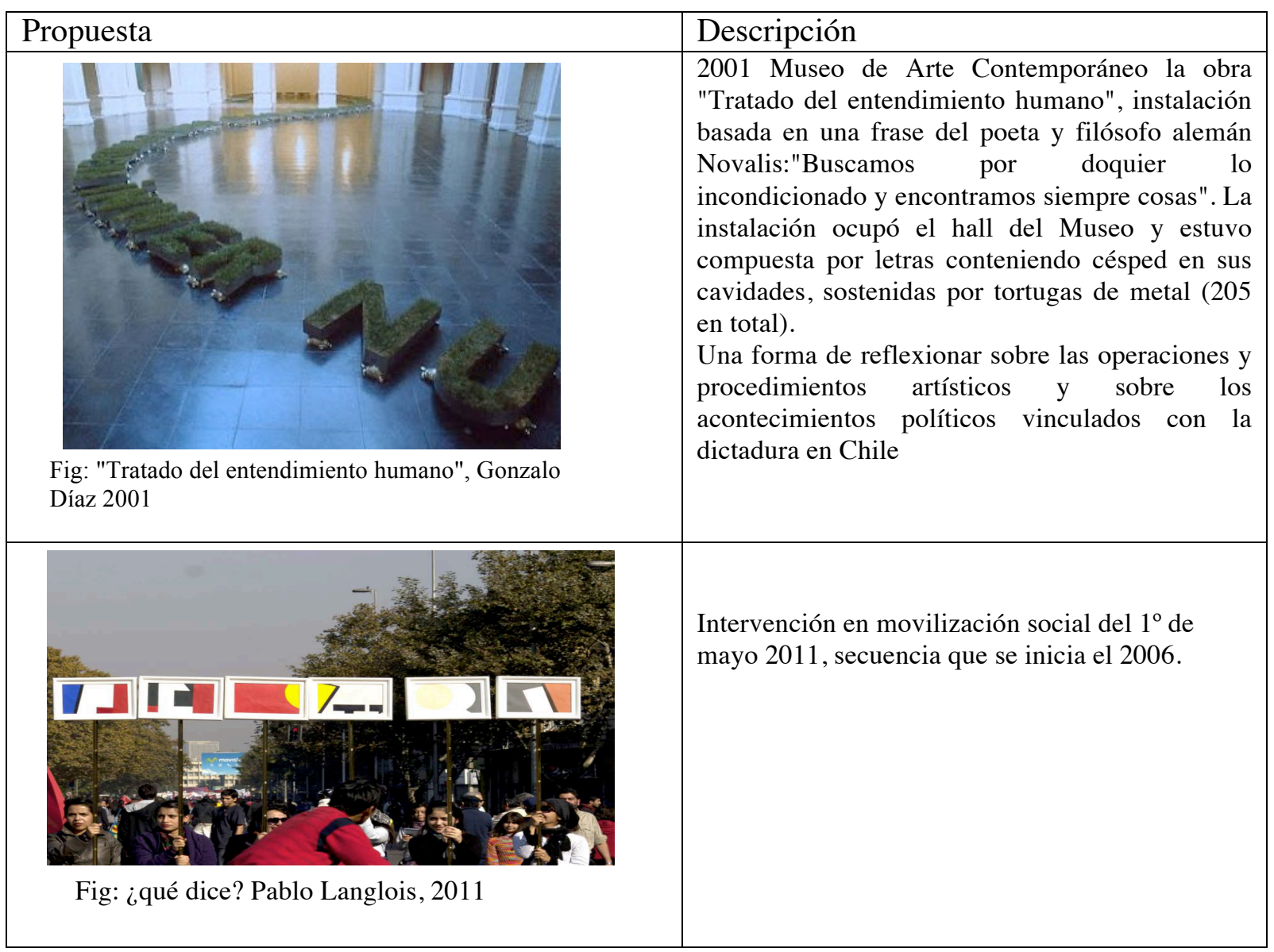




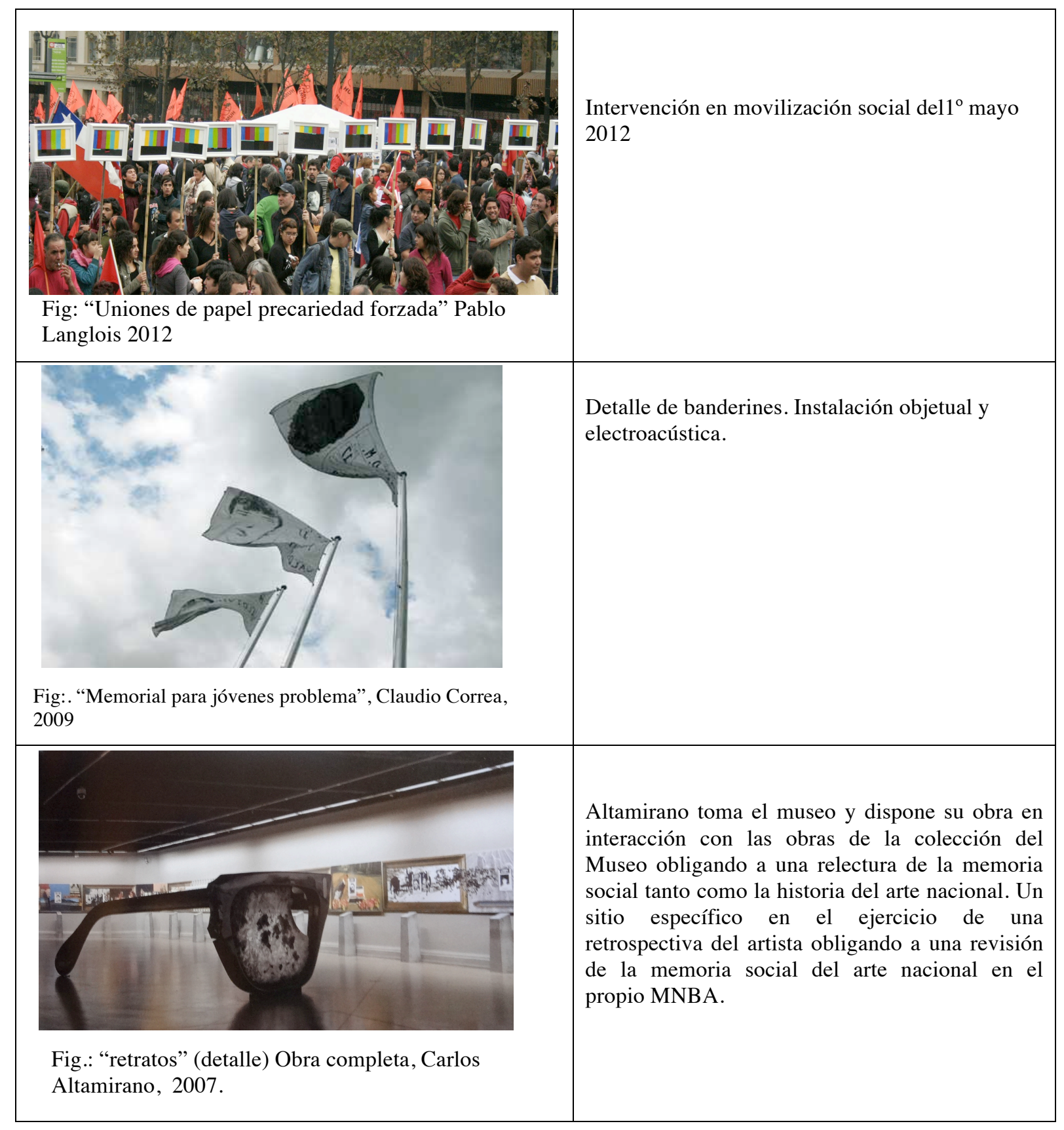

Habiéndose revisado la producción (2000-2015) de 180 artistas nacionales con una selección de 540 pinturas, en una clasificación por unidades temáticas, abordadas por ellos en su práctica pictórica, se ha encontrado: primero que la mayoría de los artistas $(82,8 \%)$ trata múltiples temas, así como problemáticas diversas. Asimismo se ha evidenciado que los pintores no condicionan su práctica al uso de un formato determinado, tampoco lo hacen fidelizándose con un tipo de procedimiento, recursos o estrategias específicas, más bien el $80 \%$ recurre a una multiplicidad de procedimientos, estrategias, recursos y referencias. En cuanto a una posible filiación estilística, la muestra da cuenta de que la producción del $58 \%, 3$ de los artistas presenta una heterogeneidad de estilos, sin filiaciones específicas. 
En relación al tema, buscamos específicamente aquellos que han abordado el retrato, el objeto, el paisaje y trataron escenas que de algún modo evidencian rasgos identitarios vinculados al imaginario nacional. 


\section{VI . CONCLUSIONES}

Responder la pregunta de investigación nos obliga a establecer algunas precisiones. Una de ellas es que el hecho pictórico es un hecho cultural correspondiente con su contexto social e histórico. Esta aseveración nos hace entender que la pintura hecha en Chile corresponde a una expresión cultural (chilena), más, no toda manifestación cultural es una expresión identitaria propia del lugar donde se produce. Esto es lo que sucede, por ejemplo, con la celebración de Hallowen; hoy en nuestro país es parte de la cultura, más no de la identidad nacional. Desde esta perspectiva los elementos o rasgos que consideramos como identitarios en la "pintura chilena" debieran tener relación con un imaginario social vinculado a la conciencia colectiva, imágenes mentales compartidas, creencias, normas y valores, que nos hacen aparecer como distintos de otros. Es decir aquellos elementos que contribuyen a la unidad, consolidando y reproduciendo ciertos sentidos, símbolos, memoria compartida y que está determinada por elementos y prácticas que nos identifican. Del total de 540 obras incorporadas al estudio podemos señalar que solo un $36,1 \%$ de los artistas orienta su práctica pictórica hacia una reflexión sobre la cultura nacional. Entendida ésta según lo señalado en las páginas de nuestro marco teórico.

Terminada la investigación, se observan diez aspectos que se desprenden a modo de conclusión:

VI. 1. En relación al imaginario de una pintura chilena contemporánea

Resulta obvio, pero no menos importante, señalar que el imaginario nacional se ha nutrido para su edificación, de toda una larga historia de imágenes que se han instalado en la escena cotidiana de nuestras vidas, como mundo privado, y en la vida social del pueblo chileno, como valor comunitario.

De esa forma, si nos guiamos por los temas más recurrentes asociados a nuestra identidad como país, podemos concluir que del análisis de los temas de 540 obras sometidas al estudio, el imaginario de las pinturas chilenas contemporáneas de los últimos 15 años, se compone y/o utiliza preferentemente:

a) Retratos de presidentes, futbolistas y héroes reconocibles; $35,6 \%$ 
b) Objetos, comidas y adornos de consumo masivo y popular; 36,4\% Paisajes asociados a espacios abiertos recurrentes (cordillera de Los Andes principalmente), a calles y mobiliario urbano (casas, edificios-símbolos). 40,5\%

d) Escenas, principalmente asociadas a recreación/divertimiento, denominas como "escenas costumbristas" (bailes, deporte, fiestas) 10,2\% y represión, revueltas callejeras, B1objetosmovilizaciones sociales, denominadas escena de acción o movimiento. 11,9\%

Desde el punto de vista estadístico, los porcentajes de recurrencia de algunos temas asociados a nuestra identidad (objetos, retratos y paisajes) son relevantes para señalar que si existe un rasgo identitario en la pintura chilena del siglo XXI.

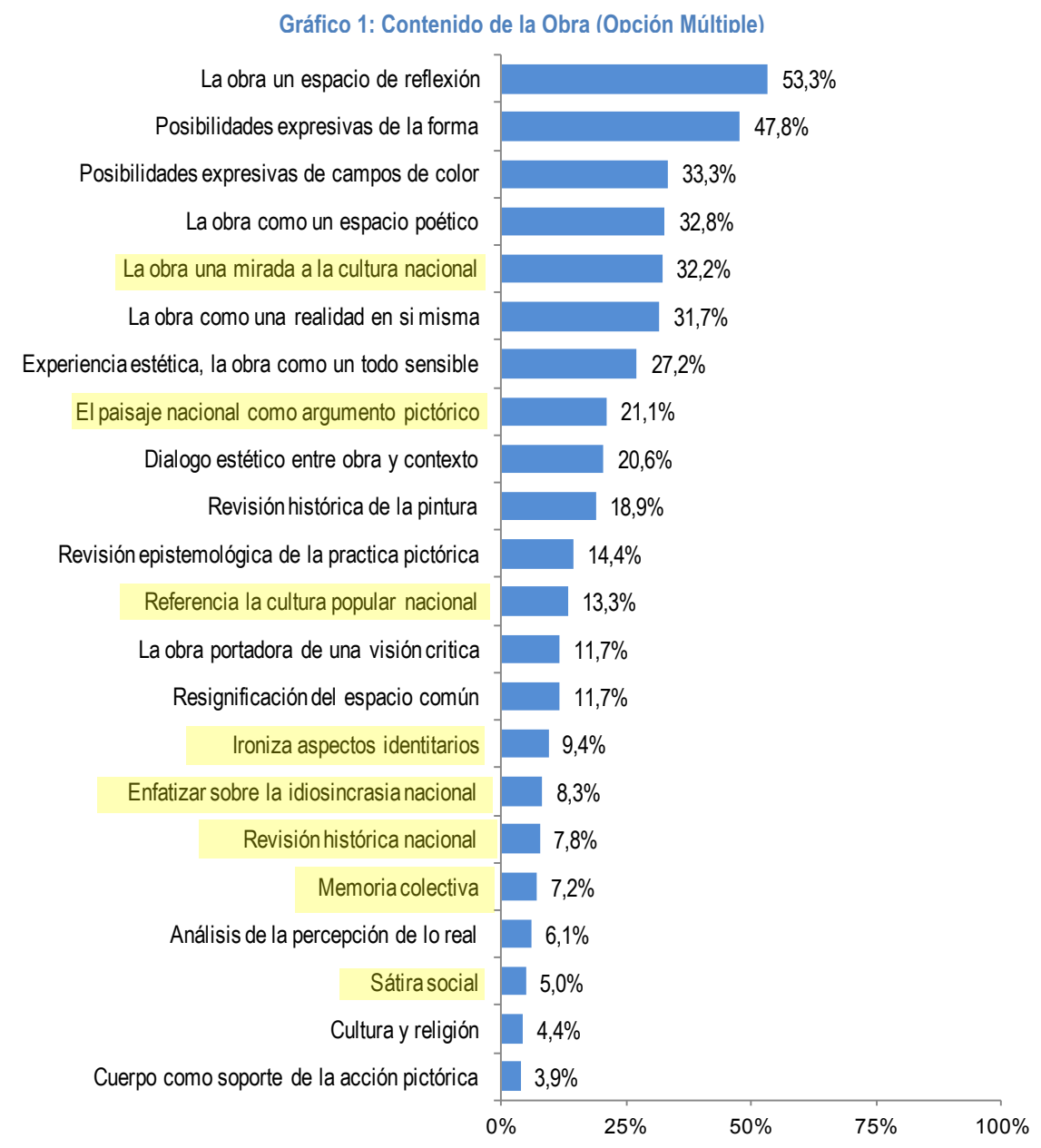


VI.2. En relación a eventos anteriores al año 2000.

Como ya se ha señalado en el punto anterior, la cultura visual se construye organizadamente a través de la instalación de imágenes (reales o no) proveniente de experiencias sociales comunes a una nación. Podemos señalar que a 42 años del golpe militar, la pintura chilena aún recorre con sus obras los temas que recuerdan dicho evento.

De la misma manera recorre otros hechos históricos (como guerras, o catástrofes), pero la persistencia del componente político en el tratamiento iconográfico de esos temas, es algo digno de destacar. Así, la figura de los militares, la bandera chilena y Pinochet son recurrentes.

\begin{tabular}{|l|c|l|}
\hline \multicolumn{1}{|c|}{ Ítem } & \multicolumn{1}{|c|}{$\begin{array}{c}\text { Recurrencia } \\
\text { (arts. que utilizan) }\end{array}$} & \multicolumn{1}{c|}{ Descripción } \\
\hline Bandera & 8 & $\begin{array}{l}\text { Representación simbólica o soporte } \\
\text { intervenido. }\end{array}$ \\
\hline Escudo & 3 & Como símbolo referencial \\
\hline Pinochet & 3 & Retrato emblemático \\
\hline Militares & 4 & Como tropa anónima \\
\hline Hecho Histórico & 2 & Evento simbólico \\
\hline Personaje histórico & 2 & Personaje emblemático. \\
\hline Guerras & 1 & Carácter simbólico. \\
\hline
\end{tabular}

VI.3. Sobre los géneros de la pintura.

Las prácticas pictóricas analizadas plantean en una revisión crítica de los géneros, tanto como de aquellos elementos considerados idiosincráticos de la identidad y cultura nacional. La pintura como disciplina tradicional del arte en Chile se pone en cuestión por los artistas de las últimas generaciones al proponer, junto con la práctica tradicional, nuevas formas, que van más allá de la pintura de caballete. El video-arte, las instalaciones, la imagen digital y el arte callejero aparecen como un nuevo tipo de pintura en Chile hoy. La pintura más allá de su ser imagen también es materia, color, forma y volumen, se propone hoy en un campo expandido que la ha hecho superar la plasticidad de su medio y encontrarse en cualquier cosa, pues todo se ha vuelto un medio válido para expresar una idea ya sea sobre o desde la pintura. La pintura de género ha ejercido una gran influencia en la creación artística y poética, en Chile, a lo largo de los años. Los pintores en la actualidad, 
como se ha visto, no solo pintan sino que citan la pintura en todas sus posibilidades, expandiendo sus límites plásticos y discursivos, dando al mismo tiempo una identidad a la producción local.

Gráfico 2: Temática de la Obra (Categoría G

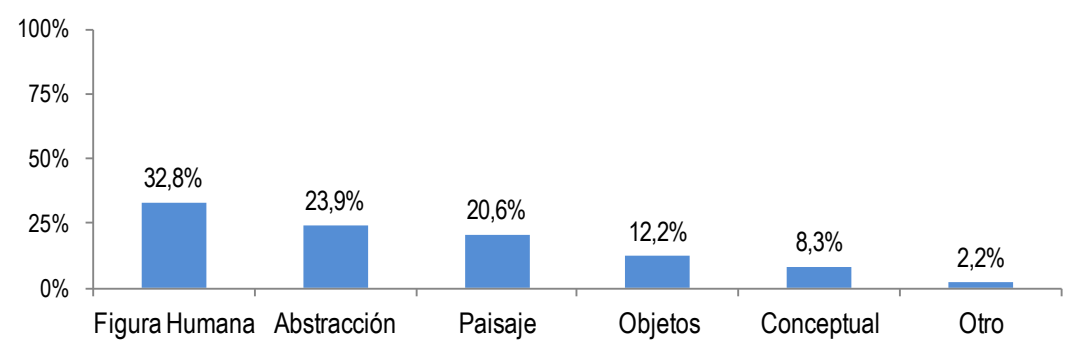

VI.4. El uso de imágenes fetichistas.

Las imágenes fetichistas incorporadas al imaginario colectivo constituye un gabinete de curiosidades, inventario ilustrativo de la productividad masiva, considera los subproductos de la industria cultural y comercial, es introducido en los lenguajes pictóricos radicalizando las propuestas, al someter la pintura a un ejercicio extremo, un 13,3\% de los artistas seleccionados, lo hace considerando la iconografía popular comercial como un sesgo identitario a partir de la revisión de aquellos referentes iconográfico visuales auténticamente propios, producidos y creados en una cultura que se ha desarrollado a partir de la apropiación e imitación de modelos importados dada su breve historia, no se trata de la recurrencia a aquellos símbolos icónicos provenientes de la cultura rural, hoy las imágenes tienen más que ver con lo urbano y corresponden al proceso de legitimación de referencias simbólicas activadas como identidad en la medida en son consideradas símbolos de unidad.

Las producciones de Bruna+Cabezas, Altamirano, J. González, P. Rueda, L. Casas, entre otros dan cuenta de ello en una especie "Inversión Crítica” según P. Zarate (2005)

VI. 5. Impacto cultural del bicentenario de la independencia.

El "bicentenario" (2010) trae consigo una serie de esfuerzos orientados a revisar la identidad del arte chileno y del chileno (tendencia en un $25 \%$ de la muestra). Esta atmósfera introduce un segundo momento en el cual opera una lógica crítica que se ha impuesto al interior de los lenguajes de la nueva escena, desatendiendo la especulación formal sobre las prácticas artísticas que marcó un primer momento post- dictadura. La pintura, más allá de su ámbito tradicional se expande. Los pintores se movilizan utilizando variados sistemas de producción o procedimientos constructivos, así como también, categorías de referencia y 
una variedad de estrategias de las cuales se sirven para proyectar su obra. Entre ellas observamos: la intervención, el desplazamiento, emplazamiento, disposición e instalación.

A propósito de la celebración del bicentenario de la nación, observamos un clima que abrió espacios a la reflexión sobre la identidad nacional y su estado actual. En ese ambiente los artistas, con un mayor énfasis, problematizan las representaciones de identidad construidas o aquellas naturalizadas por los mecanismos mediáticos y políticos, articuladores de la colectividad en nuestra sociedad. La experimentación y la investigación de nuevos lenguajes, la revisión de la memoria reciente, ancestral y del imaginario colectivo es una constante en la escena artística nacional. El artista va en busca de generar claves para entender nuestra realidad a través de las expresiones visuales.

VI.6. Operaciones de expansión la pintura chilena contemporánea.

A medida que avanzamos en el tiempo, observamos cada vez con más fuerza operaciones de expansión en la construcción y circulación de la pintura chilena actual. Materialidades, noción de museo/galería, procedimientos pictóricos canónicos, etc, han logrado que la idea de una "pintura expandida" pueda aplicarse cada vez con mayor propiedad a la producción de pintura actual. En este estudio un 10,0\% de los artistas han incursionado en expansión del campo a través de instalaciones, un 5,6\% lo ha hecho desplazándose hacia soportes digitales y un 5\% con intervenciones pictóricas sobre impresión digital.

A modo de ejemplo, se cita algunos artistas, Claudio Correa adopta el desplazamiento como una forma de extender la pintura hacia lo circundante y lo objetual, transgrediendo las sujeciones de la manualidad productiva, excediendo actitudes reverenciales respecto del arte.

En esta situación de expansión se encuentran aquellos artistas que se inscriben con propiedad en la noción de "sitio específico", obras destinadas exclusivamente a un lugar. En una maniobra destinada a resignificar los espacios. En el último tiempo, siguiendo el curso del arte internacional, se ha intensificado la ampliación hacia los dispositivos foto-gráficos, video gráficos y mediales, favorecidos por el creciente traslado de artistas de formación tradicional hacia áreas de mayor contenido tecnológico, disipando las fronteras disciplinares entre las artes.

Gonzalo Díaz establece instancias de reflexión en lo cotidiano, apuntando a una manera de hacer del arte parte de la vida habitual. A este modo de operar, le acompaña un medio, el neón, que opera en el límite entre arte y el comercio o la industria. A través de esta 
cualidad del neón se da la posibilidad de generar una instancia artística, de reflexión, en lo cotidiano.

Pablo Langlois Prado realiza una serie de intervenciones con pancartas estéticas desde el 2006 en las movilizaciones sociales en el "día del trabajo remunerado", para trabajar desde y sobre los límites de los condicionamientos institucionales. Toda práctica crítica que se ubique en algún punto del sistema conectado a diversas ramificaciones de poder y valor dominantes, sirve, también, para desplegar fuerzas de oposición y resistencia que combatan el oficialismo de las instituciones y la hegemonía del mercado. Es a donde apunta la obra de este artista. En este caso, la expansión de su obra va de la mano de acontecimientos nacionales (temas).

\section{7. Prácticas heterogéneas en la pintura chilena contemporánea.}

El análisis de las pinturas chilenas del período 2000-2015, nos muestra una tendencia progresiva a la incursión en prácticas heterogéneas tanto desde el punto de vista técnico, como iconográfico y temático. Esta heterogeneidad tal vez se explique por la ampliación de los espacios de exhibición, la apertura de carreras orientadas a las artes, la posibilidad de acceder a fondos concursables y auspicios tanto estatales como privados. Sabemos que la noción de "concursabilidad" se ha instalado en la práctica de las artes visuales chilenas y junto a ella la idea del mecenazgo estatal, lo que podría llevar a la aparición de dos tendencias: independencia de modelos previos o satisfacción a nuevos clientes (el estado).

Si consideramos como parámetro las muestras de pintura anteriores a 2000, vemos que las obras hoy sometidas al estudio apuntan a un distanciamiento de los modelos basados en la consigna política pro gobierno (antes del 73) y contra el gobierno (desde 1973 y hasta 1990). Hoy, podemos observar una mirada irreverente, hasta cierto punto sarcástica, respecto al modelo socio-económico-cultural imperante. Podemos decir que el sello identitario de la pintura actual se basa en la práctica de múltiples procedimientos y diversidad de estilos.

Los gráficos, a continuación, resumen la situación que se observa en la práctica pictórica de los artistas nacionales.

Gráfico 8: Diversidad de nrocedimientos

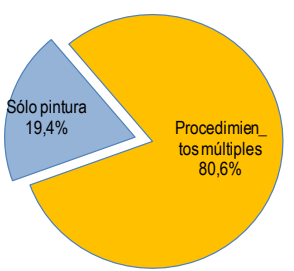

Gráfico 9: Diversidad de estilos

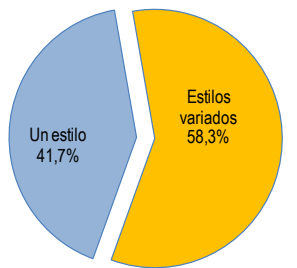


VI. 8. Sobre la influencia de los modelos internacionales

Desde una escena artística radicada en un contexto social y político, pasamos a uno más permeable al contexto internacional y a los nuevos cambios experimentados por el lenguaje del arte, consecuencia de una sociedad cada vez más mediática y globalizada, que tiende a aceptar ideas, temas, formas, imágenes y soluciones técnicas ya probadas en el extranjero.

Gráfico 3: Lugar donde ha realizado exposiciones individuales (Sólo artistas que han realizado exposiciones individuales. N=179)

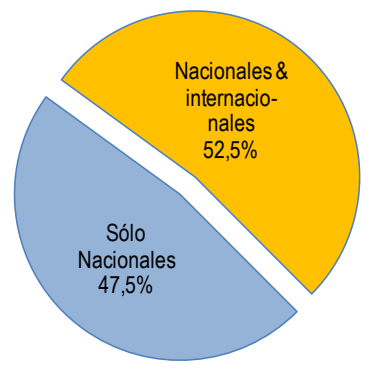

La ampliación de los espacios de exhibición, que privilegian el arte experimental, tanto a nivel privado como estatales, la apertura de nuevas carreras de arte, junto a ello el desarrollo de programa de posgrado en la especialidad las universidades con mayor historia, inducen a una constante revisión de las prácticas a través de la experimentación. Por otro lado, la posibilidad de exceder a fondos concursables y auspicios, la agilidad expositiva y el creciente intercambio internacional, a través de residencias, exposiciones, becas, así como la participación e inscripción en Bienales de renombre, han permitido una apertura hacia la experimentación tecnológica, mediática y de nuevos lenguajes en el ámbito del campo expandido de la pintura. Este aspecto impacta en la revisión e inclusión desprejuiciada en las propuestas pictóricas de aquella imaginería popular así como el uso de objetos del cotidiano y la representación de escenas comunes pero inherentes a la idiosincrasia nacional. Vemos esto en la propuesta de M. Torres, M. Ibarra, N. Maza, entre muchos otros.

\section{9. Estrategias}

El estudio muestra básicamente tres estrategias principales a las que acuden los pintores; ninguna de ellas escapa a una tendencia internacional sobre la exploración en formas de productividad: el archivo, lo objetual y el traspaso, no pudiéndose reconocer en ellas algún dato que la acerque a una noción de identidad nacional. 
El archivo: la clasificación, ordenación, evocación y el recuerdo que se presenta fragmentariamente. Ello implica algunas operaciones que permiten el reconocimiento de la ironía, la parodia, el desdén. Es el caso de Altamirano, ironizando con el deseo de orden proponiendo infinitas combinaciones, deconstruyendo la historia en pro de la construcción de su relato político.

Otra estrategia constructiva es lo objetual. Como una tendencia de los últimos años, capaz de ampliar posibilidades de concreción material, originando nuevas experiencias, dirigidas a la representación de lo real, con la incorporación de objetos a la representación bidimensional.

Los traspasos: Hay procesos de reproducción donde el original es sometido a una serie de traspasos, conformando una nueva formalidad, por medio de efectos de reiteración y repetición. Las imágenes fetichistas incorporadas al imaginario colectivo constituyen un gabinete de curiosidades impresas, inventario ilustrativo de la productividad masiva. Considera los subproductos de la industria cultural y comercial, es introducido en los lenguajes pictóricos radicalizando las propuestas, al someter la pintura a un ejercicio de extremo, considerando lo "pictórico como inversión crítica" (Zarate 2005). Por ejemplo, Ignacio Gumucio propone el inverso de la representación académica, operando con traspasos, calcos o veladuras; una especie de reproducción de imágenes, cercano a los mecanismos de duplicado, como la fotografía, fotocopia, el grabado, el molde cerámico.

V. 10. La formación académica de los pintores activos.

El 88,9\% de los artistas incorporados al estudio, provienen de la enseñanza universitaria. Este rasgo da cuenta de la existencia de un contingente "erudito" de pintores activos. Si bien no se vincula directamente a nuestra investigación, esta conclusión abre puertas a la posibilidad de generar otras investigaciones vinculadas a este hecho.

\begin{tabular}{|l|r|r|}
\hline $\begin{array}{c}\text { Tabla 1: Estudios Artísticos } \\
\text { (Opción Múltiple } 23 \text { ) }\end{array}$ & \multicolumn{1}{|c|}{$\%$} & N \\
\hline Licenciado en Arte & $75,0 \%$ & 135 \\
\hline Otra carrera universitaria & $28,3 \%$ & 51 \\
\hline En taller de un artista & $23,3 \%$ & 42 \\
\hline Título de postgrado en Artes & $18,3 \%$ & 33 \\
\hline Autodidacta & $8,9 \%$ & 16 \\
\hline Pedagogía en Artes & $6,7 \%$ & 12 \\
\hline Otros & $0,6 \%$ & 1 \\
\hline Total & $\mathbf{1 0 0 , 0 \%}$ & $\mathbf{1 8 0}$ \\
\hline
\end{tabular}

\footnotetext{
${ }^{23}$ En las preguntas de opción múltiple, se puede seleccionar más de una alternativa por cada pintor. Por lo tanto, la suma de los valores y porcentajes puede superar el $100 \%$
} 


\section{BIBLIOGRAFÍA}

\section{1 Libros}

Acuña, H. y Fabrega. J. (1990). Perfiles y tendencias de la cuenca del Pacífico, una visión desde Chile. Santiago de Chile: Funturo.

Albó, Xavier (1988) (comp.). Raíces de América: el mundo Aymara, Madrid: UnescoAlianza.

Albwachs, M. (1967). La memoria colectiva. México: Fondo de Cultura Económica. Aninat, I. (2003). Pintura Chilena Contemporánea. Buenos Aires: Grijalbo.

Área de Artes Visuales de la División de Cultura del Ministerio de Educación. (2002). Colección de Arte Contemporáneo Galería de Arte Gabriela Mistral. Santiago de Chile: Ministerio de Educación-Galería de Arte Gabriela Mistral.

Arnheim, R. (1971). El pensamiento visual. Buenos Aires: EUDEBA.

Arnheim, R (1979). Arte y Percepción visual Madrid: Alianza Editorial.

Aumont, J. (1992) La Imagen. Barcelona: Ediciones Paidós Ibérica.

Azara, P. (1995). La imagen y el olvido. El arte como engaño en la filosofía de Platón. Madrid: Siruela.

Baeza, M. (2000). Los caminos invisibles de la realidad social. Santiago de Chile: RIL Editores.

Baxandall, M. (1978). Pintura y vida cotidiana en el Renacimiento: arte y experiencia en el Quattrocento. Barcelona: Gili.

Bengoa, J. (1996). La comunidad Perdida. Ensayos sobre identidad y cultura: los desafíos de la modernización en Chile. Santiago de Chile: Ediciones SUR. 
Bengoa, J. (2000). La emergencia indígena en América latina. México: Fondo de Cultura Económica.

Berger, R. (2002). El conocimiento de la pintura, el arte de verla. Barcelona: Noguer.

Bontá, M. (1959). Cien años de la Pintura Chilena. Santiago de Chile: Escuela de Artes Aplicadas U. de Chile.

Bourriaud, N. (2007). Postproducción. Buenos Aires: Adriana Hidalgo Editora S.A..

Bindis, R. (2009). Pintura Chilena 200 años. Santiago de Chile: Origó. Ediciones,

Bryson, N. (1991), Visión y pintura. La lógica de la mirada. Madrid: Alianza.

Brunner, J. (1994), Bienvenidos a la modernidad. Santiago de Chile: Planeta

Castel, R. (1997). La metamorfosis de la cuestión social. Buenos Aires: Paidós.

Camnitzer, L. (2009). Didáctica de la Liberación; arte conceptualista latinoamericano. Murcia: CENDEAC.

Candau, J.(1998). Memoire et Identité. Paris: Presse Universitaires de France.

Carrasco, E. y Negrón, B. (2005). La Cultura durante el periodo de transición a la Democracia. Santiago de Chile: CNCA.

Castoriadis, C. (1993), La institución imaginaria de la sociedad, en Colombo (coord.), El imaginario Social, Altamira y Nordan Comunidad, Montevideo

Centro Casaverde. (1987). Concurso de Pintura Estimulemos el Arte. Santiago de Chile: Autor.

Chebel, M. (1998). La formation de l'identité politique. Paris: Payot.

Combalía, V. (2005). La Poética de lo Neutro. Barcelona: Random House Mondadori. 
Corporación Amigos del Arte. (1984). Becados 1978-1984. Galería La Fachada. Santiago de Chile: Autor.

Corporación Amigos del Arte. (1996). Veinte Años Amigos del Arte. Santiago de Chile: Autor.

Corporación Amigos del Arte. (1991). Memoria 1978-1990. Santiago de Chile: Autor.

Cruz, I. (1984). Historia de la pintura y la escultura en Chile de la Colonia al siglo XX. Santiago de Chile: Edit. Antártica.

Danto A. (2002). La Transfiguración de un lugar común. Barcelona: Paidós.

De Nordenflycht, J., Ampuero, C., Novoa, P. y Schwember, F. (2015). Pintura Chilena Contemporánea: práctica y desplazamientos disciplinares desde la Escuela de Arte UC. Santiago de Chile: Ediciones Universidad Católica.

De La Parra, M. A. (1999). La Mala Memoria. Santiago de Chile: Editorial Planeta Chilena.

Díaz, E. (1992). Poesía chilena de hoy. Santiago de Chile: Documentas.

Duque, F. (2001). Arte Público y Espacio Político. Madrid: Akal.

Durkheim, E (1974). Lecciones de sociología: física de las costumbres y del derecho. Madrid: La Pléyade.

Durkheim, E. (2012). El estado y otros ensayos. Buenos Aires: Eudeba.

Eisner, E. (1995). Educar la Visión Artística. Barcelona: Paidós Ibérica.

Eisner, E. (1998). El ojo ilustrado; indagación cualitativa y mejora de la práctica educativa. Barcelona: Paidós Educador.

Eisner, E. (2004). El arte y la creación de la mente. Barcelona: Paidós Ibérica. 
Eagleton, T. (2001). La Idea de Cultura. Barcelona: Paidós.

Foster, H. (Ed). (2008). La posmodernidad. Barcelona: AKAL.

Fernández, C. y Gordon, D. (Comp.) (1986). La comunicación humana: ciencia social. México: McGraw Hill.

Focillon, H. (1983) La vida de las formas y elogios de la mano, Madrid, XARAIT Libros SA

Galaz, G. y Ivelic, M. (1981). La Pintura en Chile: Desde la Colonia hasta 1981. Valparaíso: Ediciones Universitarias de Valparaíso.

Galaz, G. y Ivelic, M. (1998). Chile Arte Actual. Valparaíso: Ediciones Universitarias de Valparaíso.

Garcés, M. (Ed). (2000). Memorias para un nuevo siglo. Chile, miradas a la segunda mitad del siglo XX. Santiago de Chile: LOM Ediciones.

García Canclini, N. (1995). Culturas Hibridas; estrategias para entrar y salir de la modernidad. Buenos Aires: Ed. Sudamericana.

García Canclini, N. (1995). Consumidores y Ciudadanos; conflictos multiculturales de la globalización. México: Ed. Grijalbo.

García Canclini, N. (1999). La Globalización imaginada, México: Paidós.

Garretón, M. A. (2000). La sociedad en que viví(re)mos. Introducción sociológica al cambio de siglo. Santiago de Chile: LOM Ediciones

Gellner, E. (1989). Cultura, identidad y política: el nacionalismo y los nuevos cambios sociales. Barcelona: Gedisa,

Geertz, C. (1996). Los usos de la diversidad. Barcelona: Paidós. 
Gissi, J., Larraín, J., Sepúlveda, F. (1995). Cultura e Identidad en América Latina. Santiago de Chile: ICCHEH

Gissi, J. (2002). Psicología e Identidad Latinoamericana. Socio-psicoanálisis de cinco premios nobel de literatura. Santiago de Chile: Ed. Universidad Católica de Chile.

Gombrich, E. H. (1983). Arte, Percepción y realidad. Barcelona: Paidós Ibérica.

Gombrich, E. H. (2003). Meditaciones sobre un caballo de Juguete. Madrid: Debate.

Gómez Molina, J. (Coord.) (1995). Las lecciones del dibujo. Madrid: Cátedra.

Gómez Molina, J. J., Cabezas, L. Bordes J., (2005) El manual de dibujo: estrategias de su enseñanza en el siglo $x x$. Madrid: Cátedra.

Gómez Molina, J. (Coord.) (2007) La representación de la representación: danza, teatro, cine, música: dibujo y profesión. Madrid: Cátedra

González, J., Bravo, V. y Zeballos, M. (2003). Cambio de aceite. Pintura Chilena Contemporánea. Santiago Chile: Ocho Libros Editores.

González, J. (2010). Revisión técnica. 100 pintores, pintura en Chile 1980-1910. Santiago de Chile: Ocho Libros Editores.

Gorosito, A. (1997). Identidad Cultura y Nacionalidad. Buenos Aires: Ediciones Ciccus.

Guasch, A. M. (2000). El arte último del siglo XX. Del posminimalismo a lo multicultural: 1968-1995. Madrid: Alianza Forma.

Gutiérrez E. M, León-Portilla, M., Gossen, Gary H. y Klor de Alva J. (1997). De Palabra y Obra en América. Volumen 3 y 4. Madrid: Siglo XXI.

Gutiérrez, E. (1985). Imaginación y autonomía estética en la Crítica del juicio de Kant. Buenos Aires: Universidad de Buenos Aires

Gutiérrez, M., Estévez, M., Dascak, J. y de Salas, M. (Eds.). (2001). La Pluralidad y sus atributos; usos y maneras en la construcción de la persona. Madrid: Fundación Duques de Soria, Biblioteca Nueva. 
Guzmán, F., Cortés, G. y Martínez, J. (Comp.). (2003). Iconografía, identidad nacional y cambio de siglo $(X I X-X X)$. Santiago de Chile: RIL Editores.

Habermas, J. (2008). El discurso filosófico de la modernidad. Buenos Aires: Katz.

Halbwachs, M. (1967). La memoria colectiva. México: Ed. Fondo de Cultura Económica.

Hopenheim, M. (1994). Ni apocalípticos ni integrados. México: Fondo de Cultura Económica.

Ivelic, M. y Ulibarri, L. (1989). Intimidades, Veinte Artistas Visuales Chilenos. Santiago de Chile: Edit. La Puerta Abierta.

Ivelic, M. (1987). Doce Artistas de Hoy. Valparaíso: Ilustre Municipalidad de Valparaíso/Galería Municipal de Arte Valparaíso.

Jameson, F. y Zizek, S. (1998). Estudios Culturales; reflexiones sobre el multiculturalismo. Buenos Aires: Paidós.

Jiménez, J. y Castro, F. (Eds.) (1999). Horizontes del Arte Latinoamericano. Madrid: Tecnos, S.A.

Jocelyn-Holtz, A. (1998). El Chile perplejo. Santiago de Chile: Planeta.

Joly, M. (1999). Introducción al análisis de la imagen. Buenos Aires: La marca.

Kant, I. (1951). Crítica de la razón práctica; de la crítica del juicio; Crítica del juicio estético. Buenos Aires: El Ateneo.

Kepes, G. (1969). El lenguaje de la Visión. Buenos Aires: Akal.

Kingman G, E. (comp.) 1992 “Ciudades de los Andes: visión histórica y contemporánea”, Quito, Ecuador. Centro de investigaciones CIUDAD. 
Kottak, C. (2002). Antropología cultural. Madrid: McGraw-Hill.

Krauss, R. (1979) . La escultura en el campo expandido. Barcelona: Paidós.

Krauss, R. (1996). La originalidad de la vanguardia y otros mitos modernos. Madrid: Alianza Editorial.

Lara, C., Machuca, G. y Rojas, S. (2005). Chile arte extremo / nuevas tendencias en el cambio de siglo. Santiago de Chile: CNCA-Fondart.

Larraín, J., Sepúlveda, F. y Gissi, J. ( 1995). Cultura e identidad en América Latina. Santiago de Chile: ICHEH

Larraín, J. (1996). Modernidad, Razón e Identidad en América Latina. Santiago de Chile: Andrés Bello.

Larraín, J. (2001). Identidad chilena. Santiago de Chile: LOM ediciones.

Larraín, J. (2005). “¿América Latina moderna?: globalización e identidad”. Santiago de Chile: LOM ediciones.

Lee Van Cott, D. (1995). Indigenous peoples and democracy in Latin America. New York: St.Martin's Press.

Lechner, N. (2002). Las sombras del mañana: la dimensión subjetiva de la política. Santiago de Chile: LOM ediciones.

Lippard, L. (2004). Seis días- La desmaterialización del objeto artístico. Barcelona: AKAL.

Lipschutz, A. (1963). El Problema racial en la conquista de América y el mestizaje. Santiago de Chile: Austral.

Lobo, L. (1983). Exposición de Profesores de Artes Plásticas. Santiago de Chile: Universidad de Chile/Facultad de Artes. 
Lomnitz, C. (1982). Evolución de una sociedad rural. México: Fondo de Cultura Económica.

López, J. (2007). El extravío de los límites. Claves para el arte contemporáneo. Buenos Aires: EMECE editores.

Lucie-Smith, E. (1998). Los Movimientos artísticos desde 1945. Barcelona: Destino. Machuca, G. (2011). El traje del Emperador, arte y recepción pública en el Chile de las cuatro últimas décadas. Santiago de Chile: Metales pesados.

Machuca, G. (2011). El traje del Emperador, arte y recepción pública en el Chile de las cuatro últimas décadas. Santiago de Chile: Metales pesados.

Mafesoli, M. (1993). La transfiguration du politique. La tribalization du monde. Paris: Livre du poche.

Mafesoli, M. (1990). El tiempo de las tribus. El declive del individualismo en las sociedades de masas. Madrid: Icaria.

Mafesoli, M.l (1997). Du nomadisme. Vagabondages initiatiques. Paris: Livre de poche.

Manguel, A. (2003). Leer Imágenes. Madrid: Alianza Editorial.

Martín-Barbero, J. (2001). Al sur de la modernidad: comunicación, globalización, y multiculturalidad. Pittsburgh: Pittsburgh University Press.

Mead, M. (1977). Cultura y compromiso: el mensaje de la nueva generación. Barcelona: Granica.

Mellado, J., Madrid, A., De Nordenflycht, J. y Honorato, P. (2000). Chile 100 años Artes Visuales. Santiago de Chile: Museo Nacional de Bellas Artes.

Melucci, A. (2001). Vivencia y convivencia: teoría social para una era de la información. Madrid: Trotta. 
Mirzoeff, N. (2003). Una introducción a la cultura visual. Barcelona: Paidós.

Mosquera, G. (Ed.). (2006). Copiar el Edén. Arte reciente en Chile. Santiago de Chile: Ediciones Puro Chile

Moulián, T. (1997). Chile Actual, anatomía de un mito. Santiago de Chile: LOM-ARCIS

Museo de Arte Contemporáneo/Universidad de Chile. (2001). La (re) Ubicación de las Cosas. Santiago de Chile: Autor.

Museo Nacional de Bellas Artes de Chile. (1989). Aquellos años 80. Santiago de Chile: Autor- El Mercurio.

Museo Nacional de Bellas Artes de Chile. (1988). Exposición Donaciones: Un Decenio 1978 1988. Santiago de Chile: Autor.

Museo Nacional de Bellas Artes de Chile. (1997). La Figura Humana: Arte Contemporáneo Chileno. Santiago de Chile: Espacio Abierto Museo Nacional de Bellas Artes.

Ministerio de Educación de Chile. (1997). FONDART 1992-96. Santiago de Chile: Autor.

Oszlak, O. (Comp.) (1984). Teoría de la burocracia estatal: enfoques críticos. Buenos Aires: Paidós.

Panofsky, E. (2008). El significado en las artes visuales. Madrid: Alianza.

Panofsky, E. (2006). Renacimiento y renacimientos en el arte occidental. Madrid: Alianza.

Parsons, M. (2002). Como entendemos el arte: una perspectiva cognitivo-evolutiva de la experiencia estética. Madrid: Paidós.

Perniola, M. (2010). Los Situacionistas. Madrid: Acuarela.

Platón, (1957). Diálogos escogidos; apología de Sócrates. Buenos Aires: Ateneo.

Prendeville, B. (2001). El realismo en la pintura del siglo XX. Barcelona: Edic. Destino. 
Puerta, F. (2001). Análisis de la forma, fundamentos y aproximación al concepto. Valencia: Editorial UPV.

Rancière, J. (2002). La división de lo sensible. Salamanca: Argumentos.

Rodríguez, M. y Novoa, P. (2010). Chile, dos siglos de pintura. Santiago de Chile: Kactus.

Rojas B, A. (2013). Expansión centralista y exclusión regional. Chile (1854-1952).

Santiago de Chile: U. Autónoma.

Rojas, M. (1969). La imagen artística de Chile. Santiago de Chile: Edit. Universitaria.

Rojas, M. (1997). Los cien nombres de América, eso que descubrió Colón. San José: Editorial de la Universidad de Costa Rica.

Romera A. (1976). Historia de la pintura chilena. Santiago de Chile: Andrés Bello.

Romera, A. (1969). Asedio a la pintura chilena. Santiago de Chile: Universitaria.

Ricœur, P. (1995). Tiempo y Narración. Configuración del tiempo en el relato histórico. México: Siglo XXI.

Salazar G, y Pinto, J. (2012). Historia contemporánea de Chile II - Actores, Identidad y movimiento. Santiago de Chile: LOM Ediciones.

Schwartzman, F. (1992). El Libro de la Revoluciones. Santiago de Chile: Universitaria.

Stoichita, V. (2006). Breve Historia de la Sombra. Madrid: Siruela.

Strauss, L. (1993). Raza y Cultura. Madrid: Cátedra.

Subercaseaux, B. et al. (2006). La cultura durante el periodo de la transición a la Democracia, 1990 - 2005. Santiago de Chile: Ediciones B. 
Subercaseaux, B. (1996). Chile, ¿Un país moderno?. Santiago de Chile: Ediciones B.

Tatarkiewicz, W. (2006). Historia de seis ideas Arte, belleza, forma, creatividad, mímesis, experiencia estética. Madrid: Tecnos.

Tironi, E. (1999). La irrupción de las masas y el malestar de la elites. Santiago de Chile: Grijalbo.

Vattimo, G. (1990). La Sociedad Transparente. Buenos Aires: Paidós.

Vattimo, G. (1991). Ética de la Interpretación. Barcelona: Paidós.

Virilio, P. (1998). Estética de la Desaparición. Barcelona: Anagrama.

Virilio, P. (2001). El procedimiento silencio. Buenos Aires: Paidós.

Walter, J. y Chaplin, S. (2002). Una introducción a la Cultura Visual. Barcelona: Octaedro- EUB.

Zarate, P. (Ed.) (2009). Centenario; colección museo nacional de bellas artes,1910 2010. Santiago de Chile: Arte \& Ciudad, Ediciones Culturales.

\section{VII.2. CAPÍTULOS DE LIBROS}

Gorosito, A. M. (1997). Identidad, Cultura y Nacionalidad. En R. Bayardo y M. Lacarrieu (Comps.), Globalización e Identidad Cultural (pp. pp. 101-111). Buenos Aires: Ediciones Ciccus.

Guadarrama, P. (1992). Pensamiento filosófico e identidad cultural latinoamericana. En H. Dieterich (Ed.), Nuestra América frente al V Centenario (pp. 99-121). Santiago de Chile: Ediciones Lar.

Margullis, M. (1997). Cultura y discriminación social en la época de la globalización. En R.

Bayardo y M. Lacarrieu (Comps.), Globalización e Identidad Cultural (39-60). Buenos Aires: Ediciones Ciccus. 
Véliz, C. (1999) "Nacionalismos, globalizaciones y la sociedad chilena" Estudios internacionales. P 123-142. En Miranda, R. (2003) Argentina en el cono Sur; las relaciones interculturales. Argentina: Ediciones Universidad Católica de Salta.

Zarate P.(2005) "las artes visuales en la (post) transición". (informe 1990-2005) en La Cultura durante el periodo de la transición a la democracia. p.157-172, Carrasco E., Negrón B. Editores. Chile,: Consejo Nacional de la Cultura.

Zea, L. (1993). América Latina: largo viaje hacia sí misma. En L. Zea (Comp.), Fuentes de la cultura latinoamericana. Vol. I, pp. 287-298 Ciudad de México: FCE.

\section{VII..3 - REVISTAS.}

Castillo, M. (2011). Paul Ricœur, lector de Aristóteles: un cruce entre mímesis e historia. Revista de Filosofía y Teoría Política, 42, 35-42.

Fressard O. (2006) El imaginario social o la potencia de inventar de los pueblos Revista Trasversales $\mathrm{N}^{\mathrm{o}} 2$. (58-63) primavera 2006

Góngora, M. (1979). Reflexiones sobre la tradición y el tradicionalismo en la historia de Chile. Revista Universitaria, 2, 29-34.

Larraín, J. (2000). Globalización e identidad nacional. Revista Chilena de Humanidades, 20, 21- 35 .

Martín-Barbero, J. (1991). Investigar las culturas en Latinoamérica: memorias con algunos trazos generadores de futuro. ECA, Vol. 63, 293-305.

Vergara, J. y Vergara, D. (2002). Cuatro tesis sobre la identidad cultural latinoamericana una reflexión sociológica. Revista de Ciencias Sociales, 12, 77-92.

Villegas, I. (2014). La acreditación de las carreras artísticas de pregrado en Chile. Calidad en la educación, 40, 130-169.

Galaz G. (1997)Prologo para un rescate testimonial de un acto fallido// p. 9-17 y Arte y revolución: los artistas jóvenes y el cuestionamiento del arte p. 51-118 Cuadernos de la Escuela de Arte $\mathrm{N}^{\circ} 4$ - Oct.1997 
Mellado J.P. (2000) Algunas consideraciones sobre el poblamiento pictórico del territorio p. 39-62 // Notas sobre la identidad plástica chilena, p. 157- 167 // Cuadernos de Arte № 7Oct. 2000. Escuela de Arte PUC. Santiago, Chile

Atria, F. ¿Qué es educación pública? P. 45-67 Revista de Estudios Sociales No 117/ 2009 "Educación superior en Chile: transformación, desarrollo y crisis.” CPU, Santiago, Chile. .

\section{VII.4 - AUDIO}

Vergara, J. (2002). La situación en crisis de la sociedad chilena y el estudio de las identidades culturales. En: Noción de identidad cultural -- Identidades culturales en la sociedad chilena actual. [grabación, 1 cassette son. (ca. 60 min.) estéreo C 306.0983 V494s 2002]. Santiago de Chile: Biblioteca San Joaquín UC.

\section{VII.5 - WEB.}

Bengoa, J. (2009). Nación, nacionalismo e identidades comunitarias. "Discusión Bibliográfica del Proyecto "Identidad e Identidades. La Construcción de la Diversidad en Chile” (2003-2008)1. Discusión Bibliográfica acerca de Nación, nacionalismo, identidades sociales y comunitarias. 2. Discusión Bibliográfica acerca de identidad e identidades en Chile. 3. Discusión bibliográfica acerca del método de los Relatos de vida y los estudios acerca de identidad e identidades. Recuperado de https://identificacion.wordpress.com/proyecto-identidad-e-identidades/discusin-bibliogrfica/

Castillo, M. C. (2011). Paul Ricoeur, lector de Aristóteles: un cruce entre mímesis e historia. Revista de Filosofía y Teoría Política. Recuperado de www.memoria.fahce.unlp.edu.ar/art_revistas/pr.5103/pr.5103.pdf

Zamorano, P. (2011). Artes visuales en Chile durante la primera mitad del siglo xx: Una mirada al campo teórico.p (193-212) . Recuperado de http://dx.doi.org/10.4067/S071804622011000200011.

Fernández, A. (2012). Una mirada al paisaje nacional: Generación del 40.

Recuperado de

http://mavut.utalca.cl/archivos/pdf/generacion_40.pdf.

Mellado, J. (2013). Cine y Arquitectura: el muralismo expandido en Valparaíso.

Recuperado de

http://justopastorvalparaiso.blogspot.com/2013/04/cine-y-arquitectura.html

Montecino, S. (2010). 1960 Anales Universidad de Chile "Breve historia de la pintura en Chile" (157-170). Recuperado de

http://www.anales.uchile.cl/index.php/ANUC/article/viewFile/27387/29034 
Museo Nacional de Bellas Artes de Santiago de Chile. (2014). Biografías del sitio Artistas Plásticos Chilenos. Recuperado de http://www.artistasplasticoschilenos.cl

Museo Nacional de Bellas Artes de Santiago de Chile. (2014). Colección de Pintura Chilena Contemporánea. Recuperado de http://www.portaldearte.cl/agenda/pintura/2005/coleccion_pintura.htm

Museo Nacional de Bellas Artes de Santiago de Chile. (2014). Ejes temáticos de la pintura chilena en COLECCIÓN EN VIAJE organizan MNBA y la Fundación Itaú. Obras de arte chileno del MNBA en ciclo de itinerancias. Recuperado de http://www.portaldearte.cl/agenda/pintura/2010/mnba.html 


\section{ANEXOS}

\section{INFORME SISTEMATIZACION FICHAS PINTURA CHILENA 2015}

\section{CARACTERIZACIÓN DE LOS ARTISTAS}

Se completaron 180 fichas correspondientes a pintores y pintoras chilenas, de acuerdo a los criterios de selección establecidos por el investigador. Para el ingreso de la información (digitación de las fichas) se utilizó Lime Survey ${ }^{24}$, plataforma de encuestas en línea de código abierto (software libre).

Entre los 180 artistas analizados se repiten algunas características que se presentan en las tablas siguientes: la mayoría son hombres (tabla 1), de entre 40 y 60 años (de acuerdo al año de nacimiento, tabla 2), provenientes de Santiago y con estudios superiores formales en Arte, en las universidades de Chile o Católica.

Tabla 2: Sexo

\begin{tabular}{|l|r|r|}
\hline & \multicolumn{1}{|c|}{$\%$} & $\mathrm{~N}$ \\
\hline Mujer & $35,0 \%$ & 63 \\
\hline Hombre & $65,0 \%$ & 117 \\
\hline Otro & -- & -- \\
\hline Total & $100,0 \%$ & 180 \\
\hline
\end{tabular}

Tabla 3: Año de nacimiento

\begin{tabular}{|l|r|r|}
\hline & \multicolumn{1}{|c|}{$\%$} & $\mathrm{~N}$ \\
\hline Antes de 1940 & $3,3 \%$ & 6 \\
\hline $1940-1944$ & $3,3 \%$ & 6 \\
\hline $1945-1949$ & $3,9 \%$ & 7 \\
\hline $1950-1954$ & $7,2 \%$ & 13 \\
\hline $1955-1959$ & $15,0 \%$ & 27 \\
\hline $1960-1964$ & $14,4 \%$ & 26 \\
\hline $1965-1969$ & $20,6 \%$ & 37 \\
\hline $1970-1974$ & $16,1 \%$ & 29 \\
\hline $1975-1979$ & $8,3 \%$ & 15 \\
\hline $1980-1984$ & $3,9 \%$ & 7 \\
\hline $1985-1989$ & $1,1 \%$ & 2 \\
\hline Sin Información & $2,8 \%$ & 5 \\
\hline Total & $100,0 \%$ & 180 \\
\hline
\end{tabular}


Tabla 4: Año de nacimiento (reclasificación)

\begin{tabular}{|c|c|c|}
\hline & $\%$ & $\mathrm{~N}$ \\
\hline Antes de 1950 & $10,6 \%$ & 19 \\
\hline $1950-1959$ & $22,2 \%$ & 40 \\
\hline 1960-1969 & $35,0 \%$ & 63 \\
\hline $1970-1979$ & $24,4 \%$ & 44 \\
\hline 1980-1989 & $5,0 \%$ & 9 \\
\hline Sin Información & $2,8 \%$ & 5 \\
\hline Total & $100,0 \%$ & 180 \\
\hline
\end{tabular}

Tabla 5: Lugar de Nacimiento

\begin{tabular}{|l|r|r|}
\hline & \multicolumn{1}{|c|}{$\%$} & $\mathrm{~N}$ \\
\hline XV a IV Región & $1,7 \%$ & 3 \\
\hline V a VIII Región & $21,1 \%$ & 38 \\
\hline IX a XII Región & $2,2 \%$ & 4 \\
\hline Región Metropolitana & $68,9 \%$ & 124 \\
\hline Fuera de Chile & $6,1 \%$ & 11 \\
\hline Total & $\mathbf{1 0 0 , 0 \%}$ & $\mathbf{1 8 0}$ \\
\hline
\end{tabular}

Tabla 6: Estudios Artísticos (Opción Múltiple ${ }^{25}$ )

\begin{tabular}{|c|c|c|}
\hline & $\%$ & $\mathrm{~N}$ \\
\hline Licenciado en Arte & $75,0 \%$ & 135 \\
\hline Otra carrera universitaria & $28,3 \%$ & 51 \\
\hline En taller de un artista & $23,3 \%$ & 42 \\
\hline Título de postgrado en Artes & $18,3 \%$ & 33 \\
\hline Autodidacta & $8,9 \%$ & 16 \\
\hline Pedagogía en Artes & $6,7 \%$ & 12 \\
\hline Otros & $0,6 \%$ & 1 \\
\hline Total & $100,0 \%$ & 180 \\
\hline
\end{tabular}

${ }^{25}$ En las preguntas de opción múltiple, se puede seleccionar más de una alternativa por cada pintor. Por lo tanto, la suma de los valores y porcentajes puede superar el $100 \%$. 
Tabla 7: Año de egreso

(Sólo artistas con estudios superiores completos. $\mathrm{N}=161$ )

\begin{tabular}{|l|r|r|}
\hline & \multicolumn{1}{|c|}{$\%$} & $\mathrm{~N}$ \\
\hline Anterior a 1960 & $3,1 \%$ & 5 \\
\hline $1960-1969$ & $3,7 \%$ & 6 \\
\hline $1970-1979$ & $8,1 \%$ & 13 \\
\hline $1980-1989$ & $23,0 \%$ & 37 \\
\hline $1990-1999$ & $34,8 \%$ & 56 \\
\hline 2000 o posterior & $12,4 \%$ & 20 \\
\hline Sin Información & $14,9 \%$ & 24 \\
\hline Total & $100,0 \%$ & 161 \\
\hline
\end{tabular}

Tabla 8: Institución donde estudió

(Sólo artistas con estudios superiores completos. $\mathrm{N}=161$ )

\begin{tabular}{|l|r|r|}
\hline & \multicolumn{1}{|c|}{$\%$} & $\mathrm{~N}$ \\
\hline Universidad de Chile & $41,6 \%$ & 67 \\
\hline Universidad Católica & $24,8 \%$ & 40 \\
\hline Otra universidad o instituto privado de Chile & $14,3 \%$ & 23 \\
\hline Otra universidad estatal de Chile & $10,6 \%$ & 17 \\
\hline Universidad u otra institución extranjera & $6,2 \%$ & 10 \\
\hline Sin Información & $2,5 \%$ & 4 \\
\hline Total & $100,0 \%$ & 161 \\
\hline
\end{tabular}




\section{TRAYECTORIA ARTISTICA}

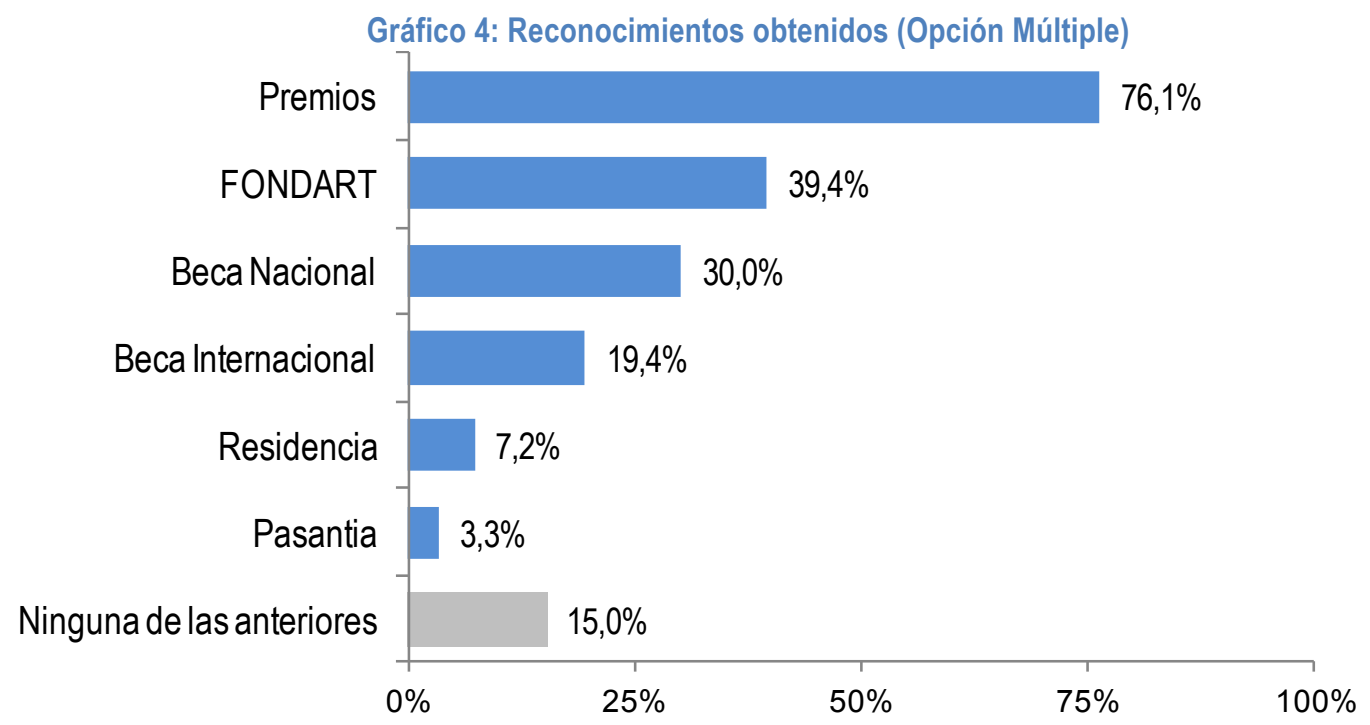

Gráfico 5: Número de exposiciones individuales

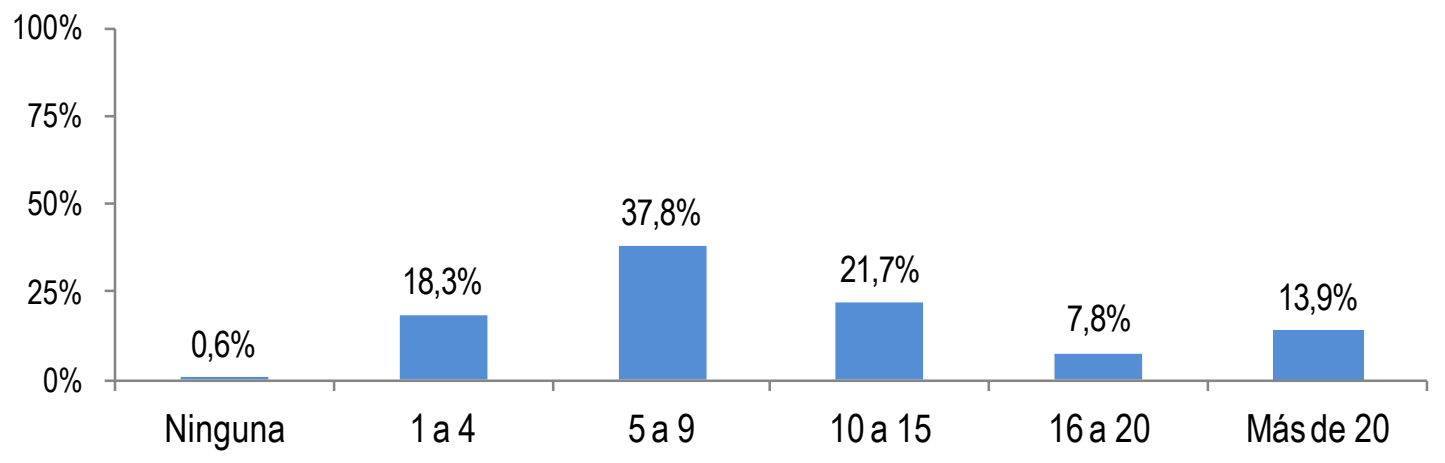

Gráfico 6: Lugar donde ha realizado exposiciones individuales (Sólo artistas que han realizado exposiciones individuales. $\mathrm{N}=179$ )

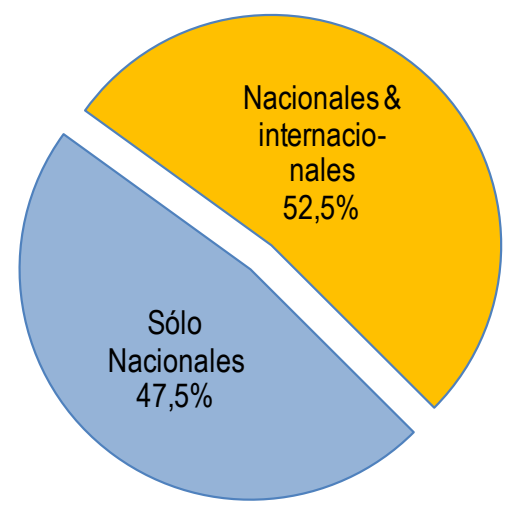




\section{CARACTERISTICAS DE LAS OBRAS ANALIZADAS}

\subsection{Dimensión referencial}

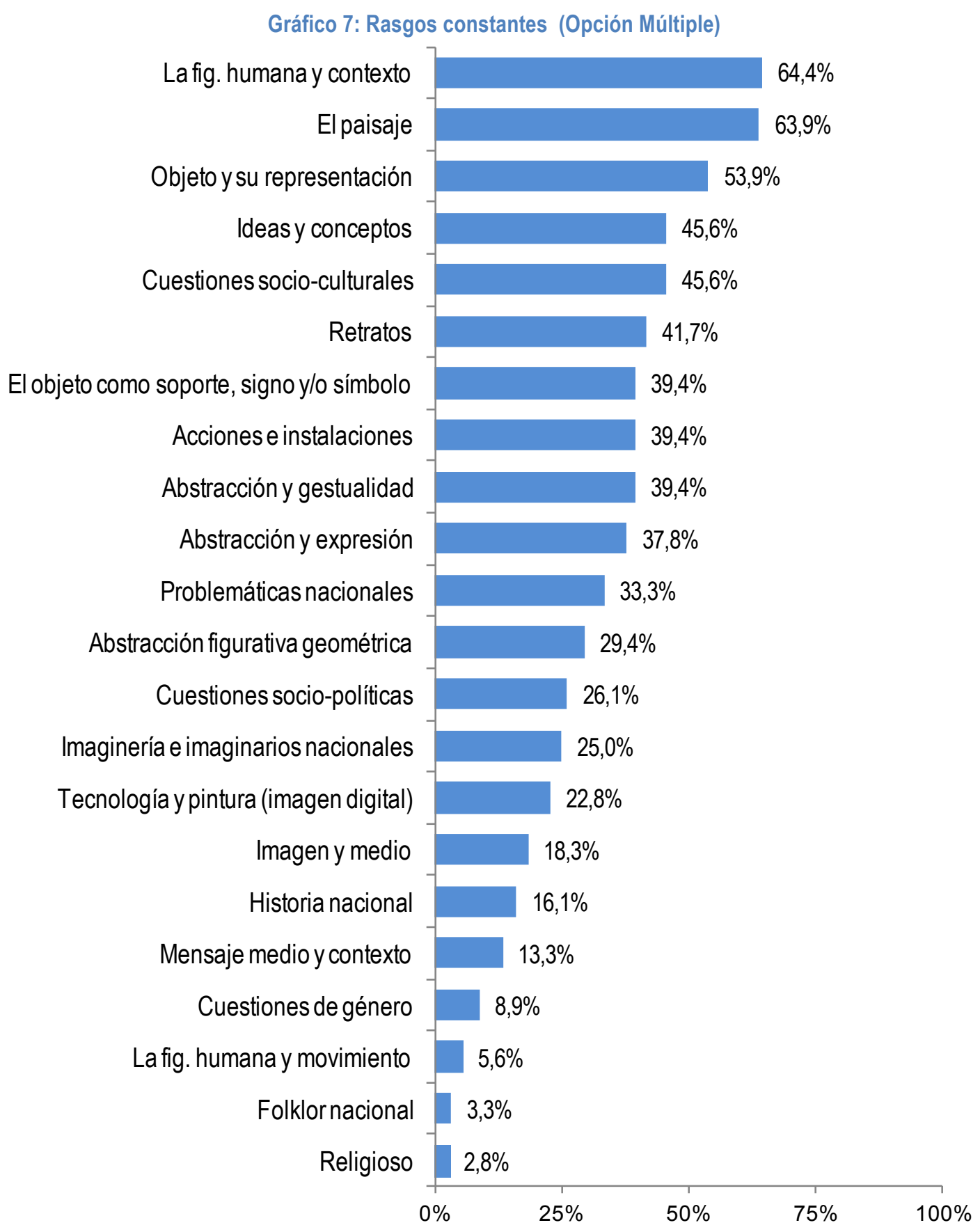


Gráfico 8: Diversidad de temáticas

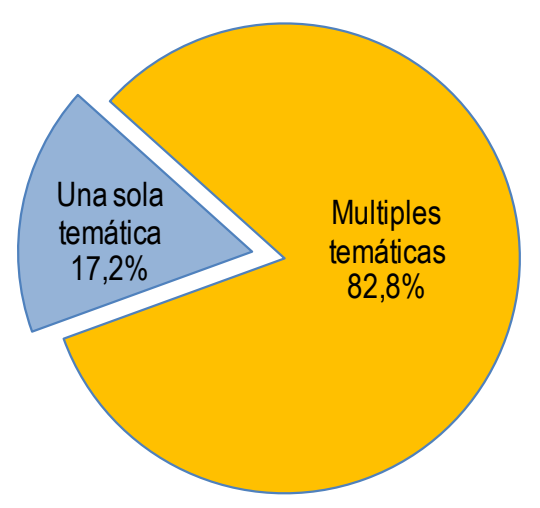

Gráfico 9: Diversidad de problemáticas

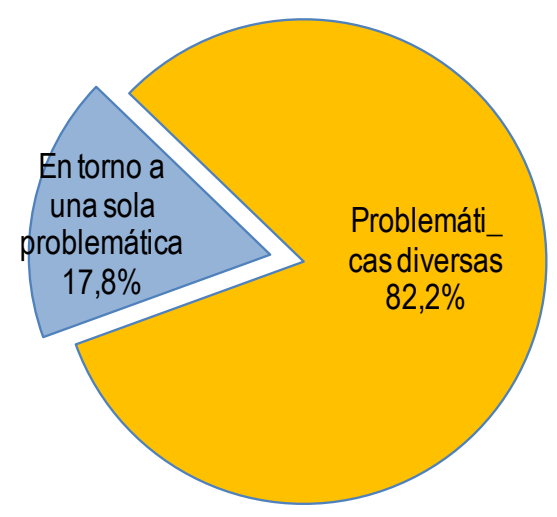

Gráfico 10: Diversidad de formatos

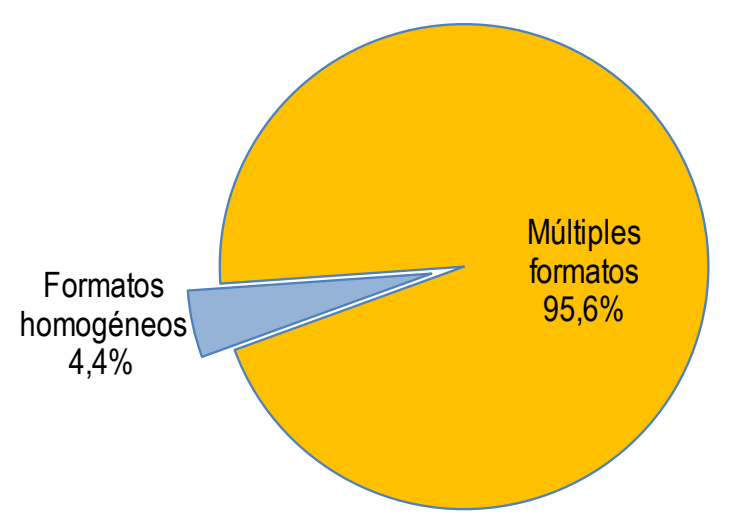


Gráfico 11: Diversidad de procedimientos

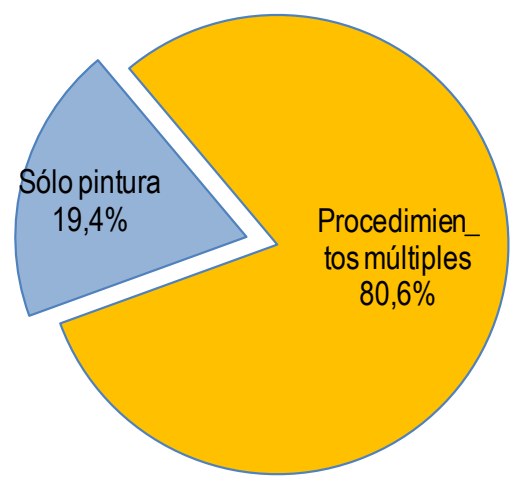

Gráfico 12: Diversidad de estilos

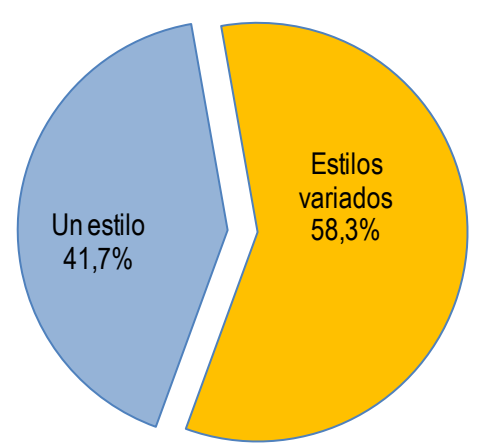




\subsection{Dimensión Formal}

\section{El Formato}

Gráfico 13: Forma

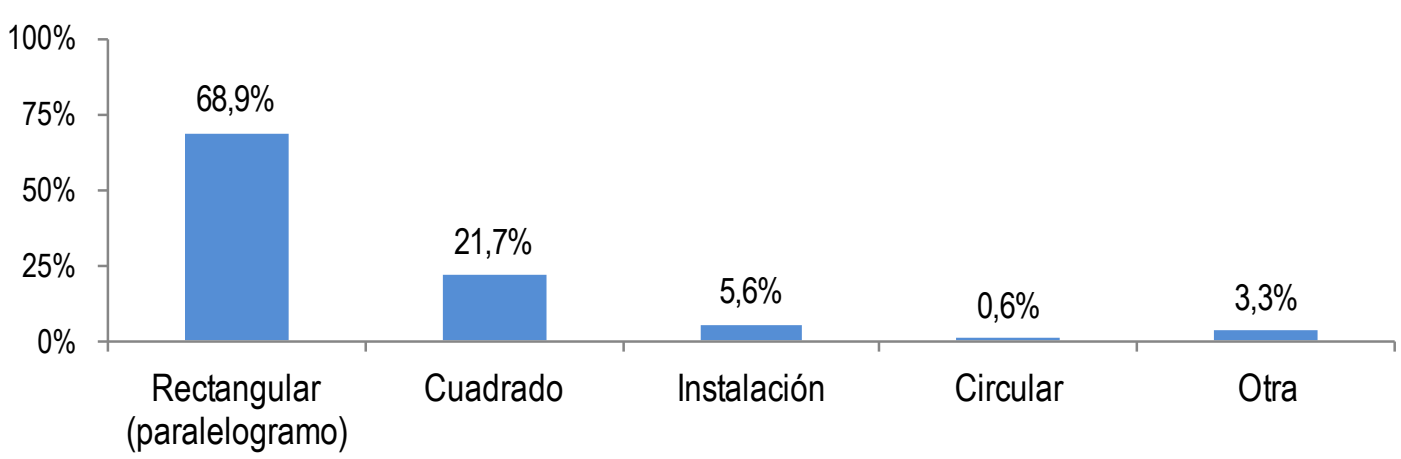

Gráfico 14: Tamaño / Dimensiones

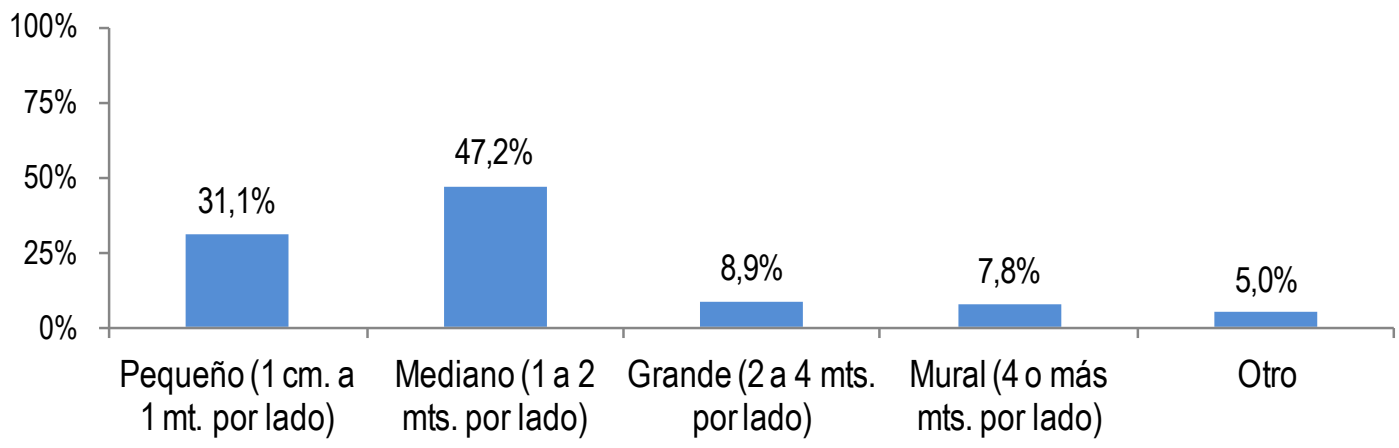

Procedimiento Técnico

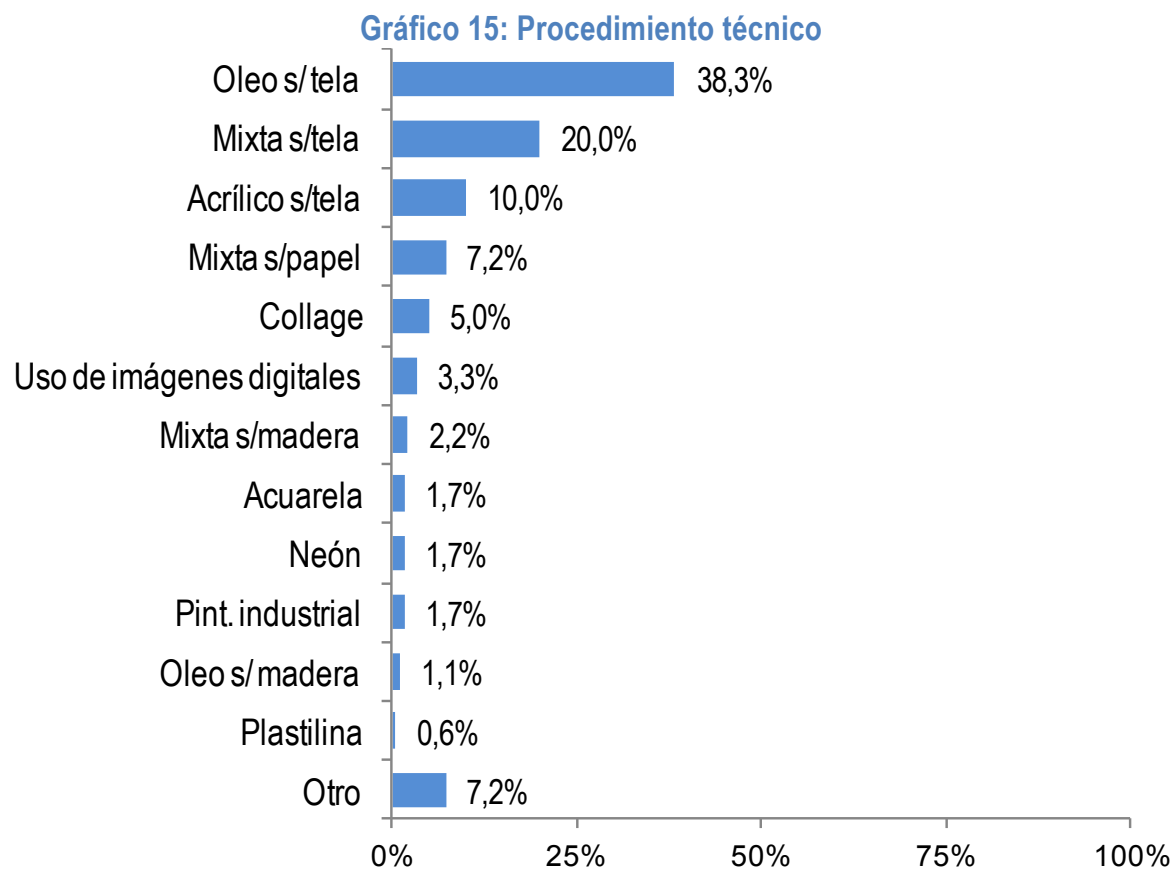


Formas de expresión

Gráfico 16: Estrategias

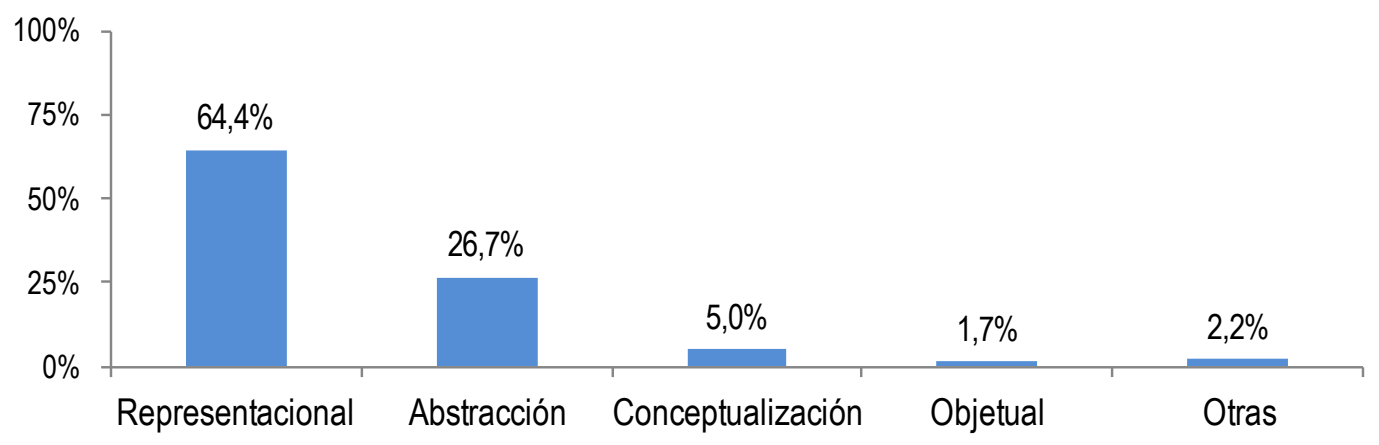

Gráfico 17: Recursos iconográficos (Opción Múltiple)

\begin{tabular}{|c|c|c|}
\hline Formas regulares & $51,7 \%$ & \\
\hline Simbólico & $50,6 \%$ & \\
\hline Formas irregularesu orgánicas & $44,4 \%$ & \\
\hline Manchas & $36,7 \%$ & \\
\hline Realismo & $33,3 \%$ & \\
\hline Naturalista & $27,8 \%$ & \\
\hline Chorreado/gestual & $18,9 \%$ & \\
\hline Figuración & $18,3 \%$ & \\
\hline Ficción & $17,8 \%$ & \\
\hline Objetos & $15,6 \%$ & \\
\hline Otro & $15,0 \%$ & \\
\hline Collage & $12,8 \%$ & \\
\hline Signos icónicos y palabras & $12,2 \%$ & \\
\hline Texto & $10,6 \%$ & \\
\hline Instalación & $10,0 \%$ & \\
\hline Impresión digital & $5,6 \%$ & \\
\hline Impresión digital//pintura & $5,0 \%$ & \\
\hline Acciones & $2,8 \%$ & \\
\hline Objeto soporte & $2,8 \%$ & \\
\hline \multirow[t]{2}{*}{ Performance } & $1,1 \%$ & \\
\hline & $25 \%$ & $75 \%$ \\
\hline
\end{tabular}




\subsection{Dimensión Temática}

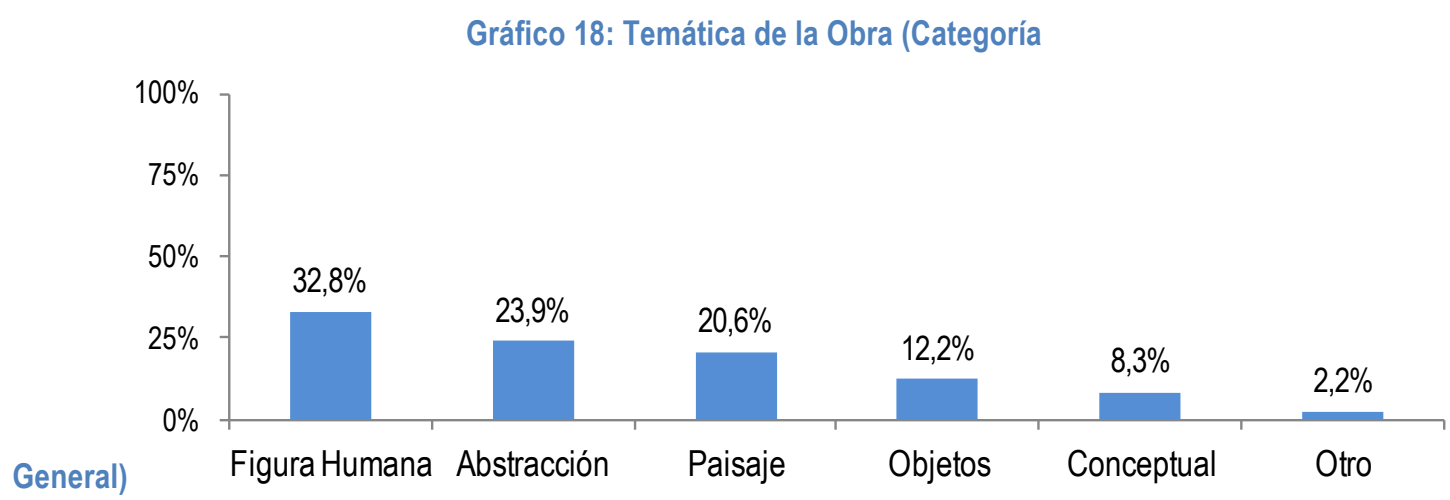

Tabla 9: Sub categorías (Opción Múltiple)

Categoría "Figura Humana". N=59

\begin{tabular}{|l|r|r|}
\hline & \multicolumn{1}{|c|}{$\%$} & $\mathrm{~N}$ \\
\hline Escena no costumbrista & $50,8 \%$ & 30 \\
\hline Retrato / Autorretrato & $35,6 \%$ & 21 \\
\hline El desnudo & $13,6 \%$ & 8 \\
\hline En acción o movimiento & $11,9 \%$ & 7 \\
\hline Escena costumbrista & $10,2 \%$ & 6 \\
\hline Otro & $11,9 \%$ & 7 \\
\hline Total & $100,0 \%$ & 59 \\
\hline
\end{tabular}

Tabla 10: Sub categorías (Opción Múltiple)

Categoría "Abstracción". N=43

\begin{tabular}{|l|r|r|}
\hline & \multicolumn{1}{|c|}{$\%$} & $\mathrm{~N}$ \\
\hline Color & $58,1 \%$ & 25 \\
\hline Juego de formas & $55,8 \%$ & 24 \\
\hline Gestual & $37,2 \%$ & 16 \\
\hline Monocromo & $4,7 \%$ & 2 \\
\hline Formas orgánicas & $2,3 \%$ & 1 \\
\hline Formas regulares & $2,3 \%$ & 1 \\
\hline Óptico & $2,3 \%$ & 1 \\
\hline Otro & $27,9 \%$ & 12 \\
\hline Total & $\mathbf{1 0 0 , 0 \%}$ & $\mathbf{4 3}$ \\
\hline
\end{tabular}


Tabla 11: Sub categorías (Opción Múltiple)

Categoría "El Paisaje". $\mathrm{N}=37$

\begin{tabular}{|c|c|c|}
\hline & $\%$ & $\mathrm{~N}$ \\
\hline Interior psicológico & $24,3 \%$ & 9 \\
\hline Psicológico & $21,6 \%$ & 8 \\
\hline Costero & $21,6 \%$ & 8 \\
\hline Urbano & $21,6 \%$ & 8 \\
\hline Forestal & $16,2 \%$ & 6 \\
\hline Atmosférica & $10,8 \%$ & 4 \\
\hline Interior habitación & $10,8 \%$ & 4 \\
\hline Cordillerano & $5,4 \%$ & 2 \\
\hline Marino & $5,4 \%$ & 2 \\
\hline Ambientación & $2,7 \%$ & 1 \\
\hline Otro & $43,2 \%$ & 16 \\
\hline Total & $100,0 \%$ & 37 \\
\hline
\end{tabular}

Tabla 12: Sub categorías (Opción Múltiple)

Categoría "Objetos". $\mathrm{N}=22$

\begin{tabular}{|l|r|r|}
\hline & \multicolumn{1}{|c|}{$\%$} & $\mathrm{~N}$ \\
\hline Representación de objetos & $59,1 \%$ & 13 \\
\hline Objeto simbólico & $36,4 \%$ & 8 \\
\hline Presentación de objetos & $27,3 \%$ & 6 \\
\hline Naturaleza muerta & $27,3 \%$ & 6 \\
\hline Bodegón & $18,2 \%$ & 4 \\
\hline El objeto como soporte y signo & $13,6 \%$ & 3 \\
\hline Flora & $9,1 \%$ & 2 \\
\hline Otro & $22,7 \%$ & 5 \\
\hline Total & $100,0 \%$ & $\mathbf{2 2}$ \\
\hline
\end{tabular}


Tabla 13: Sub categorías (Opción Múltiple)

Categoría "Conceptual". $\mathrm{N}=161$

\begin{tabular}{|l|r|r|}
\hline & \multicolumn{1}{|c|}{$\%$} & $\mathrm{~N}$ \\
\hline Enunciados & $33,3 \%$ & 5 \\
\hline Contexto & $20,0 \%$ & 3 \\
\hline Acciones & $20,0 \%$ & 3 \\
\hline Análisis y percepción de la realidad & $20,0 \%$ & 3 \\
\hline Arte analítico & $20,0 \%$ & 3 \\
\hline Proyectos art & $13,3 \%$ & 2 \\
\hline Propuestas-Declaraciones & $6,7 \%$ & 1 \\
\hline Video art & $6,7 \%$ & 1 \\
\hline Otro & $40,0 \%$ & 6 \\
\hline Total & $100,0 \%$ & 15 \\
\hline
\end{tabular}

Tabla 14: Sub categorías (Opción Múltiple) Categoría "Otra". $\mathrm{N}=4$

\begin{tabular}{|l|r|r|}
\hline & \multicolumn{1}{|c|}{$\%$} & $\mathrm{~N}$ \\
\hline Política & $75,0 \%$ & 3 \\
\hline Sociocultural & $75,0 \%$ & 3 \\
\hline Otro & $50,0 \%$ & 2 \\
\hline Total & $100,0 \%$ & 4 \\
\hline
\end{tabular}




\subsection{Dimensión Configuracional}

\section{Sistemas de Configuración - Forma}

Gráfico 19: Sistemas de Configuración - Forma (Opción Múltiple)

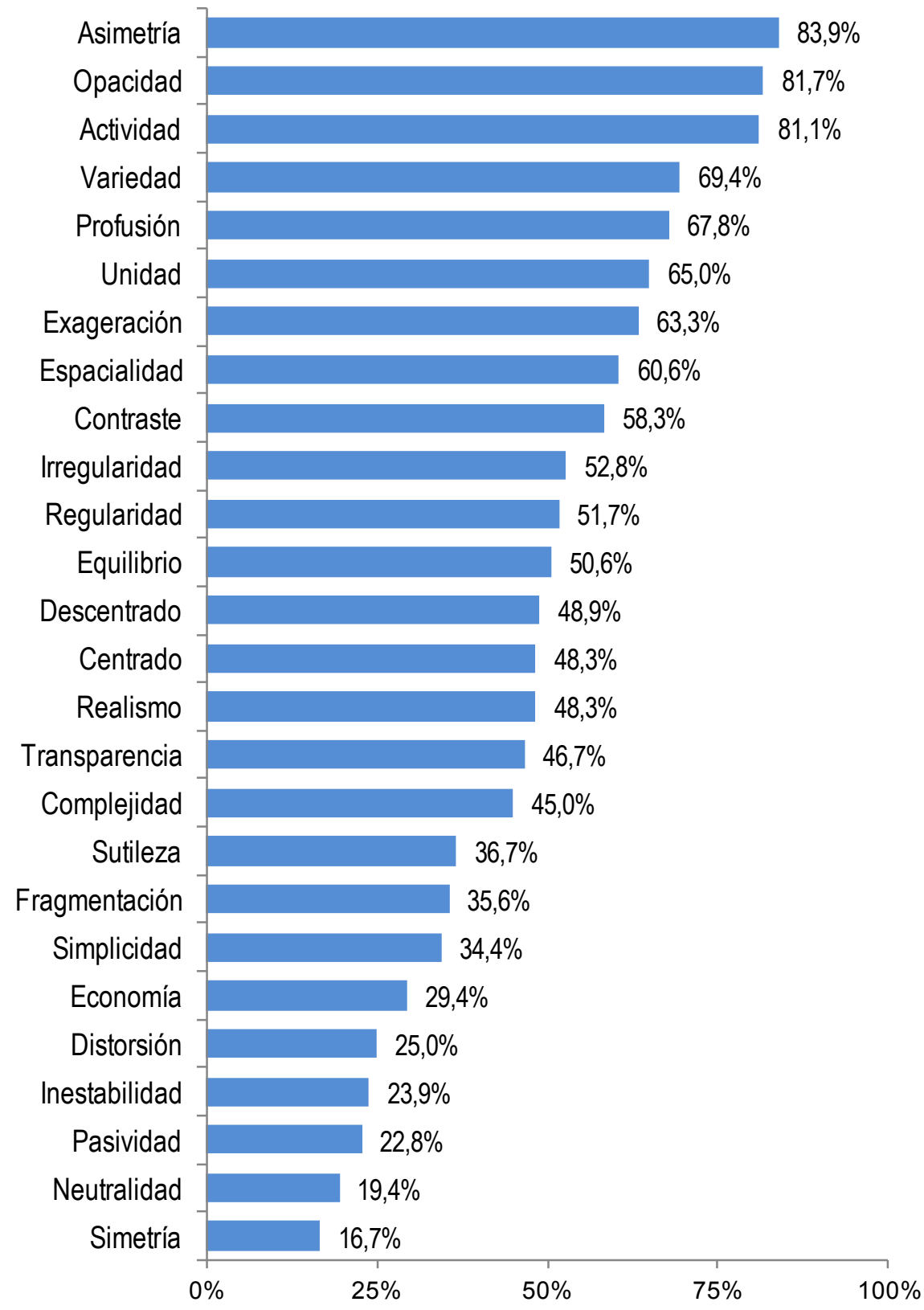


Tratamiento de la Forma

Gráfico 20: Delimitación de la Forma

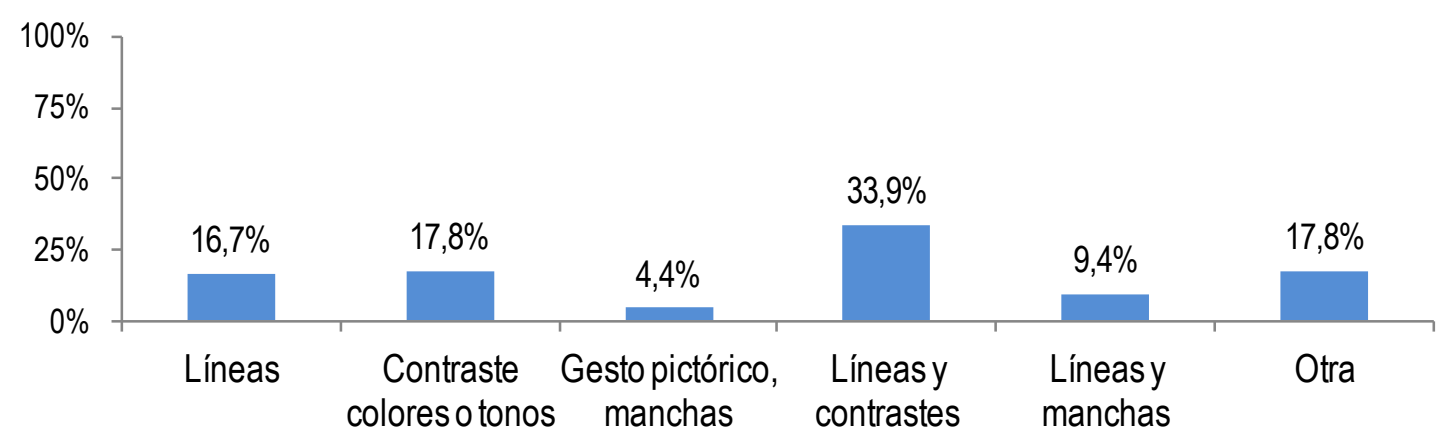

Gráfico 21: Caracterización de la Forma (Opción Múltiple)

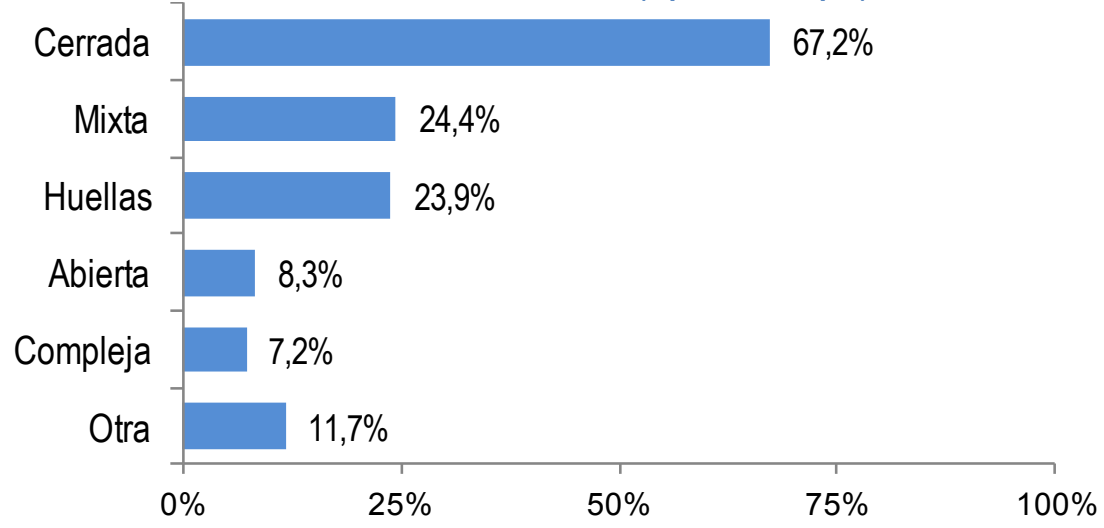

Gráfico 22: Tratamiento de la Forma (Opción Múltiple)

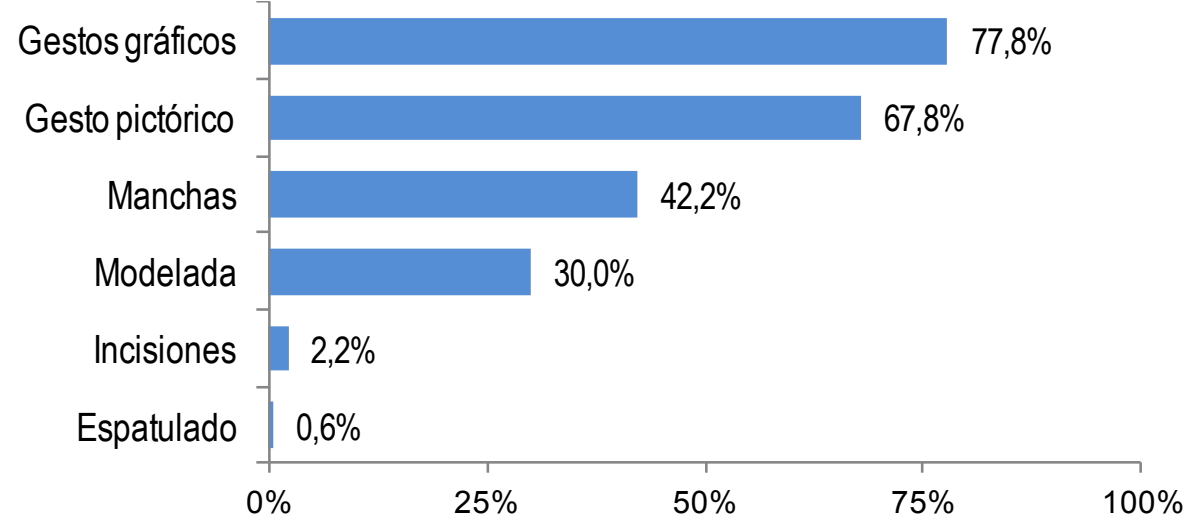




\subsection{Análisis Connotativo}

Tabla 15: Estilo de la Obra

\begin{tabular}{|c|c|c|c|c|c|}
\hline & $\%$ & $\mathrm{~N}$ & & $\%$ & $\mathrm{~N}$ \\
\hline Conceptual & $11,7 \%$ & 21 & Realismo simbólico & $1,7 \%$ & 3 \\
\hline Expresionismo - abstracto & $10,0 \%$ & 18 & Fotorrealismo & $1,7 \%$ & 3 \\
\hline Neofiguración & $6,7 \%$ & 12 & Realismo naturalista & $1,7 \%$ & 3 \\
\hline Abstracto pospictórico & $6,1 \%$ & 11 & Hiperrealismo & $1,7 \%$ & 3 \\
\hline Postmodernismo & $5,0 \%$ & 9 & Naif & $1,7 \%$ & 3 \\
\hline Surrealismo & $5,0 \%$ & 9 & Neo pop & $1,7 \%$ & 3 \\
\hline Expresionismo simbólico & $3,9 \%$ & 7 & Street art & $1,1 \%$ & 2 \\
\hline Neo expresionismo & $3,9 \%$ & 7 & Arte bruto & $1,1 \%$ & 2 \\
\hline Expresionismo & $3,9 \%$ & 7 & Fovismo & $1,1 \%$ & 2 \\
\hline Realismo mágico & $3,3 \%$ & 6 & Romanticismo & $1,1 \%$ & 2 \\
\hline Realismo social & $3,3 \%$ & 6 & Postal art & $0,6 \%$ & 1 \\
\hline Pintura digital & $2,8 \%$ & 5 & Pintura metafísica & $0,6 \%$ & 1 \\
\hline Transvanguardia & $2,8 \%$ & 5 & Minimal & $0,6 \%$ & 1 \\
\hline Arte pop & $2,8 \%$ & 5 & Existencialista & $0,6 \%$ & 1 \\
\hline arte informal & $2,8 \%$ & 5 & Orfismo & $0,6 \%$ & 1 \\
\hline Impresionismo & $2,8 \%$ & 5 & Art nouveau & $0,6 \%$ & 1 \\
\hline Simbolismo & $2,2 \%$ & 4 & Otro & $1,1 \%$ & 2 \\
\hline Neo impresionismo & $2,2 \%$ & 4 & Total & $100,0 \%$ & 180 \\
\hline
\end{tabular}

Gráfico 23: Estilo de la Obra (Clasificación General)

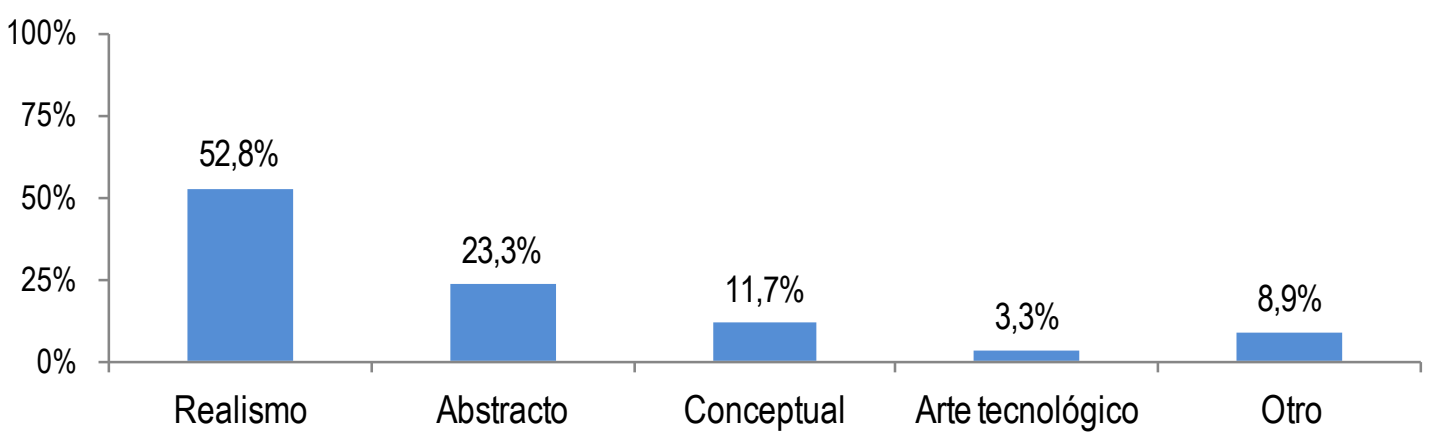


Gráfico 24: Contenido de la Obra (Opción Múltiple)

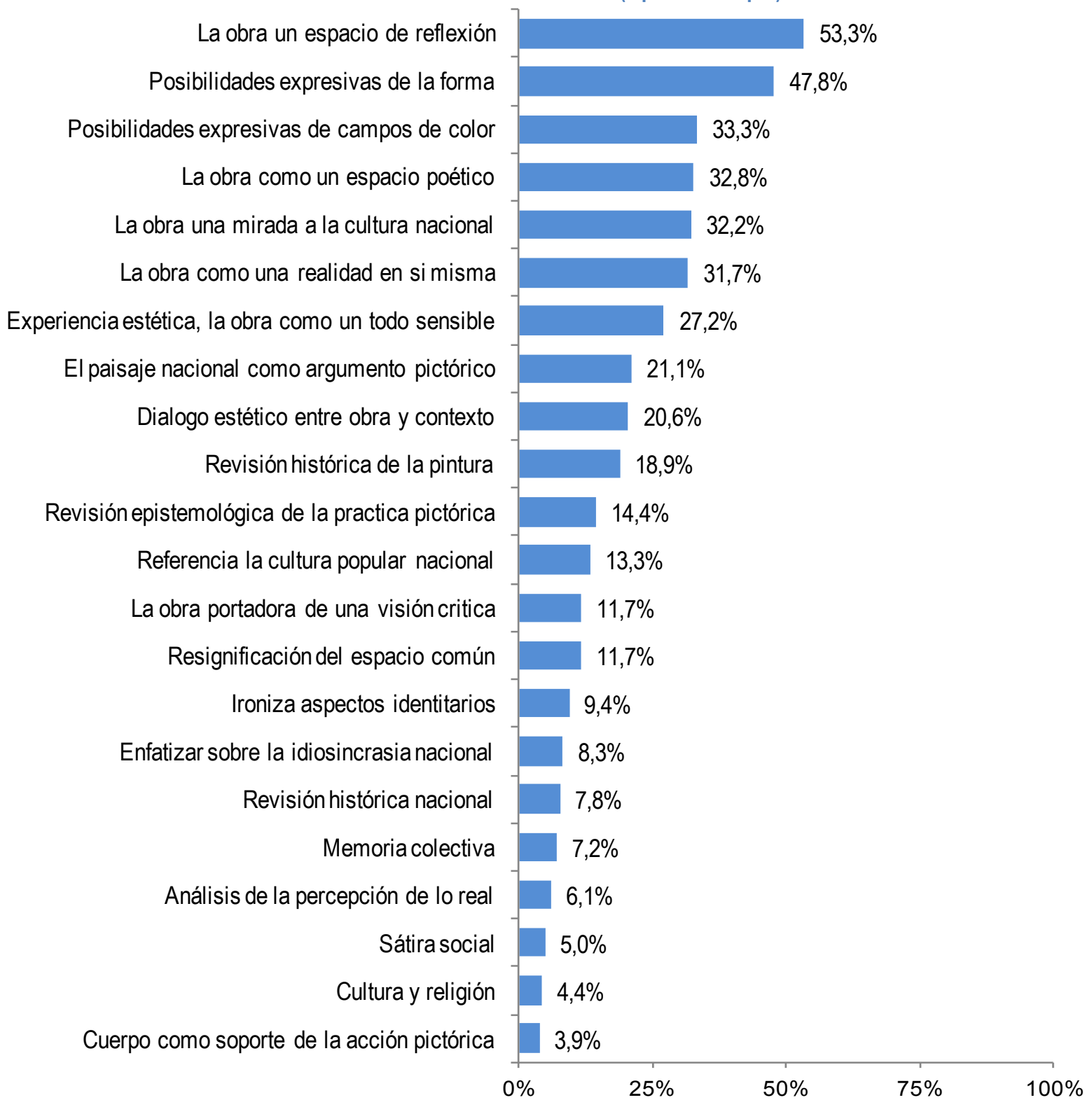


Gráfico 25: Problemática de la Obra (Opción Múltiple)

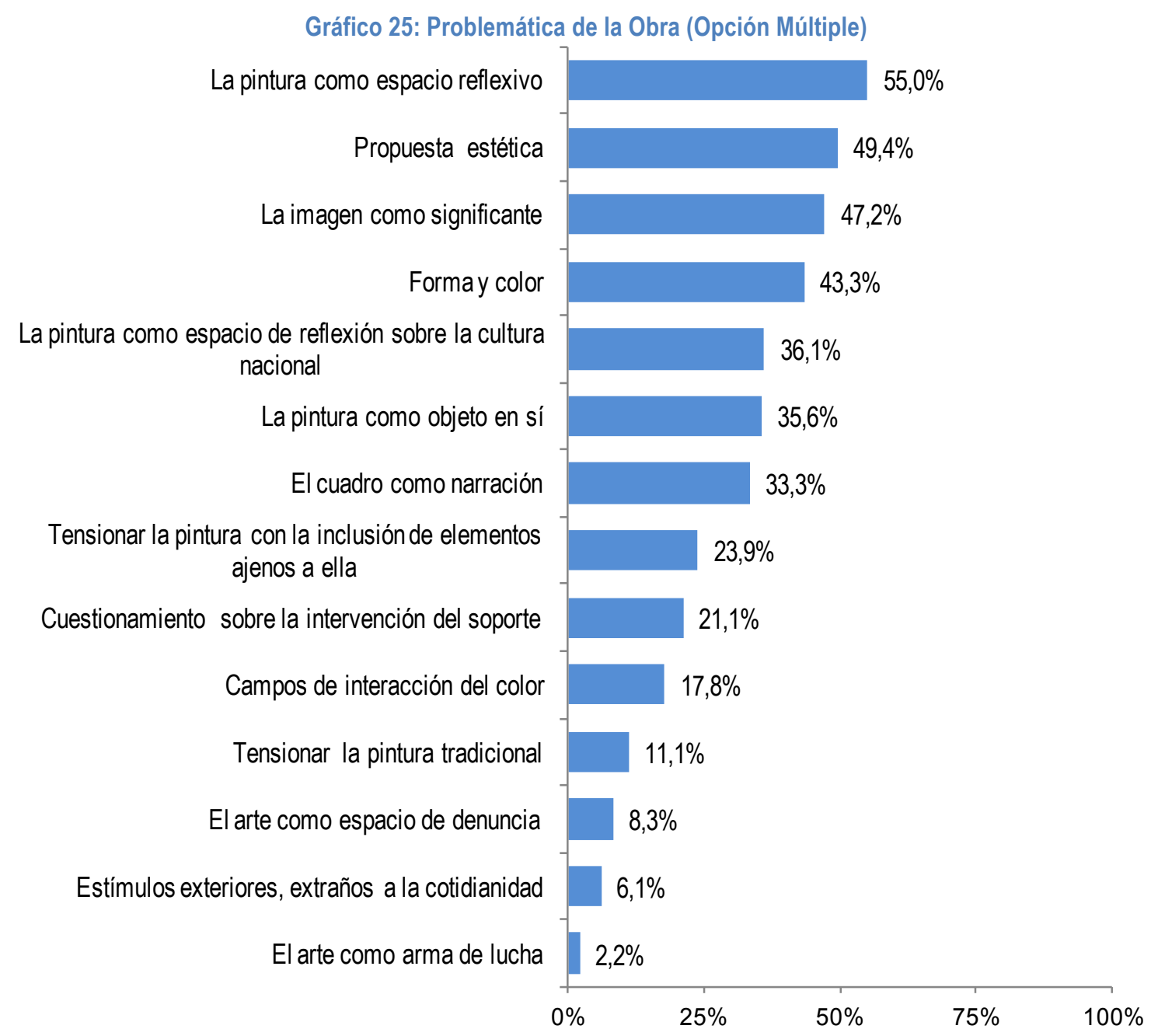

